Cornegie Institute

Washingam

$2019-10-29$

Spreasstreet 


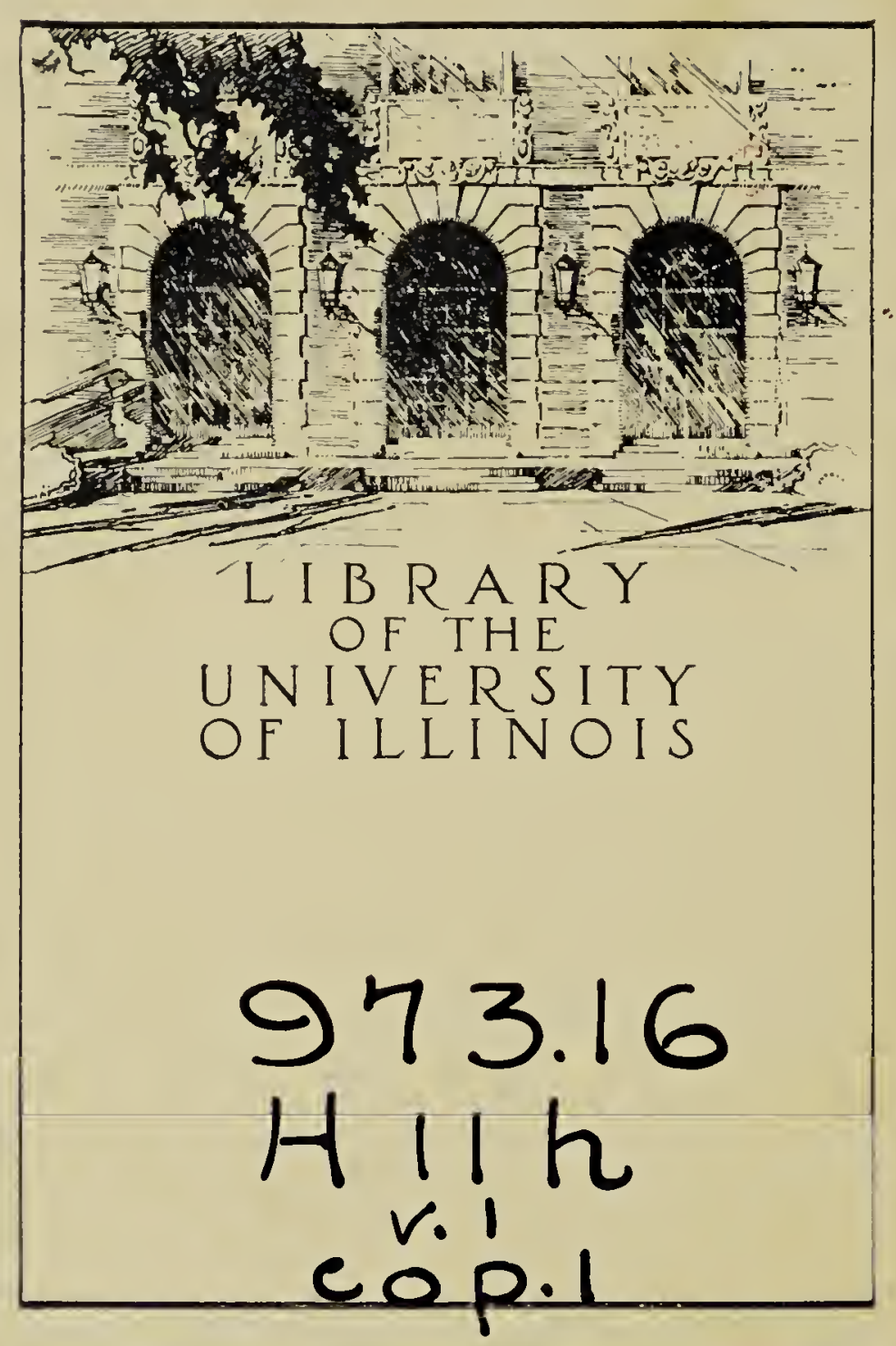


Return this book on or before the

Latest Date stamped below.

Theft, mutilation, and underlining of books are reasons for disciplinary action and máy resulf in dismissal from the University.

University of Illinois Library

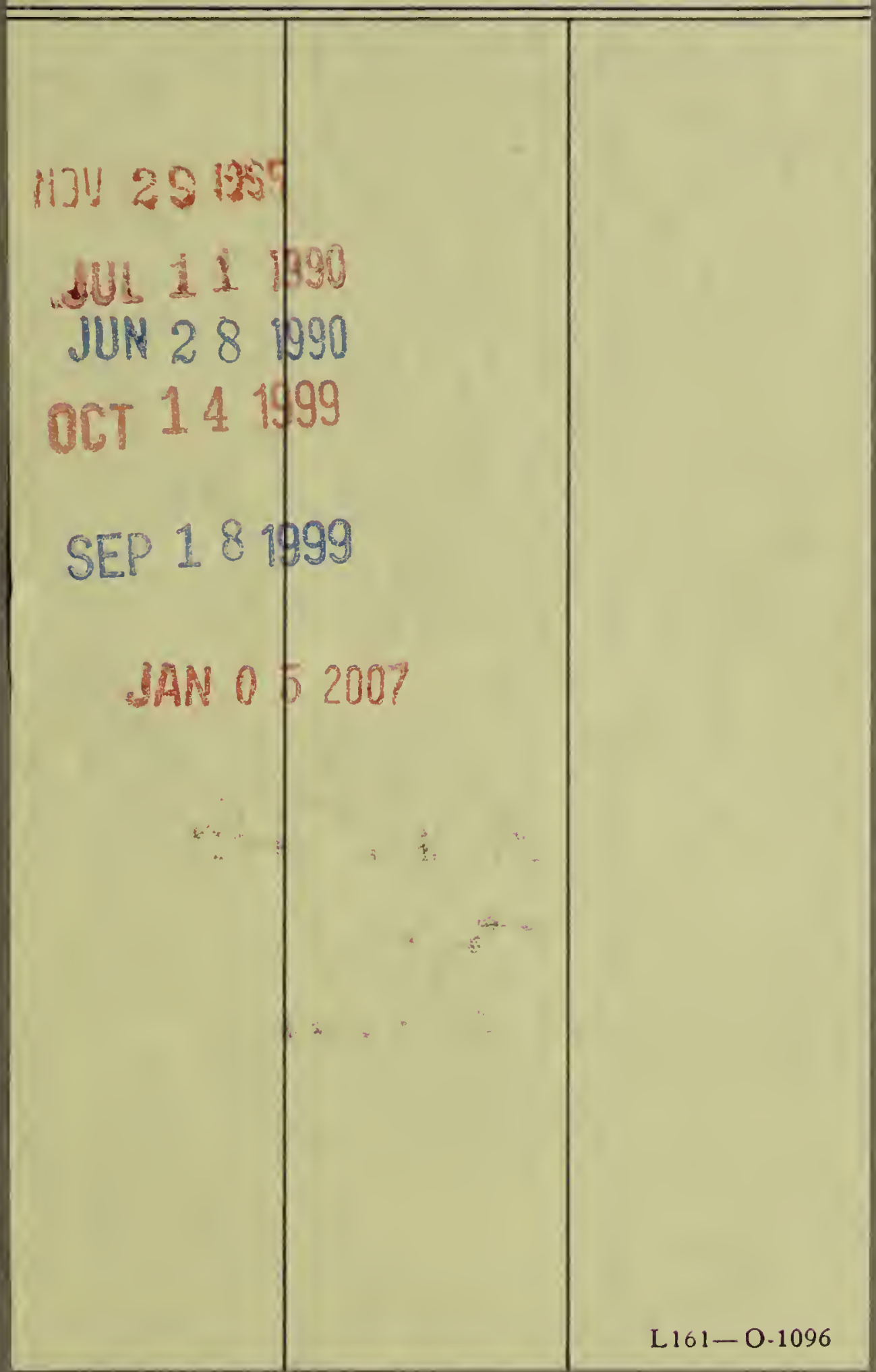




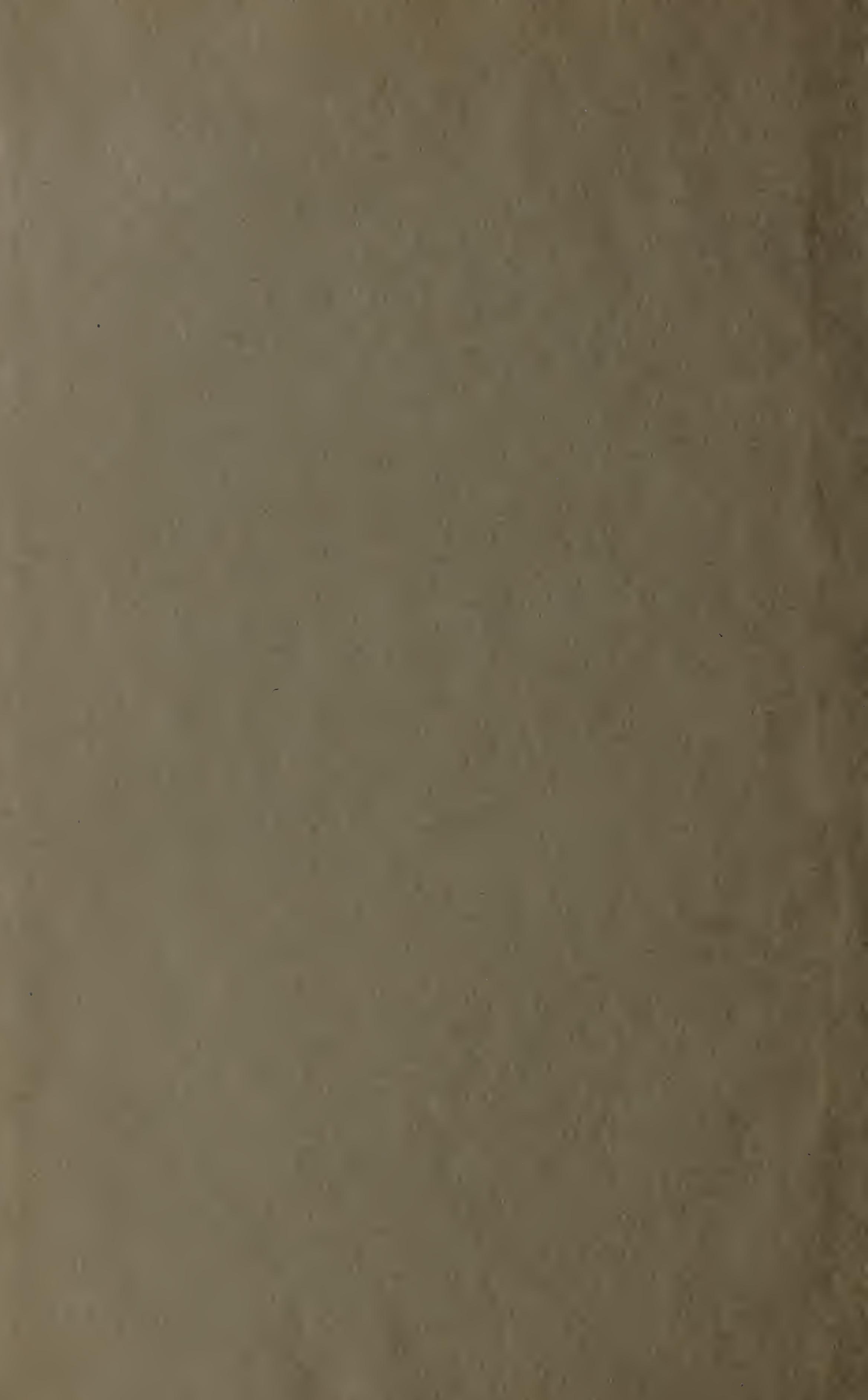




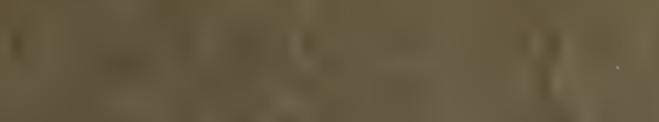

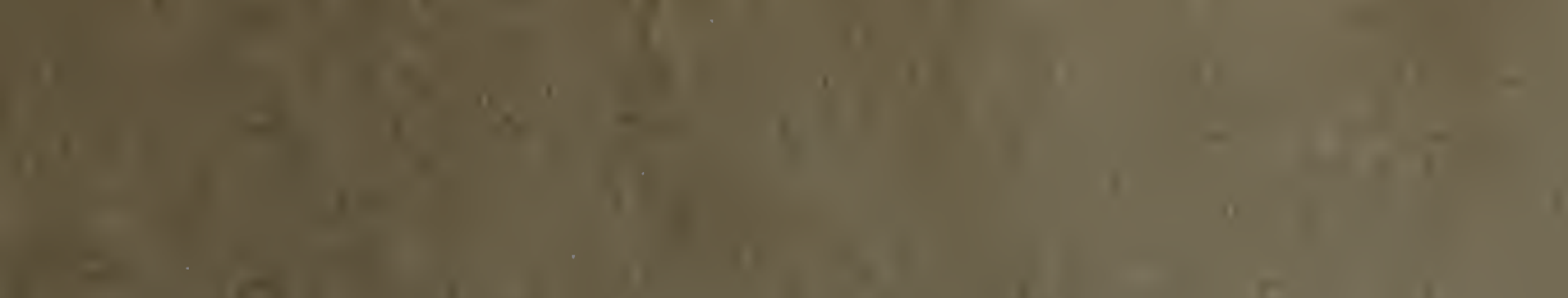

a 1 it

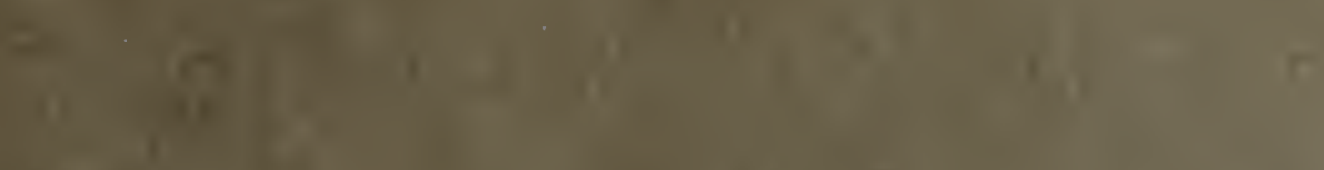

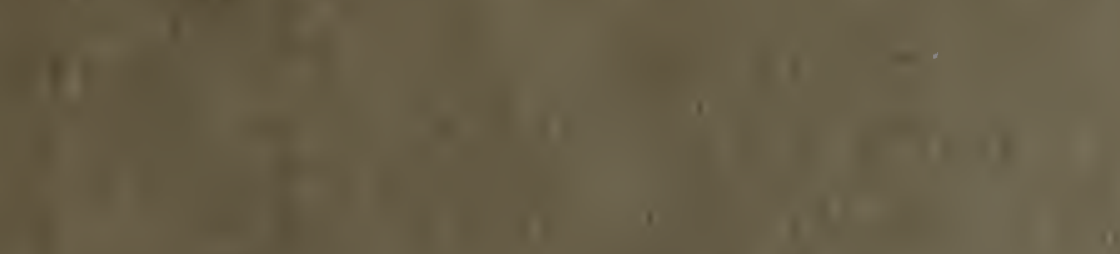

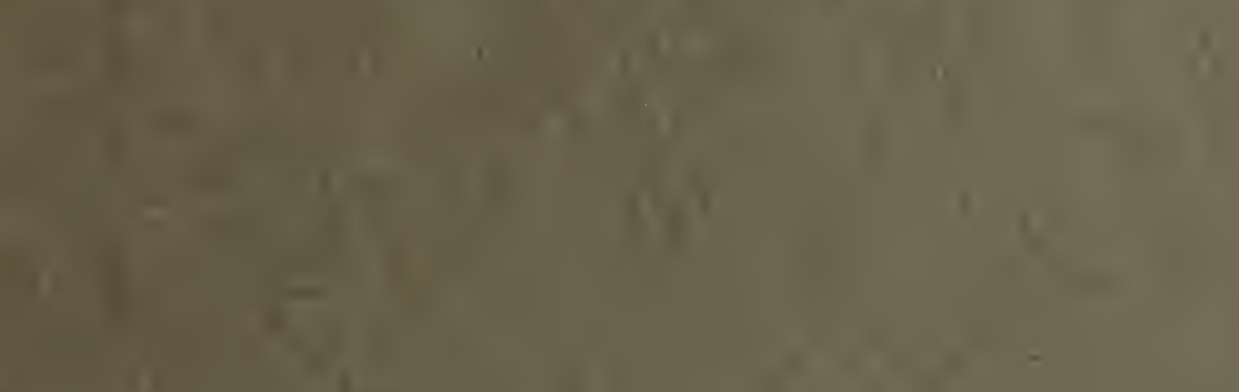

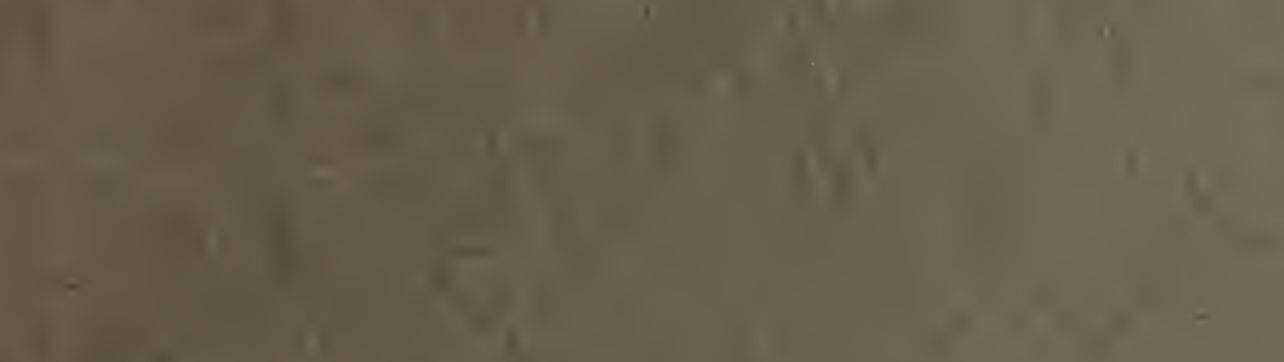

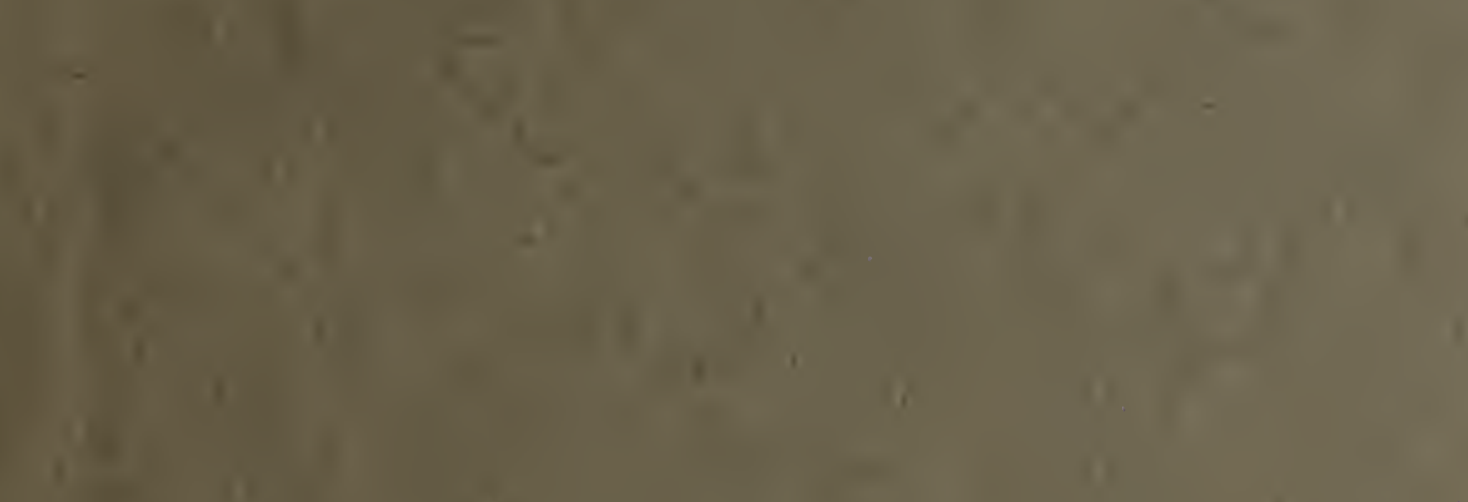

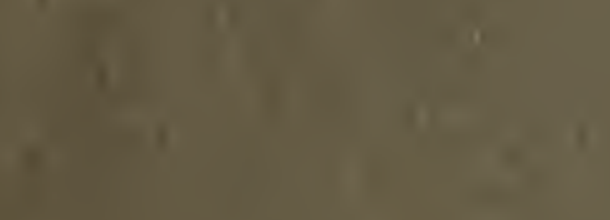

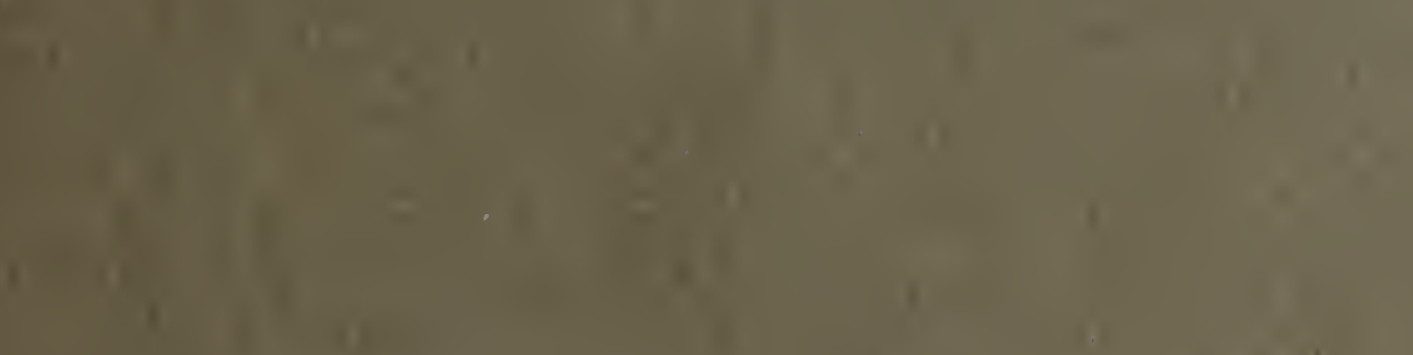

1)

1

$1=1$

$1+1$

(1)

(1.

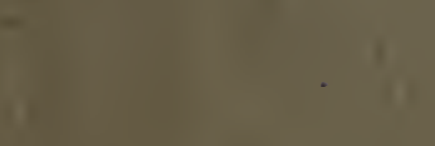

1.

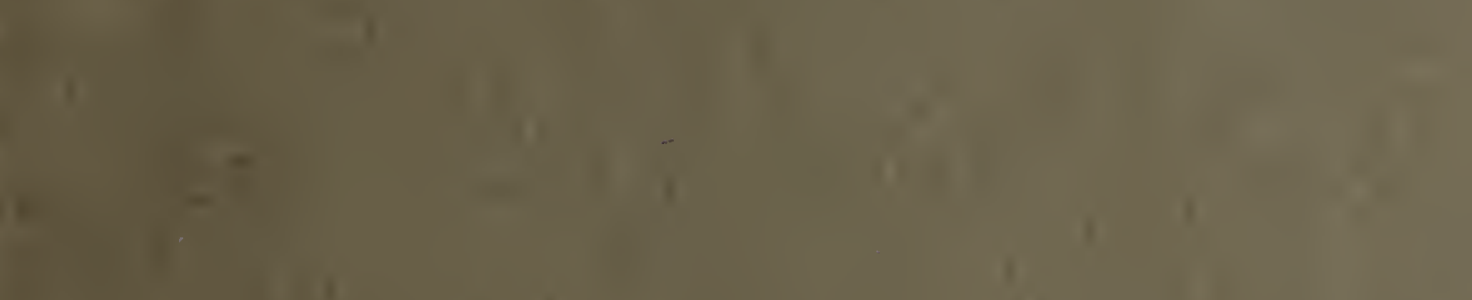

1

$(1)$

$+1=1$

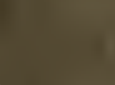

$\left(1+2 x^{2}\right.$

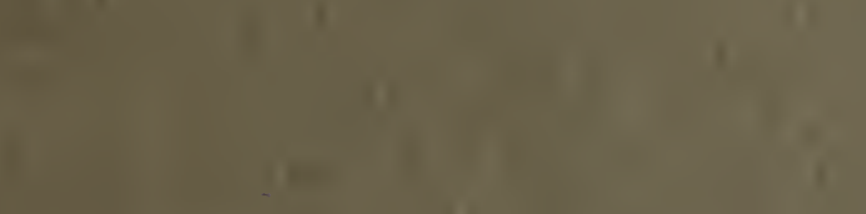

(1)

$$
\text { (1) }
$$

17

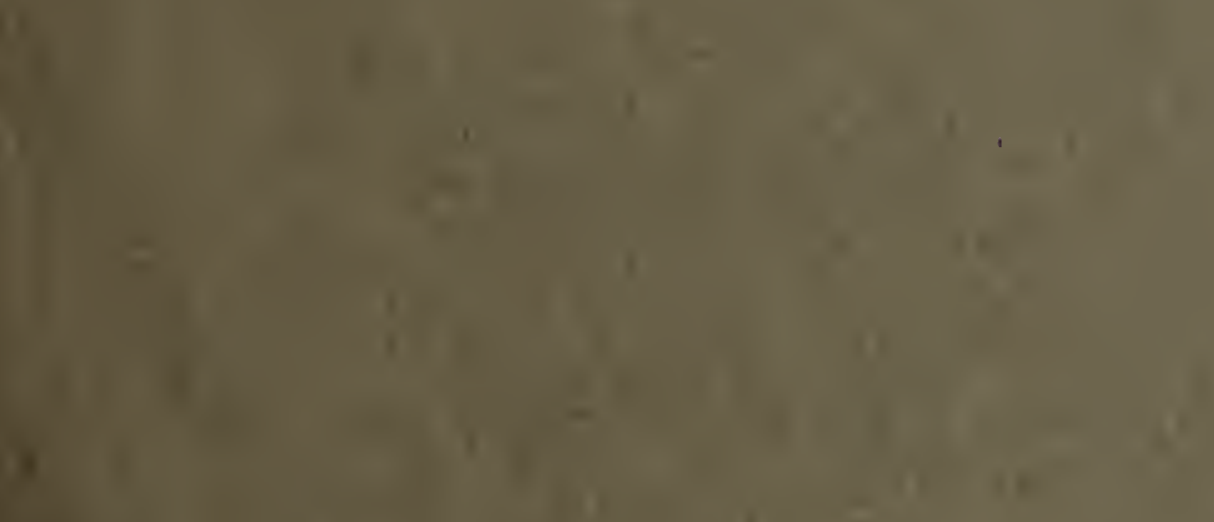

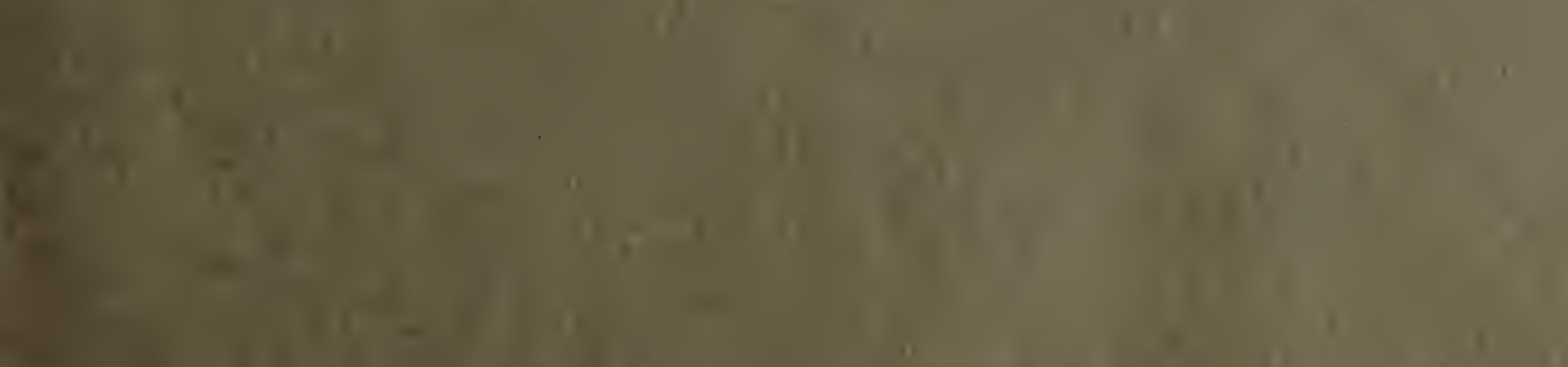

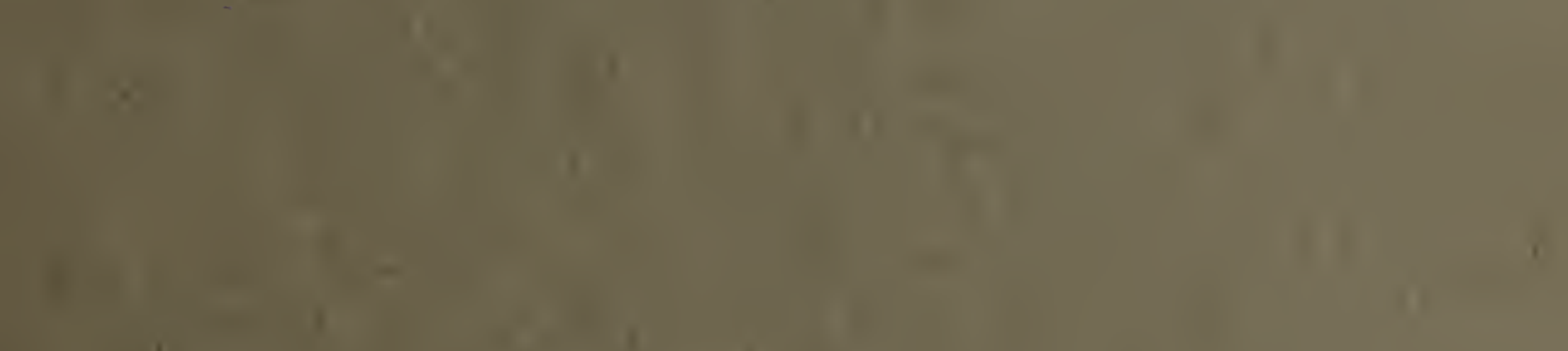



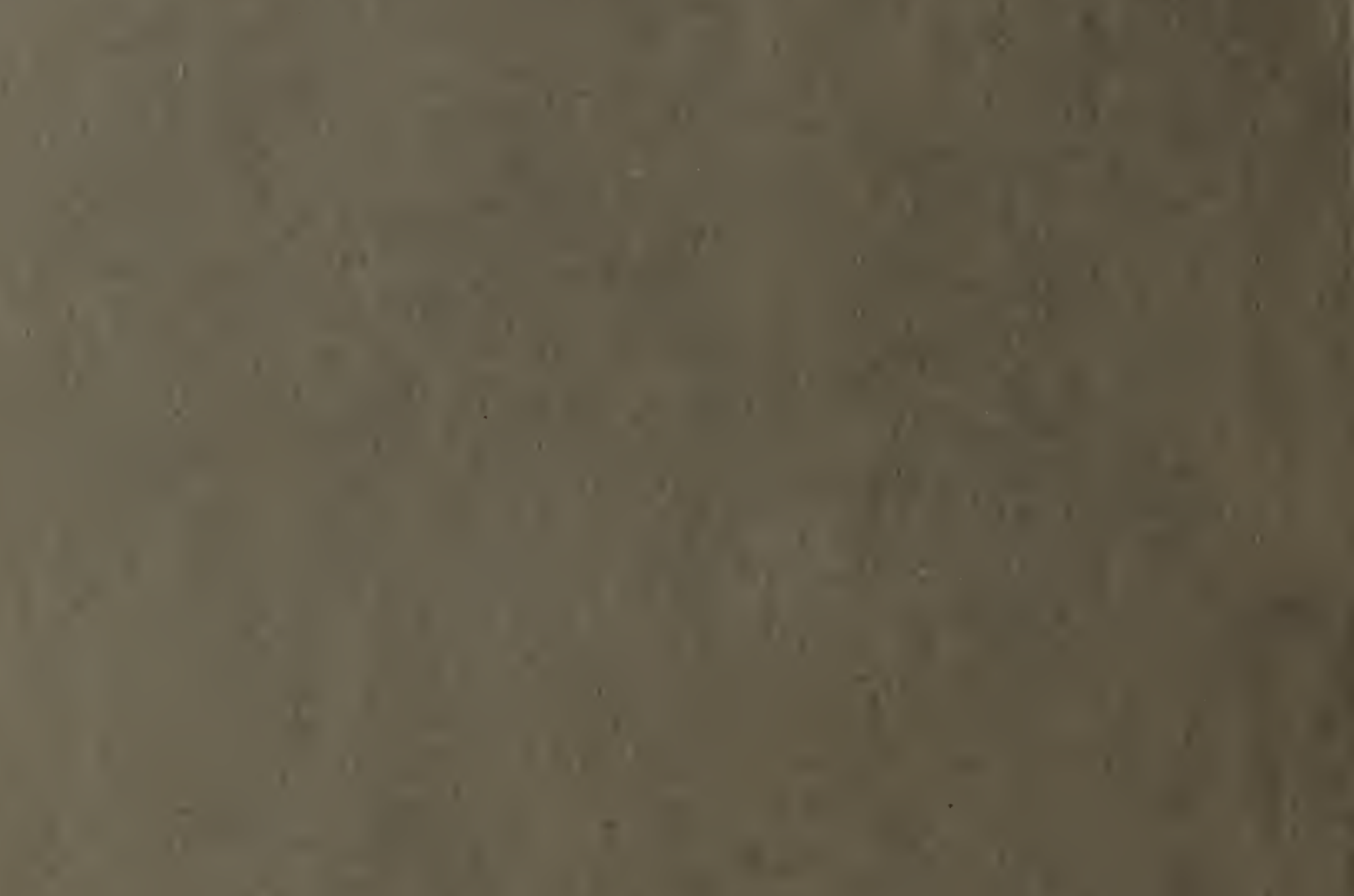

1). 9

11

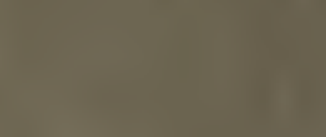
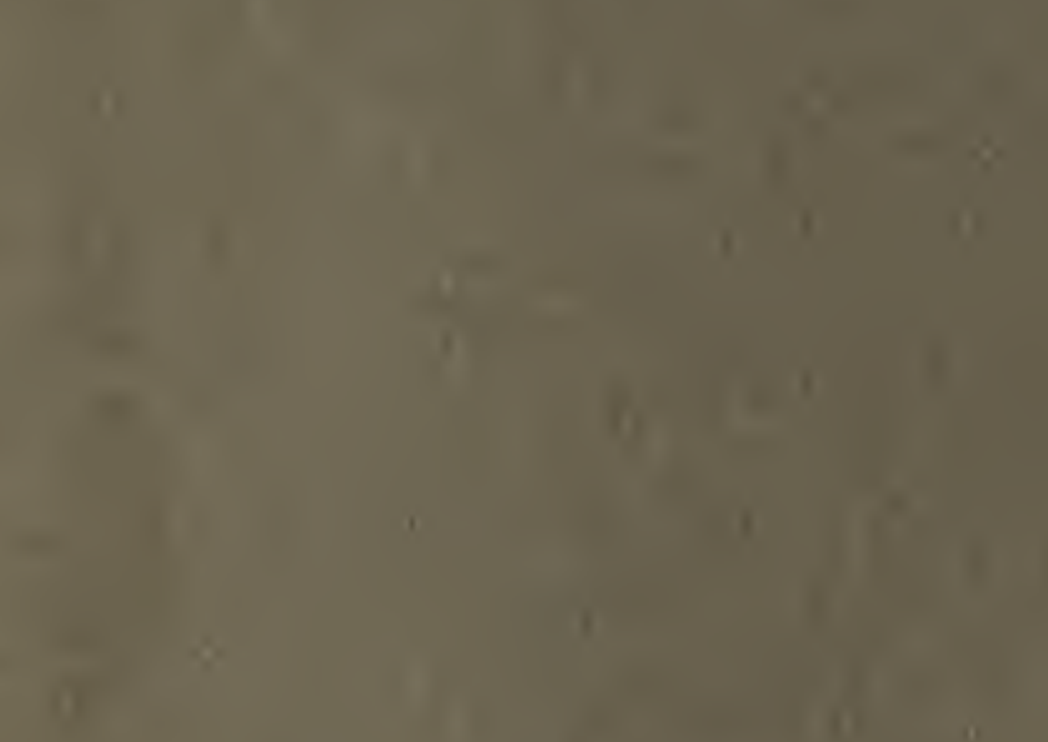

b) $=1$ 


\title{
Historical Documents relating to New Mexico, Nueva Vizcaya, and Approaches Thereto, to 1773
}

\author{
COLLECTED BY \\ ADOLPH F. A. BANDELIER AND FANNY R. BANDELIER

\section{SPANISH TEXTS AND ENGLISH TRANSLATIONS} \\ EDITED WITH INTRODUCTIONS AND ANNOTATIONS \\ BY \\ CHARLES WILSON HACKETT, Ph. D. \\ Associate Professor of Latin American History in the University of Texas
}

VOLUME I

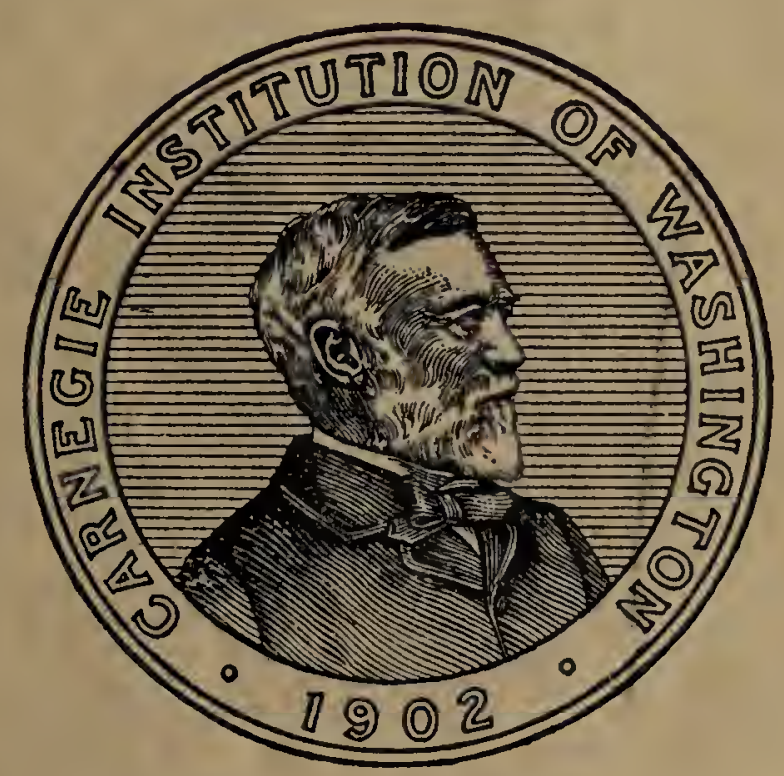

WASHINGTON, D. C.

Published by the Carnegie Institution of Washington

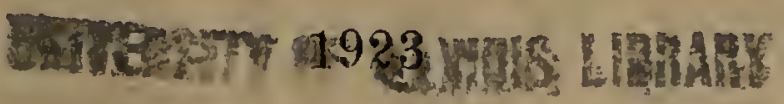

36N 277324 
i 


\section{Historical Documents relating to \\ New Mexico, Nueva Vizcaya, and Approaches Thereto, to 1773}

COLLECTED BY

ADOLPH F. A. BANDELIER AND FANNY R. BANDELIER

SPANISH TEXTS AND ENGLISH TRANSLATIONS

EDITED WITH INTRODUCTIONS AND ANNOTATIONS

BY

CHARLES WILSON HACKETT, Ph.D.

Associate Professor of Latin American History in the University of Texas

\section{VOLUME I}

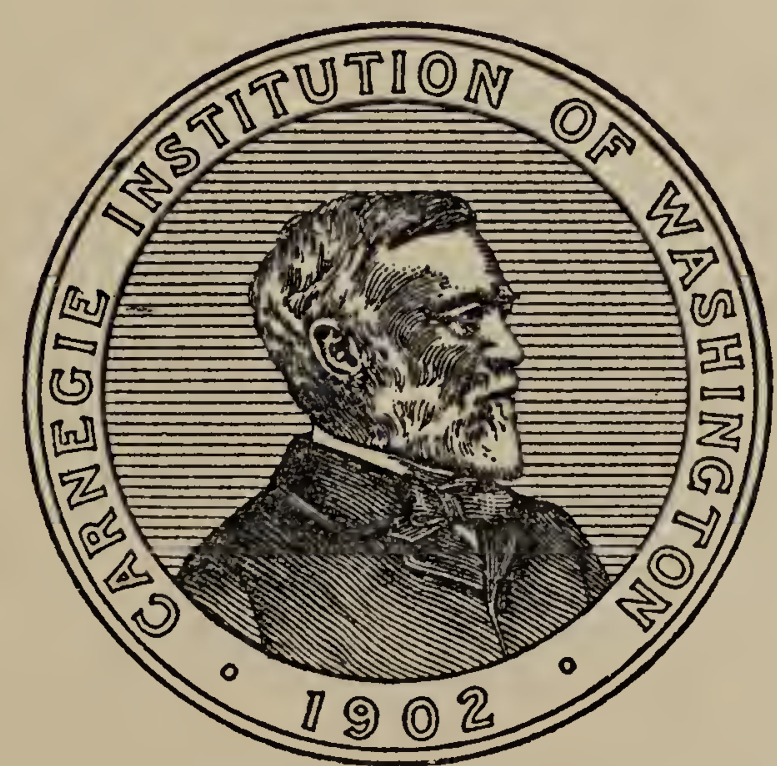

WASHINGTON, D. C.

rs Published by the Carnegie Institution of Washington 
CARNEGIE INSTITUTION OF WASHINGTON

PUBLICATION NO. 330 , VOL. I

Papers of the Department of Historical Research

J. FRANKLIN JAMESON, EDITOR 


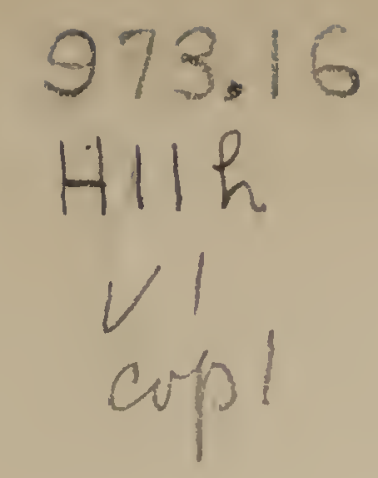

\section{INTRODUCTORY NOTE.}

In I9Io Dr. Adolph F. A. Bandelier published his Documentary History of the Rio Grande Pueblos: Bibliographic Introduction. ${ }^{1}$ In this introduction Dr. Bandelier outlined his plan for a proposed larger work concerning the Pueblo Indians of New Mexico. In pursuance of this plan, and under a grant made by the trustees of the Carnegie Institution of Washington in October, I9I I, he spent parts of the years I9I2 and I9I 3 in research in the Archivo General in Mexico City. ${ }^{2}$ In the latter part of I9r3, under the same grant continued, Dr. and Mrs. Bandelier went to Spain to search in the Archivo de Indias at Seville for further materials concerning the Pueblo Indians. At the time Dr. Bandelier was in bad health, and his own work in those archives continued only till December I8, but under his direction Mrs. Bandelier made researches and copied documents designated by him. On March I8, I9I4, Dr. Bandelier died in Seville, before he had been able to accomplish more than a minor part of the work which he had undertaken. Mrs. Bandelier, however, continued until the end of I $^{1} 5$, under the auspices of the Institution, the work of research and of copying documents in the archives. The entire collection of transcripts made both in Mexico and in Spain was then turned over by her to the Institution.

The materials thus delivered consist of two distinct parts, a bound volume of about five hundred pages and a collection of unbound transcripts amounting in all to some nine hundred pages. The bound volume contains seventy-two transcripts made by Dr. and Mrs. Bandelier in Mexico City in I9I2 and I9I3. About half of these, however, are copies or extracts from printed books, evidently made for subsidiary use in the future; the rest are transcripts of documents in the Archivo General in Mexico City. The nine hundred pages of unbound transcripts were all made in Seville.

In view of the circumstances under which the work was done, it was natural that the material copied should have little unity or organization. As a matter of fact it is confessedly miscellaneous. Many of the documents were, in a sense, casual finds; many were merely supplementary to documents already discovered by Dr. Bandelier in the course of his earlier researches. Sometimes only fragments of documents and parts of expedientes were copied; this is particularly true of the materials copied in Mexico City from the papers of the Inquisition, and of the group of

1 Papers of the School of American Archaeology, no. I3 (Cambridge, 1910).

${ }^{2}$ Report in Year Book No. II (for I912), pp. 258-260, No. I2 (for 1913), p. 294.

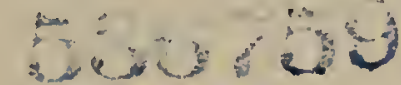


royal cédulas relating to the Oñate episode which were copied in Seville. In spite however of all the deficiencies resulting from Dr. Bandelier's lamented illness and death, the collection as a whole contains much valuable material which is not restricted, as was his original plan, to a subject so limited as the "Documentary History of the Rio Grande Pueblos". Indeed the material is of such range that to understand it one must keep in mind the outlines of Spanish achievements in North America from the very beginning, as a glance at the table of contents will show. Yet the majority of the documents, as was to be expected, relate to the Spanish provinces of New Mexico and Nueva Vizcaya and the Rio Grande region in general.

In the conviction that, however far from completeness or perfection, the collection as it stood deserved publication as a valuable contribution to an important part of American history, the Executive Committee of the Board of Trustees, by vote in 19I7, approved a series of recommendations submitted at their request by the undersigned, director of the Department of Historical Research, for preparing the collection for publication. In pursuance of these recommendations, the task of preparation was placed in the hands of Dr. Charles W. Hackett, then connected with the University of California, now associate professor of Latin American history in the University of Texas, to whom we are indebted for the editing of the volumes now presented.

The instructions under which Dr. Hackett was invited to act called for the making of a transcript of the texts, suitable for the printer, the preparation of a proper translation of them into English, and the provision of such introductions and annotations as might be required for their proper understanding. It was expected that he would omit from his volumes all documents that had already been printed, or of which good English translations were already in print, and such few as were of insignificant value. On the other hand, in cases where a given group of the documents could be directly supplemented or completed by the addition of analogous documents from among those previously collected by Dr. Bandelier in New Mexico and Mexico, or by others, it was desired that such reinforcement should, within restricted limits, be effected. The source chiefly had in mind was the Bandelier collection preserved in the Peabody Museum at Cambridge, whose trustees kindly gave their permission for the use desired. With similar generosity, also, Mr. Edward E. Ayer of Chicago, the authorities of the Bancroft Library at the University of California, and Professor Herbert E. Bolton of that institution, permitted the use of transcripts in the Newberry Library, the Bancroft Library, and Dr. Bolton's private possession. From all these sources, additions amounting to somewhat more than one-tenth were made to the original collection, rounding it out by filling gaps and otherwise. Footnotes to these additional documents indicate their derivation. 


\section{Introductory Note}

A fresh transcription of the texts was made necessary by the determination to expand abbreviations, which the copyist had conscientiously reproduced from the original, but the permanent retention of which would have made the texts unreadable; to separate words which in the original had been run together; and to modernize the use of $u$ and $v$ and of $i$ and $j$. The details of the editorial work carried out by Dr. Hackett, or under his general supervision, are described by him in the ensuing preface.

The results of Dr. Hackett's labors are presented to the reading world with gratitude to him, to Dr. and Mrs. Bandelier, to Señor Don Pedro Torres Lanzas, director of the Archives of the Indies, and to those named above from whose collections supplementary materials have been derived, and with confidence that they will be thought to have furnished a signal addition to the materials for understanding the early history of the Southwest.

The work is expected to consist of four volumes. The index to the present volume has been prepared by Mr. David M. Matteson.

J. Franklin Jameson. 
ripris)

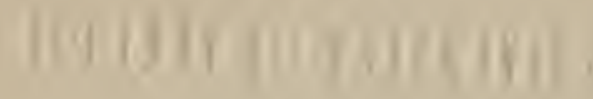

aixatit 


\section{PREFACE.}

The documents presented in this collection have been arranged under six subject headings, each of which, in a sense, constitutes a chapter, or a division of the whole subject treated. Within each of these groups a chronological order is, in general, followed. In both cases this plan of organization is adhered to regardless of the archive or the section of an archive in which a document was found.

In expanding abbreviated words the base of the word has been copied as it occurred, even though it may have been spelled incorrectly, but the added portion has been spelled according to modern rules. Thus the abbreviation "capp an " when expanded becomes "cappitan." Apart from extending the abbreviation and separating words that were run together, the only other change in form has been to capitalize the first words of sentences and paragraphs where in the original they are in lower case, and to change to lower case any capital letters occurring in the middle of a word.

As for punctuation and accentuation, no effort has been made to punctuate or accent according to modern rules; on the contrary, the integrity of the text in these respects has been preserved in so far as it was possible. However, it was decided that in all doubtful cases of punctuation the benefit of the doubt should be on the side of intelligibility, modern practices of punctuation in such cases being followed. Furthermore, where it was evident that a sentence had ended, periods have been added where none occurs in the original. Otherwise it may be said that the punctuation of the original has been preserved.

For the copying of the Bandelier transcripts and the carrying out of the suggestions given above, the greatest credit is due to Mrs. Beatrice Quejada Cornish, a native of Mexico and a member of the Spanish department in the University of California. Mrs. Cornish copied the major portion of the Bandelier transcripts; after a serious illness her place was ably filled by Miss Padilla of San Francisco, a most competent copyist. The editor took it upon himself to read all of the texts of the recopied transcripts.

The major part of the translating was done between August, I9I7, and December, I9I9, by Dr. Herbert I. Priestley of the Bancroft Library staff, at present associate professor of Mexican history in the University of California, and by Mrs. Nellie V. Sánchez, an expert translator and a scholar of high standing, of Berkeley, California. That the translating was done by such competent and well-known scholars is a matter of 
great satisfaction to the editor; this work will, he is confident, meet with general approbation and commendation. In the table of contents, immediately following the English translations of the titles of those documents translated by Dr. Priestley, will be found an asterisk $(*)$; a double asterisk (**) follows the English translations of the titles of those documents translated by Mrs. Sánchez. Where no such mark or marks appear the document was translated by the editor.

In all cases where it is given in the Bandelier transcripts the archive designation is indicated in a foot-note on the first page of the printed document. Since the English translation is printed opposite the Spanish transcript, the archive designation is not repeated. In a foot-note at the end of all documents copied by Mrs. Bandelier are to be found the initials F. R. B., and, wherever available, the date on which the copy was made; this is not repeated in the English translations. All annotations made by Dr. or Mrs. Bandelier, which are usually in Spanish, are likewise initialed, and these are repeated, and translated where necessary, in the English translations. Where annotations were made by the translator they are followed by the initials N. V. S., or H. I. P., as the case may be. Annotations not initialled are those of the editor. Words, phrases, sentences, and numerals in brackets are those which for clearness have been added by the editor, sometimes at the suggestion of the translators. Where parentheses occur they are to be found in the original document. Textual annotations, upon the Spanish texts, are placed below them, at the foot of the left-hand pages. Explanatory annotations are placed at the end of the respective sections; the figures referring to them are inserted in the English texts, on the right-hand pages.

The introductions to the various Parts into which the collection of documents is divided are not altogether first-hand studies based on primary sources; instead, they are in some cases summaries of the most scholarly opinions and monographs relating to the various subjects discussed, although many primary sources have been used. In these introductions the endeavor has been made to limit the discussion to what was regarded as absolutely necessary for an understanding of the text. The various introductions are intended to serve both as independent chapters for each of the several Parts, and also as connected chapters in the whole subject discussed. The introduction to Part $\mathrm{I}$. is necessarily longer and more general than the others, for the reason that it serves not only to introduce Part I. but also as a background for the entire work.

In the introduction and annotations it has been the rule to italicize those Spanish words for which there is no English equivalent, as real hacienda and maestro de campo, and those which by common usage among scholars of Hispanic American history are considered not to have become Anglicized. Spanish words which through common use have become Anglicized, as alcalde, audiencia, cédula, fiscal, peso, and pueblo, have regularly been left in Roman type. 
Finally, the editor desires to make grateful acknowledgments to Professors Herbert E. Bolton, Charles E. Chapman, and Herbert I. Priestley of the University of California, all of whom, in the earlier and more critical stages of the work, gave many helpful suggestions as to organization, form, and subject-matter. Dr. Priestley and Mrs. Sánchez in translating, and Mrs. Cornish in typing, never wearied or slackened in their efforts to co-operate with the editor in every possible way. In the University of Texas the editor has had the advice and assistance of Dr. Eugene C. Barker, chairman of the school of history, and of Mrs. Mattie Austin Hatcher, archivist. My wife has constantly encouraged and helped in the work from the outset.

Austin, Texas.

Charles Wilson Hackett. 



\section{CONTENTS.}

INTRODUCTORY NoTE $\ldots \ldots \ldots \ldots \ldots \ldots \ldots \ldots \ldots \ldots \ldots \ldots \ldots \ldots \ldots \ldots$

PREFACE

I. The Expansion of Spain in North America, to i590.

I. Introduction.

The West Indies, Castilla del Oro; and New Spain, to I535.......

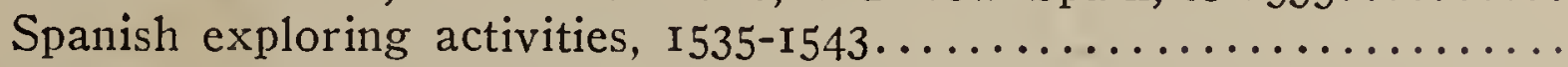

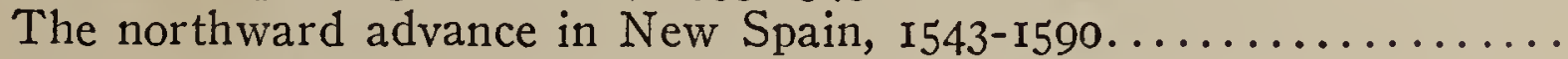

Governmental institutions and colonial administration............

The Spanish Indian Policy; the encomienda system...............

2. Reports relating to the Services and Merits of Explorers and Conquerors of New Spain.

Informaciones veridicas de las personas que se hallaron en la Conquista de la Nueva España y Ziudad de Mexico que pasaron con el Marques del Valle.

True reports concerning persons who took part in the conquest of New Spain and the City of Mexico, who went thither with the

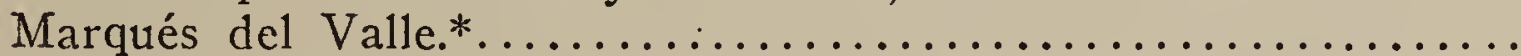

El adelantado Cabeza de baca pide un caravelon que esta en el rio de Sevilla en que vino preso presenta informacion. [1543 ?]

Governor Cabeza de Vaca asks for a brigantine which is in the River of Seville and in which he came as a prisoner. He offers

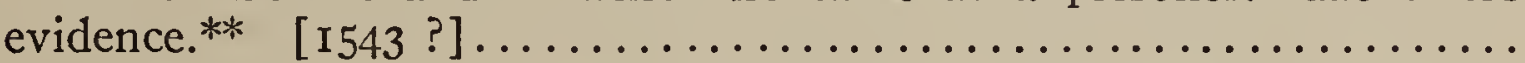

Probanza de servicios y meritos de Gregorio de Villalobos, uno de los primeros descubridores y conquistadores de Nueva España: seis meses antes que Hernan Cortez ganase a Mexico, donde fue el primero (Villalobos) que entro ganado vacuno para su cria. Mexico 22 Octubre, 1554.

Evidence of the services and merits of Gregorio de Villalobos, one of the first explorers and conquerors of New Spain-six months before Hernán Cortés captured Mexico-where he (Villalobos) was the first to bring in cattle for breeding purposes. Mexico, October

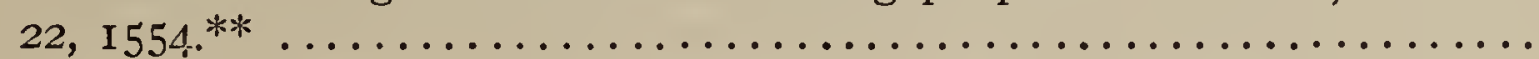

Ynformacion de los servicios hechos por Cristoval Mendez, con el Gobernador Cristobal De oñate y con el Capitan Francisco Vasquez Coronado, en la conquista del golfo dulce de Valençuela, Civola, y Jalisco, á su costo con armas y caballo, por los años de I538 [-I54I], en las que recibio varias heridas.

Evidence submitted with regard to the services performed by Cristóbal Méndez, with Governor Cristóbal de Oñate and with Captain Francisco Vásquez Coronado. During the years 1538 [-I54I], at his own expense, armed and mounted, he served in the conquest of Golfo Dulce de Valenzuela, Cíbola, and Jalisco. In the

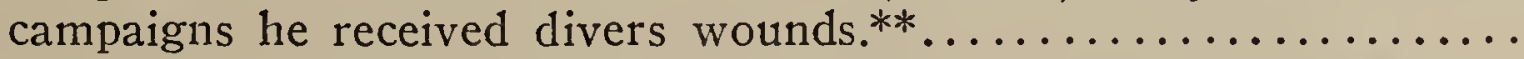

Ynformacion Recibida en la audiencia rreal de la nueva españa, A pedimento de Johan de Paladinas. Ba ante su Magestad. [1560.]

Evidence received in the royal Audiencia of New Spain, on petition of Juan de Paladinas; it goes before his Majesty.** [1560.].......

Probanza de los meritos y servicios de Juan de Cespedes en el Descubrimiento y conquista de la tierra nueba de Cibola, adonde fue con el Adelantado Francisco Vasquez Coronado, y en el levantamiento de nueba españa. Mexico a I9 de Enero, I568. 
Evidence of the merits and services of Juan de Céspedes in the exploration and conquest of the new land of Cíbola, where he went with Governor Francisco Vásquez Coronado, and in the uprising

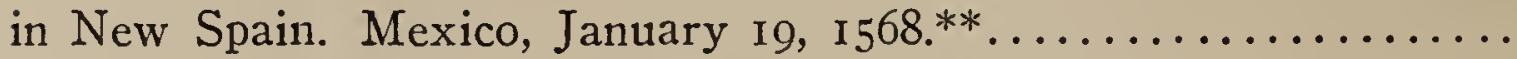

Ynformacion de los meritos y servicios del Adelantado de la Nueva Galicia, Don Tristan de Arellano. Mexico 7 de Marzo de 1575.

Evidence submitted of the merits and services of Don Tristán de Arellano, governor of Nueva Galicia. Mexico, March 7, 1575.**... Probanza de los meritos y servicios de Alonzo Rodriguez, y de Juan Rodriguez Parra su hijo descubridores y conquistadores de la provincia de Cibola con el gobernador Francisco Vazquez Coronado. 23 de noviembre de 1576 .

Evidence of the merits and services of Alonso Rodríguez and of Juan Rodríguez Parra, his son, explorers and conquerors of the province of Cíbola with Governor Francisco Vásquez Coronado.

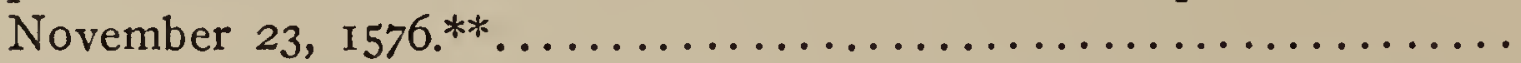

Ynformacion de los meritos y servicios de Francisco de Santillana, y Pedro de Santillana su hijo en la conquista de la tierra nueva y siete ciudades de Cibola con el General Francisco Vasquez Coronado. Merida de Yucatan 7 de Diciembre, I588.

Evidence submitted of the merits and services of Francisco de Santillana, and of Pedro de Santillana, his son, in the conquest of the new land and Seven Cities of Cíbola, with General Francisco Vásquez Coronado. Mérida, Yucatán, December 7, 1588.**...... [Petición del Doctor Francisco de Sandes. I589?

Petition of Doctor Francisco de Sandes.* I589 ?].............

Informacion de los meritos y servicios de Garcia Rodriguez, uno de los Conquistadores de las siete Ciudades de Cibola, y uno de los primeros pobladores de Mexico y Nueva España. Mexico 26 de Abril de I6r8.

Report concerning the merits and services of García Rodríguez, one of the conquerors of the Seven Cities of Cíbola, and one of the first settlers of Mexico and New Spain. Mexico, April 26, I618.*...

Informacion de los meritos y servicios de Bernardo Diez del Castillo uno de los primeros Conquistadores y pobladores de Nueva España. Mexico I4 de Mayo [de I566].

Report on the merits and services of Bernardo Díaz del Castillo, one of the first conquerors and settlers of New Spain. Mexico,

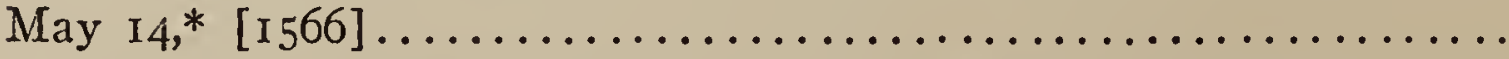

Ynformacion de los servicios de Diego de Madrid Avendaño uno de los primeros pobladores de Mexico y conquistador de Cibola. Mexico 26 de Abril [de I6I8].

Evidence of the services of Diego de Madrid Avendaño, one of the first settlers of Mexico and conqueror of Cíbola. Mexico,

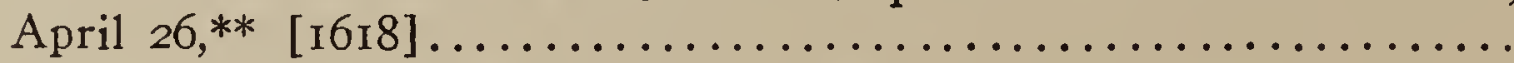

Ynformacion de filiacion y meritos de don Augustin de la torre Altamirano. Para 1lebar al Real Consejo. [1623.]

Evidence of the relationships and merits of Don Agustín de la Torre Altamirano. To be taken to the royal Council.** [I623.]...

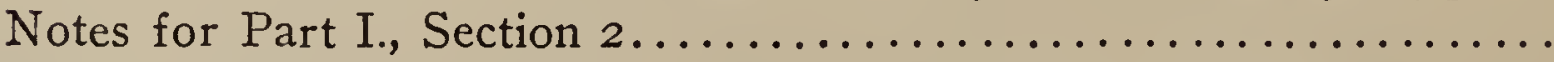

3. Fourteen Cédulas and Letters relating primarily to Indian Affairs in Nueva Galicia, Nueva Vizcaya, and Adjacent Regions, I562-I597.

[Real Cédula. El Rey al Virrey de la Nueva España Relativos á los gastos de Pedro de Ahumada de Samano en la Jornada contra los Indios Zacatecas y Guachichiles. Madrid a diez y siete de Octubre de 1562 . 
Royal cédula. The king to the viceroy of New Spain concerning the expenditures of Pedro de Ahumada de Samano in the campaign against the Zacatecas and Guachichiles Indians. Madrid, October

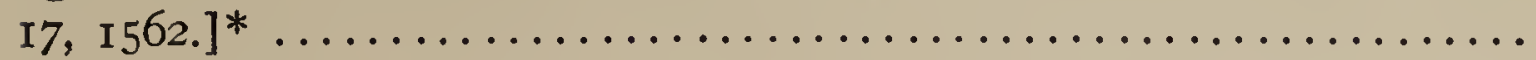

Respuesta a los oydores, alcaldes mayores de la Nueva Galicia Sobre lo de la Sal. [1562.]

Reply to the oidores, alcaldes mayores of Nueva Galicia concerning the matter of salt.* $\left[{ }_{1562 .]} \ldots \ldots \ldots \ldots \ldots \ldots \ldots \ldots \ldots \ldots\right.$

El Rey a la Audiencia [de la Nueva Galicia] sobre lo de los frayles. [I566.]

The king to the Audiencia [of Nueva Galicia] concerning friars.*

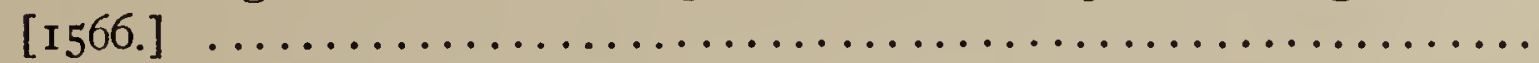

Concierto con goncalo lopez sobre sus yndios. [1567.]

Agreement with Gonzalo López concerning his Indians.* [1567.]. .

[Real orden] Para que los Indios de la Nueva Galicia se junten en pueblos y bivan en policia. [1570.]

[Royal order] commanding that the Indians of Nueva Galicia be gathered into towns, where they may live under an organized gov-

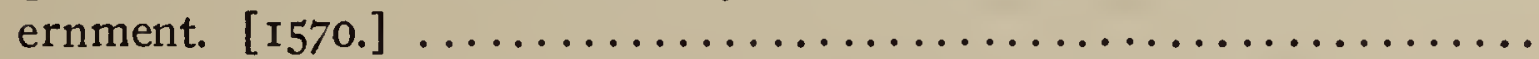

El Rey Al Governador de la Provincia de Vizcaya sobre las Salinas de aquellas tierras. [1575.]

The king to the governor of the province of Vizcaya concerning the salt deposits of that country.* [I575.] .................

Al Virrey de la nueva España que de Orden como se aseguren los caminos de la provincia de la nueva galicia donde hacen rovos y muertes indios chichimecas gastando para ello en lo forçoso con Moderacion lo que fue Necesario de la hazienda Real. [I580.]

To the Viceroy of New Spain, asking him to issue an order for the safeguarding of the roads of the province of Nueva Galicia, where the Chichimecas are committing robberies and murders; for this he is to expend from the royal treasury such sums in moderation as

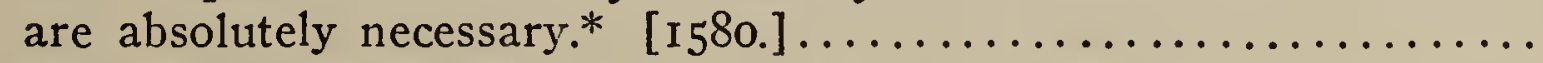
Diego de ybarra a su Magestad. Mexico I4 de henero de I582.

Diego de Ibarra to his Majesty. Mexico, January 14, I582.**....

Diego de ybarra a Su magestad. Mexico I2 de abril I582. A la Sacra Catolica Real Magestad el rrey Nuestro señor en su rreal consejo de Indias.

Diego de Ibarra to his Majesty. Mexico, April I2, I582. To his Sacred Catholic Royal Majesty, the king, our lord, in his royal

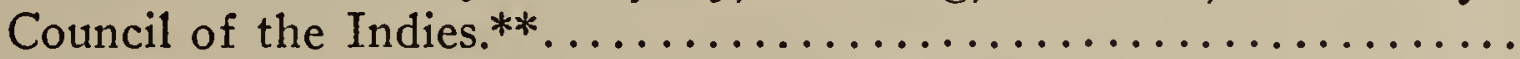

Diego de Ibarra A la sacra catolica Real magestad el rrey don felipe nuestro señor en sus rreales manos. (Mayo [Octubre] de I582.)

Diego de Ibarra to his Sacred Catholic Royal Majesty, the king, our lord, Don Felipe, in his royal hands. (May [October], I582.)**

[Diego de Ybarra al Rey. Mexico, Io de Noviembre de 1582.

Diego de Ibarra to the king. Mexico, November 10, I582.]**....

[Diego de Ybarra al Señor Secretario Juan de Ledesma. Mexico, Io de Noviembre de 1582 .

Diego de Ibarra to the Señor Secretary, Juan de Ledesma. Mexico,

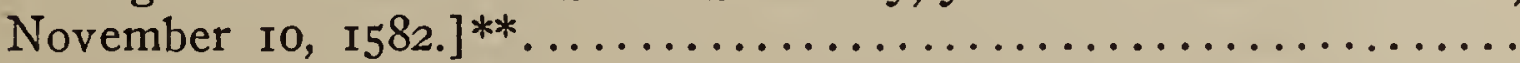

Carta del Contador Alonso Calderon á Su Magestad. 2 de nobiembre I582.

Letter of the Contador Alonso Calderón to his Majesty. Novem-

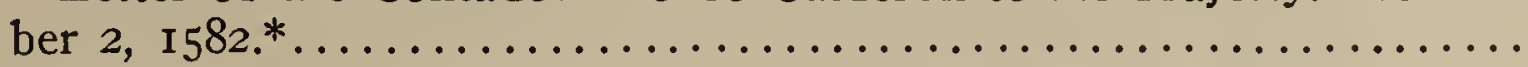

Respuesta [del Rey] al Virrey de la nueva españa. [I597.]

Reply [of the king] to the viceroy of New Spain.* [I597.] .....

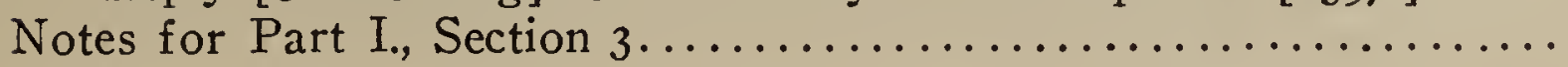

9I

IOI 
4. Documents relating to the Early Colonial Administration of New Spain.

[Memorial al Rey de los Procuradores de la Nueva España. Sin fecha.

Memorial of the Procuradores of New Spain to the king. Un-

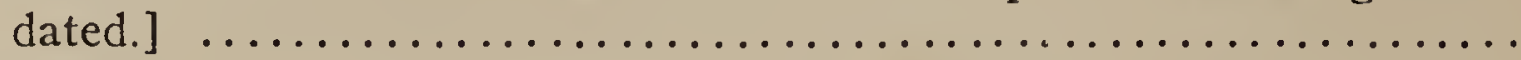

[Petición de los Procuradores de la Nueva España y Gran Ciudad de Mexico. Sin fecha.

Petition of the Procuradores of New Spain and the great City of

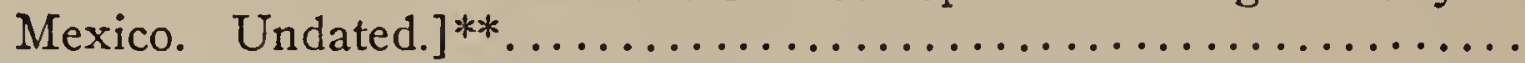

[Declaración de los Procuradores de la Nueva España. Sin fecha. Statement of the Procuradores of New Spain. Undated.]**.....

Traslado del Parezer que dió el Doctor Hernan Lopez del Consejo de las Yndias, sobre la perpetuidad dellas [el año de 1545].

Copy of the opinion given by Doctor Hernán López of the Council of the Indies on the matter of their perpetuity [in the year I545].**

Al Virrey de la Nueva España que embie relacion con su parecer sobre que se ha avisado que para reducir y pacificar los Yndios Chichimecas convernia usar de los medios que aqui se rrefieren fundando en su comarca pueblos y monasterios. [1566.]

To the viceroy of New Spain ordering him to send a report with his opinion concerning the suggestion that it would be suitable for the reduction and pacification of the Chichimecas to use the methods here recited; namely, to establish towns and monasteries in their

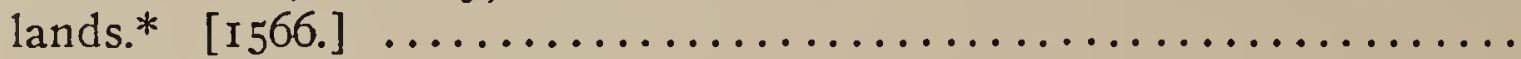

Al Virrey de la Nueva España que embie Razon con su parecer sobre que se ha avisado que convernia mandar que los pueblos de Yndios que oviese cerca de las chichimecas fuesen de cien Vezinos por Lo menos y que a los que reduxeren no se les pida tributo por uno ó dos años. [1566.]

To the viceroy of New Spain, ordering him to send a report with his opinion concerning the suggestion that it would be fitting to command that the Indian towns to be founded near the Chichimecas should contain at least one hundred heads of families, and that tribute should not be demanded for one or two years from those

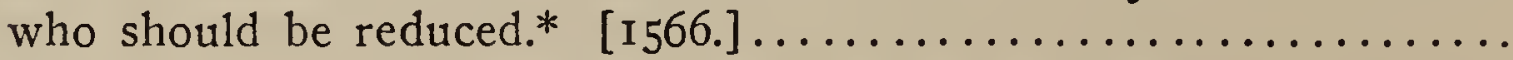

Memorial que dio el bachiller Luis -Sanches residente en Chillaron de Pareja al presidente Espinosa en Madrid á 26 de agosto de 1566.

Memorial presented by the Bachiller Luís Sánchez, a resident of Chillarón de Pareja, to President Espinosa in Madrid, on August 26, I566.*

Al Virrey de la Nueva España sobre lo que a de hazer para el Remedio del exceso de los Juegos y tablajes. [1594.]

To the viceroy of New Spain concerning what is to be done to remedy the excess of gambling and gambling-houses.* [1594.].... I6ro. Testimonio de Providencia dada por Don Luis de Velasco Virrey de la Nueva España a fabor de Francisco de Sosa Peñalosa Administrador y Protector de los Yndios Chichimecas, para que aquellas justicias no conociesen de las causas de dichos Yndios.

I610. Certified copy of the decree issued by Don Luís de Velasco, viceroy of New Spain, in favor of Francisco de Sosa Peñalosa, administrator and protector of the Chichimecas Indians, to prevent the justices there from trying the cases of the said Indians.**.....

Resolucion y Sumario de las Provincias y pueblos de sus cargos y Datos a los naturales de ellos de los tributos y servicio Real. [1653I656.]

Résumé and summary of the charges and requisitions made upon the natives of the provinces and towns in tributes and royal service.**

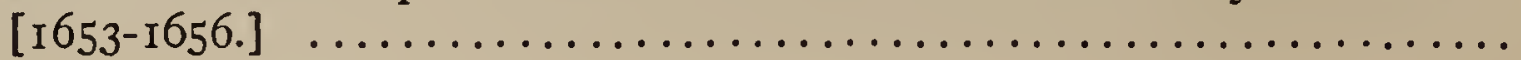


E1 Marques de mançera Virrey de la Nueva españa 5 de Abril de I6 6 I.

Da quenta del aumento que an tenido en el tiempo de su Govierno las rentas de tributos $Y$ real servicio.

The Marquis of Manzera, viceroy of New Spain. April 5, r67r. He gives account of the increase in the revenues from the tributes and royal service which has occurred during the time of his administration.**

Ordenanzas y preceptos de tierras para medir Sitios criaderos de ganados mayores, y menores, Caballerías, y demas tierras [etc.].

Land ordinances and regulations for measuring sitios, criaderos de ganados mayores and menores, caballerias, and other lands [etc.].*

Notes for Part I., Section 4..........................

II. The Founding of New Mexico, i580-I600.

I. Introduction.

Renewed exploration and attempted settlement of New Mexico, I580-

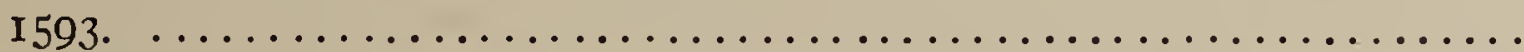

Competition for the position of adelantado of New Mexico, I583-I595.

Contest between Don Juan de Oñate and Don Pedro Ponce de León for the governorship of New Mexico, I595-1598..............

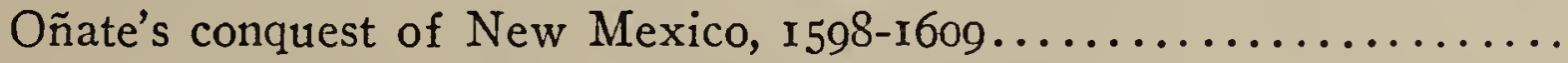

2. Documents relating to the Founding of New Mexico.

Al audiencia de la nueba españa sobre que proceda conforme a Justicia contra gaspar castaño y los demas culpados por haver hecho una entrada en la nueba mexico y dado algunos yndios por esclavos sin tener orden ni licencia para ello y que a los dichos yndios que entendiere ser esclavos les haga dar livertad y no permitan que ningunos lo sean. Corregida. [Madríd a 17 de Enero de 1593.$]$

To the Audiencia of New Spain, ordering it to proceed judicially against Gaspar Castaño and other guilty persons for having made an expedition into New Mexico and for having taken certain Indians for slaves without order or license to do so; also ordering that the Indians who may be found to be slaves shall be given their liberty and that no others shall be permitted to be enslaved.* [Madríd,

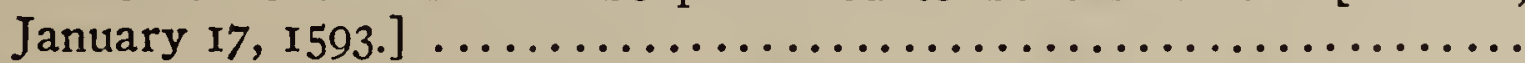

Carta de don Diego [Luís] de Velasco a Su Magestad. [Mexico, 30 de Enero de 1595.]

Letter from Don Diego [Luís] de Velasco to his Majesty.**

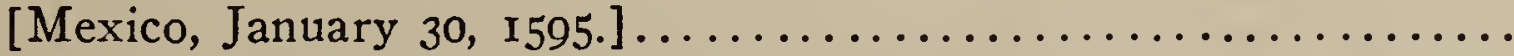

Petición al virrey Don Luís de Velasco para la jornada de descubrimiento ..... y capitulaciones del virrey con Don Juan de Oñate. Mexico, 2I de Septiembre de 1595.

Petition to the viceroy, Don Luís de Velasco, for the journey of exploration ..... and capitulations of the viceroy with Don Juan de

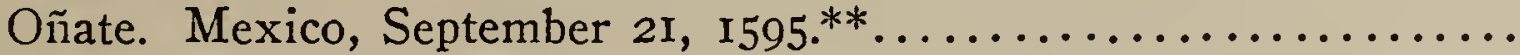

Carta de don luis de velasco a Su Magestad. [Mexico, I4 de Octubre de I595.]

Letter of Don Luís de Velasco to his Majesty.** [Mexico,

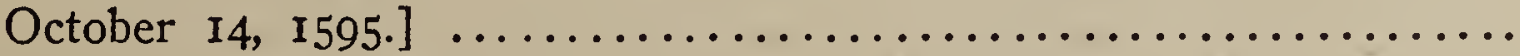

Carta del Conde de monte Rey a Su Magestad. [Mexico, 20 de Diciembre de I595.]

Letter from the Count of Monterey to his Majesty.** [Mexico,

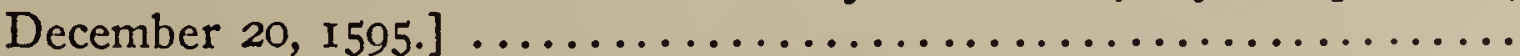
Carta del Conde de monterey a Su Magestad. [Mexico, 28 de Febrero de 1596.]

Letter from the Count of Monterey to his Majesty.** [Mexico,

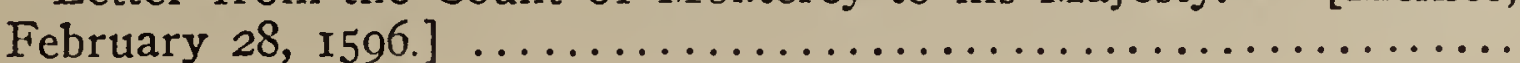


Las capitulaciones que el Virrey Don Luís de Velasco hizo con Don Juan de Oñate gobernador y capitan general de las provincias de la Nueva Mexico en conformidad de las ordenanzas y las moderaciones del Virrey Conde de Monterrey con las conveniencias que se siguen de que confirmen las capitulaciones del Virrey Don Luís y los inconvenientes que traen consigo las dichas moderaciones que hizo el dicho Conde de Monterrey. [I595 ?]

The articles of agreement which the viceroy, Don Luís de Velasco, made with Don Juan de Oñate, governor and captain-general of the provinces of New Mexico, in accordance with the royal ordinances for such discoveries, together with the modifications of the viceroy, the Count of Monterey, and with the advantages that follow from the confirmation of the articles of the viceroy, Don Luis, and the disadvantages brought with them by the modifications made by the said

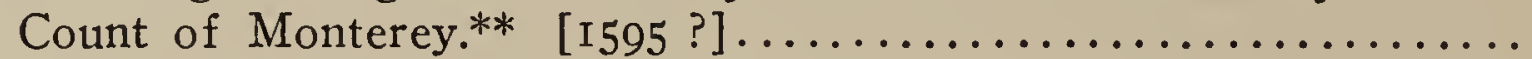

[Nota de lo que ofrecen Don Juan de Oñate y Don Pedro Ponce de León para hacer el descubrimiento, pacificación y población de Nuevo Mexico. I596?

Statement of what Don Juan de Oñate and Don Pedro Ponce de León offer for the exploration, pacification, and settlement of New

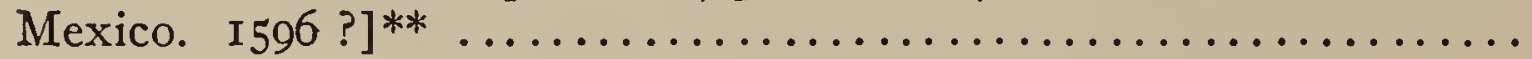

Consejo de Indias. 7 de Abril [de I596]. Consulta sobre lo que parece en la pretension de Don Pedro Ponce de León.

The Council of the Indies. April 7, [1596]. Statement of opinion with regard to the claim of Don Pedro Ponce de León.**.........

Don Pedro Ponce de León suplica a vuestra merced proponga a los señores del consejo le hagan merced en las capitulaciones siguentes. [Madríd, 23 de Abril de I596.]

Don Pedro Ponce de León prays that your worship will propose to the members of the Council that they shall grant him what is stated in the following articles.** [Madrid, April 23, I596.]......

[Decreto.

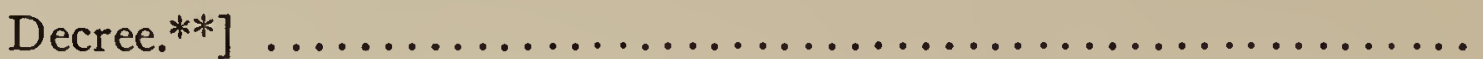

Consejo de yndias. 25 de Abril I596. En el particular de don Pedro ponce de leon, Sobre el descubrimiento de la nueva mexico.

The Council of the Indies. April 25, I596. In the matter of Don Pedro Ponce de León, with respect to the exploration of $\mathrm{New}$

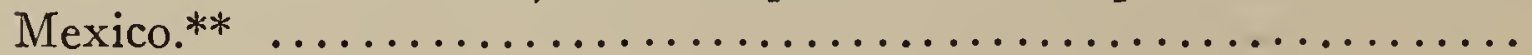
[Real decreto.

Royal decree.**]

Al birrey de la nueba españa que suspenda la ejecucion de lo capitul... con don Juan de oñate sobre el descubrimiento del nuebo mejico asta que Vuestra magestad mande otra cosa. [Aceca, 8 de Mayo de I596.]

To the viceroy of New Spain: That he shall suspend the execution of the agreement with Don Juan de Oñate in regard to the exploration of New Mexico until your Majesty shall order otherwise.**

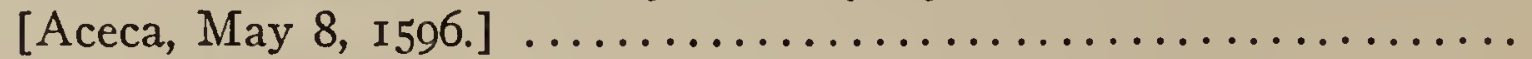

Consejo de Yndias. I9 de Mayo I596. Con la Relazion de lo que se a tratado y asertado con Don Pedro Ponze de Leon.

The Council of the Indies. May I9, I596. With account of what was discussed and agreed upon with Don Pedro Ponce de León.**. . [Real decreto.

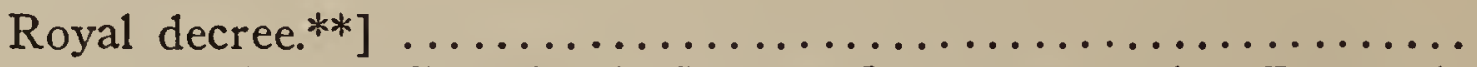

Primer despacho de Consejo de Yndias [con Don Pedro Ponce de León]. 7 de Septiembre I596.

First patent of the Council of the Indies [with Don Pedro Ponce

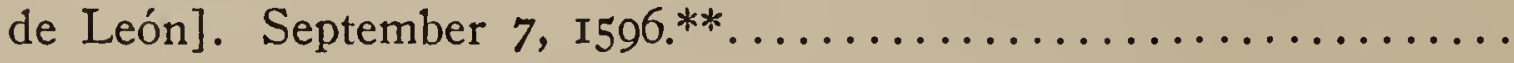


Assiento y cappitulacion con don pedro Ponze de leon sobre el descubrimiento Pacificaçion $y$ poblaçion de la Nueva mexico. [San Lorenzo, 25 de Septiembre de I596.]

Contract and agreement with Don Pedro Ponce de León with regard to the exploration, pacification, and settlement of New Mexico.** [San Lorenzo, September 25, I 596.]................

Facultad para encomendar yndios a don pedro ponce de Leon que ba por governador y cappitan general a las provincias del nuevo mexico. [San Lorenzo, I6 de Octubre de I596.]

Power granted to Don Pedro Ponce de León, who is going as governor and captain-general to the provinces of New Mexico, to give Indians in encomienda.** [San Lorenzo, October I6, I596.]....

Para que don pedro Ponce de Leon que ba por governador y Cappitan general de la nueva mexico pueda nombrar maese de campo Capitanes y oficiales de guerra nesçesarios y Levantar en la nueva españa y nueva galicia 300 Soldados Casados y Solteros Conforme a Un capitulo de su Asiento. [San Lorenzo, I9 de Octubre de I596.]

Power granted to Don Pedro Ponce de León, who is going as governor and captain-general of New Mexico, to name the maese de campo, captains, and necessary military officers, and to recruit in New Spain and Nueva Galicia three hundred soldiers, married and single, in accordance with an article of his contract.** [San Lorenzo, October I9, I596.] ...............................

Titulo de Governador y cappitan general de Los Reynos y Provincias de la nueva mexico para don Pedro Ponce de leon. [San Lorenzo, 26 de Octubre de I596.]

Title of governor and captain-general of the kingdoms and provinces of New Mexico in favor of Don Pedro Ponce de León.** [San Lorenzo, October 26, I596.].........................

[Copias o extractos de treinta y cuatro cédulas reales relativos a la capitulación que se tuvo con Don Pedro Ponce de León. i2 de Octubre de I596 hasta 2 de Abril de 1597.

Copies or extracts of thirty-four royal cédulas relative to the contract which was made with Don Pedro Ponce de León. October I2,

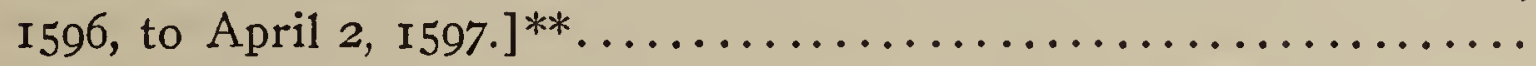

Consejo de Indias. 7 de Febrero I597. Que conviene se tome Resolucion en lo que sea consultado cerca de las pretenciones de Don Pedro Ponce de Leon.

The Council of the Indies. February 7, 1597. It is necessary that a decision be made as to what shall be advised in the matter of the claims of Don Pedro Ponce de León.**................... [Real decreto.

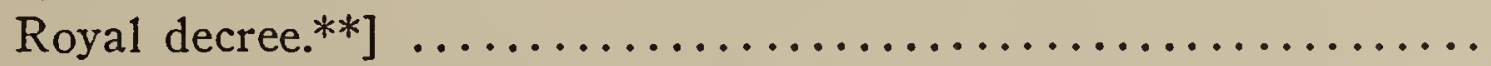

Consejo de Indias. I8 de Febrero I597. Con todas las consultas que se an hecho y papeles que an benido En Raçon del descubrimiento del nuevo Mexico Sobre que se a tomado asiento Con don pedro ponce de leon y capituló alla El virrey don luys de belasco con don Juan de Oñate.

The Council of the Indies. February I8, I597. With all the communications that have been made and papers that have come in regard to the exploration of New Mexico, about which a contract has been made with Don Pedro Ponce de León, and an agreement made there by the viceroy Don Luís de Velasco with Don Juan de

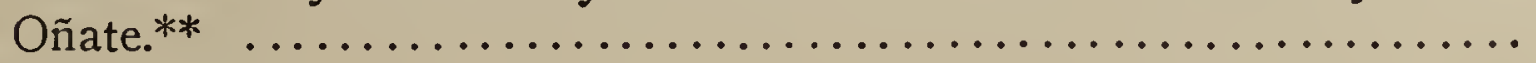
[Real decreto.

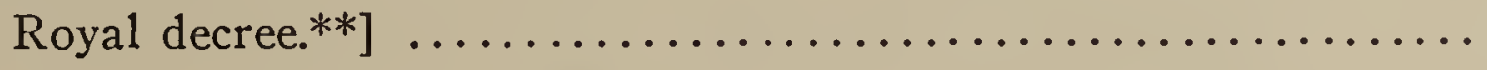


Consejo de Yndias. 7 de Março I597. Lo que pareze se podria Responder a Don Pedro Ponce de Leon porque no se entretenga con esperanzas haciendo gastos aqui y en Sevilla.

The Council of the Indies. March 7, I597. Opinion as to the answer that should be given to Don Pedro Ponce de León so that he shall not be kept in hopes and be spending money here and in

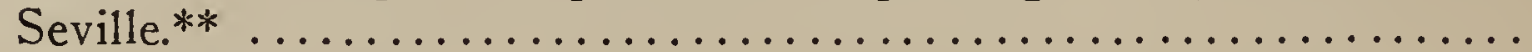

[Real decreto.

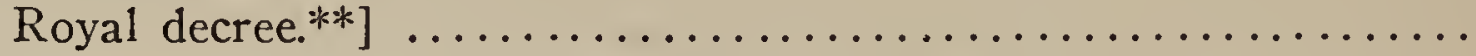

Notificacion a don juan de oñate. [Río de las Nazas, Nueva Vizcaya, 9 de Septiembre de I596.]

Notification to Don Juan de Oñate.** [Río de las Nazas, Nueva

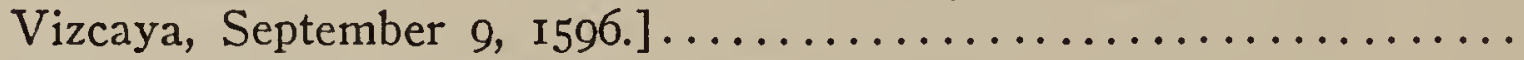

Copia de la carta de don juan de oñate para el Conde de monterey su Fecha en el Rio de las Nasas a I3 de setienbre I596.

Copy of the letter of Don Juan de Oñate to the Count of Monterey, dated at the Río de las Nazas, September I3, I596.**........

[Carta del Doctor Santiago del Riego á Su Magestad sobre lo de Juan de Oñate. Mexico, to de Noviembre de I596.

Letter from Doctor Santiago del Riego to his Majesty with regard to the affair of Juan de Onate.** Mexico, November ro, I596.]....

Carta del Conde de Monterey á Su Magestad sobre lo de la jornada á Nuevo Mexico. [Mexico, I5 de Noviembre de 1596.]

Letter from the Count of Monterey to his Majesty with regard to the expedition to New Mexico.** [Mexico, November I5, I596.]....

Las Razones que se ofrescen para que don Juan de oñate haga La entrada, en el nuebo Mexico como le esta encargada, en virtud de la capitulacion que con el se hizo y para que no venga de españa otro a hazerla alterando lo tratado son las siguientes. [Mexico, I5 de Noviembre de I596.]

The reasons presented why Don Juan de Oñate should make the entrance into New Mexico as he was commissioned to do, in virtue of the agreement made with him, and why no other person should come from Spain to do it, in disruption of the compact, are as follows.**

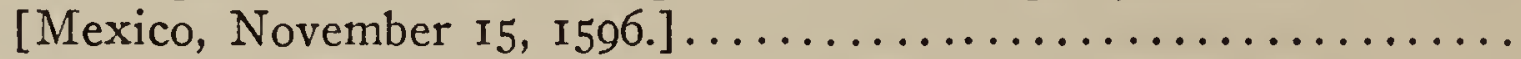

[Respuesta del fiscal:] Relación de lo que ha pasado acerca de quitar la jornada de nuevo Mexico á Don Joan de Oñate y darla á Don Pedro Ponce de Leon, y de los papeles que en el ultimo navio de aviso á embiado el Virrey acerca desto. [Sin lugar; sin fecha.]

[Report of the fiscal:] Statement of what has been done in regard to taking the expedition to New Mexico from Don Juan de Oñate and giving it to Don Pedro Ponce de León, and of the papers in regard to this which were sent by the viceroy on the last despatch boat.** [No place; no date.]...........................

Carta del Gobernador y Capitan General de la Nueva Mexico, Don Juan de Oñate al Rey. [Río de las Conchas, I5 de Marzo de I598.] Letter from the governor and captain-general of New Mexico, Don Juan de Oñate, to the king.** [Río de las Conchas, March I5,

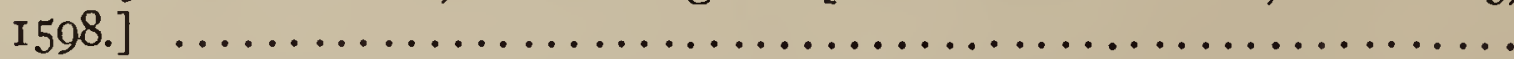

Don Juan de oñate. Titulo de adelantado de las provincias del nuevo Mexico para don Juan de oñate governador $\mathrm{Y}$ capitan general dellas. [Villalpando, 7 de Febrero de I602.]

Don Juan de Oñate. Title of adelantado of the provinces of New Mexico for Don Juan de Oñate, governor and captain-general of

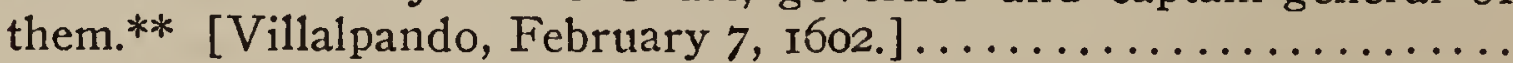

[El Consejo de Indias al presidente de la Casa de Contratación. Valladolid, I2 de Junio de I602.

The Council of the Indies to the president of the Casa de Contratación. Valladolid, June $12,1602.]^{* *} \ldots \ldots \ldots \ldots \ldots \ldots \ldots \ldots$ 
[Real cédula. Al virrey de la Nueva España. San Lorenzo, 4 de Julio de 1602 .

Royal cédula. To the viceroy of New Spain. San Lorenzo, July

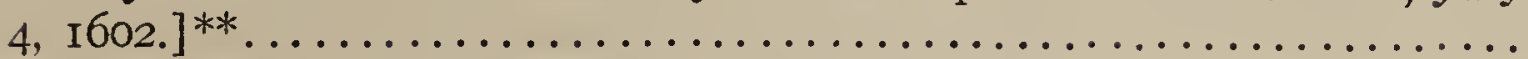

[Real decreto. San Lorenzo, 8 de Julio de I602.

Royal decree. San Lorenzo, July 8, 1602.]**...............

[E1 Consejo de las Indias al Rey. Valladolid, I9 de Mayo de I603. The Council of the Indies to the king. Valladolid, May 19, I603.]**

[Real cédula. Al presidente de la Casa de contratación. Burgos, 23 de Junio de 1603.

Royal cédula. To the president of the Casa de Contratación. Burgos, June 23, I603.]**............................

[Real cédula. A los oficiales de la Casa de Contratación. Valladolid, 8 de Septiembre de 1603.

Royal cédula. To the officials of the Casa de Contratación. Valla-

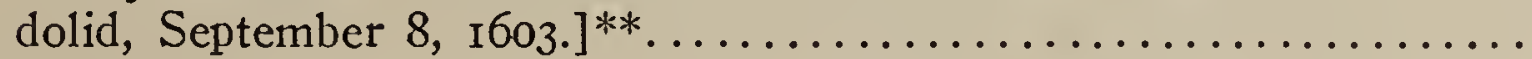

[Real cédula. Al virrey de la Nueva España. Valencia, 2I de Enero de I604.

Royal cédula. To the viceroy of New Spain. Valencia, January

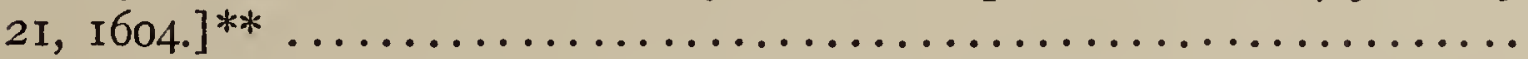

[Instrucción del Consejo. Valladolid, 23 de Febrero de I604.

Instruction of the Council. Valladolid, February 23, I604.]**....

[Decreto del Consejo. Valladolid, I9 de Julio de I604.

Decree of the Council. Valladolid, July I9, I604.]**...........

Al marques de montesclaros que haga cesar y que no pase adelante el descubrimiento del nuevo mexico y que ynvie a llamar y le detenga en Mexico a don joan de oñate que por via de asiento se encargo del dicho descubrimiento y que haviendo hecho desbaratar toda la gente de guerra ponga governador que Govierne lo descubierto. [Madrid, I7 de Junio de r606.]

To the Marquis of Montesclaros: He shall cause the exploration of New Mexico to cease and be discontinued, and he shall order the recall and detention in Mexico of Don Juan de Oñate, who was commissioned by contract to make the said exploration; when the soldiers have all been disbanded he shall place a governor over the explored country.** [Madrid, June 17, I606.] ...............

Respuesta al marques de Montesclaros en lo tocante A la conquista del nuebo mexico. [San Lorenzo, i9 de Agosto de I606.]

Reply to the Marquis of Montesclaros in the matter of the campaign to New Mexico.** [San Lorenzo, August 19, I606.]........

Ynformacion del tiempo que el capitan don luis Velasco sirvio a su magestad en las provincias y governacion de la nueva viscaya. [I596-I6I4.]

Evidence submitted concerning the time that Captain Don Luis Velasco served his Majesty in the provinces and government of

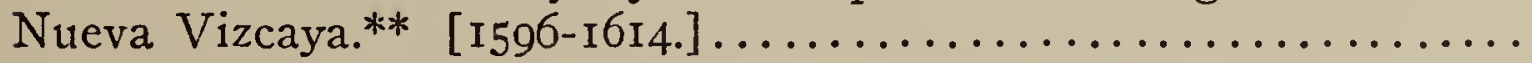

Manifestacion que hisso el capitan don luis de Velasco de los bienes que lleva armas e cavallos Para servir a su magestad en la xornada de la nueva mexico de que va por governador y capitan general don Juan de oñate.

Manifest made by Captain Don Luís de Velasco of the gocds, arms, and horses which he is taking to serve his Majesty in the expedition to New Mexico, of which Don Juan de Oñate goes as

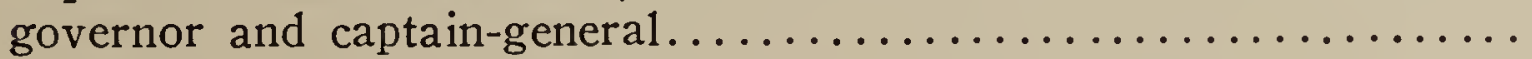

Ynformacion de officio Rescivida Por la audiencia Real de la nueva españa sobre la que dio Don fernando de Oñate sobre su calidad Meritos $\mathrm{Y}$ servicios y de don fernando de oñate su padre y aguelos. [1612.] 
Evidence officially received by the royal Audiencia of New Spain upon what was submitted by Don Fernando de Oñate in regard to his character, merits, and services, and those of Don Fernando de

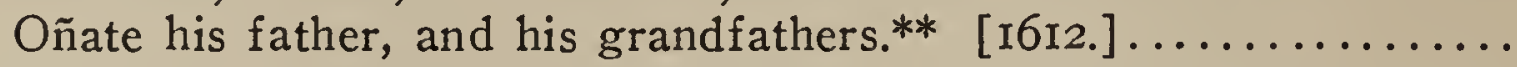
Pareser de la Real audiencia de mexico sobre los meritos y servicios de don Fernando de oñate y de sus padres. [1612.]

Opinion of the royal Audiencia of Mexico in regard to the merits and services of Don Fernando de Oñate and his ancestors.** [1612.] Ynformacion de officios Recibidos En La Real audiencia de mexico sobre lo que dixo E1 Capitan Juan belarde colodro Sobre sus Servicios. Ba ante $\mathrm{Su}$ Magestad $\mathrm{Y}$ su real Consejo de yndias. [1612I6r4.]

Statement of reports received in the royal Audiencia of Mexico concerning what Captain Juan Velarde Colodro said with regard to his services. This statement is to go to his Majesty and his royal

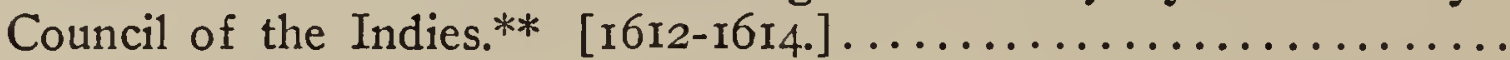

Notes for Part II................................... 484

INDEX 
I. EXPANSION OF SPAIN IN NORTH AMERICA I 492-I 590 



\section{I. INTRODUCTION.}

\section{The West Indies, Castilla del Oro, and New Spain, to I535. ${ }^{1}$}

Of the various islands of the West Indies discovered by Columbus in the course of his first and second voyages, I492-I495, Española (Santo Domingo) was selected as the one on which to establish the first colony. Misfortune attended the first two efforts to found a settlement, and it was not until 1496 that the town of Santo Domingo-the first permanent European settlement in the new world-was founded. Thus it came about that the island of Española became the base from which colonization spread not only to the other large islands of the Indies, but also to the mainland.

For more than a decade after the founding of Santo Domingo, however, the energies of the Spaniards were directed almost exclusively to the exploration of the mainland coast-regarded then as a troublesome body of land preventing direct passage to India, and through which it was hoped would be found a navigable strait. By I5O4 the entire mainland coast had been explored, and, in some places, re-explored many times, from Cape Gracias á Dios in Honduras to a point several degrees south of the equator in Brazil. Until I 5 I 3 all of this mainland which had been explored and was claimed by the Spaniards was called Tierra Firme.

From Santo Domingo as a base the conquest of the mainland began in I 509. In that year Alonso de Ojeda attempted to settle the province of Urabá, or that part of Tierra Firme lying east of the Atrato River. Failure attending his efforts, Ojeda soon returned to Española; the survivors of his expedition finally crossed the Gulf of Urabá and founded the settlement of Santa María de la Antigua del Darién, where Vasco Núñez de Balboa soon became the dominant figure. At the same time that Ojeda undertook to settle Urabá, Diego de Nicuesa, with a colonizing expedition raised primarily in Española, attempted to settle the province of Veragua, or that part of Tierra Firme which extended from the Atrato River to Cape Gracias á Dios - then the northern limit of exploration. Misfortune attending his efforts, he and the survivors of his expedition finally joined Ojeda's colonists at Santa María de la Antigua del Darién, which, in fact, had been located within the jurisdiction of Veragua. Since Ojeda did not return, and because Nicuesa was soon exiled, Balboa continued to exercise authority at Santa María ; finally the king appointed him governor and captain-general ad interim of the so-called "province of Darién." In this capacity Balboa consolidated and strengthened the colony and carried on a series of explorations which culminated in the discovery of the South Sea (Pacific Ocean) in September, I5I3.

1 This section of the Introduction is based upon C. W. Hackett, "The Delimitation of Political Jurisdictions in Spanish North America to I535", published in The Hispanic American Historical Review, I. 40-69 (Feb. I9I8) and upon the references therein cited. 
Prior to this, however, the king in Spain had effected a complete reorganization on the mainland. On July $27, \mathrm{I}_{5} \mathrm{I} 3$, that body of land theretofore called Tierra Firme was ordered to be called Castilla del Oro, with the exception that this was not to include the original province of Veragua - the land explored by Columbus on his fourth voyage-nor the land discovered by Pinzón and Solís, nor the province of Paría. In the same royal order the province of Darién was renamed Andalucía la Nueva. Also, at the same time, the king appointed Pedrarias Dávila as captaingeneral and governor of Castilla del Oro. Later, in September of that year, after learning of the explorations of Balboa, he created the provinces of Panamá and Coiba, and Balboa was named adelantado (frontier governor) of these provinces and of the South Sea, though subordinate to Pedrarias. Internal friction and disputes which followed hindered the development of the colony; these apparently having been settled, Balboa made plans for conquering Peru, but he fell a victim to the jealousy of Pedrarias in 1519 and plans for expansion to the south were thereby checked. However, interest in the South Sea continued and in August, I5I9, the town of Panamá was founded and soon afterward became the capital of Castilla del Oro. The chief significance of the founding of Panamá lies in the fact that it became the base from which Espinosa, Niño, and Gil González Dávila, prior to I 524, explored the coast country as far as Fonseca Bay, and from which lieutenants of Pedrarias in the year I 524 founded the towns of Bruselas, Granada, and León; the latter, which was about half-way between the Gulf of Fonseca and Lake Nicaragua, marked the northern limit of Spanish advance from Panamá before other Spaniards, who were operating in the same region, were encountered.

It was not until I 509 that from Santo Domingo as a base the other islands of the West Indies began to be occupied. In that year Juan Ponce de León was named governor of the island of Porto Rico and in the same year he established a settlement at Caparra, near the present San Juan, which was not founded until I5II. Also, in the year I509, the island of Santiago (Jamaica) was settled by Esquivel under orders from Diego Columbus, governor-general at Santo Domingo. A number of settlements were founded, a ship-yard was established, and in I $_{5}$ I7, so important had the island come to be regarded, a governor was appointed in the person of Francisco de Garay.

No effort was made to settle Cuba, the largest of the West Indian group, until I 5 I I. In that year Governor-general Diego Columbus named Diego Velásquez, a rich citizen of Española, as leader of an expedition to conquer the island; this he succeeded in doing within three years. In $\mathrm{I}_{5} \mathrm{I}_{4}$ Trinidad, Santo Espíritu, and Puerto Príncipe and in I $_{5} 5$ Santiago de Cuba and Havana were founded. Associated with Velásquez in the conquest of Cuba were Pánfilo de Narváez, Bartolomé de las Casas, and Hernando Cortés.

If Santo Domingo at the outset served as a base for the establishment of the first colony on the mainland and also for the conquest and colonization of the other large and adjacent islands, it was not long to maintain 
this exclusive and commanding position. As early as I 5 I 2 or I 5 I4, Juan Ponce de León, from Porto Rico as a base, discovered and explored the "island of Florida", and in I52I he lost his life as a result of a futile attempt to establish a colony there.

After Española and Porto Rico, Cuba next came into importance as a base for the exploration and conquest of the mainland. In I5I7 Francisco Hernández de Córdoba as the leader of a slave-hunting expedition sailed west from Cuba and discovered the peninsula of Yucatán, which he mistook for an island like Cuba. Wounded in a fight with the natives, Córdoba returned to Cuba where he soon died. Governor Velásquez, disappointed that no colony had been founded by the Córdoba expedition, despatched Juan de Grijalva in April, I 5 I8, to follow up the explorations of the preceding year. Reaching the island of Cozumel, Grijalva turned north, rounded Cape Catoche, and from there followed the mainland coast as far as the Pánuco River, stopping at and naming en route the Río de Grijalva and the island of San Juan de Ulua. From the latter place booty and news of the wonders which he had seen and of which he had heard were sent back to Cuba by Pedro de Alvarado; in October the main expedition returned without having attempted to establish a settlement. Of all the exploring expeditions to the mainland this was one of the most important, not alone for geographical reasons, but because it revealed gold and a high indigenous civilization; in fact the year I5I8 marked the beginning of a new epoch.

The most significant and far-reaching result of the Grijalva expedition was that the next year Hernando Cortés arrived at San Juan de Ulua with a force, recruited in Cuba, and initiated a course of events on the mainland which led to the conquest for Spain of one of her fairest and thenceforth most important colonial possessions-New Spain. But before tracing the evolution of this significant movement it will be well to mention the other exploring and attempted colonizing movements on the mainland which had the West Indies as their base.

A second and a most important result of the Grijalva expedition of I 5 I 8 was that in I 5 I9 Governor Garay of Santiago (Jamaica) despatched his able lieutenant, Alonso de Pineda, to make further explorations along the Gulf Coast and to ascertain its limits. From Tampico Pineda for the first time traced the coast line north and east to Florida, his object being to reach open sea lying north of the Mexican coast, or to discover the supposed strait sought by Columbus. Retracing his route west and south from Florida, Pineda clearly demonstrated that the mainland was one continent, and not a string of islands as theretofore had been supposed. To the land discovered by him, namely, the region extending from the western limits of Ponce de León's explorations in Florida to the northern limit of exploration on the Mexican coast which had been reached by Grijalva and Cortés-that is, approximately from Appalachee Bay to Tampicowas given the name Amichel. In I523 Governor Garay, following up Pineda's explorations under authority granted him in I $52 \mathrm{I}$, attempted to establish a settlement in that part of Amichel later known as Vitoria Garayana, or that region which lies between the Tampico River and the 
Río de las Palmas (Río Grande). The ever alert Cortés, who had already conquered Mexico and had established a settlement at the mouth of the Río Pánuco, would brook no rival in that quarter; before the end of the year Garay died a prisoner of Cortés, and the latter's jurisdiction over the Tampico region remained unquestioned.

At the same time that Garay was attempting to settle Vitoria Garayana interest in the Florida region was developing. On the basis of claims established in I52 I Lucas Vásquez de Ayllon was in I 523 named adelantado and governor of a vast region lying north of Florida. In $\mathrm{r}_{526} \mathrm{a}$ temporary settlement called San Miguel de Gualdape was founded by Ayllon on the Atlantic coast in the neighborhood of $33^{\circ} \mathrm{N}$., but after the death of the leader the expedition went to pieces and the survivors returned to Santo Domingo. The same year Pánfilo de Narváez was given the right to explore, conquer, and settle that region extending from Florida to the Río de las Palmas, which region was at the same time officially designated as the jurisdiction of Río de las Palmas. Reaching the Tampa Bay region in 1527 , and thinking that he was near the Río de las Palmas, Narváez with over 300 followers marched inland. Unfortunately missing connection with the fleet that was to have co-operated with the party inland, and becoming discouraged, the 252 survivors finally set out in September in improvised boats from St. Marks Bay for Pánuco. After days of hardship two boats, bearing over eighty men, of whom Cabeza de Vaca, Alonso del Castillo Maldonado, and Andrés Dorantes were the best known, were cast on the Texas shore. Following eight years of servitude and wandering these three men, accompanied by a negro slave, Estevánico, finally reached Culiacán, which was at that time the northernmost Spanish outpost in the west. Aside from being the first to traverse the continent so far north, these men brought reports that were to lead the Spaniards still further to the north.

Mention has been made of the fact that the year following the Grijalva expedition Hernando Cortés landed at San Juan de Ulua with a force that had been recruited in Cuba. Under the original plans, Cortés and Governor Velásquez were to have been partners in the undertaking, but as the result of a break between the two Cortés left Cuba in February, I 519, with over 500 followers in open defiance of his superior. Landing at San Juan de Ulua in April, I5 19, he founded the municipality of Villa Rica de la Vera Cruz. From there, having been chosen by the municipality as governor and chief justice of the land-pending confirmation by the crown-and acknowledging only the superior authority of the king, Cortés set about to overthrow the empire of the Montezumas, with its capital located inland at Mexico-Tenochtitlán. The sinking of his ships; the alliance with the revolutionary element of the empire and with the Tlascalans, hereditary enemies of Montezuma; the massacre of the perfidious Cholulans; the imprisonment of Montezuma in his own capital; the defeat of Pánfilo de Narváez, sent by Governor Velásquez to arrest Cortés ; the winning over to his side of all of Narváez's force; and, finally, the recapture of the City of Mexico on August I3, I52I, following its enforced abandonment on June $\mathrm{I}_{3}$, I 520 -all these constitute a series of well-known high-handed acts by which Cortés achieved his ambition. 
The fall of Mexico City, instead of marking the end of the conquest, as is the view too commonly held, marked but the beginning of the real conquest and expansion of New Spain; those movements were to continue until the close of the eighteenth century, at which time the northernmost Spanish outposts were San Francisco and St. Louis. For the first nine years after the fall of Mexico City, however, or until I 530, the Spaniards in New Spain were interested primarily in pushing their conquests due west to the Pacific and south into the Isthmus of Tehuantepec and Guatemala; it was not until after I 530 that their attention was centred on the north. There were several reasons for this early interest in the south. In the first place the northern Indians, or Chichimecas, were exceedingly fierce and warlike. Moreover, there were no reports either of a high native civilization or of great natural wealth lying to the north. On the other hand, from the west came reports of the South Sea, and from the south reports of gold and of the material remains of the Maya and Quiche civilization-remains which surpassed even those of the Aztecs. Also, it was known that the Spaniards, operating from Panamá as a base, were pushing north toward this coveted region, and their entry into it must be anticipated as Garay's attempted conquest of the Pánuco region had been anticipated. It is these facts which explain why, for a period of nine years, the Spaniards of New Spain, save with one exception, turned their backs to the north and devoted all their energy to following up the reports of southern and western wealth and wonders.

The conquests of the first two years after the fall of Mexico City are of particular interest because theoretically they had no legal status. Yet this did not deter Cortés. To the southeast Sandoval carried Spanish authority into the province of Tuxtupeque and thence to the mouth of the Coatzacoalcos River. Orozco and Alvarado extended Spanish dominion and established Spanish institutions to the south in Tehuantepec and Tututepec. Villafuerte, Olid, and others conquered and explored westward to the Pacific where the important coast towns of Zacatula and Colima were founded. The one exception to the rule that the Spaniards at first ignored the northern regions occurred in 1522 when Cortés himself advanced as far as the Pánuco River; there by founding the municipality of San Estéban del Puerto he established superior claims on that region to any that Governor Garay might, and later in vain did make, on the basis of Pineda's explorations in I5I9.

The conquest of the Pánuco region was the last significant conquest of Cortés the rebel, for before the end of the year ${ }^{523}$ he received the coveted royal commission as governor and captain-general of New Spain; henceforth his conquest had legal status, and no longer had he anything to fear from Velásquez. Plans were accordingly made for extending the now legal conquest into the more alluring and strategically important regions to the south. This was to be effected by two movements. In the west Alvarado was to advance south from Tehuantepec, while the eastern movement was to be led by Olid, who was to proceed first from Vera Cruz to Honduras by water. Success attended the efforts of Alvarado, who conquered and occupied Guatemala, and explored far into the interior of modern Salvador. The situation in Honduras, however, resolved itself 
into a four-cornered fight in which the principal characters were Olid, who soon rebelled from Cortés; Francisco de las Casas, who was sent by Cortés to arrest Olid; Hernández de Córdoba and Hernando de Soto, lieutenants of Pedrarias, who were operating from the new town of León as a base; and Gil González Dávila, discoverer in 1522 of Lake Nicaragua. The latter, upon his return to Panamá from his exploring expedition, escaped the snares laid for him by his rival Pedrarias and made his way to Española where he organized an expedition and sailed for the east coast of the mainland, hoping to find a strait to the Nicaragua Lake country; failing so to do it was his intention to proceed thither overland. In the contest for supremacy that followed, Olid soon paid with his life for a short-lived triumph over Dávila and Las Casas; at the same time Dávila became a prisoner of Las Casas and by him was carried to Mexico City. ${ }^{2}$ Continued instability in Honduras finally resulted in Cortés's going there in person. But his absence from Mexico was the occasion for disorders which forced him to abandon the Nicaragua campaign, and in 1526 to return to Mexico City without having come to blows with the lieutenants of Pedrarias.

Cortés returned to Mexico only to lose his power. In I $_{524}$ the king, as a means of keeping a check on Cortés, had despatched a corps of royal officials to New Spain, and it was these who during the absence of Cortés had stirred up trouble for him in Mexico. Complaints of the situation resulted in the king's despatching Luis Ponce de León to conduct the residencia of Cortés. He arrived in Mexico only a few days after the return of Cortés from Honduras. With the institution of the residencia Cortés was automatically suspended as governor, although he continued for a while to hold the office of captain-general. The residencia of Cortés was suddenly interrupted by the death of Ponce two weeks after his arrival. Ponce's political powers however devolved upon his successor, Marcos de Aguilar, and, after the latter's death, upon the treasurer, Estrada, one of the royal officials who had arrived in New Spain in I 524 . During their terms of office Cortés's explorations in the South Sea were interfered with and he himself, after being deprived of his office as captaingeneral, was for a while exiled.

In the meantime the presumptuous and jealous attitude of mainland conquistadores had had its effect on the king, and in 1525 sweeping territorial changes were made. In that year Pánuco and Vitoria Garayana, with Nuño de Guzmán as governor, and Honduras, with Diego López de Salcedo as governor, were created independent jurisdictions. In I 526 Francisco de Montejo was named governor of Yucatán and the island of Cozumel, and in 1527 Pedro de Alvarado became royal governor of the independent jurisdiction of Guatemala. At the same time, disappointed and provoked with the quarrels between the various contending factions at Mexico City, the king decided to establish the audiencia form of government in New Spain. According to a royal order issued on December I3, 1527, New Spain and its provinces, Cabo de Honduras and Las Ygueras, Guatemala, Yucatán, Cozumel, Pánuco, La Florida, Río de las Palmas,

2 For further information concerning Gil González Dávila see this volume, p. 35. 
and all the other provinces between the Cape of Honduras and the Cape of Florida on both the South Sea and the coasts of the north were placed under the jurisdiction of the Audiencia of New Spain, which was composed of a president-Nuño de Guzmán-and four oidores (judges). On January I, I529, this audiencia began to function in Mexico City, both as an administrative and as a judicial body.

The audiencia that was thus installed soon proved its unworthiness in more ways than one, and in 1530 another administrative experiment was decided upon by the king. In place of an audiencia which should exercise both administrative and judicial duties, it was decided on the administrative side to establish a viceroyalty in New Spain, and on the judicial side, to name a new audiencia to take the place of the unworthy first one. The new audiencia began to function in Mexico City in January, I 53 I ; pending the arrival of the first viceroy, Don Antonio de Mendoza in I535, it functioned, as had the first audiencia, in both administrative and judicial matters.

One important result of the determination of the king to suppress the first audiencia was the spectacular advance of the frontier of settlement in the west from Colima over 400 miles northward to San Miguel de Culiacán. Aware of the reports sent to Spain of the misrule of the first audiencia, the president, Nuño de Guzmán, desirous of reviving his waning. prestige and of regaining the favor of the king, advanced into unexplored territory in the spring of 1530 and in October, I53I, founded the villa of San Miguel de Culiacán, which was some 450 miles south of the present international boundary of the United States and Mexico, and which, for a number of years, was to be the northernmost Spanish outpost in the west. An effort on the part of Guzmán to establish an independent jurisdiction under the name of Mayor España met with royal disfavor; a cédula of I53I renamed it Nueva Galicia de la Nueva España.

In the meantime Cortés, who had been stripped of all power in New Spain by his rivals, returned to Spain to plead his own case. Unable to secure reinstatement as governor of New Spain, he was, however, named Marqués del Valle de Oaxaca, a title carrying with it the vassalage of 23,000 natives. He was also reinstated as captain-general of New Spain, and was promised the governorship of any islands that he might discover in the South Sea that were not included in grants to other jurisdictions, and of any part of the mainland not previously discovered or included in grants to other jurisdictions.

In I 530 Cortés returned to New Spain, where he resolutely set to work to carry out his long delayed plans for exploration in the South Sea. An expedition sent out under Diego Hurtado de Mendoza in I 532 discovered the Tres Marias Islands and explored for the first time the coast region lying between the Sinaloa River (the northern limit of Guzmán's explorations) and the Río Fuerte. Another expedition sent out in I533 under Grijalva and Jiménez discovered the Revilla Gigedo group of islands and the southern end of the peninsula of Lower California, which was taken to be an island. By his agreement with the crown, Cortés's claims to these newly discovered lands were unquestioned. To establish these claims definitely, Cortés in I 535 led a colonizing expedition to the 
peninsula and on the site of present La Paz founded the short-lived settlement of Santa Cruz. This was the first of a long series of attempts to settle Lower California, of which Cortés is to be ranked as the first governor.

Meanwhile political readjustments were being made further to the south which materially affected the later development of New Spain. The creation of Honduras as an independent jurisdiction in I 526 was followed almost immediately by the creation of the independent jurisdiction of Nicaragua, and still later by that of Veragua. Thus by I530 the entire region now known as Central America had been settled and the independent jurisdictions of Guatemala, Honduras, Nicaragua, and Castilla del Oro (modern Panamá and Costa Rica) had been created; in that region the northern and southern streams of conquest from Panamá and Mexico, respectively, had met, with the results outlined above. Henceforth for the Spaniard in New Spain the only region which offered possibilities for exploration and conquest lay to the north. Furthermore, overshadowing and outstripping all other jurisdictions on the mainland was that of New Spain, which in I 535 formally became the first viceroyalty in the Americas. Great as New Spain was at that time, by being forced to direct and confine its attention to the north the foundation of its future greatness was in reality laid.

\section{Spanish Exploring Activities, I $535-\mathrm{I} 543{ }^{3}$}

The period immediately following the establishment of the viceroyalty of New Spain is a noteworthy one; in no period of equal length in the history of Spanish North America was there greater activity in exploration than in the eight years from I535 until I 543. This movement was in part due to and actually may be said to have begun with the arrival of Cabeza de Vaca and his three associates at Culiacán in 1536. Reports which they brought of permanent settlements and of a high indigenous civilization to the north of their route of travel excited all alike, and soon rumor connected the northern country with the legendary Seven Cities that were supposed to have been founded somewhere in the west by seven

${ }^{3}$ This section of the Introduction is based cliefly upon H. H. Bancroft, History of the North Mexican States and Texas, I. (San Francisco, I884) 79-8I ; Ad. F. Bandelier, "Cibola", in The Gilded Man and Other Pictures of the Spanish Occupancy of America (New York, I893), pp. III-257; H. E. Bolton, "The Cabrillo-Ferrelo Expedition", in Spanish Exploration in the Southwest, I542-I706 (New York, I9I6), pp. 3-39; H. E. Bolton and T. M. Marshall, The Colonization of North America, I492-I783 (New York, I920), pp. 4I-47 ; E. G. Bourne, Spain in America, 1450-I580 (New York, 1904), pp. I58-174; T. H. Lewis, "The Narrative of the Expedition of Hernando de Soto by the Gentleman of Elvas", in F. E. Hodge and T. H. Lewis (editors), Spanish Explorers in the Southern United States, I528-I543 (New York, 1907), pp. I27-270; W. Lowery, The Spanish Settlements within the Present Limits of the United States, I5I3-I56I (New York and London, I90I), pp. I72-377; "The Relation of Fray Marcos de Niza", in Ad. F. Bandelier, The Journey of Alvar Nuñez Cabeza de Vaca (New York, I905), pp. 203-23I ; Buckingham Smith, Colección de Varios Documentos para la Historia de la Florida y Tierras Adjacentes (London, I857); George P. Winship, The Coronado Expedition, I540-I542, in the Fourteenth Annual Report of the Bureau of American Ethnology, part I. (Washington, 1896), pp. 329-613. 
fugitive Christian bishops in the eighth century. One whose interest was thus quickened in the northern regions was the new viceroy, Don Antonio de Mendoza, and for good reason. This was but the second year of the viceroyalty. In a sense, then, it was on trial, and the viceroy realized that it would not be a wise policy to allow a new and powerful jurisdiction to be established to the north of New Spain. To prevent this, therefore, the ambitions of powerful rivals, as Cortés and Nuño de Guzmán, must be forestalled by bringing the entire northern country under the unquestioned jurisdiction of the viceroy.

Of the strength of his rivals Mendoza was not unaware. Cortés, by the explorations of Hurtado de Mendoza in I 532, had unquestioned claims to the regions between the Sinaloa and Fuerte rivers. Nuño de Guzmán, recently deposed governor of Nueva Galicia, could also make claims on the basis of earlier explorations. Cognizant of the validity of these claims, and not an adventurer or conquistador himself, as was Cortés, Mendoza first tried to induce Cabeza de Vaca or one of his white associates to enter his service for northern exploration. Failing in this, Mendoza then bought of Andrés Dorantes the negro slave Estevánico. Then he set about to make plans for following up the current reports with actual exploration. These plans culminated in the official reconnaissance of Fray Marcos de Niza, who, in I 539 was sent north from Culiacán with Estevánico as his guide. The latter lost his life in the undertaking, but Fray Marcos returned to tell of having seen from a distance a large cityin reality one of the Zuñi pueblos in the western part of the present state of New Mexico-which he described as larger and finer than Mexico City. In the formal report which he made on his return, Fray Marcos was careful to distinguish between what he actually saw and what he heard, but, unfortunately, he reported as fact all that he imagined and all that he imperfectly understood from the natives. While he made no mention of gold or silver, the reports of the region were exaggerated as they spread with remarkable rapidity over New Spain, and the Seven Cities, as the region came to be known, soon came to imply to the Spaniards a veritable El Dorado. As a result great excitement prevailed over New Spain, and Viceroy Mendoza at once prepared to follow up this reconnaissance with a large expedition to take possession of the country of the Seven Cities.

Cortés in the meantime had not been idle. Aware of the departure of Fray Marcos and alarmed at the prospect of his rival Mendoza securing the advantage over him, Cortés, in an effort to forestall his competitor, sent three vessels north from Acapulco in July, I 539, or about two months prior to the return of Fray Marcos. This expedition was under the command of Francisco de Ulloa, who, in the course of his expedition, explored north from the Río Fuerte-northern limit of Diego Hurtado de Mendoza's explorations in I 532-along the east shore of the Gulf of California to its head, and then turning south, followed the west shore of the gulf to Cape San Lucas. Rounding that point he turned north and followed the west coast of the peninsula of Lower California as far as Magdalena Bay and Cabo del Engaño. Ulloa's discoveries added materially to the northern and maritime discoveries that had already been made for Cortés, but an all-water route to the Seven Cities had not been discovered. But before 
Ulloa returned and the results of his expedition were known, Cortés, cognizant of the advantage which his rival Mendoza had secured by the reconnaissance of Fray Marcos, hastened to Spain to petition for the exclusive right to conquer the region explored by Niza and Ulloa. Death overtook the Great Conquistador before the matter was settled.

At the same time other claimants for the right to conquer the northern country appeared. Agents of De Soto, who in I 537 had secured the title to the Florida country, argued, and with some reason, that the Seven Cities were included in his grant. On the southern horizon appeared a possible rival in the person of Pedro de Alvarado. From Guatemala he had gone to Peru where he had been paid handsomely by the Pizarro brothers to leave the country. Returning to Spain he secured from the king the right to build a fleet and explore in the South Sea and in I 539 he began the construction of his vessels. Moreover, the claims of Nuño de Guzmán were not to be disregarded. In view of this situation Mendoza, soon after the return of Fray Marcos, decided not to await royal confirmation, but to name, on behalf of the crown, the new governor of Nueva Galicia, Francisco Vásquez de Coronado, as leader of the proposed expedition to the Seven Cities. This action later met with approval, for the Council of the Indies finally decided since the region in question was not included in any other grant, that the expedition should be made on behalf of the crown. In this way did Coronado secure official license to explore and conquer the Seven Cities.

The plans as agreed upon called for a sea expedition, which, under the command of Hernando de Alarcón, was to co-operate with the mainland expedition under the personal command of Coronado. While these plans were being perfected Melchior Díaz was sent north from Culiacán to verify the reports of Fray Marcos. He probably got as far north as the Gila River, but his report, received after the departure of Coronado's party, was unsatisfactory because no mention was made of the presence of the finer metals. Although Díaz's report was kept secret by the authorities the rumor soon spread that Fray Marcos had made a wildly exaggerated report of his reconnaissance.

The land expedition under Coronado, which was one of the most completely and splendidly equipped forces which up to that time had been organized in New Spain, advanced in the spring of $\mathrm{I}_{540}$ in two sections from Culiacán to the upper Rio Grande pueblos in northern New Mexico, going there by way of the Yaqui and San Pedro rivers and across Arizona and western New Mexico. En route a settlement was established at San Hierónimo in present Sonora, from where Melchior Díaz, as commander, explored to the mouth of the Colorado River and across that stream into present California; the Zuñi pueblos in the western part of New Mexico were conquered; and exploring expeditions were made to the Moqui pueblos in northeastern Arizona, and to the Grand Canyon of the Colorado. Reaching the Río Grande pueblos in the latter part of the year I 540, winter quarters were established there and the military occupation of the valley, which contained over seventy towns and a large native population, was effected. The following spring Coronado led a small detachment from New Mexico across present Texas and Oklahoma to Quivira 
in the present state of Kansas. Returning to the Río Grande, the expedition spent the winter of I $_{54} \mathrm{I}-\mathrm{I} 542$ there, and in the spring of $\mathrm{I}_{542} \mathrm{re}-$ turned to New Spain without having extended the frontier of settlement beyond Culiacán. The expedition brought to the Spaniards definite knowledge of a great expanse of territory and many native peoples but because no great natural wealth was encountered the expedition was disappointing, and for forty years Cíbola, as the country of the Seven Cities came to be known, was not visited again by the Spaniards. On this expedition Coronado later claimed that he spent over fifty thousand ducats of his own money.

Meanwhile the sea expedition under Alarcón in two vessels proceeded north from Acapulco. Following the route of Ulloa, Alarcón reached the head of the Gulf of California, crossed the shoals at the mouth of the Colorado River in small boats, and then ascended that river to a point near the junction of the Gila. Unable to enter into communication with the main party, which was inland to the east, Alarcón soon returned to New Spain.

During the absence of Coronado in the north, Pedro de Alvarado arrived on the west coast of New Spain with his fleet. Viceroy Mendoza at once entered into negotiations with him and as a result the two men formed a partnership. Plans were then made for a naval expedition up the west coast of California, but before these plans could be carried out Alvarado lost his life ${ }^{5}$ in the Mixton war-an uprising of the Indians of Nueva Galicia. As a result of the death of Alvarado's wife soon afterward, all of the vessels in the fleet built by Alvarado passed under the unquestionable jurisdiction of Viceroy Mendoza, who at once planned two naval expeditions. The first of these in I 542-I 543 , originally under the command of Juan Rodríguez Cabrillo, and, after his death, under the command of Bartolomé Ferrelo, explored for the first time the entire Pacific Coast from Cabo del Engaño-the northern limit of Ulloa's explorations-to a point near the southern boundary of Oregon. In November 1542, or five months before the return of the Cabrillo-Ferrelo expedition, the other division of the fleet was sent west under Ruy López de Villalobos to explore the islands north of the Moluccas and to reach China. Though he reached and named the Philippines, Indian hostility prevented the founding of a settlement; finally hostility from the Portuguese in the Moluccas caused the expedition to go to pieces after the death of the leader. The net results of the expedition were the naming of the Philippines and the securing of Spain's claims to them.

Such, between the years of I 535 and $\mathrm{I} 543$, were the exploring activities of the Spaniards by way of the west coast and on the Pacific. But this was not the full story of Spanish achievement; from Florida as a point of departure the entire southeastern part of the present United States had in the same period been explored. A period of inactivity in the east had followed the Narváez disaster. But in I 537 Hernando de Soto was appointed governor of $\mathrm{Cuba}$ and at the same time was given the right to

${ }^{4}$ See p. 33 of this volume.

5 The events leading up to the death of Alvarado are given on pp. 43,45 of this volume. 
conquer, pacify, and settle all of the territory included in the former grants of Narváez and Ayllon. Recruiting his force in Spain and stopping en route in Cuba, De Soto landed at Tampa Bay in May, I539, with 600 men. The winter was passed in the present state of Florida and the next spring De Soto began the real task of exploring the interior-an undertaking that carried him through the present states of Georgia, North Carolina, Tennessee, Alabama, Mississippi, Arkansas, and Oklahoma, and his surviving associates, after his death in May, I 542, into Texas, and later, by way of the Mississippi River, to Pánuco, the then northern outpost of New Spain in the east as Culiacán was the northernmost post in the west.

The years 1542 and I 543 , then, were very eventful ones. The summer of 1542 saw the return in disorder of the disgusted members of the Coronado expedition to Culiacán ; in November, I 542, the Villalobos expedition sailed west to the Philippines and the Moluccas where it was to go to pieces in the face of Portuguese hostility and rivalry; in April, I543, Ferrelo returned to Navidad after having reached the Oregon coast in the vicinity of $42^{\circ} 30^{\prime}$; and in September, 1543 , the survivors of the De Soto expedition arrived at Pánuco. Important as were these various expeditions on account of the first-hand knowledge gained of such vast regions and their peoples, not the least significance of them was that from Oregon south to Cape San Lucas, from the Gila and Colorado rivers east to the Rio Grande and Quivira, from Quivira and Central Texas east to the Cape Fear region and Tampa Bay, no great natural wealth and no superior native civilization had been encountered. The result was that interest in the northern region waned; after the return of the Coronado and the De Soto expeditions, New Spain was not to witness again such spectacular attempts to conquer the north. Instead, the frontier settled down to a more normal and gradual advance.

\section{The Northward Advance in New Spain, I543-I590.}

In 1543 the frontier of settlement in New Spain extended in an irregular semi-circle, with its base to the south, from Culiacán in the west to Pánuco in the east. By I590 the northernmost outposts in both the east and the west had advanced still further to the north, while the arc of the circle had in large measure been filled in. This was the result of three important and separate and distinct movements-a western by way of Zacatecas and Durango; a central by way of Querétaro and San Luís Potosí; and an eastern from Pánuco as a base. In general the three columns of frontiersmen advancing into the north by way of these three lines of approach kept fairly on a parallel with each other until in I590 the frontier of settlement stretched in an irregular line from San Felipe on the Gulf of California to Cerralvo, forty miles south of historic Mier on the Río Grande.

In the west a temporary lull followed the return of the Coronado expedition. There political changes and the discovery of rich ores ${ }^{6}$ were

${ }^{6}$ H. H. Bancroft, History of Mexico, II. (San Francisco, 1883) 55I-552. 
alike contributing factors in the northern advance. In I 548, instead of filling the governorship left vacant by the resignation of Coronado three years earlier, the king established a provincial audiencia for Nueva Galicia. ${ }^{7}$ To this body, composed of four alcaldes mayores, was entrusted both the political and the judicial administration of the province. ${ }^{8}$ About the same time the limits of its jurisdiction were widely extended. ${ }^{\circ}$ In I550 Guadalajara became the seat of the audiencia and at the same time of the new diocese of Nueva Galicia. ${ }^{10}$

After 1548 the expansion to the north was rapid. In that year rich mines were discovered in Zacatecas and shortly afterward the town of Nuestra Señora de Zacatecas was founded. ${ }^{11}$ Prompted by a desire to get control of other mining regions and at the same time to extend its jurisdiction, the Audiencia of Nueva Galicia now planned the conquest of the districts north of Zacatecas. In attempting to execute these plans the agents of the audiencia, besides encountering Indian resistance, came into conflict with Francisco de Ibarra, member of a wealthy family who had discovered as early as $\mathrm{I}_{554}$ the new mines of San Lucas, Sombrerete, Nieves, and others, and at personal expense had made the district safe for settlers. In I 558, however, Martín Pérez took forcible possession of this region for the audiencia and shortly afterward an alcaldia mayor, under the jurisdiction of Nueva Galicia, was established there. ${ }^{12}$

With the consent of the viceroy and aided by his uncle, Diego de Ibarra, a wealthy mine operator of Nueva Galicia, and son-in-law of the viceroy, who furnished him over two hundred thousand ducats, ${ }^{13}$ Francisco de Ibarra continued his personal operations on a large scale, and as a result, other rich mining areas were opened up. In I 562 an important step was taken when the entire region north of the new mining settlements in Zacatecas was detached from Nueva Galicia and the new political jurisdiction of Nueva Vizcaya, comprising modern Durango, Chihuahua, Coahuila, Sinaloa, and Sonora, and parts of Zacatecas, San Luís Potosí, and Nuevo León, was established by the viceroy. Ibarra was appointed governor and captain-general and at once began the task of occupying the province. His first efforts were devoted to the central plateau region, where, in 1563 , the villa of Nombre de Dios and that of Durango, the provincial capital, were established, and the mines of Santa

7 This audiencia was designated in royal orders of the time as "la audiencia real de la provincia de la nueva Galizia". Vasco de Puga, Provisiones, Cédulas, Instrucciones de su Magestad .. . para la Administración y Governación de esta Nueva España . . desde el Año I525 hasta ... I563, I. (Mexico, I563), ff. I6I, I80.

8 Juan López de Velasco, Geografía y Descripción Universal de las Indias... desde el año de I57I al de I574 (Madrid, I894), p. 26I ; Bancroft, History of Mexico, II. 547 .

9 López de Velasco, op. cit., pp. 182-183, 275.

10 Bolton and Marshall, op. cit., p. 55.

11 Bancroft, History of Mexico, II. 554-555.

12 Bancroft, History of Mexico, II. 595-597; Bancroft, North Mexican States and Texas, I. 97-100; Bolton and Marshall, op. cit., pp. 55-56.

13 Diego de Ibarra to the Secretary, Juan de Ledesma, Mexico, Nov. Io, I582, in this volume, p. II5; Bancroft, North Mexican States, I. III. 
Bárbara, San Juan, and Indé were opened up by Rodrigo del Río de Losa. In I564 Ibarra extended his operations across the Sierra Madre into the Sinaloa region. Within the next few years his authority was established over the coast region from Chiametla to the Río Fuerte, on which stream the temporary settlement of San Juan de Sinaloa was established. By him the country was developed and in 1567 he led an expedition, partly over Coronado's route, as far north as Casas Grandes in Northern Chihuahua. Shortly afterward the enforced abandonment of San Juan caused a recession of the frontier of settlement in the northwest to the Petatlán River. ${ }^{14}$ About ${ }^{1572}$ Francisco de Ibarra died and was succeeded as governor by his uncle, Diego de Ibarra. ${ }^{15}$

After the death of Francisco de Ibarra the failure to occupy the Río Fuerte region resulted in the establishment in 1584 of the permanent villa of San Felipe on the Río Petatlán, where, at irregular intervals until I 596, a commandant of the governor of Nueva Vizcaya was stationed. In the latter year a presidio and about the same time a Jesuit mission and Aztec and Tlascaltecan families were established there. But while the Chiametla, Culiacán, and Sinaloa regions constituted parts of the political jurisdiction of Nueva Vizcaya, Chiametla was under the judicial jurisdiction of the Audiencia of New Spain until about 1574, when it was transferred to the Audiencia of Nueva Galicia. Also as late as 1574 the Audiencia of New Spain claimed jurisdiction over the Sinaloa region north of Culiacán. ${ }^{16}$

In contrast to the unsettled condition west of the Sierra Madre, marked success attended the colonizing movement up the plateau to the east of the range, and by $\mathrm{I} 580$ an outpost had been established at San Bartolomé at the head-waters of the Río Conchos. Along this stream and the Río del Norte, or Río Grande, into which it flowed, a way to New Mexico was soon to be opened up from Nueva Vizcaya. ${ }^{17}$

As a result of the opening of the mines of Zacatecas and the need for a direct line of communication between them and Mexico City the task of occupying the intermediate region was undertaken by Viceroy Velasco. With the help of loyal native chieftains in the viceroy's service the town of Querétaro was founded about the middle of the century, and several years later Silao and Santa Fé de Guanajuato. The founding of these towns was followed by the discovery of rich mines which at one attracted settlers. As a result new towns and presidios were established and the safety and occupation of the region definitely effected. ${ }^{18}$

After Querétaro was founded it became a base for the central movement into the north. The pioneer in this movement was Francisco de Urdiñola, an agent of Viceroy Velasco, who, about 1550 , began the conquest of the region directly north of Querétaro, now San Luís Potosí,

\footnotetext{
14 Bancroft, North Mexican States and Texas, I. I02-I 16; Bolton and Marshall, op. cit., pp. 56-58.

15 See above, note 13.

${ }^{16}$ López de Velasco, op. cit., pp. 275-277.

17 Anne Hughes, The Beginnings of Spanish Settlement in the El Paso District, in University of California Publications in History, I. (Berkeley, I9I4) 296-297.

18 Bolton and Marshall, op. cit., p. 58.
} 
where, as early as 1548 , rich lodes had been discovered. A number of settlements, among them being Matehuala, San Gerónimo, and Charcas Vieja, were soon founded; in I 576 the town of San Luís Potosí was founded and became the seat of an alcaldia mayor with extensive jurisdiction to the north.

Meanwhile, however, the frontier had advanced much further northward. In I 554 Urdiñola founded Mazapil and opened up, nearby, the famous Bonanza mine. The next year the new province of Charcas was created with Urdiñola as alcalde mayor. This province, which included the settlements of Matehuala and Tula, extended on the west as far as Fresnillo and San Martín and on the north to Zapalinamé. Under Urdiñola development was rapid. In July, I555, he established the presidio of Santiago del Ojo de Agua del Saltillo, which became the centre for a number of small settlements. The same month an expedition reached present Monterey.

Urdiñola died in January, 1556 , and the viceroy appointed as his successor Francisco de Ibarra, whom he then contemplated appointing governor and captain-general of New Mexico and the Seven Cities. Ibarra was employed until I 559 in extending his conquests from Zacatecas to the Río Nazas. In the latter year he visited the settlements in Charcas and on February 2, I559, elevated the presidio of Saltillo to a villa with the appellation of Santiago del Saltillo. Leaving there his lieutenant alcalde mayor, Ibarra visited Mazapil, Matehuala, and Tula before returning to the Río Nazas settlements in March. Soon afterward all of the territory north of Zacatecas, including the alcaldía mayor of Charcas, was erected into the new province of Nueva Vizcaya with Francisco de Ibarra as governor. His interests, as outlined above, soon led him to the north and west of Durango.

In 1575 Francisco de Urdiñola, the younger, just out of college in Europe and heir to the rich mines opened up by his father, offered to extend, at his own expense, the conquests and carry on the colonizing work begun by his father in the region to the north of Mazapil and Saltillo. The viceroy accepted the proffer and by Urdiñola satisfactory peace terms were finally arranged with the bellicose Guachichiles Indians, and pueblos, both of Spaniards and of Indians, were established. At San Francisco de los Patos, in the Laguna region, Urdiñola founded, in I 575, a Spanish garrison and settlement. Still further west he established three large private estáncias, the most pretentious of which was San Pedro del Alamo. This became the centre of a veritable garden spot, and there, in addition to extensive corrals and the quarters for the Spaniards, Tlascaltecans, and slaves, a pretentious chapel was begun.

Later, on August I I, I 59I, Urdiñola was commissioned by Rodrigo del Río de Losa, then governor of Nueva Vizcaya, as his lieutenant governor and captain-general at Saltillo, in which capacity he served for a number of years. In September and October, I591, Urdiñola carried out the instructions of the governor and the viceroy when he founded at Saltillo 
the separate Tlascaltecan pueblo of San Estéban. Saltillo remained under the jurisdiction of Nueva Vizcaya for more than a century. ${ }^{19}$

During the advance of the frontier of settlement by way of the western and central lines of approach to the north, Pánuco remained in the third quarter of the century the northern outpost in the east coast region. But in I 579 Luís de Carabajal, on the basis of prior exploration, was commissioned to found a new jurisdiction north of Pánuco to which was given the name Nuevo León. This new province extended two hundred leagues north of Pánuco and hence comprised old Vitoria Garayana and part of Río de las Palmas, as granted to Narváez. About I583 Carabajal founded his provincial capital at León, now the city of Cerralvo. Turning south from there he established the villa of San Luís, which in I 596 became or was succeeded by the villa of Monterey. Subsequently the occupation of the intermediate region was effected. In I 590 Carabajal proceeded north from Saltillo and founded the temporary villa of Almadén; on the site of present Monclova. ${ }^{20}$ Before its abandonment Almadén figured in connection with the approaches to New Mexico.

At the same time that the frontier was being pushed northward in New Spain, interest was revived in the Florida region. The ambitious designs of Fray Luís Cancer in the 549 and the spectacular attempts of the viceroy's agents, Don Tristán de Luna y Arellano and Ángel de Villafañe, between the years I 559 and I 56 I to subdue and settle Florida, were alike unsuccessful. As a result Philip II. of Spain in $156 \mathrm{I}$ forbade further attempts to settle Florida. But the establishment of a short-lived French colony in the Carolina country shortly afterward, the founding of the more pretentious Fort Caroline, on the St. John's River, by French Huguenots in 1564 , and the activity of English and French pirates on the seas caused these orders to be rescinded and in ${ }_{5} 65$ Menéndez de Avilés as adelantado of Florida was commissioned to settle the country and expel the foreigners, both settlers and corsairs. St. Augustine was founded by Menéndez in 1565 , and shortly afterward the French were slain at Fort Caroline and the garrison of San Mateo established on the site, only to be destroyed by the French two years later. The aggressive policy of the Spaniards however resulted in the founding of new outposts, the occupation of San Mateo, and the establishment of presidios and colonies in what is now Florida, Georgia, and South Carolina. In I 568 three Jesuit missions were established in occupied territory, and in 570 Father Segura founded a short-lived mission in the region of

19 The above summary of the Spanish advance to and beyond Saltillo is based principally upon a documentary history of Coahuila, by Dr. R. Regino Ramón, excerpts of which are printed for the first time in chapter I. of Tomás Berlanga, Monografía Histórica de la Ciudad de Saltillo (Monterey, Nuevo León, I922). This presents an entirely new version, based upon official documents, of the establishment of Spanish dominion in Coahuila. For the activities of Urdiñola in I59I, see Berlanga, op. cit., ch. II. Also attention is directed to the old and untrustworthy account of the Spanish advance into Coahuila as given by Bancroft, History of Mexico, II. 760-764; Bancroft, North Mexican States and Texas, I. I25; and as summarized by Bolton and Marshall, op. cit., pp. 59-60.

20 H. E. Bolton, "The Spanish Occupation of Texas", in the Southwestern Historical Quarterly, XVI. (July, I9I2) I2-13; id., Spanish Exploration in the Southwest, I542-1706, p. 283 . 
Chesapeake Bay. Shortly afterward the Jesuits withdrew to Mexico. The Alleghany and Chesapeake regions were explored and in I573 Menéndez's grant was extended west to Pánuco. The grant of Carabajal six years later included the southwestern part of Menéndez's jurisdiction. The year 1573 also saw the beginning in Florida of Franciscan activity, which continued with uninterrupted success until a serious revolt in $1597 .{ }^{21}$

\section{Governmental Institutions and Colonial Administration.}

The political organization by which Spain administered her vast colonial possessions of which New Spain constituted so large a part, was made up of various organs of administration, both in Spain and in the colonies. In Spain were located the king, the Council of the Indies, and the Casa de Contratación, or Board of Trade; in New Spain were the viceroy, the captains-general, the audiencias, the provincial governors, and the various local officials and governing agencies. Without attempting to trace the historical development of these various institutions, a brief statement concerning their functions is pertinent.

When America was discovered it was treated as the private domain of the ruler of Castile, as were all of the oversea colonies. Since the king stood at the head of the whole Castilian system, and indeed of the national system, it was but natural that he should stand in exactly the same position with respect to the colonial possessions. Nor did this change when Philip II. created of the colonial possessions the Kingdom of the Indies, from which time they were administered as a separate kingdom. Since the colonies from the outset were ruled in the same detailed fashion as Castile, it was but natural that there should have been reproduced for their government the same institutions as were in Castile.

Of these the most highly developed, and the one next in authority under the king, was the Council of the Indies. Existing in germ form during the first decade of the sixteenth century and functioning informally from I 509 until I 524, the Council of the Indies was formally established on August 4, I 524. Modelled after the Council of Castile its importance for the oversea possessions came to be as great as its prototype, and as the possessions of Spain grew, so did the power of the Council of the Indies increase, until it became the great overshadowing institution of the Indies-in practice, though not in theory more powerful than the king himself. These powers were of three kinds, legislative, administrative, and judicial, and in each of these fields the Council was, under the king, supreme. At first the Council proper was composed of nine members, but by the middle of the seventeenth century the number had been increased to fourteen; these were usually appointed by the king from among high officials who had seen service in the Indies. In addition there were many

21 See, for Florida, W. Lowery, Spanish Settlements within the Present Limits of the United States, I5I3-1561, pp. 4II-427; id., Spanish Settlements within the Present Limits of the United States: Florida, 1562-1574 (New York and London, 1905) ; Bolton and Marshall, op. cit., pp. 6I-65. 
subordinate officers, as fiscals (fiscales), or royal attorneys, the secretaries, the treasurer, and clerks. ${ }^{22}$

Commercial as well as political policies contributed to the Spanish system of colonial administration. In fact there were two mainsprings of action: strict concentration of authority in the crown, and commercial exclusiveness and monopolistic control. For the former the Council of the Indies was the chief agency; for the latter the Casa de Contratación. The latter institution came into existence in $\mathrm{I}_{50} \mathrm{O}$, when, by its creation, Bishop Fonseca, who since I 493 had virtually been at the head of Indian Affairs, was relieved of many of his economic and commercial responsibilities. The Casa de Contratación had general supervision over commerce, navigation, and all economic matters relating to the Indies, but was subordinate to the Council of the Indies after the latter was established. The four chief officers were the president, the treasurer, the comptroller (contador), and the business manager (factor); in addition there were numerous minor officials. ${ }^{23}$

In connection with the Council of the Indies and the Casa de Contratación is to be noted the great code by which Spain regulated her colonial affairs and which was in process of evolution until I680. This code, which was one of the most remarkable ever devised by any nation, was called the Recopilación de Leyes de los Reynos de las Indias. It was a heterogeneous mass of laws, pragmatics, ordinances, provisions, cédulas, resolutions, and decisions which attempted to regulate the procedure, duties, and guarantees of the various governing agencies and the peoples governed. The task of codifying the laws really began in 1560 when Philip II. ordered that the various regulations then in force in the audiencia district of New Spain should be printed. Later the same was ordered done in the viceroyalty of Peru. In I570 a general compilation of laws and provisions for the Indies as a whole was begun from which obsolete laws were omitted. From time to time additions and omissions were made to this compilation and in I680 the work of codification was completed. The result was printed at Madrid in I68I as the Recopilación de Leyes de los Reynos de las Indias mandadas imprimir y publicar por la Magestad Católica del Rey Don Carlos II. Nuestro Señor, and contained only the laws in force at that time. Since then the work has passed through four other editions the last of which, published in I84I, contains

22 Lucas Alamán, Historia de Méjico desde los Primeros Movimientos que Prepararon su Independencia en el año de I808 hasta la Epoca Presente (Mexico, I849-I852), pp. 32-36; Bancroft, Central America, I. (San Francisco, I882) 280-283; Bourne, Spain in America, pp. 224-226; G. Desdevises du Desert, L'Espagne de l'Ancien Régime: les Institutions (Paris, 1899), pp. 95-102; Bernard Moses, The Spanish Dependencies in South America (New York, I914), I. 230-234; Juan de Solórzano y Pereyra, Pólitica Indiana (Madrid, I629-I639, I776), Valenzuela ed., II. 393-422; Recopilación de Leyes de los Reynos de las Indias mandadas imprimir y publicar por la Magestad Católica del Rey Don Carlos II. Nuestro Señor (Madrid, I68I), lib. 2, tit. 2.

23 Bourne, op. cit., pp. 222-223; R. B. Merriman, The Rise of the Spanish Empire in the Old World and in the New (New York, 1918), II. 222-227; B. Moses, op. cit., pp. 234-262; Joseph de Veitia Linaje, Norte de la Contratación de las Indias Occidentales (Seville, 1672 ). 
reforms down to 1820 in its index. For the laws passed from I680 until the latter part of the eighteenth century there is no complete statement or compilation. ${ }^{24}$

Of the permanent institutions that were established in the colonies, the first and one of the most important was the audiencia, a kind of supreme court. The first audiencia in the new world was formally established in Santo Domingo in September, I526, with a president, four oidores, a fiscal, and other subordinate officers. Several years later, when it became patent that the administration of Cortés was unsatisfactory, an audiencia was established in New Spain and, under the presidency of Nuño de Guzmán, was vested with both judicial and administrative powers. As a result of its misrule it was decided to substitute for the audiencia form of government a viceroyalty and a new audiencia. When' in I 535 Mendoza arrived in New Spain as viceroy this arrangement became permanent.

In general the duties of an audiencia were three-fold. First, there were duties common to a court of law; second, those concerned with the welfare of the natives; and third, those associated with the administrative agencies. From the judicial standpoint the audiencia was the supreme court of the jurisdiction in which it was located. Its members were appointed by the Council of the Indies and were removed at the pleasure of that body. In Spanish North America there were four audiencia districts-Mexico, or New Spain; Guadalajara, or Nueva Galicia; Santo Domingo, later Havana; and Guatemala. In the case of the Audiencia of New Spain there were eight oidores; four alcaldes del crimen; two fiscals, one civil and one criminal; one alguacil mayor (bailiff); and one vice-grand chancellor (teniente de gran chanciller). Until late in the Spanish régime the presiding officer of this audiencia was the viceroy of New Spain. ${ }^{25}$ An audiencia district presided over by a viceroy was the highest type in the Spanish colonial system.

At the beginning the Audiencia of Guadalajara did not have a separate seal of office and appeals could be made from its decisions to the Audiencia of New Spain. But in 1572 a chancery, composed of a president who was usually the eldest member of the court; three oidores-later increased to four-who also served as alcaldes del crimen; one alguacil mayor; and other officials, was formed and a separate seal of office granted to it. ${ }^{26}$ By 1680 all existing orders to the contrary were revoked and the president, and not the oidores, was designated as the one in charge of the government of the district. ${ }^{27}$ At the same time the president and oidores of the audiencia, as well as the governor of Nueva Vizcaya, were ordered to obey in everything the Viceroy of New Spain, and to hold with him good

24 Alamán, op. cit., I. 3I-32, and references cited; J. M. Antequera, Historia de la Legislación Española (fourth ed., Madrid, 1895), pp. 563-566; Bancroft, Central America, I. (San Francisco, I882) 285-288; Solórzano y Pereyra, op. cit., I. "Introducción".

${ }^{25}$ Recopilación, lib. 2, tit. 15 , ley 3.

${ }^{26}$ Juan López de Velasco, Geografia y Descripción Universal de las Indias . . desde el año de I57I al de I574, p. 26I; Bancroft, Mexico, II. 547.

${ }^{27}$ Recopilación, lib. 2, tit. 15, ley 7. 
relations as befitting the representative of the king. ${ }^{28}$ Such an audiencia, presided over by a president, was called a presidency.

The audiencias of Santo Domingo and Guatemala were composed of a president and four and five oidores, respectively; in each case the president of the audiencia was also governor and captain-general, ${ }^{29}$ and, as such, each exercised considerable administrative and military power, particularly the latter. An audiencia district presided over by a captaingeneral was called a captaincy-general. Audiencias in general were not intended to be courts of first instance, but, rather, courts of appeal. From the decision of the audiencia appeal could be made to the Council of the Indies.

Not the least significant of the duties of the audiencia were those in connection with the protection of the Indians, the instructions and laws being very specific in this regard. In its administrative capacity the audiencia served as an advisory council for the viceroy. In fact these relations between the audiencia and the viceroy were similar to those which existed between the king and the Council of Castile. Whenever, in this advisory capacity, the audiencia met with the viceroy, such a meeting was called a real acuerdo. ${ }^{30}$ But while the viceroy was bound to hear the advice of the audiencia he was not forced to follow it. ${ }^{31}$ Then, in addition to advisory duties the audiencia performed various duties more or less independent of the viceroy, as the right to appoint certain officers and pass upon their conduct. In brief, then, on the administrative side the audiencia shared the government with the viceroy. ${ }^{82}$

Under the Spanish colonial system the first and largest administrative sub-division derived its name from the officer who ruled it- the viceroy. With the establishment of the viceroyalty of New Spain in I535, Spain made a permanent institution of what had been an occasional one theretofore. As such the viceroy was the personal representative of the absolute Spanish monarch, a fact which, in spite of the many checks upon his power, gave him far more prestige than any other official. While the duties of the viceroy were multifarious, as is shown by the fact that seventy-four laws are found in the Recopilacion specifying them, these may be grouped under the following heads: (I) general administrative duties, as the executive officer of the jurisdiction; (2) military duties, as captain-general; and (3) ecclesiastical functions as vice-patron of the Church.

28 Recopilación, lib. 2, tit. I5, ley 52.

$29 I d$., lib. 2, tit. 15, leyes 2 and 6 , respectively.

30 Recopilación, lib. 3 , tit. 3 , ley 45.

${ }^{31}$ Lucas Alamán, op. cit., pp. 4I-42; J. M. Antequera, Historia de la Legislación Española (fourth ed., Madrid, I895), p. 567.

32 Additional references to the audiencia in the Spanish colonies are: L. Alamán, op. cit., pp. 40-45; J. M. Antequera, op. cit., pp. 567-568; Bancroft, Central America, I. 270-273; J. M. Beristain y Souza, "Audiencia de Megico", in his Biblioteca Hispano Americana Setentrional (Amecameca and Santiago de Chile, I883-1897); Bourne, op. cit., pp. 227-234; Charles H. Cunningham, The Audiencia in the Spanish Colonies as illustrated by the Audiencia of Manila, 1583-1800 (Berkeley, 1919), particularly chapter I.; Desdevises du Desert, op. cit., pp. I38-I56; B. Moses, op. cit., pp. 263-267; Recopilación, lib. 2, tit. I5-22. 
In New Spain the viceroy had general civil and military powers over the entire viceroyalty, which included all of the mainland of North America, the West Indies, and the Philippines-though not full local powers in all parts thereof. In the immediate audiencia district of New Spain the viceroy's civil and military powers were complete, the viceroy exercising therein full powers as governor and captain-general. In the audiencia district of Guadalajara, a sub-division of New Spain, which was not important enough to have a special captain-general, the viceroy exercised the military powers of captain-general, quite as he did in the audiencia district of New Spain proper. In the captaincies-general of Santo Domingo and Guatemala-audiencia districts of the viceroyalty of New Spain - the viceroy exercised only supervisory powers in civil and military matters. Throughout the entire viceroyalty, when international affairs were concerned the viceroy had ranking authority. Another administrative duty of the viceroy was to preside over the audiencia. In this capacity he did not vote in legal matters, but it is significant that he had authority to decide whether matters were judicial or administrative. Of all his duties, defense was one of the most important, and, as captaingeneral of his own immediate audiencia district, he was at the head of the army, although he could not make military appointments or promotions without first proposing them to the crown. ${ }^{33}$ In New Spain the entire northern frontier, where the fear of foreign aggression was so imminent, was directly under the viceroy until the latter part of the eighteenth century. As assistants to the viceroy there were an auditor de guerra, who was a sort of special counsel in matters of defense; fiscals, or state attorneys; and a junta de guerra, or council of war. In times of great danger when the expenditure of a large sum of money was necessary, a junta de guerra y hacienda (council of war and finance) assisted the viceroy. In time of war the viceroy had the right to impose extraordinary taxes and had other discretionary powers. Formally the viceroy was not vested with legislative powers, but many such were assumed by him, as, for example, the right to receive the royal cédulas and orders and give them his own interpretation.

Finally, as vice-patron of the Church the viceroy made recommendations ${ }^{34}$ for ecclesiastical appointments, the disposal of all of which was in the hands of the Council of the Indies, the Pope not even being consulted. The Holy Office of the Inquisition, which was established in New Spain in 1569 , was also under his supervision, while papal bulls even were received and interpreted by him.

Such were the varied duties of the viceroy of New Spain. However, he was not absolute, under the king, whom he represented. Instead, his powers were checked and controlled by the various royal cédulas and decrees of the Council of the Indies; by seventy-four laws laid down for his conduct in the Recopilacion; by the audiencia and other colonial institutions which, by being able to appeal directly to the Council of the Indies,

${ }^{33}$ H. I. Priestley, José de Gálvez: Visitor-General of New Spain, 1765-I77I (Berkeley, 1916), p. 59.

${ }^{34}$ H. I. Priestley, op. cit., p. 59. 
served as a great check on the arbitrary rule of the viceroy; by the complaints of any citizens of his jurisdiction; by his short term of office; by the residencia, or the official investigation into his conduct in office, which usually came at the end of his term; and by the visita, or the official inspection that might be made at any time during his term. ${ }^{35}$ It is thus seen that it was not the policy of the Spanish government to set up a colonial hierarchy; instead of autocracy, co-ordination and a system of checks and balances were the keynotes of the Spanish colonial system.

So much for the larger units of colonial government. Local government was as much, if not more, a matter of political evolution. At the outset the system was a simple one. Until the beginning of the second quarter of the sixteenth century local government was largely in the hands of individual conquistadores, who had personal supervision over large areas worked by native labor. This type of manorial system lasted only a few years when a definite form of local government, modelled after the Spanish governmental system, was established. This provided for three forms of local units: the gobierno, administered by a governor; the corregimiento, administered by a corregidor; and the alcaldia mayor, administered by an alcalde mayor. On the whole these various units increased in number, but all three forms were not found in any one audiencia district, while within the present United States only the gobierno was established.

The highest provincial officer was the governor. Within his province a governor might exercise only civil power, or he might exercise both civil and military power. In the former case his title was only that of governor; in the latter it was governor and captain-general. In both New Mexico and Texas it was the usual thing for the governor to exercise both civil and military power. In such isolated colonies it was also customary for the governor to be granted more discretionary powers than was the case with governors elsewhere. The governor was quite frequently appointed by the viceroy and confirmed by the Council of the Indies, though the king frequently appointed directly. While the governor was subject to the viceroy in both civil and military matters, provision was made whereby he could communicate directly with the king and the Council of the Indies. As was true of all the higher officers, the governors were usually native born Spaniards.

At the head of another subdivision was the corregidor, who was often appointed by the viceroy and confirmed by the Council of the Indies. Corregidores who were sent from Spain were supposed to serve for five years, while a Creole served for only three. Within their districts they combined all functions and their control over the inhabitants was very autocratic. While the corregidor was subject to the visita and the residencia, he was, in fact, because he was so isolated, seldom molested by

35 For further information concerning the viceroy see: Alamán, op. cit., pp. 40-45; Antequera, op. cit., pp. 566-567; Bourne, op. cit., pp. 229-233; Desdevises du Desert, op. cit., pp. I22-I33; Shepherd, Latin America (New York, I9I4), pp. 25-26; Moses, op. cit., pp. 267-275; Solórzano y Pereyra, op. cit., vol. II.; Recopilación, lib. 3, tit. 3 , leyes I-74. 
them. The principal duty of the corregidor was to judge criminal and civil questions arising among the natives of his district, or between Spaniards and natives. In case a corregidor was not a lawyer he did not try such cases but called in an asesor for this. Since they were designed to replace control by encomenderos, the corregidores were in much disfavor with the former. Instances of this unpopularity are given in Part I. of this volume. ${ }^{36}$ The alcalde mayor was at the head of a smaller jurisdiction, called an alcaldía mayor. In some instances he was supposed to be a kind of lieutenant or subordinate of the corregidor, but often he was almost as important. The alcaldias mayores were in turn subdivided into alcaldias menores, which in turn were sub-divided into encomiendas prior to the abolishment of the latter. By I650 there were over fifty corregimientos and alcaldias mayores in the audiencia district of Guadalajara alone.

The only political institution of self-government in Spanish North America was the town or city council; as established, it was one of the means of checking the arbitrary rule of high colonial officials. While there was no fixed rule, this board of city officials in the larger cities was generally called an ayuntamiento; in the smaller cities it was known as a cabildo. It was composed of alcaldes ordinarios, or municipal judges in cases of first instance, and regidores, or ordinary councilmen without judicial authority. At first the members were elected by restricted suffrage, but in time some of them came to be appointed; some inherited their offices; and others were elected or purchased their offices outright. When members held office by appointment or inheritance or purchase, ${ }^{37}$ they were supposed to secure confirmation from the Council of the Indies, although this was a slow process. As a result of the hereditary and salable features the efficiency of the ayuntamiento came to be greatly lessened. ${ }^{38}$

On the ecclesiastical side the crown, through the Council of the Indies, exercised jurisdiction over the Church and the ecclesiastical organization in the same way that it did over the civil administration. Various papal bulls, as the famous bull of demarcation of I 493 and the bull of Julius II. issued in I508, amply conceded this right to the Catholic Kings. The result was that within two decades after the discovery of America the authority of the crown over the church organization was complete. Accordingly the king had the right to appoint to church offices, to regulate the conduct of the clergy, and to dispose of ecclesiastical property and revenues as he pleased. This was known as real patronato (royal patronage). A cédula of 1574 stated that "the right of patronage of the Indies is alone and undivided forever reserved to us and our royal crown ". So complete was this control that the Council of the Indies had the right to

36 See pp. I35-I45.

37 For examples of the sale of offices see letter of Diego de Ibarra to the Secretary, Juan de Ledesma, Mexico, Nov. I0, 1582, this volume, p. II7.

${ }^{38}$ For more detailed accounts concerning provincial administration see: Alamán, $o p$. cit., I. 37-40; Antequera, op. cit., 569-570; Desdevises du Desert, op. cit., pp. I56-163 and 164-185; Wistano Luís Orozco, Legislación y Jurisprudéncia sobre Terrenos Baldios (Mexico, 1895), pp. 155-156; Shepherd, op. cit., pp. 26-27. 
prohibit the issuance of papal bulls in the Indies and to prohibit appeals to the Pope. Acts of ecclesiastical councils in America had first to be sent to the Council of the Indies and approved by that body before they could be executed or even published. But while the king was supreme, both in theory and practice, he was altogether in sympathy with the ideals and methods of the Church, with the result that the Church and the State-the two majesties so often mentioned in the documents of the period-went hand in hand with much less friction than elsewhere.

The Holy Office of the Inquisition was established in the Indies in I 569, but only Spaniards came under its jurisdiction. Tribunals of the Inquisition had jurisdiction over civil officers as well as over religious. The tribunal at Mexico City, which was under the supervision of the viceroy as vice-patron of the Church, had its own executive officers, swore witnesses, arrested prisoners, fined the guilty, and, in extreme cases, turned criminals over to the civil authorities to execute. Sentences of the Inquisition were called autos de fe. Friction between officials of the Inquisition and civil officers was very common. ${ }^{39}$

In addition to the secular clergy, or members of the Catholic hierarchy, there was the regular clergy, composed of the members of the various religious orders. In northern New Spain the three most important orders were the Franciscans, the Jesuits, and the Dominicans, and of these the Franciscans, for our purposes, were the most important. By I590 the Franciscans of New Spain were grouped into three provinces and these in turn were divided into custodias, at the head of which were custodios. At the head of the Franciscan order in New Spain was a commissarygeneral, resident at Mexico City, while in Madrid was a resident commissary-general of the Indies. The chief significance of these religious orders, as far as the political development of New Spain was concerned, lay in the fact that in the founding of missions on the frontier their members became political agents for the crown also. Likewise the missions established by them proved to be but stepping-stones for the advance and bulwarks in the defense of the whole northern frontier. ${ }^{40}$

\section{The Spanish Indian Policy; the Encomienda System.}

The natives with whom the Spaniards came in contact in the New World were from the first regarded as wards of the crown. As a consequence the Catholic kings felt obliged not only to provide a strong protective power for the Indians, but to convert and civilize them. Also it was inevitable that the exploitation of their labor should at the same time be attempted. The chief means by which it was hoped to attain these ends was the encomienda system. This system had its beginning in the island of Española. After an uprising of the natives in 1495 they were put under tribute by Columbus-either a hawksbell of gold or an arroba

39 For instance see p. 22I of this volume.

${ }^{40}$ For further details see: Alamán, op. cit., pp. 36-37; H. E. Bolton, "The Mission as a Frontier Institution in the Spanish American Colonies", in the American Historical Review, XXIII. (Oct., I917) 42-61; Moses, op. cit., pp. 206-232; Recopilación, lib. I; Shepherd, op. cit., pp. 49-59. 
(twenty-five pounds) of cotton being required of them every three months. This proving excessive, the tribute was first reduced by one-half and later commuted to personal labor on the farms of the Spaniards. Still later, in I497, Columbus allotted to the Spaniards the cultivated lands of the Indians. With these allotments, known as repartimientos, and later as encomiendas, went the forced labor of the Indians. In $\mathrm{I}_{502}$ the crown authorized the collection of tribute from the natives, but ordered that they should receive wages for their labor.

This arrangement was unsuccessful, for it was found that without compulsion the Indians could neither be induced to work nor taught nor converted. Accordingly it was ordered by the crown in $\mathrm{I} 503$ that the Indians should be given inalienable lands and that they should be settled in permanent villages under protectors known as encomenderos. These encomenderos were obliged to teach, to indoctrinate, and to protect the Indians, to suppress their native customs, and to encourage to a limited extent the intermingling of the two races. The encomenderos were also empowered to exact labor from the Indians, though for pay, and as free men, and were to share the profits with the king. Thus by I 503 had been laid the basis of the encomienda system, which was designed from the very first not only to protect and uplift the Indian but also to exploit him.

The first encomiendas in New Spain were granted by Cortes during the period of his illegal conquests and prior to May I 5, I522. Later in that year, when he was named governor and captain-general of New Spain, authority was at the same time given to grant encomiendas. The next year the granting of encomiendas was forbidden, but the order was ignored by Cortés. Later the instructions to Ponce de León called for an investigation of the subject of encomiendas and of native tribute, but the early death of Ponce left the matter unsettled and the status of encomiendas unchanged. In 1536 the encomienda system was made general for the Indies, but in I 542, largely as a result of the protests of Las Casas against the abuses of the system, ordinances thenceforth known as the New Laws ${ }^{41}$ were recommended to and approved by the king. These laws aimed at the correction of abuses and the limiting and abolition of the system on the death of the present holders. Violent protests and serious opposition followed the publication of these laws, and in Peru there was formidable rebellion as a result of the effort to enforce them. The position of the encomenderos, and the effect which they felt these laws would have on the Indies, are ably set forth in the various petitions and memorials of their attorneys, and published hereinafter. ${ }^{42}$ Finally, because of the opposition, the vital clauses of the ordinances were repealed in I 545, and it was not until the eighteenth century that the system was finally abolished. An interesting example of the annulment of a contract with an encomendero for his repartimiento of Indians, and of the incorporation to the crown of the repartimiento, is to be found in documents published hereinafter. ${ }^{43}$

${ }^{41}$ For the text of the New Laws see J. G. Icazbalceta (ed.), Colección de Documentos para la Historia de Mexico, II. (Mexico, I866) 204-227.

42 See pp. 125-I5I.

${ }^{43}$ See agreement with Gonzalo López concerning his Indians, this volume, pp. 95-101. 
As definitely established in New Spain the encomienda system was marked by the reduction of the Indians to village life where their conversion and their cultural uplift might be more easily effected. In each village a church and a priest were required to be supported and maintained by the encomendero, and in those villages the Indians, at least theoretically, chose their own officers, though in the presence of the priest. All Indians between the ages of eighteen and fifty were required to make an annual payment in kind to the encomendero if not directly to the king, though money was sometimes accepted in lieu thereof. To see that the rights of the Indians were not infringed upon, protectors were appointed and regulations were passed regarding the mingling of the two races. Slavery was strictly forbidden. Thus from its adoption by the crown the encomienda system is to be regarded as benevolent since theoretically its chief purposes were the civilizing and converting of the natives. But though benevolent by intention the system was abused, and the exploitation of the native, rather than his protection, his uplift, or his conversion, proved too often to be the chief aim of the encomendero. ${ }^{44}$

44 Bancroft, Central America, I. 262-266; Bolton, "The Mission as a Frontier Institution in the Spanish American Colonies", loc. cit., pp. 42-6I ; Bolton and Marshall, op. cit., p. 22; Bourne, op. cit., pp. 206-2II and 255-256; Sir Arthur Helps, The Spanish Conquest in America and its Relation to the History of Slavery and to Government of Colonies (Oppenheim ed., New York, 1900-1904), II.; Recopilación, lib. 6, tit. I-15; Shepherd, op. cit., p. 40; Moses, "The New Laws and the Civil War". in Spanish Dependencies, I. 204-229. 
I. 2. REPORTS RELATING TO THE SERVICES AND MERITS OF EXPLORERS AND CONQUERORS OF NEW SPAIN. 
Informaciones veridicas de las personas que se hallaron en la Conquista de la Nueva España y Ziudad de Mexico que pasaron con el Marques del Valle. ${ }^{a}$

\section{Joan Xaramillo. ${ }^{b}$ \\ Es FALLEÇIDO.}

Dize ques Vezino desta ciudad y natural de Villa nueva de balcarrota y hijo de alonso xaramillo y de mencia de matos y quel dicho su padre sirvio a su magestad en las conquistas de tierra firme y la española y que el paso a esta nueva españa con el marques del valle y se hallo en la toma desta çibdad y en las Conquistas desta nueba españa y provinçias della que declara y del rrio de grijalva y guaxaca y panuco y honduras y en rrenumeraçion de sus servicios le fue encomendado el pueblo de xilotepeq y esta adeudado y destruido y ques casado y tiene su casa poblada con sus armas y muchos cavallos y familia.

\section{Francisco Montaño. ${ }^{\circ}$}

Dize que es natural de alaejos e casado e tiene su muger e hijos alla en çiudad rrodrigo es hijo de fulano descobar que paso a estas partes con el marques del valle la primera vez e que primero vino a descubrir esta tierra con grijalva que se hallo en la conquista desta çiudad y otras partes desta nueba españa a que en rrenumeraçion de sus servicios le dio el marques a esmiquilpa e a otros pueblos e sin causa se los quitaron por absençia e que esta pobre.

\section{Juan Davila. ${ }^{\mathrm{d}}$}

Dize ques natural de la çiudad de avila e hijo legitimo de pedro martyr causino y de ysabel gutierrez y que paso a esta nueva españa con panfilo de narvaez y se hallo en la toma y pacificaçion desta çiudad de mexico $\mathrm{y}$ en otras provinçias que se conquistaron antes que ella y en panuco y a dado armas y cavallos a personas que an ydo a servir a su magestad y que a nueva Años que se caso con hija de joan de cuellar berdugo y tiene un hijo y una hija legitimos y sienpre a tenido su casa poblada dando en ella de comer a muchos pobres e con armas e cavallos en servicio de su magestad y que tiene en encomienda el pueblo de chiguantla por çedula del thesorero estrada cuyo traslado firmado del secretario esta con esta.

a A. G. I., 87-5-I. Hernando Cortés was the first Marqués del Valle de Oaxaca.

b A copy of this document is in Revista de Archivos, Bibliotecas, y Museos, tercera época, año XXI., Enero-Febrero de I9I7 (Madrid, 1917), p. 42I.

- A copy of this document is in Revista de Archivos, Bibliotecas, y Museos, tercera época, año XXI., Enero-Febrero de 1917, p. 430.

d A copy of this document is in Revista de Archivos, Bibliotecas, y Museos, tercera época, año XXI., Julio-Agosto de I9I7 (Madrid, I9I7), pp. I24-I25. 
True reports concerning persons who took part in the conquest of New Spain and the City of Mexico, who went thither with the Marques del Valle.

Juan Xaramillo, deceased.

He says that he is a resident of this city and a native of Villanueva de Balcarrota, son of Alonzo Xaramillo and Mencia de Matos. His father served his Majesty in the conquests of Tierra Firme and La Española; he himself went to New Spain with the Marqués del Valle [Cortés], and was present at the taking of this city. He also took part in the conquests of New Spain and its provinces, as he declares, and in those of the Río de Grijalva, Oaxaca, Pánuco, and Honduras. In remuneration of his services he was given in encomienda the town of Xilotepec. $\mathrm{He}$ is in debt and ruined; is married, has his home established, his arms, many horses, and a family.

\section{Francisco Montaño.}

He says that he is a native of Alaejos, and married, having a wife and children in Ciudad Rodrigo; he is a son of one Escobar who came to these parts with the first expedition of the Marqués del Valle. He says that he first came to explore this land with Grijalva; that he took part in the conquest of this city and other parts of New Spain, and that in renumeration of his services the Marqués gave him Esmiquilpa and other towns, but these were taken from him without cause; and that he is poor.

\section{Juan Dávila.}

He says that he is a native of the city of Ávila, legitimate son of Pedro Martyr Causino and Ysabel Gutiérrez; that he came to this New Spain with Pánfilo de Narváez; he was present at the taking and pacification of this City of Mexico, and took part in the conquest of other provinces taken previously, as well as in that of Pánuco. He has given arms and horses to persons who have gone into his Majesty's service. Nine years ago he married a daughter of Juan de Cuellar Verdugo, and has a legitimate son and daughter. His house has always been well filled and he has fed many poor within it; he has served his Majesty with arms and horses. He holds in encomienda the town of Chiguantla under a cédula by the treasurer Estreda, a copy of which, signed by the secretary, is herewith enclosed.

\section{Antonio de CARbajal.}

He says that he is a resident and regidor of this City of Mexico, a native of Zamora, and a legitimate son of Pedro González de Carbajal and Ysabel Delgadillo. Twenty-eight years ago he came to these parts, and twenty-six years ago to New Spain in company with a nephew who died 


\section{Antonio de Carvajal.}

Dize que es vezino y rregidor desta çiudad de mexico y natural de la de çamora e hijo legitimo de pedro gonçalez de carvajal y de ysabel delgadillo y que ha veynte y ocho años que paso a estas partes y veynte y seys que paso a esta nueva españa el y un sobrino suyo el qual murio en el çerco desta çiudad y fue uno de los capitanes nonbrados para los bergantines y se hallo en la conquista y toma desta dicha çiudad y despues en las de panuco y tututepec y costa de la mar del sur y fue visitador de algunas provinçias desta nueva españa y destruyo los ydoles y cues y que fue por procurador desta tierra a los rreynos de castilla de donde vino casado y tiene ocho hijas e un hijo y entre ellas algunas de hedad para casar y fue alcalde hordinario en esta çiudad y en ella tiene su casa poblada con sus armas y cavallos y famylia y tiene en encomienda el pueblo de çacatlan de cuya tasaçion haze presententaçion [ $\mathrm{sic}]$.

\section{Joan Aleman.}

Es vezino de los angeles y natural de la çiudad de hocenploçe que es en alemanya e hijo legitimo de hanes gelique e de margarita bergrier e que se hallo en la prision del rrey de françia y despues en la guerra de vaneçuela y santa marta y despues fue a la florida en busca de la gente que llevo panfilo de narvaez y nonbra los capitanes con quien dize que anduvo e que a dezisiete años que paso a esta nueva españa e ques casado con muger que fue de francisco de quebedo conquistador della y desta ciudad el qual tovo en encomyenda el pueblo de xilotepec que al presente tiene xaramyllo y se lo quito el marques sin causa alguna y que tiene çedula de su magestad para que vuestra señoria ylustrisima lo provea de un corregimiento de lo qual vuestra señoria le a hecho merced.

\section{El GOVERNADOR FranCISCO}

\section{VAzQUez de CoRonado.}

Dize que es natural de la ciudad de salamanca hijo legitimo de joan vasquez de coronado e de doña ysabel de luxan su muger y que es cavallero notorio y paso en estas partes con vuestra señoria ylustrisima el año de treinta y cinco que a zervido a su magestad por mandado de vuestra señoria por visitador de las mynas de la plata y en el cargo de governador e capitan general de la nueva galizia de que dio suficiente quenta de la fidelidad con que huso los cargos segun que paresçe por su rresidencia e que sirvio de capitan general en el exercito que vuestra señoria enbio por mandado de su magestad al descubrimiento de la tierra nueva e que en la jornada gasto pasados de çinquenta myll ducados y paso muchos e yntolerables trabajos como es notorio de mucho rriesgo peligro e trabajos e derramamyento de sangre e que guardo en todo las ynstruçiones que su magestad manda a los que llevan semejantes cargos sin esçeder como consta por las ynformaçiones que dello tiene dados e que a doze años que es casado con doña beatriz destrada hija del thesorero alonso destrada y que tiene hijos e hijas en cantidad suplica atento a lo mucho que a servido 
in the siege of this city. He was one of the captains appointed to command the brigantines $;^{1}$ he took part in the conquest and capture of this city, was later at Pánuco, Tututepec, and on the shore of the South Sea. He was also visitor of certain provinces of New Spain, and destroyed the idols and cues. He went to the kingdoms of Castile as proctor for this land, returning thence married. He has eight daughters and a son; some of the daughters are of marriageable age. He was alcalde ordinario of this city in which he has a house erected; he has his arms and horses and family, and holds in encomienda the town of Zacatlán to the value of which he presents attestation.

\section{Juan Alemán. ${ }^{2}$}

$\mathrm{He}$ is a resident of Los Ángeles, native of the city of Hozenploce in Germany, legitimate son of Hans Gelique and Margarita Bergrier. He was once a prisoner of the king of France, ${ }^{3}$ and was later in the war of Venezuela ${ }^{4}$ and Santa Marta. ${ }^{5}$ Later, he went to Florida in search of the men whom Pánfilo de Narváez took thither. He names the captains with whom he says he served, and states that he came to this New Spain seventeen years ago. He is married to the former wife of Francisco de Quevedo, a conqueror of New Spain and of this city who held in encomienda the town of Xilotepec now held by Xaramillo. This encomienda the Marqués took from Quevedo for no reason whatsoever, but he holds a cédula from his Majesty ordering your illustrious lordship to appoint him to a corregimiento, which your lordship has done.

\section{Governor Francisco VÁsouez de Coronado.}

He says that he is a native of the city of Salamanca, legitimate son of Juan Vásquez de Coronado and Doña Ysabel de Luxán his wife; he is a famous knight, who came to these parts with your lordship in $\mathrm{I} 535,{ }^{\circ}$ and has served his Majesty under your lordship's orders as visitor of the silver mines, and in the position of governor and captain-general of Nueva Galicia. He gave adequate account of the fidelity with which he discharged his duties as appears in his residencia. He served as captaingeneral of the army which your lordship sent at his Majesty's command for the discovery of the new land. ${ }^{7}$ On this expedition he expended more than fifty thousand ducats, and underwent numerous and intolerable labors, as is well known, enduring great risks, hardships, and shedding of blood. He observed absolutely the instructions which his Majesty gives to those who hold similar positions, committing no abuse, as appears from the reports which he has given of the matter. He has been married twelve years to Doña Beatriz de Estrada, daughter of the treasurer Alonzo de Estrada, and has numerous sons and daughters. He asks, in recognition of his great services to his Majesty, the dignity of his employments, and his personal qualifications, as well as of the fact that he cannot subsist with the Indians which he has, that he be granted some remuneration and an increase in his repartimiento. He presents an order and command herewith enclosed. 
e a la dinydad ${ }^{\bullet}$ de los cargos e a la calidad de su persona e a que no se puede sustentar con los yndios que tiene se le haga merced de le rremunerar e Acreçentar en el rrepartimiento y haze presentaçion de çierta executoria e mandamyento en ella ynsertos.

\section{Alonzo Davila.}

Dize que es hijo legitimo de gil gonçalez de avila y de doña leonor de alvarado e que los parientes de la dicha su madre fueron de los primeros conquistadores desta nueva espãna en la qual sirvieron muy bien a su magestad y tuvieron cargos y titulos y quel dicho su padre syrvio en estas partes A su magestad mas de treinta años por que vino por capitan de garay y sirvio en las conquistas de panuco e honduras y primero avia servido en tierra firme con pedrarias y cuba y que su tio alonso davila sirvio ansy mesmo en las conquistas desta nueva españa y fue la segunda persona della y por que todo dize que es notorio A vuestra señoria Yllustrisima se lo rremite e que el dicho su tio llevando desta tierra çierto presente A su magestad e yendo a otras cosas fue preso por los françeses $\mathrm{y}$ estovo mucho tiempo en prision y que los pueblos que tenia en encomyenda se los dio a su padre por averle casado y que siempre fue persona muy prinçipal.

\section{Alonso de Castañeda.}

Dize que es vezino de cospotela ${ }^{f}$ natural de el Valle de toranço que es en la montaña e hijo legitimo de joan rrodriguez y de teresa hernandez castañeda e que abra beynte años que paso A esta partes en conpañya de panfilo de narvaez en demanda de la florida donde anduvo y estuvo hasta que el armada se desbarato de donde bino a esta nueba españa y fue con nuño de guzman a la conquista de los temibles chichimecas donde sienpre a estado y servido en lo que se a ofresçido con sus armas y cavallos y ques casado y tiene su casa poblada [de] yndios en encomyenda de muy poco provecho.

\section{Francisco de Coronado.}

Dize que es vezino de guaxaca y natural de sevilla y hijo de pedro de coronado y de ana gomez de figueroa y que ha beintidos años que paso a esta nueva españa y anduvo con luis marin en la conquista de los çipotecas de donde bino al tiempo que se fundava guaxaca y es de los primeros vezinos della y ques casado y tiene seis hijos y çinco hijas y dos sobrinas en su casa y padesçe neçesidad por no thener otra cosa para su sustentaçion sino la merced que vuestra señoria Yllustrisima en nonbre de su magestad le haze.

\section{JoAn de Beteta.}

Dize que rreside en las mynas de tasco e ques natural de la Villa de beteta y hijo legitimo de francisco probençio y de maria lopez de beteta

e Evidently a miscopy for "dignidad".

f Evidently a miscopy for "Compostela". 


\section{Alonzo Dávila.}

He says that he is a legitimate son of Gil Gonzáles de Ávila and Doña Leonor de Alvarado, and that relatives of his mother were among the first conquistadores of this New Spain, wherein they served his Majesty well, holding positions and titles. His father served his Majesty in these parts more than thirty years, for he came as a captain under Garay, served in the conquests of Pánuco and Honduras, having first served in Tierra Firme under Pedrarias and in Cuba. His uncle Alonzo Dávila served also in the conquests of this New Spain in which he was second in rank. Inasmuch as all that he says is well known to your illustrious lordship, the remainder is omitted. His uncle, carrying from this land a certain present for his Majesty, and going also for other purposes, was taken prisoner by the French and was a long time in prison. ${ }^{8}$ The towns which he held in encomienda were given to his father when he was married; he was always an important person.

\section{Alonso de Castañeda.}

He says that he is a resident of Compostela, native of the Valle de Toranzo in La Montaña, legitimate son of Juan Rodríguez and Teresa Hernández Castañeda, and came to these parts about twenty years ago in company with Pánfilo de Narváez bound for Florida, where he was and remained until the fleet was destroyed. Thence he came to New Spain and was with Nuño de Guzmán in the conquest of the terrible Chichimecas. $^{9}$ Here he has remained and served as occasion offered with his arms and horses. He is married, has a home established, and Indians in encomienda, from which he derives scant benefit.

\section{Francisco de Coronado.}

He says that he is a resident of Oaxaca, native af Seville, son of Pedro de Coronado and Ana Gómez de Figueroa, and came to this New Spain twenty-two years ago. He was with Luís Marín ${ }^{10}$ during the conquest of the Zipotecas; thence he returned at the time of the founding of Oaxaca, of which he is one of the first settlers. He is married and has six sons, five daughters, and two nieces in his house, and is in want because he has nothing for his subsistence other than the grant which your lordship makes to him in the name of his Majesty.

\section{JuAn de Beteta.}

He says that he resides in the mines of Tasco, is a native of the villa de Beteta, legitimate son of Francisco Probencio and María López de Beteta, and that it is nine years since he came to this New Spain and went to Cíbola. He is married and has always maintained arms and horses; his father is serving his Majesty as a man-at-arms.

\section{Juan Rodríguez Francés.}

He says that he is a native of Bejar del Castañar, lives in Tasco, is a legitimate son of Francisco Rodríguez Francés and Leonor Muñiz; it is 
que ha nueve años que paso A esta nueva españa y fue a çibola y ques casado y siempre a sustentado armas y cavallos y quel dicho su padre sirve a su magestad de onbre de armas.

\section{Joan Rrodriguez Françeses.}

Dize ques natural de bejar del castañar y que rreside en tasco e hijo legitimo de francisco Rodriguez françes y de leonor muñiz e que ha dezisiete años que paso a esta nueva españa y con don luis de castilla a jalisco con sus armas y cavallos y despues con diego hurtado en descubrimyento de la mar del sur y despues con el marques a la california donde perdio quanto tenia e ques casado e nunca se le a hecho ninguna merced.

\section{Anton Perez Buscavida.}

Dize ques vezino de conpostela y natural de la Villa de conyl que es del duque de medina sidonya hijo legitimo de alonso perez rrecio e de joana gonçalez e que a que paso a esta nueva españa doze años los diez. de los quales a rresidido en la nueva galizia y que fue a çibola con francisco Vazquez y tiene cospostela un poblezuelo que tenia çinquenta personas muy pobres que no bastan a darle de comer y esta pobre y es casado y tiene su muger y casa poblada.

\section{Pedro de Ledesma.}

Dize ques vezino de guadalajara y no declara de donde es natural ny cuyo hijo e que paso a esta nueva españa en el navio que vuestra señoria Yllustrisima bino y fue á la tierra nueva de çibola donde gasto y se adeudo en mucha cantidad y ques casado con hija de melchior perez la qual tiene en encomyenda el pueblo de cuyupuztlan el qual es tan poca cosa como vuestra señoria Yllustrisima lo podra aver por la visita que hizo el electo de jalisco.

\section{JoAN DE ARze.}

Dize ques vezino de conpostela y natural del valle de buelna que es en las montañas de santander e hijo legitimo de hernando de arze y de doña joana de bustamante y quel dicho su padre y sus Abuelos sirbieron a la corona rreal en las guerras de granada e que a diez años que paso a esta nueva españa y se halló en la ultima pacificaçion de la nueva galizia con sus armas y cavallo y que tiene en encomyenda por francisco Vazquez coronado unos yndios serranos yndomitos que no le dan ninguna cosa por lo qual padesçe neçesidad.

\section{Francisco Destrada.}

Dize ques vezino de guadalajara y natural de santo domingo de la calçada y hijo legitimo de antonyo destrada y de doña maria de vallejo y que a veynte tres años que paso A esta nueva españa y fue con el capitan Juan Ruiz de Villa fuerte a la conquista de los yopelgugos y despues de los chontales por lo qual le fue encomendado el pueblo de malcaltepec en guaxaca el qual le fue quitado a pedimyento del marques por ser subjecto a teguantepec e que agora tiene unos yndios en la nueba galizia que le 
seventeen years since he came to this New Spain and went to Jalisco with Don Luís de Castilla ${ }^{11}$ with his arms and horses. Later he was with Diego Hurtado in his discoveries on the South Sea, and went also with the Marquis to California, ${ }^{12}$ where he lost all that he had. He is married, and never has received any favor.

\section{Anton PÉrez Buscavida.}

He says that he is a resident of Compostela, native of the villa de Conyl on the estate of the Duke of Medina Sidonia, legitimate son of Alonso Pérez Recio and Juana González, and came to this New Spain twelve years ago, during ten of which he has resided in Nueva Galicia. He went to Cíbola with Francisco Vázquez; he holds Compostela, a small town of some fifty very poor persons who do not suffice to provide him with subsistence. He is poor, is married, and has a wife; he also has a home established.

\section{Pedro de Ledesma.}

He says that he is a resident of Guadalajara; does not declare his nativity nor parentage; he came to this New Spain in the same ship as your illustrious lordship, and went to the new land of Cíbola, where he spent a great deal and got deeply in debt; he is married to a daughter of Melchior Pérez; she holds in encomienda the town of Cuyupuztlan, which is a very small holding as your illustrious lordship may learn from the report of the visitation performed by the [bishop-] elect of Jalisco.

\section{JuAn DE ArCe.}

He says that he is a resident of Compostela, a native of the Valle de Buelna in the mountains of Santander, legitimate son of Hernando de Arce and Doña Juana de Bustamante; his father and his grandfathers served the royal crown in the wars of Granada. ${ }^{13}$ Ten years ago he came to this New Spain and took part in the final pacification of Nueva Galicia with his arms and horse. He holds in encomienda from Francisco Vázquez Coronado a few unconquered mountain Indians, who yield him no income, wherefore he suffers want.

\section{Francisco de Estrada.}

He says that he is a resident of Guadala jara, a native of Santo Domingo de la Calzada, legitimate son of Antonio de Estrada and Doña María de Vallejo. He came to this New Spain twenty-three years ago and went with Captain Juan Ruíz de Villafuerte to the conquest of the Yopelgugos and, later, to that of the Chontales. ${ }^{14}$ For these reasons he was given in encomienda the town of Malcaltepec in Oaxaca, which was taken from him at the request of the Marqués because it was subject to Tehuantepec. He now has a few Indians in Nueva Galicia, granted to him by Francisco Vázquez when they were given up by Costanza Sarmiento. He is married and has nine children; he is poor because the aforesaid Indians are poor themselves and of little profit, as will be seen from the visitation. 
deposito francisco Vazquez por dexacion de costança sarmyento y ques casado y tiene nueve hijos y es pobre porque los dichos yndios lo son Asi mysmo y de poco provecho como paresçera por la visita.

\section{Solteros y Biudos que dizen tener sus Mugeres en España.}

\section{Hernando de Alvarado.}

Dize ques natural de las montañas e hijo legitimo de joan sanchez de alvarado y de doña mençia de salazar el qual tiene la casa prinçipal y cabeça de las demas deste apellido y que a dezinueve años que paso á esta nueva españa con el marques del valle los quales $\mathrm{A}$ gastado en serviçio de su magestad en el descubrimyento primero de la mar del sur y en la jornada quel dicho marques hizo y en la jornada de çibola y por mandado del general descubrio y conquisto mas de dozientas leguas adelante en las quales descubrio las vacas en todas estas jornadas sirvio con cargos de capitan A su costa con muchos cavallos y criados sin llevar sueldo de su magestad ny de otra persona y no a sido Remunerado A cuya causa bive con necesidad.

\section{JoAN RRODRiguez.}

Dize ques natural de la Villa de alauje de estremadura e hijo legitimo de francisco garcia y de ynes sanchez e que a doze años que paso a esta nueva españa e que sirvio a su magestad tres años en la guerra de chiapa y en tavasco y fue a la tierra nueva de çibola y que esta pobre.

\section{JOAN DE CEPEDA.}

Dize que es natural de la çiudad de toledo e hijo legitimo de pedro de cepeda y de catalina alvares y que al tiempo que se descubrio el peru y el y un su hermano vendieron çierta hazienda que tenyan de su patrimonyo y pasaron a tierra firme y en el nonbre de dios andavan çiertos negros alçados en cuya pacificaçion se hallo y mataron a su hermano y que en cartajena y en santa marta sirvio a su magestad en çiertas entradas y que avre diez años que vino a esta nueva españa y fue en el armada de çibola hasta cuynacan donde quedo enfermo de donde vino con ciertos despachos a vuestra señoria Yllustrisima que se ynbiavan de çibola y mato en la jornada dos cavallos y que no tiene officio y sienpre a estado aparejado con sus armas y cavallos y que esta presto de casarse y sino lo a hecho a sido por no tener con que poderse sustentar y que esta adebdado.

El adelantado Cabeza de baca pide un caravelon que esta en el rio de Sevilla en que vino preso presenta informacion. [ [543?]

Muy poderosos Señores: Albar nuñez cabeza de baca adelantado e governador de las provincias del Rio de la plata digo que a Vuestra Alteza

8 A. G. I., I44-I-I5. 
Single Men and Widowers who say they have Wives in Spain.

\section{Hernando de Alvarado.}

He says that he is a native of La Montaña, legitimate son of Juan Sánchez de Alvarado and Doña Mencia de Salazar. His father possesses the principal house and is at the head of those of his family name. $\mathrm{He}$ came to this New Spain with the Marqués del Valle nineteen years ago, and has spent those years in the service of his Majesty in the first discovery of the South Sea, on the expedition which the said Marqués made, and on the expedition to Cíbola. By command of the general he made explorations and conquests more than two hundred leagues beyond [Cíbola]; on this expedition he ${ }^{15}$ discovered the cows [buffaloes]. On all of these expeditions he served as captain at his own expense with many horses and servants, receiving no salary from his Majesty nor from any other person, and he has not been remunerated; hence he lives in necessity.

\section{JuAN Rodríguez.}

He says that he is a native of the villa de Alauje in Estremadura, is a legitimate son of Francisco García and Inez Sánchez. He came to this New Spain twelve years ago, served his Majesty three years in the war of Chiapa and in Tabasco; he went to the new land of Cíbola, and is poor.

\section{Juan de Cepeda.}

He says that he is a native of the city of Toledo, and a legitimate son of Pedro de Cepeda and Catalina Álvarez. At the time of the discovery of Peru, he and one of his brothers sold a certain farm which they held as their patrimony, and went to Tierra Firme. In Nombre de Dios ${ }^{16}$ there were a number of negroes in insurrection. They took part in the pacification of these negroes, his brother being killed by them. He served his Majesty in Cartagena ${ }^{17}$ and Santa Marta ${ }^{18}$ in a number of expeditions. Ten years or so ago he came to New Spain, and went on the fleet of the Cíbola expedition ${ }^{19}$ as far as Culiacán, where he fell ill. Thence he returned with some despatches for your illustrious lordship which had been sent from Cíbola. On this journey he killed two horses. He has no office, but has always maintained himself equipped with his own arms and horses. He is ready to marry, though he has not done so because he has nothing on which to subsist; he is in debt.

Governor Cabeza de Vaca asks for a brigantine which is in the River of Seville and in which he came as a prisoner. He offers evidence. [ I543 ?]

Most powerful sirs: I, Alvar Núñez Cabeza de Vaca, chief and governor ${ }^{20}$ of the provinces of the River de la Plata, declare that as your Highness has been informed through the proceedings and acts presented in 
a constado por procesos y terminos presentados en vuestro Real consejo de yndias como al tienpo que se levantaron contra mi en la dicha provincia del Rio de la plata todos los oficiales de vuestra magestad e otras personas particulares me tomaron todos mys bienes e me metieron en un caravelon que se nombra san marcos que tenia hecho con otros navios para yr por el Rio ariva e me truxejon a estos Reynos sin darme cosa alguna de los bienes que me tomaron y el dicho caravelon se quedo en el Rio de Guadilquebir donde a estado y esta e porque aquel es myo como paresca por esta informacion que presento, pido y suplico a vuestra alteza mande dar su cedula para que me sea entregado que pueda disponer a mi voluntad pues no tengo que comer ni que gastar para lo qual.

[Hay una rubrica.]

\section{Al Señor licenciado Sandoval \\ Venga al consejo.}

Probanza de servicios y meritos de Gregorio de Villalobos, uno de los primeros descubridores y conquistadores de Nueva España: seis meses antes que Hernan Cortez ganase a Mexico, donde fue el primero (Villalobos) que entro ganado vacuno para su cria. Mexico 22 Octubre, I554. ${ }^{h}$

(Folio 2) . . . Pregunta 2-que el dicho Gregorio de Villalobos paso a esta parte de la nueva españa por el año de mill y quinientos $E$ veinte $E$ uno con sus armas e cavallo para servir a su magestad y llego seis antes de la toma é conquista de mexico (de la ciudad) El qual por mandado del marquez del Valle governador a la sasson que era se quedo en la costa del norte con cierta cantidad de gente que estubo en guarnicion de la costa. ...

Pregunta 3-que despues de apaciguada la dicha ciudad de mexico E1 dicho marquez del Valle tenyendo entendido que el dicho gregorio de Villalobos Era persona muy honrada é de toda confianza le dio cargos preheminentes en la dicha cibdad de la Vera cruz que otro nombre se llamava Quisahuistlan y le hizo tiniente de governador . . . y con los dichos cargos hizo gran servicio a dios nuestro señor y a su magestad rrecogiendo la gente española que a la sazon vinieron de las yslas de cuba y Santo domingo y otras partes abrigandolos y haciendolos curar de enfermedades. . . .

Pregunta 4-que despues de pacificado la ciudad de mexico y las demas provincias desta nueva españa el dicho gregorio de Villalobos con intento de permanecer en ella al tiempo que passo de las yslas de santo domingo ttruxo contidad de bezerras para que oviese ganado y fue el primero que las truxo y passo a la nueva españa. ${ }^{1}$

b A. G. I., I-2-7/27.

1 F. R. B., Sevilla. 
your royal Council of the Indies, at the time when all the officials of your Majesty rose against me in the said province of the River de la Plata, they and other private persons took all my goods and put me in a brigantine named the San Marcos, which I had made with other vessels to go up the river, and brought me to these kingdoms without giving me any of the goods that they took from me. The said brigantine stopped in the Guadalquivir River, where it has been and is, and as it is mine, as appears by this evidence which I present, I ask and supplicate that your Highness order your decree to be given that it shall be delivered to me to dispose of as I wish, for I have nothing to eat nor means to get it.

[There is a rubric.]

To the señor licentiate Sandoval, Come to the council.

Evidence of the services and merits of Gregorio de Villalobos, one of the first explorers and conquerors of New Spain-six months before Hernán Cortés captured Mexico-where he (Villalobos) was the first to bring in cattle for breeding purposes. Mexico, October 22, 1554.

Question 2.-That the said Gregorio de Villalobos went to this part of New Spain in the year I52I, armed and mounted, in order to serve his Majesty, and arrived six months before the capture and conquest of Mexico. By order of the Marqués del Valle, ${ }^{21}$ who was governor at that time, he remained on the northern coast with a certain number of soldiers as garrison for the coast. . . .

Question 3.-That after the pacification of the City of Mexico, the Marqués del Valle, having heard that Gregorio de Villalobos was an honest man and worthy of confidence, gave him very important offices in the city of Vera Cruz, called also by the name of Quisahuistlan, and made him lieutenant governor. . . . In the said offices he rendered great service to God, our Lord, and to his Majesty, by assembling the Spaniards who came at that time from the islands of Cuba and Santo Domingo and other parts and sheltering them, and ministering to their ailments. . . .

Question 4.-That after the pacification of the City of Mexico and the other provinces of this New Spain, the said Gregorio de Villalobos, with the intention of remaining in it permanently, at the time that he came from the islands of Santo Domingo brought a number of calves, so that there might be cattle, he being the first to bring them to New Spain. 
Ynformacion de los servicios hechos por Cristoval Mendez, con el Gobernador Cristobal De oñate y con el Capitan Francisco Vasquez Coronado, en la conquista del golfo dulce de Valençuela, Civola, y Jalisco, á su costa con armas y caballo, por los años de I538 [-I54I], en las que recibio varias heridas. ${ }^{j}$

En la gran ciudad de temistitan mexico de la nueva españa en Siete dias del mes de nobiembre de mill y quinientos y cinquenta y nueve años estando los señores presidente e oydores del audiencia rreal de la nueva españa en el acuerdo, Y por presencia de mi Antonio de Turcios escrivano maior de la dicha real audiencia y governacion della por su magestad parecio presente Cristoval Mendez, Vezino desta ciudad Y traxo Y presento Una peticion y un ynterrogatorio de preguntas El tenor de lo qual es el que se sigue.

Muy poderosos señores. Cristoval mendez digo que treinta $\mathrm{Y} U \mathrm{Un}$ años y mas que yo bine de los rreinos de Castilla A estas partes de Yndias en el armada que vino por capitan general don pedro de Alvarado Adonde Vinieron los oydores Matienço y Delgadillo Y la dicha Armada llegó al puerto de Santo Domingo adonde estava una armada para yr A conquistar El golfo dulze de balenzuela y en la dicha armada fue por soldado y en la conquista padecio muy grandes travajos, heridas en mi persona y hambre y muchos trabajos. $\mathrm{Y}$ a mas de veynte y ocho años que bine $\mathrm{A}$ esta nueva españa $E$ yendo $A$ la conquista de cibola en seguimiento del capitan francisco Velazque ${ }^{\mathrm{k}}$ de coronado Y llegue a Xalisco al tiempo que los yndios se alçavan $\mathrm{E}$ rrevelavan. Recogio la gente que pudo $\mathrm{E}$ yo me junte con el con mis armas y cavallo y el dicho Cristoval de Oñate con la gente fue sobre un peñol que se dize el miston ${ }^{1}$ adonde estavan muchos yndios rrebelados $\mathrm{Y}$ el dicho Cristoval de oñate con la gente peleando con los Yndios no los pudo vencer, y en la pelea murieron muchos españoles e negros $\mathrm{E}$ yndios que yban con el dicho Cristoval de Oñate y en su favor $\mathrm{E}$ yo fui mas malamente herido de muchas heridas $\mathrm{Y}$ los dichos Yndios vinyeron Sobre el dicho Cristoval de oñate. Y los que con el estavamos $\mathrm{Y}$ mataron mucha gente $\mathrm{Y}$ nos desbarataron y Robaron quanto teniamos e venimos A la villa de guadalaxara y nos fué forçoso rretraernos A guadalaxara adonde llegamos con muy gran travaxo. Y a la sason don pedro de alvarado estava en las provincias de avalos con Gente de armada para yr a la especeria y aviendo venydo a su noticia el estrago que los Yndios avian hecho vino en Socorro del dicho Cristoval de oñate y aviendose Juntado toda la gente que se pudo aver el dicho don pedro de alvarado, y Cristoval de oñate, y miguel de Ybarra $Y$ don luis del Castillo y Juan de alvarado Capitanes fueron sobre un peñol de Nochistlan donde estavan muchos yndios Alçados y Revelados y aviendo conbatido la Gente del Peñol mataron a estos españoles $\mathrm{E}$ yo muy malamente herido en el Conbate e visto por los dichos capitanes la gran fuerza y poder de los Yndios se rretruxieron para se bolver a guadalaxara y los dichos Yndios

j A. G. I., I-3-10/I.

k Vázquez.

1 Mixton. 
Evidence submitted with regard to the services performed by Cristóbal Méndez, with Governor Cristóbal de Oñate and with Captain Francisco Vásquez Coronado. During the years 1538 [-154I], at his own expense, armed and mounted, he served in the conquest of Golfo Dulce de Valenzuela, Cibola, and Jalisco. In the campaigns he received divers wounds.

In the great city of Temistitán, ${ }^{22}$ Mexico, in New Spain, on the seventh day of November, I559, the president and oidores of the royal Audiencia of New Spain having met in regular session, Cristóbal Méndez, resident of this city, appeared before me, Antonio de Turcios, chief clerk for his Majesty of the royal Audiencia and government of New Spain. $\mathrm{He}$ brought with him and presented a petition and an interrogatory, the purport of which is as follows:

Most powerful sirs:

I, Cristóbal Méndez, affirm that it is more than thirty-one years since I came, in the fleet commanded by Captain-general Don Pedro de Alvarado, from the kingdoms of Castile to these parts of the Indies, ${ }^{23}$ where came the oidores, Matienzo and Delgadillo. The said fleet went to the port of Santo Domingo, where there was a fleet ready to sail for the conquest of Golfo Dulce de Valenzuela. ${ }^{24} \mathrm{He}$ [I] went as a soldier in the latter fleet, and in the conquest I experienced great hardships-wounds in my body, hunger, and many troubles. More than twenty-eight years ago I came to New Spain. On my way to the conquest of Cíbola, in the wake of Captain Francisco Vázquez de Coronado, I arrived at Jalisco at the time when the Indians rose in rebellion. $\mathrm{He}^{25}$ collected all the troops that he could and I joined him with my arms and horses. The said Cristóbal de Oñate ${ }^{26}$ marched with the soldiers to a large rock called El Mixton, where many of the Indian rebels had gathered, but though he and his men fought with the Indians they could not conquer them. In the battle many Spaniards, negroes, and Indians who accompanied Cristóbal de Oñate, and gave him their support, were killed and I received many serious wounds. The Indians fell upon Cristóbal de Oñate and those of us who were with him, killed many people, routed us and robbed us of all that we had. We came to the villa of Guadalajara, to which place it was necessary for us to retreat, but we reached there with great difficulty. At that time Don Pedro de Alvarado was in the provinces of Avalos ${ }^{27}$ with a force ready to sail to the Spice Islands. Having learned of the havoc the Indians had wrought, he came to the aid of Cristóbal de Oñate. As soon as all the available soldiers were assembled, Captains Don Pedro de Alvarado, Cristóbal de Oñate, Miguel de Ybarra, Don Luís del Castillo, and Juan de Alvarado marched to the large rock of Nochistlan, where were many Indian rebels. In the battle which ensued the people on the rock killed these Spaniards, and I was very badly wounded. The captains, seeing the great force and strength of the Indians, withdrew, in order to effect a retreat to Guadalajara. Thereupon the Indians took the offensive against the Spaniards, at whom they shot arrows; horses and soldiers were killed, and we were robbed of all that we had. In a pass the horse on 
dieron sobre la gente de los españoles flechandolos y matando los cavallos y gente y Robandonos quanto teniamos en un paso rrodo el cavallo en que Yba don pedro de alvarado el qual murio y con muy gran trabajo llegamos a guadalaxara A donde los Yndios nos quemaron la yglesia y nos rrobaron todo quanto teniamos y nos fue forçado hacernos fuertes en una casa Adonde padecimos muy gran trabajo $\mathrm{Y}$ fue tanto el conjunto de los yndios que fue necessario que el muy excellente visorrey don antonio de mendoça fuese como fue con muy gran exercito de gente A conquistar y apaciguar los yndios lo qual se hizo con mucho trabajo y peligro y muertes de españoles y de yndios que con el fueron y en la guerra que hobo yo fui muy malamente herido y especialmente en la cabeza de que quede muy malo y muy enfermo en tanta manera que continuamente tengo baguidos y dolores de cabaza que todo me procedio de las heridas. . . .

[ $Y$ pide se le haga merced de un repartimiento de Yndios, etc.-F. R. B.]

Ynformacion Recibida en la audiencia rreal de la nueva españa, $A$ pedimento de Johan de Paladinas. Ba ante Su Magestad. ${ }^{m}$ [I560.]

Sacra Catolica Real Magestad. A Pedimiento de Johan de paladinas Se rrescibio En esta rreal audiencia ynformacion sobre el tienpo, que A que esta en esta tierra, y como a Servydo a Vuestra Magestad en lo que se a ofrecido especialmente en la Jornada de Cibola para con ella ocurrir ante Vuestra Magestad y suplicar le haga merced de algun corregimiento o cavalleria de tierras y otras cosas con que se pueda sustentar, demas de la ynformacion que de su pedimiento Se rrecibió. Se tomo esta de oficio por la qual paresce que Johan de Paladinas A mas de veynte E cinco Años que esta en esta tierra y que fue a la provincia de cibola, en servycio de Vuestra magestad con el governador Francisco Vazquez de coronado y que sirbio en la Jornada en lo que fue mandado y su muger a uno cargo de curar los enfermos y hazer otras obras buenas bive al presente en esta ciudad, y husa su oficio de sastre y questa pobree podra se le hazer la merced que Vuestra Magestad fuere servydo.

\section{El doctor HoRosco; Doctor vasCo DE PUGA.}

[Otras firmas illegibles.-F. R. B.]

En la ciudad de Mexico Seiss dias del mes de Junio de mill y quinientos y sesenta Años. El muy magnifico señor doctor puga oydor por su magestad en el audiencia Real de esta nueva españa y en presencia de mi, Agustin pinto escrivano de su magestad de officio hizo parescer ante si A Joan gomez de salazar vezino de esta ciudad del qual su merced tomo E rrescibio juramento ... dixo que lo que de este caso sabe es que puede aber veinte años antes mas que menos que en esta ciudad se mando hazer la Jornada para cibola en la qual este testigo fue con francisco basquez coronado $\mathrm{E}$ andubo en toda ella $\mathrm{E}$ de esta ciudad ansi mismo salio Juan de Paladinas con el dicho general e llebo sus armas E cavallos $\mathrm{E}$ criados $\mathrm{E}$ adereços de su persona a su costa y en la dicha Jornada sirbio

m A. G. I., I-3-Io/I. 
which Don Pedro de Alvarado was riding fell, and he was killed. With great difficulty we reached Guadalajara, where the Indians burned the church, robbed us of all that we had and compelled us to fortify ourselves in a house, where we endured great hardships. The gathering of Indians was so large that it was necessary for his Excellency, the viceroy, Don Antonio de Mendoza, to go, as he did, with a very large army to conquer and pacify them. This was accomplished at the expense of much trouble and danger, and the lives of Spaniards and Indians who went with him. In the fighting that took place I was very badly wounded, especially in the head. As a result I was left so very weak and ill that I constantly have vertigoes and pains in the head, all of which are caused by my wounds. ...

[And he asks that he be granted an allotment of Indians, etc.-F. R. B.]

Evidence received in the royal Audiencia of New Spain, on petition of Juan de Paladinas; it goes before his Majesty. [1560.]

Sacred Catholic Imperial Majesty. On petition of Juan de Paladinas, evidence was received in this royal Audiencia as to the time he has been in this country and how he has served your Majesty whenever an opportunity has offered-especially in the expedition to Cíbola-so that he might apply with it to your Majesty and beg that he be favored with some office or tract of land and other things with which he may support himself. Besides the evidence which was received upon his petition, this was taken officially, by which it appears that Juan de Paladinas has been in this country more than twenty-five years; that he was in the province of Cíbola in the service of your Majesty with Governor Francisco Vásquez de Coronado; and that on the expedition he served in the office given to him and his wife of caring for the sick and doing other good works. He lives at present in this city by the exercise of his trade as tailor. Since he is poor perhaps your Majesty will be pleased to grant him the favor.

\section{Doctor HorosCo-Doctor VASCO DE PUGA. ${ }^{28}$}

[Other signatures illegible.-F. R. B.]

In the City of Mexico, the sixth day of June, I 560 , the right honorable Doctor Puga, his Majesty's oidor in the royal Audiencia of New Spain, caused to appear before him in the presence of myself, Agustín Pinto, official clerk for his Majesty, Juan Gómez de Salazar, resident of this city, from whom his Grace took and received the oath. . . . He said that what he knows about the matter is that it may be twenty years ago-rather more than less-that the expedition was ordered in this city to go to Cíbola, and that this witness went with Francisco Vásquez Coronado and travelled all through the expedition. At the same time Juan de Paladinas went from this city with the said general, taking his arms, horses, servants, and personal equipment at his own expense, and served well on the expedition, like a good soldier, and in everything that he was ordered and 
bien como buen soldado y en todo lo que se le encargava y mandava $\mathrm{E}$ dio de todo buena quenta $\mathrm{E}$ por la buena Relacion y conceto que se tenia y hubo en la dicha Jornada dicho Juan de paladinas El general francisco vasquez le hizo alguacil del campo en lo qual sirvio a su magestad muy bien $\mathrm{E}$ padescio muchos trabajos hanbres $\mathrm{E}$ nescesidades hasta que bolbio el general a esta ciudad de mexico . . . y bio que maria maldonado, mujer del dicho Juan de Paladinas fue ansimismo en la dicha jornada, $\mathrm{E}$ con toda Voluntad la susodicha curaba y curo a los enfermos del dicho exercito $\mathrm{E}$ los cosia $\mathrm{E}$ remendava lo mejor que podia $\mathrm{E}$ hizo otras muchas obras buenas a los soldados del campo donde ansimismo padescio otros muchos trabajos. . . .

Testigo: Pedro nieto [folio 2] . . . y vido que por ser el dicho Juan de Paladinas onbre muy onrrado y para mucho tenian quenta con el y se le encargavan cosas del exercito $E$ siempre iba por delante y trabajo en ello muy mucho y tanto como seis onbres de los que iban en el dicho exercito. ... ${ }^{\mathrm{n}}$

Probanza de los meritos y servicios de Juan de Cespedes en el Descubrimiento y conquista de la tierra nueba de Cibola, adonde fue con el Adelantado Francisco Vazquez Coronado, y en el levantamiento de nueba españa. Mexico a IO de Enero, I568.

I. Sacra Catolica Real Magestad. Y el capitan Joan de cespedes dize que a mas de treynta Años que sirve a Vuestra Magestad en la nueva españa desde que fueron governadores de ella don Antonio de Mendoça y don Luys de Velasco y despues la rreal Audiencia y despues el marques de falces y despues el licenciado Alonso muñoz y doctor luys carillo de vuestro rreal consejo y don Martin Enrriquez que Al presente govierna por Vuestra Magestad hasta este Año de Setenta y cinco y A servydo En todas las ocasiones que se an ofrecido en Aquella tierra hasta lo tocante Al Alzamiento y Revelion que Sucedio en ella en todo el qual dicho tiempo A servido a Vuestra Magestad de ser Vuestro capitan gobernador como Vuestro corregidor y Alcalde mayor en las mejores y mas principales provincias del dicho Reyno Asi en ciudades de españoles como de los naturales haziendose de su persona la confianza que se requeria como todo mas largamente consta y parece por las ynformaciones y probanzas que tiene hechas y presentadas en la Vuestra rreal Audiencia de la nueba españa y en Vuestro rreal consejo de yndias y titulos que tiene de aber sido Vuestro capitan y Aber usado de vuestro rreal nombre los dichos cargos y oficios y Vuestro rreal consejo de yndias lo tiene mandado poner en el memorial y sus servizos y meritos An sido y son muy publicos . . . . A VII de Diziembre I 575.

n F. R. B., Sevilla.

o A. G. I., I-3-I5/6. 
charged with he gave satisfaction. On account of the good reports and opinion that he received and held of Juan de Paladinas on the expedition General Francisco Vásquez made him alguacil de campo, in which office he served his Majesty. well, and suffered much hardship, hunger, and deprivation until the general returned to this City of Mexico. . . . And he saw that María Maldonado, wife of Juan de Paladinas, also went on the expedition and most kindly ministered to the sick of the army, besides sewing and mending for them the best she could and doing many other good works for the soldiers in the field, where she on her part also suffered great hardships.

Witness: Pedro Nieto ... and he saw that because the said Juan de Paladinas was an honest man and because they placed great dependence upon him, he was charged with affairs of the army and always went ahead, working hard for it and doing as much as six of the other soldiers in the army. ...

Evidence of the merits and services of Juan de Céspedes in the exploration and conquest of the new land of Cibola, where he went with Governor Francisco Vásquez Coronado, and in the uprising in New Spain. Mexico, January I9, I568.

I. Sacred Catholic Royal Majesty. Captain Juan de Céspedes affirms that he has served your Majesty in New Spain more than thirty years, since the time when Don Antonio de Mendoza and Don Luís de Velasco were governors of it, and afterwards the royal Audiencia, afterwards the Marqués de Falces, afterwards the licentiate Alonso Muñoz, and Doctor Luís Carillo of your royal Council, and Don Martín Enríquez, ${ }^{29}$ who governs for your Majesty at present, up to this year of '75; and that he has served on all occasions that have presented themselves in that land, even in the affair of the uprising and rebellion which occurred in it. In all that time he has served your Majesty as your captain and by governing as your corregidor and alcalde mayor in the best and most important provinces in the kingdom, in Spanish cities as well as in native, winning for himself the confidence that was required. All of which appears more at length in the reports and proofs which he has made and presented in your royal Audiencia of New Spain and in your royal Council of the Indies, with the titles which he has of having been your captain and having practised in your name the said duties and offices. And your royal Council of the Indies has ordered it placed in the memorial. His services and merits have been and are very well known. . . December 7, I 575 . 
II. Sacra Catolica Real Magestad. El capitan Juan de Cespedes dize que A Vuestra Magestad dio en el pasado Un memorial y otro A los del $V$ uestro rreal Consejo de Yndias y en ellos dize como a servido A Vuestra Magestad en las yndias de la nueba españa de mas de treinta años a esta parte. Asi en el descubrimiento de otras muchas nuevas yndias como es de civola y tierra nueva y siete ciudades de que fue por capitan general francisco basquez de coronado . . . A A 30 de enero de $1576 .^{p}$

Ynformacion de los meritos y servicios del Adelantado de la Nueva Galicia, Don Tristan de Arellano. Mexico 7 de Marzo de $1575 .^{q}$

\section{Don Tristan de Luna.}

Don Tristan de Luna y arellano gobernador que a sido de la ciudad de tlaxcala en la nueba españa dize que el a servido a Vuestra Magestad el dicho officio tres años . . . . y demas de sus servicios, don Tristan de Luna y Arellano y doña Ysabel de Roxas su muger, abuelos del dicho Don Tristan fueron de los primeros pobladores y conquistadores de la Nueva España y La dicha doña Ysabel fue casada de primero matrimonio con francisco Maldonado que fue de los primeros conquistadores de la nueva españa y mas de quarenta años continuos el dicho Don Tristan su aguelo sirvio a Vuestra Magestad en todo lo que se ofrecio con muncho cuidado en especial en la Jornada que se hizo a Zibola fue nombrado por maestre de campo a donde hizo munchos y señalados servicios y ansimismo en la Jornada de la florida. . . .

Probanza de los meritos y servicios de Alonzo Rodriguez, y de Juan Rodriguez Parra su hijo descubridores y conquistadores de la provincia de Cibola con el gobernador Francisco Vazquez Coronado. . . . 23 de noviembre de 1576 .

\section{YNTERROGATORIO.}

I. Primeramente si conocen Alonzo Rodriguez E a Juan rrodriguez parra su hijo y de que tienpo A esta parte.

II. A la segunda pregunta si saven que al tienpo que articula Juan Rodriguez parra fue a la conquista de cibola el dicho Alonzo Rodriguez parra su padre En conpania Del gobernador francisco bazquez coronado no pudo ser Por ser Una Jornada por tierra tan larga De mas de seiscientas Leguas de hida é otras tantas de buelta $E$ que para hazer una jornada tan larga no tenia el dicho alonzo rrodriguez parra posibilidad para ello antes se ha de creher hiba arrimado alguna persona que le hiciese la costa $\mathrm{E}$ demas de esto se dexa entender que si su magestad o su gobernador no le

p F. R. B., Sevilla.

q A. G. I., I-3-2I/I2.

F. R. B., Sevilla. 
II. Sacred Catholic Royal Majesty. Captain Juan de Céspedes affirms that in the past he presented a memorial to your Majesty and another to those of your royal Council of the Indies, and in thern he states that he has served your Majesty in the Indies of New Spain for more than thirty years in this part, as in the exploration of many new Indies, such as Cíbola and the new land and Seven Cities, of which General Francisco de Coronado went as captain. ... January 30, 1576.

Evidence submitted of the merits and services of Don Tristán de Arellano, governor of Nueva Galicia. Mexico, March 7, 1575.

Don Tristán de Luna.

Don Tristán de Luna y Arellano, former governor of the city of Tlaxcala, in New Spain, affirms that he served your Majesty in the said office for three years. . . And besides his services, his grandparents, Don Tristán de Luna y Arellano and his wife, Doña Isabel de Roxas, were among the first settlers and conquerors of New Spain. The said Doña Isabel was previously married to Francisco Maldonado, who was among the first conquerors of New Spain. For more than forty years continuously Don Tristán, his grandfather, served your Majesty in every way that offered, and with great zeal especially in the expedition to Cíbola ${ }^{30}$ in which he was appointed maestro de campo, and where he rendered many and important services; as likewise in the expedition to Florida. . . . .

Evidence of the merits and services of Alonso Rodriguez and of Juan Rodriguez Parra, his son, explorers and conquerors of the province of Cíbola with Governor Francisco Vásquez Coronado. . . . November 23, 1576 .

\section{INTERROGATORY.}

I. First, whether they know Alonso Rodríguez and Juan Rodríguez Parra, his son, and how long they have been in this part.

II. Second, whether they know that at the time certified by Juan Rodríguez Parra that his father, Alonso Rodríguez Parra, went on the campaign to Cíbola in the company of Governor Francisco Vásquez Coronado, it could not have been so, for it was such a long journey by land, more than six hundred leagues each way going and coming and Alonso Rodríguez had not the means to make such a long journey, unless one is to believe that he went under the support of some person who paid the expense for him. Otherwise it is to be understood that if his Majesty or his governor did not aid him in the expense he could not have made the journey. Let them state what they know. 
dieran Ayuda de costa no podia El hazer la dicha Jornada digan lo que saben.

\section{Testigos.}

I. Francisco Muñoz . . . a la segunda pregunta dixo . . . que a oydo decir a muchas personas que el dicho alonzo rrodriquez parras fue aquella Jornada de cibola con francisco bazquez coronado governador que dizen fue pero no sabe fuese por soldado. . . .

II. Juan rruiz . . . á la segunda pregunta dixo . . . que save que el dicho alonzo rrodriguez parra su padre hiba por soldado de francisco basquez coronado $\mathrm{E}$ queste testigo lo bio por bista de ojos por que tanbien hiba este testigo Por soldado en la dicha Jornada E save que el dicho alonzo rrodriguez parra hiba por soldado de a pie $\mathrm{E}$ que hera de la guarda del gobernador Porque lo bio como tiene dicho $\mathrm{E}$ sabe no se le dio sueldo de su magesfad ni de su gobernador En su nombre porque si se le diera Este testigo lo supiera. . . .

III. Esteban Martin . . . preguntado por la segunda pregunta dixo ... que (este testigo) fue uno de los soldados que fueron a la conquista de cibola $Y$ este testigo le bio por soldado en la dicha conquista $E$ yendo en la dicha Jornada El dicho alonzo rrodriguez parra y este testigo juntos Le dixo a este testigo muchas vezes que en desenbarcando Sin parrar en la nueba españa se abia benido esta Jornada e que alcanzo El rreal E canpo en la villa de culiacan $E$ que Sienpre le conocio ser soldado $E$ que hera de la guarda del gobernador francisco bazquez $E$ save que fue a su costa sin sueldo de su magestad y esto lo sabe muy bien porque si otra cosa lo supiera $\mathrm{E}$ no pudiera ser menos.

IV. Alonso Albarez del balle ... que sabe que fue como soldado a su costa Por que su magestad a los soldados no les dava ayuda de costa ninguna. ... s

Ynformacion de los meritos y servicios de Francisco de Santillana, y Pedro de Santillana su hijo en la conquista de la tierra nueva y siete ciudades de Cibola con el General Francisco Vazquez Coronado. Merida de Yucatan 7 de Diciembre, I588. ${ }^{t}$

I. Maria de espinosa Santillana y ana nieto de santillana Hijas de pedro de santillana difunto Vecino que fue de la ciudad de merida de Yucatan, dicen que francisco de santillana su abuelo, y el dicho pedro de santillana su padre fueron [con]quistadores y Pobladores antiguos de aquella tierra, y en ella hicieron a Vuestra Alteza muchos y señalados servicios con armas y cavallos a su costa y el dicho su abuelo en la pacificacion de la tierra nueba y siete ciudades de civola y de la Vatalla que se dio a los naturales salio herido de un fflechazo; Y aunque vuestra Alteza Le hiço merced de Un oficio de Portero de la Audiencia Real de mexico con quinientos pesos de oro de salario no lo goço, Por averle Proveydo

s F. R. B., Sevilla.

t A. G. I., I-3-26/I7. 


\section{WitNESSES.}

I. Francisco Muñoz . . . answered to the second question that he has heard many persons say that Alonso Rodríguez Parra went on the expedition to Cíbola with Francisco Vásques Coronado, the governor who they say went, but he does not know whether he went as a soldier. . . .

II. Juan Ruiz ... answered to the second question ... that he knows that the said Alonso Rodríguez Parra, the father [of Juan], went as a soldier with Francisco Vásquez Coronado. This witness was an eye-witness because he also went as a soldier in the said expedition. $\mathrm{He}$ knows that Alonso Rodríguez Parra went as a foot soldier, and that he was in the governor's guard, because, as already stated, he saw him. He knows also that no pay was given to him by his Majesty or the governor in his name, for if it had been given him this witness would have known it. ... .

III. Estéban Martín . . . being asked the second question answered ... that (this witness) was one of the soldiers that went on the campaign to Cíbola and that he saw him as a soldier in the said campaign. While this witness and Alonso Rodríguez Parra were travelling together in the expedition he told this witness many times that when he disembarked he had come on this expedition without stopping in New Spain, and had caught up with the camp at the town of Culiacán. He always knew him to be a soldier, and that he was in the guard of Governor Francisco Vásquez, and he knows that he went at his own expense, without pay from his Majesty. This he is sure of, for had it been otherwise he would certainly have known of it.

IV. Alonso Alvares del Valle . . . knows that he went as a soldier at his own expense, because his Majesty gave no aid whatever to the soldiers in their expenses. ...

Evidence submitted of the merits and services of Francisco de Santillana, and of Pedro de Santillana, his son, in the conquest of the new land and Seven Cities of Cíbola with General Francisco Vásquez Coronado. Mérida, Yucatán, December 7, 1588.

I. María de Espinosa Santillana and Anna Nieto de Santillana, daughters of Pedro de Santillana, deceased former resident of the city of Mérida in Yucatán, affirm that Francisco de Santillana, their grandfather, and Pedro de Santillana, their father, were conquerors and old settlers of that land; that there they rendered many and important services to your Highness, furnishing arms and horses at their own expense; and that their grandfather, in the pacification of the new land and Seven Cities of Cíbola and the battle fought with the natives, was wounded by an arrow. Your highness gave him as a reward the office of doorkeeper (portero) of the royal Audiencia of Mexico, with five hundred dollars in gold as salary; but as the viceroy had already conferred it [upon some one else], he did not enjoy it. And, although in the past year of '94 your Highness, in con- 
el Virrey y Puesto que el año passado de noventa y quatro Vuestra Alteza en consideracion de lo sobredicho hiço merced al dicho Pedro de Santillana Su padre de confirmar la de 200 pessos de oro de minas en cada un año Por su vida de ayuda de costa en los yntereses que se quitaron a la de Licenciado montejo y su muger y hijos quel governador don guillen de las casas le hiço, y mandar se le pagasen desde el dia de la dicha situacion (que fue en quinze de setienbre del año 82) tan poco la goço El dicho su padre ansi por aver otras situaciones mas antiguas, como porque murio Luego el año siguiente de noventa y seys, como todo consta de los rrecaudos que pressenta.

Testimonio de Don guillen de las cassas, governador y capitan general por su magestad en estas provincias de Yucatan, coçumel E tavasco: Por quanto ante mi parecio Pedro de santillana Vezino desta ciudad de merida e me Hiço rrelacion diziendo que avia quarenta y cinco años Poco mas ó menos que el y Francisco de Santillana su Padre Pasaron a estas Partes de las Yndias de los rreinos de Castilla Y que estando en la ciudad de mexico de la nueva españa haziendosse la conquista y entrada de la tierra nueva y ssiete ciudades de cibola por mando de la magestad del enperador nuestro Señor E yendo por General della ffrancisco Vazques de coronado avia ydo el dicho ffrancisco de Ssantillana ssu padre a la dicha Jornada el qual avia ssido muy nesecario para ella por ser official de alveytar y herrador con el qual dicho officio y en su perssona y criados armas y cavallos fue ssirviendo a ssu magestad y Para hazer la dicha Jornada gasto mucha suma de pessos de Oro En la qual Usso El dicho officio de herrador ssin por ello llevar premio alguno y que aviendo llegado el dicho General y gente que llevava a Un assiento de ciudad llamado tixu los naturales sse Pusieron en arma y dando cierta batalla ssalio della herido el dicho ffrancisco de ssantillana de Un fflechasso en una espalda del qual quedo manco del vrasso derecho ssin mas sse poder servir del hasta que murio siendo Uno de los mejores maestros del dicho officio que avia en la nueva españa con que sse sustentava e por ser la dicha tierra esteril sse despoblo Por horden del dicho general y se salieron della y de los soldados que escaparon della Vinos " avia sido uno el dicho ffrancisco de santillana al qual ssu magestad teniendo noticia de lo que le avia sservido le avia hecho merced del officio de portero de la rreal audiencia de mexico con quinientos pesos de oro de ssalario en cada un año Por toda su vida, $\mathrm{E}$ por aver proveydo el dicho officio el vissorrey don antonio de mendoça en Un francisco Gentil no avia avido effeto la dicha merced. . . .

\section{[Petición del Doctor Francisco de Sandes. I589? ${ }^{w}$ ]}

Señor: El doctor francisco de Sandes dise que haviendo passado sus estudios con toda aprobacion de colegio, cathedra y Juzgado ha mas de veynte y dos años que paso a Mexico por fiscal de aquella audiencia con los licenciados Jarava, Muñoz y Carillo, y al negocio de su comission y

u Evidently a miscopy for "vivos".

$\checkmark$ F. R. B., Sevilla.

w A. G. I., 87-8-I. 
sideration of the aforesaid, rewarded Pedro de Santillana, their father, by confirming a life grant made to him of two hundred pesos annually in gold from the mines, as aid in the expense of the properties taken away from the grant made to the licentiate Montejo ${ }^{32}$ and his wife and children by Governor Don Guillén de las Casas, ${ }^{33}$ and by ordering that this should be paid from the day of the said assignment (which was on September I 5 , of the year '82), neither did their father enjoy it, partly because there were other previous assignments and partly because he died soon after, in the following year ' 96 . All of this appears in the records offered.

Testimony of Don Guillén de las Casas, governor and captain-general for his Majesty in these provinces of Yucatán, Cozumel, and Tabasco: Inasmuch as Pedro de Santillana, resident of this city of Mérida, appeared before me and made a statement to me, affirming that it was forty-five years, a little more or less, since he and Francisco de Santillana, his father, came to these parts of the Indies from the kingdoms of Castile, and that, being in the City of Mexico of New Spain at the time of the campaign and entrance in the new land and Seven Cities of Cíbola by order of his Majesty, the emperor our lord, Francisco Vásquez de Coronado being general in command, Francisco de Santillana his father had gone upon the said expedition, to which he was very necessary in his capacity of veterinary surgeon and blacksmith. In this office and in his person, with servants, arms, and horses, he went in the service of his Majesty, and in order to make the journey he spent a considerable sum in gold. In it he practised the aforesaid office of blacksmith without receiving any pay for it. When the general and his soldiers reached the site of a city called $\mathrm{Tixu}^{34}$ the natives took up arms and made quite a fight, from which Francisco de Santillana came out wounded by an arrow in one of his shoulders. From this his right arm was maimed, so that he was never able to make use of it while he lived, although he was one of the best workmen in the said trade to be found among those who supported themselves by it in New Spain. As the land was sterile, it was abandoned by order of the general and they left it, Francisco de Santillana being one of the soldiers who escaped from it alive. His Majesty, having heard of the services he had rendered, had rewarded him with the office of doorkeeper (portero) of the royal Audiencia of Mexico, with a salary of five hundred dollars in gold yearly during his life; but as Viceroy Don Antonio de Mendoza had bestowed this office upon one Francisco Gentil, the reward had not taken effect.

\section{[Petition of Doctor Francisco de Sandes. I589?]}

My lord: Doctor Francisco de Sandes ${ }^{35}$ says that, having passed with entire approbation his studies in the colegio, the university, and the legal course, he went to Mexico more than twenty-two years ago as fiscal of the Audiencia of that city in company with the licentiates Jaraba, Muñoz, and Carrillo, ${ }^{36}$ and was engaged upon the business of their commission. Being promoted to the office of alcalde del crimen of the same Audiencia, he discharged the duties appertaining thereto for only two years but in a highly satisfactory manner. Among numerous important services which 
promobido a officio de alcalde del crimen de aquella audiencia Lo uso solo dos años con grande aprobacion, y entre otros grandes Servicios que en el a Vuestra Magestad hizo fue uno que descubrio un hombre que con un cuño falso defraudaba los reales quintos de la plata y hizo de el Justicia confiscandole La mitad de los bienes, el qual tenia cient mill ducados y promovido a oydor de la misma audiencia y sirbiendo con buena opinion como informara el real consejo de Indias, y habiendo aprobado en la guerra de chichimecas, que lo fue conmetida, donde hizo notables servicios fue probeydo por Gobernador y Capitan General de las Islas filipinas: las quales goberno de manera que hallandolas Robadas y saqueadas y quemadas de cosarios y temerosas de moros en special del Rey moro de Borney y los Indios alçados que no querian pagar los tributos ni acudir a la doctrina y de estas causas los españoles pobres, Cobro la Reputacion perdida que con galeras y artilleria que hizo vencio en batalla nabal al dicho Rey de Borney, que con cinquenta galeras muy artilladas Le aconmetio y Le hizo huyr y prendio sus galeras y veynte y siete dellas y quatrocientas pieças de artilleria traxo a manila en despojo que con otros despojo entrego a los oficiales de Vuestra Magestad Sin tomar para si cosa alguna de lo que las leyes dan a los capitanes generales ni pretendio mas que la gloria del muchissimo nombre de Vuestra Magestad lo qual alcanço castigando el atrevimiento de los dichos moros y su Rey que tractaban de turbar el estado de aquellas Yslas que tanto havia costado de hazienda y sangre de Basallos de Vuestra Magestad y navegando donde nunca capitan de Vuestra Magestad llego en las ultimas noticias de la tierra siempre tubo Victorias con sus estandartes de Vuestra Magestad de manera que en su tiempo no Hubo cossarios cossa antes y despues muy ussada y acrecento tierras y artilleria que toda fue de Bronze e navios y Reputacion con todas aquellas naciones, specialmente de Justicia conbencidos y con estrangeros mostrandoles en ello el Retrato de Vuestra Magestad a su modo que era entre ellos cosa de maravillar que el bencedor no Robasse ni profanase el derecho natural contra los vencidos y como quiera que de tantos señalados servicios espera en la Real grandeza y Justicia de Vuestra Magestad le daran el galardon que suele a sus criados que assi Le sirven. Agora supplica a Vuestra Magestad que porque haviendose Visto en el dicho consejo la Visita de Mexico y la Residencia de las Filipinas y por lo que Resulto de la dicha Residencia a sido condenado en seis mill ducados para gastos de Justicia y passaje de Frayles y por la visita en quinientos puesto que solo el quedo sin ser suspendido entre los demas sus compañeros que manifiesta La fidelidad y legalidad con que a exercido sus cargos, le haga Vuestra Magestad merced de remittirle La dicha condenacion, o la parte que fuere servido para que con este Ynditio, se comience a entender La acceptacion de sus servicios. Pues aunque de Justicia el consejo Le aya condenado en la dicha quantidad, Aunque esperaba que conforme al intento que siempre tubo de açertar se figurarian Las cossas de otra manera tiene necesidades causadas de tantas peregrinaciones, molestias y dilaciones de pleytos de asistencia de esta corte, en la qual ha dos años que esta, y tres que no lleba salario de Vuestra Magestad de que esta gastado mucho y 
he rendered to your Majesty was his discovery of a man who was defrauding the royal fifths ${ }^{37}$ of silver by means of a false coining stamp. Sandes executed justice upon him, confiscating half of his possessions, these being: one hundred thousand ducats.

Sandes was then promoted to be oidor of the same Audiencia, in which position he earned a good reputation, as the royal Council of the Indies will report. Then, after having served successfully in the war with the Chichimecas, which was intrusted to him, he was appointed governor and captain-general of the Philippine Islands. There he governed so wisely, that, finding the islands robbed and sacked and burned by the corsairs, the inhabitants living in fear of the Moros, especially of the Moro king of Borneo and the revolted Indians who refused to pay tribute or attend Christian instruction, and finding the Spaniards thereby impoverished, he restored the lost reputation of the government. Using galleys and artillery which he manufactured, he vanquished the king of Borneo in a naval battle in which the latter attacked him with fifty galleys well armed with artillery. Sandes put him to flight, and, seizing his galleys, took twentyseven of them and four hundred pieces of artillery to Manila as booty. All these spoils he turned over, with other booty, to your Majesty's treasury officers, without taking for himself anything of that which the laws allow to captains-general. He claimed nothing for himself save the exaltation of the name of your Majesty which he achieved by punishing the boldness of the Moros, and their king, who were trying to disturb the peace of those islands which had cost so much of the blood and treasure of your Majesty's vassals. Sailing where no captain of your Majesty had ever been, he reached the most remote parts of the land, always gaining victories for the standards of your Majesty, so that in his time there were no corsairs, as there had been before and frequently after. He increased the possessions of the king, took much artillery, all of bronze, as well as ships, and gained great reputation among all those nations, especially in the execution of justice, toward those conquered and toward strangers, acting as the mirror of your Majesty so that he caused them to marvel that a conqueror should not rob nor profane the natural rights of the conquered.

Although he expects, for such distinguished services, to receive from your Majesty's grandeur and justice the reward usually given to the servants who thus serve you, he now beseeches your Majesty, since the visitation of Mexico and the residencia of the Philippines have been reviewed by the Council of the Indies, and since as a result of the residencia he has been fined six thousand ducats for the costs of justice and transportation of friars, and in the visitation five hundred ducats-he alone of all his companions not having been suspended, [which is] proof of the fidelity and uprightness with which he discharged his duties-to be so gracious as to remit to him the said fine or such part of it as you will, so that by this indication he may begin to understand that his services have been acceptable. For, granting that the Council has justly fined him the amount specified notwithstanding he had hoped that, in recognition of his continuous intention to do right, his actions would have been differently estimated, he has necessities caused by such wide wanderings, so much 
assi ocurre á Vuestra Magestad con sus sentimientos cuya clemencia es Unico Remedio de sus criados para poder mejor continuar a le servir que es lo que desea para que Vuestra Magestad sea servido mandar a su consejo, assi lo haga adonde ha dado peticion, y pues de tantas fortunas de Mar y guerra ha llegado Salbo con la honrra que Vuestra Magestad Le ha dado a sus Reales pies le Supplica humilmente le Valga para que despues de Veynte y dos años de buena fortuna no se Vea penar ni executar algunos de los meritos se refieren en el Memorial incluso en general por no hazer prolixa scriptura que lo fuera si se specificaran.

[No esta firmada ni tiene fecha alguna. . . . F. R. B.]

Informacion de los meritos y servicios de Garcia Rodriguez, uno de los Conquistadores de las siete Ciudades de Cibola, y uno de los primeros pobladores de Mexico y Nueva España Mexico 26 de Abril de I6I8. ${ }^{x}$

Antonio de moya en nombre del doctor Joan nieto de avalos en la mejor Via y forma que de derecho Lugar aya paresce ante Vuestra alteza y digo que el susodicho es bisnieto de Garcia Rodriguez uno de los primeros Conquistadores y pobladores de La nueva españa y natural de La ciudad de Mexico, y es abogado de La Real audiencia della examinado y approbado y Ha servido el officio de Relator del tribunal de Cruzada en ella mas tiempo que de quatro años, y assi mismo ha servido en officios de Justicia, y se ha occupado en otras Cosas del servicio de Vuestra Alteza como todo consta y paresce por las informaciones que se hizieron con citacion de Vuestro fiscal en la dicha Real audiencia y por el parescer que dio en ellas y por la de parte que es La de que hago presentacion con el juramento necessario para que se junten con Las de Officio que estan ante el presidente Secretario por todo lo qual a Vuestra Alteza pido y supplico Sea servido de que en remuneracion de los servicios del dicho Garcia Rodriguez su bisabuelo y de sus padres que assi mismo fueron pobladores de aquellos Reynos y de los del dicho mi parte y de su calidad y Sufficiencia le haga Merced de Una plaça de Una de las audiencias de Las yndias, y de una de las dignidades o Canonigas de Una de Las yglesias cathedrales dellas, y de otro qualquier officio que se offresca del servicio de los dichos Sus padres y abuelos y de los Suyos en que rescibira bien y merced Con Justycia que pide y para ello.

Del memorial para officios con sus partes servicios y calidades en merced $3 \mathrm{I}$ de henero de I6I8 años.

El Doctor Salzedo de cuervas.

A. G. I., I-4-34/3. 
trouble and delay of suits which have kept him residing in this court for two years past, and for three years without salary from your Majesty, whereby his expense has been great. He therefore applies to your Majesty, whose sentiment of clemency is the only refuge of your servants who desire to be better able to continue to serve you, as this suppliant desires, beseeching that your Majesty be pleased to command your Council to do as he has petitioned. And since he has come back safe from so many hazards of sea and war with the honor which your Majesty conferred upon him, he beseeches humbly that you will so assist him that he shall not, after twenty-two years of good fortune, be penalized nor left unrewarded for [at least] some of the merits referred to in the memorial herewith enclosed and now cited only in general so as not to make this petition too prolix, which it would be if they were specified.

[It has no signature nor date. ...-F. R. B.]

Report concerning the merits and services of Garcia Rodriguez, one of the conquerors of the Seven Cities of Cibola, and one of the first setlers of Mexico and New Spain. Mexico, April 26, I6I8.

I, Antonio de Moya, in the name of Doctor Juan Nieto de Avalos, appear before your highness in the proper form according to law, and say: That the above-named person is the great-grandson of García Rodríguez, who was one of the first conquerors and settlers of New Spain; is a native of the City of Mexico and an attorney before the royal Audiencia of that city, having been examined and approved. He has served in the office of clerk [relator] of the court of the cruzada ${ }^{38}$ in Mexico City for more than four years, has also served in judicial positions, and in other affairs pertaining to the service of your Highness. This is all made evident and apparent from the reports which were made upon request of your fiscal of the royal Audiencia, from the opinion which that official rendered thereon, and from the ex parte representation which I offer herewith under necessary oath, so that the foregoing documents may be filed with the official reports which are now before the president and secretary. Upon the representations contained in them all I pray and beseech your Highness to be pleased to grant [to Juan.Nieto de Avalos], in remuneration of the services of García Rodríguez, his great-grandfather, and of. those of his parents, who were also settlers of those kingdoms, as well as of the services of my client, and in recognition of his qualifications and fitness, the favor of a place in one of the audiencias of the Indies and one of the prebends or canonships of one of the cathedral churches therein, and of any other office which may be available as a reward for the services of his parents and grandfathers and his own. From such a grant which he justly asks for, he will receive benefit and favor, and for it. . . .

From the petition for office, accompanied by recommendations, statement of services and qualifications for a grant, January 3 I, I6I8.

Doctor Salcedo de Cuervas. 


\section{Provanças.}

Testigo: Luis pacheco de figuera.

Cuarta pregunta: Dixo este testigo que es nieto de conquistador desta nueva españa y a sus padres y a otros ancianos que fueron conquistadores (que fueron conquistadores) della oyo dezir quel dicho garcia rrodriguez avia sido poblador antiguo etc., y que avia sido Uno de los conquistadores de cibola y asi era notorio y publico en tiempo antiguo quando eran bivos muchos de los dichos conquistadores. . . .

Gabriel carrillo de guzman, Testigo.

De la quarta pregunta dixo este testigo que es hijo $\mathrm{E}$ nieto de conquistador y asi en muchas ocasiones que se juntavan todos los que eran que son ya difuntos en que concurrian sus padres y abuelos oyo muchas vezes dessir que el dicho garcia Rodriguez avia sido de los primeros pobladores desta nueva españa y conquistador de las ciudades de cibola y Californias En que a su costa etc. ...

\section{Peticion.}

Muy poderosso señor E1 bachiller Joan nieto de avalos abogado desta Real audiencia en la mexor via y forma que de derecho aya Lugar digo que a mi derecho conviene hazer averiguacion de La calidad y servicios de mis padres y abuelos y de los mios proprios Para ocurrir a Vuestra Real persona y Vuestro Real consejo de las yndias Para que me haga merced de ocuparme emplaça de Una de sus rreales audiencias de las yndias o en Uno de los officios de Justicia de ellas o Presentarme Para Una dignidad o canongia de la yglesia cathedral desta ciudad de mexico y de la de los angeles o en Lo que mas fuere servido Por ser como soy soltero dispuesto capaz de qualquiera destas mercedes. . . .

Preguntas V: Yten si saven qel dicho garcia Rodriguez mi Visibuelo fue Uno de los primeros pobladores desta ciudad de mexico y nueva espanna y conquistador de las siete ciudades de ssibola donde sirvio a su magestad con sus armas y caballos y criados. . . .

\section{ProbanÇA DE LoS MERITOS DE GARCIA RRODRIGUess BISAgUELO DEL BACHILLER JUAN NIETO DE AVALOS.}

En la ciudad de mexico a diez y siete dias del mes de nobiembre de mill y quinientos. $E$ setenta $E$ ocho años estando los señores Presidente e oydores de la audiencia rreal de la nueva España en acuerdo por presencia de mi sancho Lopez de agurto escrivano de camara della se Presento esta peticion e ynterrogatorio de preguntas por el conthenido.

\section{Peticion.}

Muy poderosso Sseñor garcia rrodriguez clerigo Presbitero beneficiado del pueblo de tasco y del pueblo de tagamasapa que esta en Vuestra rreal corona y del pueblo de camistla que esta en encomienda en alonso peress digo que yo tengo nesesidad de haser por ynformacion de los meritos de mi 


\section{ProOFs.}

Witness, Luís Pacheco de Figuera.

Fourth question: This witness said that he is a grandson of a conqueror of New Spain, and that he has heard his fathers and other old men who were conquerors thereof say that García Rodríguez was an old settler, that he had been one of the conquerors of Cíbola, and that the fact was common and public knowledge in the old times when many of the conquerors themselves were living.

Gabriel Carrillo de Guzmán, witness.

To the fourth question this witness said that he is a son and grandson of a conqueror, and that as such, ofttimes when all those who were conquerors but are now dead met with his fathers and grandfathers, he frequently heard it said that García Rodríguez had been one of the first settlers of New Spain, and a conqueror of the cities of Cíbola and of California. In these activities he did at his own cost, etc.

\section{Petition.}

Very powerful lord: I, the bachiller Juan Nieto de Avalos, a lawyer before this royal Audiencia, do, in the best legal manner and form, say that it is within my right to attest to the qualities and services of my fathers, my grandfathers, and of myself, in order to come before your royal person and your royal Council of the Indies with a request to be employed in one of your royal audiencias of the Indies or in one of the judicial offices in one of them, or to be presented to a prebend or canonship in the cathedral church of this City of Mexico, or in that of Los Angeles ${ }^{39}$ or in whatever position you may be pleased to bestow, inasmuch as I am a single man, ready and capable to discharge any of these offices. ... .

Question V. Also, whether they know that García Rodríguez my greatgrandfather was one of the first settlers of this City of Mexico in New Spain, and a conqueror of the Seven Cities of Cíbola, where he served his Majesty with his arms, horses and servants. . . .

\section{Proof of the Merits of García Rodríguez, Great-Grandfather of the Bachiller Juan Nieto de Avalos.}

In the City of Mexico on the seventeenth day of the month of November, I 578, the president and oidores of the royal Audiencia of New Spain being met in acuerdo in the presence of myself, Sancho López de Agurto, clerk of the chamber thereof, there was presented this petition and interrogatory containing the following questions:

\section{Petition.}

Very powerful lord: I, García Rodríguez, priest and presbyter in the benefice of the town of Tasco and the town of Tagamasapa, which is under the jurisdiction of your royal crown, and of the town of Camistla, which is under the encomienda of Alonzo Pérez, say that I am under necessity to present a report to your Majesty upon my personal merits 
perssona y serviscios que e hecho en esta nueva espanna a su magestad Para ocurrir en ella a Vuestra rreal persona y Vuestro rreal consejo de yndias para que se me haga merced de una provenda en la sancta yglesia desta sciudad o en la parte que mas fuere servido.

\section{Preguntas.}

IV. Yten si saven etc., que el dicho garcia rrodriguez bino a esta nueva espana moço soltero Por el año passado de mill y quinientos y treynta y ocho años en compania y servicio de rrodrigo de albornoss contador de su magestad en esta nueva espanna y le sirvio en el dicho officio de contador muchos dias, etc.

V. Yten si saven que despues del año de mill y quinientos y quarenta el dicho garcia rrodriguez fue a la jornada y descubrimiento de la tierra nueva y siete ciudades de cibola yendo por general de armada francisco Vasquez de coronado governador de la probincia de Xalisco, etc.

VI. Yten si saven que en la dicha Xornada y descubrimiento de las dichas siete ciudades sirvio a su magestad $\mathrm{El}$ dicho garcia rrodriguez yendo por soldado y con sus armas y cavallos y con dos criados en el qual descubrimiento se ocupo con el dicho francisco Vasquez de coronado su general mas tiempo de dos años y medio en que paso mucho travaxo hanbre cansancio y otras adbersidades por ser el camino largo y despoblado, etc.

VII. . . . Que de la dicha xornada rresulto aber descubierto mas de mill leguas de tierra y que por esta caussa a sido y es poblada mucha Parte della Por ser como es tierra rica y de ... minas de que a rresultado mucho aumento a la rreal hazienda.

X. Que por ser como es El dicho garcia Rodrigues buena lenge mexicana y amigo de haser bien entendiendo La falta que avia en esta nueva españa de clerigos que fuessen Para poder confessar Los naturales se hordeno y hisso clerigo y cantto missa por el año passado de mill y quinientoss y cinquenta y siete y despues aca a servido de cura y bicario en muchas y dibersas Partes asi em pueblos de españoles como de yndios y siempre a dado muty buena quenta, etc.

\section{Provanças.}

Juan de paladines testigo.

VI. Que en la dicha xornada de cibola el dicho garcia rrodrigues Sirvio a su magestad en todo que se le offrecio y le fue mandado con sus armas y dos cavallos dos criados que llevo consigo a su costa como buen soldado y siendo este testigo alguacil mayor en la dicha jornada bio que en las belas guardias y descubrimientos servio el dicho garcia rrodriguez y hacia todo lo que se le mandava En la qual jornada Se ocuparon hasta bolver a esta ciudad de mexico el tiempo contenido en la pregunta el qual el dicho garcia rrodriguez como los demas Soldados Passo travajos de hambre y cansancio y otros que se offrecieron por el camyno y en el dicho descubrimiento.

VII. .. Q Que en la dicha xornada de cibola se descubrieron mucha cantidad de leguas de tierra y mucha parte dellas estan pobladas el dia de 
and services performed in this New Spain, that I may appear therewith before your royal person and your royal Council of the Indies and ask to be granted a prebend in the holy church of this city or in whatever place you may be most pleased to grant it.

\section{Questions.}

IV. Also, if they know, etc., that García Rodríguez came to New Spain an unmarried youth in the year I 538 in company with and in the service of Rodrigo de Albornoz, the contador of his Majesty for New Spain, and that he served Albornoz in the position of contador for many days, etc.

V. Also, if they know that, after the year I 540, García Rodríguez went upon the expedition and exploration of the new land and the Seven Cities of Cíbola which went under the general Francisco Vázquez de Coronado, governor of the province of Jalisco, ${ }^{40}$ etc.

VI. Also, if they know that García Rodríguez, on that journey and exploration to the Seven Cities of Cíbola, served his Majesty as a soldier with his arms, horses, and two servants, upon which exploration he was engaged, in company with Francisco Vázquez de Coronado, the general, for over two years and a half, during which time he endured much hardship, hunger, weariness, and other adversities because the road was long and without inhabitants, etc.

VII. That from the journey mentioned there resulted the exploration of more than a thousand leagues of land, much of which has consequently been and is now being settled, because it is rich land and contains mines, wherefrom has resulted much increase to the royal treasury.

$\mathrm{X}$. That since García Rodríguez is a good Mexican linguist and desires to do good, knowing the lack which exists in New Spain of priests who can confess the natives, he took orders, became a priest, and said mass in the year I 557 , since which time he has served as parish priest and vicar in many and divers places, both in Spanish and in Indian towns, in all of which he has given a good account of himself, etc.

\section{Proofs.}

Juan de Paladines, witness.

VI. That on the journey to Cíbola, García Rodríguez served his Majesty in every way which presented itself or was enjoined with his arms, two horses, and two servants which he took with him at his own cost, like a good soldier. This witness, being alguacil mayor on the journey, saw that in the watches, the guarding, and the explorations, García Rodríguez served and did all that he was commanded; that he was engaged upon this journey until he returned to this City of Mexico during the time mentioned in the question. During this time Garcia Rodríguez, like the rest of the soldiers, endured the hardships of hunger, weariness, and other difficulties which occurred upon the road and during the exploration.

VII. . . That on the journey to Cíbola many leagues of land were explored, many of which are settled to-day, because in them have been dis- 
oy porque en ellas se an descubierto muchas minas Ricas Las quales estan pobladas y dellas se an sacado mucha cantidad de marcos de plata de que a rresultado servicio particular a su magestad, etc.

El alcalde bernardino de albornoz.

VI. . . . De que en la dicha Jornada de cibola el dicho garcia rrodriguez sirvio a su magestad como los demas soldados que en ella fueron....

VII. . . . Que en la dicha jornada que hizo el dicho governador francisco basquez coronado rresulto que se descubrio la provincia de culiacan y otras muchas tierras donde se an descubierto minas rricas. . . .

Juan Xaramillo.

VII. . . Q Que de la dicha Jornada de cibola rresulto servicio a su magestad Porque se descubrio mucha tierra que los que la yban demarcando dessian que avian descubierto mas de mill leguas de tierra y que en el dicho camino a tierra que descubrieron estan pobladas al presente algunas minas especial las de chiametla De las quales se a sacado y saca mucha cantidad de plata de la qual a rresultado aumento a la rreal hazienda. . . .

Informacion de los meritos y servicios de Bernardo Diez del Castillo uno de los primeros Conquistadores y pobladores de Nueva España Mexico I4 de Mayo [de 1566].

Muy poderoso Señor: Francisco de Barrios Leon Vezino de la ciudad de mexico digo que como consta y parece Por estas Informaciones de que Hago Presentacion en forma, yo Estoy casado Legitimamente con doña Bernardina Lainez del castillo Hija Legitima de diego diez Lainez del Castillo Y de doña ysabel farfan de los Godos Y nieta Legitima de Bernardo diez del castillo, Uno De los primeros conquistadores $Y$ pobladores de La nueva españa y que por esta Razon Vuestra Alteza el año pasado de 565 se sirvio de dar y Librar A Los susodichos dos cedulas para que de su Real caxa Le diesen al dicho diego diez del castillo Trecientos pesos de oro comun en quitas y Vacaciones por todos Los dias de su vida y asimismo para que fuese Proveydo y Ocupado en los officios y cargos de Justicia que se comtienen y declaran en una de Las dichas cedulas y es assi que No embargante Lo mandado por ellas ninguno de Los birreyes de la dicha nueba españa ocuparon al dicho diego diez del castillo en ninguno de Los officios de Justicia en que era la boluntad de Vuestra Alteza fuese ocupado mediante sus muchos servicios Por Lo qual y ser como eran tan cortos Los dichos alimentos, murio el susodicho muy pobre $\mathrm{Y}$ nescessitado Y assi Lo a estado y esta La dicha mi muger. E Yo mediante aver cesado Los dichos alimentos que aunque era cosa tan tenue se sustentaba con ellos alguna parte de Nuestras obligaciones y pues por Las dichas cedulas y

y F. R. B., Sevilla, July 26, rgr4.

z A. G. I., I-4-34/3. 
covered many rich mines which have been settled, and from them a large number of marks of silver have been taken, which has resulted in an especial service to his Majesty, etc.

The alcalde Bernardino de Albornoz.

VI. That on the journey to Cíbola García Rodríguez served his Majesty like the other soldiers who went on the journey. . . .

VII. . . . That from the journey which the governor Francisco Vás. quez Coronado made, there resulted the exploration of the province of Culiacán and many other lands, in which rich mines have been discovered. ...

Juan Jaramilla.

VII. . . . That from the journey to Cíbola there resulted service to his Majesty because much land was explored which those who had gone on the exploration declared to contain more than a thousand leagues; and because on that road and land which was explored some mines are now settled, especially those of Chiametla, from which there has been and is now being taken a great quantity of silver, resulting in increase of the royal treasury. ...

Report on the merits and services of Bernardo Diaz del Castillo, ${ }^{41}$ one of the first conquerors and settlers of New Spain. Mexico, May I4, , $\left[I_{5} 66\right]$.

Very powerful lord: I, Francisco de Barrios León, a resident of the City of Mexico, say, as is shown and appears by these reports of which I make presentation in form, that I am legally married to Doña Bernardina Laínez del Castillo, who is a legitimate daughter of Diego Díaz Laínez del Castillo and Doña Isabel Farfán de los Godos, and is a legitimate granddaughter of Bernardo Díaz del Castillo, one of the first conquerors and settlers of New Spain. By reason of this relationship your Highness was pleased last year, 1565 , to give to the a foresaid two cédulas ordering three hundred pesos of common gold paid to the said Diego Díaz del Castillo, the same to be paid from the proceeds of removals and vacancies for all the days of his life, and also ordering that he should be appointed and employed in the offices and employments of justice which are contained and declared in one of the said cédulas. But notwithstanding what is commanded by these cédulas, none of the viceroys of New Spain has placed the said Diego Díaz del Castillo in any of the offices of justice in which it was the will of your Highness that he should be placed on account of his many services. For this reason, and because the said pension was so small, he died very poor and needy, and his daughter, my wife, has been and is the same. Now therefore I, because this pension has ceased, which, although it was so small, yet served to meet some part of our obligations, and because in the aforesaid cédulas and reports the merits and services of the said Diego Díaz Laínez del Castillo are so clearly set forth, and because of my necessities, I being a person capable and sufficient for 
imformaciones consta tan a la clara De los meritos y servicios del dicho diego diez Lainez del castillo y de mi nescesidad y Ser persona capaz Y sufficientes para qualquiera officio de justicia en que Vuestra Alteza fuere servido de ocuparme por concurrir como concuren en mi Las partes Nescesarias y Rrequisitas para su Adminnistracion.

A Vuestra Alteza Pido y supplico sea servido de continuar en mi Y en La dicha mi muger por el tiempo de Nuestras vidas Los dichos trecientos pesos de alimentos Segun y como se Le Pagavan al dicho diego diez del castilla con que La paga dellos sea en La Real caxa $Y$ en execucion de la dicha cedula Real que Habla en rrazon de los dichos officios de Justicia se me Haga merced de uno de los cinco que comtiene sin Remitirlo Al birrey que es o fuere de aquel Reyno Por que es cierto no Vendra a tener efecto como no Lo tubo El dicho diego diez Lainez del castillo Para que Le proveyesen como Vuestra Alteza manda en que Recibire bien y merced.

Ottrosi digo que Para mayor abundamiento $\mathrm{Y}$ Justificacion de La Merced que Pido Hago asimismo Presentacion de un Privilegio y blaçon de Armas que Vuestra Alteza Hizo merced Al dicho diego diez del castillo en rremuneracion de Los dichos sus meritos y servicios A Vuestra Alteza pido y supplico mande berlo Juntamente con Las dichas Ymformaciones y bistas se me Haga La Merced que pido con Justicia.

Francisco de Barrios Leon.

El fiscal disse que se le a de denegar a esta peticion Lo que pide Por que los titulos que presenta se estinguieron con la persona de Diego diass del castillo que goço de la rrenta todo el tienpo que bivio y que lo que se podria haser siendo el conssejo servido seria darle Una Cedula de rrecomendacion para que el birrey de la nueva españa conforme a los servicios de su suegro y por la Calidad y suficiencia de su persona Le ocupe en Las cosas que se ofrecieren en Madrid a 9 de Abril de I6I9 años.

Francisco de barrios Leon suplica a Vuestra Alteza que no embargante Lo rrespondido por el Señor fiscal se ha de hazer Lo que tengo Pedido. $\mathrm{Y}$ concluyo.

Francisco de Barrios Leon.

Que en quanto a la rrenta no a lugar lo que pyde y que se le de cedula de rrecomendacion como lo dice el Señor fiscal en mexico a I 3 de abril de 6 I9 años.

JuAN Velasquess.

\section{Real Cedula.}

El Rey: mi bissorey de la nueva españa y Bos El Presidente Y oidores de la nuesttra audiencia Real della que rreside en la ciudad de mexico diego dies del Castillo me a hecho Razon que Bernal dies del Castillo Su Padre fue Uno de los Primeros descubridores y Conquistadores de esa ciudad de mexico y nueva españa Porque paso con francisco Hernandez de Cordova y Juan de grijalva Primeros descubridores Y despues Bolvio con el marques del balle don fernando Cortes donde Con su persona armas y cavallos no savia servido muy principalmente $\mathrm{Y}$ Con gran ttravaxo $\mathrm{Y}$ 
any office of justice in which your Highness might be pleased to employ me, since there are combined in me, as they are, the necessary and requisite qualities for its administration, I beg and supplicate your Highness to be pleased to continue to me and to my wife for the duration of our lives the said pension of three hundred pesos just as it was paid to Diego Díaz del Castillo, provided that the payment thereof shall be from the royal treasury. And in fulfillment of the royal cédula which speaks concerning the said offices of justice, I pray that you will be pleased to give me one of the five positions mentioned without submitting the appointment to him who is or may be viceroy of that kingdom-because it is certain that it will never come to have effect any more than it did for the said Diego Díaz Laínez del Castillo-so that they may order it as your Highness commands, whereby I shall receive benefit and aid.

Again, I say that in greater amplification of and justification for the plea I make for this favor I herewith present a privilege and coat of arms which your Highness granted to the said Diego Díaz del Castillo in recompense for his many merits and his services to your Highness, and beg you to command that it be considered together with the aforesaid reports, and when they have been considered that the favor which I justly ask be conceded.

Francisco de Barrios León.

The fiscal says that this petition should be denied because the titles which are presented were extinguished upon the death of Diego Díaz del Castillo, who enjoyed the income as long as he lived. What might be done, if the Council pleased, would be to grant him a cédula recommending that the viceroy of New Spain should employ him, in whatever capacity may offer, in recognition of the services of his grandfather and of his own personal qualifications and aptitude. Madrid, April 9, I6I9.

Francisco de Barrios León begs your Highness that notwithstanding the recommendation of the fiscal, that which he has requested shall be done. I make an end.

Francisco de Barrios León.

As to the matter of the income, there is no reason for granting what is asked, and it is recommended that he be given a cédula of recommendation according to the suggestion of the fiscal in Madrid, April I3, I6I9.

JuAN. Velásquez.

\section{Royal Cédula.}

The King. To my viceroy of New Spain, and to you, the president and oidores of our royal Audiencia which resides in the City of Mexico: Diego Díaz del Castillo has presented me an account of how Bernal Díaz del Castillo, his father, was one of the first explorers and conquerors of that City of Mexico and of New Spain, for he went with Francisco Hernández de Córdoba and Juan de Grijalva the first explorers, and later returned with the Marqués del Valle, Don Fernando Cortés, where he has, with his person, arms, and horses, served us with distinction, with 
Riesgo de su perssona $Y$ bida y todo a su costa $Y$ mincion ${ }^{a}$ Como bueno y leal Vasallo Servidor Nuestro hasta tanto que esa dicha ciudad Y toda la mas Parte desta dicha nueva españa ffue puesta Debaxo. Dentro dominio Y corona Real y Despues fue a conquistar y pacificar las Provincias de guaçaqualco yucatan tavasco Honduras y otras muchas Partes de las Nuestras Yndias donde ansimismo nos avia servido muy Bien Como mas claramente dijonos constava Por ciertas Ynformaciones y ottros Recaudos ansi suyos como del dicho su padre De que an tenido En el nuestro Consejo De las indias hico Presentacion atenro ${ }^{b}$ a lo qual y Por ser hijo de tal Conquistador y estar pobre Y necesitado don luis de Velasco nuestro bissorrey que fue dessa tierra le mando dar en nuestro nombre de ayuda de Costa ciento $Y$ cinquenta pessos de oro comun librados Por Un año en las quitas y bacaciones Con los quales y Por ser Poca la cantidad Y no tener El ottros ningunos bienes ni hacienda Con que se poder sustentar Conforme a la calidad De su persona abia ocurrido Que nos En el nuestro Consejo de las indias a nos ynformar y Representar los Servicios del dicho superioridad y calidad suya para que en Reconpensa dellos se los mandassemos Ratificar Y darle de Comer En essa tierra y bisto por los del dicho nuestro consejo las dichas sus Ynformaciones y los demas rrecaudos por $\mathrm{El}$ presentados $\mathrm{Y}$ abiendonos consttado de lo sobredicho aviamos tenido por bien De mandar que los dichos ciento y cinquenta pesos de oro comun que ansi se le dieron por el dicho nuestro Bissorrey y Por el dicho tiempo se le diesen y Pagasen Por todos los Dias de su vida $\mathrm{O}$ mas ottros ciento y cinquenta pesos de oro que fuesen Por todos Trecientos pesos de oro livrados En las dichas quitas y Vacaciones y que aunque El avia assetado la dicha merced Por ser poco la cantidad y baler en esa tierra los mantenimientos a muy essesivos Precios no se Podia sustentar Con ellos Conforme a la calidad de su persona nos suplico que atento lo susodicho no En bargante El dicho entretenimiento como a hijo de tal Conquistador de la dicha Nueba españa le mandasemos proveer y Preferir antes y primero que a otra persona alguna en Uno de los Corregimientos y cargos que estavan En comarca de la dicha audiencia que eran las Provincias De tlaxcala tepiacachalco cholula xilotepeque $U$ ottro que fuese muy bueno honorroso $\mathrm{E}$ Provechosso $\mathrm{Y}$ que dando buena quenta no se le quitase ni rremobiese hasta que por nos ottra cossa se Proveyese En contrario o como la mi merced fuesse $Y$ porque como sabeis En las nuevas leyes y ordenanssas Por el Enperador rrey mi Sseñor de Gloriossa memoria hechas para el Vuen Govierno de Esas Partes y Vuen ttratamiento de los naturales dellas ay un capitulo del tenor siguiente: y por que es Razon que los que an servido en el descubrimiento de las dichas Yndias y tanbien los que ayudan a la poblacion dellas que tienen alla las mugeres sean preferidos en los aprovechamientos mandamos a los nuestros Vissorreyes presidentes y oydores de las dichas nuestras audiencias que prefieran En la probission de los corregimientos $\mathrm{Y}$ ottros qualesquiera aprovechamientos A los Primeros Conquistadores y despues dellos a los pobladores Cassados siendo personas aviles Para ello y que hasta que estos sean

a Evidently a miscopy for "manutencion".

b Evidently a miscopy for " atento". 
great labor and risk to his person and life, all at his own cost and maintenance, as a loyal vassal and servant of ours, until the said city and all the rest of the said New Spain was placed under our dominion and royal crown. Afterwards, he went to conquer and pacify the provinces of Guazacualco, ${ }^{42}$ Yucatán, Tabasco, Honduras, and many other parts of our Indies, where he has also served us very well, as was most clearly made manifest to us by certain reports and other documents both from him and from his father, which he presented to our Council of the Indies. In consideration of these, and of the fact that he was the son of such a conqueror, poor, and in need, our former viceroy of that land, Don Luís de Velasco, commanded that he be given in our name a gratuity of one hundred and fifty dollars in common gold, to be paid for a year from the proceeds of removals and vacancies. He having only this quantity, which was small, and no other goods nor estate whereby he might sustain himself in accord with his qualities of person, it has occurred to us in our Council of the Indies to obtain information and report the superior qualities of his service in order that we might in recompense therefor command that they should be approved and he be given a living in that land. The abovementioned reports and other documents presented by him having been seen by the members of our Council, and we having been convinced of the truth of the foregoing, we have thought well to command that the said one hundred and fifty pesos in common gold which were given to him by our viceroy for the time stated shall be given and paid to him during all the days of his life, and in addition another one hundred and fifty pesos gold or a total of three hundred pesos gold, to be paid from the said proceeds of removals and vacancies.

Notwithstanding that he has received this favor, he supplicated us that, in view of the fact that the favor itself was small and the expense of maintenance was so excessive in that land that he could not support himself on the grant according to his rank, we should command that he, as a son of such a conqueror of the said New Spain, should, notwithstanding the pension, be appointed and preferred above any other person for one of the corregimientos and positions existing within the territory of the said Audiencia, and that is, in the provinces of Tlaxcala, Tepiacachalco, Cholulu, Xilotepeque, or to any other position which is very good, honorable, and profitable; and that, so long as he should give a good account of his office, it should not be taken from him nor should he be removed from it until some other order should be issued by us providing a contrary arrangement, or whatever my grant might be.

And because, as you know, in the new laws and ordinances made by the emperor my father, of glorious memory, for the good government of those parts and the good treatment of the natives of them, there is a paragraph the tenor of which is as follows: "Because it is right that those who have served in the discovery of the said Indies and also those who aid in the settlement of them and have their wives there, should be preferred in official appointments, we command our viceroys, presidents, and oidores of our audiencias to prefer, in appointments to corregimientos or any other offices, the first conquerors, and after them the married settlers who are qualified for such positions, and until all these are pro- 
Probeidos Como dicho es no se Pueda Probeer a ottra persona alguna Y agora acarando a que el dicho bernal diess del castillo su padre nos a servido ansi en esta dicha nueva españa Como en ottias ${ }^{\circ}$ rreales de las nuestras Yndias y aquel dicho diego dies del castillo su Hijo que ttiene deseo de bivir y Permanecser en ella y Ser deudo de Criados y Serbidores nuestros tengo boluntad de le mandar favorescer y hascer merced Por ende y porque os encargo $\mathrm{Y}$ mando que beais El dicho capitulo y ley que de susso va Yncorporado Y Conforme a el lo guardeis y Cunplais en todo y por todo segun y como En el se Contiene y declara con el dicho diego diesz del castillo y En guardandolo y Cunpliendolo no enbargante El Entretenimiento de los ttrecientos Pesos de oro comun de que por nos lesta fecha merced Para ayuda a su sustentamiento es nuestra determinada Voluntad de que le Proveais y Prefirrais Como a hijo de Conquistador en Uno de los Corregimientos Y cargos que de susso se hasse mincion que son las dichas probincias De tlascala tepeaca chalco cholula jilotepeque $U$ ottro que sea muy bueno honrosso y Provechosso lo qual os mandamos que ansi Hagais Y Cunplais sin que en ello ni Parte dello Pongais Ynpedimento escusa ni dilacion alguna Por quanto como dicho es nuestra merced Lo ansi proveer $\mathrm{E}$ mandar $\mathrm{Y}$ Proveyendole de officios y ottras cargos de nuestro servicio En que nos Pueda servir y ser honrrado $Y$ aprovechado $\mathrm{y}$ en Los demas aprovechamientos de esa tierra tengais quenta con El para le Proveer dellos que En ello me tendre de vosottros Por bien servido ffecho en madrid a Primero de abrill de mill $Y$ quinientos y sesenta $Y$ cinco años. Yo El RREY. ${ }^{d}$

Ynformacion de los servicios de Diego de Madrid Avendaño uno de los primeros pobladores de Mexico y conquistador de Cibola Mexico 26 de Abril [de I6I8].e

Muy Poderosso Señor:-de parte De Don Jhoan de Porras y Ulloa Hijo Legitimo del Llicenciado estevan de porras y De Doña Isabel Zores De Ulloa nieto de Don Diego de madrid avendaño uno de los primeros pobladores Desta ciudad y conquistador de Las provincias De Cibola y higueras Digo que pretendo ocurrir a suplicar a su magestad que en remuneracion De los servicios De mi Padre y antepassados me haga Merced De ocuparme en officios de Justicia y ministerios de su Real hazienda. . . .

\section{Preguntas.}

III. . . . y especialmente si saben que el dicho Diego de madrid avendaño Padre de dicho Llicenciado porras fue Uno De los Primeros pobiadores desta ciudad de mexico Y conquistador De las Provincias de Cibola a donde sirvio el officio de alferez mayor De el General Phelippe Gutierrez

- Evidently a miscopy for "ottras".

d F. R. B., Sevilla, July 29, I9r4.

A A. G. I., I-4-34/3. 
vided for as has been said, no other person whatsoever may be appointed to them."

Now therefore, in view of the fact that the said Bernal Díaz del Castillo, his father, has served us both in this said New Spain and in other parts of our Indies, and that the said Diego Díaz del Castillo, his son, desires to live and remain in New Spain, he being a relative of servants of ours, I am pleased to command that he be favored and given a grant, wherefore and to which end I order and command you to take notice of the said paragraph and law herein incorporated above, and in conformity with it to keep it and fulfill it in all and through all according to that which it contains and declares with respect to the said Diego Díaz del Castillo. And in keeping it and complying with it, notwithstanding the allowance of the three hundred pesos of common gold which has been granted to him by us for assistance to his support, it is our determined will that you appoint and prefer him, as a son of a conqueror, to one of the corregimientos and positions made mention of above in the said provinces of Tlascala, Tepeaca, Chalco, Cholula, Jilotepeque, or to any other position which may be very good, honorable, and profitable. This we command you to do and fulfill without opposing to the order or any part of it any impediment, excuse, or delay whatever; for, as has been said, it is our desire that he be so appointed, for by appointing him to offices and other positions in our service he may serve us and be honored and benefited. And in other appointments in that land you will bear this order in mind and appoint like persons to them. If you do so, I shall consider myself well served by you. Dated at Madrid, April I, I565. I the KIng.

Evidence of the services of Diego de Madrid Avendaño, one of the first settlers of Mexico and conqueror of Cibola. Mexico, April 26, [I6I8].

Very powerful sir: On the part of Don Juan de Porras y Ulloa, legitimate son of the licentiate Estéban de Porras and Doña Isabel Zores de Ulloa, grandson of Don Diego de Madrid Avendaño, one of the first settlers of this city and conqueror of the provinces of Cíbola and Higueras, I declare that I wish to supplicate his Majesty, in remuneration of the services of my father and ancestors, to do me the favor to appoint me to offices of justice and administration of his real hacienda [royal finance].

\section{Questions.}

III. . . and especially whether they know that the said Diego de Madrid Avendaño, father of the said licentiate Porras, was one of the first settlers of this City of Mexico and conqueror of the provinces of Cíbola, where he served in the office of alférez mayor of General Felipe Gutiérrez, and of the provinces of Higueras, and that he served in both expeditions, armed and mounted, like a brave man and noble gentleman, always giving very good and loyal account of what was entrusted to him.... 
y de las Provincias de higueras y en la una y otra jornada sirvio con sus armas y cavallos como hombre Valeroso, cavallero hijo dalgo dando siempre muy buena y loable quenta De Lo que se le encommedava y encargava....

El Fiscal De su magestad Disse que siendo Vuestra Alteza servido esta informacion se puede rescebir el Llicenciado espinosa De La plaça.

En la ciudad de mexico a dosse Dias del mes De febrero de mill y seiscientos y nueve años . . . estando los Sseñores presidente $E$ oydores de la Audiencia Real de la nueva españa en el acuerdo aviendo Visto Lo pedido por don Joan de porras y Ulloa açerca de que se le rreciva informacion de su calidad y meritos y servicios para que su magestad Le haga merced y La repuesta del fiscal de su magestad De la dicha Real audiencia Digeron que mandavan y mandaron se le resciba $\mathrm{La}$ informacion que offresce $\mathrm{y}$ que su Excelencia Del virrey desta nueva españa nombre uno de los señores oydores de ella atente quien se haga y su Excelencia nombro al señor Llicenciado Pedro Xuares de Longorio oydor desta Real audiencia. . . .

Muy Poderoso señor, Don Jhoan de Porras y Ulloa en La informacion De meritos que he pedido se me resciba pido y suplico a Vuestra Alteza mande que demas de las preguntas que tengo pressentado se examinen Los testigos por este. ...

I. Si saben que el dicho don Juan de Porras y Ulloa fue allcalde mayor de las minas de sichu y El palmar de vega y capitan de sus fronteras de yndios chichimecos de guerra por provision de esta real audiencia governando en que sirvio a su magestad ansi en conservar Los assientos y reales de Las dichas minas y mineros dellas que por sus muchas necessidades Las querian despoblar y desamparar y para que no las Desampararen Los cocorrio el dicho don Juan de porras y Ulloa con su hazienda Limpiando a costa della La mina Descubridora con Lo qual se quietaron Los dichos mineros y se conservaron Las dichas poblaciones que ha sido y es de muy gran ymportancia al cervicio de su magestad por ser los presidios mas importantes desta nueva españa para la defensa y amparo de la guerra de chichimecos que tambien ha redundado y redunda en aumento del rreal aver por la plata que de las dichas minas se saca. . . .

II. . . Que por su mucha prudencia govierno y buena industria pacifico el dicho don Jhoan de Porras y Ulloa Los indios chichimecos de guerra de las dichas fronteras de tal manera que muchos dellos se abaxavan de pas y trayan sus hijos para que se los baptisassen como se los baptisaron algunos de Ellos y porque Los bolvian a llevar a sus rancherias no se baptisaron muchos dellos Digan, etc., y remitanse a la residencia que se tomo al dicho don Jhoan de porras y Ulloa.

III. Yten si saben que por el año de seiscientos y quatorze en conformidad De una cedula real fue nombrado por comissario de La conversion de los yndios mascorros y huachichiles ${ }^{\circledR}$ El Padre fray Jhoan

' More commonly spelled "Guachichiles". 
The fiscal of his Majesty declares that if your Highness please this evidence may be received by the licentiate Espinosa de la Plaza.

In the City of Mexico, the twelfth day of the month of February, r609 [I6I9]. . . . The señor president and señores oidores of the royal Audiencia of New Spain, being in regular session and having examined the petition made by Don Juan de Porras y Ulloa that evidence should be received concerning his character, merits, and services, so that his Majesty may reward him, and the reply of the fiscal of his Majesty of the said royal Audiencia, ordered that the evidence offered be received, and that his Excellency the viceroy of this New Spain name one of the señores oidores before whom it should be done, and his Excellency named the señor licentiate Pedro Juárez de Longorio, oidor of this royal Audiencia.

Very powerful sir: I, Don Juan de Porras y Ulloa, in the list of merits which I have petitioned for, I ask and pray that your Highness order that besides the questions that I have already presented, the witnesses be examined for this. ...

I. Whether they know that the said Don Juan de Porras y Ulloa was alcalde mayor of the mines of Sichú and El Palmar de Vega and captain of their frontiers of hostile Chichimecos Indians, by order of this royal Audiencia, during which governorship he served his Majesty also in preserving the sites and camps of the said mines and miners, which because of their great privations, they wished to desert and abandon. In order that they should not abandon them, the said Don Juan de Porras y Ulloa assisted them out of his fortune, opening at his own expense the mine Descubridora. With this he quieted the said miners and the said towns were preserved, which has been and is of very great importance to the service of his Majesty, for the presidios are the most important of this New Spain for the defense and support of the war with the Chichimecos. Also it has redounded and does redound to the increase of the royal fortune, because of the silver which is taken from the said mines. . . .

II. . . . That by his good judgment, management, and diligence the said Don Juan de Porras y Ulloa pacified the hostile Chichimecos Indians of the said frontiers in such a manner that many of them humbled themselves for peace and brought their children to be baptized. Some of them were baptized, but not many, because they took them back again to their villages. Let them make their statements, etc., and let them refer to the account that was taken from the said Don Juan de Porras y Ulloa.

III. Item: Whether they know that in the year I6I4, in conformity with a royal decree, the father Fray Juan Bautista de Molinedo, of the Order of the glorious Saint Francis, was named as commissary of the conversion of the Mascorros and Guachichiles ${ }^{43}$ Indians; and that he, by commission of the most excellent señor, Marqués de Guadalcázar, went to explore and visit all the country of the said Guachichiles and Mascorros Indians and the rest of the nations, and, returning to give account of what he had done, brought in his company four captains of the Mascorrosthe most amenable and obedient of all the said nations-named Don Juan, Don Bartolomé, Don Pedro, and Don Joseph. They, because of their 
baptista de Mollinedo de la horden del gloriosso san francisco el qual con commission del excelentisimo Señor marques de guadalcaçar fue a explorar y visitar toda la tierra de los dichos yndios huachichiles ${ }^{\mathrm{g}}$ y mascorros y las demas naciones y bolviendo a dar rasson de Lo que avia hecho truxo en su compania quatro capitanes mascorros Los mas respectados y obedecidos de todas las dichas naciones nombrados don Jhoan, don bartolome, y don pedro y don Josephe Los quales por el conoscimiento que tenian del dicho don jhoan de porras y Ulloa a su contemplacion y Persuadidos y atraydos del dicho fray Jhoan baptista de mollinedo Vinieron a dar la obediencia A su magestad y al dicho Señor Visorrey en su nombre y el dicho don Jhoan de porras y ulloa Los recibio y hospedo en su casa donde Los tuvo mas de quatro meses regalandolos dandoles de comer y curandolos de algunas enfermedades para mejor atraerlos a $\mathrm{La}$ profession de La Ley Evangelica y a la obediencia y servicio de la real magestad. ...

IV. . . Que aviendo dado Los Dichos capitanes por si y en nombre de todos Los de sus parcialidades La obediencia al dicho señor Vissorrey en nombre de su magestad Los recibio el dicho señor Visorey con mucho amor regalandolos y acariciandolos dandoles de vestir para si y Para sus mugeres dineros y cavallos con que se pudieran bolver a su tierra con Lo qual Los dichos indios capitanes conociendo La merced que se les avia hecho se bolvieron a sus tierras con muestras de muy gran contento reconosciendo La merced y beneficio que avian rescebido y esperavan recebir. . . .

V. . . . Que aviendose buelto Los dichos capitanes a sus tierras convocaron todos los yndios de su parcialidad y de las naciones comarcanas y les refirieron La merced que avian rescebido y lo mucho bien que les estaria a todos ellos ser cristianos y vasallos de su magestad y darse de paz y todos vinieron en ello. . . .

VI. . . Que por mandado del dicho Señor Visorey bolvio el dicho padre fray jhoan baptista de mollinedo a visitar La dicha provincia y tierras della ansi para Saber si los yndios perseveravan en su buen proposito como para asignar Los puestos y lugares donde convendria haser Lugares y conventos para la abitacion de los indios y aviendo ydo el dicho padre fray Jhoan baptista a visitar La tierra para el dicho effecto hallo Los dichos quatro capitanes que Le estavan esperando a el y al dicho don Jhoan de porras y Ulloa para congregarse en el puesto y lugar que se les señalese y acompañando al dicho padre fray Jhoan baptista fueron corriendo toda la dicha tierra hasta llegar a la provincia que llaman del Xaumava que es una muy gran provincia y de mucha gente y los indios della por la noticia que tenian ya y por La que les dieron Los dichos quatro capitanes rescibieron con mucho gusto al dicho Padre fray Jhoan baptista dissiendo que querian tambien ser cristianos y vasallos de su magestad. . . .

VII. . . . que aviendo buelto el dicho fray jhoan baptista de mollinedo con Relacion y testimonio $\mathrm{E}$ ynformaciones de lo arriba referido Se ordeno y mando por el excelentisimo señor Visorey que se fundasse Un 
acquaintance with the said Don Juan de Porras y Ulloa, in view of it, and being persuaded and invited by the said Fray Juan Bautista de Molinedo, came to render obedience to his Majesty and to the said señor viceroy in his name, and the said Don Juan de Porras y Ulloa received them as guests in his house, where he had them more than four months, entertaining them, giving them food, and curing them of some ailments, the better to attract them to the profession of the evangelical law, and the obedience and service of the royal Majesty. . . .

IV. . . . That, the said captains having given for themselves and in the name of all their allies obedience to the said señor viceroy in the name of his Majesty, the said señor viceroy received them with much kindness, entertaining them, caressing them, and giving them clothing for themselves and their wives and money and horses with which to return to their country. With this the said Indian captains, appreciating the favor which had been shown them, returned to their countries with signs of great satisfaction, recognizing the favor and benefit which they had received and expected to receive. . . .

V. . . . That, the said captains having returned to their countries, they convoked all the Indians of their band and of the neighboring nations and told them of the favor which they had received, and what a good thing it would be for all of them to be Christians and subjects of his Majesty and submit to peace; and they all agreed to it. ...

VI. . . . That by order of the said señor viceroy the said father Fray Juan Bautista de Molinedo went again to visit the said province and countries to find out whether the Indians were persevering in their good intention, as well as to mark out the places where it would be suitable to place towns and convents for the habitation of the Indians; and the said father Fray Juan Bautista, having gone to visit the country for the said purpose, found the said four captains, who were waiting for him and the said Don Juan de Porras y Ulloa in order to congregate at the place that should be pointed out to them. In company with the said father Fray Juan Bautista they went over all the said country until they reached the province called El Jaumave, which is a very large province with many people, and the Indians there, because of the information which they had already received and that which had been given them by the said four captains, received with much pleasure the said father Fray Juan Bautista, saying that they also wished to be Christians and subjects of his Majesty. ...

VII. ... That, the said Fray Juan Bautista de Molinedo having returned with the account and evidence of what is related above, it was ordered by the most excellent señor viceroy that a convent of Franciscan friars should be founded in the place called Río Verde so that the Mascorros Indians and the other nations of their alliance might congregate there, giving to the said Don Juan de Porras y Ulloa the command of captain and commission for the building of the convent that was to be made; in the fulfillment of which Fray Juan Bautista, and Don Juan de Porras y Ulloa went with the said [Indians] to the said place without any provision for defense, and with no other arms than those of love and the good treatment that they have always used with the said Indians, which 
convento De Frayles franciscanos en la parte que llaman rio Verde para que alli se congregassen Los indios mascorros y demas naciones de su parcialidad dando conducta de capitan al dicho don Jhoan de porras y Ulloa y comision para la fabrica del convento que se avia de hosser en cuyo cunplimiento fue con los dichos fray Jhoan baptista y don Jhoan de porras y Ulloa al dicho puesto sin ninguna prevencion de defensa ni mas armas que las del amor y buen tratamiento con que siempre han precedido con Los dichos indios que ha sido el medio eficacissimo de Reduzirlos y atraerlos Lo qual no se ha podido antes de agora conseguir por fuerza de armas en que su magestad ha gastado muchos millones de ducados y con mucho gusto y contento de Los dichos indios an hecho Los dichos fray Jhoan baptista de mollinedo y don Jhoan de porras y Ulloa dicha congregacion intitulada San Francisco, Rio verde y Un convento donde residen Los frayles franciscos de que es guardian fray Jhoan de cardenal y los indios estan con mucha paz y contento. . . .

VIII. . . Q Que para mejor conservacion y Para que tuviesen substento hizieron a su costa El dicho don Jhoan de Porras y Ulloa de su proprio caudal y el dicho Padre fray Jhoan baptista de mollinedo de limosnas que recogio Una sementera de maiz dandoles para ello bueyes y rexas y semillas El año de seisscientos y diez y siete hasta que despues el dicho Señor Visorey Les mando dar a quenta de su magestad dozientas fanegas de maiz para sembrar y cinquenta vacas con dos toros y dozientas ovejas con sus padres y veynte y quatro cabeças de ganado de cerda todo ello para criar para que su magestad sea relevado de costa de darles de comer. ...

IX. . . . que el dicho don Jhoan de porras y Ulloa ha hecho Este servicio a su magestad a su costa y minsion sin salario ni ayuda de costa alguna que ha sido y es de muy gran consideracion porque con la reduccion $\mathrm{y}$ conversion de los dichos indios mascorros y huachichiles ${ }^{\mathrm{h}}$ de su parcialidad se ha asegurado aquella provincia y sus comarcas y han sesado los muy grandes daños que Los dichos indios hazian. . . .

XI. . . Que el Llicenciado estevan de porras Padre del dicho don jhoan de porras y Ulloa ha quarenta años que sirve a su magestad En el officio de Relator desta real audiencia y actualmente Lo esta sirviendo con satisfacion y aprovacion de Los señores presidente $\mathrm{E}$ oydores y de los ministros y officiales de la real audiencia y de los litigantes y de toda la republica procediendo con mucha fidelidad y Rectitud y viviendo virtuosa y cristianamente y ha Patrocinado y aydado En todo lo que ha podido. La causa de la conversion reducion y congregacion de Los indios chichimecos, mascorros guachichiles y demas naciones. . . .

En la ciudad de mexico a Veynte y seis dias del mes de abril de mill y seiscientos y diez y ocho años ... mandaron se lleve al fiscal de su magestad desta real audiencia.

El fiscal dize que por aora no tiene que advertir el Llicenciado don Jhoan Xuarez de ovalle.

Muy Poderoso señor. Don Jhoan de Porras y Ulloa Digo que La informacion de mis meritos y servicios se çometio al Llicenciado Pedro

h More commonly spelled "Guachichiles". 
has been the very efficacious means of reducing and attracting them, which it has not been possible to accomplish before now by force of arms, in which his Majesty has spent many millions of ducats. To the great pleasure and satisfaction of the said Indians, the said Fray Juan Bautista de Molinedo and Don Juan de Porras y Ulloa have assembled the said congregation entitled San Francisco at Río Verde, and built a convent, where the Franciscan friars, of whom Fray Juan de Cardenal is superior, reside, and the Indians are very peaceful and content. . . .

VIII. . . . That, for their better conservation and sustenance, the said Don Juan de Porras y Ulloa, at his own expense and out of his own fortune, and the said father Fray Juan Bautista de Molinedo with alms which he collected, caused a crop of maize to be raised in the year I6I7, giving them for it oxen, ploughs and seeds, until afterwards when the said señor viceroy ordered them to be given, on account of his Majesty, two hundred bushels of maize for planting, fifty cows with two bulls, two hundred sheep with their rams, and a herd of twenty-four pigs-all for breeding - so that his Majesty might be relieved of the cost of supporting them. ...

IX. . . . That the said Don Juan de Porras y Ulloa has rendered to his Majesty at his own cost, without salary or any aid in expense, this service, which has been and is of very great importance, for, with the reduction and conversion of the said band of Mascorros and Guachichiles Indians, that province and its neighboring territories have been made safe, and the very great damage which the said Indians did has ceased. . . .

XI. . . . That the licentiate Estéban de Porras, father of the said Don Juan de Porras y Ulloa, has served his Majesty for forty years in the office of relator of this royal Audiencia, and is at present serving in it with the satisfaction and approbation of the señores president and oidores and of the ministers and officials of the royal Audiencia, and of the litigants and all the government, conducting himself with great fidelity and rectitude and living in a virtuous and Christian manner. He has supported and aided in every way that he could the matter of the conversion, reduction, and assembling of the Chichimecos, Mascorros, and Guachichiles Indians and the other nations. ...

In the City of Mexico, the twenty-sixth day of the month of April, I6r8 ... they ordered it to be taken to his Majesty's fiscal of this royal Audiencia.

The fiscal says that for the present there is nothing to be reported by the licentiate Don Juan Juárez de Ovalle.

Very powerful sir: I, Don Juan de Porras y Ulloa, declare that the report on my merits and sepvices was intrusted to the licentiate Pedro Juárez de Longorio, and at the time of his death it had been commenced. I ask and pray that your Highness will intrust it to another of the señores oidores, so that it may be finished and the opinion sent away by the first fleet or ship that sails; by which I shall receive benefit and favor with the justice that I ask, and for it, etc. Don Juan de Porras y Ulloa. 
Xuares de longoria y con su muerte quedo començada a Vuestra Alteza pido y suplico Se Cometa a otro de los señores oydores para que la acabe y se enbie El parescer en la primera ocasion de flota o navio En que rescibire bien y merced con Justicia que pido y para ello, etcetera. Don JHOAN DE PORRAS Y ULLOA.

En la ssiudad de mexico a treynta dias del mes de Julio de mill y seisscientos y veinte años estando en el acuerdo Los señores visorrey y Presidente y oydores de La audiencia real desta nueva españa se leyo esta peticion y visto por su excelencia virrey desta nueva españa Dixo que remitia y Remitio esta causa al Señor Llicenciado Diego gomez cornejo oydor desta real audiencia. . . .

\section{Provanças.}

Guillermo de Leon testigo.

V. ... Y sabe este testigo que respecto de ser fronteras de yndios chichimecos hizo muy gran servicio a su magestad en conservar Las dichas poblaciones y resulto tambien Servicio a Su magestad por la plata que se ha sacado. ... .

De la segunda pregunta anidida ${ }^{i}$ Dixo que como dicho tiene este testigo tomo La residencia de El officio de tal allcalde mayor de las minas de Sichu y palma de vega al dicho don Jhoan de porras y Ulloa y en el tiempo que duro el tomarla vido este testigo que Los yndios de guerra de las comarcas de las dichas minas se venian y baxavan de las sierras en que habitavan y residian por la buena maña $E$ yndustria del dicho don Jhoan de porras y Ulloa y se baptizavan de ellos y otros se bolvian y esto vido este testigo algunas veces. ...

III. . . . De la tercera anidida . . . que por el año de mill y seisscientos y catorze que refiere la pregunta . . . vido y comunico en esta dicha ciudad al padre fray Jhoan baptista de mollinedo de la horden de san francisco y vido la cedula que Refiere La pregunta y este testigo Le hizo Los memoriales que dio a su excelencia del señor virrey marques de Guadalgazar de que Resulto yr con la comission que refiere la pregunta y este testigo fue con el y vido toda la tierra y este testigo se quedo en las minas de sichu y el dicho frayle passo adelante y despues quando bolvio el dicho religioso a esta ciudad donde este testigo avia llegado antes del $\mathrm{y}$ vio traer a los yndios capitanes contenidos en la pregunta los quales tuvo y ospedo en su casa El dicho don Jhoan de porras y Ulloa los regalo por tener comotinia conoscimiento con el y algunos cayeron enfermos y los curo el dicho don Jhoan. ...

VII. . . El susodicho (Jhoan de porras) enseño a este testigo su comision y le dixo como yba en compañia del dicho padre Fray Jhoan, etc., y los vio salir desta ciudad y al cabo de seis meses poco mas ó menos vino a esta dicha ciudad el dicho fray. . . . El qual conto y dixo a este testigo aver hecho el susodicho y el dicho don Jhoan de porras todo lo que refiere la pregunta y que quedavan Los yndios muy contentos y asentados y que se avian baptisado mucha cantidad dellos. . . .

i Evidentitly a miscopy for "añadida". 
In the City of Mexico, July 30, I620, the señores viceroy, president, and oidores of the royal Audiencia of this New Spain being in regular session, this petition was read and examined by his Excellency, the viceroy of this New Spain. He said that he was referring and did refer this affair to the señor licentiate Diego Gómez Cornejo, oidor of this royal Audiencia. . . .

\section{EVIDENCE.}

Guillermo de León, witness.

V. . . . And this witness knows that in the matter of the frontier of Chichimecos Indians he rendered very great service to his Majesty in preserving the said towns, and it resulted also to advantage of the king, because of the silver that has been taken out. . . .

To the second question he said that, as this witness has already declared, he took the account of the said office of alcalde mayor of the mines of Sichú and Palma de Vega from the said Don Juan de Porras y Ulloa, and during the time that the examination lasted this witness saw that the hostile Indians in the neighborhood of the said mines came down from the mountains where they lived, because of the good management and efforts of the said Don Juan de Porras y Ulloa, and some were baptized and others returned. This witness saw this several times. ...

III. . . . To the third added question. . . . that in the year I6I4 to which the question refers ... he saw and communicated with in this said city the father Fray Juan Bautista de Molinedo of the Order of Saint Francis, and he saw the decree to which the question refers, and this witness made for him the petitions which he presented to his Excellency, the señor viceroy, Marquis of Guadalcázar, from which it resulted that he went with the commission to which the question refers. This witness went with him and saw all the country, and this witness remained at the mines of Sichú, and the said friar went on ahead. Afterwards when the said religious returned to this city, where this witness had arrived before him, he saw him bring the Indian captains mentioned in the inquiry. The said Don Juan de Porras y Ulloa, because of their acquaintance with him, took them as guests into his house and entertained them, and when some of them fell ill he cured them. . . .

VII. ... The above-mentioned (Juan de Porras) showed his commission to this witness and told him how he was going in company with the said father Fray Juan, etc., and he [this witness] saw them depart from this city. At the end of six months, a little more or less, the said friar came to this said city . . . and he told this witness that he and the said Don Juan de Porras had done what is mentioned above and all that is related in the inquiry; and that the Indians were well satisfied and settled, and a large number of them had been baptized. . . .

Captain Alonso de Peralta y Sidonia, witness.

II. . . . At the said mines Chichimecos Indians were [always] coming and going, and in order to preserve the peace he treated them kindly, which was important for the service of his Majesty. 
Capitan Alonso de peralta y Sidonia testigo.

II. . . Entravan y Salian indios chichimecos en Las dichas minas a los quales acariciava para que Conservasen la paz Lo qual fue de consideracion para El servicio de su magestad.

III. . . . Que por el año de seiscientos y siete y por el de nueve hasta aura quatro años poco mas ó menos administravan por via de visita a las naciones del rio Verde los religiosos de la orden de san agustin que avian de poblar en conca y Puxinquia y el Padre fray Jhoan baptista de mollinedo de la horden de santo francisco de quattro años a esta parte poco mas o menos bolvio a entrar al rio verde y sus rancherias convocandolos para que alçasen y poblasen pueblos con que se assegurasse la paz que de onze años a esta parte han conservado y Para este buen effecto se proveyo por el señor Virrey marques de guadalçacar por capitan y comissionario al dicho don Jhoan de porras y Ulloa donde fue asistiendo por tiempos interpolados de dos años y medio a esta parte en la dicha congregacion y Poblacion que de averse hecho ha sido assigurar la paz que pudieran bolver a alterar por no aver complido con sus devidos asientos Los religiosos de Santo agustin porque aunque Los congregavan en el valle de conca el Padre fray francisco de azebedo de la horden de san augustin por quitarle ha mas de ocho o nueve años su provincial ceso el efecto de la Dicha poblacion y los demas Religiosos de su orden Los Visitavan y administravan por via de visita sacandolos de sus Rancherias y por averlos poblado el dicho fray Jhoan baptista y el dicho don Jhoan de porras de los años y medio a esta parte han hecho gran servicio a Dios nuestro señor y a su magestad. . . .

Baltasar de la cadena testigo.

II. . . Y Y conocio a diego de madrid avendaño vezino que fue en esta ciudad ... padre del dicho estevan de porras y conocio a beatriz mendez de sotomayor Los quales sabe que fueron casados. . . .

III. . . . Conoscio en esta ciudad al dicho diego de madrid avendaño puede aver mas tiempo de cinquenta años y fue tenido por uno de los pobladores de esta ciudad de mexico $\mathrm{E}$ oyo Dezir a algunos de los conquistadores desta nueva españa de cuyos nombres no se acuerda que el dicho diego de madrid avendaño avia servido a su magestad en las jornadas que Refiere. . . .

Llicenciado ambrosio de Lacerna relator que fue en esta real audiencia, testigo ... de las añididas de La primera pregunta añadida Dixo que este testigo sabe que el dicho don Jhoan de porras y Ulloa fue allcalde mayor de las minas de sichu del palmar de vega y capitan de sus fronteras de indios chichimecos a cuyos titulos este testigo se remite y en todas las demas preguntas que se siguen dize este testigo que respecto de no aver salido de esta dicha ciudad no vio por vista de ojos ninguna de Las contenidas en ellas mas de la publica boz y fama que de toda ello se ha estendido en esta dicha ciudad a cuya causa su excelencia que agora govierno marques de guadalcasar viendo la mucha utilidad que se seguia en aquellas partes de la asistencia del dicho don Jhoan de porras y que avia reduzido a aquellos indios gualchichiles del venirse de paz y reducirse a servicio de su magestad Le prorogo este officio que antes Le avia dado La real audi- 
III. . . That in the years 1607 and 'o9 until now, four years a little more or less, the religious of Saint Augustine administered by the visiting method the nations of the Río Verde, who were to settle in Concha and Puxinquia. The father Fray Juan Bautista de Molinedo of the Order of Saint Francis, [after being] in this region four years, a little more or less, returned to the Río Verde and its villages and called them together to construct towns and settle in them so that the peace which they have preserved in this part for eleven years might be assured. For this good purpose the señor viceroy, Marquis of Guadalcázar, appointed as captain and commissary the said Don Juan de Porras y Ulloa, in which [office] he served intermittently for two years and a half in this part in the said congregation and settlement. By doing this he preserved the peace, which might have been broken again because the religious of San Agustín had not carried out their pledged contracts; for, although the [Indians] were congregated in the valley of Concha by the father Fray Francisco de Azevedo of the Order of Saint Augustine, through his removal by his provincial eight or nine years ago the accomplishment of the said settlement was stopped and the other religious of his order carried on their administration by the visiting method, taking them out of their villages. The said Fray Juan Bautista and Don Juan de Porras, by settling them in towns during the two years and a half in this part, have rendered a great service to God, our Lord, and to his Majesty. . . .

\section{Baltasar de la Cadena, witness.}

II. . . . And he knew Diego de Madrid Avendaño, who was a citizen of this city ... father of the said Estéban de Porras, and Beatrice Méndez de Sotomayor, who he knows were married. . . .

III. . . . He knew in this city the said Diego de Madrid Avendaño for perhaps more than fifty years, and he was considered to be one of the settlers of this City of Mexico; and he heard some of the conquerors of this New Spain, whose names he does not recall, say that the said Diego de Madrid Avendaño had served his Majesty in the expeditions referred to. . . .

Licentiate Ambrosio de Lacerna, formerly clerk [relator] in this royal Audiencia, witness .... in addition to the additions to the first question he said that this witness knows that the said Don Juan de Porras y Ulloa was alcalde mayor of the mines of Sichú and Palma de Vega and captain of the frontiers of Chichimecos Indians, to which titles this witness refers; and in all the other questions that follow this witness declares that because of not having left this said city he was not an eye-witness of any of the matters mentioned in them, but that he knows them by public report and rumor that have been spread abroad in this city concerning all this. For this reason, his Excellency who is now governing, the Marquis of Guadalcázar, seeing the great advantage which resulted in those parts from the service of the said Don Juan de Porras, and that he had reduced the Guachichiles Indians to agree to peace and to submit to the service of his Majesty renewed for him this office which the royal Audiencia, while directing the government, had previously given him, and he is to-day 
encia governando y el dia de oy esta actualmente con tercero año de prorogacion Lo que no se suele hazer sino con los honbres del valor y prudencia que el dicho don Jhoan tiene. ... .'

\section{Ynformacion de filiacion y meritos de don Augustin de la torre Altamirano. Para llebar al Real Consejo. ${ }^{k}$ [I623.]}

\section{Pressentacion.}

En la ciudad de mexico a ocho dias del mes de febrero de mill y seiscientos $\mathrm{Y}$ veinte y tres años ante don francisco Davila Corregidor se leyo esta peticion.

\section{Peticion.}

Don Agustin de la torre altamirano digo que a mi derecho conviene que el Pressente escrivano me de Un testigo authoriszado y en manera que haga fee desta Ynformacion de mis meritos Y servicios de mis padres $Y$ aguelos de que haga demonstracion para ocurrir con ellas al Real consejo a donde mas me convengan a Vuestra Magestad pido $Y$ supplico que el presente escrivano me de el dicho testimonio autoriszado $Y$ en manera que Haga ffee para el efecto Referido $Y$ esto fecho se me buelvan las dichas Ynformaciones horiginales que en ello Resivire merced con Justicias que Pido $\mathrm{Y}$ en lo nesesario, etc. don AGUSTIN DE LA TORRE ALTAMIRANO.

\section{Peticion.}

Excelentissimo señor: don agustin de la torre altamirano hijo Legitimo del Licenciado Luis de la torre $Y$ de doña Joana altamirano digo que Yo pretendo haber ynformacion de como soy Viznieto de los primeros conquistadores deste reino en orden de que Vuestra Excelencia y los señores Virreyes que adelante fueron me hagan merced de proveerme en officios de alcaldes mayores y corregimientos honrrosos conforme a la Calidad de mi Persona en cumplimiento de las Reales cedulas Libradas en ffabor de los conquistadores desta nueva españa $Y$ sus decendientes.

\section{PREgUNTAS.}

VI. . . . Que los dichos Joan rruis De alanis $Y$ alonso de Venavides abuelos paternos $\mathrm{Y}$ maternos del dicho Licenciado luis de la torre $\mathrm{Y}$ Visaguelos del dicho don agustin de la torre fueron de los primeros conquistadores que Vinieron $\mathrm{Al}$ descubrimiento conquista y pacificacion desta nueva españa donde sirvieron a su magestad con muy grande puntualidad arresgando sus Vidas. ... .

VII. . . . Que los dichos Joan altamirano Saabedra y doña Petronila altamirano fueron de los primeros Pobladores desta nueva españa en la qual estubieron muchos años hasta que murieron.

J F. R. B., Sevilla, July 24, I9I4.

is A. G. I., I-4-35/4. 
[enjoying] the third year of renewal, which does not usually happen except with men of the worth and judgment which the said Don Juan possesses. ...

Evidence of the relationships and merits of Don Agustin de la Torre Altamirano. To be taken to the royal Council. [I623.]

\section{Presentation.}

In the City of Mexico, February 8, I623, before Don Francisco Dávila, corregidor, this petition was read:

\section{Petition.}

I, Don Agustín de la Torre Altamirano, declare that it is necessary for my rights that the present clerk shall give me a copy, certified and attested, of these proofs of my merits and the services of my parents and grandparents, as shown in them, so that I may appear with the proofs before the royal Council, where they will serve my interests best. I beg and pray of your Majesty that the present clerk be ordered to give me the said copy, certified and attested, for the purpose referred to, and that when this is done the original evidence be returned to me. By this I shall receive the favor and justice which $I$ am asking for, and it is necessary to me, etc. Don Agustín de la Torre Altamirano.

\section{Petition.}

Most Excellent Sir: I, Don Agustín de la Torre Altamirano, legitimate son of the licentiate Luís de la Torre and Doña Juana Altamirano, declare that I ask to have evidence submitted that I am the great-grandson of first conquerors of this kingdom, so that in consideration of it your Excellency and the gentlemen that may be viceroys in the future shall do me the favor of appointing me to offices of alcaldes mayores and honorable corregimientos in accordance with my rank and in fulfillment of the royal decrees issued in favor of the conquerors of this New Spain and their decendants.

\section{QUestions.}

VI. . . . That the said Juan Ruís de Alanís and Alonso de Benavides, paternal and maternal grandfathers of the said licentiate Luís de la Torre and great-grandfathers of the said Don Agustín de la Torre, were among the first conquerors who came to take part in the exploration, conquest, and pacification of this New Spain, where they served his Majesty with very great fidelity, at the risk of their lives. . . .

VII. . . . That the said Juan Altamirano Saavedra and Doña Petronilla Altamirano were among the first settlers of this New Spain, where they remained many years, until they died. 


\section{Peticion.}

Alonsso de eredia en nombre de antonio Ruis de castañeda hijo legitimo de Joan rruis de alanis Uno de los primeros conquistadores y descubridores desta nueva españa digo que Para ynformar a Vuestra Real Persona de los meritos $\mathrm{Y}$ servicios De mi padre $\mathrm{Y}$ Calidad de su persona y mia para que me hagan merced tengo nesesidad de los testigos que presentare se manden exsaminar $\mathrm{Y}$ exsaminen por los articulos $\mathrm{Y}$ preguntas siguientes:

\section{Preguntas.}

VI. . . Que el dicho antonio Ruisz de Castañeda conforme a la Calidad de su persona $Y$ de la dicha su muger y tres hijos que tiene padece mucha nesesidad $Y$ no tiene como sustentar su cassa y ffamilia $Y$ aunque susedio En la mitad del pueblo de teguacan a Venido en mucha diminucion Y renta muy poco Por aver los Yndios passado el pueblo a otra parte donde aun no tiene edificadas sus cassas ni hechas sus sementeras ni milpas $\mathrm{Y}$ es en tierra caliente $\mathrm{Y}$ se an $\mathrm{Ydo}$ muchos $Y$ ndios a bivir a otras Partes. ...

Testigo: bernardo de albornos.

VI. . . . Que tiene entendido que el dicho antonio Ruis de castañeda Padeser nesesidades por que es Publico $Y$ notorio en esta ciudad no tener con que sustentar Su persona a [ sic] su muger $\mathrm{Y}$ cassa $\mathrm{Y}$ a oydo decir que el pueblo que tiene en encomienda a venido en diminucion $\mathrm{Y}$ assi es publico $Y$ notorio En esta nueva españa. . . .

\section{Cedula Real.}

E1 Rey nuestra Vissorrey Presidente $\mathrm{E}$ oydores de la nuestra audiencia Real De la ciudad de mexico de la nueva españa e nuestros officiales de la Real hacienda della e a Cada Uno de bos a quien lo de Yusso toca Saved que Haviendose tratado Pleito en nuestro consejo de las Yndias entre antonio Ruisz de Castañeda Como maride Y conjunta persona de doña antonia de Venavides su muger y maria de la torre biuda muger que fue de andres de orantes disco ${ }^{1}$ Veszino dessa ciudad Sobre el Repartimiento de Yndios de maxcalcingo Por sentencias de vista Y Revista sea mandado Poner e Yncorporar en nuestra Real Corona La mitad del Pueblo de teguacan que tenia encomendado el dicho antonio Ruis de Castañeda en nuestra Real Corona Como lo estava la otra mitad Y Para que esto se cumpla Y aya effecto os mando que luego que esta veais Pongais en nuestra Corona Real Para que quede Yncorporado en ella la mitad del dicho pueblo Repartimiento de teguacan Juntamente Con la otra mitad Sin que le podais encomendar ni encomendeis en ningun tiempo a persona alguna $Y$ bos Los dichos nuestros officiales Cobrareis los tributos y Rentas del como haszeis $Y$ deveis haszer de los demas Repartimientos que se an puestos en nuestra Real Corona $Y$ haszeros cargo dellos $Y$ porque teniendo Consideracion a lo bien y lealmente que el doctor don ssancho sanches de

I Probably "difunto". 


\section{Petition.}

I, Alonso de Eredia, in the name of Antonio Ruís de Castañeda, legitimate son of Juan Ruís de Alanís, one of the first conquerors and explorers of this New Spain, declare that in order that your royal person may be informed of the merits and services of my father and of his and my rank, so that some favor shall be granted to me, I need that orders be given that the witnesses whom I shall present be examined in the following articles and questions:

\section{Questions.}

VI. . . . That the said Antonio Ruís de Castañeda, in view of his rank and that of his wife and the three children that he has, is suffering from great poverty and has not enough to support his household and family. And though it has happened that in the half ${ }^{44}$ of the town of Teguacán there has been a great diminution, and the revenues are now very small, through the departure of the Indians from the town to another place, where they have not yet built their houses nor planted their fields and gardens, and as it is in a hot country many of the Indians have gone to live in other parts. . . .

Witness: Bernardo de Albornos.

VI. . . . That he has heard that the said Antonio Ruís de Castañeda is suffering from poverty, and it is public and notorious in this city that he has nothing with which to support himself and his wife and household, and he has heard it said that the town that he holds in encomienda has deteriorated very much and this is public and notorious in this New Spain. . . .

\section{Royal CÉdula.}

The King. To our viceroy, president and oidores of our royal Audiencia of the City of Mexico in New Spain, and our officials of its real hacienda and to each one of you whose right it is to know it: A lawsuit having been brought in our Council of the Indies between Antonio Ruís de Castañeda, as husband and partner of Doña Antonio de Benavides, his wife, and María de la Torre, widow and former wife of Andrés de Orantes, deceased resident of this city, in regard to the apportionment of the Indians of Maxcalcingo, by the decisions resulting from the examination and re-examination, let it be ordered that the half of the town of Teguacán which had been apportioned to the said Antonio Ruís de Castañeda be added to and incorporated in our royal crown, as the other half was. In order that this may be fulfilled and carried into effect, I command you as soon as you see this to add to our royal crown, so that it may be incorporated in it, the half of the said pueblo in the apportionment of Teguacán, together with the other half, without your having the power to apportion it or that you shall apportion it at any time to any person, and you, our said officials, shall collect the tributes and rentals of it, as you do and it is your duty to do in the other apportionments that have been added to our royal crown, and you shall take charge of them. And, in considera- 
muñon me ${ }^{m}$ escuela de la metropolitana Yglesia dessa ciudad nos a servido y Particularmente lo que hiszo en el descubrimiento de la Rebellion que se Yntento en ella contra nuestro servicio e tenido por bien de le haszer merced de dos mill pesos de tipus que De Renta ${ }^{\mathrm{n}}$ en cada Un año Por los dias de su bida Situados Los Frutos y Rentas del dicho Repartimiento de teguacan Como Vereis por la cedula que dellos le e dado es nuestra boluntad que anssi se haga $Y$ Cunpla Luego que se acave de poner El dicho Repartimiento en nuestra Real corona guardando en todo y por todo El Thenor y Forma Contenida En la dicha nuestra cedula de que de suso se hasze mincion y dar le les en virtud della se despacho que Conbenga para que desde el dicho dia que se hisziere a la vela en estos Reinos Por toda su bida se le den Y Paguen o a quien su poder hubiese los dichos Dos mill pesos enteramente sin desquento alguno Sin enbargo De que el dicho Repartimiento este en nuestra Corona Real y de qualesquier mersedes Situaciones $Y$ encomiendas que se ayan fecho en los tributos de los dichos Yndios a otras personas Porque queremos $Y$ es nuestra boluntad que se cumpla y Pague Primero Y ante todas Cossas Lo que Confforme a lo sussodicho hubiere de aver el dicho Doctor muñon ffecho en san Lorenço el Real a Veinte $Y$ quatro de Junio de mill y quinientos $Y$ setenta y tres años. Yo EL ReY. ${ }^{\circ}$

\section{Extracto de Provanças. ${ }^{p}$}

Don Agustin de la Torre altamirano Hijo Legitimo del licenciado Luis de la Torre y de doña Juana Altamirano nieto y visnieto de Conquistadores $Y$ pobladores de la nueva españa $Y$ conquistas della Dice que como consta de las provanças que Ante Vuestra Magestad presenta El dicho su abuelo tubo En Encomienda La mitad de los yndios del pueblo de teguacan y por siniestra Relacion se le quito cuyo Pleito esta en grado de Segunda Suplicacion ante Vuestra Magestad Y por La pobreça del suplicante no a podido benir a Seguillo por no se le haver echo merced ninguna Como consta de la certificacion de los oficiales reales Y el Suplicante Sirve a Vuestra Magestad En lo que se ofrece: a quien Umilldemente Suplica Se le haga merced de cederla para que Los Virreyes en obediencia de Vuestra Magestad se la hagan, atento a estar desposeido de su Encomienda de que se le de oficio Uno de quatro tlascala, La puebla, cretano ó atrico, pues sabra servirlo y dar Residencia como lo a dado de los que a tenido mandandolo asi Vuestra Magestad que Recevira merced.

[Copia de lo mismo en otra foja y debajo de esta hay: "desele la çedula de recomendacion ordinario que pide, en merced a 27 de febrero de 625 años."-F. R. B.]

m $M e$ is probably a copyist's error for de la.-N. V. S.

n Tipus que De Renta is evidently a miscopy for tributos y rentas. $-\mathrm{N}$. V. S.

o F. R. B., July 20, I9r4.

p A. G. I., I-4-35/4. 
tion of the loyal services to us of Doctor Sancho Sánchez de Muñon, of the school of the archiepiscopal church of that city, especially in what he did in the discovery of the rebellion that was attempted there against our service, I have determined to grant him two thousand pesos income from tributes and rents annually for all the days of his life, to be paid from the products and rentals of the said apportionment of Teguacán; and, as you will see by the decree that $I$ have issued to him in regard to them, it is our will that it shall be thus done and carried out as soon as the said apportionment has been finally added to our royal crown, observing in all and by all the purport and form contained in our said decree of which mention is made above, and giving them [the said rentals] to him in virtue of it. It was ordered that from the day that he should set sail to these kingdoms the said two thousand pesos should be given and paid during his lifetime to him or anyone holding his power of attorney, without any discount, notwithstanding that the said apportionment belongs to our royal crown and notwithstanding any other grants, assignments or apportionments that may have been made of the tributes of the said Indians to other persons, for we wish and it is our will that what the said Doctor Muñon is to have, in accordance with the aforesaid, shall be carried out and paid first and before everything else. Done at San Lorenzo el Real. June 24, I573. I THE KING.

\section{AbSTRACT OF PROOFS.}

Don Agustín de la Torre Altamirano, legitimate son of the licentiate Luís de la Torre and Doña Juana Altamirano, grandson and great-grandson of the conquerors and settlers of New Spain and its conquests, declares that as appears from the proofs which he presents before your Majesty, his aforesaid grandfather held in encomienda half of the Indians of the town of Teguacán, but because of a dishonest report it was taken from him [Agustín de la Torre], and the suit is now in the stage of second appeal before your Majesty, and because of the poverty of the supplicant he has not been able to come to prosecute it, no grant having been made him. As appears from the affidavits of the royal officials and the supplicant, he serves your Majesty in every way that offers and he humbly begs that you will grant him the favor that the viceroys, in obedience to your Majesty, shall give him officially, in consideration of his having been dispossessed of his encomienda, one of these four [apportionments] Tlascala, La Puebla, Cretano, or Atrico. He will know how to administer it and make a report, as he has given of those that he has held, if your Majesty will so order that he shall receive the grant.

[There is a copy of the same on another page and under this heading: "Let the decree of ordinary recommendation of which he asks the favor be granted. Feb. 27, I625."-F. R. B.] 


\section{Notes for Part I., Section 2.}

1 Thirteen brigantines were launched by Cortés with fitting ceremonies on Lake Texcoco on Sunday, Apr. 28, I52I. Twelve of these vessels aided materially in the siege of Mexico City. F. A. MacNutt, Fernando Cortés and the Conquest of Mexico, I485-I547 (New York, I909), pp. $337 \mathrm{ff}$.

2 Castañeda, the chronicler of the Coronado expedition, mentions a Juan Alemán, who "lived in Mexico". "Relación de la Jornada de Cibola compuesta por Pedro de Castañeda de Naçera", in G. P. Winship, The Coronado Expedition, loc. cit., p. 434.

3 Reference is here made to Francis I. of France, who waged war against Charles V. of Spain at intervals from 1522 until I 544.

4 In 1527 Juan de Ampues founded the first permanent settlement in Venezuela; later the province was for a time turned over to the Welser family of Germany as a proprietary grant. B. Moses, The Spanish Dependencies in South America, I. 57-79 and 29-45.

5 Santa Marta, in present Colombia, was founded by Rodrigo de Bastidas from Santo Domingo as a base on July 29, I525 (Moses, op. cit., p. 46).

${ }^{6}$ Reference is evidently made to Viceroy Antonio de Mendoza, who arrived in New Spain in 1535 .

7 The land of Cíbola, or New Mexico and adjacent territory.

8 Alonso de Ávila was a member of a commission sent by Cortés in June, I522, to represent him at the court of Charles V. With them the members carried choice jewels and treasures for the king. Soon after passing the Azores the fleet bearing the commission was attacked by French corsairs and Ávila, who had been intrusted with most of the treasure, was captured and taken prisoner to France. The treasure captured with him thus fell into the hands of Charles V.'s bitterest rival, Francis I. of France. See Bancroft, History of Mexico, II. 83.

9 The Chichimecas of Nueva Galicia.

${ }^{10}$ Luís Marín was a lieutenant of Cortés stationed at Espiritu Santo, near the mouth of the Coatzacoalcos River. In I524 he made a spectacular but unsuccessful campaign into Chiapas. See Bancroft, History of Mexico, pp. 35 and I28; and Bancroft, Central America, II. 2 I 5 ff.

11 Don Luís de Castilla was a lieutenant of Cortés who was sent to occupy and hold Jalisco, or the region south of the Tololotlan River, at the time of the founding of Nueva Galicia by Nuño de Guzmán (Bancroft, Mexico, II. 369-370).

12 This was in 1535 . See p. 9 of the Introduction, this volume.

13 The final campaign against the Moors in Spain, ending with the fall of Granada in I492.

${ }_{14}$ The Chontales lived in Tabasco. H. H. Bancroft, The Native Races (San Francisco, 1882), I. 645 .

15 For details of Alvarado's explorations see Lowery, Spanish Settlements within the Present Limits of the United States, 1513-156I, pp. 312-316, and references cited there.

${ }_{16}$ Nombre de Dios became, after 1519, the northern terminus of the road crossing the Isthmus of Panamá from Panamá City.

${ }_{17}$ Cartagena, in the present Colombia, was founded by Pedro de Heredia on January 2I, I533, with colonists enlisted for the most part in Spain (Moses, op. cit., I. 53).

18 See note 5 , above.

19 Reference is made to the naval expedition under Hernando de Alarcón. See Introduction, this volume, pp. I2, I3.

20 For the career of Cabeza de Vaca after leaving New Spain in 1536 see Bandelier, Introduction, in The Journey of Alvar Nuñez Cabeza de Vaca, pp. xi-xii.

¿1 Cortés did not receive the title of Marqués del Valle de Oaxaca until eight years after the capture of Mexico City.

22 Another name for Mexico-Tenochtitlán.

${ }^{23}$ Reference is made to the return of Pedro de Alvarado from Spain to Honduras and Guatemala in 1539. See Bancroft, Central America, II. 203-205.

${ }^{24}$ Evidently the modern Golfo Dulce in eastern Guatemala which opens into the Gulf of Honduras. 
25 From the context it is apparent that "He" does not refer to Coronado, who started for Cíbola prior to the outbreak of the Mixton War (Winship, The Coronado Expedition, p. 408), but, most likely, to the "said Cristóbal de Oñate," mentioned in the next sentence. Evidently the confusion is due to an omission.

${ }^{26}$ Cristóbal de Oñate was lieutenant-governor of Nueva Galicia at the time of the Coronado expedition to Cíbola. During the absence of Governor Coronado the defense of the province fell to him during the uprising known as the Mixton War (Bancroft, Mexico, II. 490 ff.)

${ }^{27}$ Don Alonso de Ávalos was one of the first conquerors of Colima. As late as 1742 the region conquered by him was known as "the provinces of Avalos". Matías Ángel de la Mota Padilla, Historia de la Conquista de la Provincia de la Nueva-Galicia escrita ....en 1742 (Mexico, I870-I872), p. 69.

28 Vasco de Puga, an oidor of the Audiencia of New Spain, compiled and published in the year 1563, by order of the king, his famous Provisiones, Cédulas, Instrucciones de su Magestad para la Administración y Governación de esta Nueva España . . . desde el año I525 hasta... I562. This contained such regulations as were then in force within the audiencia district of New Spain and was a forerunner of the later Recopilación de Leyes de los Reinos de las Indias. See Bancroft, Central America, I. 285-286.

29 For a list of the viceroys and governments of New Spain, with date, see H. E. Bolton, Guide to Materials for the History of the United States in the Principal Archives of Mexico (Washington, 1913), pp. 469-470.

30 Castañeda lists Don Tristán de Arellano as one of the captains of the Coronado expedition ("Relacion de la Jornada de Cibola", loc. cit., p. 420). When Coronado and the advance guard left Culiacán Don Tristán was left in command of the main army with instructions to follow (ibid., p. 423). See also ibid., pp. 443 and 445.

31 This expedition commanded by De Luna in 1559 contained over I500 persons. See Lowery, op. cit., pp. $358 \mathrm{ff}$., for details.

32 On Dec. 8, I526, Francisco de Montejo was named the first royal governor of Yucatán. In addition to being named governor and captain-general for life, he and his heirs were to have the perpetual titles and honors of alguacil mayor and adelantado. Montejo made his first permanent settlement in 1528 , but, on account of Indian hostility, the province was not fully conquered until I549 (Hackett, "Delimitation of Political Jurisdictions in Spanish North America to I535", loc. cit., p. 58, and references cited).

${ }^{33}$ Don Guillén de las Casas was governor of Yucatán between the years 1577 and 1582 or I583. E. Ancona, Historia de Yucatán (Barcelona, I889), II. I09-II7.

34 Evidently a corruption of "Tiguex". The province of Tiguex, in the upper Río Grande valley, contained in 1540 twelve pueblos. In this province Coronado and his army spent the winters of I540-I54I and I54I-I542 (Winship, The Coronado Expedition, pp. 392-402).

35 Dr. Francisco de Sandes, after having seen service in New Spain, was named governor of the Philippines in 1575 . In 1580 he returned to Mexico, having been succeeded as governor by Don Gonzalo Ronquillo. Upon his return to Mexico he became oidor of the Audiencia. In 1594 he went to preside over the Audiencia at Guatemala City. Two years later he was appointed president of the Audiencia of Granada (Cartas de Indias, pp. 840-84I), where he was serving at the end of the century. (Moses, Spanish Dependencies, I. 301).

${ }^{36}$ On June 16,1567 , Dr. Luís Carillo, Alonso Muñoz, and one Jarava were appointed to go to New Spain to investigate the acts of the second Marqués del Valle. Jarava died en route. The other two commissioners entered upon the assigned duty in Nov., I567. Because of the high-handed and despotic acts of the two they were very unpopular and were suspended from power in 1568 . They returned to Spain on the same ship that carried the ex-viceroy, the Marqués de Falces (Cartas de Indias, pp. 734, 810-8I I).

37 The king received as his share one-fifth of all mined metals.

38 The Holy Office of the Inquisitiori.

39 The city of Puebla de los Angeles, about fifty miles southeast of Mexico City.

${ }^{40}$ Coronado was governor of Nueva Galicia and not of Jalisco.

41 Bernal Díaz del Castillo was one of the most gallant and romantic of the early conquistadores. He was a member of the Córdoba expedition of 1517 , that of Grijalva of 1518 , and that of Cortés of $1519-$ the only person, so far as is known. who was in 
all three of these famous expeditions. Before his death Bernal Díaz wrote his famous Historia Verdadera de la Conquista de la Nueva España. This was finally published in 1632 by a Mercedite friar, Alonso Remón by name. "From that time", says the late and illustrious Mexican historian, Genaro Garcia, "this book was universally recognized as the most complete and trustworthy chronicle of the conquest of New Spain." The book has passed through at least five editions in Spanish and translations of it have been made into English, French, and German. A more perfect copy, made from the original manuscript, still preserved at Guatemala City, was published by Genaro García in I904; of this an English translation, with full notes, was made by Alfred P. Maudsley and published by the Hakluyt Society of London (Hakluyt Society Publications, second series, vols. XXIII.-XXV., XXX., and XL.). See G. García (ed.), "Introducción" to the Historia Verdadera de la Conquista de la Nueva España por Bernal Díaz del Castillo uno de sus Conquistadores: Única Edición hecha según el Códice Autógrafo, 2 vols. (Mexico, I904), pp. ix-xcvi.

42 Evidently the Coatzacoalcos River region.

43 These Indians lived in Zacatecas and San Luis Potosí (Bancroft, Native Races, I. 572,6 I4).

44 Castañeda held half of the Indians of the town of Teguacán in encomienda (see royal cédula of 1573 which follows). 
I. 3. FOURTEEN CÉDULAS AND LETTERS RELATING PRIMARILY TO INDIAN AFFAIRS IN NUEVA GALICIA, NUEVA VIZCAYA, AND ADJACENT REGIONS, I562-I597. 
[Real Cédula. El Rey al Virrey de la Nueva España Relativos a los gastos de Pedro de Ahumada de Samano en la Jornada contra los Indios Zacatecas y Guachichiles. Madrid a diez y siete de Octubre de 1562.$]^{a}$

E1 Rey: Nuestro Visorrey de la nueva españa y presidente de la Audiencia real que en ella reside pedro mexia melgarejo en nonbre de Pedro de ahumada samano estante en essa tierra me ha hecho Relacion que como era notorio los yndios çacatecas y guachichiles que confinan con las minas de los çacatecas y san martin y avino se avian alçado y revelado contra nuestro servicio el año pasado de sesenta y uno y avian muerto a muchas personas y Rovado y quemado estancias y aliado con otros yndios y hecho mucho daños lo qual visto por los nuestros oydores Allcaldes mayores de la Audiencia Real de aquella tierra y que siempre continuavan en sus delitos y rebelion Proveyeron y mandaron al dicho pedro de ahumada que fuese con gente a la pacificacion y castigo de lo susodicho el qual fue con quarenta hombres de a caballo y quatrocientos yndios amigos y deshizo a los dichos yndios y les dio algunos alcances hasta los hechar de la comarca donde andavan y Pacificado aquello. Bolvio sobre las sierras que estan en el despoblado entre san miguel y çacatecas y deshiço dellas muchas Rancherias de yndios chichimecas saltadores que avian hecho los dichos Rovos y muertes y quemas de aquel camino con gran travajo en lo que se ocupo ocho meses y mas tiempo e hizo en ello gran servicio a dios nuestro señor y a nos y avia hecho grandes gastos y espensas todo a su costa y mision por que aviendosele oficiado que le libraban y darian con que hiziese la dicha jornada Venido a efecto los nuestros officiales del dicho nuevo Reyno de galicia no avian querido ni quisieron aceptar las libranças que Vos avia deshecho en llos diziendo que no tenia del poder para librar en nuestra real caxa de lo qual el avia Recibido mucho agravio y daño porque gasto en la jornada en socorrer a soldados y darles harmas y otras cosas mas de veynte y seis mill pesos por valer todas las cosas en aquella tierra a excesivos precios y sin poderse escusar cossa alguna dello porque si ansi no se hiziera pudiera ser perderse toda la tierra como todo dixo constava y Parecia por cierta ynformacion de que ante nos en el nuestro Consejo de las yndias presento en el dicho nombre y me suplico le mandase pagar la dicha cantidad que ansi gasto de su hazienda y hazerle alguna merced en gratificacion de su travajo y servicio o como la mi merced fuese lo qual visto Por los del nuestro consejo de las yndias Juntamente con la dicha informacion que de suso se haze minsion fue acordado que devia mandar dar esta merced. Para Vos e yo tuve lo por vien Porque Vos mando que veis lo susodicho y atada la parte del nuestro fiscal dessa Audiencia Agais ynformacion y sepace que gastos hizo el dicho

a A. G. I., I03-3-I. 
[Royal cédula. The king to the viceroy of New Spain concerning the expenditures of Pedro de Ahumada de Samano in the campaign against the Zacatecas and Guachichiles Indians. Madrid, October I7, I562.]

The King. To our viceroy of New Spain and president of the royal Audiencia which resides there: Pedro Mexía Melgarejo, in the name of Pedro de Ahumada Samano, being in that country, has reported to me that it is well known that the Zacatecas and Guachichiles Indians, whose territory borders upon the mines of Zacatecas and San Martín and Avino, had arisen in revolt against our service last year, I56I; that they had killed many persons, robbed and burned farms, and, in alliance with other Indians, had committed many other depredations. This matter having been considered by our oidores, alcaldes mayores of the Audiencia of that country and cognizance being taken of the fact that the Indians were continuing in their crimes and rebellion, the oidores ordered and commanded Pedro de Ahumada to go with soldiers to pacify and punish them. He went with forty men on horseback and four hundred Indian allies and defeated the above-mentioned Indians and pursued them, overtaking them several times, until he drove them out of the territory where they were roving. Having completed the pacification, he returned over the mountains in the desert between San Miguel and Zacatecas. $\mathrm{He}$ destroyed many villages of the Chichimeca robbers who had committed the murders and robberies and incendiarisms along that route. He worked diligently at this task, which occupied him for eight months and more, therein performing a great service to God our Lord and to us. He had also made great expenditures at his own cost and initiative, for, though it had been ordered that he should be given the money necessary to make the expedition, yet, when he arrived for the purpose, our officials of the new kingdom of Nueva Galicia did not wish to and would not accept the drafts which you had made upon them, saying that they did not have the power to draw from our royal treasury. As a result he was very much injured, for he spent on the journey in succoring soldiers, providing them with arms and other things, more than twenty-six thousand pesos, everything in that country being at very high prices. Yet he was not able to avoid any of this expense, because if he had neglected anything it might have resulted in the loss of the entire country. All this Melgarejo said as appeared in a certain report which he presented before us in our Council of the Indies in the name of Ahumada, and supplicated me to order paid the said amount which he had expended from his estate, and to make hin some grant in reward of his labors and service or in whatever way I should desire. The petition being considered by the members of our Council of the Indies together with the report above mentioned, it was agreed that you be ordered to concede him the following favor. And I considered the advice good; wherefore I command you to examine the foregoing, and, 
pedro de ahumada samano en la dicha jornada contra los dichos yndios y hecho dello ynformacion Bastante todo aquello que por ella aberiguaredes y os constare aver gastado en la dicha jornada se lo lybreis en los nuestros officiales de la dicha provincia de la nueva Galicia a los quales mando que de los maravedis del cargo del nuestro thesorero den y paguen al dicho pedro ahumada o a quien su poder ovieze lo que ansi libraredes Por Razon de lo susodicho que con esta mi cedula o su traslado signado de escrivano publico y su carta de page o de quien el dicho su poder oviese y con libramiento vuestro mando que les sea Recevido y pasado en quenta lo que en ello se montare fecha en madrid a diez y siete De otubre de mil e quinientos y sesenta dos años Yo EL REY Refrenada de ERASSo y señalada de Vazquez Castro Valderrama don gomez Capata El doctor francisco hernandez Delievana.

Respuesta a los oydores, alcaldes mayores de la Nueva Galicia Sobre lo de la Sal. ${ }^{\mathrm{b}}$ [1562.]

E1 Rey: Nuestros oydores, alcaldes mayores de la Audiencia rreal de las provincias de la nueva Galicia por lo que nos escribistes en veinte y quatro de março de este año he visto lo que decis de que este rreyno En comarca de las minas de los çacatecas Se an descubierto unas Lagunas En que se recoge agua en tiempo de aguas y que despues con sol se cuaja y haze Cantidad de buena Sal la qual por ser necessario para el beneficio de la plata con el açogue que es lo que al presente mas se continua beneficiar $\mathrm{y}$ ateniendo al segund valor porque antes no le tenia y que porque los mineros y otras personas Enpaçaban Sobre ello a tener diferencias en el coger y aprovechamiento de ella y se desperdiciava y la cogian Sin estar bien coajada teniendo respecto a esto y a que Siendo puesto rrecaudo En Ella Serian los Mineros y otras personas mas bien proveidas y aprezaos [sic] que pudiesen sin mucho gasto gozar de ella acordastes de declarar que era y es nuestra y la pusistes en nuestra rreal corona Como a parescido por el auto que sobre ello distes... del bosque de Segovia 22 de Settiembre I 562-YO EL REY. ${ }^{\circ}$

El Rey a la Audiencia [de la Nueva Galicia] sobre lo de los frayles. $^{d}[$ [ 566.$]$

E1 Rey.-A1 los oydores allcaldes maiores de la nuestra Audiencia de la nueva Galizia bien tendreis entendido la obligacion con que thenemos

b A. G. I., 103-3-I.

c F. R. B., Sevilla.

d A. G. I., I03-3-I. 
after taking the advice of our fiscal of our Audiencia there, you make an investigation and ascertain what expenses were incurred by Pedro de Ahumada Samano in the campaign against the aforesaid Indians. When you have ascertained sufficiently and are informed what amount he expended, you will draw upon our officers of the province of Nueva Galicia for that amount. And I command them to take from the maravedis ${ }^{1}$ which are in charge of our treasurer and pay to Pedro de Ahumada, or whoever holds his power of attorney, the amount that you draw in com. pensation of the above-mentioned services upon presentation of this my cédula or a transcript thereof signed by a public notary, taking therefor his receipt or that of his representative. Upon your warrant the amount shall be paid and so entered upon the books. Dated at Madrid, October I7, I 562. I the KInG. Countersigned by ERASO, and signed by VÁsQUez, Castro, Valderrama, Don Gómez Zapata, Doctor Francisco HerNÁNDEZ DE LIEVANA.

Reply to the oidores, alcaldes mayores of Nueva Galicia concerning the matter of salt. [ [562.]

The King. To our oidores, alcaldes mayores of the royal Audiencia of the provinces of Nueva Galicia: In your letter written to us on March 24 of the current year, I have noted what you say concerning a discovery, in that kingdom in the district of the mines of Zacatecas, of certain lakes in which the water collects in the rainy season, and afterwards, being evaporated by the sun, leaves a large quantity of good salt. This, being necessary for refining silver with mercury, silver being the metal now most continuously refined, has acquired a value second only to quicksilver, because it has not hitherto been obtainable. Therefore, because the miners and other persons were beginning to quarrel over the collection and use of the salt, wasting it and gathering it before it was thoroughly crystallized, you have considered in view of these things that if a tax were placed upon it the miners and other persons would be better supplied and might without much expense enjoy the use of it. And you have voted to declare that this salt was and is ours and have made it a crown monopoly, as appears from the auto which you have issued concerning the matter. . . . From the Forest of Segovia, September 22, I 562. I the King.

\section{The king to the Audiencia [of Nueva Galicia], concerning friars. [ 1566.$]$}

The King. To the oidores, alcaldes mayores of our Audiencia of Nueva Galicia: You know very well the obligation under which we hold those lands and the kingdom of the Indies, which is to effect in every way and by good means the conversion of the natives to our holy Catholic faith. Inasmuch as the religious who have been and are now in that land have had special care of this work ever since the first discovery, and have har- 
essas tierras y Reino de las yndias que es procurar por todas vias y Buenos medios la conversion de los naturales dellas a nuestra santa fee Catholica y porque desto desde el primer descubrimiento dellas los religiosos que an estado y estan en dicha tierra han thenido muy especial cuydado y ansi han hecho mucho fruto en la conversion y doctrina de los yndios y al servicio de dios nuestro señor y descargo de nuestra real conciencia conbiene que tan sancta hobra no ceze y los ministros della sean favorecidos y animados mucho Vos encargo y mando que a los dichos Religiosos de las tres hordenes que rresiden en esa nueva Galizia de quien thenemos entera satisfacion que hazen lo que deven y se ocupan en la dicha doctrina y conversion con todo cuydado de que dios nuestro Señor ha sido y es muy servido y los naturales muy aprovechados les deis todo el favor para ello necesario y los honrreis mucho y animeis para que como hasta aqui lo an hecho de aqui adelante lo hagan lo mesmo y mas, si fuere posible como de sus personas y Vondad esperamos que lo haran y de lo que esto sujieredes nos tendremos de vosotros por muy servidos en madrid a XIX de Junio de I 566 años yo EL REY refrendada de ERASSo señalada de los del Consejo.

Este dicho dia se escribio una carta del thenor desta al obispo de la dicha provincia.

\section{Concierto con goncalo lopez ${ }^{\circ}$ sobre sus yndios. ${ }^{\perp}$ [I567.]}

El Rey.-Nuestro Visorrey presidente e oidores de la Audiencia rreal que rreside en la cibdad de mexico y nuestros oidores alcaldes mayores de la Audiencia rreal de la provincia de la nueva galicia y a otros qualesquier juezes e justicias de las dichas Probincias y a los nuestros oficiales dellas y a cada uno qualquier de Vos a quien lo en esta my cedula contenido yncumbe sabed que nos avemos mandado tomar y tomamos cierto asiento y concierto con goncalo lopez hijo de diego lopez vezino e veintiquatro de la cibdad de sevilla sobre el rrepartimiento de yndios que tiene encomienda en la dicha Probincia de la nueva galicia que son los Pueblos de ysbabitu que es en el valle de culiacan y el Pueblo de tapira con tres estancias que tiene junto al dicho Pueblo y el Pueblo de toperi y baiame y bitaremi y cobaltama y nabolama y quiçcrey cuno miramaya tayacoato y tenebama y baustacama y badarami y babeteme y ovacania y aristu y tedomo que primero estubieron encomendados en el dicho diego lopez su padre su tenor del qual dicho asiento es este que se sigue lo que se asienta y concierta entre su magestad y gonçalo lopez hijo de diego lopez veintiquatro de la cibdad de sevilla cerca del rrepartimiento de yndios que tiene encomendado por cedula y encomienda que dellos le dio francisco Vazquez de coronado gobernador y capitan general que fue de la Probincia de galicia de la nueva españa que son los pueblos de ysbabitu que es en el valle de culiacan y el Pueblo de tapira con tres ystancias que tiene junto al dicho Pueblo y el Pueblo de toperi y bayame y bitaremi y

- For note concerning Gonzalo López see p. I22.

P. G. I., I 44 -I-I 5 . 
vested much fruit in the conversion and indoctrination of the Indians, and inasmuch as it is fitting to the service of God our Lord and to the peace of our conscience that a work so holy should not cease, and that its ministers should be favored and greatly encouraged, I charge and command you that the religious of the three orders who reside in Nueva Galicia, in whom we have entire confidence that they do as they ought, busying themselves in this indoctrination and conversion with great carefulness, whereby God our Lord has been and is well served and the natives much benefited, shall be given by you all the aid necessary for this work, and that you honor them much and encourage them to the end that they may continue in the future as they have in the past, with great earnestness if possible, as we hope from their character and goodness that they will. Whatever you may suggest in this matter, we shall consider ourselves well served by you. Madrid, June I9, I 566. I the King. Countersigned by ERASo and signed by the members of the Council.

On this same day a letter of the same tenor as this was written to the bishop of the same province.

\section{Agreement with Gonzalo López ${ }^{2}$ concerning his Indians. [ 1567.$]$}

The King. Our viceroy, president, and oidores of the royal Audiencia which resides in the City of Mexico, our oidores, alcaldes mayores of the royal Audiencia of the province of Nueva Galicia, all other judges and justices of those provinces, and all our officers in them, to each and several of you whom the contents of this my cédula concern: Know ye, that we have commanded to have made, as we do make with Gonzalo López, son of Diego López, for twenty-four years a citizen of the city of Seville, a contract and agreement concerning the repartimiento of the Indians which he has in encomienda in the said province of Nueva Galicia. These encomiendas are in the towns of Ysbabitu in the valley of Culiacán, Tapira - with three farms close to the said town-Toperi, Baiame, Bitaremi, Cobaltama, Nabolama, Quizcrey, Cuno, Miramaya, Tayacoato, Tenebama, Baustacama, Badarami, Babeteme, Ovacania, Aristu, and Tedomo, all of which were first given in encomienda to the said Diego López, his father. The terms of the contract are as follows: A contract and agreement between his Majesty and Gonzalo López, son of Diego López, for twenty-four years 'a citizen of the city of Seville, concerning the repartimiento of Indians granted to him by cédula and encomienda by Francisco Vázquez de Coronado, former governor and captain-general of the province of Galicia in New Spain. These encomiendas are the towns of Ysbabitu in the valley of Culiacán, Tapira-with three farms near the said town-Toperi, Bayame, Bitaremi, Cobaltama, Nabolama, Quescrey, Cuno, Miramamaya, Taiacoato, Tenebama, Babetacama, Badarami, Babiteme, Ovacania, Aristo, and Tedomo, which were first given in 
cobaltama y nabolama y quescrey y cuno miramamaya taiacoato y tenebama y babetacama y badarami y babiteme y ovacania y aristo y tedomo que Primero estubieron encomendados a diego lopez veintiquatro de la cibdad de sevilla Padre del dicho gonçalo lopez es lo siguiente.

Primeramente e Por quanto el dicho goncalo lopez vino a estos rreynos de la dicha Provincia de galicia de la nueva España con licencia de dos años que Para ello le dieron los oidores alcaldes mayores de la Audiencia rreal de aquella tierra y que durante ellos Pudiese gozar y gosase de los. frutos y rrentas de los dichos yndios con que diese fiancas legas lanas y abonadas que bolviera aquella tierra dentro del dicho termino donde no que bolveria y rrestituyria a la caxa rreal de su magestad todos los dichos tributos y rrentas que oviesse cobrado el o otra persona en su nombre la qual dicha licencia le avia sido prorrogada por su magestad en diferentes tiempos por otros tres años mas que por todos heran cinco años con condicion que se embarcase en la primera flota que partiese destos rreynos para la dicha nueva España despues de la ultima prorrogacion su magestad tiene por bien que no embargante que el dicho gonçalo lopez no aya buelto a rresidir en los dichos sus yndios dentro del dicho termino como estaba obligado ny dado las dichas fianças conforme a la ultima prorrogacion aya de gozar y goze enteramente de todo lo que ubieren rrentado y balido los dichos yndios en los dichos cinco años sin que dellos se descuente cosa alguna para su magestad ny para otra persona alguna y que los fiadores que tenia dados para bolber los dichos tributos y rentas en caso que no bolviese a rresidir en los dichos yndios fuesen dados por libres sin que contra ellos obiese recurso yridio alguno.

Yten que demas de los dichos cinco años arriba declarados se prorrogo al dicho goncalo lopez un año mas que corra y se quente despues de los cumplidos y acabados los otros cinco años y aya de gozar y goze de todo lo que valieren y rrentaren el dicho año los dichos yndios segund y como lo a llebado e gozado hasta agora el tiempo que los a tenido descontandose de los dichos tributos y rrentas lo que fueren menester para la dotrina administracion y guarda de los dichos yndios los quales desde luego se ayan de Poner y pongan en la cabeça de su magestad y el dicho gonçalo lopez haga dexacion dellos y de qualquier derecho que a ellos puedan tener y tenga y desde agora se ayan asy Por Puestos en cabeça de su Magestad y pasados los dichos seis años se ayan de llevar y lleben enteramente su magestad lo que rrentaren e valieren los tributos de los dichos yndios sin quel dicho goncalo lopez ni otra persona por ellos aya de llebar ny llebe ny cosa alguna dello Por ninguna via.

Otrosi que los dichos oficiales rreales de su magestad desde luego cojan y cobren todos los tributos frutos y rrentas de los dichos rrepartimientos de yndios que ansi estaban encomendados al dicho goncalo lopez y cobrados primero que los metan en la caxa rreal acudan con ellos al dicho gonçalo lopez o a la persona que su poder oviere sacando primeramente del monton de los dichos tributos las costas que Ubieren hecho o hicieren en la defensa y doctrina y otras cosas que fueren necesarias para los dichos yndios como dicho es y de lo que ansi entregaren los dichos oficiales tomen su carta de pago con la qual queden libres y se les rreciban en quenta. 
encomienda to Diego López, for twenty-four years a citizen of the city of Seville, father of the said Gonzalo López.

First: Inasmuch as the said Gonzalo López came to these kingdoms of the said province of Galicia in New Spain with a license for the purpose for two years given by the oidores, alcaldes mayores of the royal Audiencia of that land [Nueva Galicia], under the terms of which he might for the time specified enjoy the profits and income from the said Indians, provided he gave bonds legas lenas y abonadas, guaranteeing that he would return to the land within the above-mentioned period of time, or, failing to do so, would redintegrate to the royal treasury of his Majesty all of the tributes and rents which he, or any other person in his name, had collected, [and] the said license had been extended in time by his Majesty at various times for another three years, that is, for five years in all, under the condition that he should embark in the first fleet that should leave these kingdoms for New Spain after the last extension of the license, his Majesty considers that, although the said Gonzalo López has not yet gone back to live among his Indians within the specified term, as was his duty, and has not given the specified bonds in conformity with the terms of the last extension of the time of the license, nevertheless he is to enjoy the entire income which the said Indians have produced during the said five years, without any discount whatever in favor of his Majesty nor any other person whomsoever: and the securities which he has given to return the said tributes and income in case he did not go back to reside among the said Indians, shall be released, and no Indian shall have recourse whatsoever against said securities.

Item: In addition to the five years above specified, the said Gonzalo López was conceded yet another year, to count as beginning after the close and completion of the other five, during which he might enjoy all the proceeds and income from the said Indians, on the same terms as he has enjoyed them until the present during the time which he has had them, but discounting from the said tributes and rents whatever might be necessary for the religious instruction, administration, and safeguarding of the said Indians. After the conclusion of this added year they are to be and shall be put under the care of his Majesty, and the said Gonzalo López shall relinquish them and whatever right he may or shall have in them; and henceforth they shall be considered and held to be in charge of his Majesty. And when these six years have been completed, his Majesty shall receive any and all income and revenues from the tribute of the said Indians, nor shall the said Gonzalo López nor any other person receive from them anything in any way whatsoever.

Another item: The officers of the treasury of his Majesty shall at once collect all the tributes, proceeds, and income from the said repartimientos of Indians who were thus given in encomienda to the said Gonzalo López; when they have collected these revenues, they shall deposit them in the royal treasury, where they shall meet with Gonzalo López or the person who holds his power of attorney, and, taking first from the gross returns of the tributes the costs incurred in the defense, indoctrination, and other necessary services rendered to the Indians as has been specified, and for what they so transfer they shall take his receipt, whereupon their responsi- 
Yten que las demas cosas que fueren necesarias al dicho rrepartimiento las ayan de poner y Pongan los dichos oficiales de su magestad como lo hazen en los demas rrepartimientos de yndios que estan en su rreal corona y no el dicho goncalo lopez ny otra persona por el.

Yten que este dicho asiento y todos los capitulos en el contenidos se guarden e cumplan en todo y por todo asi con el dicho goncalo lopez como con sus herederos y fiadores y con quien su poder del o dellos oviere y es de cedula de su magestad en forma para qual visorrey presidente e oydores alcaldes mayores de la Audiencia rreal de la nueba galicia y otras qualesquier justicias de las dichas probincias que la hagan guardar y cumplir sin embargo de qualesquier leyes y ordenanças Pragmaticas usos y costumbres que contra ellos sean o ser puedan los quales su magestad deroga en lo que a esto toca y no en mas y que no cumpliendose este dicho asiento no pare perjuicios al dicho goncalo lopez ni a los dichos sus herederos ny fiadores Por no aver buelto a las dichas Probincias de la nueba España dentro del termino ny prorrogaciones que tenian por no aver dado las fianças como le estaba mandado por quanto lo dexa de hacer por rrazon de este asiento que toma con su magestad y no por culpa suya y para que cumplira el dicho gonçalo lopez todo lo susodicho segund y como en esta capitulacion se contiene por lo que le toca obligo su persona y bienes muebles e rraize avidos y por aver y dio Poder cunplido a todas a qualesquier justicia de su magestad Para que se lo hagan guardar y cunplir y en firmeza dello otorgo esta capitulacion ante diego de Encinas escribano de su magestad y testigos infrascriptos que fue fecho y otorgado en la villa de madrid estando en ella la corte y consejo rreal de su magestad a veinte e nueve dias del mes de henero de mill e quinientos e sesenta e siete años siendo Presentes por testigos francisco de galvez y francisco de valmaseda y damian de la serna estantes en esta corte y el dicho otorgante lo firmo de su nonbre al qual doi fee que conozco goncalo lopez Paso ante my diego de Encinas E yo diego de Encinas escribano sobredicho Presente fin a lo que dicho es en uno con los dichos testigos y lo fize escrebir segund que ante my Paso por ende fize aqui este mio signo y firma que es a tal en testimonio de verdad DIEGO DE ENCINAS.

Porque nuestra Voluntad es que el dicho asiento y capitulacion suso incorporado se guarde y cumpla vos mando que lo veais y lo guardeis y cunplais y hagais guardar y cunplir en todo y por todo segund y como en el se contiene y guardandole y cunpliendo le pongais luego en nuestra Corona rreal el dicho rrepartimyento y pueblo de yndios de ysbabitu que es en el valle de culiacan y el Pueblo de tapira con tres ynstancias que tiene junto al dicho Pueblo y el pueblo de toperi y bayame y bitaremi y cobaltama y nabolama y quicerey y cuno miramaya taracoato y tenebama y baustacama y badarami y babeteme y ovaxania y aristo y tedomo que ansi a tenido encomendados en la dicha Probincia de la nueva galicia el dicho goncalo lopez y asy puestos aquellos que de nuestra parte se ubiere de hazer provereis que se haga y cumpla sin que en ello aya escusa ni dilacion alguna y que conforme al dicho asiento se acuda al dicho goncalo lopez o a quien su poder oviere con todo lo que ubieren rrentado los dichos yndios durante los dichos dos años de licencia que ansi truxo para venir a estos rreynos y estar en ellos y tres de prorrogacion que por nos le fueron 
bility for the sum involved shall be considered ended and their accounts accepted.

Item: Anything else necessary for the said repartimientos shall be supplied by his Majesty's treasury officials, as is done in the other repartimientos of Indians which are incorporated unto the crown, and such things shall not be provided by the said Gonzalo López nor by any other person for him.

Item: This said contract and all the articles in it contained shall be compiled within their entirety, in respect to Gonzalo López, his heirs, securities, or any one who may hold his or their power of attorney, and, in conformity with his Majesty's cédula duly drawn, the viceroy, president and oidores, alcaldes mayores of the royal Audiencia of Nueva Galicia, and all other justices of the said provinces shall see that these articles are kept and fulfilled, in spite of whatever laws, ordinances, pragmatics, usages, or customs may be invoked against them. And all such laws and customs his Majesty hereby revokes in so far as they concern this contract, but in nothing else. And if this contract is not fulfilled no prejudice shall be wrought thereby to the said Gonzalo López, his heirs, nor securities, through his failure to return to the said provinces of New Spain within the term specified or its extensions, or for not having given the securities as commanded, in so far as he fails to do so with respect to this contract which he makes with his Majesty, provided such failure is not his fault. And as a guarantee that he would upon his part comply with all the foregoing as contained in this capitulation, the said Gonzalo López obligated his person and his goods, both chattels and real estate in his actual or future possession, and gave full power to any and all justices of his Majesty to see that this capitulation should be kept and fulfilled. In witness whereof he executed this capitulation before Diego de Encinas, notary of his Majesty, and the undersigned witnesses, the instrument being dated and executed in the villa of Madrid, the court and royal council of his Majesty being there, on January 29, I567. Present as witnesses were Francisco de Gálvez, Francisco de Valmaseda, and Damián de la Serna, they being in Madrid. And the said contracting party signed it with his name, to all of which I take oath, and that I know Gonzalo López. Drawn before me, Diego de Encinas. And I, Diego de Encinas, the aforesaid notary, concluded that which has been said, together with the said witnesses, and had it written as it occurred in my presence. And finally I here affixed this my sign and signature, doing so in witness of the truth. DIEGo DE Encinas.

Whereas it is our pleasure that the foregoing contract and capitulation as above incorporated shall be kept and fulfilled I command that you do so keep and fulfill it and have it kept and fulfilled in every particular and in its entirety as prescribed in it. And in compliance therewith you will at once incorporate unto our royal crown the repartimiento and town of Indians named Ysbabitu in the valley of Culiacán, the town of Tapira, with three farms near the said town, and the towns of Toperi, Bayame, Bitaremi, Cobaltama, Nabolama, Quicerey, Cuno, Miramaya, Taracoato, Tenebama, Baustacama, Badarami, Babeteme, Ovaxania, Aristo, and Tedomo, which the said Gonzalo López has held in encomienda in the 
Prorrogados en diferentes tienpos sin que dellos se diese cuenta cosa alguna para nos ny para otra persona alguna no enbargante que no se aya enbarcado e ydo a esa tierra a rrecidir en los dichos sus yndios dentro del termino en la prorrogacion ultima declarada ny dado las fiancas que por ella se manda que para en quanto a esto nos dispensamos con el en todo lo que por nos cerca dello esta ordenado y mandado quedando en su fuerza $\mathrm{y}$ vigor para en todo lo demas con tanto que si alguno Ubiere cobrado los dichos tributos de los dichos cinco años o parte dellos que al dicho goncalo lopez le quede su dinero a salbo sin ser nos obligado a la paga y seguridad dello y ansi mismo le hagais acudir y acudais con todos los tributos que los dichos yndios obieren rrentado o rrentaren el dicho año de Prorrogacion que por el dicho asiento ansi a de gozar y le prorrogamos ante y Primero que lo metais en la nuestra caxa rreal sacando Primero del monton de todo ello lo que fuere menester Para la doctrina administracion y guarda de los dichos yndios y como o en vez pasados los dichos seis años cobrareys para nos todo lo que los dichos yndios valieren y rrentaren vos los dichos nuestros oficiales de la dicha Probincia de la nueva galicia como se cobra lo demas que rrentan los yndios que en esa tierra estan puestos en nuestra rreal Corona lo qual ansi hazed y cunplir no'enbargante que tanpoco vaya a rresidir el dicho año en los dichos yndios y los unos ni los otros no fagades ni fagan en deal so Pena de la nuestra merced y de cient mill marevedis Para la nuestra camara fecha en madrid a diez de hebrero de mill e quinientos y sesenta y siete años yo EL RREY. Rrefrendado de ERASo señalado del.

[Real orden] Para que los Indios de la Nueva Galicia se junten en pueblos y bivan en policia. $\quad$ [1570.]

El Rey. Nuestros oydores Alcaldes mayores de la audiencia de la provincia de la Nueva Galicia Juan de la peña en nombre del Consejo justicia regimiento De la ciudad de Guadalaxara me a hecho Relacion que a causa de no se juntar los yndios naturales de la provincia en pueblos y que tengan Republica Redundan muchos daños e yncombenientes asi en lo que toca A su combersion y doctrina como en no se criar y bivir con la policea y orden que combiene a su salvacion y comserbacion porque como estavan dibididos por los montes y desciertos no podian los Religiosos

B A. G. I., I03-3-I. 
province of Nueva Galicia. When they have been so placed, as they should be in our name, you will at once order that, without excuse or delay whatsoever, there shall, in conformity with this contract, be delivered to Gonzalo López or whoever holds his power of attorney, all the revenue from the above-mentioned Indians during the two years of the license which he took for the purpose of going to those kingdoms and staying there, as well as for the three years' extension which was conceded to him by us at various times, reserving nothing whatever for ourselves or any person whatsoever, notwithstanding that he may not have embarked for and gone to that land to reside among his Indians within the space of the last extension of time allowed, or that he may not have given the securities demanded by the contract; for, in this respect, we free him from whatever obligation toward us is commanded and ordered, the remainder of the contract to remain in full force and vigor, provided that if anyone shall have collected the said tributes for the whole or part of the five years, the said Gonzalo López shall have his money without injury or diminution, but we shall not be obligated for the payment of it or security for it. You will also turn over or cause to be turned over to him all the tributes which the Indians have or may have paid during the above-mentioned year of extension during which, by the terms of the extended contract, he is to enjoy such tributes. First, however, you will deposit them in our royal treasury after having deducted from the gross receipts whatever has been necessary for the Christian instruction, administration, and preservation of the Indians; and when the six years are concluded you, the royal treasury officers of the province of Nueva Galicia, will collect for us all the revenue which the Indians produce, just as the revenues are collected elsewhere in that land from Indians under our royal crown. All this you will do and comply with, notwithstanding he may not go to reside for the prescribed year among his Indians; this none of you shall fail to do, under penalty of loss of our favor and a fine of one hundred thousand maravedis to be applied to the account of our [cámara]. Dated in Madrid, February IO, I 567. I THE KING. Signed by ERASO and countersigned by him.

[Royal order] commanding that the Indians of Nueva Galicia be gathered into towns, where they may live under an organized government. [I570.]

The King. To our oidores, alcaldes mayores of the Audiencia of the province of Nueva Galicia: Juan de la Peña, in the name of the council of justice and government of the city of Guadalajara, has made a report to me saying that because the Indian inhabitants of the province are not gathered into towns where they may have political government, much harm is done and many difficulties arise in their conversion and indoctrination, and they are not taught to live under the control and ordered system conducive to their salvation and welfare. For, scattered as they are over the mountains and deserts, the religious are unable to go every- 
bisitarlos ni acudir a todas partes y tambien se yban huyendo los dichos Yndios por que no se entienda su bida y costumbres y tener mejor aparejo De salir a saltear y rrovar y matar por los caminos a los españoles e yndios que estan de paz como lo havian hecho y hazian muchas vezes suplicandome que para remedio de ello mandasse que los yndios de esa provincia que andan ausentados Por los montes se Recogiesen y Juntasen y biviesen en pueblos conosidos y toviessen su Republica para que mejor fuesen ynstruidos en las cossas de la fee y no se les consintiesse que Poblasen de la manera que lo hazen en los montes y lugares escondidos Por el grande ynconveniente que dello redundaria, y visto por los del nuestro consejo de las Yndias y quanto bien se les sigue en ello a los dichos Yndios lo he avido por bien Por ende yo vos mando que proveais y deis orden como los yndios dessa provincia que andan por los montes se Recogan A bivir en Pueblos politicamente y tengan sus Republicas para que se puedan comunicar mejor los unos con los otros y tengan manera y orden de bivir y se pueda hazer mas fruto de su doctrina y combersion y se hebitan los daños e ymcombenientes que de lo contrario y de bivir por los montes y desciertos se puedan seguir en lo cual demas de cumplir con la obligacion que terneis nos ternemos por servidos y de como asi se haze y cumple nos dareis abisso fecha en el carpio a veinte y seis de Mayo de I57O-YO EL REY. ${ }^{\mathrm{a}}$

\section{El Rey Al Governador de la Provincia de Vizcaya sobre las Salinas de} aquellas tierras. $^{i}$ [ ${ }^{\text {5575.] }}$

Francisco de Ybarra nuestro Governador de la Provincia de la Nueva Vizcaya, a nos se ha hecho relacion que en essa vuestra Governacion ay algunas Salinas Las quales tomandose por hazienda nuestra como lo son y beneficiandose en nuestro nombre, podrian ser de fruto a nuestra Real hazienda y por lo que toca a nuestro servicio y al bien de ella os mando que platiqueys con personas ynteligentes, del beneficio y aprovechamiento que se puede sacar de las dichas salinas, arrendandosse ó beneficiendose por nuestra quenta y de lo que en ello trataredes; y os pareciere, nos embiareys relacion particular para que vista se provea Lo que comvenga y tambien comunicareys sobre este negocio, con la nuestra Audiencia Real de la provincia de la Nueva Galicia para que con mejor acuerdo Se tome determinacion en ello, fecha en villaçeca a 27 dias de abril de 1575 añosYo el Rey.j

\footnotetext{
h F. R. B., Sevilla.

1 A. G. I., I03-3-7.

J F. R. B., Sevilla.
} 
where to visit them; moreover, the Indians began to flee for the purpose of preventing interference with their manner and custom of life, and of securing better opportunities to assault, rob, and kill both Spaniards and peaceful Indians on the highways as they had repeatedly done. De la Peña supplicated me to order as a remedy for this that the Indians of that province who are wandering about in the mountains should be gathered together and made to live in established towns where they might have political organization for their better instruction in the things of the faith, and not be allowed to live as they do in the mountains and out-of-the-way places, because of the difficulties which would result. The plan suggested has been discussed by the members of our Council of the Indies, who considered how much benefit to the Indians would accrue from it; I have therefore approved it, and do now command you to issue orders and instructions for gathering the Indians of that province who are wandering in the mountains into towns where they may live in a civilized manner and have their organized government, that they may better communicate with each other, have order and system in their living, be more advantageously converted and indoctrinated, and escape the dangers and difficulties which may attend the opposite mode of living in the mountains and deserts. Whatever you may do in this matter above your ordinary obligation we shall accept as service to us, and you will report to us how this order is complied with and executed. Dated at El Carpio, May 26, I 570. I THE KING.

The King to the governor of the province of Vizcaya concerning the salt deposits of that country. [I575.]

To Francisco de Ibarra, our governor of the province of Nueva Vizcaya. It has been reported to us that there are in your government some salt deposits which, if they were taken as part of our estate, as they really are, and were worked in our name, would be a source of income to our royal treasury. Since this matter concerns the good of our service, I command you to consult with intelligent persons concerning the method of working these salt deposits and the profit which can be obtained from them either by leasing them or working them for our account. You will send us a detailed report of what you do and what your opinion may be, so that after proper deliberation suitable orders may be issued. You will also communicate with our royal Audiencia of the province of Nueva Galicia concerning this business, in order that the most harmonious action may be taken in the matter. Dated at Villaseca, April 27, I575. I тHE KING. 
Al Virrey de la nueva España que de Orden como se aseguren los caminos de la provincia de la nueva galicia donde hacen rovos y muertes indios chichimecas gastando para ello en lo forçoso con Moderacion lo que fue Necesario de la hazienda Real. ${ }^{k}$ [I580.]

El Rey.-Conde de coruña Pariente a quien avemos proveydo por nuestro Virrey Governador y cappitan general de la nueva españa o a la persona o personas a cuyo cargo es o fue el govierno dessa tierra saved que aviendosenos avissado por cartas y Relaciones que se nos han embiado de la provincia de la nueva galicia que los indios chichimecas hacen en los caminos della muchas muertes y Rovos a españoles e indios de paz y es causa de no yr en mucho aumento la dicha provincia demas de los dichos daños y que no podria aver seguridad en los dichos caminos no dandose Orden como a costa de nuestra hazienda oviese soldados que se ocupassen enasegurarlos, visto y platicado sobre ello por los del nuestro Consejo de las indias y con nos consultado acatando lo susodicho avemos tenido por bien de lo mandar proveer y asi, os mandamos que luego como vieredes esta nuestra cedula os informeis de los daños que hazen los dichos indios chichimecas y en que partes y en donde mas combiniente y fuere forcosso hagais poner gente que lo asegure por la orden que mas combenga gastando para ello con toda moderacion y limite lo que fuere menester de nuestra hazienda que sea lo que fuere forçoso y no se pudiere escusar que Por la presente mandamos a los nuestros officiales de esa tierra cumplan las librancas que dieredes en ellos para este efecto, sin embargo de lo proveido en contrario que por esta vez y para en quanto a esto dispensamos con ello y de lo que hicieredes y del efecto que tuviere esta prevencion nos avissareis fecha en badajoz a catorze de Junio de mill y quinientos y ochenta años yo EL REY Refrendada de ANTONIO DE ERASSO y librada del Presidente don Antonio de Padilla Don Santillan Eraso çuñiga Tlenas Vaillo Hinojosa.

Diego de ybarra a su Magestad Mexico I4 de henero de I582.

A la Sacra Catolica Real Magestad el rrey don felipe en su rreal consejo de Indias.

Sacra Catolica Real Magestad: En el primer nabio de abiso di quenta a Vuestra magestad de lo que hasta entonces se habia ofrecido en las cosas de la gobernacion de la nueba bizcaya y dije como en ella habia abido algunos descubrimientos de minas nuebas y el uno de ellos que son las que se llaman de sant andres hera de metales Ricos y de mucha lo qual se

k A. G. I., 744-I-I5.

${ }^{1}$ A. G. I., 66-6-I8. 
To the viceroy of New Spain, asking him to issue an order for the safeguarding of the roads of the province of Nueva Galicia, where the Chichimecas are committing robberies and murders; for this he is to expend from the royal treasury such sums in moderation as are absolutely necessary. [I580.]

The King. Count of Coruña, relative, whom we have appointed as our viceroy, governor, and captain-general of New Spain, or to the ferson or persons in whose charge the government of that land is or was: Know that we have been informed by letters and accounts which have been sent to us from the province of Nueva Galicia, that the Chichimeca Indians are committing many robberies and murders on the roads of the province upon Spaniards and peaceful Indians. This is the reason for the slight advancement of the province, aside from the crimes themselves, nor can there be any security on those roads unless orders are given to have soldiers placed upon them at the cost of our treasury to maintain them in peace.

This matter having been taken up and discussed by the members of our Council of the Indies, and consultation having been held with us concerning it, we have thought well to command that the safeguard suggested shall be provided; we therefore command that as soon as you see this our cédula you report to us the damages done by these Chichimeca Indians, and in what places. You will then place soldiers wherever it will be most fitting or necessary to place them in order to secure the roads, in the most suitable arrangement, spending for the purpose in moderation whatever may be necessary from the royal treasury, using only such amounts as may absolutely be required and cannot be avoided. We therefore now command our treasury officers of that country to honor the warrants which you may draw upon them for this purpose, existing orders to the contrary notwithstanding, because for this once and in this matter we dispense with this prohibition. You will also report to us what you have done, and what effect has resulted from the measures taken. Dated at Badajóz, June I4, I580. I the King. Countersigned by Antonio DE Eraso and issued by the president, Don Antonio De Padilla. Don Santillán, Eraso, Zuñiga. Tlenas [Llenas?], Vaillo, Hinojosa.

\section{Diego de Ibarra ${ }^{3}$ to his Majesty. Mexico, January I4, I582.}

To the Sacred Catholic Royal Majesty, the king, Don Felipe, in his royal Council of the Indies.

Sacred Catholic Royal Majesty: By the first despatch-boat I sent an account to your Majesty of what had occurred up to that time in the affairs of the province of Nueva Vizcaya. In it I stated how there had been some discoveries of new mines there, and that those called San Andrés were rich in high-grade ore, which was evidenced by the fact that in less than five months more than I0,000 marks in silver were taken from them. After the discovery had been made, many miners [engaged], 
habia hechado de ber porque en menos de cinco meses se habian sacado dellas mas de diez mill marcos de plata y estando ya hecho el descubrimiento y muchos mineros asentadas sus haciendas me escriben los oficiales de la rreal hacienda de Vuestra magestad como en birtud de las nuebas cedulas an pedido mina para de Vuestra magestad a hestaca de la descubridora poniendo pleyto a las personas que la poseyan

trayase la cedula de esto y labraban de lo qual se an agrabiado todos los becinos de las dichas minas diciendo el daño que de quitarles la dicha mina se siguia y de hacer los oficiales de Vuestra magestad esta nobedad en esta tierra en la qual en ninguna parte de minas della tal se habia hecho ni començado a hacer y que caso que se hubiese de hacer habia de ser al punto que se hacia el dicho descubrimiento y no despues que los que lo habian hecho estaban en posesion y beneficiaban los metales y luego que rrecibi las cartas que sobre esto se me escribieron las llebe al conde de coruña birrey de esta nueba españa para con el comunicar lo que tocaba a este negocio como a ynteres de la rreal hacienda de Vuestra magestad el qual como celoso de su rreal serbicio se hiço cargo de dar quenta dello a Vuestra magestad para que sea serbido probeher lo que mas conbenga y en el ynterin se escribio a los dichos oficiales no apretasen el negocio porque no se ynpidiese el beneficio de las dichas minas y que de oy mas en todos los descubrimientos que hubiere ynbien persona que en nonbre de Vuestra magestad tome mina a estaca de la descubridora y con esto cesaran semejantes ynconbenientes y llegado yo que sera muy en brebe procurare en todo el rreal serbicio de Vuestra magestad cuya Sacra Catolica Real persona nuestro señor guarde y en mayores rreynos y señorios acreciente como los leales basallos de Vuestra magestad deseamos de mejico I4 de henero-I582. Sacra Catolica Real magestad de Vuestra magestad criado y basallo que sus rreales pies y manos besa DIEGO DE YBARRA.

Diego de ybarra a Su magestad. Mexico 12 de abril 1582. A la Sacra Catolica Real Magestad el rrey Nuestro señor en su rreal consejo de Indias. $^{m}$

Del governador diego de yvarra de Mexico I2 de abril I582. Vista proveyda dentro.

Sacra Catolica Real Magestad: Por la ultima que escribi a Vuestra magestad en el segundo navio de Abiso que salio desta nueva españa El mes de henero deste año di a Vuestra magestad particular quenta de todo lo que entonces se of recia de la gobernacion de la nueva Vizcaya y por no aber cosa de nuebo sere brebe en esta con avisar a Vuestra magestad como en aquella probincia cada dia ay nuebos descubrimientos de minas de plata y fuera de las que se tratan y benefician de presente ay otras, por muchas noticias sera nuestro Señor servido baya aquella probincia en mucho aumento ansi en lo espiritual como en lo tenporal por aberse

m A. G. I., 66-6-18. 
and works established, the officials of the real hacienda of your Majesty wrote to me, and, in virtue of the new decrees, asked for a mine for your Majesty at the stake of the Descubridora, bring-

Let the decree for this be brought. ing suit against the persons who were in possession of it and were working it. By this all the residents of the said mines were aggrieved and said that great harm would result if the said mine should be taken from them and the officials of your Majesty should introduce this innovation into the mines of this country, in no part of which has such a thing ever been done or even attempted, or if it were done it should be at the time when the said discovery was made, and not after those who had made it were in possession and taking out the ore. As soon as I received the letters that were written to me about this, I took them to the Count of Coruña, viceroy of this New Spain, to consult with him about this matter and its relation to the interests of the real hacienda of your Majesty. $\mathrm{He}$, as a zealous subject in the royal service, took it upon himself to give account of it to your Majesty, so that you might take the proper measures according to your pleasure. In the interim he wrote to the said officials that they should not press the affair, so as not to interfere with the working of the said mines, and that in all the discoveries that may be made in the future they should not send any one in the name of your Majesty to take up a mine at the stake of the Descubridora. With this these disturbances will cease, and as s.oon as I arrive, which will be in a very short time, I will try to act in everything for the royal service of your Majesty, whose holy Catholic royal person may our Lord guard and increase in kingdoms and principalities, as we, the loyal subjects of your Majesty, desire. Mexico, January I4, I582. Servant and vassal of your sacred Catholic Royal Majesty, whose royal feet and hands I kiss. Diego DE Ibarra.

Diego de Ibarra to his Majesty. Mexico, April I2, I582. To his Sacred Catholic Royal Majesty, the king, our lord, in his royal Council of the Indies.

From Governor Diego de Ibarra, Mexico, April I2, I582. Opinion presented is within.

Sacred Catholic Royal Majesty: In the last letter that I wrote to your Majesty by the second despatch-boat that left this New Spain in January of this year, I gave your Majesty a detailed account of all that was then happening in the province of Nueva Vizcaya, and as there is nothing new I will briefly inform your Majesty in this that in that province there are new discoveries every day of silver mines, and, according to many reports, there are others besides those that are now being worked. Our Lord will be served, for that province is making great progress, in spiritual matters as well as in temporal, through the sending of some religious of the Order of Saint Francis to take charge of it and preach the Holy Gospel to the natives and take particular care for their good treatment and see that no 
ynbiado algunos Religiosos de la horden de San francisco para aquella custodia a que prediquen a los naturales el santo evangelio y tener particular cuenta en el buen tratamiento dellos y no se les haga ningun agrabio para el sustento destos rreligiosos conbiene que Vuestra magestad mande a sus oficiales de la rreal hacienda los probean de lo hordinario que se les suele dar de comida y bino para misas y haceyte para las lamparas del santisimo sacramento hasta agora yo les he probeydo de mi hacienda porque no se despueblen porque los vecinos de la Villa de durango y otras billas pobladas de españoles son tan pobres que no tienen con que se sustentar.

Ansi mismo he dado abiso a Vuestra magestad como aquella gobernacion be en mucho aumento conbiene se probea de prelado para que tengan particular cuenta de los naturales porque la

Cedula con esta Relacion para El virey y arçobispo de mexico que informe con su parescer.

silla catedral de la nueba galicia esta ochenta leguas de la villa de durango donde esta la caxa de Vuestra magestad y ay mucho discuydo con tan larga ynstancia ${ }^{\text {n }}$ y los diezmos de la nueva Vizcaya son bastantes para el sustento del prelado que vuestra magestad fuere servido probeher como sea del rrio grande alla y porque desto y otras cosas que conbienen al servicio de dios y Vuestra magestad he dado larga rrelacion no terne ${ }^{\circ}$ a que me alargar en esta sino es a decir que en esta de que ba por general don alvaro manrrique se ynbian a Vuestra magestad cinco mill y seyscientos marcos de plata de lo procedido en aquella provincia de sus rreales quintos y derechos y aunque poco para lo que se espera adelante es buen principio y porque de hordinario se dará avisso a Vuestra magestad de lo que se ofreciere no me alargo a mas de suplicar a Vuestra magestad humilmente sea servido mandar se bean las que tengo escrito y prober en ellas lo que mas Al rreal Servicio de Vuestra magestad conbenga cuya sacra catholica Real persona nuestro Señor guarde y acreciente en mas rreynos y senorios como los leales bassalos de Vuestra merced deseamos de mexico y abril I2, I582. Sacra Catolica Real magestad de vuestra sacra catolica Real magestad fiel vasallo que sus rreales pies vesa DIEGO DE YBARRA.

Diego de Ibarra A la sacra catolica Real magestad el rrey don felipe muestro señor en sus rreales manos. (Mayo [Octubre] de I582.)p

Sacra Catolica Real Magestad: En la flota que salio de esta nueba españa este año escribi a Vuestra magestad dando cuento particular del estado en que quedaban los negocios que tocan a la nueba Vizcaya y la plata que los officiales della ynbiaban a Vuestra magestad en la dicha flota y a esta causa no serbira mas de abisar a Vuestra magestad como

"Evidently a miscopy for "distancia".

- Evidently a miscopy for "sirve".

p A. G. I., 66-6-18. 
offense is committed against them. For the maintenance of these religious it is necessary that your Majesty order your officials of the real hacienda to provide them with what it is customary to give them in food, wine for masses, and oil for the lamps of the holy sacrament. Up to this time I have supplied them from my own funds, to prevent the country from being abandoned, for the residents of the town of Durango and other towns settled by Spaniards are so poor that they cannot maintain themselves.

I also informed your Majesty that since that province is making great progress it is necessary that a prelate be appointed, so that particular care may be taken of the natives, for the bishop's

Decree with this account that the viceroy and archbishop of Mexico shall make a statement of their opinion.

see of Nueva Galicia is eighty leagues from the town of Durango, where the treasury of your Majesty is, and because of the long distance there is much carelessness. The tithes of Nueva Vizcaya are sufficient for the support of the prelate whom your Majesty may be pleased to appoint, if it be from the Rio Grande to there. As I have given a long account of this and other things that pertain to the service of God and your Majesty, it is useless for me to lengthen this out, except to say that in the ship commanded by Don Álvaro Manrique there were sent to your Majesty 5,600 marks in silver, the issue of that province for its royal fifths and duties. And although it is little, compared with what is expected in the future, it is a good beginning. As your Majesty will always be informed of what may occur, I will not lengthen this out further than humbly to pray that your Majesty will be pleased to order that the reports that I have written be examined and measures taken upon them that will be most to the advantage of the royal service of your Majesty, whose holy Catholic royal person may our Lord keep and increase in more kingdoms and principalities, as we, the loyal subjects of your Grace, desire. Mexico, April I2, I 582. Sacred Catholic Royal Majesty, I, faithful vassal of your Sacred Catholic Royal Majesty, kiss your royal feet.

Diego de Ibarra.

Diego de Ibarra to his Sacred Catholic Royal Majesty, the king, our lord, Don Felipe, in his royal hands. (May [October], I582.)

Sacred Catholic Royal Majesty: By the fleet that left New Spain this year I wrote to your Majesty giving a detailed account of the state in which the affairs of Nueva Vizcaya were, and of the silver which its officials were sending to your Majesty by the said fleet, and, for that reason, nothing more is necessary than to inform your Majesty that I received by the fleet that just arrived the three decrees that your Majesty ordered sent to me, dated at Badajóz in September of last year. In regard to your Majesty's orders on the point that I shall report on what is going on in the said province in connection with matters referred to in the 
rrecibi en la que agora bino las tres cedulas que Vuestra magestad mando se me ynbiasen cuya fecha es en badajos por setienbre del año pasado sobre el particular de las quales vuestra magestad me manda abise y de rraçon de lo que cerca dellas pasa en la dicha probincia la primera es aber ynformado a vuestra magestad que los yndios naturales della pagan a las personas que los tienen en encomienda ecesibo tributo y que los que les administran Justicia no los defienden destos agrabios y lo que cerca desto pasa es que todos los naturales de aquella tierra son tan pobres y miserables que casi no se les conoce propios ningunos de donde puedan pagar tributo y el que les esta tasado y por mi señalado den esso lo serbicio personal y queste le hagan con tan poca bejacion que ninguno biene a serbir en todo el año mas que tres semanas y esto porque no salgan de la comunicacion y trato de los españoles y del amparo de los rreligiosos de la horden de san francisco que les administran los sacramentos y las justicias no los lleban ynterese ninguno como a vuestra magestad an echo Relacion porque seria yr contra la rreal boluntad de Vuestra magestad y sus rreales cedulas y los salarios que las tales justicias se les a señalado que son muy pocos se les libra en gasto de Justicia.

Por la segunda cedula me manda Vuestra magestad no se de lugar a que los negros que ay en la dicha probincia entren ni se comuniquen con los yndios naturales della por los muchos ynconbinientes que de ellc rresulta en daño de los dichos naturales por los malos tratamientos que de ellos rreciben cerca de lo qual sepa Vuestra magestad que los negros que ay en la dicha probincia estan distintos y apartados de las poblaçones de los dichos naturales rrespecto de que los Españoles cuyos se se sirben dellos del benefficio de las minas en las quales tienen asentados sus ingenios y casas donde biben y no enbargante esto de oy mas se tendra gran cuydado de lo que Vuestra magestad manda para que ebite que los negros no hagan ningun mal tratamiento a los naturales para lo qual se pondran grabes penas.

En la tercera me manda Vuestra magestad no se de lugar a que entre los dichos naturales aya pleytos y diferencias los quales sirben de consumirlos y gastarlos demas de los perjuros que en seguimiento de los dichos pleytos hacen los unos y los otros y lo que acerca desto tengo que decir es abisar a Vuestra magestad como entre los naturales de aquella probincia y gobernacion hasta oy no e sabido hayan tenido pleyto lo qual nace de ser ellos pocos y estar tan divididos y apartados unos de otros y no tener propios como a dicho de donde nace el ynterese de todos los pleytos de ocho meses a esta parte se an descubierto muchas minas de plata en aquella gobernacion las quales son de fundicion y rricas donde vuestra magestad tendra mucho aprovechamiento de sus quintos y derechos rreales y sera bien unibersal para toda esta nueva españa y sobre todo se entiende será nuestro Señor serbido porque en aquella comarca donde estas minas estan pobladas ay de presente mas de quatrocientos españoles y rraçonable poblaçon de yndios naturales que no tenian lumbre de fee y con este descubrimiento la ternan porque yo procuro bayan rreligiosos a predicarles el sancto Ebangelio.

Estas minas que digo estan la tierra adentro al norte quarenta y cinco leguas de la villa de Durango donde esta la caxa rreal los officiales propie- 
decrees, the first thing is to inform your Majesty that the Indian natives of the province pay an excessive tribute to the persons who hold them in encomienda, and those who administer justice to them do not defend them from these injuries. The truth about this is that all the natives of that country are so wretchedly poor that they have almost no recognizable property with which they can pay tribute, and what they are charged with I have determined that they shall give in personal service, and that they shall do this with so little trouble that no one comes to serve more than three weeks in the entire year, and this is done only so that they may not lose communication and intercourse with the Spaniards and the protection of the religious of the Order of Saint Francis who administer the sacraments to them. The justices do not charge them anything, as they have reported to your Majesty, for it would be going contrary to your Majesty's royal wish and your royal decrees, and the said justices depend on the salaries that you have granted them, which are very small, for the expenses of justice.

By the second decree your Majesty orders me not to allow the negroes in the said province to hold any communication with the native Indians, because of the many difficulties that result from it and the injury to the natives from the ill treatment which they receive from them. In regard to this your Majesty should know that the negroes in the said province are separate and apart from the settlements of the natives, for the Spaniards employ them in the working of the mines, where they have placed their mills and houses, and where they live; but, notwithstanding this, in the future great care will be taken to carry out your Majesty's order to prevent the negroes from ill-treating the natives, and heavy penalties will be imposed for it.

In the third your Majesty commands me not to permit lawsuits and disagreements to arise among the said natives, as they only serve to exhaust and destroy them, besides the injuries they do each other in consequence of the said lawsuits. Concerning this, what I have to say is to inform your Majesty that up to this time I have not heard of a lawsuit among the natives of that province and district. This results from their being few in numbers, widely separated from each other, and having no property, which, as I have said, is the origin of all lawsuits. Within these last eight months many silver mines have been discovered in that district in which the ore is both rich and fusible, and from which your Majesty will make a good profit in tithes and royal duties. It will be a universal benefit to all this New Spain, and above all it is thought that our Lord will be served, for, in the district where these mines are situated there are at present more than four hundred Spaniards, and a moderate population of native Indians who have not received the light of the faith, which with this discovery they will have, for I am taking steps to send religious to them to preach the holy gospel.

These mines of which I speak are in the interior, forty-five leagues to the north of the town of Durango, where the royal treasury and the proprietary officials of your Majesty are, and, although it is somewhat distant, they are provided from there with food and other necessaries until the country shall be settled and crops planted. 
tarios de vuestra magestad y aunque algo lexos de alli se probeen de bastimentos y las demas cosas necesarias hasta que la tierra se pueble y hagan sementeras.

De otros muchos descubrimientos de minas se tiene noticia por los ensayes que se han hecho dellas y doy horden como con la brebedad que lugar ubiere se descubran sera nuestro Señor serbido encaminarlo para que aquellos naturales se conbiertan y Vuestra magestad tenga muy gran 'aprobechamiento.

Por otras a dado abiso a vuestra magestad como por mi poca salud bine a curarme a esta ciudad de mexico con poner mis lugares tenientes a personas bastantes para ello y agora y agora [sic] que estoy con alguna mejoria ando de camino para la dicha Gobernacion de la nueba Vizcaya donde abisare a vuestra magestad de todo lo demas que se ofreciere cuya Sacra Catolica Real magestad nuestro señor guarde y acreciente con muchos Reynos y señorios como por este criado de Vuestra magestad se desea de mexico 14 de otubre de I582 Sacra Catolica Real magestad de vuestra magestad menor criado y basallo que sus Reales pies y manos vesa DIEGO DE YBARRA.

\section{[Diego de Ybarra al Rey. Mexico, Io de Noviembre de I582."]}

Sacra Catolica Real Magestad: La flota que desta tierra Salio por el mes de mayo deste año, general don albaro manrrique escrivi a Vuestra magestad dando quenta del estado en que entonces estavan las cosas de la governacion de la nueva Vizcaya y dixe la plata que de ella se embiava a Vuestra magestad de sus Reales quintos y como se havia echo ciertos descubrimientos de minas Ricas las quales estan oy pobladas con cantidad de españoles y aunque los metales no son al presente de tanta ley como al principio mostraron todavia por el mucho beneficio que dellos se haze espero en nuestro Señor se embiara a Vuestra magestad mas cantidad que hasta aqui a ydo y que cosas de aquella provincia han de yr cada dia en tanto aumento que los basallos que Vuestra magestad en ella tiene sean de mucho provecho para su rreal Servicio.

Dentro de un mes que la flota Partio tube nueba como tres Religiosos de la orden de San francisco y con ellos nueve Soldados que fueron en su compañia descubrieron quinientas legoas desta ciudad de mexico a la parte del norte cierta poblazon de mucha jente bestida y con algun genero de Pulicia pues tenian casas de tres y quatro Sobradas y mas y mucho bastimento acordaron entre ellos que los Religiosos se quedasen en aquella tierra y los soldados biniesen a dar noticia al birrey desta nueva españa de lo que hallaron en ella, y de alli a pocos dias se tubo noticia por bia yndios amigos que havian ydo con los dichos Religiosos como los yndios de aquella Provincia donde quedaron los mataron y porque de todo esto hara Relacion a Vuestra magestad el birrey dexo de darla yo en particular, solo quiero, havisar a Vuestra magestad que conforme al distrito que se conoce

Q A. G. I., 66-6-I8. 
There is news of the discovery of many other mines by assays made, and I am giving orders that as fast as time allows they shall be opened. Our Lord will be pleased to help it along in order that the natives may be converted and your Majesty receive great profit.

In other letters I have informed your Majesty how on account of my poor health I came to the City of Mexico to recover, appointing as my deputies persons competent for it; and now that I am somewhat better, I am on the road to the said district of Nueva Vizcaya, where I will inform your Majesty of anything else that may occur. May our Lord guard your Sacred Catholic Royal Majesty and grant you increase of many kingdoms and principalities, as is desired by this servant of your royal Majesty. Mexico, October I4, I 582. Sacred Catholic Royal Majesty, I, the meanest servant and vassal of your Majesty, kiss your royal feet and hands. DiEgo DE IbARRA.

\section{[Diego de Ibarra to the king. Mexico, November I0, I582.]}

Sacred Catholic Royal Majesty: By the fleet which left this country in the month of May of this year, Don Álvaro Manrique commanding, I wrote to your Majesty giving an account of the state in which the affairs of the district of Nueva Vizcaya then were, and I spoke of the silver which was being sent by it to your Majesty from your royal tithes, and how there had been certain discoveries made of rich mines. These are now settled by a number of Spaniards, and, although the ores are not at present of such high grade as they at first appeared, yet, from the great profit that is being drawn from them I hope in our Lord that there will be sent to your Majesty a greater sum than has hitherto gone, and that the affairs of that province will make such daily advancement that the subjects of your Majesty who are there will be very useful to the royal service.

Within a month after the departure of the fleet, I had news of how three religious of the Order of Saint Francis, accompanied by nine soldiers, ${ }^{4}$ discovered, five hundred leagues north of this City of Mexico, a certain settlement containing many people who wore clothing and had some sort of government; they have houses of three and four stories and more, and plenty of provisions. They agreed among themselves that the religious should remain in that country, and that the soldiers should come to give information to the viceroy of this New Spain of what they had found in it. A few days afterwards news was received by means of friendly Indians who had gone with the said religious that the Indians of the province where they had remained had killed them; but, as the viceroy will give an account of all this to your Majesty, I omit giving it in detail. I only wish to inform your Majesty that, according to the territory that the district of Nueva Vizcaya is known to cover, the jurisdiction 
tener la governacion de la nueva Vizcaya parece, pertenecerle la jurisdicion deste descubrimiento porque se sabe que personas della a muchos dias que tenian noticia de el y los soldados que agora fueron con los dichos Religiosos lo heran de la compañia del governador martin lopez de ybarra mi lugartheniente y desto ni de otra cosa que a ello toque no e querido tratar mas de yrme con la boluntad del Virrey el qual hasta saver la de Vuestra magestad en este particular no a querido proveer ninguna cosa Vuestra magestad bista la rrelacion proveera lo que mas sea servido que a lo que a mi se me mandare acudiré como leal basallo de Vuestra magestad, el dicho martin lopez de ybarra que tambien servia el officio de thesorero por nombramiento del governador francisco de ybarra el qual le dio por ser el dicho martin lopez uno de los primeros conquistadores y pobladores de aquella Provincia, murio habra cinco meses y por su fin y muerte Provey en el dicho cargo de thesorero a juan de ybarra mi sobrino persona abil y suficiente para exercerle a Vuestra magestad Umilmente suplico sea servido confirmalle el dicho nombramiento y satisfago a Vuestra magestad le hize en el mas Respecto de su abilidad y suficiencia que por ser deudo mio, guarde nuestro Señor la Sacra catolica Real persona de Vuestra magestad con acrecentamiento de mayores Reinos y señorios como los leales basallos de Vuestra magestad desseamos de mexico ro de noviembre 1582 .

Sacra Catolica Real Magestad de vuestra sacra catolica Real magestad criado que sus Reales pies vesa DIEGO DE YBARRA.

\section{[Diego de Ybarra al Señor Secretario Juan de Ledesma. Mexico, ro de Noviembre de I582.']}

Señor secretario juan le ledesma.

Illustrisimo Señor: Aunque Vuestra merced tenga por cosa nueba tener carta mia tengo a mucha dicha se ofresca ocasion de hazer principio en esta y ofrezerme a que Vuestra merced de oy mas me tenga por su serbidor y me ynbie a mandar en esta ciudad y fuera della que sera particular merced para mi.

Lo que de presente se me ofrece que suplicar a Vuestra merced es que biendo el menoscabo que por mis haciendas han benido y las muchas deudas que debo determine hacer ynformaciones de los muchos serbicios que a su magestad e hecho asi en el descubrimiento de las minas de las çacatecas como en la conquista y Pacificacion de la provincia de la nueba Galicia hallandome con mi persona en ella y francisco de ybarra mi sobrino con la suya en el descubrimiento conquista y pacificacion de la probincia de la nueba Vizcaya dandole yo de mi hacienda el socorro de dinero que para ello tenia necesidad, que fueron en cantidad de mas de ducientos mill ducados. Sin que de hacienda de su magestad se aya gastado en esto un rreal solo y aberle ydo en la flota pasada de solo la dicha Probincia y de los quintos della mas de cinco mill y seiscientos marcos de plata y en esta

r A. G. I., 66-6-18. 
of this discovery appears to belong to it, for it is known that persons of this district had news of it many days ago, and the soldiers who just went with the said religious were from the company of Governor Martín López de Ibarra, my deputy. With this or anything else connected with the matter I have not wished to deal, except to yield myself to the will of the viceroy, who, until he learns the wish of your Majesty on this point, has not desired to take any steps. When your Majesty has examined the account you will take such measures as please you, and I will carry out the orders given to me like a loyal subject of your Majesty. The said Martín López de Ibarra, who also served in the office of treasurer by appointment of the governor, Francisco de Ibarra, ${ }^{5}$ who gave it to the said Martín López because he was one of the first conquerors and settlers of that province, died about five months ago. On account of his death I appointed to the said office of treasurer my nephew, Juan de Ibarra, ${ }^{6}$ a person able and qualified to fill it. I humbly beg that your Majesty will be pleased to confirm him in the appointment, and I assure your Majesty that I made it more because of his ability and qualifications than because he is my relative. May our Lord guard the Sacred Catholic Royal person of your Majesty, with increase of greater kingdoms and principalities, as we, the loyal subjects of your Majesty, desire. Mexico, November Io, I 582 .

Sacred Catholic Royal Majesty, I, servant of your Sacred Catholic Royal Majesty, kiss your royal feet. DIEGo DE IbARRA.

\section{[Diego de Ibarra to the Señor Secretary, Juan de Ledesma. Mexico, November IO, I582.]}

Señor Secretary, Juan de Ledesma.

Most Illustrious Sir: Although your Grace may be surprised to receive a letter from me, I regard it as great good fortune that the occasion offers to make a beginning in this and to offer myself to your Grace as your servant in the future and to place myself under your orders in this city and outside of it, which will be a special favor to me.

What I have to place before you at present is that, in consideration of the diminution of my fortune and the many debts that I owe, I determined to make a report of the many services that I have rendered to his Majesty, in the discovery of the mines of Zacatecas as well as in the conquest and pacification of the province of Nueva Galicia, serving in person in it, while my nephew, Francisco de Ibarra, served in the exploration, conquest, and pacification of the province of Nueva Vizcaya, in which I aided him from my estate with money that he needed, amounting to more than two hundred thousand ducats, and not a single real was spent in this from the funds of his Majesty. [I wish also to report] that there went to him by the last fleet, from the tithes of the said province alone, more than five thousand six hundred marks in silver; and I believe that by the present one much more will go, because there have been more discoveries and 
de agora creo yran mucho mas por aber nuebos descubrimientos y aber mas benefficio en ellas todo ba bastantemente probado y tanto que me aseguran personas que an bisto las probanças son las mejores y de mas calidad que desta tierra an ydo despues que ella se gano como alla Vuestra merced lo bera por ellas y por el parecer que acerca de ello dieron Virrey y audiencia las de officio ban en el pliego de su magestad a vuestra merced suplico la ampare con su fabor y ayuda haciendome en todo la merced que hubiere lugar la qual ofresco servira a vuestra merced con particular boluntad y en mi nombre las presentaran juan Ramirez de Velasco y pedro de arriola y daran memorial de lo que en gratificacion de todo pretendo. Por fin y muerte del thesorero martin lopez de ybarra que sirbio el cargo de thesorero de la nueba Vizcaya, como gobernador de ella probey la dicha thesoreria en juan de ybarra mi sobrino y criado y serbidor de Vuestra merced. El qual escribe a vuestra merced dandole particular quenta de lo que pasa y como tengo tanta satisfacion de su persona que hara el deber en serbir a su magestad pretendo me haga merced de confirmarme el dicho officio en juan de ybarra y como acerca desto ynporta mas el dinero que representar serbicios y que esto a de parar en quien mas dineros diere enbio mi poder a juan Ramirez de velasco para que este officio se de en lo que la contaduria de la nueba Vizcaya de la qual se le hiço merced a Alonso Calderon en propiedad en cantidad de seys mill ducados y si en menos fuere posible se procure en lo que Ubiere lugar y si acaso Ubiere algunos pretensores que quieran subir de esto el dicho juan Ramirez de Velasco dara la horden que conbiniere a quien me remito tanbien escribe juan de ybarra al Señor Conde de chinchon sobre ello y entiendo acudira su señoria con todas beras como negocio de criado y echura de su casa, torno a suplicar a Vuestra merced lo ampare todo como a cosa desta su casa en el un negocio y en el otro doña ana y todos los della besan las manos de Vuestra merced cuya illustre persona nuestro señor guarde y en estado y prosperidad de mayor acrecentamiento que deseo mexico Io de nobienbre 1582 Illustrisimo Señor besa las manos de Vuestra merced su serbidor DIEGO DE YBARRA. [Rúbrica.]

Carta del Contador Alonso Calderon á Su Magestad 2 de nobiembre I582."

Sacra Católica Real Magestad: Luego que llegue a estas provincias de la nueva vizcaya a servir a Vuestra Magestad de contador de su rreal hazienda he procurado de mirar $\mathrm{El}$ aumento y aprovechamiento dellas ansi para lo que toca a los pobladores como A la hazienda de Vuestra Magestad y con haver veinte años que se empeço a poblar esta al presente bien poco poblada a Causa que los governadores y sus tenientes y oficiales de la hazienda de Vuestra Magestad se lo han rrepartido Entre sy no guardando El horden que Vuestra Magestad dio en lo de las nuevas poblaciones y conquistas como se vera Por un testimonyo que ymbio de las posesiones que adquirio y tomo para si martyn lopez de ybarra tesorero

A. G. I., 66-6-22. 
more work done in the mines. All goes well, so much so that persons who have seen the samples assure me that they are the best and richest that have come out of this land since it was conquered, as your Grace will see there by them and by the opinion which the viceroy and the Audiencia gave about it. The official opinions go in the parcel for his Majesty, and I beg that your Grace will give them your support and assistance and grant me all the favor possible, for which I offer to serve you with special good will. Juan Ramírez de Velasco and Pedro de Arriola will present them in my name, and will give a statement of what I ask for in reward for all. Because of the death of Martín López de Ibarra, who served in the office of treasurer of Nueva Vizcaya, I, as governor of it, appointed to the said treasurership Juan de Ibarra, my nephew and servant of your Grace. He is writing to your Grace, giving you a detailed account of all that is happening, and as I am satisfied that he will do his duty in serving his Majesty, I beg that he [his Majesty] will do me the favor of confirming my appointment of Juan de Ibarra. As in this matter money is more important than setting forth services, and as this will fall to him who gives the most money, I convey my power of attorney to Juan Ramirez de Velasco to give the same for this office as was given for the auditor's office of Nueva Vizcaya, which was granted to Alonso Calderón for property to the amount of six thousand ducats, and if it be possible let it be procured for less. ${ }^{\top}$ If any claimants bid higher than this I give my power to the said Juan Ramírez de Velasco to give the necessary order. Juan de Ibarra is also writing to the señor Count of Chinchón about it, and I understand that his lordship will earnestly assist him, as the matter concerns a servant and henchman of his house. I again beg your Grace to give your support to all this as an affair of this your house for the one business and the other. Dona Ana and all those here kiss the hands of your Grace, whose illustrious person may the Lord guard and grant increase and prosperity, as I desire. Mexico, November IO, I582. Most Illustrious Sir, your servant kisses your Grace's hand. DiEgo DE IBARRA. [Rubric.]

Letter of the Contador Alonso Calderón to his Majesty, November 2, I582.

Sacred Catholic Royal Majesty: Ever since I arrived in these provinces of Nueva Vizcaya to serve your Majesty as contador [auditor] of your. real hacienda, I have endeavored to seek their welfare and increase both in respect to the settlers and to your Majesty's treasury. Although it is twenty years since the province began to be settled it is at present very sparsely populated, because the governors, their lieutenants, and the offcers of your Majesty's treasury have parcelled it out among themselves, neglecting to obey the order which your Majesty gave concerning new settlements and conquests. This may be seen from the deposition [testimonio] sent by Martín López de Ibarra, your Majesty's treasurer and lieutenant-governor, of the possessions which he acquired and took for 
de Vuestra Magestad y Teniente de governador que creo yo que El solo tenia mas tierras que es toda vizcaya y siendo El solo uno y haviendo otros muchos que tengan tanto Como El y lo mejor ni ay que dar ni adonde que sea de provecho para otros y ansi yra en dimynucion cada dia y ellos y sus haziendas en aumento de que se sigue a Vuestra Magestad notable daño.

Demas desto los tenientes de governador han rrepartido y dado muchos yndios En encomienda siendo cossa rreservada a la persona de Vuestra Magestad y ansi mismo an rrepartido y dado oficios de escrivanos y Alguazilazgos mayores En propiedad sin tener para ello poder. Porque conforme a lo que Vuestra Magestad capitulo con francisco de ybarra primero governador y descrubidor a El solo y a su suçessor se le dio facultad desto y no a sus tenyentes ny a los governadores despues de las dos vidas que ya son acabadas y aora lo usan y provehen y rreparten yndios En confianza y vuestros oficiales de vuestra hazienda se sirven de ellos y hazen que se los rrepartan a sus hijos contra lo que esta por vuestra Magestad mandado.

Tanbien en la capitulacion que hizo Vuestra Magestad con francisco de ybarra como por ella paresçe le dio comission para que nombre oficiales para la rreal hazienda de Vuestra Magestad hasta tanto que se enbian los por Vuestra Magestad provehidos y esto se a estado ansy sin que nadie aya dado noticia dello y de tres que nombro francisco de ybarra los dos son muertos que aora murio El thesorero que haviendole Vuestra Magestad de vender se hallaran aqui doze myll pesos por El y El de factor lo puede Vuestra Magestad conforme a lo capitulado En El horden de nuevas poblaciones que suplico a Vuestra magestad mande se vean: proveher lo que a estado husurpado hasta aora y sin licencia ni aprobacion de Vuestra magestad ha llevado El que la sirve quarenta myll pesos de salario que aunque meresciera mucho era suficientissima gratificacion yo havisso a Vuestra magestad de lo que entendiendo es pro de su rreal hazienda con que quedo descargado.

[Al margen se lée:] trayase la capitulacion y titulo que llevo. [Rúbrica.]

Ansymismo ay otro Capitulo en la capitulacion que se tomo con francisco de ybarra En que manda Vuestra magestad lo que se a de dar de tierras y solares a los descubridores y Conquistadores yo en nombre de toda esta provincia suplico a Vuestra magestad y para El aumento y ampliamiento de poblacion della sea servydo de mandar dar su cedula para que En El repartimyento de las tierras y yndios y officios se guarde en lo pasado y porvenir lo por Vuestra magestad mandado y concedido en las dichas capitulaciones que dello resultara aumento a Vuestra magestad en su rreal Hazienda y pro general a todos sus vasallos y nuestro señor La sacra Catolica Real persona de Vuestra magestad guarde con aumento de mayores Reynos por muy largos años como los criados y vasallos de Vuestra magestad havemos menester de la villa de san sebastian de chiametla y nobiembre 2 de 82 . 
his own. For I think that he alone held more lands than the whole of Vizcaya, ${ }^{8}$ and he was only one of many, there being others who must have as much as he and that of the best, so that there is no longer any land to give nor any profitable place for others. Hence the province, as well as the settlers and their holdings, will deteriorate in value every day, and if that situation continues it will result in marked injury to your Majesty.

Furthermore, the lieutenants of the governor have divided the Indians and given many of them in encomienda, this being a power reserved to your Majesty; they have also distributed and bestowed the proprietary offices of notary [escribano] and alguacil mayor without the power to do so. For, in conformity with the capitulation of your Majesty with Francisco de Ibarra, the first governor and explorer, to him and his successor only the faculty to do this was given, but not to his lieutenants nor to the governors after the two first lives, which have now ended. Nevertheless, the lieutenants use the power and furnish and apportion Indians to their friends, and your officers of your treasury make use of them and cause them to be apportioned to their children, in contravention of your Majesty's commands.

There was also in the capitulation which your Majesty made with Francisco de Ibarra, as it appears, a provision whereby he was given the commission to name the officers of your Majesty's real hacienda until such time as there should be sent others named by your Majesty. This they have continued to do, no one having taken notice of the matter. Now, however, two of the three named by Francisco de Ibarra are dead, the treasurer having just died, and if your Majesty desires to sell the office, twelve thousand pesos can be found for it here. The office of business manager. [factor] your Majesty may also sell, in conformity with that which was agreed upon in the orders for new settlements, and I beseech your Majesty to order appointments made for those positions which have until now been usurped without license or approbation of your Majesty. The present incumbent has received forty thousand pesos' salary, and, although the position merits a good salary, this is a very ample amount; I offer your Majesty this advice, understanding that it is for the benefit of your real hacienda, wherewith I have discharged my obligation.

[In the margin it reads:] Bring the capitulation and the appointment which he received. [A rubric.]

There is also another paragraph in the capitulation made with Francisco de Ibarra, in which your Majesty commands how much land and how many building lots are to be given to the explorers and conquerors. Now I, in the name of all this province, beseech that your Majesty will for the sake of the increase and prosperity of the population, be pleased to order a cédula issued commanding that, in both the past and the future apportionment of lands and Indians and offices, what your Majesty commanded and conceded in these capitulations shall be observed. The result will be increase to your Majesty's real hacienda and the general benefit of all your vassals. May our Lord guard the sacred Catholic royal person of your Majesty, with increase of greater kingdoms, for many long years, as the servants and vassals of your Majesty have need. From the villa of San Sebastián de Chiametla, November 2, I 582. 
[Al margen dice:] ydem.

Sacra Catolica Real Magestad.

De Vuestra magestad leal vassallo y fiel Criado que sus rreales pies y manos bessa. ALONSO CALDERON. [Rúbrica.]

[Al dorso se lée:] Vista y proveida dentro trayase lo que se pide. [Rúbrica.]

\section{Respuesta [del Rey] al Virrey de la nueva españa. ${ }^{t}$ [1597.]}

El Rey.-Conde de monterey pariente mi virrey governador y capitan general de la nueva españa en carta de 28 de febrero me escrivis la falta que ay de lenguas de los naturales entre los religiosos de la orden de san francisco que tienen a cargo las doctrinas en la comarca de guadina de la provincia de la nueva vizcaya y el impedimento que Ponen a los Religiosos de la compañia de Jesus que sabien lengua de los dichos naturales para que no entren a confesar y predicar por aquellos pueblos y como quiera que al Comisario general de la orden de san francisco que rreside con mi corte se a ordenado que advierta desto a los prelados de su orden de essa provincia y de la poca rrazon que tienen en no poner personas en aquellas doctrinas que sepan la lengua de los naturales y en estorvar la entrada a los dichos rreligiosos de la compañia de Jesus y Al provincial de la misma orden de sant francisco de essa provincia escrivo tambien sobre ello a Vos como a quien principalmente toca el cuydado de proveer y ordenar todo lo que combenga para que en ninguna parte aya falta de ministros de doctrinas que sepan la lengua de los yndios os encargo le tengan de procurar que entren en la dicha provincia de guadiana todos los rreligiosos que la supieren a entender en su doctrina y Predicacion del evangelio y los de la compañia de Jesus agradeceris de mi parte el cuydado con que en acudido A ello y los animareis para que lo continuen.

Tanbien decis la necesidad que han pasado el arzobispo de la philipina que quedo en mexico esperando enbarcacion a que no a sido justo dar lugar y assi os encargo y mando que si todavia estuviere ay le agays prover de todo lo necesario para su entretenimiento y viage a quenta de la rrenta de su yglesia y no aviendo de ella por tenerlo consignado lo areis de otra qualquiera manera que assi es mi voluntad: en lo que decis sobre la presentacion que la nueva vizcaya tiene de que se divide del obispado de Guadalaxara se ba mirando: de sant lorenco a veynte y cinco de Junio de mill y quinientos y noventa y siete años-Yo EL REY-Refrendada de JUAN DE YBARRA y señalada del presidente y de los del consejo.

tA. G. I., 87-5-I. 
[In the margin it says:] The same.

Sacred Catholic Royal Majesty: The loyal vassal and faithful servant of your Majesty, who kisses your feet and hands, Alonzo Calderón. [A rubric.]

[On the back it reads:] Seen, and provided for within; bring what is ordered. [A rubric.]

\section{Reply [of the king] to the viceroy of New Spain. [ [597.]}

The King. Count of Monterey, relative, my viceroy, governor, and captain-general of New Spain: In your letter of February 28 you wrote me concerning the existing lack of knowledge of the native languages among the religious of the order of Saint Francis who have charge of the doctrinas in the vicinity of Guadiana in the province of Nueva Vizcaya; you also told how they prevent the religious of the Company of Jesus who know the native languages from going among those towns to confess and preach. Although the commissary-general of the order of Saint Francis, who resides in Madrid, has been ordered to call this matter to the attention of the prelates of his order in that province, showing them how unwisely they act in not placing in those doctrinas persons who understand the native languages, and in opposing the entry of the religious of the Company of Jesus; and although the same order has been sent to the provincial of the order of Saint Francis of the province itself, I am writing concerning the situation to you also, you being the one upon whom falls the principal care of providing and ordering all that is suitable for preventing lack anywhere of ministers of doctrinas who understand the language of the Indians. I therefore charge you that they are to see that all the religious who understand the language shall enter the province of Guadiana to engage in instruction and the preaching of the gospel; and the Company of Jesus you will thank in my behalf for the solicitude with which they have offered themselves for this, and you will encourage them to continue so doing.

You also speak of the inconviences suffered by the Archbishop of the Philippines, who had to wait in Mexico for a vessel; it was not proper that this should occur, and I therefore charge and command you that if he is still there you will have him provided with everything needed for his maintenance and voyage at the expense of the income of his church. If there are no funds available from this source because they are already assigned to other uses, you will make provision in some other way, for this is my pleasure. As to what you say with reference to the request of Nueva Vizcaya to be separated from the bishopric of Guadalajara, this is being looked into. San Lorenzo, June 25, I 597. I THE KING. Countersigned by JUAN DE IBARRA and signed by the president and members of the Council. 


\section{Notes for Part I., Section 3.}

1 An old Spanish coin of the value of about one-sixth of a cent.

2 "López (Gonçalo) - Attorney of Mexico, to whom the governor of Yucatán apportioned certain Indians in the pueblo of Acatlán, the third part of whom he had possession of in the year I548" (Cartas de Indias, p. 787). See also ibid., p. 75 .

${ }^{3}$ For other documents, written about 1563 , which relate to the activities of the Ibarras in Nueva Galicia see Colección de Documentos Inéditos, relativos al Descubrimiento, Conquista, y Organización de las antiguas Posesiones Españolas de America y Oceanía, XIV. 553-56r.

* The reference is to the expedition of Fray Agustín Rodríguez and Francisco Sánchez Chamuscado to the Pueblo region in New Mexico in 158I. See p. 193.

${ }^{5}$ Francisco de Ibarra was the founder and first governor of Nueva Vizcaya, and served from 1562 until after 1570 . He was a nephew of the writer of this letter.

${ }^{6}$ One Joan López de Ibarra was a member of the Espejo expedition to New Mexico in 1582-1583. "Account of the Journey which I, Antonio Espejo . . . made ... to the Provinces and Settlements of New Mexico ..." [English translation], in Bolton, Spanish Exploration in the Southwest, pp. 170 and 185 .

$\checkmark$ Offices on the frontier frequently went to the highest bidder.

${ }^{8}$ Reference is to the province of Vizcaya in Spain. 
I. 4. DOCUMENTS RELATING TO THE EARLY COLONIAL ADMINISTRATION OF NEW SPAIN. 


\section{[Memorial al Rey de los Procuradores de la Nueva España. Sin fecha. ${ }^{a}$ ]}

Sacra Catolica Cesarea Magestad. Lo que los procuradores de la nueva españa pretenden y suplican vuestra magestad haga merced A aquella tierra para que en ella se plante y perpetue nuestra santa fe Catholica y nueva yglesia y el servicio de vuestra magestad y el patrimonio y Rentas Reales y para la quietud y crecimiento de los yndios naturales y españoles que en ella biven y han de tomar Raizes son las siguientes:

Lo primero que con toda brevedad vuestra magestad haga merced a aquella tierra de mandar no aya en ella Corregimientos y que todos los pueblos de yndios asi los que estan encomendados a españoles como los que estan en cabeca de vuestra magestad salvo algunas cibdades principales de todos los demas se haga Repartimiento perpetuo entre los españoles vassallos de vuestra magestad sienpre fieles que la ganaron y conquistaron a su costa y con su sangre y trabajos y a los pobladores que la tienen poblada y entre aquellos que vuestra magestad mas servido sea teniendo sienpre Respecto a que los conquistadores sean preferidos y a la calidad de las personas y servicios.

Lo otro que por quanto vuestra magestad tiene en la nueva españa y en estos sus Reynos personas de gran credito ciencia conciencia y fidelidad Caballeros prelados y Religiosos sea servido cometer y señalar luego quien haga el dicho Repartimiento perpetuo y dalles la comision necesaria para que con toda brevedad se efetue con tanto que las personas que lo ovieren de hazer sea en la cibdad de mexico y no en estos Reynos porque teniendo la masa personas y servicios presentes esta muy cercano el acertarle a hazer y de hazerse aca no biendo es muy cierto herralle.

Lo otro que vuestra magestad sea servido de mandar con muy gran brevedad hemendar suspender y Revocar los capitulos de las leyes que vuestra magestad a aquella tierra enbio de que la nueva españa tiene supplicado que parecera por los abtos y provanca hecha ante vuestra Real abdiencia que esta presentado por los procuradores y en poder del secretario mandando no se huse dellos porque su graveza y Rigor han cabsado gran daño en la tierra y en los moradores della y cabsallo y an muy mayor si pasasen adelante porque hazer esto en el entretanto que se haze y acaba el dicho Repartimiento perpetuo es lo que mas conbiene al Real servicio de vuestra magestad.

$\mathrm{Y}$ porque las cabsas evidentes por do claramente consta y parece ser justo esto que aquel nuevo mundo pide pretende y suplica y todo el servicio de dios nuestro señor y de vuestra magestad y acrecentamiento del Real patrimonio y al asiento y perpetuydad de aquella tierra esta dicho por la peticion de los dichos procuradores que adelante deste memorial esta y provado por la dicha ynformacion y abtos piden y suplican se vea todo.

Gonzalo lopez.-Alonso de villanueva. [Rubricados.]

${ }^{a}$ A. G. I., I45-7-9. 


\section{[Memorial of the Procuradores of New Spain to the King. Undated.]}

Sacred Catholic Imperial Majesty: The procuradores [attorneys] of New Spain petition and supplicate your Majesty to grant to this land-so that there may be planted and perpetuated in it our holy Catholic faith and new church, the service of your Majesty, the royal patrimony and revenues, and the peace and advancement of the native Indians and Spaniards who live and are to take root in it-the following measures:

First, that your Majesty grant the favor to that land as soon as possible of ordering that there shall be no corregimientos in it, and that in all the Indian towns, those which are vassal to the Spaniards, as well as those which are under the authority of your Majesty, except some principal towns of all those remaining, this shall be done : perpetual partition among the ever faithful vassals of your Majesty, the Spaniards who won and conquered it at their own expense and with their blood and labors, and the settlers who have settled it, as it may please your Majesty among them, always taking care that the conquerors be preferred and the character and services of the persons [be considered].

The other is, that inasmuch as your Majesty has in New Spain and in these, your kingdoms, persons of great credit, knowledge, honesty, and fidelity-cavaliers, prelates, and religious - that you be pleased at once to charge and appoint persons to make the said perpetual partition, and to give them the necessary commission so that it may be done with all promptitude; and so much the better if the persons who are to do it shall be of the City of Mexico and not of these kingdoms, for, with the body of persons and services present it is easy to hit the mark, while to do it here, without seeing, would surely cause it to be missed.

And may your Majesty be pleased likewise to order without delay that the articles of the laws which your Majesty sent to that land be amended, suspended, and revoked-as New Spain has supplicated, as will appear in the autos and proof made before your royal audiencia and presented by the attorneys and now in the possession of the secretary-by commanding that they be not followed, for their gravity and rigor have caused great injury to the land and its inhabitants, and will cause even greater if they continue. To do this in the interval while the said perpetual partition is being made and finished is what is most advantageous to the royal service of your Majesty.

And, since the evident reasons by which this that the New World asks, claims, and supplicates, clearly appears and seems to be just, and entirely in the service of God, our Lord, and your Majesty, and the increase of the royal patrimony and the solidity and perpetuity of that land, are stated in the petition of the said procuradores which antedated this memorial and are proved by the said evidence and autos, they ask and beg that all be read.

Gonzalo López. ${ }^{1}$-Alonso de Villanueva.-[Signed with rubrics.] 


\section{[Petición de los Procuradores de la Nueva España y Gran Ciudad de Mexico. Sin fecha. ${ }^{b}$ ]}

Sacra Catolica Cesarea magestad: Los procuradores de la nueba españa y gran cibdad de mexico y de las otras cibdades villas y lugares della que a esta parte somos venidos besamos los Reales

Toda esta es importante.

pies y manos de vuestra magestad y dezimos que despues que dios nuestro señor por su ynfinita bondad en los gloriosos y felizes tienpos de vuestra magestad despues que muchos millares de años fue serbido que aquellas grandes provincias de le nueva españa y moradores della que avian estado detenidas e ocupadas por el demonio syn ninguna claridad ni lunbre de fee donde hera sacrificado con muchos rritos y supresticiones bibiendo todos o los mas dellos enbueltos en pecados nefandisimos contra toda naturaleza humana se oviesen ganado por los españoles que a los principios de su primer descubrimiento en ella se hallaron y por los que despues subcedieron ensanchando e dilatando nuestra fee y Religion cristiana por todas las provincias de la dicha nueva españa subjectandolas al señorio y corona destos rreynos de castilla syn que vuestra magestad en ello oviese gastado de su Real hazienda ni patrimonio poniendo los que se hallaron en su primer descubrimiento sus personas en tanto descrimen pasando tantos peligros por mares no sabidos e tierras no conocidas entre gentes tan barvaras tan apartadas de nuestro emisperio gastando sus patrimonios e haziendas desterrandose de su naturalezas con celo del serbicio de dios y de traer a su conocimiento aquellas tierras y gentes no sabidas e siendo esto ansy y aviendose echo en todo ello grandisimos servicios dinos de ynmortal memoria y de perpetua Remuneracion vuestra magestad se tubo por muy servydo como la calidad de la cosa lo Requeria y es ansy que para en parte de rremuneracion y paga de lo que abian serbido tubo por la vien que toda dicha tierra se rrepartiese por las personas que se avian hallado en su descobrimiento y despues la oviesen ayudado a conquistar y poblar para que gozasen de lo que con tantos trabajos y a su costa avian ganado y que fuesen Remunerados quedando para vuestra magestad los derechos Reales y el señorio e juridicion y por aver lo vuestra magestad tenido por bueno el marques del valle que fue el que descubrio la dicha tierra a quien vuestra magestad encomendo la gobernacion della y despues el licenciado luys ponce de leon y los otros que gobernaron y el presidente y oydores que a los principios fueron rrepartieron los yndios della para que fuesen pagados y rremunerados sus serbicios con la mesma tierra los que la avian ganado y sustentavan y que ansy conbenia porque a ello obligaba toda rrazon dibyna y humana especialmente en casos tan grandes y en serbicios tan señalados y despues en confirmacion desto mando poner en su rreal cabeca algunos pueblos principales porque los demas quedasen para los conquistadores y pobladores y demas desto vuestra magestad por muchas cartas rreales suyas y por medio del presidente e oydores que han Residido en ella de cada dia les ofrecia que se Repartiria toda la tierra en los vezinos que en ella obiese 


\section{[Petition of the Procuradores of New Spain and the great City of Mexico. Undated.]}

Sacred Catholic Imperial Majesty: We the procuradores [attorneys] of New Spain and the great City of Mexico, and the other cities, towns, and villages of it, upon whose behalf we have All this is important. come, kiss the royal feet and hands of your Majesty. And we declare that God, our Lord, in his infinite goodness, in the glorious and happy times of your Majesty, after many thousands of years, was pleased to grant that those great provinces of New Spain and its inhabitants-which had been retained and occupied by the devil, without any light or fire of faith, where sacrifice was made with many superstitious rites, all, or the most of them, living enwrapped in abominable sins contrary to all human nature-should be gained by the Spaniards who were there at the beginning of its first exploration, and by those who afterwards followed, extending and spreading our faith and Christian religion through all the provinces of the said New Spain, and subjecting them to the dominion and crown of these kingdoms of Castile, without your Majesty having spent anything from the royal treasury or patrimony, those who were in the first exploration exposed their persons to great hardship and passed great dangers in unknown seas and lands, among a very barbarous people, far distant from our empire, and spent their wealth and property, exiled from their kind, with zeal in the service of God and to bring to a knowledge of him those unknown lands and peoples. This being so, and they having given in all this great services worthy of immortal memory and perpetual reward, your Majesty was well pleased, as the nature of the matter required, and as partial remuneration and pay for the services they had given, to decide that all the said land should be divided among the persons who were there at its exploration and had afterwards aided in conquering and settling it, so that they might enjoy what they had gained with so much labor and at their own expense, and so that they should be remunerated, your Majesty retaining the royal rights and dominion and jurisdiction. And because your Majesty passed this judgment, the Marqués del Valle, who explored the said land and to whom your Majesty intrusted its government, and afterwards the licentiate Luís Ponce de León ${ }^{2}$ and the others who governed it and the president and oidores $^{3}$ who were there at the beginning, divided the Indians, so that those who had gained and held it might be paid and remunerated for their services by the land itself. This was right, for every reason, divine and human, imposed it, especially in cases so great and services so distinguished. Afterwards, in confirmation of this, your Majesty ordered to be placed under your royal authority some principal towns, the rest to remain for the conquerors and settlers; and, besides this, your Majesty, in many royal letters of your own, and through the medium of the president and oidores who resided in it, daily promised that all the land should be divided among the residents that might be in it, granting increased allotments to those who had them and giving to those who had none. For this you ordered an inventory to be made of all the land, so that in 
cunpliendo de mayores Repartimientos a los que los tenian y dando a los que faltaban y para ello mando hazer discrecion de toda la tierra para que vista se fiziese el Repartimiento y en el entretanto mando que las personas que tenian Repartimientos gozasen dellos y despues de sus muertes sus hijos y mugeres teniendo sienpre entendido quel dicho rrepartimiento general se avia de hazer porque ansy conbenia e conviene para lo que toca al serbicio de dios y conserbacion de los naturales y acrecentamiento de vuestras Rentas y perpetuydad de la tierra por las Razones que se diran y estando esperando este perpetuo Remedio cada dia fueron a la nueba españa ciertas leyes y hordenancas que vuestra magestad mandaba guardar con algunas de las quales no solamente no se les dio el Remedio que esperaban y conbenia pero fue quitarles lo que ellos avian ganado y lo que vuestra magestad por sus serbicios les avia dado y ellos tenian tan bien merecido dandoles pena en lugar de premio todo en total destruycion de la dicha tierra y de los españoles que en ella estaban y lo mas es de doler y lo que con lagrimas entrañables se llora es ber y sentir que el demonio procura bolber Asy aquellas tierras que en tantos millares de años tubo tan subjetas a su juridicion lo qual dios no permita porque necesariamente segun lo que se vee y entiende syno se Remedia con brebedad no podrian dexar de subceder casos muy deasstrados ynpensados de los honbres que el henemigo de naturaleza humana busca con Rodeos porque demas de las Razones que se diran constara por estas ynformaciones echas con prelados y con personas de rreligion y letras y doctrina y enxenplo y espiriencia y allende de la ebidencia y muestra de lo que a pasado y pasa ques la mejor prueba de todas que ya no viene a estar la cosa en palabras syno en obras porque de sola la nueba españa se an benido casi seyscientos casados syn otra mucha gente de que se ynchieron todos los nabios que avia y que en todos los que fueren se hara lo mesmo muestrase mas por la diminucion de vuestras rrentas rreales y que ya los tratantes destos rreynos dexan el comercio de las yndias que hera el mayor e mejor de lo que esta agora se sabe syn que aya necesidad de Referir los desasosyegos y turbaciones que con estas nueba leyes ay en el peru y en todas las yndias ques arto daño solamente por lo que aquel nuebo mundo toca suplicamos con todo el acatamiento que podemos y devemos mande vuestra magestad prover en el Remedio dello y que sea con toda brebedad posible probeyendo en dos cosas principales.

La una que rrequiere mas presteza que la otra aun questa segun las cosas estan no es menester suplicarla con mucha ynstancia pero por lo que debemos al servicio de vuestra magestad suplicamos que luego con toda brebedad y presteca posible se Remedie y sosiegue la alteracion en que queda la nueva españa mandando espresamente que no se huse de las dichas hordenancas porque sy esto no se ynbia luego ningun Remedio ni esperanca de salud ternan ${ }^{c}$ los que alla estan con palabras ni provisiones ni otra seguridad y para prober $^{\mathrm{d}}$ esto no son menester mas causas de la esperiencia que se a visto y bee y sy mas se espera verna ${ }^{\theta}$ el Remedio A

c Evidently a miscopy for "tendran".

d Evidently a miscopy for "probar".

e Evidently a miscopy for "vendra". 
view of it the partition could be made, and in the meantime you ordered that the persons holding allotments should enjoy them, and after their deaths their children and wives, it always being understood that the said partition was to be made, for it was and is to the advantage of all that touches upon the service of God, the preservation of the natives, the increase of your revenues, and the perpetuity of the land, for the reasons that will be stated. While this permanent remedy was being expected every day, certain laws and ordinances, ${ }^{4}$ which your Majesty ordered should be observed, went to New Spain, by some of which not only was the measure that they expected, and which was right, not given, but what they had gained and what your Majesty had given them for their services and which they had well merited was taken away from them, giving them punishment instead of reward, to the total destruction of the said land and of the Spaniards who were in it. What is still more grievous and with anguished tears is bewailed, is to see and feel that the devil is trying to return to those lands which he held under his rule for so many thousands of years-which may God not permit-for, according to what is seen and understood, unless some measure is quickly taken, very disastrous occurrences, unforeseen by man, which the enemy of human nature seeks with subterfuges, cannot fail to take place. Besides the reasons that will be stated, it will be evident from the reports made by prelates, and by persons of religion, learning, Christianity, example, and experience, and furthermore by the evidence and demonstration of what has happened and is happening, which is the best proof of all, that the matter has come to be no longer an affair of words but of acts. That from New Spain alone there have come nearly six hundred married couples, besides many other people who crowded all the boats that there were-and the same will happen in those that are to go-appears, moreover, in the diminution of your royal revenues, and in the fact that the merchants of these kingdoms are abandoning the commerce of the Indies, which was the greatest and best of any hitherto known. There is no need to refer to the disquiet and disturbances which have arisen in Peru and in all the Indies from these New Laws, which is sufficient injury but only for what concerns the New World we beg, with all the reverence that we owe and are capable of, that your Majesty order measures to be taken to remedy this, and that it be done as quickly as possible, by taking measures in two particular matters.

One requires more haste than the other, for which, as things are, there is no need to ask with much insistence; but for what we owe to the service of your Majesty, we supplicate that immediately and with all the haste possible the disturbed state existing in New Spain be remedied and quieted by ordering positively that the said ordinances be not put in practice, for if this be not sent at once those who are there will have no remedy nor hope for safety with words, or measures, or other security. To prove this, no more reasons are necessary than the experience which has been had and is being had, and if there is longer delay the remedy will come at a time when there will be no need for it. It is clear that, even though the said laws were not injurious and harmful for the land, reason shows the 
tienpo que no sea menester pues esta claro que aunque las dichas leyes no fueran tan dañosas e agraviadas para la dicha tierra una nobedad y mobimiento tan grande en unas tierras tan lexos de vuestra presencia Real la Razon muestra los desasosiegos y daños que podia y puede traer porque aunque toda la tierra tiene creyda la Real yntincion de vuestra magestad fue mobyda con santo celo como cristianisimo y catolico principe tanbien tiene entendido que no fue vuestra magestad vien ynformado y porque proveyendose esto como conviene por lo que toca al servicio de vuestra

El remedio universal de la tierra.

Repartimiento perpetuo. magestad. La otra causa principal a que nosotros en nonbre de la dicha tierra venimos es por el remedio universal y perpetuydad de la tierra que de cada dia como de suso es dicho estavan aguardando humillmente suplicamos a vuestra magestad lo mande prober y Remediar por lo que toca al serbicio de dios nuestro señor ques lo que vuestra magestad sienpre ha deseado y por lo que toca a la conserbacion de los naturales de aquella tierra y al acrecentamiento de vuestras Reales Rentas y para que los españoles que estan en aquellas partes sean Remunerados de sus serbicios y asienten e pueblen la tierra ques lo principal y en que consiste el fundamento de todo porque para que esto se deba ansy hazer entre otras muchas Razones que para ello ay se pueden ver las siguientes.

Lo uno que se debe considerar lo que al principio desta nuestra peticion deximos ques que los españoles que en ella estan y han ydo ganaron y descubrieron toda aquella tierra a sus propias espensas syn sueldo ni acostamiento de vuestra magestad y la han sostenido y sostienen aviendo puesto y poniendo sus personas e haziendas en defensa y conservacion della aviendo muchas vezes derramado su sangre y muerto en ella sus padres y hermanos y parientes y aviendo gastado sus vydas e haziendas.

Lo otro porque siendo esto ansy esta claro que de derecho dibino e humano les es devyda Remuneracion perpetua pues lo que ganaron es perpetuo y que seria cosa ynhumana que en sus vejezes fuesen a buscar de nuebo de comer para sy e para sus mugeres e hijos.

Lo otro porque todos los que gobernaron entendiendo que conbenia ansy al serbicio de vuestra magestad y al descargo de su Real conciencia rrepartieron la tierra y ansi se hizo desde que la tierra se gano asta el año de treynta con consetimiento y aprobacion de vuestra magestad.

Lo otro porque como dicho es y en mayor confirmacion del Repartimiento que les estaba echo vuestra magestad por sus provisiones hizo merced a la dicha nueba españa y vezinos della y personas que tenian los yndios encomienda que subcediesen en ellos despues de sus dias sus hijos e mugeres y que pudiesen con ellos dotar sus hijas e hijos ofreciendoles la perpetuydad en ello y que se daria horden en lo demas como toda la tierra se Repartiese.

Lo otro que confiados con esta merced y esperanca perpetua muchos se casaron e llevaron mugeres destos Reynos enpeñando sus haziendas sosteniendo en sus casas muchos españoles que han ydo aquella tierra que hasta agora han estado el Remedio universal della. 
disquiet and mischief that a change and disturbance so great in a country so far from your royal presence might and can bring, for, although all the country has faith that the royal intention of your Majesty was influenced by holy zeal, as a Christian and Catholic prince, it also understands that your Majesty was not well informed of the reasons why this measure is to the advantage of what concerns the service of your Majesty.

The other principal cause for which we came in the name of the said land is for the universal remedy and perpetuity of the land, for which, as

The universal remedy for the land:

Permanent repartimiento. above said, they were waiting every day. We humbly supplicate that your Majesty order remedial measures to be taken for what concerns the service of God, our Lord, the preservation of the natives of that land and the increase of your royal revenues, and in order that the Spaniards who are in those parts may be remunerated for their services and may settle and populate the land, which is the principal thing, and the foundation of all the reasons why this ought to be done. Among other reasons that there are for it the following may be examined:

One. What we said at the beginning of this, our petition, ought to be considered, which is that the Spaniards who are in it and have gone there, gained and explored all that land at their own expense, without pay or emolument from your Majesty, and that they have maintained and do maintain it by having placed and now placing their persons and property in its defense and conservation, many of their fathers and brothers and relatives having shed their blood and died there and having used up their lives and property.

Another reason. This being so, it is clear that by divine and human right, perpetual remuneration is owing to them, for what they gained is perpetual, and it would be an inhuman thing if in their old age they should have to go out anew to seek food for themselves and their wives and children.

Another reason. All those who governed, understanding that this way would be to the advantage of the service of your Majesty and the relief of your royal conscience, divided the land, and it has been thus since the country was acquired, up to the year of ' 30 , with the consent and approbation of your Majesty.

Another reason. As has been said, and in greater confirmation of the partition that was being made to them, your Majesty, by your provision, granted to New Spain and its inhabitants and the persons who held the Indians in encomienda, that after their days were ended their wives and children should succeed to them, and that with them they could endow their sons and daughters, offering them perpetuity in it, and that orders would be given for the rest as soon as all the land should be divided.

Another reason. Confiding in this grant and perpetual hope, many married and took wives from these kingdoms, mortgaging their property and supporting in their houses many Spaniards who have gone to that land, and until now they have been waiting for the universal measure for it. 
De las quales Razones juntas e de cada una dellas se ynfiere a colige el agrabio tan grave que se siguiria sino se fiziese la Remuneraçion perpetua porque seria quitarles su derecho syn culpa ni demeritos.

Porque cierto es cosa de sentir ver los maridos e las mugeres cargados de hijos los llantos que hazen teniendose por engañados de averlos hecho casar con la esperanca de la perpetuydad y ber que muriendo agora an de quedar pobres desterrados de sus tierras entre gentes tan barbaras syn ningun Remedio abenturando las almas y las honrras que aunque esto se podria engrandecer con muchas palabras con todas ellas no se puede allegar a la menor parte de lo que por vista de ojos se syntio viendo juntar corrillos de mugeres y ber sus lagrimas y ber el sentimiento que hazian.

Pero dexado esto aparte y que en ninguna cosa se tubiese consideracion a la justicia que tienen los vezinos de la nueba españa syno que para sostener aquella Republica se oviese menester hordenar de nuebo esta claro que lo que de aquellas probincias se debe pretender son quatro cosas la una el servicio de dios y la segunda es el buen tratamiento de los naturales y conbersion y conserbacion dellos la tercera la perpetuydad de la tierra y moradores que en ella estan e an ydo e fueren la quarta el acrecentamiento de vuestras Rentas e para que estas se consigan conviene que se de perpetuydad aquella tierra por las Razones siguientes.

Conviene que para que los que han Recibido la fee cristiana la conserben y los que no la han rrecibido la alcancen aya muchos cristianos españoles segun la grandeza de la tierra esten en ella con muchos rreligiosos e personas que entiendan en ello para que con la conversacion y continuacion dellos se conserben en esta cristiandad y tomen policia de vivir estando sienpre entre cristianos y en poder dellos y ansy necesariamente conviene que aya entre ellos sienpre españoles e Religiosos que tengan mucho cargo para que con la diturnidad del tienpo deprendan lo que la flaqueza de sus entendimientos en poco tienpo no puede llevar.

Lo otro porque siendo como es necesario y forcoso lo contenido en el capitulo antes deste se sigue que los españoles conviene que tengan quietud e yntincion de permanecer en la tierra ansy para que los yndios conoscan que con ellos y entre ellos a de ser su abitacion y cobren amor y familiaridad y olbiden los pensamientos que sienpre han tenido e tienen que los españoles se han de acabar y que se han de quedar como antes estavan porque a esto les mueve la natural ynclinacion que tenian antes de bibir libremente y para que ansy mismo de parte de los españoles visto que alli han de bivir ellos e sus hijos y se ha de perpetuar su posteridad los traten con buenas obras e amor e les hagan toda caridad por el beneficio que dellos han de rrecibir y porque syn ellos no se podran sustentar.

Lo otro porque sabiendo los españoles y los yndios que han de permanecer ansy los unos como los otros se darian a cultibar la tierra e a vibir en horden e concierto en toda la cristiandad y policia porque los españoles pornian ${ }^{f}$ plantas e harian hedificios y los mesmos yndios por el consiguiente ymitandolos y desto se aprobecharian los unos e los otros porque con la abundancia de los frutos y de los ganados que segun la calidad de la tierra vernian ${ }^{\mathbb{B}}$ brebemente en crescimiento llegara la cosa

"Evidently a miscopy for "ponian".

g Evidently a miscopy for "vendrian". 
From these reasons together and from each one of them is inferred and deduced the very grave injury that would follow if the perpetual remuneration should not be given, for it would be to take away from them their rights without blame or fault [on their part.]

It certainly is a sad thing to see the husbands with wives burdened with children, and the tears they shed, believing that they were deceived into marrying with the hope of the perpetuity, and seeing that if they [the husbands] die now the wives and children will be left poor, exiled from their country and risking their souls and honor among a barbarous people without any remedy. Even though this were enlarged upon with many words, with all of them one could not express the smallest part of what was felt as an eye-witness on seeing the gatherings of women and their tears and the grief they felt.

But, leaving this apart, and leaving out all consideration of justice to the inhabitants of New Spain, and considering only that in order to maintain that commonwealth it would be necessary to make new regulations, it is clear that four things ought to be sought for these provinces: first, the service of God; second, the good treatment of the natives and their conversion and preservation; third, the perpetuity of the land and the inhabitants that are in it and have gone there and may go there; fourth, the increase of your revenues. In order that these things may be secured it is desirable that perpetuity be given in that land, for the following reasons :

It is desirable, in order that those who have received the Christian faith may preserve it, and that those who have not received it may acquire it, that there shall be many Spanish Christians, according to the greatness of the land, in it, with many religious and persons versed [in religion], so that with their conversation and constant presence the Indians may be kept in this Christianity and may learn proper living by being always among Christians and in their power. It is thus necessarily desirable that always there shall be among them Spaniards and religious who shall take care that with the passage of time they shall learn what, because of the feebleness of their understandings, they cannot acquire in a short time.

Another reason. Since what is contained in the article before this is necessary and indispensable, it follows that it is desirable that the Spaniards shall have tranquillity and the expectation of remaining in the land; also that the Indians shall understand that their habitation is to be with them and among them, and shall acquire love and familiarity with them, and shall forget the belief that they have always had and still have that the Spaniards are to come to an end and that they are to be as they were before, for they are moved to this by the natural inclination which they had before to live in freedom; also on the part of the Spaniards, seeing that they and their children are to live there and their posterity is to be perpetuated, that they shall treat the Indians with kindness and love and show them every charity, for the benefits which they are to receive from them, and because without them they cannot support themselves.

Another reason. Knowing that they are to remain thus permanently, both the Spaniards and the Indians would devote themselves to cultivating 
a tanto que la mesma abundancia cause Riqueza entre los naturales y entre los españoles y esta traera mas sosiego e quietud en las almas y en los cuerpos como naturalmente se bee de que se podra mejor serbir dios.

Lo otro porque de hazer lo contenido en el capitulo antes deste allende de darse horden en la perpetuydad se sygue que los yndios se exerciten y ocupen y no esten ociosos porque de su natural ynclinacion lo son y henemigos de trabajar que no ay cosa mas cierta que esto e ansy no pensaran en los vicios en que se an criado ni en desasosiegos ni bollicios de que son amigos.

Lo otro porque lo susodicho no se puede hazer syno se dan yndios perpetuos y no basta dar tributos ni que anden en coregimientos porque siendo perpetuos conserbanlos y hazen como en heredad propia acrecentanlos cada dia y conocen a su señor y el señor los conoze y trata y quando been que no pueden conplir el tributo o se lo quitan o les esperan lo que no se haze ni puede hazer por el corregidor ni por los oficiales de vuestra magestad porque el corregidor como mercenario no tiene cuydado syno de su salario e de que se le pague adradiado ni le duele que se pierdan o se ganen porque otro año le an de dar otro coregimiento el coregidor no planta ni sienbra ni cria ganado en su corregimiento ni fuera del solamente procura de hazer dinero e venirse porque como no tiene casa ni lugar cierto todas sus obras y pensamientos son para apañar hazienda e venirse por no dexar su muger e hijos entre gentes barbaras perdidos.

Lo otro porque aunque se de a muchos hombres de comer con los coregimientos y con salarios e que ansy se diga que estos pueden sustentar la tierra esto es muy grande engaño y la Razon y esperiencia muestra lo contrario porque estos no tienen ni pueden tener caudal para sostener gente en su casa pues ni tienen hereflades ni plantan ni crian ni tienen donde y no lo teniendo no puede aver comercio ques lo que sostiene la Republica lo que es al Rebes en los que tovieren yndios e pueblos porque los de unas partes senbraran y en otras partes plantaran arboles e vyñas y en otras criaran ganados en otras criaran seda en otras descubriran minas y ternan ${ }^{\mathrm{h}}$ esclavos con que sacar horo e plata y en otras partes se haran otras grangerias segun las calidades de los lugares y tierras para que lo que faltare en unas se provea de las otras y ansy aya comercio entre unos y otros lo qual totalmente a faltado y ha de faltar en los coregidores y en los pueblos que estuvieren en cabeca de vuestra magestad porque ni ay quien lo haga ni pueden hazer ni se puede tener cuydado dello.

Lo otro porque no se a visto que los yndios en el plantar ni en las otras grangerias usen de la tierra como usan los españoles para los Respetos dellos porque estan criados en aquello que su natural les ynclina y lo que sus pasados se criaron porque no tienen cuydado de subcesyon ni de perpetuydad syno de lo que tienen presente y han menester para sy syn pensar en el dia de mañana antes se ha visto por esperiencia muchos Desto. pueblos que estovieron encomendados en españoles muertos los españoles averse puesto en cabeca de vuestra magestad haver dexado en los dichos pueblos vyñas e frutales y arbole-

b Evidently a miscopy for "tendran". Similar instances of this apparent miscopy are to be found in the remaining part of this document, although attention is not directed to them by specific notes. 
the land and to living in order and concord in all Christianity and propriety. The Spaniards would set out plants and erect buildings, and the Indians would naturally do the same in imitation of them. By this both would profit, for with the abundance of fruits and herds, which, according to the quality of the land, would soon come in increasing measure, the thing would reach such a point that the very abundance would result in riches among the natives and the Spaniards. This would bring more peace and quiet to their souls and their bodies, as is naturally evident, and God would be better served.

Another reason. By doing what is contained in the article before this, besides giving the order for perpetuity, it follows that the Indians will be exercised and employed and will not be idle, for they are naturally so by inclination and are enemies of work, and there is nothing more certain than that by this way they will not think of the vices in which they were reared nor of the uproars and disturbances to which they are addicted.

Another reason. The above cannot be done except by giving the Indians in perpetuity, and it is not enough for them to give tributes nor that they shall come under corregimientos. If they are given in perpetuity, the Spaniards take care of them, treat them as their own property, and improve them every day, and they know their master and the master knows them and deals with them; and when they [the masters] see that they cannot fulfill the tribute they either relieve them of it or wait for them. This is not done nor can it be done by the corregidor nor the officials of your Majesty, for the corregidor, being a hireling, has no care for anything but his salary and that he be paid on time, nor does it trouble him whether there is loss or gain, for the next year he will be given another corregimiento. The corregidor does not plant or sow or raise cattle in his corregimiento nor outside of it; he only tries to make money and come away, for as he has no house nor fixed home, all his acts and thoughts are to get property and come away, in order not to leave his wife and children lost among barbarous people.

Another reason. Although a living is given to many men with the corregimientos and with salaries, and it is said that these can thus support the country, this is a great mistake, and reason and experience prove the contrary, for these have not nor can they have means to support people in their houses, for they have no farms nor do they plant crops or raise cattle nor have they where to do it, and not having it, there can be no commerce, which is what sustains the commonwealth. It is the opposite with those who may have Indians and towns, for those in some parts will sow grain, in other parts they will plant trees and vines, in others they will raise cattle, in others they will produce silk, in others they will discover mines and will have slaves to take out the gold and silver; and in other parts they will produce other products, according to the quality of the places and lands, so that what is lacking in some may be provided from the others. In this way there will be commerce among them all, which has been and will be totally lacking in the corregidores and the towns under the rule of your Majesty, for there is no one to do it, nor can they do it, nor can there be any care for it. 
das y moreras y otras grangerias y ganados y arrancarlos los mesmos yndios y quitarlos porque no pareciese vestigio ni señal pues mucho menos querran plantar de nuevo ni criar ganados.

Lo otro porque contra esto no se puede dezir que los mesmos yndios para pagar los tributos que se an de cobrar para vuestra magestad an de hazer sementeras e grangerias e que se lo mandaran y que ansy ellos lo podian sostener porque esto es syn fundamento porque antes que fuesen de cristianos pagaban a sus caciques estos tributos y otros muchos mas y mayores pero no por eso se aplicavan ni cultibaban y los tributos que agora dan son de las cosas que ellos crian e azen que son mantas y mayz y frisoles y otras cosas desta calidad.

Lo otro porque dado caso que los criasen y plantasen y edificasen esta cierto que ni haran lo uno ni lo otro sino es teniendo dueños perpetuos esto que criaren e dieren en tributos no ay

Que los tributos de los indios que estan en caveza de su magestad se gasta en salarios de corregidores $y$ ansi no bastan. con quien se comercie ni a quien se venda ni para quien sea porque si dizen que para los coregidores o personas a quien se dieren salarios esta claro que ni ellos los conpraran ni tienen con que ni para que porque los salarios que se dan de los pueblos que estan en caveca de vuestra magestad se gastan en la comida de los mesmos coregidores a los quales ninguna cosa les sobra como dicho es ni puede sobrar ni tienen para que lo conprar pues ni tienen casa ni vyña ni tierra ni donde lo tener syno ay perpetuydad y ansy necesariamente lo que sobra para vuestra magestad de mantas y toldillos y cosas de la tierra no quedaria para quien se bender ni con quien se contratar y se perderia.

Lo otro porque en tener los españoles los pueblos perpetuos sienpre se a visto que tienen frayles o clerigos con ellos e llevan alli sus mugeres e hijos e criados e criadas e animan a los yndios e rregalanlos no les hazen mal tratamiento ninguno ni tienen porque hazersele $\mathrm{y}$ ansy se a visto $\mathrm{e}$ bee por esperiencia que nunca o muy poquitas vezes acaesce que aya pleytos ni querellas de los españoles encomenderos lo qual se vee al contrario que esta sienpre llena la audiencia de pleytos de agrabios y malos tratamientos que se hazen en los pueblos de vuestra magestad que estan puestos en corregimiento por los coregidores.

L.o otro porque en los pueblos encomendados se a visto e bee por esperiencia los tenplos que se an hecho los hornamentos y cosas que se han dado y dan para el culto divyno de mucha Riqueza por los que tienen lo qual no se a echo por los coregidores ni tienen con que.

Lo otro porque ansy mismo la esperiencia muestra el mejor tratamiento que los yndios Reciben de los españoles en quien estan encomendados que no los que son Regidos por coregidores por que estan claras las molestias y bejaciones que Reciven por los muchos señores que tienen que son por una parte todos los oficiales de vuestra magestad y sus criados y los corregidores y alguazilles e otras personas y con color que se haze en nonbre de vuestra magestad no se osan querellar lo que es al Rebes en el que estan encomendados.

Lo otro porque de darse perpetuos los dichos yndios y tenerlos los españoles demas de lo que esta dicho del servicio de dios y buen tratami- 
Another reason. It has not been experienced that the Indians make use of the land as the Spaniards use it, by observing them, either for planting or other purposes, for they are brought up to do whatever their nature inclines them to do and what their ancestors were brought up to do. They have no care for succession or perpetuity, but only for what they have in front of them and have need of for themselves, without any thought of the morrow. Rather it has been learned by experience that in many towns that were under encomiendas, when the Spaniards

Note this. died and the towns were placed under the rule of your Majesty, vines and fruit-trees and orchards and mulberries and other crops and cattle that were left there were torn out and cut away by the Indians themselves, so that no vestige or sign remained. Much less, then, would they be willing to plant anew or raise cattle.

Another reason. Against this it cannot be said that the Indians themselves, in order to pay the tributes to be collected from them for your Majesty, would raise crops or what was ordered, and that they could maintain it thus, for this is without foundation. Before they became Christians they paid their caciques these tributes and many others much larger, but they did not for this reason apply themselves to cultivating the land, and the tributes that they give now are of the things that they raise and make-such as blankets, maize, beans, and other things of that sort.

Another reason. Supposing that they will raise cattle and plant and build, it is certain that they will do neither the one nor the other except by having perpetual masters. And if they

The tributes of the Indians who are under the rule of your Majesty are spent in the salaries of corregidores, and thus are not enough. do raise cattle and give tributes there will be no one with whom to trade, nor to whom to sell, nor for whom it will be done; for if they say it is for the corregidores or persons to whom salaries will be given, it is clear that neither will they buy nor will they have the means or motive, for the salaries that are given in the towns that are under the rule of your Majesty are spent on the living of the corregidores themselves, and there is nothing left, as has been said, nor can there be anything left, nor have they any reason to buy, since they have neither house nor vineyard nor land nor wherein to put it, unless there be perpetuity. Thus, necessarily, for what would remain above your Majesty's share of blankets and awnings ${ }^{5}$ and things of the land, there would be no one to sell them to, nor with whom to trade them, and they would be lost.

Another reason. When the Spaniards have held the towns in perpetuity it has always been the custom to take friars or clergymen with them, and to take their wives and children and male and female servants, and they encourage the Indians and treat them well. They do not ill treat them in any way, nor have they any reason to do it, and therefore it has been proved by experience that it seldom or never happens that there are disputes or quarrels on the part of the Spanish encomenderos. On the contrary, the experience is that the audiencia is always full of disputes about 
ento de los yndios y del acrecentamiento y coltura de la tierra estan muy notorios los grandes beneficios que se pueden seguir porque se a visto que los que an tenido encomendados pueblos an edificado y plantado en ellos arboles e vyñas y frutales y moreras y todos los generos de grangerias que la tierra sufre y demas de tener muy pobladas sus casas con sus mugeres e hijos e criados con muchos caballos y personas que han ydo destos Reynos lo que no se ha echo ni podido hazer con los pueblos que estan puestos en corregimientos porque quando mucho se an sostenido con los dichos pueblos son fasta dozientos corregidores que son personas que apenas se pueden sostener asy syn tener casa ni familia e que en los lebantamientos que avido en la tierra ni podian ni tenian con que yr a servir lo que a sido al Reves en los encomenderos porque de los españoles que en mexico y su comarca tenian pueblos encomienda que podian ser hasta ciento e cincuenta salieron hasta quinientos de caballo con el bisorrey para la jornada de la nueba galicia de los yndios que se rrebelaron syn la gente que quedo en la dicha cibdad para la guarda della que esta cierto si la defensa oviera de estar en los coregidores ya estobiera perdida la tierra y estovieran llevantados los yndios.

Lo otro porque aunque es cierto que el dia de oy estubiese la tierra llena de españoles sino tobiesen perpetuydad no se podian sostener porque no se aplicaran a labrar la tierra ni cabar ni criar ganado porque aunque lo criasen y se cogiese no tienen a quien bendello ni quien se lo conpre ni pueden tener comercio con los yndios y es cierto que los yndios no conpran ni se aprobechan de las cosas que se plantan e crian por los españoles ni se espera que se aprobecharan en muchos años porque no son como los aldeanos destas tierras porque todos andan desnudos con unas mantas de la tierra e con sus calcados que ellos hazen no tienen en sus casas axuar ni lo conpran y poco aprobecharia en estos rreynos ni en ninguna parte del mundo que todos fuesen labradores pues con dibersidad de estados se haze o sostiene la Republica lo que no podria aber en la nueba españa syno ay perpetuydad $\mathrm{y}$ esta no la puede aver sino tienen yndios porque ninguno quiere yr dos mill leguas y bender lo que aca tiene a arar y cabar pues en estos Reynos ternian artas partes donde lo hazer y por no lo hazer ay muchas partes despobladas.

Lo otro porque ansi mismo se muestra la necesidad que ay que los yndios se den perpetuos a los españoles por la esperiencia que se a visto de los yndios de las yslas e tierra firme que por no se aver encomendado perpetuos se destruyeron todos porque heran mercenarios y no pastores $y$ solamente procuraron de beber sus sudores y venirse que ni plantaron ni hedificaron ni criaron porque no tenian heredad propia y esta sola esperiencia basta para conocer el daño de no hazerse y el provecho que se seguira de darse la dicha perpetuydad.

Lo otro porque en la mesma nueba españa la esperiencia a mostrado que en los pueblos encomendados que han sido de dibersos dueños no estan tan vien tratados por la mudanca como los que an tenido un dueño y hesto se a mostrado hebidentisimamente en los yndios que han benido a ponerse en corregimientos ansi en que ninguna cosa ay plantada ni hedificado en ellos como en que ay menos numero de yndios. 
injuries and ill treatments that take place in the towns of your Majesty which are put under corregimiento by the corregidor.

Another reason. In the towns under encomienda it has been experienced that churches have been built and ornaments and other very rich things have been given and are given for the divine worship by those who have the means, which has not been done by the corregidores, nor have they the means to do it.

Another reason. Experience also shows that the Indians who are placed with Spaniards in encomiendas receive better treatment than those who are ruled by corregidores, for it is clear that the latter received many injuries and oppressions from the many masters that they have, who are, for one thing, all officials of your Majesty or servants of them and of the corregidores and alguaciles and other persons, with the pretense that it is done in the name of your Majesty the Indians do not dare to complain. It is the opposite with those who are in encomiendas.

Another reason. By giving the Indians to the Spaniards in perpetuity, besides what has been said of the service of God and the good treatment of the Indians and the increase and cultivation of the land, the great benefits that may follow are very well known, for it has been seen that those who have had towns under encomienda have built houses in them and planted trees and vines and orchards and mulberries and all the kinds of crops that the land permits, besides having their houses well filled with their wives and children and servants, with many horses and persons who have gone from these kingdoms. This has not been done nor could it be done in the towns that are under corregimientos, for the most that have been supported with the said towns are about two hundred corregidores, persons that can hardly support themselves thus without house or family, and when there were uprisings in the country they could not go to serve nor did they have the means to do it. It is the opposite with the encomenderos, for of the Spaniards who had towns in encomienda in Mexico and its vicinity, which might be as many as I5O (towns), there went out as many as 500 mounted with the viceroy on the expedition to New Galicia, where the Indians had rebelled, ${ }^{6}$ to say nothing of the people who remained in the city to guard it. It is certain that if the defense had depended on the corregidores the country would now be lost and the Indians would be in rebellion.

Another reason. It is certain that even though the country were full to-day of Spaniards, unless they had perpetuity they could not maintain themselves; for they would not apply themselves to work the land, nor plant vines, nor raise cattle. Even though they should raise and plant, they would have no one to whom to sell it nor any one to buy it. Nor can they have trade with the Indians, for it is certain that they do not buy or make use of the things that are planted or raised by the Spaniards, nor is it expected that they will make use of them for many years. They are not like the villagers of this country, for they all go about naked, with only some blankets of the country and footgear that they make. They have no furniture in their houses nor do they buy it. It would be of little advantage in these kingdoms or in any part of the world if all were farmers, for it is with a diversity of conditions in life that the com- 
Lo otro porque notoria cosa es que los yndios tienen gran aficion y amor a los encomenderos que los an tenido y les amuestran gran Reconocimiento y los siguen y toman sus exenplos y sus nonbres lo que no se haze por los que estan puestos en coregimientos porque no conozen dueño e con el encomendero faborecense para con los otros yndios sus vezinos que no les tomen sus tierras e terminos y labrancas ni les tomen sus mugeres ni hijos que acaesce tomarse unos a otros.

Pues solamente Resta mostrar demas de lo susodicho que no conbiene que esten en corregimientos porque de darse perpetuos los yndios e que los tengan españoles demas de gran beneficio que Reciben vueOjo a esto. stras Rentas Reales seran mas acrecentadas porque esto se colige de las Razones que estan dichas que poblandose la tierra y plantandose y perpetuandose anse de hazer pueblos de cristianos demas de los que estan echos que esten en comarca de los pueblos de yndios como estan en españa y en todo el mundo con esto se fortifica e asegura la tierra hazese union de fieles hazerse an edificios perpetuos aprobecharse an de los materiales de la tierra ynbentaran de que se hagan y trabajaran en ello los yndios Recibiran hemolumento de sus travajos pues no se les a de pedir ni llevar mas de sus tributos y lo que hizieren fuera dello se les pagara destos Reynos yran mercaderias de las cosas que alla faltaren traeran a estos Reynos la que alla se criaren abra continuo comercio de que vuestra magestad tiene alla sus quintos y su almojarifazgo las yglesias ternan sus diezmos quanto mas creciere que necesariamente an de crecer y creceran los ministros hazerse a verdaderamente Republica cristiana.

Lo otro porque sino se diesen perpetuos los yndios e tributos syno que con todo ello se acudiese a vuestra magestad y que vuestra magestad dellos diese la parte que fuese serbido a unos mas e a otros menos ya esta dicho el daño porque con esto los honbres que alla estoviesen estarian como en guarnicion de frontera que ni entenderian ni podian entender en la conbersyon de los naturales syno en cobrar sus gajas ni plantarian ni edificarian la tierra los yria consumiendo aviase de ynviar gentes forcosas destos Reynos para que se ynchiese el numero de los muertos no abria quien sostuviese los Religiosos ni los clerigos ni las yglesias ni quien diese diezmos ni a quien se vendiesen los frutos de los yndios porque los españoles con solos salarios es herror muy grande pensar que an de plantar ni hazer granjerias como esta dicho porque no ternan donde ni para que sino benirse a sus tierras para gozar de lo que ovieren ganado de sus sueldos.

Lo otro porque ya que se presupusiese y dixiese que estava claro que llevar vuestra magestad todos los tributos que hera enriquecerse mas porque lleva todo lo que los encomenderos y que lo que ellos gastan en lo uno y en lo otro lo ganaria vuestra magestad y sosternia la tierra como ellos la sostienen con honbres que estubiesen como dicho es en ella como algunos diz que an querido dezir no podemos creer que esto proceda de vuestra rreal yntincion porque allende de ser cosa que no se podria sufrir y que ay dichas causas vastantes por donde se perderia desta manera la tierra ningun español permaneceria en ella y se debe presuponer un principio notorio y es que los tributos que los yndios dan como esta dicho son de mantas y mayz y otras cosas que la tierra produze que ni dan horo ni 
monwealth is made and sustained. This cannot be in New Spain unless there is perpetuity, and that cannot be unless they have Indians. No one wishes to sell what he has here and go 2000 leagues to plough and dig, for they could find in these kingdoms plenty of places to do that, and because it is not done there are many parts depopulated.

Another reason. The necessity that the Indians shall be given in perpetuity to the Spaniards is shown also by the experience that has been had that the Indians of the islands and Tierra Firme, through not being given in perpetual encomienda, were all destroyed; for they [the Spaniards] were hirelings and not farmers, and only tried to drink their sweat and come away. They did not plant, or build, or raise cattle, because they had no property of their own. This experience alone is enough to make known the benefit that would follow from granting the said perpetuity, and the harm from not doing it.

Another reason. In New Spain experience has shown that in the towns given in encomienda which have had many masters, because of the constant change they are not so well treated as those that have had but one master; and this has been shown very markedly among the Indians who have been placed in corregimientos, not only in the utter lack of planting and building, but also in the decrease in the number of Indians.

Another reason. It is well known that the Indians have great affection and love for the encomenderos who have had them, and show them much gratitude and follow them and accept their examples and take their names. This is not done by those placed in corregimientos, for they do not know their masters. With the encomendero they are protected from the other Indians, their neighbors, so that they cannot take their lands and property and farms, or their women and children, which they are in the habit of taking from each other.

It only remains to show, besides the above, that it is not desirable that the Indians shall be in corregimientos, for by giving them to the Spaniards in perpetuity, besides the great advantage to your Give attention to this. royal revenues, they would be greatly benefited. It is deduced from the reasons given that by settling the land and planting and perpetuating it, also by establishing towns of Christians, besides those already established, so that they shall be in the territory of the Indian towns as they are in Spain and all the world, the land will be fortified and made safe, the faithful will join in making permanent buildings and making use of the materials of the country and will invent things to make of them and will work at it. . The Indians will receive pay for their work, for no more is to be asked or taken from them than their tributes, and for what they do above that they are to be paid by these kingdoms. There will be trade in the things that are lacking there, and those that are raised there will be brought to these kingdoms. There will be constant commerce there, in which your Majesty will have your fifths and your duties, and the churches will have their tenths, and as it grows they necessarily must and will grow, if the ministers establish a truly Christian government.

Another reason. Unless the Indians and tributes be given in perpetuity, and unless your Majesty agrees to all this, and to divide them, according 
plata e sy alguno dan es en pocos pueblos y en poca cantidad pues de semejantes cosas claro esta que no se arian grandes Rentas para vuestra magestad ni lo que a venido a vuestra magestad a sydo de lo que se avido de los tributos syno de lo que los españoles que han tenido yndios an dado por su yndustria buscando las minas conprando esclavos y herramientas ynviando por ello a estos Reynos los quales conpran para sus esclabos los mantenimientos y las mantas de los tributos que dan los yndios y comercian unos con otros y este comercio haze subir el balor de las cosas sacase con esto horo e la plata de que se paga los derechos a vuestra magestad por manera que por una parte dan balor a las cosas y animanse a plantar e criar por esta causa e ay diezmos por otra viene a tener vuestra magestad no solamente el quinto que se le da pero los quintos de todas las haziendas que sirven para quintar a vuestra magestad porque lo que saco con cinco esclavos es el quinto para vuestra magestad y ansy de las otras cosas pues no aviendo este trato claro esta que se perdera la hazienda de vuestra magestad porque no teniendo perpetuydad no se podra hazer ninguna cosa destas ni ay con quien.

Lo otro porque esto se vio por esperiencia que al tienpo que vuestra magestad el año de treynta mando que se posiese en cabeca de vuestra magestad los yndios comencaron a valer muy poco precio los mantenimientos y las otras cosas porque valia una fanega de trigo un Real una carga de mantas la mejor tres pesos que son veynte e quatro Reales de plata e una de mayz medio Real los ganados e bestias en muy baxos precios y no abia quien lo conprase y con esto viendo las personas que lo senbraban e criaban que avia travajo y no ganancia lo dexavan e vendian sus haziendas y se querian venir y se despoblara todo sy vuestra magestad no ynbiara la neerced de la subcesyon e provisiones para que se hiziese la discrecion de la tierra para que se Repartiese todo y luego con la nueva de la perpetuydad que de cada dia estavan esperando comencaron los tratos de los que tenian yndios tomaron otros precios las cosas que subio la carga de las mantas a veynte pesos y mas y el trigo a ducado y el mayz a tres Reales y mas y ansy de las otras cosas y agora como llegaron las hordenancas torno todo a baxar porque cada uno queria vender su hazienda para se venir y todos han perdido la voluntad de criar e plantar porque ben que todo se ha de perder y que no lo han de gozar ellos ni sus mugeres ni hijos.

Lo otro porque esta claro que los que tienen yndios an sostenido y sostienen la tierra porque ellos son los que hazen dichas grangerias y que ynbian a estos Reynos por las mercaderias y con saber que tienen hazienda y que han de quedar en la tierra les dan fiado lo que an menester y aunque no lo an de aver de tributos con las grangerias dellos buscan artificios de donde lo han avydo y entienden unos en minas otros en yngenios de acucar otros en ganados y en sedas otros en otras grangerias que faltando los yndios an de perecer porque no abra españoles para quien sea.

Lo otro porque es cierto que los corregidores que hasta agora an estado no se abrian mantenido sino que comen en casa de los comenderos y ellos los sostienen pues syno huviese perpetuydad no abria donde se mantener ni se acoger.

Lo otro porque menos se puede traer en consideracion dezir que los encomenderos que ay en la tierra no son los que la sostienen porque ya 
to your pleasure, giving some more and others less, harm will result as already stated, for in that case the men there would be like a garrison on a frontier, and neither would nor could take any interest in the conversion of the natives, but only in collecting their salaries. They would not plant nor build, the country would go on using them up, and it would be necessary to send people by force from these kingdoms-but only to swell the number of deaths. There would be no one to support the religious or the clergy or the churches, nor any one to give tithes, nor to whom to sell the products of the Indians. It is a great error to think that the Spaniards, with salaries alone, will plant or raise crops, as has been said, for they will have no place to do it, nor any motive except to return to their own land and enjoy what they may have saved from their pay.

Although it may be assumed and said-as some say and have wished to say-that it is evident that your Majesty, by taking all the tributes, would enrich yourself more, since you would take all that the encomenderos [take] and what they spend in one thing and another you would gain, and that you would sustain the country as they sustain it, with the men, as has been said, that would be in it-we cannot believe that this proceeds from your royal intention, for, besides being a thing that could not be endured, there are sufficient reasons already given why in this way the land would be lost. No Spaniard would remain in it, and it must be granted as a well-known fact that the tributes given by the Indians, as has been said, consist of blankets and maize and other things which the country produces. For they do not give gold or silver, or if any do give them, it is in but a few towns, and in small quantity. From such things it is clear that there would be no large revenues for your Majesty, and what has come to you has not been from the tributes but from what the Spaniards who have had Indians have given, through their industry in looking for mines, and buying slaves, and tools, for which they sent to these kingdoms. They buy for their slaves the food, necessaries, and blankets which the Indians give in tribute, and they trade with one another, and this commerce causes the things to rise in value. With this, gold and silver are produced with which to pay the duties to your Majesty, so that, on the one hand, value is given to the things produced, and, for this reason, encouragement to plant and raise cattle, and, on the other hand, tithes are provided for. It results that your Majesty has not only the fifth which is due you, but the fifths of all the estates that are worth enough to pay the percentage to your Majesty, for what is produced by five slaves constitutes the fifth for your Majesty, and similarly with the other things. Therefore, if this trade does not exist, it is evident that the revenue of your Majesty will be lost, for, if there be no perpetuity, none of these things can be done, nor will there be any one to do them.

Another reason. It has been seen by experience that at the time when your Majesty, in the year '30, ordered that the Indians should be placed under your rule, the food, necessaries, and other things began to run down very much in price. A bushel of wheat was worth one real, a load of the best blankets three dollars, which are twenty-four reales in silver, and one of maize one-half real. The cattle and animals were held at very low prices, and there was no one to buy them. When the persons 
esta dicho y es ansy la verdad que estos la han sostenido y los que en su casa han estado con la esperanca que tenian de la perpetuydad e subcesyon y agora como han visto lo que vuestra magestad provee los echan de sus casas e aorran lo que pudieren para benirse y mas querran benir pobres que no esperar aquellos y sus mugeres sean muertos porque necesariamente se ha de despoblar la tierra y los yndios apoderarse della y de los que alla estovieren y para esto no sera causa detenerlos los hedificios que agora tienen echos ni las grangerias que tienen comencadas pues acabandose ellos se acabado todo y esta cierto el daño y peligro porque aunque se pudiesen sostener algunos por algun poco tienpo sera con mucho trabajo y sobresalto y al fin de pocos años ellos dexaran la tierra o la tierra les acabara.

$Y$ porque demas destas Razones ay otras muy ebidentisimas por donde en ninguna manera se puede sufrir que no benga en total destruycion la dicha tierra sy luego no se probee como esta suplicado dando horden en la perpetuydad pedimos y suplicamos a vuestra magestad con todo acatamiento e ynstancia lo mande luego prober ansy como esta pedido syn que aya dilacion.

Alonso de Billanueba.-Gonzalo Lopez.-[Rubricados.] 
who were planting and raising cattle saw that it was labor lost they began to leave and sell their farms and get ready to come away, and all would have been abandoned if your Majesty had not sent the grant of succession and the order to make an inventory of the land so that it might all be divided. Immediately, with the news of the perpetuity, which they expected every day, trade began among those who had Indians and things took on better prices. Blankets went up to twenty dollars a load or more, wheat to a ducat, maize to three reales and more, and the same with other things. But now that the ordinances have come everything has gone down again, for every one wishes to sell his farm, in order to come away, and all have lost the desire to raise cattle or plant, for they see that all must be lost, and that neither they nor their wives and children will enjoy it.

Another reason. It is clear that those who have Indians have supported and do support the country, for they are the ones who raise crops and send to these kingdoms for merchandise, and as it is known that they have property and are to remain in the land, they are given credit for what they need. And even though their crops yield no taxes, they seek occupations which do yield them, and employ themselves, some in mines, others in sugar-mills, others in cattle and silk culture, and others in other crops, which, if Indians are lacking, must perish, for there will be no Spaniards, no matter for whom.

Another reason. It is certain that the corregidores who up to now have been there could not have lived except by eating in the houses of the encomenderos, and they support them; therefore, unless there be perpetuity there will be no place for them to live or take shelter.

Another reason. Still less should the statement be given any consideration that the encomenderos who are in the country are not those who sustain it, for it has already been said, and it is the truth, that they have sustained it, and they have remained in their houses in the expectation which they had of perpetuity and succession. But now, since they have seen what your Majesty orders, they are leaving their houses and are saving what they can in order to come away, for they would rather come away poor than wait until they and their wives are dead, for the country must necessarily be abandoned, and the Indians will possess themselves of it and of those who may be there. For this reason neither the buildings which they have already erected nor the crops they have begun will be sufficient cause to detain them. When they are ended all will be ended, and the injury and danger is certain, for even though some might maintain themselves for a short time, it would be with much trouble and fear, and at the end of a few years they would leave the country or the country would make an end of them.

Besides these reasons there are others very evident why it cannot by any means be admitted that the land will not come to total destruction unless measures be immediately taken, as is petitioned, to give the order for perpetuity. We ask and pray your Majesty, with all respect and urgency, that you order this measure to be taken at once, as is petitioned, without any delay.

Alonso de Villanueva.-Gonzalo López-[Signed with rubrics.] 


\section{[Declaración de los Procuradores de la Nueva España. Sin fecha. ${ }^{i}$}

Sacra Catolica Cesarea Magestad. Los procuradores de la nueba españa dezimos que como quiera que por las ynformaciones y paresceres y peticiones que tenemos dadas claramente se muestra como conbiene que para lo que toca al serbicio de dios y de vuestra magestad y bien de los naturales de aquellas partes y perpetuydad dellas y de los españoles que en ellas an de rresidir los yndios que ay en ella se den perpetuos e que de otra manera ninguna de las cosas susodichas se pueden hazer pero que a venido a nuestra noticia que por los Religiosos que de alla an venido se an dado paresceres y pues nosotros benimos por aquella probincia y estamos ynformados de las cosas della y el fin e celo catolico de vuestra magestad es saber la verdad para lo probeer y Remediar suplicamos umillmente a vuestra magestad mande que se nos muestren porque podamos vistos aquellos satisfacer en lo que oviere duda o perplexidad.

Porque sabra vuestra magestad que todos los Religiosos de la nueba españa se juntaron e con acuerdo de todos cada orden por si dieron sus pareceres y los ynbiaron ante vuestra magestad y no seria justo que lo que con tanta deliberacion se dio por todos se alterase agora particularmente siendo persuadidos e atraydos para ello no sabemos por quien ni con que espiritu ellos lo saben pues tan ynconsideradamente en tan brebe tienpo y tan sin fundamento se an mudado y para que mas conste de la forma que en ello se a tenido suplicamos a vuestra magestad mande que los Religiosos de las ordenes de santo domingo y sant agustin muestren y declaren lo que todos entre si tenian acordado y el parescer que tenian dado porque no conbiene que lo que nosotros y todos los estados y prelados de las yndias pedimos tan justamente se escuresca con pasiones particulares y se ponga duda donde no la ay y tienen jurado lo contrario.

Otrosi dezimos que particularmente se procuran paresceres de personas que estan en esta corte suplicamos a vuestra magestad que se mande ynformar de la calidad de los tales y la espiriencia que pueden tener y de lo que por ellos se pretende porque por fines particulares se lo an de los pareceres que dan y siendo vuestra magestad serbido ynformaremos de las personas.

Otrosi dexado todo lo susodicho aparte y sin enbargo de qualesquier paresceres que se den dezimos que pues las cosas se an de conoscer de sus hefetos que se bean los ynconbinientes que de cada dia an subcedido y subceden y se espera que subcederan en lo que de presente esta probeydo que siempre ba de mal en peor como es notorio y por esto siendo vuestra magestad serbido se debe probeer con brebedad.

$Y$ demas de lo que esta dicho en confirmacion de aquello y para que vuestra magestad haga en aquel nuebo mundo las mercedes que tenemos suplicado dezimos que aunque sea verdad que a los principios que las yndias se descubrieron oviese por falta de espiriencia o de meritos de los yndios algunos malos tratamientos en algunas partes de las yndias esto no a sido asi en la nueba españa ni por los que en aquello ofendieron seria justo que padescan los presentes y por venir quanto mas que lo que agora 
[Statement of the Procuradores of New Spain. Undated.]

Sacred Catholic Imperial Majesty. We, the procuradores [attorneys] of New Spain, affirm that it is necessary, as is clearly shown by the evidence and opinions and petitions which we have given, that, for what touches upon the service of God and of your Majesty and the good of the natives of those parts and the perpetuity of them and of the Spaniards who are to reside in them, the Indians who are in them shall be given in perpetuity, and that by any other way none of the aforesaid things can be done. But it has come to our notice that opinions have been given by the religious who have come from there, and, since we came through that province and are informed upon its affairs, and since the purpose and Catholic zeal of your Majesty is to know the truth, in order to take proper measures, we humbly supplicate that your Majesty order that they [the opinions of the religious] shall be shown to us, so that, after seeing them, we can explain whatever may be doubtful or perplexing.

Your Majesty must know that all the religious of New Spain joined together, and, with the agreement of all, each order gave its opinions for itself and sent them before your Majesty. And it would not be just that what was given with so much deliberation by all should be altered now, especially as they have been persuaded and drawn to it by we do not know whom, nor in what sense they understand it, since they have changed so inconsistently in so short a time and with so little foundation. In order that it may appear more clearly in what form it has been given, we supplicate that your Majesty command the religious of the orders of Saint Dominic and Saint Augustine to show and declare what all had agreed upon among themselves and the opinion which they have given, for it is not proper that what we and all the states and prelates of the Indies so justly ask for shall be obscured by individual passions, and that doubt shall be placed where there is none and where they have sworn the contrary.

We say, moreover, that especially there should be procured the opinions of persons who are in this court. We beg that your Majesty inform yourself upon the character of such persons and the experience that they may have, and what motives they have to give their opinions for personal ends and, if your Majesty please, we will submit evidence concerning these persons.

Moreover, leaving all the aforesaid apart, and notwithstanding any opinions that may be given, we say that since things must be judged by their results, let the difficulties be considered that have arisen every day, still arise, and may be expected to arise, in what at present is proved to be always going from bad to worse, as is well known. For this reason, if it pleases your Majesty, measures should be taken quickly.

And besides what has been said in confirmation of this, and in order that your Majesty may make in this New World the grants that we have prayed for, we say that although it may be true that at the beginning of the discovery of the Indies there may have been, through lack of experience or of merit in the Indians, some [cases of] ill-treatment in some parts of the Indies, it has not been so in New Spain, nor would it be just that those of the present and future should suffer for those who offended 
por nuestra parte se pide y por tan hebidentes Razones se funda si cesase el serbicio de dios y el de vuestra magestad y se perderia todo y todos los que an ynformado juntando y encaresciendo malos tratamientos de yndios an callado los muchos buenos tratamientos y obras buenas que se an hecho en la nueba españa y de cada dia se hazen que conpensadas exceden a las malas de los tiempos pasados que por ventura combino que entonces se hiziesen lo que agora no se puede juzgar pues no estan bibos los que dizen que las hizieron e aun dios por pocos buenos que hallara en los pueblos que mando abrasar los perdonara e ansi para el Remedio perpetuo no se a de traer en consideracion lo que a muchos años que por personas particulares y por ventura ocasionada y necesitadamente se cometio porque si miramos lo que en españa se comete en un año si se Refiriese junto pornia ${ }^{j}$ mucho mas escandalo que todo lo de las yndias de muchos años que para ganarse convino por ventura hazerse pero ya no estamos en tener licencia para tratar mal los yndios sino en buscar Remedio como se perpetuen pues con el que pedimos se hara.

Otrosi suplicamos a vuestra magestad mande que se bean las Razones que tenemos dadas y se podrian dar otras muchas que no puede aver perpetuydad syn que se den yndios porque no abria quien labrase ni cultibase la tierra ni buscase artificios ni se ocupe en granjerias para que aya Rentas ni los españoles se aplicaran a ello si no saben que an de tener yndios perpetuos porque el comercio de los españoles haze crescer el trato y españoles no los puede aver si no es por la via que tenemos dicha y destos se an avido y de cada dia se an y traen las grandes Riquezas que se an traydo que no de lo que los yndios dan sino lo que los españoles que an tenido yndios an procurado e sin esto es fundamento falso dezir que se perpetuara dando juros y Rentas perpetuas a los españoles y los que esto dizen no miran que falta el principio de donde e como se an de aver estas Rentas y sobre todo no miran que los Religiosos que alla an ydo y estan y las yglesias no las sostienen los yndios sino los españoles e con lo que los españoles hazen tienen los Religiosos con que predicar la doctrina cristiana.

Devese ansi mismo considerar que a los yndios no se les lleba ni pide sino lo que pueden dar el que tiene tributos que dar de las cosas que entre ellos se crian dan solo aquello quando basta y los que no lo tienen dan serbicio personal y este no les es dañoso ni a las almas ni a los cuerpos ansi por la ociosidad que les quitan y poco trabajo que les dan e comunicacion que toman y policia que deprenden como porque siempre se uso en aquellas partes desde su fundacion estos serbicios personales y pues lo uno y lo otro se puede en lo que oviere exceso poner en limites de Razon y los yndios son tan entendidos en no consentir agravio y lo saben Reclamar tan bien como un sabio español bastara que los que en nombre de vuestra magestad gobernaren tengan cuydado dello que muy mejor tratados y Relebados son que los vasallos de castilla mayormente que lo que procuramos es para su bien de los naturales por las Razones que en este Articulo tenemos dichas e consta por ynformaciones que suplicamos que se bean y lean y en lo que oviere duda vuestra magestad sea serbido de nos mandar llamar e oyr por una cosa tan grande se pueda bien conoscer pues venimos en nombre

'Evidently a miscopy for "ponia". 
in that respect, the more so as that which is now asked upon our part is founded upon such evident reasons that if the service of God and that of your Majesty should cease all would be lost. And all those who have reported, collecting and exaggerating ill-treatments of Indians, have kept quiet about the many good treatments and good works that have been done and are done in New Spain every day, which, in compensation, exceed the bad ones of past times, which I admit may have occurred. This cannot now be judged of, for those who they say did them are not alive, and even God, because of the few good ones that he might find in the towns which he commanded to be burned, would pardon them. ${ }^{7}$ Thus, for the measure of perpetuity, what was committed many years ago by individual persons, perhaps with reason and necessity, ought not to be taken into consideration, for if we look at what is committed in Spain in one year, if it were reported jointly, much more scandal would be aroused than by all which I admit may have been done for gain in the Indies in many years. But we are not now trying to get permission to ill-treat the Indians, but to seek a means by which they may be perpetuated, and with what we ask it will be done.

We beg, moreover, that your Majesty command that an examination be made of the arguments which we have given. Many others could be given why there cannot be perpetuity unless Indians are awarded, for there would be no one to cultivate the land or practise trades or work on farms, so that there might be profits. Nor will the Spaniards apply themselves to it unless they know that they are to have Indians in perpetuity. Intercourse with the Spaniards increases trade but there cannot be Spaniards except in the way that we have said. From these, great riches have come and are still drawn every day, which have been drawn, not from what the Indians give, but from what the Spaniards who have Indians have secured. Besides this, it is a false premise to say that it will be perpetuated by giving annuities and perpetual incomes to the Spaniards, and those who say this do not consider that the basis of where and how these incomes are to be provided is lacking. And above all, they do not consider that the religious, who have gone there and are still there, and the churches are not supported by the Indians but by the Spaniards, and that it is with what the Spaniards do that the religious have the means of preaching the Christian doctrine.

It ought also to be considered that nothing is taken nor asked from the Indians except what they are able to give. He who has to give tributes of the things that are raised among them only gives it when there is enough, and those who do not possess this give personal service, which is not injurious to them, either in their souls or their bodies, as well because of the idleness from which it frees them, the light work given them, the intercourse that they receive, and the manners they acquire, as because it has always been the custom in those parts since their foundation to have those personal services.

To avoid the possibility of excess, both the one and the other [personal service and tribute] may be placed within the limits of reason. And besides the Indians are too intelligent to consent to injury and know how to resist it as successfully as educated Spaniards. If those who govern 
de tan señalada probincia en el mundo y tenemos espiriencia de las cosas della para las dezir con aquella libertad y verdad que se deve tener delante tan alto acatamiento porque ynformado de todo vuestra magestad provea como mas a su serbicio convenga. ${ }^{k}$

Alonso de billanueba.-Gonzalo lopez.-[Rubricados. $]$

[En el dorso se lee:] en valladolid IX de Junio.

Traslado del Parezer que dió el Doctor Hernan Lopez ${ }^{2}$ del Consejo de las Yndias, sobre la perpetuidad dellas [el año de I545]. ${ }^{m}$

Sacra Catolica Cesarea Magestad. Ansi por la grandeza de este negocio y mi Poca esperiencia En ellos como porque al tiempo que Vuestra Magestad me mando servir en este lugar estaba ya este articulo sobre que Vuestra Magestad quizo ser ynformado muy al cabo yo me escuse de hablar en el y porque mi escusa no fue admitida me fue forçado con lo poco que en este breve tienpo pude ynformarme y colegir dar my parecer aunque Agora No sirva mas de para cumplir con el lugar que Vuestra Magestad fue servido darme-y porque nynguno duda que para el Aumento y conservacion de aquella tierra sean Necesarios españoles y tampoco se duda que la mejor manera que para tener Seguros los que alla estan y conbidar a otros muchos que Vayan es hazelles Vuestra Magestad merced de dalles alguna cosa perpetua aunque se araiguen y cobren Amor a la tierra y olbiden el que tienen en esta. La dificuldad Solo esta en saver que manera de perpetuidad Sera mas en servicio de Vuestra Magestad y Aumento de $\mathrm{Su}$ Real patrimonyo por mayor contentamiento de los españoles y utilidad y provecho de los Yndios Ansi de los Cuerpos como de las Animas de que Vuestra Magestad tanto cuidado ha siempre tenido y tiene.

$Y$ porque en esto ha habido tres pareceres en el primero que es que por agora se suspenda y se enbie de alla mas ynformacion, en este yo no estoy ansi por lo que me parece que ynporta la brevedad de rremedio cierto como por que los que alla han rrecevido esto mal pensaran que el solo Asegurallos y conpensamiento que se les han de quitar los desfrutaran en

k F. R. B., Sevilla, April 29, I9I 5.

1 Evidently a miscopy for "Perez".-C. W. H.

[On back of sheet: Parecer que dio El Doctor hernan perez del consejo de las Yndias sobre lo de la perpetuidad dellas el año de $1545 .-F$. R. B.]

m A. G. I., I45-7-9 (?). 
in the name of your Majesty take heed of it, it will assure them better treatment and care than are received by the vassals of Castile, especially since what we are asking for is for the good of the natives, for the reasons which we have stated in this article and which appear in the reports. We beg that these be examined and read, and that in whatever seems doubtful your Majesty will be pleased to order us to be called and heard, so that this great matter may be well understood; for we came in the name of this celebrated province of the world, and have [sufficient] experience in its affairs to speak of them with that freedom and truth which ought to be shown before such an exalted presence, so that your Majesty, being informed of all, may take such measures as are most suitable to your service.

Alonso de Villanueva.-Gonzalo López-[Signed with rubrics.] [On the back is written: "In Valladolid, June 9."-F. R. B.]

Copy of the opinion given by Doctor Hernán López ${ }^{8}$ of the Council of the Indies on the matter of their perpetuity [in the year 1545].

Sacred Catholic Imperial Majesty: Partly because of the importance of this business and my small experience in such affairs, and partly because at the time when your Majesty ordered me to serve in this capacity the question upon which your Majesty wished to be informed was already fully reported, I excused myself from speaking about it. But as my excuse was not accepted, I was forced, with the little information that I could collect in so short a time, to give my opinion, although it now serves for nothing except to fulfill the task which your Majesty was pleased to give me. No one doubts that for the advancement and conservation of that land Spaniards are necessary, and as little is doubted that the best way to keep constant those who are there and to invite others to go is for your Majesty to grant them something perpetual, so that they take root and acquire love for that land and forget that which they had for this. The sole difficulty is to know what means of perpetuity will be most to the benefit of your Majesty and to the increase of your royal patrimony, for the greater contentment of the Spaniards, and for the profit and advantage of the Indians, in their bodies as well as their souls, of which your Majesty has always taken and still takes so much care.

In this there have been three opinions. The first is that for the present the matter be suspended and more information be sent from there. I do not agree to this, not only because it seems to me important that the remedy should be prompt and sure, but also because those who receive it there will wrongly think only of making themselves secure, and with the thought that they are to be taken away, they will advantage themselves to the great prejudice of the Indians, and this, I understand, has already been running in their minds for many years.

The second remedy, which is to give them perpetual contributions, appears to me no more desirable, for, as the owners of them would have no 
grande perjuizio de los Yndios y ya esto segund tengo entendido ha muchos años que handa en sus pensiones.

El segundo Remedio que es dalles tributos perpetuos tanpoco me parece convinyente porque como los señores dellos No tengan tierra propia no crecera tanto la aficion y aun fuera desto desta forma no se escusavan corregidores y seria dificultoso pagar los corregidores y mas Darlos tributo A los demas $Y$ por otros ynconvenyentes que Aqui no pongo.

El tercero Remedio que es hazer Vuestra Magestad yn perpetua A los conquistadores del basalleje de algunos lugares de Aquella tierra Sin Jurisdicion civil u criminal que Dando Sienpre debaxo de la rreal corona de Vuestra Magestad todas las cabeceras y lugares grandes de la tierra y aun muchos de los chicos porque dandose perpetuo se contentarian ó ternyan rrazon de contentarse con mucho menos y habria en lo que agora tiene en encomienda Solo Un comercio Para Satisfazer A dos y a tres propietarios y en algunos a mas.

Digo que no se rreparta todo Ansi porque a Vuestra Magestad le queden los pueblos principales y cabezeras como porque Vuestra Magestad pueda y tenga con que hazer nuevas mercedes y aunque no las haga no esten los que ella fueren desconfiados de que sirviendo bien a Vuestra Magestad tiene Vuestra Magestad en que hazerselas.

$\mathrm{Y}$ ansi mismo ynporta esto porque teniendo los Yndios que Asi se diesen en Vasallaje facultad de mudar su bibienda de Un lugar A otro Siendo maltratados de sus señores pudiesen pasarse A pueblos de Vuestra Magestad y los hallasen sienpre en comarca lo qual Daria a los señores grand ocasion de buen tratamiento y que este tercero Remedio Sea mas cunplidero Al servicio de Vuestra Magestad ansi porque del rresultaria aumento $\mathrm{Y}$ conservacion de la tierra conque Vuestra Magestad Seria mas servido como porque de otra manera se Avian de darlos tributos y mas pagar los corregidores y ansi mismo es mas Sin duda que seria mas a contento $Y$ provecho de los españoles pues ellos lo piden y es notorio, $Y$ ansilo. que parece que pone en ello duda es Ver si es en provecho de los Yndios y sin falta Si los encomenderos han de ser quales hasta agora han sido yo bien creo que para los Yndios No seria provechoso pero siendo como es rrazon que Sean Y guardandolas condiciones con que Vuestra Magestad les haze la merced es notorio que a ellos les estava bien tener un defensor y quien tubiese cuidado de ynstruirlos en la Santa Fee catolica en rresolucion que siendo el señor qual deve a Dios y a Vuestra Magestad parece que a los Yndios les convernia tenelle y por esto me parece que el principal cuidado havia de ser sobre que este fuese tal y guardase las condiciones con que se le haze la merced y al que no las guardase le privasen de los Yndios y se aplicasen a la corona Real de Vuestra Magestad y para esto parece que convernia hazer lo siguiente:-

Lo primero tasar los pueblos de que Ansy Vuestra Magestad hubiese de hazer la merced: en una cantidad muy moderada y que de tiempo a tiempo pudiese la audiencia hazer Retasa para que si el pueblo se hubiese Disminuido se baxasen y Si crecido Se acrescentasen los tributos para el señor y esto postrero A my parecer Seria muy bastante ocasion para que qualquiera Señor procurase el aumento de su tierra. 
land of their own, attachment would not be aroused so much; and, even aside from that, by this plan corregidores would be necessary, and it would be difficult to pay the corregidores and give contributions to the others besides. There are other drawbacks that I do not set down here.

The third remedy is that your Majesty give in perpetuity to the conquerors, in vassalage, some towns of that land, without jurisdiction, civil or criminal, the capitals and large towns of the land, as well as many of the small ones, always remaining under the royal crown of your Majesty; in this way, by giving them in perpetuity they will be satisfied and will have reason to content themselves with much less, and there would be, in what one encomienda alone now has, a trade sufficient for two or three proprietors, and in some even more. I say that all should not be divided thus, but that there shall remain to your Majesty the principal towns and capitals, so that your Majesty may have something with which to make new grants, and even though you do not make them, that those who are there may not be distrustful that after they have served your Majesty well your Majesty may not have anything with which to reward them.

And this is likewise important because, as the Indians thus yielding themselves to vassalage would have the right to change their residence from one town to another, in case they were ill-treated by their masters, they could go to the towns of your Majesty, which they would always find in the district, and this would give the masters a strong reason for good treatment. This third remedy would be more advantageous to the service of your Majesty, as well because there would result from it the improvement and conservation of the land with which your Majesty would be most served, as because by the other way it would be necessary to give contributions and pay corregidores besides. Likewise there is still less doubt that it would be more to the satisfaction and advantage of the Spaniards, for it is well known that they ask for it. What appears to throw doubt upon it is the question whether it is to the advantage of the Indians; and certainly if the encomenderos are to be of the same sort as they have been up to now I sincerely believe that it would not be advantageous for the Indians. But if they [the encomenderos] should be what is right and the conditions under which your Majesty would make the grant should be kept, it is well known that it would be a good thing for them [the Indians] to have a defender and some one to instruct them in the holy Catholic faith. In short, if the master is what he owes to God and your Majesty, it seems that it would be advantageous to the Indians to have him, and for this it seems to me the principal care would be that he should be such, and that he should keep the conditions under which the grant would be made to him, and that any one who should not keep them should be deprived of the Indians and they should be added to the royal crown of your Majesty. For this it appears that it would be proper to do the following:

First, to place a tax on the towns of which your Majesty would thus make the grant, at a very moderate rate. From time to time the Audiencia could make a revaluation, so that if the town should have diminished the 
Que En esta tasacion que tengo Dicha no se tasasen Ningunos derechos personales Si no fuese labor de heredades con moderado trabajo y moderado Salario.

Que En esta tasacion tubiese Vuestra Magestad alguna parte por Via de cota como para como Veintena para que con mas facilidad Se pudiese Saver por la parte que cupiese a Vuestra Magestad y las quel señor llevava Si el cedia a la tasacion.

Que tubiesen estos Señores Aunque No hubiese quexas de Yndios Visitas por los oydores de las audiencias Donde cayesen Y si con estas diligencias el encomendero o señor fuese bueno el Negocio estaria qual de Via y si fuese malo los Yndios del malo Se yncorporarian en la corona Real de Vuestra Magestad y sin obligacion de darlos tributos dellos Anadie Yo creo que la falta de espiriencia y otras faltas me habran hecho herrar pero se que no herrare en el deseo de hazertar en el Servicio de Vuestra Magestad cuya Vida y Real estado Acresciento nuestro señor por muchos Años.

Sacra Catolica Cesarea Magestad. Besa los Reales pies de Vuestra Magestad Su criado y Servidor.

Doctor Herman Perez S. ${ }^{n}$

Al Virrey de la Nueva España que embie relacion con su parecer sobre que se ha avisado que para reducir y pacificar los Yndios Chichimecas convernia usar de los medios que aqui se rrefieren fundando en su comarca pueblos y monasterios. ${ }^{\circ}$ [I566.]

El Rey: Marques de Villamanrique ... yo soy informado que los Yndios chichimecas, que ay reveldes en esa tierra estan en la mayor pujança, que nunca estubieron y la costa que se hace contra ellos se Va aumentando y la orden que se tiene es procurar su reducion, y pacificacion, y asegurar los caminos con presidios de soldados no se tiene por buen remedio; y ya toda la gente que los ha andado siguiendo esta cansada, y que asi seria necessario tomar otros medios, y a hombres muy platicos havia parecido que convernia se hiziesen tres ó quatro pueblos en una Cordillera que cerca el paso de la mesma tierra de los dichos chichimecas y de los dichos pueblos se les atajase el dicho paso y se hiziese guerra en su avitacion sin aguardar a que ellos salgan a hazeria, y juntamente con los pueblos se fundasen tres o quatro monasterios de frayles para que con blandura los atraxesen despues de tenerlos acosados y apretados con las dichas poblaciones y esto medios se entendia serian los mejores para acavar con los dichos Yndios y los dichos Pueblos se abrian

n F. R. B., Sevilla, May I, 1915.

o A. G. I., I03-3-I. 
tributes for the master could be lowered, and if it should have grown they could be increased. This last, it seems to me, would be a very sufficient reason for any master to try to improve his land.

In this valuation of which I have spoken no personal rights should be taxed, unless it should be labor on farms with moderate work and a moderate wage.

In this taxation your Majesty should have a part as your quota, such as one-twentieth, so that it would be more readily known what part would fall to your Majesty and what the master would take, if he agreed to the valuation.

And, even though there should be no complaints from the Indians, visits should be made to these masters by the oidores of the audiencias where they should be situated, and if with these measures the encomendero or master should turn out to be good the business would be on the right road, while if he were bad the Indians of the bad one should be incorporated in the royal crown of your Majesty, without obligation to give them [him] their contributions. I add that I believe lack of experience and other faults may have caused me to err, but I know that I do not err in my desire to do right in the service of your Majesty, whose life and royal state may our Lord increase for many years.

Sacred Catholic Imperial Majesty, your servant kisses the royal feet of your Majesty.

Doctor Hernán PÉrez S.

To the viceroy of New Spain, ordering him to send a report with his opinion concerning the suggestion that it would be suitable for the reduction and pacification of the Chichimecas to use the methods here recited; namely, to establish towns and monasteries in their lands. [ $\left.{ }^{5} 566.\right]$

The King. To the Marquis of Villamanrique: ... I am informed that the rebel Chichimecas of that country are waging more formidable warfare than ever before, expenditures of combating them are increasing, and the present order to effect their reduction and pacification and to secure the roads by presidios of soldiers is not considered suitable, as all the men who have been pursuing the Indians are tired out, and that it would therefore be necessary to adopt some other course. It has seemed fitting to very expert men to establish three or four towns on a cordillera which encloses the pass into the Chichimeca lands from the said towns, to keep the pass closed, and make war on the Indians in their own lands, instead of waiting for them to come out for the same purpose. It is also suggested that together with the towns three or four monasteries of friars should be founded, for the purpose of attracting the Indians with gentle methods after harassing and constraining them by use of the towns. These methods it was considered would be the best means of doing away with the Indians. The towns were to be settled by natives of Tlascala and other parts, the settlers to be free from tributes and to have other advan- 
de poblar de naturales de Tlaxcala y otras partes haciendoles libres de tributos y otras ventajas porque con esto habria muchos que fuesen a poblar y la gente de guerra que se aumentaria para los dichos pueblos seria muy poca, porque los mismos soldados de los presidios y los capitanes que andan en compañia haziendo entradas podian servir para este efecto; y el gasto y cuydado seria el fundar los pueblos y monasterios y llevar la gente; porque hecho esto habria paz y seguridad para adelante é haviendose visto por los de mi consejo de las Yndias, y platicado sobre ello porque quiere tener Razon vuestra de lo que en todo pasa y convernia proveer os mando que me la embieys con vuestro parecer en la primera ocasion ... fecha en Sant Lorenço a I9 de Junio de I566 años.-Yo EL REY-

Al Virrey de la Nueva España que embie Razon con su parecer sobre que se ha avisado que convernia mandar que los pueblos de Yndios que oviese cerca de las chichimecas fuesen de cien Vezinos por Lo menos y que a los que reduxeren no se les pida tributo por uno ó dos años. ${ }^{p}$ [I566.]

El Rey: Marques de Villamanrique ... haseme hecho relacion que convernia mandar que todos los pueblos de Yndios que estuviesen en tierra de guerra cerca de los chichimecas ó propincos a ellos se reduxesen y juntasen y que no oviese pueblo de Yndios de menos de cien Vezinos porque de haver pueblos de á diez ó veynte y treynta Yndios y mas pequeños es causa que los dichos Yndios chichimecas allegan a los dichos pueblos y los queman y matan los Yndios de ellos y que porque los que se oviesen de reducir dejando sus casas y sementeras no ternian de que pagar los tributos por ser tan pobres y miserables todos. Los que se pasasen de Unos pueblos a otros debrian de ser reservados de pagar tributo por uno ó dos años hasta que hiziesen casas y bolviesen a labrar porque desta manera se mudarian de buena gana y estando Juntos se anparavan y defenderian Unos a otros y demas de esto se siguiria que serian bien doctrinados y se les administrarian Los sacramentos con Comodidad. . . . San Lorenzo I9 Junio I 566.-Yo EL ReY-

Memorial que dio el bachiller Luis Sanches residente en Chillaron de Pareja al presidente Espinosa en Madrid á 26 de agosto de I566.q

Muy illustrisimo Señor. Si bien se mira es cierto que todas las cossas y negocios que de las yndias se pueden decir y tratar vienen a parar y

p A. G. I., I03-3-I.

q A. G. I., 2-I-2/19. 
tages in order to induce many to go and settle. The increase in the number of soldiers for these towns would be very little, for the presidial soldiers and the captains who move with expeditionary companies would serve for this purpose. The expense and trouble would arise only from construction of the towns and monasteries and transporting the people, for after these things had been accomplished there would be peace and safety in the future. The matter having been considered and discussed by the members of my Council of the Indies, it was thought necessary to have your report of all that was occurring and what would be proper to order. I therefore command you to send me your report and opinion at the earliest opportunity. Dated at San Lorenzo, June I9, I566. I THE KING.

To the viceroy of New Spain, ordering him to send a report with his opinion concerning the suggestion that it would be fitting to command that the Indian towns to be founded near the Chichimecas should contain at least one hundred heads of families, and that tribute should not be demanded for one or two years from those who should be reduced. [I566.]

The King. To the Marquis of Villamanrique: It has been reported to me that it would be fitting to command that all the Indian towns which are situated in lands affected by war near the Chichimecas, or among them, should be reduced and gathered together, and that there should be no Indian town of less than one hundred heads of families, because if there are towns of ten, twenty, or thirty Indians or less, the result is that the Chichimecas will come to these towns, burn them, and kill the inhabitants. It is also suggested that those who are to be reduced by being taken away from their houses and fields would have nothing to pay tribute with, as they are all so poor and miserable; hence those who are to be taken from one town to another ought to be excused from paying tribute for one or two years until they have built their houses and gone back to work. Under such a plan they would gladly move, and, being near together, they would assist and defend each other. Moreover, it would follow that they would be well instructed and the sacraments would be administered to them easily. San Lorenzo, June I9, I 566. I the King.

Memorial presented by the Bachiller Luis Sánchez, a resident of Chillarón de Pareja, to President Espinosa in Madrid, on August 26, I566.

Very Illustrious Sir: If they are properly viewed, it is certain that all the things which may be said concerning the affairs of the Indies are reducible to a single point, namely, the protection of the bodies and souls of the Indians, or their destruction and extinction, which has been and is going on daily. Those who truly favor the Indians both with words 
Resumirse, en solo un punto, y es en favorescer alma y cuerpo de los yndios, e destruyllos y acaballos como hasta oy se a hecho y hace. Los quales favoresce de veras (que es con obras y palabras) son tan raros, que en 18 años que e estado en las yndias no e visto quatro. Todos los demas son sus contrarios y los asuelan y destruyen. De aqui viene que dare por quenta mil y quinientas y algunas mas leguas Despobladas en las yndias por manos de españoles que estava llenas de yndios, y en las mas dellas no a dexado criatura, y en las otras tan poca gente que se pueden llamar despobladas. La caussa deste mal es que todos quantos pasamos a las yndias vamos con intencion de volver a españa muy ricos. Lo qual es imposible (pues de aca no llevamos nada, y alla holgamos) sino a costa del sudor y sangre de los yndios. La manera como se an despoblado tantas tierras (no hablo de mexico porque alla entiendo a sido siempre un poco de justicia y favor para los yndios) y creo no quedara nada sino se remedia.

Lo peor a sido Las crueles y injustas guerras que los españoles an hecho $\mathrm{y}$ hacen a los yndios matandolos robandolos falando y ahuyentandolos de sus tierras Todo contra La orden y instrucciones muy christianas que de nuestros reyes llavava. En estas guerras y Jornadas (que llama) en sola la governacion de popayan despues que yo estoi alla e visto conquistar y poblar once pueblos de españoles como cada 20 y 30 leguas de terreno cada uno, y otras cinco jornadas y en ello e visto con estos ojos cosas y crueldades nunca vistas que no las cufrira a oyr ningun christiana quanto mas Vuestra Señoria pues que sera en otras infinitas partes que lo e oido a personas que se hallaron presentes.

Lo segundo que a destruydo Las yndias, fue Los esclavos que con muy falsas informaciones y no entendiendose los negocios se hizieron hasta que su magestad siendo desengañado los dio por libres y aunque Las dos dichas cosas a destruydo mucho pero La que viene a asolado mas que ambas y quasi Las dos son ya passadas y esta es como una carcoma y a suella oy mas que nunca, y no se siente, y es el repartimiento de los yndios, porque no usan los españoles dellos como vesallos, sino como esclavos y enemigos. En minas, cargas, y bujos personales y en las mas partes no guardan mas tasa y viven tan sin ley como si no fuesen christianos esto no se puede bien entender sino se platica.

A ayudado mucho a la destruccion de tanta multitud de gentes ser Los yndios de su natural tan debiles y ruin complexion que con poco mal trabajo que les den se muere especialmente sacandolos de sus tierras y provincias como los an sacado muchas Leguas y pocos volvian a sus casas y ansi se dice que el yndio es como el pescado que en sacandolo del agua se muere.

Todos cuantos daños y robos dichos y quantos se a hecho en las yndias Los a causado la incaciable codicia de los españoles La qual crescio mucho porque no a avido freno de parte de la justicia tambien desta a nascido tantas guerras civiles unos españoles con otros en el piru y otras partes mil a mil y quinientas a quinientas y cien a cien hasta acabarse unos con otros y esto con grandissimo daño de los yndios que siempre es mal para el cativo que es $\mathrm{El}$ yndio que mientra ay guerras que quasi no an faltado todos hacen lo que quieren a los yndios y acontece llevar el tyrano con su campo ocho y diez mil yndios de carga y los leales otro tanto Lo dicho sea que al Cuerpo y republica del yndio. 
and deeds are so rare that I have not seen more than four of them in the eighteen years which I have spent in the Indies. All the others are precisely the opposite; they desolate and destroy them. Thus it is that I am able to indicate lands in the Indies more than fifteen hundred leagues wide which have been desolated by the hands of the Spaniards, lands which were once full of Indians, but in which they have for the greater part left not a living creature, and in other parts so few people that they may be said to be depopulated. The reason for this evil is that all of us who come to the Indies come with the intention of returning to Spain very rich. This is impossible (since we take nothing from here, and over there we are idle) except at the cost of the blood and sweat of the Indians. Judging from the way in which so many lands have been depopulated (I do not speak of Mexico, for I understand that there has always been in Mexico a show of justice and favor toward the Indians), I think that there will be nothing left unless the situation is remedied.

The worst feature has been the cruel and unjust wars which the Spaniards have waged and are waging against the Indians, killing, robbing, attacking them, and driving them from their lands, all contrary to the very Christian orders and instructions which they have received from our kings. In these wars and expeditions-jornadas, as they are calledI have seen within the government of Popayán ${ }^{9}$ alone since I have been there eleven Spanish towns conquered and settled at intervals of twenty to thirty leagues. I have also been on five other expeditions, on which I have seen with my own eyes such unheard of cruelties that no Christian ear would endure to hear them, much less your lordship's. What, indeed, then, must have occurred in other countless places concerning which I have heard from persons who were present themselves?

The second thing which has destroyed the Indies was the making of slaves of the natives, which was done by dint of untrue reports and without understanding of the situation until his Majesty, becoming undeceived, set them free. These two things have indeed destroyed much, but the next cause has destroyed more; the first two are really now passed, but this last is like a cancer, more devastating now than ever without being perceived. I refer to the repartimiento of the Indians, under which system the Spaniards do not treat the Indians as vassals, but as slaves and enemies, in the mines, in carrying burdens, and in personal services. In most places they do not observe any rotation in selection of Indians, and they live as lawlessly as though they were not Christians at all, a situation not to be understood well save through conversation concerning it.

The destruction of such a great number of people has been greatly assisted by the fact that the Indians are by nature so weak and of such feeble constitution that they die quickly from the little labor and the mistreatment which they receive, especially when they are taken from their lands and provinces as they have frequently been carried many leagues, few of them ever returning to their homes. Hence it is said that the Indian is like a fish which dies on being taken out of the water.

All the injuries and robberies spoken of which have occurred in the Indies have been caused by the insatiable greed of the Spaniards, which has been increasing greatly because it has had no check from the magis- 
Quanto a su alma bastara decir que de tantas provincias despobladas y millones de gentes que por la codicia de españoles an sido muertos no an sydo La centesima parte cristianos sino ansi los echavan al ynfierno y los matavan como si fueran brutos pues en los que emos coxido y son baptisados yo prometo a Vuestra Señoria que no ay en ellos onza de fe si se pudiera pesar (dexo aparte los de mexico que entiendo ay algo mas) porque no se levanta El entendimiento del yndio Dos dedos del suelo en lo que toca a su alma y de su natural son como monas en las aparencias muy Diligentes muy amigos de disciplinarse y ofrescer confesion llorar en La confesion oyr missas y sermones que parece viene de buena gana a todo y si los dexan de alli a dos horas no ay nada. Esto entiendo por mas que publiquen por ay gentes que yo tambien e gastado mi tiempo en ello pedicado y doctrinado yndios, y creo que no e hecho de fructo valia de un Real. Pero desta poca fe y christiandad de los yndios echemos La mitad de la culpa a los Ruinos pedicadores y a su mal exemplo que es lastima verlo que les decimos una cosa y hacemos otra y el pobre del yndio ignorantissimo mira muy bien lo que hago y olvida lo que digo. Si Vuestra Señoria me peguntare todos estos daños y crueldades, etc., que en el alma y cuerpo y Republicas de los yndios se an hecho como en 74 años que a que se descubrieron las yndias no se an remediado Digo que porque no se a entendido ni creo que se acabara de entender aunque esta bien claro y lo vemos por los ojos y podra ser sea juizio de Dios si no que no lo alcacamos que quiere nuestro señor Castigar a estos yndios por sus enormes pecados, y no quiere se entiendan las yndias para ponerse El Remedio hasta que El sea servido dexemoslo a su divina Voluntad.

Pero humanamente hallo yo tres causas por donde Las yndias no sean entendido. La primera es que como son tantas Las tierras de las yndias y tan Remotas de españa, tantas provincias tan differentes unas de otras y en nada se parece a las de aca cada una tiene necessidad de sus particulares leyes y cada dia acotece que dan una misma ley para todas y ansi que aprobecha a Una Daña a otra y tambien como los que desean Las govierna no las a visto an de governar forcoso por lo que otros dicen o escriven, $y$ tambien quando un señor del consejo comienca a entender Las yndias luego le mudan por lo qual no se entiende y si se acierta es acaso.

Lo segundo quasi todos los que vienen de yndias y desde alla escriven ynformacion mal y a su gusto que es el interess, El qual an de sacar forcoso de los yndios y en esto todos son aun a todos desean vivir en aquella Libertad y anchura y que nadie Les vaya a la mano y no an de ynformar lo que a ellos Les esta mal porque no se Remedie, y como se an governado por estas informaciones ase errado muchas vezes y ya a caydo en esto el cosejo y con Razon no sabe a quien crea.

Lo tercero viene tambien De las yndias personas De bien y Religiosas huyendo de las grandes males que alla ay con gran ferbor y zelo de ynformar aca la Christianidad para que se Remedie. Estos son muy pocos y conocer sea en que vienen pobres, y no bien quistos de gente de yndias estos con gran Calor comienca a decir verdades y a desengañar de las cosas de yndias y como aca todos y el cosejo estan escarmentados de las mentiras que a todos los demas an oido no saben aqui quien crean y como a los buenos no les dan credito, ni a las veces oidos y si los oyen tibiamente 
trates. From the same cause also have arisen the numerous civil wars which the Spaniards have waged against each other in Peru and other parts, a thousand against a thousand, five hundred against five hundred, or a hundred against a hundred, until they have exterminated each other. This has caused the greatest injury to the Indians, for it is always bad for a captive, such as is the Indian, for everyone to be free to do as he pleases against them during practically incessant wars; it often happens that the usurper carries off to his camp eight or ten thousand Indians as burden bearers, while the loyalists do the same. The result has been injurious to the body and political condition of the the Indian.

As for his soul, it is safe to say that in all these devastated provinces, among the millions of people who have been killed by the covetousness of the Spaniards, not the hundredth part have been Christians; thus they have been cast into hell, killed as though they were brutes. Indeed, among those whom we have caught and who are baptized, I declare to your lordship there is not an ounce of faith that could be weighed (except among the Indians of Mexico who, I understand, have a little more); for the understanding of the Indian, in so far as his soul is concerned, does not rise two inches from the ground. They are very much like monkeys as to externals; they are very diligent, easy to discipline, willing to confess, they weep at confession, hear mass and sermons with apparent willingness in everything, but if they are left to themselves a matter of two hours, all is undone. This I assert in spite of what people may publish over there, for I also have spent my time in this labor of preaching to and teaching Indians, and I believe that in it I have not harvested fruit to the value of a real. However, we may ascribe the half of the blame for this little faith and Christian spirit among the Indians to the fault of those base sinners and their bad example; for it is a shame to see how we tell them one thing and then do the opposite, and the poor ignorant Indian sees very well what I do and forgets what I say. If your lordship should ask me all the injuries and cruelties, etc., which have been perpetrated against the physical, spiritual, and political welfare of the Indians during the seventy-four years since the Indies were discovered, and are yet without remedy, I should say that the reason has never been understood nor do I believe that it ever will be, although the fact is patent and we see it with our own eyes. It may be a judgment of God that what we do not achieve is due to the desire of our Lord to punish these Indians for their enormous sins, and to prevent the Indies from being understood so that the remedy may be applied until it shall please him. This we shall have to leave to His divine pleasure.

But humanly speaking, I find three causes why the Indies have not been understood. The first is that the lands of the Indies are so vast and so remote from Spain, with provinces so numerous and so different one from the other, being in no wise similar to those on this side, that each. one has need of its own particular laws, whereas it happens every day that the same law is given for them all. Thus that which benefits one injures another. Also, those who desire to govern them have not seen them, and are hence obliged to govern according to what others say or write. Also, as soon as a member of the Council begins to understand 
cansase y dexanlo y tambien quando echan ojo, en lo que trabajo el buen obispo de chiapa y en su gran costancia, y en lo que padecio mi buen amigo El obispo de popayan y como ambos murieron en este pio de que se supiese la christiandad de lo que en las yndias pasa y se remediasa, y ambos sacaron poco fructo de sus trabajos como vee esto desanimase y dexalo y asi no se acaba de aberiguar la christiandad de lo que en las yndias pasa.

Quien tenga la culpa de tantos males y daños yo lo dire y no la tiene nuestro buen Rey y señor como algunos atrevidamente y malamente sin entendello hablan porque bastantissimamente descarga con poner un cosejo tan christiano y de tantas letras y $\mathrm{El}$ tan de buena gana oye a todos y lo que a su noticia viene nada Remediar y a hecho y hace tan grandes limosnas en las yndias edificado yglesias monasterios y hospitales y colegios y gastado tantos dineros ebiando alla frailes y clerigos que pediquen El Santo evangelio. Pues El que de indias tan poco tiene Culpa de estos males pues con diligencia hace lo que esies, procurado de ebiar alla obispos y Juezes los mejores que puede hallar, y si alla sepa vierte o culpa tiene basta hacelles tomar Residencia y castigallos, pues Las probisiones cedulas ynstructiones que enbia y lo que alla mandada sanctissimo es.

La culpa de todos los males cometidos en las yndias a mi juizio Reparto yo en tres generos de personas. La tercia parte desta culpa (y aunque le echara la mitad no errara) tiene todos los Juezes eclesiasticos y seglares desde el mayor hasta el menor que an estado y estan oy en las yndias quales alaban mucho, por no exequtar nada dizen no conviene esequtar esto, stantamente Les manda ni las nuebas leyes ni otras mil provisiones y instructiones que para El buen govierno de las yndias cada dia les embian los unos especialmente inferiores no lo hace por estar hechos a la Ra. ${ }^{\mathrm{s}}$ y corropidos en los encomederos en codicia los otros muy prudetacos a los quales alaban mucho, por no exequtar nada dizen no conviene esequtar esto, yo informare a su magestad no es tiempo no conviene para esta tierra no la entiende $\mathrm{El}$ governador y ansi se quedan los delictos sin castigo y no se esequta Justicia y por esto y no por otra causa sea levatado alla tantos tyranos en el piru y otras partes porque el fin de la Justicia bien vemos que es la paz y los buenos Juezes que ay que son pocos como sus companeros y todos son que ellos no pebalece ni llega su voto al fogon de todo esto podre grandes exemplos que e bisto y oido alla.

La segunda tercia parte de la culpa destos males echo a todos los clerigos y frailes que esta y an estado en las yndias, que por hacerse Ricos se an coformado con todos los males que astelan Las yndias y los cofiesan y absuelven sin Restituir lo que an hurtado a los yndios y absuelven a los tyranos dexadolos a todos en su propio estado sobresanandoles sus peccados, viendo claramente consumirse los yndios y acabarse por fuirse dellos hasta que muere y declarar esto es un abismo.

La ultima 3 a parte repartan entre si los propios coquistadores y encomenderos de yndios y sus criados y los soldados que son todos los moradores de las yndias por ser ellos, los perpetradores destos delitos que si los obiese de contar seria no acabar y me madaria vuestra señoria callar

r Evidently a miscopy for "executado".

s Not decipherable. 
the Indies he is given some other employment; as a result, the country is not understood, and if a wise course is pursued it is by accident.

The second cause is that almost all those who come from the Indies or who write from there send incorrect reports according to their tastes, which are dictated by a self-interest which is only to be served by forcible extortions from the Indians. In this respect all are alike; all desire to live in liberty and at ease, with no one to restrain them; they do not want to report anything against themselves lest it should be remedied. As these reports have been followed the wrong course has often been pursued. The Council has itself fallen into this error and very naturally does not know whom to believe.

The third reason is that there frequently come from the Indies persons of good character and religion, fleeing from the great ills which exist there, with great fervor and zeal to report conditions to Christendom here in order that they may be improved. These persons are few, it goes without saying that they are poor, and not in favor with the Spaniards in the Indies. They begin to tell the truth with great heat, disclosing the affairs of the Indies; but, since everyone here, including the Council, is wary on account of the lies which they have heard from everyone else, no one here knows whom to believe, so that credit is not accorded even to those who are upright. No attention is paid to representations; if they are heard at all it is only in a lukewarm manner and no action is taken. Also, when they notice the great labors and constancy of the good bishop of Chiapas, and how much my good friend the bishop of Popayán suffered, and how they both died cherishing this anxious desire that the Christian world should know what was going on in the Indies so that it might be remedied, though neither achieved much fruit from their laborswhen they see this they become discouraged and give up; for this reason Christendom has not yet ascertained what is going on in the Indies.

Upon whom the blame for all these injuries and ills should fall I will say; it is not our good king and lord, as some say boldly and evilly without understanding. For he is most completely exonerated by placing as he has done so Christian and wise a Council in charge. Besides, he himself willingly listens to everyone, and whatever is brought to his attention he orders remedied; he has given and continues to give large alms in the Indies for the erection of churches, monasteries, hospitals, and colleges; and he has spent huge sums in sending thither friars and clericals to preach the holy Gospel. Neither is the Council of the Indies to blame for these ills, because it discharges its duties diligently, making efforts to send thither the best judges and bishops that can be found, and if any of these there does wrong or is to blame, it is sufficient to order their residencias taken and have them punished, for the provisions, cédulas, and instructions which this body sends thither, and that which is there commanded, are most righteous.

The blame for all the ills committed in the Indies I attribute according to my judgment to three classes of people. One third of the blame (and if I should say half I should not be far wrong) is attributable to the ecclesiastical and secular judges, from the highest to the lowest, who have 
porque no podrian orejas tan Christianas oyr tan graves delitos como españoles an cometido y oy comete en las yndias.

El remedio para que no pasen adelante tantos males De lo Dios nuestro Señor que los hombres poco alcacan Pero seria algun medio y entenderhia que se quiere Remediar ciertas cosas de las yndias se procura por de entender lo qual no se puede hacer sin hacer una grande Junta como conviene a negocio tan importante donde este presente su magestad o vuestra señoria y el propio consejo de yndias y otros grandes theologos todos por Juezes y alli en medio como en un consejo, a una parte poner todos los buenos Religiosos y otras personas y ay de gran virtud y trata. Este negocio que tenga todos expiriencia de las yndias; y de la otra parte poner un hato desta gente que a venido de yndias y cada uno de lo que a visto y sabe de cada provincia por si averiguese alli delante tan buenos juezes La christiandad y haran confesar los buenos a la gente de yndias lo que alla pasa y asi clara y abiertamente se veran los malos que alla ay y averiguado esto que es lo que toca al hecho vuestra señoria y el govierno determinen El derecho y den La orden general que convenga y vayase a executar que poco a poco se hara mucho en el servicio de Dios y en la conversion de los yndios y no haciendose siempre andaremos a tiento. Vuestra Señoria me perdone si e sido largo que no convenia como persona tan ocupada La qualidad del negocio me desculpa y avermelo mandado Vuestra Señoria.

Este memorial dio El bachiller luis Sachez que vive en chillaron de Pareja. Diolo al señor presidente espinosa en madrid a 26 de Agosto de I 566 años. ${ }^{t}$

t F. R. B., Sevilla, June 25, I9I4. 
been or are to-day in the Indies, for they never have executed properly the constant commands which the government sends them from here, neither the New Laws nor a thousand other orders and instructions which are every day sent to them for the good government of the Indies. Some of them, especially those of lower grades, do not obey commands because they are heaped with honors and attentions and corrupted among the encomenderos in covetousness. Others, who are more prudent, are praised for performing nothing. They say: It is not fitting to do this, I will inform his Majesty that this is not the right time, the order is not fitting for this country, or, the governor does not understand; thus crimes go without punishment and justice is not executed. For this and for no other reason so many tyrants have sprung up in Peru and in other places, for the end of justice we well know is peace, but good judges over there are few, and their companions are of such character that their opinions do not prevail nor do decisions ever take effect. I will cite notorious instances of all this, which I have seen and heard over there.

The second third of the blame for these evils I attribute to all the clericals and friars who now are or have been in the Indies, who for the sake of enriching themselves have condoned all the evils which desolate the Indies and have confessed and absolved their authors without demanding restitution of what has been stolen from the Indians. They absolve the tyrants, leaving them all in their actual state, forgiving them their sins, although they see plainly that the Indians are being consumed and exterminated in fleeing from their persecutors until death overtakes them. Then the religious assert that this is unfathomable.

The last and third part of the blame is shared by the conquerors themselves, the encomenderos of the Indians, their servants, and the soldiers, that is, among all the residents of the Indies, since they are the perpetrators of these crimes. If I had to count them I should never finish, and your lordship would command me to be silent, for ears so Christian as yours could not bear to hear of such serious crimes as the Spaniards have committed and are to-day committing in the Indies.

May God our Lord provide the remedy whereby these many ills may be stopped, for men are not equal to the task. It would, however, provide some amelioration, and would make manifest that there is a desire to remedy certain things in the Indies if an effort were made to attempt to understand them. This could not be done without convoking a large committee suitable for such an important affair, at which his Majesty or your lordship should be present, with the Council of the Indies itself and others, great theologians, all sitting as judges. Then, when they should all be sitting together as a council, all the good religious and other persons of virtue who have knowledge of this business, having had experience in the Indies, should be placed on one side, and on the other should be put the crowd of those people who have come from the Indies, and let each one tell what he has seen and knows concerning each of the provinces. In this way Christendom might ascertain before such good judges, by taking the testimony of good people from the Indies, what is occurring there; the evils which exist there might thus be clearly and openly seen. When this has been ascertained, it being the point of the inquiry, your lordship and the 
Al Virrey de la Nueva España sobre lo que a de hazer para el Remedio del exceso de los Juegos y tablajes. ${ }^{u}$ [I594.]

El Rey. Don Luys de Velasco mi Virrey, Governador y Capitan general de la nueva españa por diversas vias he entendido que algunos de los ministros de justicia de esa su audiencia son tan remisos y descuidados en sus officios y tan dados a sus contentamientos y ynteres particulares que padece mucho la buena administracion de la justicia siendo esta la que conserva los Reynos y los mantiene en paz y quietud y que deviendo los del crimen dar mejor exemplo de si en todas las ocasiones y corregir y castigar los eccesos son los que los cometen y consienten y en especial notan al licenciado don Francisco Thello oydor y a su muger y al licenciado marcos Guerrero alcalde del crimen que tienen en sus casas tablage publico con todo genero de gentes hombres y mugeres donde de dia y de noche se pierden haziendas y honrras tratandose de la de algunas doncellas y casadas sin que se remedie de que ay alla tanta nota y publicidad que con la misma lo rreprehenden los predicadores en los pulpitos y encargan la enmienda sin que se ponga y Porque yo tengo esto por de tanta consideracion que no se puede disimular sin escrupulo de consciencia y me maravillo que teniendolos vos Presente y oyendo las murmuraciones y escandalo del pueblo no lo ayays Remediado o dadome quenta dello y deseo y me combiene que sin dilacion se atage os mando que luego que esto recivais llameys en el acuerdo a los dichos licenciados don francisco thello y marcos Guerrero y le digays de mi parte que me ha desplacido mucho de haver sabido este gran exceso suyo Por lo que demas de ser en ellos tan rreprehensible a dado occasion a tanta nota y escandalo y a las otras perdidas tan grandes de onrras y haciendas y que si bien es verdad que conviniera hazer con ellos alguna extraordinaria demostracion he entretenido el castigo esperando en lo de adelante Procederan de manera que el pueblo todo conosca y vea la enmienda y que asi por ninguna via den lugar a que se juegue en sus casas en poca ni en mucha quantidad ni ellos ni la muger del oydor vayan a jugar otra cassa particular y si habiendo vos hecho

u A. G. I., 87-5-I. 
government might determine what ought to be done, and give general orders suitable to the purpose; if such orders were executed, much would gradually be done in the service of God for the conversion of the Indians. If this is not done we shall always be working blindly. Your lordship will pardon me if I have written too profusely, as I should not have done to a person who is so busy. The character of the business is my excuse, as is the fact that your lordship has commanded me to present this memorial.

This memorial was presented by the Bachiller Luís Sánchez, who lives in Chillarón de Pareja. He gave it to President Espinosa in Madrid on August 26, I 566.

To the viceroy of New Spain concerning what is to be done to remedy the excess of gambling and gambling-houses. [1594.]

The King. Don Luís de Velasco, my viceroy, governor, and captaingeneral of New Spain: By divers means I have learned that certain of the ministers of justice of your Audiencia are so remiss and so careless of their offices, and so given to their own entertainment and private interests, that the proper administration of justice which preserves kingdoms and maintains them in peace and quiet suffers much. But the criminal judges, who ought to set a better example upon all occasions by correcting and punishing excesses, are the very ones who commit them and give their consent to them. Especial notice has been taken of the licenciado Francisco Tello, the oidor, and his wife, and of the licenciado Marcos Guerrero, alcalde del crimen, who have in their houses public gaming-tables with all manner of people, both men and women, where both by day and by night estates and honors are lost, especially those of certain women, both single and married. There is no reform of this situation, which is so notorious and public that even the preachers reprehend it in their pulpits and demand improvement without effect. Inasmuch as I consider this situation so serious that it cannot be passed over without scruple of conscience, I am surprised that you, knowing it and hearing the complaints and knowing the astonishment of the public, have neither remedied the matter nor reported it to me; and since I desire and it is my pleasure that it should stop at once, I command you that immediately upon your receipt of this you call into consultation the said licenciados Don Francisco Tello and Marcos Guerrero, and tell them for me that it has displeased me much to learn of this their great excess, for, aside from its being so reprehensible in themselves, it has occasioned such great notoriety and scandal, and to others such great losses of both honors and estates, that, if it is indeed true, it will be fitting to make a special example of them; but that I have withheld the punishment hoping that in the future they will so comport themselves that the entire people may know and see their reformation; and that they shall by no means permit gaming in their houses for any sum either large or small; nor shall they or the wife of the oidor go to 
esta diligencia vieredes y entendieredes que no se enmiendan los suspendereis de los officios sin aguardar otra orden mia y para que de todo junto se dexarra y que la mala costumbre que ay se a yntroducido de jugar las mugeres tan excessivamente Vos myrareys el orden que se tendra en havisar a sus maridos y a ellas que cessen y no lo permitan y no bastando esto ordenareys a las justicias que las castiguen con penas pecuniarias y destierros como lo merecieren sus excessos sin excesion de personas y para lo de los tablages vereys si combendra acresentar las penas de las leyes y hazerlo eys como os pareciere pero de manera que no se convierta en Utilidad de la justicia sino que sirva de terror y castigo para los culpados acudiendo en todo al remedio de suerte que no quede rastro de lo pasado y sepan todos que si exceden asi de sentir sobre si muy rigorosos castigos fecha en san lorenco a siete de septiembre de mill y quinientos y noventa y quatro años-YO EL REY-Por mandado del rey nuestro señor JUAN DE IBARRA y señalada del consejo.

I6Io. Testimonio de Providencia dada por Don Luis de Velasco Virrey de la Nueva España a fabor de Francisco de Sosa Peñalosa Administrador y Protector de los Yndios Chichimecas, para que aquellas justicias no conociesen de las causas de dichos Yndios.

I6ı. Don Luis de Velasco cavallero de la horden de santiago birrey lugar theniente del rrey nuestro señor su gobernador y capitan general de la nueva españa y presidente de la audiencia rreal que en ella rreside, etc. Por quanto francisco de sosa peñalosa me a hecho rrelacion que estandole cometida la administracion y anparo de los yndios chichimecas que estan rreducidos de paz y poblados con algunos tlaxcaltecos en chalchiguitis y su comarca y para rreçibir en la dicha Paz los que de nuebo la biniesen ofreçiendose se entremeten En ello las Justiças hordinarias que alli ay pretendiendo conoçer de las causas y negoçios que ofreçiesen entre los dichos yndios, no lo pudiendo ni debiendo hazer de que se siguen muchos ynconbenientes y conpetençias pidiendome Para rremedio de ello mandase que las dichas Justiçias no conoçiesen de las dichas causas dexandolas al capitan o caudillo que alli obiese y Por mi visto por la presente mando a las Justiçias hordinarias de la dicha comarca de chachiguitis que no se entremetan en manera alguna a conocer de las causas y negoçios de los yndios tlaxcaltecos y chichimecos que en ellas estan poblados y de aqui adelante se poblazen ni de las del que los administra o administrare En lo que fuere tocante a los yndios dichos dexandolo todo a el capitan y caudillo a cuyo cargo fuese su administraçion y anparo para que El conozca de las dichas causas En conformidad de la horden que para ello le esta dada, con aperçibimiento que haziendo lo contrario las dichas Justiçias se proçedera contra ellos

vA. G. I., 5-3-20/14. 
gamble in any other private house. If you, after performing this duty, see or learn that they have not reformed, suspend them from their offices without awaiting further command from me. And in order that all this may stop, as well as the evil custom which has been introduced there of excessive gambling among the women, you will take notice of the conduct observed by them after you warn them and their husbands to desist and to cease permitting it. If this is not sufficient you will command the judges to punish them with the pecuniary fines and exile which their excesses merit, without regard of persons. As to gambling-houses, you will ascertain whether it would be suitable to increase the legal penalties; if so, you will act according to your judgment, but in such a way that it will not be turned to the profit of justice, but may rather serve as a terror and punishment to the guilty. You will in everything so attend to the reform that there shall remain no trace of what has passed, and that all may know that if they transgress in this manner they shall experience rigorous punishment. Dated in San Lorenzo, September 7, I 594. I the King. By command of the king, our lord, JuAn De IbarRa. Signed by the Council.

I6Io. Certified copy of the decree issued by Don Luis de Velasco, viceroy of New Spain, in favor of Francisco de Sosa Peñalosa, administrator and protector of the Chichimecas Indians, to prevent the justices there from trying the cases of the said Indians.

I6ro. Don Luís de Velasco, cavalier of the Order of Santiago, viceroy, deputy of our lord, the king, his governor and captain-general of New Spain, and president of the royal Audiencia sitting in it, etc.: Inasmuch as Francisco de Sosa Peñalosa has made me a statement that, although the administration and protection of the Chichimecas Indians who are reduced to peace and settled with some Tlaxcaltecos in Chalchiguitis and its vicinity, and the receiving into the said peace of those who may come to renew it was entrusted to him, yet the regular justices there are meddling in it and attempting to try the cases and affairs that occur among the said Indians. This they have not the power or right to do, with the results that there are many difficulties and disputes. And he asks me as a remedy for it to order the said justices not to try the said cases but to leave then to the captain or chief that may be there. And [the statement] having been examined by me, by the present writing I order the regular justices of the said district of Chalchiguitis not to interfere in any manner in trying the cases and business of the Tlaxcaltecos and Chichimecas Indians who are settled there, or will settle there in the future, nor in those of the one who administers or may administer the affairs of the said Indians, but to leave all to the captain or chief under whose charge administration and protection may be, so that he may try the said cases in conformity with the order which has been given for it, with warning that if the said justices do the contrary, action will be taken against them as against persons 
como contra personas que usan de Jurisdizion En casos que no lo pueden ni deben hazer por no tener comision ni facultad para ello. Fecho en mexico a diez y seis dias del mes de septiembre de mill y quinientos y nobenta y tres años-don LUIS DE BELASCO-por mandado del birrey PEDRO DE CANPOS.

Don luis de Velasco-caballero de la horden de santiago birrey y lugar theniente del rrey nuestro señor gobernador y capitan general de la nueva españa $E$ presidente de la audiençia y chancillera rreal que en ella rreside, etc. Por quanto los yndios chichimecos y tlaxcaltecos de la Poblaçion de chalchiguites $\mathrm{Me}$ an fecho rrelaçion que son molestados de las Justiçias del distrito de guadalaxara que los conpelen acudir alla a Reconoçer y Por sus Eleçiones y las demas cosas que se ofrecen y con esto les causan ynquietud $\mathrm{y}$ ocasion a que Padezcan agrabios y me pidieron mandase rremediar como mas conbenga a su conserbaçion por tanto atento a lo susodicho y Porque conbiene que en todo lo posible sean los dichos yndios de la dicha pobla. çion anparados y escusarles Molestia y bexaçion Para que bayan adelante y que a esto ayuden todos los Juezes y ministros de su magestad Por el presente mando que las dichas Justiçias de guadalaxara no se entremetan En cosa tocante a los dichos yndios de Justicia gobierno ni otro genero ni los ynquieten agrabien ni den ocasion de quexa So pena de caer En caso grabe de que se Probeera contra el que exçediere como conbenga de cuyo cunplimiento tenga espeçial cuydado El theniente de capitan general que tengo nonbrado para lo tocante a los dichos yndios. Fecho en mexico a diez y ocho dias del mes de hebrero de mill y quinientos y nobenta y cinco años. Don luis de Velasco Por Mandado del birrey Martin LOPEZ DE GAUÑA.

Yo bartolome de colmenares escrivano de camaro y gobierno de la Real audiençia del nuevo rreyno de la galizia-certifico como Por Mandado de los Señores presidente $E$ oydores de la dicha rreal audiençia Saque este treslado de otro treslado que esta firmado de Jhoan tenorio escrivano reçeptor de la dicha rreal audiençia que esta cosido en la causa de los autos de la bisita que El licenciado gonzalo Panella fuentes del consejo del rrey nuestro señor y su oydor de la dicha rreal audiencia hizo siendo bisitador de este rreyno en la bisita de las billas de llerena $\mathrm{E}$ san martin que queda en mi oficio y archibo A que me rrefiero fecho En la çiudad de guadalaxara a Veinte y cinco dias del mes de abril de mill y seisçientos y diez años siendo testigos a lo ber sacar corregir y conçertar Pedro gil de laudenas $\mathrm{E}$ francisco martin de rribera estantes en esta dicha çiudad.

En fee de lo qual fize mi signo [aqui hay un signo] En testimonio de verdad-BARTOLOME DE COLMENARES [rubricada] derechos gratis. 
who exercise jurisdiction in cases in which they have not the power or right to do it, through having no commission or authority for it. Done in Mexico on the sixteenth day of the month of September, I593. Don Luis de Velasco. By order of the viceroy. Pedro de Campos.

Don Luís de Velasco, cavalier of the Order of Santiago, viceroy and deputy of our lord the king, governor and captain-general of New Spain, and president of the Audiencia and royal chancery sitting there, etc. In regard to the Chichimecas and Tlaxcaltecos of the settlement of Chalchiguitis, it has been reported to me that they are molested by the justices of the district of Guadalajara, who compel them to go there for inspection and for their elections and other affairs that occur among them. This causes them annoyance and offense, and they petitioned me to order it to be remedied in the way best suited to their conservation. Therefore, in view of the above, and because it is right that the said Indians of the said settlement shall be protected and saved from the molestation and annoyance as far as possible, so that they may make progress, and that all the judges and ministers of his Majesty shall aid in this, by these presents I order that the said justices of Guadalajara shall not interfere in anything affecting the said Indians in justice, government, or any other matter. Nor shall they disturb or offend them or give cause for complaint, under penalty of committing a grave offense, for which the proper proceedings will be taken against any one who commits it. Let special care be taken to carry this out by the lieutenant captain-general whom I have named for all that concerns those Indians. Done in Mexico, February I8, I595. Don Luís DE Velasco. By order of the viceroy. Martín López de Gauña.

I, Bartolomé de Colmenares, clerk of the council and government of the royal Audiencia of the new kingdom of Galicia, certify that by order of the Señores president and oidores of the said royal Audiencia, I took this copy from another copy which is signed by Juan Tenorio, treasurer of the said royal Audiencia, which is bound in with the autos of the inspection which the licentiate Gonzalo Pañella Fuentes, of the council of our lord the king and his oidor of the said royal Audiencia, made when he was inspector of this kingdom, in the towns of Llerena and San Martín, and which is in my office and archive, to which I refer. Done in the city of Guadalajara, on the twenty-fifth day of April, I6 Io, the eyewitnesses to its drawing up, correction, and comparison being Pedro Gíl de Laudenas and Francisco Martín de Ribera, residents of this said city.

In certification of which I fixed my signature [here there is a signatureF. R. B.] in testimony of the truth. Bartolomé de Colmenares. [With rubric.] Free of charge. 
Resolucion y Sumario de las Provincias y pueblos de sus cargos y Datos a los naturales de ellos de los tributos y servicio Real. ${ }^{w}$ [I653-I656.]

Resolucion y Sumario de las Provincias y pueblos de sus cargos y Datas a los naturales de ellos de los tributos y servicio Real que pagan a su Magestad en generos segun lo que cada Provincia y pueblo tiene por obligacion de su tasacion a pagar en cargas de mantas de Ropa de algodon que cada una tiene Veinte mantas de a Cinco varas. Cargas de cacao de a Veinte y quatro mill Cada una. Petates que son como esteras de españa. Pilones de Sal blanca. Hilado de algodon. Guipiles Ropa con que se bisten las Yndias de estos Reinos. Maiz que se remata en la Real Almoneda, y el que su Magestad da a los ministros de doctrina para su sustento por su ocupacion en la administracion de los Sanctos Sacramentos que se comprehende su Satisfacion y cobranza en la relacion tomada que en este tribunal a presentado el contador don Martin de San Martin que corre desde primero de henero de mil y seiscientos y cinquenta y tres años hasta fin de Diciembre de mill y seiscientos y cinquenta y seis años por no ser esta cobranza de su obligacion, pues la que tiene es solo entregar a fin de cada Un año a Jueces y officiales reales de esta corte Una memoria firmada de su nombre de lo que montan estos tributos y servicio Real en especie con testimonio del escrivano de la Real Caxa, como Consta lo a hecho en los quatro años de esta quenta que son para rematar en la Real almoneda dichos generos $\mathrm{Y}$ cobrar los dichos officiales Reales para que sus enteros Se ajusten Con la cantidad de lo que montaren en dinero a quien se deve Cargar la resulta ó Resulttas del devido cobrar. Y este es el estilo que se halla en este tribunal aunque no quentta tomada de este genero desde su fundacion, que por menor Sus generos y cantidades son en esta manera. [Dos rúbricas.]

[Here follow the accounts.-F. R. B.]

El Marques de mançera Virrey de la Nueva españa 5 de Abril de I67I. Da quenta del aumento que an tenido en el tiempo de su Govierno las rentas de tributos $Y$ real servicio. ${ }^{x}$

Señora: Uno de los Principales ramos de que se compone la Real hazienda de este Reyno es el de los Tributos y servicio Real de los Yndios, y por entenderlo asi he aplicado muy particular cuydado no solo en la puntual recaudacion de la renta solicitando que el contador General de ella cumpla con su obligazion sin dejar los rezagos que ó por negligencia ó por maliçia solian reconocerse en otros tiempos sino en no permitir que con pretexto de diminuçion de Yndios se hiçiesen façilmente y sin madura y exacta consideracion las revajas que tambien solian experimentarse en

w A. G. I., 4-6-I $32 / 5$.

x A. G. I., 4-6-145/18, Mexico. 
Résumé and summary of the charges and requisitions made upon the natives of the provinces and towns in tributes and royal service. $[1653-1656$.

Résumé and summary of the charges and requisitions made upon the natives of the provinces and towns in tributes and royal service, which they pay to his Majesty in articles such as each province and town produces, by obligation of their appraisement to pay in bales of cotton cloth, each bale to have twenty pieces of five varas; bales of cacao, each containing 24,000; mats, which resemble Spanish matting; loaves of white salt; cotton thread; huipiles-clothing worn by the Indians of these kingdoms; maize, which is auctioned in the Real Almoneda [royal auction], and which his Majesty gives to the ministers of the gospel for their sustenance, because of their occupation in the administration of the holy sacraments. The payment and collection of this maize are embraced in the copied account which was presented in this tribunal by Don Martín, the auditor of San Martín. This runs from January I, I653, to the end of December, 1656 , for he is not under obligation to make this collection but only to hand at the end of each year to the judges and royal officials of this court an account signed by his name of what these tributes and royal service amount to in specie, with the attestation of the cashier, as it is known that he has done in the four years of this account. The said goods are to be auctioned in the Real Almoneda and the said royal officials to collect, so that their total amounts may agree with the sum to which they amount in money, and to them the result or results of the required collection should be charged. This [the following account] is the method that is used in this tribunal, and although it is not an account taken in this way since its foundation, at least its goods and quantities, are in this manner.

[Two rubrics.]

[Here follow the accounts.-F. R. B.]

The Marquis of Manzera, viceroy of New Spain. April 5, I67I. He gives account of the increase in the revenues from the tributes and royal service which has occurred during the time of his administration.

Madam: ${ }^{10}$ One of the principal branches of which the real hacienda of this kingdom is composed is that of the tributes and royal service of the Indians, and, understanding it to be so, I have given very particular attention, not only to the punctual collection of the revenue-taking care that the auditor-general fulfills his duty and does not allow the delinquencies that were wont to occur in other times, either through negligence or illintention-but in not permitting that, with the pretext of the diminution of the Indians, there should be made, easily, and without mature and careful consideration, the reductions that also used to occur, to the grave impairment of the royal assets; and, what is more important, in procuring personal information of the growth and increase of Indians in all the 
grave menoscabo del Real haver, y lo que es mas en procurar notiçias individuales de los Creçimientos y augmentos de Yndios en todos los Pueblos y Provinçias del distrito, y partiçipandolas al fiscal para que en conformidad de las Reales çedulas pidiese nuebas quentas. De esta Vigilançia y buena orden resulta que quando es casi unibersal en todas las Yndias el clamor de que se ban acabando y consumiendo sus naturales y aun las naçiones estrangeras lo atribuien al mal trato que reçiben de los Españoles se halla la Nueva españa en primero del Corriente con doçe mill treçientos y veinte y cinco Tributarios y medio mas de los que tenia en I 5 de octubre del año de 1664 quando me encargue deste Govierno como consta de la inclusa çertificaçion del Contador General de tributos y la Real hazienda con augmento de mas de veinte y tres mill pesos de renta cada año segun pareze de la regulaçion final porque la rebaja de los Diezmos de las speçies nunca podra pasar de setezientos á ochoçientos pesos cada año de que e Juzgado conveniente dar notizia a Vuestra Magestad Cuia Catolica Real Persona Guarde Dios como la Christiandad a menester. Mexico 5 de Abrill de I67r. El Marques de Manzera.

Es copia de la original que queda en esta secretaria de este oficio de donde se saco para enbiar a la Contaduria del Consejo en Virtud del decreto de I I deste mes. Madrid 28 de Setiembre de I67I. hay una rúbrica.

Ordenanzas y preceptos de tierras para medir Sitios criaderos de ganados mayores, y menores, Caballerías, y demas tierras sacadas de las que se hicieron y promunciaron por los Señores, y Cabildo de la Real Audiencia de Mexico confirmadas por el Excelentisimo Señor Don Antonio de Mendoza Virey que fué de esta Nueva España, las quales fueron pregonadas en la Plaza publica de esta dicha Ciudad, por voz de Juan de Montilla pregonero publico: el dia Martes 4 de Julio de I536 años siendo testigos, etc. . . . las quales ordenanzas son asiento para toda esta nueva España: asi lo mandaron firmaron y proveyeron en dicho dia mes y año.

\section{CONFIRMACION DE DICHAS ORDENANZAS CORROBORADAS Y ANADIDAS. ${ }^{2}$}

En la Ciudad de Mexico de la nueva España en diez y nueve dias del mes de Septiembre de mil quinientos setenta y siete años, El Excelentisimo Señor Don Gaspar de Peralta Marqués de Falzés Conde de Santiestevan Mayordomo de Su Magestad en el Reyno de Navarra, su Virey Gobernador y Capitan General en Esta Nueva España Presidente de ésta Real

y This document was copied by Dr. Ad. F. Bandelier in Mexico, February I8, I9I2. Unfortunately Dr. Bandelier does not state whether the copy was made from a manuscript, or from some old print. There is, then, neither archive designation nor bibliographical data available concerning this document. In the Bancroft Library there is a bound manuscript entitled: "Libro de las Ordenanzas y Medidas de Tierras, y Aguas; $V$ ista de Ojos, con el modo de medir las Minas, y nestecidad que ay de su ynteligencia, y otras cosas muy curiósas y necessarias que en el se contienen etc." A comparison of the 
towns and provinces of the district and informing the fiscal of it, so that, in conformity with the royal decrees, he may charge them by new calculations. From this vigilance and good management it results that while the cry is almost universal in all the Indies that the natives are dying out, and even the foreign nations attribute this to the ill-treatment which they receive from the Spaniards, New Spain is found on the first of the current month with 12,325 tributaries, one-half more than it had on the fifteenth of October of the year 1664, when I took charge of this government, as appears from the enclosed affidavit of the auditor-general of tributes and real hacienda. There is also to be noted an increase of more than 23,000 dollars in revenue every year, as appears from the final account, for the reduction of the tenths, when changed into specie, can never exceed seven or eight hundred dollars a year. Of this I have thought it proper to inform your Majesty, whose royal Catholic person may God keep, for Christianity's sake. Mexico, April 5, I67I. The Marouis of Manzera.

This is a copy of the original which is with the secretary of this office, from which it was copied in order to send it to the auditor's office of the Council, in virtue of the decree of the eleventh of this month. Madrid, September 28, I67 I. There is a rubric.

Land ordinances and regulations for measuring sitios, criaderos de ganados mayores and menores, caballerias, and other lands; taken from those made and issued by the members and chamber of the royal Audiencia of Mexico and confirmed by the excellent lord, Don Antonio de Mendoza, former viceroy of this New Spain, and published in the public plaza of this city by the mouth of Juan de Montilla, public crier, on July 4, I536; witnesses whereunto are, etc. . . . These ordinances are of force for all of this Nere Spain, for thus they ordered, signed, and prescribed on the said day, month, and year.

Confirmation OF SAID ORDINANCES, With CORRECTIONS AND ADDITIONS.

In the City of Mexico of New Spain, on the nineteenth day of the month of September of the year I 577, the most excellent lord, Don Gaspar de Peralta, ${ }^{11}$ Marquis of Falces, Count of Santiestévan, majordomo of his Majesty in the kingdom of Navarre, his viceroy, governor, and captaingeneral in this New Spain, president of this royal Audiencia during the time in which it was governed by his excellency in the name of his majesty:

There has been conceded and granted a large quantity of farming land, for sitios de ganado mayor and sitios de ganado menor, caballerías, and other lands, but the proper method and procedure have not been completely enunciated for locating, setting up the boundaries, measuring, and giving possession to these sitios and other lots of land, [wherefore the viceroy] commanded that these ordinances be corrected by amplifying them and adding certain ones which are lacking, retaining the punishment 
Audiencia en el tiempo que gobernó por Su Excelencia en nombre de Su Magestad se há proveido, y se hizo merced de mucha cantidad de sitios de Estancia asi para ganados mayores como menores, y demas tierras y Caballerias, y no estan en el todo declaradas el orden y fundamento que se ha de guardar en centricar, amohonar, medir, y dar posesiones en dichos sitios y demas suertes de tierras: mandaba y mandó corroborar dichas ordenanzas ampliando, y añadiendo algunas que faltan, suscitando la dicha pena impuesta por otros Señores dexandola en su fuerza y vigor la qual es el pedimento de qualesquiera tierras, llebandose á debida execucion á las personas que no obedecieren dichos Reales preceptos advertencias y ordenanzas, las que son como se siguen.

first five pages of this book with the first three pages of the Bandelier copy shows a marked similarity between the two. For instance, compare the first paragraph of the Bandelier copy with the first two paragraphs in the book. The two paragraphs in the latter read: "Estas Ordenanzas Reales, y Preceptos para Medir Suertes de Tierras, como son Cavallerias, y demas Tierras, Citios de Ganado Mayor, y Menor, de las que se hizieron y proveyeron por los Señores Oydores y Cavildo de la Real Audiencia de Mexico; confirmadas por el Excelentisimo Señor Don Antonio de Mendoza Virrey, que fue de esta Nueva España: dispuestas por el Maestro Don Joseph Zaenz de Escobar Abogado de la Real Audiencia Las quales fueron pregonadas en la Plaza publica de dicha Ciudad por voz de Juan Montilla, Pregonero Publico el dia Martes quatro de Jullio de I536 Años.

"Y luego el Licensiado Loyza de parte del Señor Virrey Dixo: y mando que ninguna persona haga, ni pueda hazer contra estas Ordenanzas so pena de perdimiento de las Tierras, que fueren Causa, Origen de Vomper, y quebrantar dichas Ordenanzas y demas preceptos, aunque las tengan, y posean con lexitimo Titulo, y Merced, que por haver hecho contra las Reales Ordenanzas, sean las Mercedes en si de ningun valor, ni effecto, porque todas se han hecho, se hazen, y se han de hazer, devaxo de estas Ordenanzas, sujetandose a ellas, y otras condiciones que pertenecen a el derecho Real como consta de las Mercedes hechas por Su Magestad o en su nombre, las quales Ordenanzas con assiento para toda esta Nueva España, assi lo proveyeron, y mandaron el dicho dia quatro de Julio de mil quinientos treinta y seis años."

z The Bancroft Library copy of the Confirmación reads:

"En la Ciudad de Mexico de la Nueva España en diez y nueve del mes de Septiembre de mil quinientos treinta y siete años, el Muy Excelentisimo Señor Doctor Don Gaston de Peralta, Marquez de Falces [viceroy from I566-1568], Conde de Santi Esteban, Mayordomo de Su Magestad en el Reyno de Navarra, su Virrey Governador y Cappitan General en esta Nueva España de esta Real Audiencia, en el tiempo que Governo, y por su Excelencia en nombre de Su Magestad Se ha proveido, y se hizo Merced de mucha Cantidad de Sitios de Estancia de Ganados Mayores, y Menores, y demas tierras, y Cavallerias, y no estan en el todo declaradas el Orden y fundamento el Orden que se ha de guardar en Centruar, Amojonar, Medir, y dar Posseciones en dichos Citios, y demas Suertes de Tierras; Mandava, y mando Corrovorar dichas Ordenanzas, ampleando, y añadiendo algunas que faltan, substanciando dicha pena ympuesta por dichos Señores, dexandola en su fuerza, y rigor, la qual es, el perdimiento de qualesquiera tierras, la qual se llevara a devida Execucion a la Personas, que no obedecieren dichos Preceptos, advertencias, y Ordenanzas Las quales son en la manera siguiente."

Here follow statements, very similar to those in the Bandelier copy, concerning Cordel; Sitio de Ganado Mayor; Sitio de Estancia de Ganado Menor; Criaderos de Ganados Mayores, y Menores; Cavallerias; Una Huerta; and Solar para Hazer Casa.

Mariano Galván (Ordenanzas de Tierras y Aguas, etc., Mexico and Paris, 1855, pp. I54-164), discusses at some length the ordinance of 1536 issued by Viceroy Mendoza; agrarios medios; sitios de ganados mayores y menores; and caballerias de tierra. While citations are lacking, it appears that the above document constitutes his chief authority. See also Wistano Luís Orozco, Legislación y Jurisprudencia sobre Terrenos Baldíos, I. (Mexico, I895), 27-28. 
imposed by other rulers and leaving it in force and vigor, said punishment being the loss of any such lands, and putting it into effect against any persons who have not obeyed the said royal provisions, admonitions, and ordinances, which are as follows:

\section{The Measuring Yard.}

The ancient measuring yard is the same as that used by Solomon, which consists of five spans [tercias], which is not now used; it is to be noted that the measuring yard named here for measuring all kinds of land is the ordinary common yard, called the Castilian yard, which has four handbreaths, and is that which is used by merchants.

\section{The Cordel.}

It should be noted that the cordel with which all kinds of land are to be measured must be fifty Castilian yards in length, and it must be drawn straight and as taut as possible.

\section{The Sitio de Ganado Mayor.}

A farm site for large cattle-raising [must measure] three thousand paces of the measure of Solomon; each pace contains five spans (it is understood that this dimension is from east to west) ; and from north to south it must also measure three thousand paces. From the centre to any of the four sides or edges, it must measure fifteen hundred paces of Solomon; reducing these measures to the common yard, the sitio measures five thousand yards from east to west, five thousand from north to south, and two thousand five hundred yards from the centre to any one of its four sides.

If such a sitio de ganado mayor is reduced to caballerias, it contains forty-one of the latter, with 14,272 yards left over, which make a dwelling site of II 9 and a scant one-third yards on each of the four sides. Such a sitio de ganado mayor, measured with a cordel fifty yards long, must measure one hundred cordeles or five thousand yards from east to west and the same distance from north to south, and from the centre to any one of the sides fifty cordeles, which make 2,500 yards; from the centre to any one of its corners it must measure seventy cordeles, which make 3,500 yards.

\section{The Sitio de Ganado Menor.}

A farm site for small cattle-raising measures two thousand paces of Solomon (each five spans long) from east to west, and two thousand paces (also of five spans each) from north to south; from the centre to any one of its four sides, one thousand of the same paces of five spans' length.

Reduced to common Castilian yards, this sitio de ganado menor measures from east to west $3,333^{\mathrm{T}} / 3$ yards, and the same distance from north to south; from the centre to any one of its four sides $1,6762 / 3$ yards. 


\section{VARA DE MEDIR.}

La vara de medir antigua es lo mismo que paso Salomon Que consta de cinco tercias la qual hoy dia no se usa, y se advierte que la vara de medir aqui se nombra para medir todo genero de tierras que es la vara ordinaria, y comun que llaman castellana, y tiene quatro palmos, y es la que usan los Mercaderes.

\section{CORDEL.}

Sea notorio que el cordel con que se ha de medir todo genero de tierras ha de ser de cinquenta varas castellanas, y ha de estar cerrado y estirado lo posible.

\section{Sitio de Ganado Mayor.}

Un sitio de estancia de ganado mayor de tres mil pasos de Salomon, y cada paso tiene cinco tercias, y se entiende desde Oriente á Poniente, y de Norte á sur tiene otros tres mil pasos, y desde el centro á qualquiera de sus quatro orillas, ó costados, un mil y quinientos pasos de Salomon, y reducido dicho sitio á varas de medir comunes tiene de oriente á Poniente cinco mil varas, y de Norte á Sur otras cinco mil, y del centro á qualquiera de sus quatro costados dos mil y quinientos varas.

Reducido éste sitio de ganado mayor á caballerias, hace quarenta y una Caballeria, y mas catorce mil docientas setenta y dos varas, que hacen un solar de ciento diez y nueve varas, y una tercia escasas por cada cavezada. Medido dicho sitio de ganado mayor con cordel de cincuenta varas ha de tener de oriente á Poniente cien cordeles que hacen cinco mil varas y de Norte á Sur otro tanto, y del centro á qualquiera de sus costados cinquenta cordeles, que hacen dos mil y quinientas varas, y desde el centro á qualquiera de sus quatro esquinas setenta cordeles que hacen tres mil y quinientas varas.

\section{Sitio de Ganado Menor.}

Un Sitio de estancia para ganado menor consta de dos mil pasos de Salomon de á cinco tercias, de oriente á Poniente, y otros dos mil pasos de Norte á sur de dichas cinco tercias, y del centro á qualquiera de sus quatro costados mil de dichos pasos de á cinco tercias.

Reducido éste sitio de ganado menor á varas de medir comunes castellanas tiene de Oriente á poniente tres mil trecientos treinta y tres varas y una tercia y otras tantas de Norte á Sur, y del Centro á qualquiera de sus quatro costados mil seiscientas setenta y seis varas y dos tercias midiendo éste sitio con cordel de cinquenta varas tiene de oriente á poniente sesenta y seis cordeles, y treinta y tres varas y una tercia, y lo mismo de norte á sur, y del centro á qualquiera de sus quatro costados ha de tener treinta $\mathrm{y}$ tres cordeles y seis varas y una tercia, y se ha de medir éste sitio segun y como el de ganado mayor y del centro á qualquiera de sus quarto esquinas ha de tener quarenta y seis cordeles y treinta y tres varas.

Reducido éste sitio á caballerias ha de tener diez y ocho de ellas y un selar de trecientas sesenta y seis varas y una tercia. 
This sitio, measured with a fifty-yard cordel, measures sixty-six cordeles thirty-three and one-third yards, and has the same measurement from north to south; from the centre to any one of its four sides it must measure thirty-three cordeles and six and one-third yards; this sitio must be measured in the same manner as the sitio de ganado mayor, and from the centre to any one of its four corners it must measure forty-six cordeles and thirty-three yards.

If this sitio is reduced to caballerias it must contain eighteen of them, and a building site of $366 \mathrm{r} / 3$ yards.

\section{The Criadero de Ganado Mayor y Menor.}

A criadero de ganado mayor is the fourth part of a sitio de ganado mayor, and a criadero de ganado menor is also the fourth part of a sitio [de ganado menor]. Hence a criadero de ganado mayor must measure north and south and east and west fifteen hundred of Solomon's paces, and from the centre to any one of its four sides it measures 750 of Solomon's paces.

If the measurement of this criadero is reduced to common Castilian yards, it will extend 2,500 yards from north to south, and the same distance from each to west; from the centre to any of its four sides it extends $\mathrm{I}, \mathrm{I} 5 \mathrm{O}$ yards. It must measure, in the same manner as the sitios above mentioned, from one corner to the other passing through the centre, 3,500 yards.

From the centre to any of its four sides or edges it measures 1,750 yards. If this criadero is reduced to caballerias of land, it will contain ten and one-fourth of them, besides a building site fifty-nine yards long and as many wide. The same is to be understood of the criadero de ganado mayor estimated as the fourth part of a sitio de ganado mayor, to which it corresponds.

\section{The Caballería.}

A caballeria of land is I,IO4 yards long and 552 wide, and its area is 609,408 common Castilian yards. Half a caballería is $55^{2}$ yards long and the same in width; its area is three [hundred and four] thousand seven hundred four common yards. One fourth of a caballeria is $55^{2}$ yards long, and 276 wide.

For measuring a caballería of land the cordel must be sixty-nine yards long instead of fifty, which is the length required in measuring the sitios. Starting in one of the four corners, the length of the caballeria must measure sixteen cordeles, which make the required [one thousand] one hundred and four yards; on the other side there must be eight cordellengths, which make the required five hundred and [fifty] two yards.

\section{The Huerta and Suerte.}

The garden plot of land is 552 yards long and 276 wide; it is the same as the fourth part of a caballería. 


\section{Criadero de Ganado Mayor Y Menor.}

Un Criadero de ganado mayor es la quarta parte de un sitio de ganado de éste, y un criadero de ganado menor es tambien la quarta parte de un sitio, y asi el criadero de ganado mayor ha de tener de oriente á poniente, y de norte á sur, mil y quinientos pasos de salomon, y del centro á qualquiera de sus quatro costados tiene setecientos cinquenta pasos de Salomon.

Reducido éste criadero á varas de medir comunes castellanas tiene dos mil y quinientas varas de norte á sur, y lo mismo de oriente á poniente, y del centro á qualquiera de sus quatro costados mil ciento y cinquenta varas, y se ha de medir segun y como los sitios antecedentes, y de una esquina á otra, pasando por el centro tiene tres mil y quinientas varas.

Y del centro á qualquiera de sus quatro orillas ó costados tiene mil setecientas y cinquenta varas. Reducido éste criadero á caballerias de tierra tiene diez y un quarto, y mas solar de cinquenta y nueve varas de largo, y otras tantas de ancho. Y lo mismo se debe entender del criadero de ganado mayor regulado por la quarta parte de un sitio de ganado menor que es lo que toca.

\section{CABalleria.}

Una Caballeria de tierra tiene mil ciento quatro varas de largo y quinientas cinquenta y dos de ancho, y en todo su centro seis mil novecientas quarenta y ocho varas comunes castellanas. Media Caballeria tiene de largo quinientas cinquenta y dos varas, y lo mismo de ancho, y en todo su centro tres mil setecientas, y quatro varas comunes, un quarto de Caballeria tiene de largo quinientas cinquenta y dos varas, y de ancho docientas setenta y seis.

Para medir una Caballeria de tierra ha de tener el cordel sesenta y nueve varas, á diferencia de los sitios, que ha de ser de cinquenta varas, y puesto en una de sus quatro esquinas se han de medir por lo largo diez y seis cordeles que hacen las dichas ciento y quatro varas, y por cabeza ocho cordeles, que hacen las quinientas y dos.

\section{Huerta y Suerte.}

Una huerta y suerte de tierra tiene quinientas cinquenta y dos varas de largo, y docientas setenta y seis de ancho; y es lo mismo que una quarta parte de una Caballeria.

\section{SOLAR.}

Un solar para edificar Casa deve tener cinquenta varas castellanas por uno de sus quatro costados.

\section{VENTA.}

Una venta se compone de cinquenta varas de largo, y las mismas de ancho. 


\section{The Solar.}

A building site upon which to build a house should measure fifty Castilian yards on one of its four sides.

\section{The Venta.}

A venta is a plot of land fifty yards long and the same in width.

\section{The Molino.}

A molino [mill-site] is also fifty yards long and the same width.

The Batán.

A batán ${ }^{12}$ is also fifty yards long and as many wide.

The Cuadra Menor.

The cuadra menor is ${ }^{1} 3^{8}$ yards long and six wide.

The Cuadra Mayor.

The cuadra mayor has a length of 276 yards, and a width of I 38 .

The League.

A league is composed of three thousand of Solomon's paces, which make five thousand Castilian yards or three miles, which compose a league.

\section{Method of Measuring the Sitios.}

First, 2,500 yards are to be measured along the east side toward the north, and another two thousand toward the south. Then, on the west side there are to be measured 2,500 yards toward the north, and as many more toward the south. Next, on the north side there are to be measured 2,500 yards toward the east, and as many more toward the west. Next, on the south side there are to be measured 2,500 yards toward the west and as many more toward the east. These frontages are to be given to the sitio de ganado mayor, and the sitio de ganado menor is to be measured in the same fashion, giving to each one the amount of land which belongs to it; the same is to be done with the criadero, as has been set forth in the proper place, giving to each the contents which properly belong to it.

In measuring the sitio de ganado mayor with a cordel of fifty yards length, fifty such lengths are to be drawn from the centre to any one of the four sides, thus giving the lateral bounds. On the front running east and west there are to be measured one hundred lengths of the cordel, and one hundred on the front running from north to south, each one hundred lengths making five thousand Castilian yards, which is the same as a league. By measuring this sitio in these two ways it is made square and has four equal corners, and any one who sets out from one of these four corners and walks around the four sides or edges of the sitio will 
Molino.

Un Molino tiene las mismas cinquenta varas de largo y lo mismo de ancho.

\section{BATAN.}

Un Batan tiene las mismas cinquenta varas de largo, y otras tantas de ancho.

\section{Quadra Menor.}

La quarda menor tiene ciento treinta y ocho varas de largo, y seis de ancho.

\section{Quadra Mayor.}

La quadra mayor tiene docientas setenta y seis varas de longitud, y ciento treinta y ocho de latitud.

\section{LEgUA.}

Una legua se compone de tres mil pasos de salomon, que hacen cinco mil varas castellanas y tres millas que componen una legua.

\section{Modo de Medir los Sitios.}

Puesto en la orilla del Oriente se han de medir dos mil y quinientas varas asi al norte, y otras dos mil quinientas házia el sur. Puesto en la orilla del poniente se han de medir dos mil quinientas varas ázia el norte, y otras tantas ázia el sur. Puesto en la orilla del norte se han de medir dos mil y quinientas varas ázia el Oriente, y otras tantas ázia el poniente. Puesto en la orilla del sur se han de medir dos mil quinientas varas ázia el poniente y otras tantas ázia el oriente. Estas Cavezadas se dan al sitio de ganado mayor, y en la misma forma se mide el de ganado menor, dandole a cada una la tierra que le corresponde, y lo mismo á el criadero, como queda declarado en su lugar, lo que le cabe á cada uno.

Midiendo el sitio de ganado mayor con cordel de cinquenta varas desde el centro á qualquiera de sus quatro costados, se tiran cinquenta cordeladas, y asi las demas partes; y en el todo de oriente á poniente cien cordeladas, y otras ciento de norte á sur, que hacen cinco mil varas castellanas, que es lo mismo que una legua. Y midiendo este sitio de estas dos maneras, viene á quedar quadrado con quatro esquinas iguales, y el que saliere de una de éstas quatro esquinas, y corriere todos los quatro vientos, y costados de dicho sitio habrá caminado cuatro leguas, por tener el sitio de ganado mayor segun las medidas susodichas una legua de oriente á poniente, y otra de norte á sur, y por que tres mil pasos de salomon hacen cinco mil varas, y éstas una legua.

Adviertese que el medio las caballerias de tierras ha de ser con los titulos y mercedes que Su Magestad ha hecho, por que alli hay señales tales, como Peñascos, Cerros, riscos, cañadas, lagunas, y piedras muy grandes, aunque sean llanos salitrales infructiferos, y tierra inutil, se ha de ir buscando lo mas util y de plan Para sembrar aunque sean algo pedregosas de piedra suelta, aunque sea por laderas y lomas tendidas, y no empinadas, ni 
have gone four leagues, because the sitio de ganado mayor measures, according to the dimensions given above, one league from east to west, and the same distance from north to south, and because three thousand paces of Solomon make five thousand yards, which constitute a league.

Attention is directed to the fact that measurement of caballerias of land must be in conformity with the titles and grants which his Majesty has given, for in these grants are landmarks such as rocks, hills, cliffs, canyons, lakes, and very large stones; and although the level land may be saline and unfruitful, the most useful ground level enough to be planted must be sought out, although it may be somewhat encumbered with loose stones, or on slopes and gentle hillsides, but not steep. No attention shall be paid to useless ground if small in quantity, provided such land does not exceed the eighth part of the caballeria which may have been measured; but if the bad or useless land exceeds the eighth part of the caballeria which may have been measured, it must be compensated for in another place which is contiguous and unoccupied. In this compensation attention must be given to the priority of the title or grant, for if a grant is more recent than another no injustice is done even though much land is taken from the more recent one, for in such a case the prior grant is to be preferred, and the compensations are to be made seriatim in the order of priority, and the most recent of the grantees must be content with what he may find, or with what may be left to him, although this may be rough, useless, and small in extent.

When the centre for criaderos, sitios de ganados mayores, and menores, and caballerias has been established as prescribed, there shall be measured first and with complete compensations for useless land whatever grant or title shall be found to be the earliest, even though the priority may be of only a day or an hour, after which the others shall come in their turn, and the one which is most recent of all must be content with what may be left even though the land may be of small extent and poor, for he has no other right.

From the above it is to be inferred and ordered that no person may oppose him who has the oldest grant without first showing sufficient legal reason; so also no person, although he may be the prior grantee according to his title or grant, may take possession, measure, or set up landmarks, without having previously notified the settlers who have or who represent those who have lands contiguous to his, for anyone who does to the contrary shall have his actions made of no force or effect.

It is called to attention and commanded that in the criaderos and sitios de ganado mayor and menor the measurements are to be made from east to west and from north to south; but if any other agreement is made among the settlers concerned, the land may be measured in accord with any compact or agreement which they may make. In measuring these criaderos and sitios, the settlers must leave in whatever ones they measure a cross with arms, foot, and head; the foot and the head of the cross must have the same length as the left arm, and from the extremities or ends of the arms of the cross the measurements must be equal, and the cross shall lie. within a square with four equal corners, and the arms shall radiate from the centre exactly toward the east, west, north, and south. 
tampoco se debe hacer caso, si la tierra inutil es poca, tal que no exceda la octaba parte de la caballeria de la que hubiere medido, pero si ha excedido de la octaba parte de la caballeria de la que hubiere medido lo que fuere malo é inutil se ha de enterar en otra parte que en su linde hubiere desocupado, y se ha de entender á el mas antiguo segun su titulo y merced, que si fuere menos su merced no se le hace agravio aunque le cojan mucha tierra que en éste caso ha de preferir el mas antiguo, y se le ha de enterar luego como se siguieren sus antiguedades, y el que fuere menos antiguo de todos se ha de contentar con lo que hallare, ó con lo que le dexaren aunque sea aspero inutil, y poco.

Asentado el centro de criadores y sitios de ganados mayores y menores, y caballerias como dicho es se debe medir primero, y enterar completamente de que se reconociere sea mas antiguo segun su titulo y merced aunque la antiguedad sea de un dia y de una hora, se le ha de guardar, y despues los que fueren siguiendo, y el que se hayare menos antiguo de todos se ha de contentar con el que le dexaren aunque sea poco y malo, pues no tiene otro derecho.

De lo dicho se infiere y manda que ninguna persona pueda contradecir al que fuere mas antiguo, sin mostrar primero razon de derecho suficiente, y asi mismo ninguna persona aunque sea mas antiguo segun su titulo y merced pueda tomar poseción medirse ni amohonarse sin haber citado antes á los vecinos que tubieren tierras linde de las suyas ó al que de ellos tubiere poder, por que el que lo contrario hiciere será de ningun valor ni efecto.

Se advierte y manda que en los criaderos y sitios de ganado mayor y menor se han de hechar las medidas de oriente á poniente, y de norte á sur si hubiere otro concierto entre los vecinos interesados, que habiendo pacto ó compromiso se podrá medir como se convinieren. Al medir dichos criaderos, y sitios han de dexar en qualquiera que midan formada una cruz, con los brazos pie y cabeza, por debajo del pie y cabeza de ella ha de tener la misma medida que el extremo del brazo izquierdo, y han de medir por los costados ó extremos de los brazos de la cruz medida que hubiere del un extremo de la misma al otro, y quedará la cruz dentro de un cuadro con quatro esquinas iguales, que desde el centro se ha de mirar en igualdad á oriente, poniente, norte y sur.

Adviertase que el medir criaderos y sitios de ganado mayor, y menor por legitimo pacto, y concierto, si no se midieron de norte á sur, y de oriente á poniente, se ordena y manda, que no falten á la orden de medir desde el centro donde siempre se ha de entender la medida sobre peñas, riscos, subiendo y baxando cerros, Lomas, y saltando barrancas lagunas y riscos, y si fueren breñosas se laboreen senderos y salidas fabricando entradas y pasadisos.

Habiendo medido qualesquiera suerte de tierras, y sitios de ganado mayor, y menor, criaderos, y Caballerias se manda que cada uno se mohone.

Adviertiendo que los linderos de cada suerte de tierras con entradas, y salidas, los mismos vecinos sin perjudicarse los unos á los otros han de dexar cada uno por su parte diez varas de tierra libres de cerca, y mohon para dichos pasos, y siendo necesario á ello los pueden obligar. Asi mismo 
It is to be noted that if in measuring criaderos and sitios de ganado mayor and menor under a legal pact and agreement the lines are not drawn from north to south and from east to west, it is ordained and commanded that the regulation prescribing measurement from the centre shall not be omitted, no matter whether or not the measurement has to be made over rocks, cliffs, up and down hills, crossing ravines, lakes, or cliffs; and if the lines of measurement are covered with undergrowth there shall be constructed pathways and exits, entryways and passages.

It is ordered that whenever any kind of lands and sitios de ganado. mayor and menor, criaderos and caballerías have been measured, each one of them shall be marked with landmarks.

It is to be noted that on the boundaries of every plot of land the settlers themselves are each to leave without prejudice to each other ten yards of land for entries and exits, free from enclosure or boundary-mark for said passages, and if need be they may be compelled to do this. It is also to be noted that no person may settle nor build his house on his boundaryline nor very close to it on account of the injury which this might cause to his neighbors, except in case he has the consent of the neighbor to do so. But without such consent a settler may build his house within sixty paces of the boundary but not closer, it being noted that sixty paces make one hundred yards in the Castilian measurement.

\section{Royal CÉdula. [Madrid, June I2, I695.]}

The King. To the president and the oidores of my royal Audiencia of Mexico: Representation has been made to me on the part of the farmers of that New Spain that the troubles and vexations are many which they experience and suffer on account of the suits which are constantly brought against them by the Indians, redounding not only to the depreciation of their estates but to that of mine also. To remedy this they supplicate that I be pleased to order that the privileges shall be preserved which have been conceded to them by the kings, my predecessors, and that these privileges shall be observed literally and without interpretation. They ask that they be conceded a protector for their lawsuits, and that he shall be a minister of the royal Audiencia, for the Indians, in order to deprive them of their lands for cultivation or grazing, resort to building huts of grass or of stone and mud, and, having done this, appear before the Audiencia asking that, in conformity with the ordinance issued by the Marquis of Falces, Count of Santiestévan, on May $26,1577,{ }^{13}$ they may have measured out to them five hundred yards which must intervene between the farms of the Spaniards and those of the Indians, by which method the latter intrude within the holdings of the former. Although this injury is of great seriousness, that which ensues under the cédula issued on June 4 , I687, is even greater, for by this cédula there are conceded to the Indian towns another one hundred yards in addition to the five hundred, with the command that they shall be measured in all four directions counting from the last house, so that the entire environs of the town are left free. As this regulation is so greatly to the detriment of the farmers, they ask that it shall not be observed, and that the scope of the ordinance shall be 
se advierte que ninguna persona pueda poblar ni edificar casa en su lindero ni muy cerca de él, por el perjuicio que podra causar á los vecinos, salvo si para ello hubiere licencia del vecino. Y sin dicha licencia se podra poner á edificar sesenta pasos y no mas, advirtiendo que sesenta pasos son cien varas de medir castellanas.

\section{Real Cedula. [Madrid, I2 de Junio de i695.]}

E1 Rey:-Presidente y Oydores de mi Real Audiencia de Mexico, por parte de los Labradores de esa Nueva España se me ha representado, ser muchas las vexaciones y molestias que reciben y padecen á causa de los Pleytos que continuamente les mueben los Yndios, de que reduna no solo el menoscabo de sus Haciendas si no tambien de la mia. Para cuyo remedio suplican sea servido de mandar se guarden los privilegios que les estan concedidos por los Señores Reyes mis predecesores observandolos literalmente, sin interpretacion. Que se les conceda un protector para sus causas; que éste lo sea un Ministro de la Real Audiencia respecto que para quitarles los Yndios las Haciendas de labor y ganados, se valen de fabricar jacalillos de sacate, ó de piedra y lodo, y con éste motibo ocurren á esa Audiencia para que conforme á la Ordenanza del Marqués de Falces Conde de Santiestevan de 26 de Mayo de 1577 se les midan las 500 varas que debe haber desde sus Haciendas y las de los Yndios, consiguiendo estos por éste medio entrarse en las suyas, y que aunque éste perjuicio es de tanta gravedad, aun es mayor el que resulta de la Cedula expendida en 4 de Junio de 1687 pues se les concede á los Pueblos de los Yndios otras IOO varas mas sobre las 500, mandandose les midan por todo 4 vientos, desde la ultima Casa, quedando libre el casco del Pueblo, y siendo esto tan en detrimento de los Labradores, piden no se practique, y la decision de la Ordenanza se entienda en aquellos Pueblos que estubieren poblados antes de las mercedes y fundaciones de sus Haciendas, y que las medidas se entiendan no desde la ultima Casa del Pueblo, si no desde el centro de la Yglesia que está en medio, y que esto solo sea con aquellos que fueren Cabezera donde estubiere el Santisimo Sacramento, Gobernadores, Alcaldes mayores, pues de entenderse generalmente con qualquiera Poblazon, Barrio, ó congregacion, fuera de gravisimo perjuicio, por haber muchos de estos sugetos á las cavezeras para que las dichas varas se midan á los Yndios desde la Yglesia como piden es bastante motibo, el que estos no tienen sus Casas en forma regular, por que distan unas de otras 34 varas, y algunas quasi un quarto de legua en que son damnificadas sus Haciendas, Que no le permita á los Yndios que hagan Jacales ni Ermitas en las tierras de sus labranzas, pues con éste motibo fomentando una informacion Falza lo hacen Pueblo, y se les da la medida de tierras y ellos son despojados de sus Haciendas, y otros puntos que sobre las Ventas, que los Yndios hacen de ellas, y otros bienes, cantidades que los Labradores pueden adelantar á los Yndios Jornaleros tales, y que mas executen en los Montes y Vistas que hacen los Gobernadores y Alcaldes mayores en sus Haciendas y estancias por sus fines particulares é intereses, llebando exesidisimos derechos y Salarios, sobre que habiendose visto en mi Consejo de las Yndias, con la atencion que requiere la materia, lo que vos informasteis 
understood to apply only to those towns which were settled before the grant and establishment of their farms, and that the measurements shall be understood to extend not from the last house [of the town], but from the centre of the church, which is in the centre, and that even so this regulation shall apply only to those towns which are political centres of districts, where there are located the holy sacrament, governors, and alcaldes mayores; for, if the ordinance is to be applied to every village, ward, or congregation, it would be most seriously injurious, for there are so many. of these which are subject to the head towns. It is also set forth that there is sufficient motive to command that the number of yards mentioned should be measured out to the Indians counting from the church as is asked, because the Indians do not have their houses in regular order, for they are distant one from another thirty-four yards, some of them being almost a quarter of a league apart, whereby the Spaniards' farms are limited. The latter ask that the Indians be not permitted to build huts nor hermitages in their farming lands, for after doing so they then present a false report that they have there made a town, and they are given the measure of land prescribed, and the Spanish farmers are despoiled of their farms. The petitioners also make other points concerning the ventas [fifty-yard plots] and other holdings which the Indians establish, the amounts which the farmers may advance to the Indian day-laborers, etc., and stating that they do more work in the forests and vistas than the governor and alcaldes mayores do on their estates and farms for their own particular ends and purposes while drawing high salaries and enjoying excessive privileges.

This representation having been considered in my Council of the Indies with all the attention which the matter requires, together with your report concerning the question in our letter of January $\mathrm{I} 7$ of this year, and the opinion concerning the whole matter by the fiscal, I have resolved that the cédula of which you acknowledge receipt, issued on June 4, I687, as cited, shall be observed, complied with, and enforced exactly, provided that it is understood that the distance of six hundred yards which must intervene between the lands and fields of the Indians of that jurisdiction and those of the farmers shall be counted from the centre of the towns, understanding this point to be the church, and not from the last house; and that the same interpretation shall be given with respect to the eleven hundred yards' distance which must intervene between the town and the farms, and which are to be measured from the lands apportioned to the Indians to those which are owned by the farmers, so that they shall be separated the one from the other, and the intervening distance shall be lengthened in the place deemed most appropriate and least prejudicial to both parties. And if there are no lands apportioned to the Indians, nor lands held in composition by the farmers, from which the injury can be remedied, the intervening space shall be taken from lands belonging to me, and you shall see that this is done with such equality that no ground for complaint shall be given to the Indians and that no law-suits shall be caused among them, but that all shall be treated with such equity that they shall all be inspired to content themselves within the limits which pertain to them; and you shall attend very especially to the welfare and benefit of the Indians as I 
cerca de ella en la Carta de I 7 de Enero de este año, y lo que en razon de todo dixo el Fiscal, hé resuelto se guarde cumpla y execute precisamente la cedula expedida en 4 de Junio del año pasado de I687 que va citada, y de que avisais el recibo, con que se entienda que la distancia de las 600 varas que ha de haber de por medio de las tierras, y sementeras de los Yndios de esa Jurisdiccion, á las de los Labradores se cuenten desde el centro de los Pueblos entendiendose esto desde la Yglesia de ellos, y no desde la ultima Casa, y que lo mismo se practique en quanto á la distancia de las I IOo varas que ha de haber desde el Pueblo á las estancias, y se han de contrar del propio repartimiento de los Yndios, como á las de los Labradores se les resarciran á unos y otros, alargando sus distancias por el paraje que se reconociere mas á proposito, y menos perjudicial á unas y otras partes. Y no habiendo tierras asi de Repartimiento de Yndios, como de composiciones de los Labradores, de que poder resacir el perjuicio, se haga de las que á mi me pertenecen, y vos cuidareis de que esto se haga con tanta igualdad, que no se dé motibo de quexa á los Yndios, ni que entre ellos se susciten pleitos, antes bien se use con todos de tanta equidad, que se les aliente á que cada uno se contenga en los limites que le tocan, y atendereis muy especialmente al bien y probecho de los Yndios como lo tengo mandado, de suerte, que en quanto quepa que queden beneficiados, que asi es mi voluntad y del recibo de este Despacho, y quedar en observancia lo dispuesto, me avisareis en la primera ocasion.

Fecha en Madrid á I2 de Julio de I695 años. Yo el Rey.

Por mandado del Rey Nuestro señor. Bernardino Antonio de Pardiñas, Villlar de Franco.

[Es copia, posterior al año de I695, y sin certificacion de ser Testimonio. Tiene muchos errores que aparecen manifestos, errores de copista. Por ejemplo dice "pedimiento de bienes" en lugar de "perdimiento." En el encabezado del documento dice " y luego el Licenciado Loayza de parte del señor Virey dixo y mandó, que ninguna persona haga ni pueda hacer contra contra éstas Ordenanzas so pena de perdimiento de las tierras que fuere causa y origen de romper ó quebrantar dichas ordenanzas, y demas preceptos aunque las tengan y posean, con legitimo titulo y merced que por haber hecho contra las Reales Ordenanzas son las mercedes en si ningunas y de ningun valor ni efecto por que todas se han hecho, se harán, y se han de hacer debajo de éstas ordenanzas sujetandose á ellas, y otras condiciones que pertenescan al derecho Real como consta de las mercedes hechas por Su Magestad ó en su nombre, las quales ordenanzas son asiento para toda ésta nueva España; asi lo mandaron firmaron y proveyeron en dicho dia Mes y año".] "

a Ad. F. B., Mexico, Feb. I8, I912. 
have commanded you, so that, in so far as possible, they shall be benefited, for such is my will. You will advise me at the first opportunity of the receipt of this despatch and of the observance of its dispositions.

Dated in Madrid, July I2, I695. I the King.

By command of our lord the king, Bernardo Antonio de Pardiñas, VILLAR DE FRANCO.

[This is a copy, posterior to the year I695, and without certificate that it is a transcript. It contains many errors which appear as the manifest mistakes of the copyist. For example it says "pedimiento de bienes" in place of " perdimiento".

At the head of the document it says: "And at once the licentiate Loaysa, on the part of the lord viceroy, said and commanded that no person should or might do anything in contravention of these ordinances, under penalty of loss of the lands which had been the cause or origin of the breaking or violation of said ordinances and other regulations, although such lands might be held and possessed by legitimate title and grant; for if acts are committed against the royal ordinances, the grants are in themselves nothing nor of any value nor effect, for they all have been made, will be, and are to be made, under and subject to these ordinances and other conditions which pertain to the royal rights as appear in the grants made by his Majesty or in his name. These ordinances are of force for all this New Spain; thus they commanded, signed, and prescribed on the said day, month, and year:"-Ad. F. Bandelier. Mexico, Feb. 18, 1912.] 


\section{Notes for Part I., Section 4.}

1 See this volume, p. 122, for note relating to Gonzalo López.

2 Luís Ponce de León was the judge sent to conduct the residencia of Cortés. He arrived in Mexico in July, 1526 . See Introduction, this vol., p. 8.

3 Reference is evidently to the first Audiencia of New Spain, of which Nuño de Guzmán was president. See Introduction, p. 9.

4 Reference is here made to the New Laws of 1542. See p. 27.

5 Used for covers for camp wagons and probably made of Indian cloth or grass.N. V.S.

${ }^{6}$ Reference is made to the Mixton War of 1540 [see pp. 43, 87]. Viceroy Mendoza went in person to suppress the uprising of the natives.

7 Reference is made to the Lord's intention to destroy Sodom in case a certain number of righteous should not be found there. See Genesis, xviii. 20-23.

${ }^{8}$ Apparently a miscopy for "Pérez".-C. W. H.-On back of sheet: "Opinion given by Doctor Hernán Pérez of the Council of the Indies on the matter of their perpetuity in the year I545."-F. R. B.

9 Popayán is in the southern part of modern Colombia. In 1566 it was administered by a local governor who was subject to the president and audiencia of Bogotá (Moses, op. cit., I. I08, 278.)

10 The queen, Mariana of Austria, widow of Philip IV., and regent for Charles II.

11 Don Gastón de Peralta was viceroy from I566 until 1568 ; the name and date as given above apparently are miscopies.

12 A batan is a fulling-mill where cloth is fulled, or cleaned, as from oil and grease.

13 Evidently a miscopy for 1567 ; see note II above. 


\section{THE FOUNDING OF NEW MEXICO}

I $580-1609$. 



\section{I. INTRODUCTION.}

\section{Renewed Exploration and Attempted Settlement of \\ New Mexico, I 580-I593.}

The advance of the frontier of settlement in Nueva Vizcaya and Nuevo León was followed by reports of explorers and adventurers which caused a revival of interest in the Pueblo region to the north, a region which had been practically forgotten since Coronado's expedition of I 540-I 542. The result was the renewed exploration and attempted settlement, after I 580 , of New Mexico, in the course of which new routes to that country were opened up. The first expedition to New Mexico after that of Coronado was made in I581. In that year Fray Agustín Rodríguez and Francisco Sánchez Chamuscado led an expedition composed of three friars, nine soldiers, and a number of Indian followers from Santa Bárbara, near the headwaters of the Río Conchos, to New Mexico. The route followed was down the Conchos to the Río Grande and then up that river and north to the Pueblo region. By the members of the expedition the country was explored to the east as far as the Pecos River and to the west as far as Ácoma and Zuñi, after which the soldiers of the expedition returned to Nueva Vizcaya. One of the missionaries, Father Santa Maria, was killed soon after reaching the Pueblos; the other two, Fathers Rodríguez and Francisco López, remained in one of the Tigua pueblos after the soldiers left for Nueva Vizcaya. ${ }^{1}$

Upon the return of the soldiers to Santa Bárbara, the Franciscans there, anxious concerning the safety of Fathers Rodríguez and López, promoted another expedition to New Mexico. This expedition was led by Fray Bernaldino Beltrán and Antonio de Espejo, organizer and chief of a military escort of twelve soldiers. The journey was made in the winter of I 582-I 583, the route followed being that opened up by the Rodríguez expedition of the year before. After reaching the Tigua pueblos, where the death of the missionaries was ascertained, the country was explored beyond Zuñi and Moqui to some mines in western Arizona. On the return the expedition divided. Espejo and one division, after visiting the Queres and Tanos tribes, south and southwest of modern Santa Fé, descended the Pecos River for I2O leagues and then crossed to the mouth of the Conchos River, which they ascended to San Bartolomé. Father Beltrán and the other division returned to Nueva Vizcaya by the more direct route. ${ }^{2}$

In 1590 while many persons were clamoring for the position of adelantado of New Mexico, a definite attempt to settle that country was made by Castaño de Sosa, lieutenant-governor of Nuevo León. In that year, accompanied by the entire body of settlers of Almadén, Sosa proceeded north to the junction of the Pecos and the Río Grande and thence

1 H. E. Bolton, Spanish Exploration in the Southwest, pp. I37-160.

2 Bolton, op. cit., pp. I63-I95. 
up the former stream to the Pueblo region. An exploring party visited most of the pueblos on the east side of the Río Grande from Isleta to Taos and some of the pueblos west of the river. Sosa's arrest by an agent of the viceroy, notwithstanding the now clearly proved legality of his undertaking, resulted in the expedition returning to New Spain, by way of modern El Paso, without having realized its purpose. ${ }^{3}$

Three years later an unauthorized expedition was made to New Mexico from Nueva Vizcaya by Francisco Leyva de Bonilla and Antonio Gutiérrez de Humaña. After remaining in the Pueblo region about a year the country was explored to the northeast probably as far as the Platte River. On the return most of the members of the party were killed by the Indians. ${ }^{4}$

\section{Competition for the Position of Adelantado of New Mexico, I 583 - I 595 .}

The reports made by members of the Rodríguez expedition, after their return to New Spain, greatly interested the viceroy, and by him plans were at once considered for sending out a colonizing expedition to New Mexico. In this connection advice was asked of Rodrigo del Río de Losa, lieutenant-captain-general of Nueva Galicia, who not only recommended the subjugation of the Indians of New Mexico but the exploration and occupation of the country beyond Quivira as far as the supposed strait, called Anian, in case it could be reached. This report the viceroy sent to the king, together with his own account of the Rodriguez expedition. As a result, a cédula was issued on March 29,1583 , in which the viceroy was instructed to appoint some suitable person to attempt, under existing regulations-referred to in the documents hereinafter printed as the " ordinances for new settlements", but better known as the "laws of settlement of 1573 " - and without royal expense, the reduction of the Indians of New Mexico. Before going into effect, however, it was stipulated that the viceroy's appointment must be approved by the Council of the Indies. This cédula was received by the viceroy in August, I 583, and it, together with the new enthusiasm aroused by the return of the members of the Espejo expedition and their reports of mineral possibilities and other attractions, resulted in a spirited contest for the position of adelantado of New Mexico. ${ }^{6}$

The first proponent for the right to conquer New Mexico was Cristóbal Martín, a wealthy citizen of Mexico City. In return for the title of gov-

3 Dorothy Hull, "Castaño de Sosa's Expedition to New Mexico in I590", in Old Santa $F e ́$, III. 307-332 (October, I9I6) ; "Ytinerario" of Onate's expedition, in Col. Doc. Inéd., XVI. 244-245.

4 Bolton, op. cit., pp. 201-202; Bancroft, Arizona and New Mexico (San Francisco, 1886), pp. 107-108.

5 The regulations laid down for making new discoveries are found in "Ordenanzas de Su Magestad hechas para los Nuevos Descubrimientos, Conquistas, y Pacificaciones. Julio de I573", in Col. Doc. Inéd., XVI. I42-187.

6 "Testimonio dado en Méjico sobre el Descubrimiento de Doscientas Leguas Adelante de las Minas de Santa Bárbola, gobernacion de Diego de Ibarra", etc., in Col. Doc. Inéd., XV. 97-100; Bolton, op. cit., pp. 139, I66, I99; and Bancroft, op. cit., pp. 92-94. 
ernor and captain-general for himself and family for three generations, and other exclusive rights and privileges, including that of exploring and settling one thousand leagues beyond New Mexico and of opening up ports on the North and the South seas, Martín offered to conduct at considerable expense to himself an expedition of two or three hundred men to New Mexico. Martín's plan was finally approved by the Audiencia of New Spain, to which body it was presented, but apparently was not approved by the Council of the Indies. ${ }^{7}$

Espejo, shortly after his return, petitioned the king directly for the right to conquer and settle New Mexico at his own expense, but with the proviso that it should be independent of the viceroy. He proposed to enlist four hundred soldiers, of whom one hundred were to be heads of families, and to try and find a port on the North Sea as a base of communication and supplies, similar in these respects to Vera Cruz. To reach New Mexico two routes were to be followed, one by way of the Río Grande and the other up the Pecos. ${ }^{8}$

Another applicant for the position of adelantado of the country to the north was Francisco Díaz de Vargas, alguacil mayor and regidor of the city of Puebla in Tlascala. Vargas was not primarily interested in the Pueblo region, but rather in the region lying between Quivira and the Strait of Anian, and he proposed with sixty or seventy men to pass two hundred leagues beyond New Mexico to explore, and, if desirable, to settle the country. ${ }^{\circ}$

In I 589 Juan Bautista de Lomas y Colmenares of Nueva Galicia offered, in case certain exacting demands and exclusive rights were granted, to become the conqueror of New Mexico. Among other demands was that jurisdiction over all the country beyond the Río Conchos be given to him. The viceroy approved Lomas's proposition but it failed to meet the approval of the Council of the Indies, and a new contract was made with Francisco de Urdiñola. Nothing came of this, however, because of the criminal charge being preferred against him of the murder of his wife. When the viceroy was informed of this charge he submitted the evidence to the Audiencia of Guadalajara, which ordered him to be arrested and his goods sequestered. In I 592 and again in I 595 Lomas presented his proposition but it did not meet with approval. ${ }^{10}$

7 "Asiento con Cristobal Martín por el que se Ofrece á Ir en Persona al Descubrimiento, Pacificacion, y Poblacion del Nuevo México, Baxo las Condiciones que Expone. México á 26 de Octubre de 1583", in Col. Doc. Inéd., XVI. 277-301; Bolton, op. cit., p. 199; Bancroft, op. cit., pp. 94-95.

8 "Expediente y relacion del viaje que hizo Antonio de Espejo con catorce soldados y un religioso de la órden de San Francisco, llamado Fray Agustin Rodríguez; el cual debía de entender en la predicacion de aquella gente", in Col. Doc. Inéd., XV. 15I-162; Bolton, op. cit., p. 199; Bancroft, op. cit., pp. 95-97.

9 Petition of Francisco Díaz de Vargas, in Col. Doc. Inéd., XV. 126-137; Bolton, op. cit., pp. 199-200; Bancroft, op. cit., pp. 97-98.

10 "Asiento y Capitulaciones que el Virey de la Nueva España, Marqués de Villamanrique, hizo con Joan Bautista de Lomas Colmenares, sobre el Descubrimiento y Poblacion de las Provincias del Nuevo México á 15 de Febrero de 1589 ", in Col. Doc. Inéd., XV. 54-80; Bolton, op. cit., p. 200 ; Bancroft, op. cit., pp. 99-100. 
Contest between Don Juan de Oñate and Don Pedro Ponce de León For the Governorship of New Mexico, I 595-I 598.

In 1595 , after a spirited twelve-year contest for the position of adelantado of New Mexico, the viceroy, under authority granted him by the king, ${ }^{11}$ finally let the contract in September, I 595, to Don Juan de Oñate, a member of a wealthy and prominent family of Zacatecas, in Nueva Galicia. But hardly had the contract been made before there was a change of viceroys, the terms of the contract were amended by the new viceroy, and, in less than a year, the entire contract was annulled, and a new one was made in Spain with Don Pedro Ponce de León, a rich citizen of the town of Bailén. Oñate, backed by loyal supporters, however, did not surrender his claims, and, as a result, a three-year contest ensued between him and Don Pedro Ponce de León for the right to conquer, settle, and explore New Mexico. Practically none of the sources for this contest, so far as the author's information extends, have heretofore been published or made use of by investigators, while of the secondary writers only Villagrá, ${ }^{12}$ in his famous epic poem narrating the events of the conquest, makes any authoritative mention of Don Pedro Ponce de León. Most of the documents printed hereinafter, therefore, contain altogether new information with regard to the three-year period immediately preceding the actual founding of New Mexico and cause the entire episode to be seen in a new light. Briefly the outlines are as follows:

It was on September 2I, I 595, that Oñate presented a petition to Viceroy Velasco asking for the right to explore, pacify, and conquer New Mexico. In this petition Oñate stated what would be his own personal obligations and rights should the contract be awarded to him; made a list of the provisions, materials, and supplies which he offered to take; stipulated the various contributions which the crown should make for the undertaking, such as ammunition, quicksilver for mining operations, mission paraphernalia, and even six friars; and recorded the various privileges, honors, distinctions, and hereditary rights which he and his heirs after him were to enjoy. One of these significant provisions was that Oñate and his heirs were to be under the direct control of the Council of the Indies so that none of the viceroys of New Spain and none of the adjacent audiencias could interfere in his government. Another significant provision was that if, after this contract was signed, a person should come from Spain with a similar contract signed by the king, this was not to annul his contract, but on the other hand he was to be permitted to execute it notwithstanding. Oñate promised to have everything assembled at Santa Bárbara and ready to proceed from there into New Mexico by March, I 596. The contract as thus presented to Viceroy Velasco by Oñate was accepted by the viceroy without serious modifications on the same day that it was presented. ${ }^{13}$

11 The documents granting this authority to the viceroy are mentioned in Petition to the viceroy Velasco for the journey of exploration .... and capitulations of the viceroy with Onate, Mexico, Sept. 2I, I595. This volume, p. 225.

12 Historia de la Nueva México por el Capitán Gaspar de Villagrá (Alcalá, 1610).

13 Petition to the viceroy Velasco, for the journey of exploration and capitulations of the viceroy with Oñate, Mexico, Sept. 2I, I595". This volume, p. 225. 
At the very time, however, that this contract was entered into between Viceroy Velasco and Oñate, a new viceroy, the Count of Monterey, who had arrived at Vera Cruz on September I8, was en route to Mexico City from that port, where he was to relieve Velasco, who had been named viceroy of Peru. Three weeks later, on October I4, Velasco, in a letter to the king, made a brief and what was the first announcement of the contract which he had made with Onate and the reasons for his having done so. ${ }^{14}$

As soon as the Count of Monterey arrived in Mexico City the retiring viceroy, Velasco, took up with him the proposed entrada of Oñate into New Mexico and urged him to approve it. But the new viceroy was unwilling to do this; in a letter to the king, dated December 20, I595, he stated that he had been unwilling to sanction the expedition without further deliberation on the matter..$^{15}$ The reason for this is not clear, but at the outset the Count of Monterey did nothing whatsoever to favor Oñate. In fact an official of the Council of the Indies even reported that " everything that the count has done has been to diminish and cut down the powers and dignity of Don Juan, always addressing him as 'you', with the result that many who were inclined to go did not get ready" ${ }^{16}$

When the Count of Monterey did consider the contract which his predecessor had made with Oñate, he decided, in spite of the fact that Don Juan had small means and many debts, to allow him, because of his wealthy relatives, to make the expedition, after certain provisions which he regarded as far too liberal were modified. Accordingly the contract was further modified in the following important particulars: (I) Oñate's right to raise men and to appoint officers of war was limited to this one occasion, special permit being necessary thereafter; (2) the right to name royal officials was on condition that their salaries should not exceed those of officials of Mexico; (3) independence of the viceroy in matters of war and finance, and of the Audiencia of New Spain in matters of justice, was annulled; (4) the right to bring vessels direct to his jurisdiction was on condition that special permission for so doing should first be secured from the viceroy of New Spain; (5) the Indians of New Mexico were, if possible, to be persuaded to give voluntarily the tributes, the appraisement to be fixed by royal officials instead of by Oñate and his successors; (6) account of the apportionment of the Indians was to be confirmed by the king within three years after the apportionment was made, instead of Onate and his successors having this sole right; $(7)$ certain prerogatives and privileges were to be enjoyed only by those who remained in the undertaking as long as five years. ${ }^{17}$

Having finally modified the contract the Count of Monterey instructed Onate to collect provisions and ammunition in the shortest time possible;

14 Letter from Velasco to the king, Mexico, Oct. I4, I595, this volume, pp. 255-257; letter from the Count of Monterey to the king, Mexico, Dec. 20, 1595, this volume, pp. 257-259.

15 Ibid.; the Council of the Indies to the king, Apr. 7, I596, this volume, p. 295.

${ }^{16}$ Articles of agreement of the viceroy Velasco with Juan de Onate, together with the ... . ordinances and modifications of the viceroy, the Count of Monterey, etc., this volume, pp. 265-279.

17 Ibid. 
later he issued the formal warrants, titles, and vouchers to Oñate, who then began active preparations for the undertaking. ${ }^{18}$ Lists were opened by him first in Mexico and in Puebla de los Angeles, and soldiers for the expedition were mustered there and in Nueva Galicia until the terms of the contract were more than fulfilled in this respect. ${ }^{19}$ Preparations having been completed, it was planned for the expedition to depart in June, I $596 .{ }^{20}$ It is not clear whether the expedition got under way by the above date; however, after it had started, so many lawless acts were committed by its members that finally the viceroy was forced to despatch an alcalde to preserve order and to stop the "many outrages . . . which were not so bad as rumor indicated". Still later when the expedition reached Zacatecas it was decided by Monterey and the real acuerdo to send Don Lope de Ulloa, captain of the viceregal guard, to maintain order as far as the last settlements, but more particularly, upon arrival at these settlements, to make an official inspection of the expedition and ascertain thereby whether or not Oñate had complied with the terms of his contract. Don Lope obeyed well his instructions. He assembled the people, got them under way, and led them to expect an official inspection upon reaching the last of the northern settlements. As a matter of fact later instructions to Ulloa had authorized him, in case that Onate seemed to have the means to carry out his contract, not to make the inspection, though of this both Onate and the members of the expedition were kept in ignorance. After leaving Zacatecas everything went well, and by the last of July, I596, the expedition had reached the Río de las Nazas, the largest river in modern central Durango and regarded as the most difficult one to cross on the way to New Mexico. This was approximately twenty leagues south of Santa Bárbara, "a very noted village and the best known among the last settlements ". ${ }^{21}$ Thus far had Oñate progressed in his undertaking when disquieting and disappointing reports from Spain, of which it is now necessary to relate, were received in New Spain.

Some time after the modification in Oñate's contract had been made by Monterey, as appears from an undated document in the collection, ${ }^{22}$ Don Pedro Ponce de León, a reputedly wealthy noble, of the town of Bailén, who had lived in New Spain, where he was well known and very popular, ${ }^{23}$ petitioned Philip II. for the right to conquer New Mexico. A comparative statement with regard to his petition and that which Don Juan de Oñate had previously presented to Viceroy Velasco was then prepared for the Council by one of its agents; this shows that Don Pedro Ponce de León proposed to organize a larger and a much more elaborate

18 Notification to Onate, Río de las Nazas, Nueva Vizcaya, Sept. 9, 1596. This vol., p. 351 .

${ }_{19}$ Letter from Doctor Santiago del Riego to the king, Mexico, Nov. 19, 1596. This volume, p. 369.

20 Letter from the Count of Monterey to the king, Mexico, Nov. 15, 1596. This volume, p. 377.

21 Ibid.

22 Statement of what Don Juan de Oñate and Don Pedro Ponce de León offer for the exploration, pacification, and settlement of New Mexico. This volume, pp. 281-293.

23 Council of the Indies to the king, Apr. 7, 1596. This volume, p. 293. 
and expensive expedition than did Oñate. For example: Don Juan offered to raise two hundred men, equipped with all things necessary to reach New Mexico; Don Pedro proposed to raise three hundred men, all mounted. Don Juan proposed to spend 2,500 pesos for flour, jerked beef, maize, and wheat for planting; for the same items Don Pedro promised to spend an additional 19,000 reales. Don Juan was to carry 6,400 head of live stock; Don Pedro offered to carry I3,800. For various items, such as iron for horseshoes, iron tools, paper, medicine, and gifts for the Indians, Don Juan was willing to spend 4,800 pesos; for corresponding sundries Don Pedro offered to spend over and above this amount, 40,000 reales. Twenty ox-carts were to be provided by Don Juan; Don Pedro agreed to take thirty. And thus it was with respect to other items. In almost every instance Don Pedro's proposition was much more generous than the corresponding proposition of Don Juan; in no instance did any of his propositions fall below the corresponding one of Don Juan. Moreover, Don Pedro volunteered to provide his expedition with considerable equipment not mentioned by Don Juan, while a number of concessions demanded by Don Juan were not asked for by Don Pedro. For instance, Don Pedro did not ask for the title of adelantado, and he refused to accept the privilege demanded by Oñate of dividing for himself and his successors thirty leagues of territory, saying that " he wished to merit it first by his services ". ${ }^{24}$

Despite the provision agreed to by the viceroy that Oñate's contract should be valid, even if someone else should come from Spain with authority to make the expedition, the Council of the Indies went on record as favoring the issuance of warrants to "Don Pedro . . . with a warning to the viceroy that any impediment placed in the way will be at his [the viceroy's] cost ". At the same time it was recommended that other liberal concessions be granted to Don Pedro. ${ }^{25}$

The date of this comparative statement, so carefully compiled by order of the Council of the Indies, is not given, ${ }^{26}$ but on April 7, I 596, the king was formally notified by the Council " that notwithstanding the contract which has been made there [in Mexico] with Don Juan de Oñate, since it had not been carried out, it will be possible to grant this expedition to Don Pedro Ponce de León ". Among the reasons for favoring him over Don Juan were these, namely, that Don Pedro was so well known in New Spain that he would have no difficulty in recruiting his forces, while his wealth guaranteed the expense of the undertaking. In case Don Juan should, in the meantime, have made "any preparations which merited recompense", the Council recommended that such recompense be made. ${ }^{27}$

${ }^{24}$ Statement of what Don Juan de Oñate and Don Pedro Ponce de León offer for the exploration, pacification, and settlement of New Mexico. This volume, pp. 28I-293.

25 Ibid.

${ }^{26}$ It was prepared by the licentiate Agustín Alvarez de Toledo, who was commissioned "to hear Don Pedro Ponce de León and examine into the conditions that he was able to offer, showing him what Don Juan de Oñate offered", etc. See the Council of the Indies to the king, May 19, I596. This volume, p. 303.

${ }^{27}$ Council of the Indies to the king, Apr. 7, 1596. This volume, p. 295. 
On April 23, I596, Don Pedro Ponce de León petitioned the king to consider certain changes which he wanted made in his proposed contract then in the hands of the Council. At the same time, inasmuch as he had heard from friends in New Spain that Don Juan had been able to raise but few people, most of whom were half-breeds and mulattoes, and that these had committed so many outrages that many had been arrested, Don Pedro asked that he be allowed to proceed to Mexico promptly in order to counteract the bad situation arising there.

Another significant proposed amendment was that four years later, at the conclusion of the administration of the then governor of Nueva Vizcaya, he should be named governor of that province. The desirability of having a lieutenant in Nueva Vizcaya who would be in a position readily to succor him with men, provisions, and munitions was the assigned reason for making this request. Also the king was urged to issue a new cédula to the viceroy of New Spain declaring the contract with Oñate null and void and ordering the viceroy to detain him. ${ }^{28}$ Such are but the more significant changes which Don Pedro desired made in the contract which he had presented to the king.

Apparently, however, the king was not willing to choose Don Pedro to conquer New Mexico without giving further consideration to the claims and qualifications of Don Juan de Oñate, and upon the latter the Council of the Indies was called to report. This report was made on April 25, $\mathrm{r} 596$, and in it the Council charged that it had proof that Don Juan was a bankrupt spendthrift; that he had failed to make good on a former exploring expedition; and that his financial and moral standing was such that none but desperadoes and vagabonds would enlist under him. At the same time the Council took occasion to point out the qualifications of Don Pedro, emphasizing the latter's high financial and moral standing and good sense. In view of the " notable disproportion" between the two applicants, and the expressed belief that no one was better qualified for the position of adelantado of New Mexico than Don Pedro, the Council recommended that a decision be reached in time for notice of it to be sent to New Spain by the ship that was then ready to sail. ${ }^{29}$

Action on the part of the king was not delayed long after receiving the above report. On May 8, I 596, a cédula instructed the viceroy of New Spain not to permit Oñate to make the expedition to New Mexico, even though he had already begun it. ${ }^{30}$ Eleven days later the Council, in a letter to the king, again urged haste with regard to closing the contract with Don Pedro Ponce de León. ${ }^{31}$ By September 7, 1596, the Council had had the contract submitted by Don Pedro examined by legal counsel, and had approved it with certain modifications. In the final form as approved by the Council the contract was sent to the king for his signature

${ }^{28}$ Petition of Don Pedro Ponce de León to the king, Madrid, Apr. 23, I596. This volume, p. 299.

29 Council of the Indies to the king, Apr. 25, 1596. This volume, p. 30 r.

30 Royal cédula to the viceroy of New Spain, Aceca, May 8, 1596. This volume, p. 303.

31 Council of the Indies to the king, May 19, 1596. Ibid. 
on the above date. ${ }^{32}$ Finally, on September 25, I 596, just a year and four days after Viceroy Velasco, acting under full authority from the king so to do, had made a contract with Don Juan Oñate for the exploration, pacification, and settlement of New Mexico, Philip II. at San Lorenzo, in Spain, entered into a contract for the same thing with Don Pedro Ponce de León. ${ }^{33}$

The sixty-two provisions of the contract as signed with Don Pedro differed in no essentials from those originally submitted by him for the consideration of the king and the Council. Among the more important and interesting provisions it was stipulated that Don Pedro must fulfill the contract within one year and a half to the entire satisfaction of the Count of Monterey; nevertheless he was to be independent of the latter and of the adjacent audiencias and was to deal directly with the Council of the Indies. If his explorations should extend to either or both seas he was to construct vessels there and explore the coasts. To aid the undertaking, the king exempted the members from the ordinary export duties on the supplies to be carried by them. For the first twenty years they were required to pay one-tenth of all mined and precious metals instead of the usual one-fifth to the king. For the same number of years they were to be exempt from the ordinary excise tax, while for a period of ten years household goods taken into New Mexico were to be exempt from the ordinary duties, unless they were sold after being taken there. Members of the expedition were exempt from submitting, on their departure from Spain, the usual special personal reports to the Casa de Contratación, provided that the married men were accompanied by their wives and that there were no undesirables among the members of the expedition. Permission was given Don Pedro to take from New Spain such arms, powder, and ammunition as he might choose; to import fifty negro slaves free of duty; and to leave New Mexico after six years, provided the pacification and conquest of the country was complete and a person could be left in charge of the government, pending its disposition by the king, who was satisfactory to the viceroy of New Spain. But the most interesting provision reads as follows: "I will order that you be given the necessary warrants . . . notwithstanding the state in which the fulfillment and execution of the said pacification, settlement, and exploration may be, or that it may have been commenced, for it is my royal and determined will that you and no other person whosoever shall undertake the said pacification ... or if it has been commenced by another that you shall continue and finish it." ${ }^{34}$

On October 16, three weeks after the above mentioned contract was signed, a special cédula authorized Don Pedro to give in encomienda, with certain qualifications, the Indians of the province. ${ }^{35}$ Three days after this,

32 First patent of the Council of the Indies with Don Pedro Ponce de León, Sept. 7, 1596. This volume, p. 305 .

${ }_{33}$ Contract of the king with Don Pedro Ponce de León, San Lorenzo, Sept. 25, 1596. This volume, pp. 305-32I.

${ }^{34}$ Ibid.

${ }^{35}$ Royal cédula to Don Pedro Ponce de León, ... San Lorenzo, Oct. 16, 1596. This volume, p. 323 . 
on October I9, another cédula gave him permission to name the maestro de campo, captains, and other necessary military officers, and to recruit in New Spain and Nueva Galicia three hundred soldiers, both married and single. ${ }^{36}$ The same day still another cédula was addressed to the viceroy. In it the king said that he had learned that, in violation of his order of May 8, I 596, Don Juan de Oñate had already started upon the expedition to New Mexico. "It is my will that he shall not do it, and I command you to cause him to desist from this expedition . . . stopping in whatever part he may be when he receives your order." ${ }^{37}$ One week later, on October 26, still another special cédula formally named Don Pedro Ponce de León governor and captain-general of New Mexico, and specified all his rights, privileges, and authority. ${ }^{38}$ In addition to the above no less than thirtythree other special cédulas were issued by Philip II. between the dates October 12 and $26 ;{ }^{39}$ these covered in detail every phase of the proposed expedition.

Thus it is clear that as late as the last of October, I 596, the king and the Council of the Indies reposed the greatest confidence in Don Pedro, and favorable progress was being made relative to his proposed plans. By February 7, I 597, however, all this had been reversed. From two communications from the Council to the king bearing the dates February 7 and $\mathrm{r} 8$, it appears that Don Pedro had just passed through a very critical illness, and, furthermore, being unable to raise the money necessary for the undertaking he had petitioned the king to lend him a "certain sum, which, added to the funds that he will be able to collect", would be sufficient. $^{40}$ In view of this sudden and unexpected turn in affairs the king now instructed the Council to deliver to him all the papers on the entire subject of the proposed expedition to New Mexico; ${ }^{41}$ these were sent to the king on February I8, I 597. At the same time the Council advised that recent despatches from Viceroy Monterey showed a marked change in the latter's opinion of Don Juan-so much so that he was unwilling to order him to desist from his plans before again hearing from the king. The Council also reported that the viceroy expressed grave doubts concerning the advisability of naming Don Pedro for the proposed expedition. This change in the viceroy's attitude was attributed to the machinations of an oidor of the Audiencia of New Spain, who was a brother-in-law of Don Juan. The Council further stated that Don Pedro, thanks to the efforts of his brother, was so far advanced with his preparations that he could depart within eight days, although he really would like to have a month. For all of these reasons they strenuously opposed a change from Don Pedro back to Don Juan, pointing out that this would be unjust to Don Pedro, and that the people collected by Don Juan for the expedition would really prefer to go under Don Pedro. This latter could be arranged, it was

36 Royal cédula, San Lorenzo, Oct. I9, I596. This volume, p. 323.

37 Royal cédula, San Lorenzo, Oct. 19, 1596. This volume, p. 335.

38 Royal cédula, San Lorenzo, Oct. 26, I 596. This volume, pp. 325-329.

39 Published in this volume, pp. 329-345.

${ }^{40}$ Council of the Indies to the king, Feb. 7 and Feb. 18, 1597. This volume, pp. 345, 347.

41 Royal decree. This volume, p. 345. 
pointed out, by Don Pedro reimbursing Don Juan for all of his expenses. ${ }^{42}$

The king's reply is significant and at the same time beautifully illustrates the character of Philip II. It was: "Since it is understood that Don Pedro Ponce de León is not so well prepared nor in such state of health as would be necessary for this undertaking, nor with the fortune that is required for it, it will be well to keep him waiting with good hopes, and in the meantime to write, secretly and soon, to the viceroy, telling him that if it is learned that Don Juan has the people and the necessary things in readiness for the expedition he shall proceed with it, and, if not, let information of it be sent promptly, so that, being informed of it, I can then make the decision that may seem best." ${ }_{43}$

The Council, in its reply of March 7, I 597, advised the king that since Don Pedro, who was but waiting authorization to proceed, was at great and constant expense " in entertaining people, and in bringing arms, provisions, and munitions, it would be better to undeceive him immediately . . . or at least to tell him that a decision cannot be made for a year or a year and a half, rather than to hold him with hopes of an early determination". ${ }^{44}$ The king's reply was laconic: "Let him be told that the decision cannot be made for a year." 45

On April 2, I597, the viceroy of New Spain was instructed to order Don Juan to proceed, in case the latter was ready; if this was not the case the king was to be advised immediately. ${ }^{46}$

In the meanwhile the officials of New Spain and Onate in particular had been very deeply disturbed because of the proposed change of leaders for the expedition.

It was the latter part of July, I596, when Viceroy Monterey received the king's cédula of May 8, of that year, in which he was ordered not to "permit or give opportunity to the said Don Juan de Oñate to make the entrance or to continue it if he had commenced it". At once the viceroy sent rigorous orders to Don Lope de Ulloa so to notify Oñate, as was done early in September, just as Oñate was preparing to cross the Río de las Nazas. ${ }^{47}$ By that time Oñate had spent Ioo,000 ducats in equipping his expedition, while the captains and soldiers who were to accompany him had spent an additional 200,000 ducats. It is not surprising then that when a copy of the king's cédula, together with the viceroy's order calling a halt in the expedition, were received by Oñate he was shocked. Nevertheless he showed a willingness to conform to the order and expressed confidence that the king, in view of certain reports and recommendations which he should have received from the viceroy after the cédula of May 8 had been issued, would authorize him to proceed. Should he be disappointed in this, Don Juan expressed his intention of

42 Council of the Indies to the king, Feb. 18, 1597. This volume, p. 347.

${ }^{43}$ Royal decree. This volume, p. 349.

44 Council of the Indies to the king, March 7, 1597.

${ }^{45}$ Royal decree. Ibid.

${ }^{46}$ Royal cédula, Apr. 2, I597. This volume, p. 345.

${ }^{47}$ Letter from the Count of Monterey to the king, Mexico, Nov. 15, 1596, this volume, p. 379; copy of the letter of Onate to the Count of Monterey, dated at the Río de las Nazas, Sept. 13, 1596, this volume, pp. 353-367. 
appealing in person to the king. ${ }^{43}$ Four days later, on September I3, Oñate wrote a letter to the Count of Monterey. In it he thanked the viceroy for encouraging him in his belief that the king, upon the receipt of later despatches, would alter his decision; complained bitterly of the viceroy's expressed lack of confidence in his willingness to obey the order to delay; expressed a willingness to delay the expedition and to hold together the people "with the greatest dissimulation that may be possible, as your lordship orders"; explained why the people under him had enlisted and why they would scatter in case they should learn that he had been superseded by another; expressed appreciation for the diplomatic way in which Don Lope de Ulloa had helped to prevent the expedition from breaking up; showed deep concern for the losses which his loyal followers would incur by this removal and the substitution of another leader; emphasized the great inconveniences and embarrassments which he was undergoing; pointed out the extraordinary precautions which he had taken to make the expedition a success, stating that it was at the point where " it is now without the lack of a single thing"; gave reasons why the expedition should set out at once, and why, in justice to himself, he should be the one to lead it ; explained why the viceroy was " under a thousand obligations to defend and support" him; implored the viceroy to order Don Lope de Ulloa to make a thorough inspection of everything that was being taken on the expedition in order that proof might be recorded of the exactness and liberality with which he had carried out his agreement, adding that upon this inspection depended all his " reputation, honor, and credit, and the fundamental reason for the right and justification that I have in the said expedition "; recommended that in view of the desertion of more than two hundred members of the expedition, suitable penalties be announced by the viceroy for deserters and disturbers of the peace; asked for permission and gave reasons for desiring to advance from the Río de las Nazas to the Santa Bárbara Valley, some twenty leagues further north; and, finally, gave notice that, should another supersede him, he would carry his case in person to the king, although to this legally appointed successor he would readily and cheerfully deliver all the arms, cattle, provisions, and other things which he had provided, and he would do all in his power to prevent the members of the expedition from making any disturbance as a result of the change. In conclusion Onate reiterated his belief that his upright and Christian king would see that justice was done him. ${ }^{49}$

Oñate was not without loyal friends who rallied to his support in this dark hour. One of these was Doctor Santiago del Riego, at that time administrator of the College of San Juan de Letrán, and for thirty-five years a member of colonial audiencias, including that of New Spain. On November IO, I596, he wrote a laudatory letter to the king with respect to Oñate and his plans. In this letter he submitted strong arguments in favor of Oñate being allowed to proceed, and adduced equally strong ones

48 Notification to Oñate, Río de las Nazas, Nueva Vizcaya, Sept. 9, I596. This volume, p. 353.

${ }_{49}$ Copy of the letter of Onate to the Count of Monterey, dated at the Rio de las Nazas, Sept. 13, I596. This volume, pp. 353-367. 
to show that Spain was not the logical base for organizing and equipping such an expedition, but rather New Spain. ${ }^{50}$

The contents of the king's cédula of May 8, I 596, were not made public by the viceroy, or by his lieutenant, Don Lope de Ulloa, then with Onate's expedition in the north. On the contrary the viceroy, by vague statements in public, " endeavored to counteract the rumor that was going about the city, through letters from individuals in Madrid, about the coming of Don Pedro". Ulloa did likewise at Oñate's camp " and with great skill and dissimulation he managed it in such a way that if the fleet or despatches should arrive at the accustomed time, or any time in October, what had been gathered together there would be found still in existence and intact ". ${ }^{51}$

Finally after deep consideration, and being greatly perturbed over the serious confusion with regard to the whole affair, and especially the danger that the people under Oñate might scatter or become altogether unruly, the viceroy laid the king's orders before the Audiencia and asked advice in the matter. The Audiencia recommended that later instructions from the king should be awaited, and, in the meantime, that Oñate should be encouraged to hold together his forces, without, at the same time, acting contrary to the king's orders. This suggestion was followed by the viceroy; on November I 5, I 596, he notified the king of all these matters and at the same time expressed confidence that Oñate would strictly adhere to the orders, adding, " although it has seemed to me and to the Audiencia that in a man of less integrity, fewer ties in this land, and more rashness, such an event might be feared ".

From unofficial reports received from Spain in Mexico during the early part of November, I596, the Count of Monterey was in doubt as to whether the contract with Don Pedro had been let, and, if so, as to whether he had left Spain by November ${ }^{5} .^{52}$ Under such circumstances, and realizing the possibility of such a report reaching Spain before Don Pedro could set out from there, the viceroy stated that " it is clearly objectionable to all persons of good judgment for the contract to be changed and a person sent from Spain " to take charge of the expedition. But more significant was the following: "It has occurred to me . . . that there is good reason for doubt on the decision of this case and that perhaps I would be choosing the right course if I should give permission to Don Juan to continue and carry out what has cost so much labor up to now and has been so long desired."

Unable to conclude that such was the best course, the viceroy again laid the matter before the Audiencia. By it the same objections to dismantling the expedition and to having a leader come from Spain were pointed out, but the members of the Audiencia hesitated to recommend that the viceroy

50 Letter from Doctor Santiago del Riego to the king, Mexico, Nov. 10, 1596. This volume, pp. 369-375.

${ }^{51}$ Letter from the Count of Monterey to the king, Mexico, Nov. I5, I596. This volume, pp. 377-383.

52 The king signed Don Pedro Ponce de León's contract on Sept. 25, I596. 
assume the responsibility of authorizing Oñate to proceed with his expedition. ${ }^{53}$

The above facts were contained in a letter from the viceroy to the king on November I 5, I 596. Accompanying it, and bearing the same date, was a statement containing thirteen principal reasons why, in the viceroy's opinion, Oñate and not a person sent from Spain should lead the expedition to New Mexico. The gist of each of the viceroy's thirteen points is as follows: (I) it would be unjust and injurious to Onate in view of his legal contract with the viceroy; (2) by removing Onate the king would lay himself liable to a civil suit in which he would most certainly lose, and that at great expense; (3) to change leaders would disappoint and embarrass many of Oñate's relatives and friends who had sold everything in order to go with him on the expedition; (4) a change of leaders would be followed by excesses and outrages by the rank and file of Oñate's men; (5) the latter would probably unite with or exert a baneful influence upon the recently conquered Chichimecas of the north, with the result that they would apostatize or rebel; (6) part of Oñate's force would probably proceed without authorization into New Mexico, where there was danger of their uniting with Captain Leyva de Bonilla, who had made an illegal expedition into New Mexico in I $593 ;(7)$ to change leaders would result in the northern provinces having a second time to experience all the annoyances of recruiting and transporting the members of the expedition that should be organized; (8) such a change of leaders would establish a bad precedent and thereby discourage others from volunteering: for similar work in the future; (9) should Oñate's force be broken up, great delay and greater expense would be incurred in collecting another one; (Io) it was doubtful whether one who had no relatives or personal property in New Spain could assemble a force at any cost, and certainly, if he did, it would be at no less cost than I,000,000 pesos; ( I I) advantage lay with Onate in that he had had years of experience with the Indians of New Spain; (12) a leader coming from Spain would not bring near relatives, all of whom would be great assets on such an undertaking; (I3) with such notable exceptions as that of Cortés and a few others, failure had usually attended similar undertakings, which had been organized in and started from Spain. ${ }^{54}$

The viceroy's letter of November I5, I 596, and the enclosed recommendations summarized above were received in Spain just at the very time when the confidence of the king in Don Pedro's ability to lead the expedition was shaken..$^{55}$ It is not surprising, therefore, that on April 2, I 597, the king authorized Oñate to proceed with his expedition. ${ }^{.6}$

53 Letter from the Count of Monterey to the king, Mexico, Nov. 15, I596. This volume, p. $38 \mathrm{r}$.

54 Statement of the viceroy, the Count of Monterey, Mexico, Nov. I5, I596. This volume, pp. 383-389. See also report of the fiscal, this volume, pp. 389-395. The above arguments deduced by Viceroy Monterey disprove Bancroft's (Arizona and Nere Mexico, p. II8) statement that "in the new viceroy's policy was his favor to one Pedro Ponce de León, who wished to make the conquest himself".

${ }^{55}$ It was on Feb. 7, 1597, that the king first learned of Don Pedro's insolvency. See p. 345 .

56 Royal cédula, Madrid, Apr. 2, I597. Ibid. 
In recapitulating with regard to this particular contest it is evident that the Count of Monterey was very largely responsible for the unfortunate circumstances leading to the revocation of Oñate's contract by the king and the latter's substitution for the undertaking of Don Pedro Ponce de León, and for the equally unfortunate delay which this occasioned Oñate after his contract had been signed by Velasco, modified and signed by Monterey himself, and after the expedition to New Mexico was well on its way. In the first place, from the documents at hand, it appears that Monterey was a very careful, painstaking, and methodical man-in these respects a man after Philip II.'s heart. It is not surprising, therefore, that he should have been unwilling to give the stamp of approval to Oñate's contract, even after it had been approved by his predecessor, until he might have the time to examine it carefully. The same was also true with regard to Vizcaino's contract, which Velasco also had approved, for the exploration and settlement of California. Specific evidence of Monterey's painstaking consideration of official matters, commendable as it was, but often injurious because of the unfortunate delay occasioned, is contained in a letter from a member of the Audencia of New Spain to Philip II. in I 596.57

When Monterey wrote to the king in December, I 595, and told him that he desired to investigate the Oñate and Vizcaino contracts, and, quite significantly, added "Your Majesty will be pleased to await my letters even though the parties ask for some confirmation of cédula ", it is easy to understand why it was, when this letter was received by the Council of the Indies, just at the time that Don Pedro Ponce de León was trying to secure appointment as governor of New Mexico, that that body, which from the outset favored De León over Oñate, should have written to the king as follows: "From what he writes in his letter, a copy of which is enclosed, it is clear that the Count of Monterey was not inclined to the agreement with Don Juan de Oñate." 58 It was upon the receipt of this letter that the king decided to abrogate Oñate's contract; a few days later, on May 8, instructions to that effect were given to the viceroy and in September Don Pedro Ponce de León was formally commissioned governor of New Mexico. However, if the viceroy's skepticism concerning Oñate's contract was in large measure responsible for the king's revocation of Oñate's contract, it was the viceroy's whole-hearted support of Oñate over De León and his even greater skepticism concerning the latter ${ }^{58}$ that greatly influenced the king to suspend his contract with Don Pedro and to allow Oñate to proceed. This latter fact does not bear out Oñate's later contention that Monterey was consistently opposing him.

\section{Oñate's Conquest of New Mexico, i 598-i6og.}

After being notified at the Río de las Nazas on September 9, I 596, of the king's instructions for him not to proceed with the expedition, Oñate

${ }^{57}$ Letter from Doctor Santiago del Riego to the king, Mexico, Nov. Io, 1596. This volume, p. 375 .

58 Council of the Indies to the king. Apr. 25, 1596. This volume, p. $30 \mathrm{r}$.

${ }^{59}$ See pp. 387-389. 
crossed that river and on November I reached the Minas del Caxco, situated four leagues from the Cacapa and twelve leagues from the Renteria crossings on the Río de las Nazas. There the expedition remained for nine months. On August I, I597-the king's instructions of April 2, I597, instructing Onate to proceed with his plans apparently having been received in the meantime-the expedition started north from the Minas del Caxco. Twenty-six leagues further on at San Bartolomé, calculated to be in $27^{\circ} 30^{\prime}$ north latitude, a halt was made from August i9 until December I7 in order that an official inspection might be made. At San Gerónimo, five and one-half leagues beyond San Bartolomé, a second inspection was made; as a result the expedition was detained there from December 20, 1597, until January 30, I 598. Six leagues beyond San Gerónimo, on January 30, the "Río de Conchas ... which runs from east to west, slightly inclined to the southeast", was reached at a point calculated to be in exactly $28^{\circ} 3 \mathrm{O}^{\prime}$ north latitude. There the official inspector bade goodbye to the expedition, and on February 7 Oñate resumed his march from the "Río de Conchas", ${ }^{58 a}$ proceeding, as he stated, "slowly . . taking eighty carts and wagons loaded with the necessary stores and provisions ".59b On March I 2 an eastward flowing river, called the Rio del Nombre de Dios, was reached. ${ }^{60}$ According to claims advanced by New Mexican citizens in I685, at that river, or four leagues further on at the Sacramento River, Onate laid claims to all the country beyond as the province of New Mexico. ${ }^{61}$ By March 15, I 598, the expedition was at

59a "Ytinerario" of the Oñate expedition, in Col. Doc. Inéd., XVI. 228-233. The "Río de Conchas" referred to above is not to be confused with the present Río Conchos, which flows in a northerly direction. From Oñate's bearings it is clear that he was in the immediate vicinity of the present city of Chihuahua, which, according to modern calculations, is in approximately $28^{\circ} 35^{\prime}$, or else was practically on a parallel with that city, possibly to the east of it. The fact that this "Río de Conchas" flowed slightly to the southeast would seem to identify it as the present Río Chuviscar, which flows into the present Río Conchos at a point approximately fifty miles east of the present city of Chihuahua.

59b Letter from Oñate to the king, Río de las Conchas, Mar. 15, 1598. This volume, p. 395 .

60 "Ytinerario" of the Oñate expedition, loc. cit., pp. 234-235. According to Onate's calculations this river was in $29^{\circ} 15^{\prime}$ north latitude, which would indicate that it lay approximately forty-five miles north of the present city of Chihuahua and approximately one hundred and seventy-five miles south of the ford on the Río del Norte, or modern E1 Paso. This is substantiated by the distances from this point as recorded in the "Ytinerario", and also by the latitudinal calculations taken after leaving the Río del Nombre de Dios.

61 Governor Cruzate, writing to the viceroy on May I, 1685, said that the records in the archives of New Mexico at that time showed that "el dho Rio de nombre de Dios se nombra Asi porque el adelantado D Juo de onate entrando a la Conquista Aprejendio desde alli la posesion por cui rason le puso el nombre de dios y luego al del Sacramto, que ay desde el primero a este cuatro leguas $\mathrm{Ya}$ como dentro de su Jurisdicion se puso este nombre el dho adelantado por que se selebre alli el Santo Sacram'to del matrimonio". (See Autos sobre los Socorros pide el Gov'r de la n'a Mexico y otras nott, as tocantes a la Sublevacion de los Yndios Barbaros de aquellas provi'as. Años de 1684-1685. In A. G. M., Provincias Internas, tomo 37, f. III. Transcripts in the Bolton Collection.)

A number of old settlers of New Mexico, writing to the viceroy on Aug. 26, 1685, stated that "Es tradicion muy antigua Sor Exmo que cuando el adelantado D Juo de 
a second "Río de las Conchas". There Oñate wrote a letter to the king, advising that he had made progress " despite the violent efforts of the Count of Monterey to dissuade" him from going on, and of his belief that the count had not ceased "putting stumbling-blocks" in his way.

On February I4, I 598, according to this letter, Oñate had sent Sargento Mayor Vicente de Zaldivar, with sixteen men to open a new and more direct route to the Río del Norte. This river Zaldivar reached after proceeding sixty leagues within two weeks time. On his return he reported that the road was a good one and had a sufficient number of good water-holes along it. Oñate concluded his letter with a passionate appeal for the king to confirm him in the privileges specified in the contract signed by Viceroy Velasco. ${ }^{62}$

So much for the events of the period from September 2I, I 595-the date when Oñate presented his petition to Velasco-to March I 5, I 598at which time he was well on his way to New Mexico-the narrative of which is herewith presented for the first time. The more than sixty documents published for the first time hereinafter, which detail these events and upon which this introduction thus far is almost entirely based, constitute, including as they do nine supplementary documents from the Ayer Collection, the most complete collection of sources yet printed or assembled, so far as the writer knows, for this significant period of two and one-half years. In fact the addition of the supplementary transcripts from the Ayer Collection makes the collection covering the years I 595 to I 598 , printed hereinafter, practically complete, ${ }^{63}$ so far as is known.

If the events from I 595 to I 598 have heretofore in largest measure been completely unknown, the outlines at least of the events of the journey from the Río de las Conchas, the planting of the colony, and the explorations of Oñate from I 598 until his resignation in I608, are fairly well known. For instance Bolton ${ }^{64}$ has published the translations of a number of the more pertinent documents dealing with these events. In his "Introduction" to these translations he also summarily lists and describes the principal printed sources for the entire episode after the expedition had got under way.

oñate, que Benia Entrando, a su descubrimiento, Y llego al Rio q llaman El de el sacram'to que por averse selebrado, alli el del Sto matrimonio con un Juo de carabajal le puso el dho adelantado este nombre del Sacramento $Y$ arbolando el Rl estandarte aprigendio la pocession para el nuo mexco". See Autos sobre los Socorros, loc. cit., f. I26.

62 Letter from Oñate to the king, Río de las Conchas, March I5, I598. This volume, p. 397.

63 The Bandelier Collection contains a large number of sources relating to events from I595 to 1598 . On the other hand the Ayer Collection, according to a manuscript catalogue of Spanish transcripts therein, has few sources on this period, but has a very large collection for the period beginning with I598. For this reason the sources for the first period have been made practically complete, so far as information now extends, by securing the supplementary documents from the Ayer Collection. On the other hand, because of the much larger number of sources in the Ayer Collection, no attempt was made to do more than to publish the few documents in the Bandelier Collection which relate to events after 1598 .

64 Bolton, Spanish Exploration, pp. 212-280. 
For these reasons it has not seemed pertinent to do more than to summarize very briefly the events of the Oñate episode after March I5, I 598, particularly so since after the latter date there are no documents in the Bandelier Collection of an earlier date than February 7, I6o2.

On April ig the expedition was divided and the passage of the sanddunes south of El Paso was begun by the vanguard. The next day it reached the Río del Norte at a place recorded as being in exactly $3 \mathrm{I}^{\circ}$ and $3 \mathrm{O}^{\prime}$ north latitude. ${ }^{65}$ There the entire force was reunited on April 26. On April 30, three leagues further up the river, Oñate formally took possession " of all the kingdoms and provinces of New Mexico, on the Río del Norte, in the name of our Lord King Philip ". ${ }^{66}$ Continuing from there five and one-half leagues up-stream, Oñate and his entire force on May 4 crossed the Río del Norte at a ford, which, according to the calculations taken at the time, must have been in $32^{\circ}$, instead of in $31^{\circ}$ north latitude, as is apparently inadvertently recorded in the "Ytinerario". This ford, since known as "el paso del Río del Norte", is, according to modern calculation, in $3 \mathrm{I}^{\circ} 47^{\prime}$ north latitude. ${ }^{6 z}$

While at the ford forty Indians voluntarily came to the Spanish camp. Their first words were manxo, manxo, micos, micos, which the Spaniards interpreted as "gentle " and "friends". ${ }^{68}$ Accordingly the term Mansos came to be applied to the Indians in the vicinity of "el paso", which from that time on served as the main gateway between New Mexico and New Spain proper.

On May I2, Oñate's expedition having advanced eight or nine leagues above "el paso," Captain Aguilar was sent ahead to explore the way. He returned on May 20, by which time the main party had encamped at a place six leagues further north. ${ }^{69}$ From there two days later Onate with sixty men went ahead to pacify the natives, seize any traitors, as Humaña and his followers, and reconnoitre the country. ${ }^{70}$ At the Queres pueblo of Santo Domingo, Oñate, on July 7, received the submission of seven chiefs representing in all thirty-four pueblos. Four days later the Tewa pueblo of Caypa, situated on the east side of the Río del Norte, opposite the junction of the Río Chama, was christened San Juan de los Caballeros. With the establishment of the governor's headquarters there San Juan became the first capital of New Mexico. On August I8 the rear-guard, which had been met and escorted up the river by Captain Vicente de Zaldivar, arrived at San Juan. Oñate had already explored as far north as Taos and to the east and west as far as Pecos and Jémez respectively. Work had also been begun at San Juan on an irrigating ditch for the proposed city of San Francisco, and between August 23 and September 8, a church was constructed and its completion celebrated.

65 "Ytinerario," in Col. Doc. Inéd., XVI. 240.

${ }^{66}$ Ibid., XVI. 242.

67 Report of the Chief of the United States Weather Bureau, I9I4-I9I5, p. 96.

68 "I'tinerario," in Col. Doc. Inéd, XVI. 243.

69 Ibid., XVI. 245-247.

70 Oñate to the viceroy, March 2, 1599 (English translation), in Bolton, Spanish Exploration in the Southwest, p. 213. The fate of the Humaña party was not known at that time. 
On September 9 representatives from all over the province formally submitted to the Spaniards, ${ }^{71}$ and soon afterwards the various pueblos were assigned to the Franciscan missionaries who had accompanied the expedition. $^{72}$

Oñate's contract, among other things, called for exploration. Accordingly, after the colony had been established and the pueblos assigned to the missionaries, preparations were made for fulfilling this requirement. First Vicente de Zaldivar was sent from San Juan on September I 5 with sixty men, a large number of horses, and supplies to hunt buffalo. $\mathrm{He}$ returned to San Juan on November 8 after having gone seventy leagues northeast from San Juan. ${ }^{73}$

On October 6 Oñate with over one hundred men started southeast from San Juan. After travelling thirty-five or forty leagues, visiting en route the salines and the Jumano pueblos, Oñate turned west with the intention of going to the sea. Ácoma, Zuñi, and the Moqui pueblos in northeastern Arizona, were visited in succession. From one of the latter pueblos Captain Marcos Farfán with eight men was sent on November 7 to hunt for some rich mines reported to be further west. The next day Oñate and the rest of the party set out for Zuñi to await reinforcements from San Juan, under Don Juan de Zaldivar, before going on to the South Sea. From Moqui Farfán went to Bill Williams Fork over the route previously taken by Espejo. He brought back flattering reports of rich mines thirty leagues distant from Moqui.

As the reinforcements under Zaldivar did not arrive Oñate resolved to return to San Juan from Zuñi before attempting to reach the sea. On December $\mathrm{I}_{3}$, while on the way home, news was received that Zaldivar and fourteen of his men had been killed in a revolt at Acoma. Seven days later Oñate's force reached San Juan and in January, I 599, Vicente de Zaldivar was sent to punish the Acomans. Many of the natives were either killed or sold into slavery and their pueblo was laid waste and burned. ${ }^{74}$

The same year Zaldivar was sent to reach the sea, but he was forced to turn back at a place reported to be only three days journey from his goal. Upon Zaldívar's return Oñate made preparations to go to the sea himself and to build boats thereon. By April, r6or, all arrangements had been made for the undertaking but because of reports concerning the country to the east the plans were abandoned and instead it was decided to make an expedition to Quivira. The new capital, San Gabriel, located on the west

71 Bolton, op. cit., p. 203; translation of Oñate's letter of March 2, I599, ibid., pp. 199222; reprint of original manuscript map, ibid., p. 212; Bancroft, Arizona and New Mexico, pp. I28-1 34 .

72 For the names of these missionaries and the pueblos to which they were assigned, see Hodge, annotations, in Benavides, Memorial (Ayer translation), pp. 196-200.

${ }^{73}$ Bolton, op. cit., pp. 203-204; translation of the official account of the discovery of the buffalo in 1599 , ibid., pp. 223-232.

74 Ibid., p. 204; translation of the official account of the journey to the salines, the Jumano, etc., and of the official account of the discovery of the mines, 233-249. 
side of the Río del Norte south of the junction of the Río Chama, ${ }^{75}$ was the point of departure for the expedition. With Oñate went seventy soldiers, two missionaries, and a number of servants. The route was by way of Galisteo, the Canadian River, and overland to Quivira at the site of the present Wichita, Kansas. Because of Indian hostilities the party soon returned, after having been gone from San Gabriel from June 23 to November 24, I601.

When Onate returned to New Mexico from his Quivira expedition in I602, he found that most of the settlers and missionaries had deserted and gone back to Santa Bárbara where they gave evidence of their displeasure with Onate by filing fifty-seven different charges against him. This is explained by the fact that the colonists disapproved of Onate's explorations because they preferred that he should devote all his energies and activities to the internal development and organization of the country. At once Zaldivar was sent by Oñate to arrest the deserter colonists and send them to New Mexico, as was done. After this Zaldivar was sent to Spain to appeal in person to the king for reinforcements for Oñate. ${ }^{78}$

In Spain Zaldivar asked for permission to recruit as many as sixty musketeers and professional ship-builders to be used for discovering a port on either the North or the South sea and for constructing vessels thereon. On June I2, I602, permission was given him to recruit forty such men and to conduct them to New Spain at royal expense not to exceed I,500 ducats. Permission was also given him to engage at Oñate's expense two expert pilots "for the mapping of the routes to be traversed in that expedition ". Finally, Zaldivar was authorized to take with him seventy harquebuses; thirty muskets; one hundred coats of mail; one hundred cuishes; fifty steel helmets; one hundred swords and daggers; and fifty leather jackets. ${ }^{77}$

About the same time three very significant royal cédulas were issued with reference to Oñate. The first of these, issued on February 7, I602, formally conferred upon Oñate, and upon his son after his death, the title of governor; at the same time the various privileges, honors, prerogatives, and immunities supplementary to the governorship were listed. ${ }^{8}$ In a second cédula, issued on July 4, 1602, Oñate was given authority, after the Indians of New Mexico had submitted, to levy tributes upon them, "provided that they do not exceed ten reales a year for each tributary

75 Bolton, op. cit., p. 203; reprint of original manuscript map, p. 212; translation of the official account of the expedition to the east, p. 251.

76 Ibid., p. 206.

77 The Council of the Indies to the president of the Casa de Contratación, Valladolid, June 12, 1602. This volume, p. 403. See also royal cédula to the president of the Casa de Contratación, Burgos, June 23, I603. This volume pp. 407-409. See also Royal cédula to the viceroy of New Spain, Valencia, Jan. 21, 1604. This volume, pp. 409-4II. See also Royal cédula to the officials of the Casa de Contratación, Valladolid, Sept. 8, 1603. This volume, p. 409.

78 Title of adelantado of the provinces of New Mexico for Don Juan de Oñate, Villalpando, Feb. 7, I602. This volume, pp. 397-399. 
who has to pay them " ${ }^{79}$ In connection with the third cédula it will be remembered that according to the contract which Velasco had made with Oñate, the latter was to deal directly with the Council of the Indies, while the viceroy and the adjacent audiencias were to have no control over him. This provision, it will be recalled, was modified by Monterey, so that Onate lost his independence of the viceroy in war and finance and of the Audiencia in judicial matters. On July 8, I602, however, Philip III. directed a cédula to the viceroy of New Spain advising him that the terms of the contract as originally drawn up should hold good in the above respects, proviso being made that in matters of government and justice appeals could be made to the Audiencia of Nueva Galicia, "which is the nearest to the said province " ${ }^{80}$ These important facts have not heretofore been presented; they, together with the granting of additional men to be sent to New Spain at royal expense, show the marked interest of Philip III. in the New Mexico enterprise and help to explain why, in the face of later disappointments and disturbances, that monarch obstinately refused to assent to the abandonment of the province.

Before the end of the year I602 Philip III. received the complaints filed against Oñate by the deserter colonists at Santa Bárbara. In view of these complaints the king instructed the Count of Monterey first to inform himself secretly as to whether Oñate and some of his associates had committed "lawless acts and crimes . . . in the year I602", and then to send a "person to make an investigation and administer punishment; if Don Juan de Oñate should be found to be so guilty and affairs in such a condition that it was not desirable that he should remain there, the expedition should be put in a state of safety so that what had been discovered might be preserved and the conversion of the Indians continued ". ${ }^{81}$ No record is available of any definite action relative to this matter that was taken by the Count of Monterey, who was soon promoted to be viceroy of Peru. However, on May 26, I603, the new viceroy, the Marquis of Montesclaros, was instructed to ascertain from the retiring Count of Monterey the result of the ordered investigation concerning the offenses of Oñate, and, in the light of such facts as might thus be obtained, to take such measures as might be deemed wise, "favoring and greatly encouraging the said Don Juan in case he was to continue it ". ${ }^{82}$

In Spain Zaldivar, to whom permission had been given in 1602 to recruit forty musketeers and ship-builders for Oñate, had been unable to recruit these professionals by May 19, I603. On that date Don Alonso de Oñate, brother of Don Juan, who seems to have superseded Zaldívar in this work, asked that, without prejudicing any of the terms of Zaldivar's contract, more time should be given him in which to recruit the requisite number of men. ${ }^{83}$ The king granted his request, and even

79 Royal cédula to the viceroy of New Spain, San Lorenzo, July 4, I602. This volume, p. 403.

80 Royal decree, San Lorenzo, July 8, I602. This volume, p. 405.

81 Royal cédula to the Marquis of Montesclaros, Madrid, June I7, I606. This volume, p. 4I3.

82 Ibid. This volume, p. 4 I5.

${ }^{83}$ Council of the Indies to the King, Valladolid, May I9, I603. This volume, pp. 405-407. 
authorized Alonso de Oñate to charter a special vessel on which to transport them to New Spain. ${ }^{84}$ Later he gave permission for the married men on the expedition to carry their wives and children along with them. ${ }^{85}$ But because merchandise was not allowed to be carried on especially chartered vessels, Alonso de Oñate was unable to find a ship-owner who was willing to transport the recruits unless he himself paid for their provisioning, and this, because of the cost involved, he was unable to do. As an accommodation to Oñate, therefore, the master of the ship which Oñate was authorized in July, I604, to charter was given permission to carry forty or fifty tons of merchandise to help pay the expenses of the voyage. ${ }^{86}$ In all these ways did the crown and the Council of the Indies aid the undertaking of Oñate, despite the fact that the viceroy had not then reported upon the investigation ordered relative to Oñate's conduct.

At the same time, in New Mexico, Oñate, in order that it might be used to support his petition for reinforcements, had been particularly anxious to make some strikingly significant discovery; finally on October 7, 1604, he left his capital with the intention of going to the South Sea. In this he did not succeed, but on January 25, I605, a fine port at the head of the Gulf of California was discovered and possession taken for the king. News of the discovery and the recorded belief that California was an island was sent to the viceroy by Oñate upon his return to New Mexico. In the meantime the viceroy, on March 3I, I605, had recommended to the king that Onate's acts be investigated and the country's resources inspected by an official of the Audiencia, and that a presidio be established in New Mexico. Before waiting for the king's reply, the viceroy, as a temporary measure of relief, sent two missionaries and twenty-four soldiers as reinforcements to the province. After Oñate's report relative to his western discoveries had been received, the recommendation that a presidio be established in New Mexico was repeated by the viceroy on October 28, I605, and at the same time the construction of vessels to follow up by sea both Oñate's and Vizcaino's discoveries ${ }^{87}$ was urged.

During the next three years the fate of New Mexico was uncertain. On March 3I, I605, the Marquis of Montesclaros, with the advice of the fiscal and three members of the Audiencia who were thought to be least prejudiced in the matter, made a secret report to the king upon the findings of Monterey's and subsequent investigations into the alleged offenses and misconduct of Onate. The report itself is not available, but it appears that in it were set forth the behavior of Oñate and the poor results which attended his efforts in New Mexico. This report was made the basis for the king's ordering the viceroy, on June I7, I606, " to cause the said discovery to cease and go no further", and "with tact and discretion, to

84 Royal cédula to the viceroy of New Spain. Valencia, Jan. 2I, I604. This volume, pp. 409-4II.

85 Instructions of the Council, Valladolid, Feb. 23, I604. This volume, p. 4II.

${ }^{86}$ Decree of the Council, Valladolid, July I9, I604. This volume, pp. 4II-4I3.

${ }^{87}$ In I602-I603 Vizcaino had explored the west coast as far north as Cape Mendocino. Bolton, Spanish Exploration in the Southwest, pp. 52-103. 
cause the said Don Juan de Oñate to be recalled for some sufficient reason, as seems best to you, so that he may come without disturbance". Upon Oñate's arrival in Mexico City he was to be detained and a "satisfactory governor, discreet and Christian", was to be named for the explored region of New Mexico. ${ }^{88}$

The next year, on August 24, I607, apparently before the viceroy could take action and apparently for the purpose of bluffing that official into sending reinforcements, Oñate sent his resignation as governor to the viceroy and with it the information that the settlers would abandon the province in case reinforcements did not arrive by June 30, I608. Oñate's resignation was accepted and Juan Martínez de Montoya, of San Gabriel, was commissioned governor ad interim on February 27, I608. Oñate, however, was instructed to remain in New Mexico until r609. At the same time supplies were sent to the settlers. On March 7, I608, the viceroy recommended to the king that New Mexico be abandoned, but the king in reply on June I 7 ordered that New Mexico be preserved, pending further consideration. On September I3, the matter was left to the discretion of the viceroy. The crisis, however, had been passed and on December I7, after encouraging reports had been received from New Mexico, the viceroy expressed the hope of reaching the province by way of the South Sea and asked for further instructions. In the meantime in New Mexico, Montoya had been rejected as governor by the cabildo at San Gabriel, and Cristóbal de Oñate, son of Juan de Oñate, had been elected governor by that body. Upon the receipt of this news a junta in Mexico City on January 29, I609, voted to send twelve soldiers and a new governor to New Mexico and to allow Juan de Oñate to return to New Spain. By March 5, I609, Don Pedro de Peralta had been named governor, and on March 30 formal instructions were issued to him. These called for the founding of a new and permanent villa and the plac:ng of the province on a firmer footing economically. The new villa and capital established by Peralta was Santa Fé, though the exact date of its founding is as yet uncertain. On September 9, I609, the Council of the Indies approved the viceroy's action in preserving New Mexico and ordered that new discoveries be promoted there. Thus New Mexico was saved and its future guaranteed. ${ }^{89}$

Of interest and value for supplementary details relating to the Oñate episode are a series of declarations and sworn statements made in Mexico between I6I2 and I6I 4 and submitted as proofs of the merits and services of three members of the Oñate expedition-Captain Don Luís de Velasco; Don Fernando de Oñate, nephew of the governor; and Captain Juan Velarde Colodro. These statements and depositions constitute the last

88 Royal cédula to the Marquis of Montesclaros, Madrid, June 17, I606. This volume, pp. 4I3-4I5.

${ }^{80}$ The above paragraph is based entirely upon a manuscript article by Professor Herbert E. Bolton, entitled "The Last Years of Onate's Rule and the Founding of Santa Fé". This article, written largely from primary sources, throws light on the hitherto practically blank period in the history of New Mexico. 
four expedientes in this volume. Of marked interest is the manifest of goods carried by Captain Don Luís de Velasco; ${ }^{80}$ likewise the depositions of Don Juan de Oñate, ${ }^{01}$ made on August I7, I6I2, and of Vicente de Zaldivar, ${ }^{92}$ made on September 6, г6 г2.

${ }^{90}$ See this volume, pp. 429-433. Professor Bolton made use of this document in his descriptive summary of Velasco's wardrobe as published in his Spanish Borderlands, pp. I7I-172.

81 See this volume, pp. 467-469.

92 See this volume, pp. $477-481$. 
II. 2. DOCUMENTS RELATING TO THE FOUNDING OF NEW MEXICO. 
Al audiencia de la nueba españa sobre que proceda conforme a Justicia contra gaspar castaño y los demas culpados por haver hecho una entrada en la nueba mexico y dado algunos yndios por esclavos sin tener orden ni licencia para ello y que a los dichos yndios que entendiere ser esclavos les haga dar livertad y no permitan que ningunos lo sean. Corregida. ${ }^{a}$ [Madríd a 17 de Enero de I593.]

El Rey. Presidente y oydores de mi Audiencia Real que Reside en la ciudad de mexico de la nueba españa yo e sido ynformado que gaspar castaño Teniente que fue del capitan luis de carvajal governador del nuebo Reyno de leon entro en el nuebo mexico con una conpañia que Junto por su propia autoridad y sin tener horden ni licencia para ello y que haviendo venido a noticia de Vos el Virrey y de que aquella gente havia hecho muchas deshordenes y excesos y dado algunos yndios Por esclavos enviastes en su seguimiento al capitan Juan morlete el qual entro en la dicha nueba mexico y trajo presos al dicho capitan gaspar castaño y sus conpañeros y Porque es Justo se castigue semejante desacato y atrivimiento os mando que conozcays de la causa del dicho gaspar castaño y demas culpados y proçedays contra ellos conforme a Justicia y no dareys lugar ni permitereys que sean esclavos yndios algunos y a los que entendieredes que lo son les dareys livertad con pregones publicos que se den en esa ciudad y la de guadalajara de la nueba galicia fecha en madrid a diez y siete de henero de mill y quinientos y noventa y tres años Yo EL REY Por mandado del Rey nuestro señor JUAN BAZQUEZ y señalada del consejo.

Carta de don Diego [Luís] de Velasco a Su Magestad. ${ }^{b}$ [Mexico, 30 de Enero de I595.]

En el primer navio de aviso que se despacho a ese reyno en 6 de novienbre pasado escrevi a Vuestra Magestad lo que se ofrecia y despues en otro despacho que hize por la havana en 22 del mismo con las nuevas que ubo de las Philipinas cuyos duplicados seran con esta y por que fuera de lo que toca a las dichas yslas que escrivio a Vuestra Magestad en carta particular no se of rece cosa que pida larga relacion no la hare.

En la tierra ay paz y salud a dios gracias y abundancia de maiz que es el sustento de los naturales trigo se cogio poco porque se elo quasi la tercia parte de lo senbrado por mediado noviembre y asi por esto como por

a A. G. I., 87-5-I.

b A. G. I., 58-3-I2. Copy of transcript in Ayer Collection; copy compared by Miss Clara A. Smith. 
To the Audiencia of New Spain, ordering it to proceed judicially against Gaspar Castaño and other guilty persons for having made an expedition into New Mexico and for having taken certain Indians for slaves without order or license to do so; also ordering that the Indians who may be found to be slaves shall be given their liberty and that no others shall be permitted to be enslaved. Corrected. [Madrid, January I7, I593.]

The King. To the president and oidores of my royal Audiencia which resides in the City of Mexico in New Spain: I have been informed that Gaspar Castaño, former lieutenant of Captain Luís de Carbajal, governor of the New Kingdom of León, entered New Mexico with a company which he collected upon his own authority without order or license to do so. ${ }^{1} \quad$ This having come to the attention of yourself, the viceroy, and you learning that those men had committed many disorders and abuses and had taken certain Indians as slaves, you sent in pursuit of them Captain Juan Morlete, who entered New Mexico and took prisoners Captain Gaspar Castaño and his companions. Since it is just that such a bold and dishonorable act should be punished, I command you to take cognizance of the case of Gaspar Castaño and the others who are guilty, and proceed against them judicially. You will give no opportunity nor will you permit any Indians to be made slaves, and any whom you may learn to be in that condition you will set at liberty through public notice by the town crier in that city and in Guadalajara, Nueva Galicia. Dated at Madrid, January I7, I593. I the KInG. By command of the king, our lord. JUAN VÁsQUez. Signed by the Council.

\section{Letter from Don Diego [Luís] de Velasco to his Majesty. [Mexico, January 30, I595.]}

By the first despatch-boat which sailed for that kingdom on the sixth of last November I wrote to your Majesty all that had happened; afterwards, in another despatch to Havana on the twenty-second of the same month, I sent the news from the Philippines, duplicates of which will be with this, And since, outside of what concerns the said islands, of which I am writing to your Majesty in a special letter, there is nothing that calls for a longer statement, I shall not make it.

In the land there is peace and health, thanks to God, and an abundance of corn, which is the sustenance of the natives. Of wheat little was gathered, for almost a third part of the crop was frozen in the middle of November, and for this reason, as well as because of the great exportation of biscuit and flour to Havana, the price is higher than it has been for many years, but as there is plenty of corn no scarcity is felt. 
la mucha saca que ay de vizcochos y harinas para la havana vale mas caro que a valido muchos años a pero con el mucho maiz no se siente la caristia. ${ }^{c}$

En la havana ubo falta de bastimentos por mediado noviembre y llego a valer una pipa de harina mas de cient ducados y un quintal de vizcocho mas de treynta pero a los postreros del mismo mes comencaron a entrar navios con la provision que de aqui se les despacho en tanta abundancia que bararon "a moderados precios y sienpre se tiene cuydado de proveerlos $\mathrm{y}$ de que los que tomaron asiento con los generales sobre los vastimentos para la armada y flotas cunplan a sus plazos como lo van haziendo.

Para poner en execuxion el arbitrio de las tierras y el de los estrangeros e dado comission y orden al doctor antonio maldonado oydor desta real audiencia por ser honbre de buen seso y discrecion en qualquier genero de negocios y lo va disponiendo para que se comience a yntroducir y se procurara hazer con la blandura y suavidad que mas convenga conforme a lo que Vuestra Magestad cerca desto me tiene ordenado.

Escripto he a Vuestra Magestad en carta particular de 26 de octubre pasado como teniendo capitulada y para concluir la pacificacion del nuevo mexico con el capitan francisco de Urdiñola se me avia dado noticia de ciertos delictos graves que se dezia aver cometido de que di quenta a la real audiencia de guadalajara para que me avisase de lo que cerca desto supiese la qual por ser de su districto le mando prender y secrestar los bienes y queriendole llevar preso le mandaron detener los ynquisidores diciendo ser familiar con que ay entre los dos tribunales conpetencia de jurisdiction que sera causa de que el negocio vaya mas a la larga y la jornada del nuevo mexico este suspensa porque como e dicho en la misma carta no hallo honbre en este reyno a quien se pueda encargar que la haga como conviene al servicio de dios y de Vuestra Magestad y bien de aquellos naturales Porque lo que principalmente se a de pretender de la persona a quien se encargare es que meta tanta prenda que esta le obligue a proseguilla hasta acavalla que si esto falta en no dando en la riqueza de minas de oro y plata que es lo que con mas cuydado van a buscar luego desisten y se buelven a sus casas desamparando la tierra y conversion de los yndios y dexando muchas criaturas baptizadas que como no ay despues quien las catequize se quedan en su gentilidad que es gran ynconviniente y salen haziendo agravios y vexaciones y aun matandolos por que les den lo que no tienen con que los irritan y ofenden y hazen odioso y aborrecible el nonbre de christianos come ya se a visto en otros descubrimientos y assi en este negocio procurando el mejor medio que se ofreciere y esperando en dios que lo dara como quien sabe y puede darlo quando fuere servido.

En carta de 6 de abril de 94 capitulo 3 he dado quenta a Vuestra Magestad de la ynportancia que son para la conservacion de la republica los repartimientos de los yndios que acuden al servicio personal con que se benefician las minas y sementeras y se hazen las obras publicas de yglesias monesterios y de los pueblos de españoles y de los mismos yndios con que este reyno se conserva y se va aumentando y tanbien referi las dificultades que en esta materia se ofrecian por la contradicion que algunos reli-

- Evidently a miscopy for "carestia".

dEvidently a miscopy for "barataron". 
In Havana there was a failure of provisions by the middle of November; a barrel of flour came to be worth more than a hundred ducats, and a quintal of biscuit more than thirty. But in the latter part of the same month ships began to arrive with provisions despatched from here in great abundance which were sold to them at moderate prices. Care is always taken to provide them and to see that those who make contracts with the commanders for the provisions for the fleet and ships fulfill their agreements, as they in fact do.

In order to put into execution the tax on the lands and on foreigners I have given a commission and order to Doctor Antonio Maldonado, oidor of this royal Audiencia-a man of good sense and discretion in any sort of business - and he is arranging to begin its introduction and will endeavor to do it with the mildness and suavity required, in conformity with what your Majesty has ordered me in regard to this.

I wrote to your Majesty in a special letter of the twenty-sixth of last October that, having contracted for the completion of the pacification of New Mexico with Captain Francisco de Urdiñola, information was given me of certain serious crimes which he was said to have committed. I gave account of this to the royal Audiencia of Guadalajara, so that it might inform me of what it knew about this, and it, being in his district, ordered him to be arrested and his goods sequestered. But when an attempt was macle to arrest him the inquisitors ordered it to be stopped, saying that he was one of their attachés. There is thus a conflict of jurisdiction between the two tribunals which will cause the business to be delayed and the expedition to New Mexico to be suspended, for, as I have said in the same letter, I do not find a man in this kingdom who may be charged with doing it as is required for the service of God and your Majesty and the good of those natives. What is especially required of the person who is charged with it is that he shall take it up with such earnestness that he will be compelled to pursue it to the end, so that the undertaking may not be a failure in case he does not encounter riches in mines of gold and silver, which is what they most earnestly seek; [failing to find them] they immediately desist and return to their homes, abandoning the land and the conversion of the Indians and leaving many children baptized, who, as there is afterwards no one to instruct them, remain in their heathenism, all of which is very objectionable. And when they come out they commit outrages and assaults upon [the Indians] and even kill them in order to make them give what they do not have, in which way they irritate and offend them and make odious and hateful the name of Christians, as has been the experience in other explorations. Therefore I am endeavoring to find in this business the best means that may offer, trusting in God that $\mathrm{He}$ will give it, as the One who knows how and can give it when $\mathrm{He}$ may be pleased to do so.

In a letter of April 6, I 594, paragraph 3, I gave account to your Majesty of the importance, for the conservation of the commonwealth, of the partition of the Indians who aid in the personal service by which the mines are worked, the crops planted, and the public works of churches, monasteries, and the pueblos of the Spaniards and the Indians themselves are constructed, and by which this kingdom is preserved and increased. 
giosos de letras hazian a estos repartimientos teniendolos por peligrosos para la consciencia y muy perjudiciales para los yndios y embie asi mismo los pareceres de las religiones para que vistos Vuestra Magestad se sirviese de proveer lo que en esta parte se a de guardar a Vuestra Magestad humillmente suplico se sirva de mandar se tome resolucion con toda brevedad en este caso para que yo pueda conforme a lo que se me ordenare acudir sin escrupulo a las necessidades de la republica que son cada dia mas urgentes en especial las de los mineros de que diversas vezes he dado particular quenta a Vuestra Magestad.

En otra de 3 de julio de 94 escrevi a Vuestra Magestad como para aconmodar las cosas desta real caxa y que en ella ubiese el buen recaudo y expediente en los negocios que convenia puse por thesorero a gordian cosasano en el ynterin que venia joan de aranda proprietario deste officio para que como oficial viejo y tan experto como lo es en este genero de papeles encaminase a carlos de yvarguen y a pedro de los rrios a quien nonbre por factor en lugar de don francisco de valverde que esta en panama que por ser los dos nuevos y poco cursados en la administracion de esta real hazienda avian menester quien los guiase joan de aranda vino en la flota que esta en el puerto y fue recevido al uso de su officio y por quedar descargado del Gordian cosasano le provey por contador general de las alcavalas assi porque quando se yntroduxeron en este reino fue el primero que las entablo y administro con mucha aprovacion hasta quel arcobispo de Mexico le saco dellas y le proveyo por contador de la Real hazienda en lugar de Melchior de legaspi a quien suspendio por los cargos de su visita como por que a muchos años que sirve a vuestra Magestad en officios y papeles de su hazienda real en que tiene gran curso y mucha fidelidad limpieça y asistencia y otras buenas partes con que haze ventaja a muchos y mereze que Vuestra Magestad le tenga en su servicio y haga merced demas que desde este puesto en que esta acude a alumbrar a los officiales de la real hazienda que por ser nuevos como e dicho tienen necessidad de ser advertidos en algunas cosas este officio an tratado de conprar algunas personas y por ser de mucha ynportancia y que rrequiere gran fidelidad y satisfacion en la que lo an de exercer y destas ay pocas no e abierto puerta a ello ni me parece que conviene venderse no mandando Vuestra Magestad otra cosa.

La nao Maestre Thomas gallardo de la flota general luis Alfonso flores se perdio en la costa de Guacaqualco salvose la gente della pero muy poca hazienda y ningun azogue de lo que traya de Vuestra Magestad que heran. ... [ Hay un claro] quintales aunque los officiales de la vera cruz enbiaron buzanos y otros onbres a procurarlo dizese y el general me lo a escripto que esta nao fue mal perdida porque no corrio tiempo forçose quando venia en demanda del puerto y que si quisieran el maestre y piloto lo pudieran tomar y que deseava prenderlos y castigarlos pero tanbien se saldran con ello como otros que han perdido otras naos con tan poca ocassion como esta cerca desto pasa un grande abuso de que se an seguido los daños y perdidas de gentes y haziendas que se an visto en esta tierra y es que por traer algunos maestres sobre las naos tanto dinero a daño que no bastan los fletes para pagarlo toman por remedio perderlas para quedar libres y sin deuda y aunque Vuestra Magestad tiene proveydo que no 
And I also related the difficulties which were being experienced in this matter because of the opposition which certain learned religious were making to these partitions, they holding them to be dangerous for one's conscience and very prejudicial to the Indians. At the same time I sent the opinions of the religious, so that, after considering them, your Majesty might be pleased to order what is to be observed in this matter. I humbly beg that your Majesty will be pleased to come to a decision with all brevity in this case, so that I may, in accordance with what may be ordered me, provide without hesitation for the necessities of the commonwealth, which are every day more urgent, especially those of the miners, of which on divers occasions I have given special account to your Majesty.

In another letter of July 3, I 594, I wrote to your Majesty that in order to put the affairs of this royal treasury in a proper state, and in order that there should be used in it such caution and expedition in its business as were necessary, I appointed as treasurer ad interim Gordián Cosasano until Juan de Aranda, the holder of this office, should arrive, so that, as an old official and very expert-as he is in this kind of papers-he might direct Carlos de Yvarguen and Pedro de los Ríos (whom I named as factor in place of Don Francisco de Valverde, who is in Panamá); for, since they are both new and little experienced in the administration of the real hacienda, it was better that there should be some one to guide them. Juan de Aranda came on the vessel which is in port and was initiated into the exercise of his office. And since Gordián Cosasano was removed from it I named him contador general of the excises, partly because when they were introduced into this kingdom he was the first one to set them up, and he administered them with great success until the Archbishop of Mexico removed him and appointed him contador of the real hacienda in place of Melchior de Legaspi (whom he suspended because of charges of his visitor), and partly because for many years he has served your Majesty in offices and duties of your real hacienda, in which he has much experience and has shown great fidelity, honesty, industry, and other good qualities with which he brings benefit to many, and merits that your Majesty shall retain him in your service and, in addition, grant him permission to go from this place where he is and enlighten the officials of the real hacienda, who, through being new, as I have said, need to be instructed in some things. Some persons have tried to buy this office, but, as it is of great importance and requires great fidelity and ability in the one who has to exercise it, and of these there are few, I have not opened the door to it, nor does it seem to me that it is proper to sell it unless your Majesty should order otherwise.

The ship, Thomas Gallardo master, of the fleet, Luís Alfonso Flores commander, was lost on the coast of Coatzacoalcos. ${ }^{2}$ The people on it were saved, but very few goods and none of your Majesty's quicksilver which it was bringing, might be ... [There is a blank.] quintals, although it is said that the officials of Vera Cruz sent divers and other men to try to save it. The commander [Flores] has written to me that this ship was dishonestly lost-for the weather was not stormy when it was searching for the port and if the master and pilot had wished to do so they could have made it-and that he wished to arrest and punish them, but that 
puedan tomar sobre la nao mas de hasta cierta quantidad no se guarda ni executa por muchos fraudes y cautelas de que usan negocio es este de mucha consideracion y que pide remedio y serlo y a que Vuestra Magestad mandase apretar esto del tomar dinero sobre las naos con otras advertencias que podran hazer el presidente y officiales de la contratacion de sevilla.

Del azoque que se quemo en el puerto de san joan de ulua como a Vuestra Magestad le e avisado se an sacado hasta ... [ Hay un claro.] quintales y todavia se va sacando aunque con alguna costa que sobre ello se haze.

Las cedulas que Vuestra Magestad me mando embiar en 27 de octubre pasado recevi a 27 deste y por el poco tienpo que a avido no se an puesto en platica procurare que se pongan y dello dare aviso a Vuestra Magestad en la flota Dios guarde la catolica persona de Vuestra Magestad en mexico 30 de enero I 595.

Don LUIS DE VELASCO.

[En el dorso hay un decreto que dice:] Vista en 20 de septiembre I 595.- - del Virrey don luys de velasco 30 de enero. a ${ }^{e}$ la otra y si faltare algo que no este probeydo se saquen los puntos para probeerlo. [Rubricado.]

Petición al virrey Don Luís de Velasco para la jornada de descubrimiento ... y capitulaciones del virrey con Don Juan de Oñate. Mexico, 2 I de Septiembre de I595.

En la Ciudad de Mexico á veinte y un dia del mes de Setiembre de mil y quinientos y noventa y cinco años ante su Señoria del Virrey Don Luis de Velasco se leyó esta peticion, y habiendo visto lo pedido y ofrecido en ella por Don Juan de Oñate dixo, que en conformidad de la Real Cedula á su Señoria dirigida su fecha en San Lorenzo á diez y nueve de Julio del año pasado de ochenta y nueve, y el Capitulo de carta de diez y siete de Enero de noventa y tres, y otro Capitulo de otra carta ultima de veinte y uno de Junio de noventa y cinco, cuyos traslados se pongan con estos recaudos, acetava y acetó el ofrecimiento de la persona del dicho Don Juan

- Evidently a miscopy for "y".

'A. G. I., Patronato Real, I-I-3/22-I2. Copy of transcript in Ayer Collection; copy compared by Miss Clara A. Smith. 
they would get out of it the same as have others who have lost other ships with as little occasion as this. In respect to this there is a great abuse going on from which have resulted the injuries and losses of people and property that have been witnessed in this land, and it is because some of the masters carry on the ships so much money in bond that the freight is not sufficient to pay it, and they adopt the plan of losing them in order to remain free of debt. Although your Majesty has ordered that they shall not take on the ship more than a certain sum, it is not observed nor carried out, because of many frauds and tricks of which they make use. This is a matter for much consideration and calls for a remedy, which would be accomplished if your Majesty would order this carrying of money on the ships to be stopped, together with other measures that could be taken by the president and officials of the [Casa de] Contratación of Seville.

Of the quicksilver that was burned at the port of San Juan de Ulua, as I have informed your Majesty, there have been taken out as many as ... [There is a blank.] quintals, and it is still being taken out, although with some expense that is caused by it.

The cédulas which your Majesty ordered to be sent to me on the twentyseventh of last October I received on the twenty-seventh of this month, and as there has been so little time since then they have not been put in practice. I will endeavor so to put them and will inform your Majesty of it by the fleet. May God keep the Catholic person of your Majesty. Mexico, January 30, I 595 .

\section{Don Luís de Velasco.}

[On the back there is a decree which says:] Examined on September 20, I 595 : that of the viceroy Don Luís de Velasco of the thirtieth of January, and the enclosure. If there is anything lacking that is not provided for let the points be drawn up so that it may be provided. [With a rubric.]

Petition to the viceroy, Don Luis de Velasco, for the journey of exploration .... and capitulations of the viceroy with Don Juan de Oñate. Mexico, September 2I, I595.

In the City of Mexico, on the twenty-first day of the month of Septenber, I 595, before his Lordship, the viceroy, Don Luís de Velasco, this petition was read. And, after he had examined what was asked for and presented in it by Don Juan de Oñate, he said that in conformity with the royal cédula directed to his lordship and dated at San Lorenzo on the nineteenth of July of the past year of I 589 , and the paragraph in a letter of January I7, I 593, and another paragraph in another and last letter of June 2I, I595-copies of which are to be placed with these memorandahe had accepted and did accept the offer of the person of the said Don Juan de Oñate, and he had chosen him and did choose him for the exploration, pacification, and conquest of the provinces of New Mexico. And responding in detail to the articles proposed by the said Don Juan, he 
de Oñate, y la elegia y eligió para el descubrimiento, pacificacion y conquista de las Provincias del Nuevo Mexico, y respondiendo en particular á los Capitulos propuestos por el dicho Don Juan proveyó lo contenido en el margen de cada uno. Don Luis de Velasco ante me Martin Lopez de Gauna.

Ilustrisimo Senor: Don Juan de Oñate vecino de la Ciudad de Nuestra Señora de las Zacatecas del Nuevo Reino de Galicia digo: que habiendo yo ofrecido á Vuestra Señoria Ilustrisima mi persona para servir á su Magestad y á Vuestra Señoria en su Real nombre en la pacificacion del nuevo Mexico, y las ocasiones que se han of recido, continuando en esto lo que hecho demas de veinte años á esta parte en la guerra y pacificacion de los Indios é Chichimecas y Guachillies y otras Naciones en los Reinos de la Nueva Galicia y Vizcaya á mi costa y mincion imitando á mi padre Cristobal de Oñate, que usando el cargo y oficio de Capitan General en el dicho Reino de la Galicia, conquistó, pacificó y pobló la mayor parte del dicho Reino á su costa, en que gastó grandisima suma de hacienda como á Vuestra Señoria le consta y es publico y notorio, siguiendo los pasos de sus antepasados, que siempre se ocuparon como Cavalleros hijos dalgo en servicio de la Corona Real de Castilla, Vuestra Señoria fué servido hacerme merced aceptando mi of recimiento, mandarme que entrase en la dicha Provincia en seguimiento del Capitan Francisco de Leyva Bonillo y consortes para que fuesen presos y recibiesen el castigo que su exceso merecia por haber entrado contrabando y orden de Vuestra Señoria y particular prohivicion de su Magestad demas de los grandes inconvenientes que habran resultado y resultaran en inquietud y mal tratamiento de los Naturales, que con esta no será adelante tan facil su conversion y pacificacion, y por que el principal intento que se debe tener y su Magestad muestra, y no menos Vuestra Señoria en su Real nombre es esta conversion, y lo uno es muy junto á lo otro, y de una vez se podrá conseguir el castigo de los dichos delincuentes y servicio de Dios y del Rey nuestro Señor en la dicha conversion y pacificacion de nuevo ofrezco á Vuestra Señoria mi persona para que ansi mismo Vuestra Señoria se sirva de ocuparla en el dicho descubrimiento, pacificacion y conversion de las dichas Provincias del Nuevo Mexico.

A Vuestra Señoria Ilustrisima suplico me haga merced de aceptar el dicho ofrecimiento y para el dicho efecto elegir mi persona y para lo que á esto toca ofrezco lo siguiente.

Primeramente me ofrezco á llevar duzientos hombres y para arriba aderezados de todo lo necesario y bastimentos necesarios para llegar á las Poblaciones hasta haber llegado á ellas todo á mi costa y de los dichos Soldados sin que su Magestad sea obligado á dar sueldo mas del que yo de mi voluntad les diere de mi hacienda.

Iten un mill y quinientos pesos de Harina y Maiz.

Iten quinientos pesos de trigo para sembrar.

Iten quinientos pesos de carne de tasajos.

Iten un mill Cabezas de ganado mayor.

Iten tres mill Obejas.

Iten mill Carneros.

Iten mill Cabras. 
ordered that which is stated on the margin of each one. Don Luís de Velasco. Before me Martín López de Gauna.

Most Illustrious Sir: I, Don Juan de Oñate, resident of the city of Nuestra Señora de las Zacatecas, of the new kingdom of Galicia, declare: That, having offered to your most illustrious lordship my person to serve his Majesty and your lordship in his royal name in the pacification of New Mexico and the occasions that have offered, continuing in this what I have done for more than twenty years up to now in the war with and the pacification of the Chichimecas and Guachichiles Indians and other nations in the kingdoms of Nueva Galicia and Vizcaya at my own cost and expense, imitating my father, Cristóbal de Oñate, ${ }^{3}$ who, while exercising the duty and office of captain-general in the said kingdom of Galicia, conquered, pacified, and settled the major part of the said kingdom at his expense. In this he spent a very large sum of money, as is known to your lordship and is public and notorious, following in the footsteps of his ancestors, who always employed themselves like noble knights in the service of the royal crown of Castile. And your lordship having been pleased to do me the favor of accepting my offer, and to order me to enter the said province in pursuit of Captain Francisco de Leyva Bonilla ${ }^{4}$ and his companions, so that they might be arrested and receive the punishment which their offense merited in having entered unlaw fully and contrary to the order of your lordship and the special prohibition of his Majesty-not to mention the great difficulties that would result and will result from the disturbance and ill treatment of the natives, for cause of which their conversion and pacification will not be so easy in the future; and because the principal purpose that should be held and which his Majesty exhibits, and no less your lordship in his royal name, is this conversion, and the one is closely joined to the other; and because it would be possible to procure the punishment of the said delinquents and at the same time the service of God and the king, our lord, in the said conversion and pacification, I again offer to your lordship my person so that your lordship may thus be pleased to employ it in the said exploration, pacification, and conversion of the said provinces of New Mexico.

I beg that your most illustrious lordship will do me the favor to accept the said offer and to choose my person for the said purpose; and for what concerns it I present the following:

First, I offer to take two hundred men and over, equipped with everything necessary and supplies sufficient to reach the settlements and until after I have reached them-all at my expense and that of the said soldiers, without his Majesty being obliged to pay them any salary besides what I will voluntarily give them from my funds.

Item: I 500 pesos worth of flour and corn.

Item: 500 pesos worth of wheat for sowing.

Item: 500 pesos worth of jerked beef.

Item: Iooo head of cattle.

Item: 3000 sheep for wool.

Item: Iooo sheep for mutton.

Item: 1000 goats. 
Iten cien Cabezas de ganado prieto.

Iten ciento y cincuenta Potros.

Iten ciento y cincuenta hieguas.

Iten dos pares de fuelles con su recaudo de herrerias.

Iten cuatro pares de fuelles para si hubiere Minas.

Iten dos mill pesos de herrage con su clavo, los quinientos pesos dellos de clavo de masiado.

Iten quinientos pesos de calcado.

Iten quinientos pesos de Medicinas.

Iten seiscientos pesos de hierro labrado que son rejas barretas picos cuña y azadones almadanas Zuelas hachas barrenas escoplos sierras y hoces.

Iten seiscientos pesos de hierro por labrar.

Iten quinientos pesos de cosas para rescatar y regalar Indios.

Iten ducientos pesos de papel.

Iten quinientos pesos de jerga y de sayal.

Iten veinte carretas aviadas de Bueyes con todo lo necesario.

Todas las cuales cosas me ofrezco á llevar fuera del matalotaje y sustento de los dichos Soldados el que fuere menester hasta llegar á las poblazones á lo cual no se ha de llegar [gastar?] por el camino sino á estrema necesidad y si de lo susodicho conviniere convertir algunos generos en otros mas necessarios siendo en la misma cantidad de dinero lo pueda hacer y se ha visto cumplir con esta memoria.

Iten me ofrezco á llevar para el adorno de mi persona las cosas siguientes.

Veinte y cinco Cavallos.

Veinte y cinco Mulas aparejadas.

Dos Carrozas con sus Mulas.

Dos Carros herrados con sus Mulas.

Seis sillas estradiotas.

Seis sillas ginetas.

Seis adargas.

Seis lanzas.

Doce Partesanas.

Seis Cotas.

Seis escarcelas.

Seis celadas con sus sobrevistas.

Seis pares de Armas de Caballos.

Seis Arcabuces.

Seis Espadas y Dagas.

Dos Coseletes enteros.

Dos Sillas de Armas.

Seis cueros de Antes. 
Item: Ioo head of black cattle.

Item : I 50 colts.

Item: I 50 mares.

Item: two pairs of bellows with their equipment of irons.

Item: four pairs of bellows in case there should be mines.

Item: 2000 pesos worth of iron for horseshoes with their nails, 500 pesos of it to be in extra nails.

Item: 500 pesos worth of footgear [calcado].

Item: 500 pesos worth of medicines.

Item: 600 pesos of iron tools, such as plowshares, crow-bars, picks, wedges, hoes, hammers, zuelas, axes, augers, chisels, saws, and sickles.

Item: 600 pesos worth of iron for making into tools.

Item: 500 pesos worth of things for trading and making gifts to the Indians.

Item: 200 pesos worth of paper.

Item: 500 pesos worth of frieze and sackcloth.

Item: Twenty carts provided with oxen and everything necessary.

All of these things I offer to take in addition to the stores and food for the said soldiers which will be required until they reach the settlements; they are not to be used along the road except in the most extreme necessity. If it should be advisable to change some articles for others more necessary, in case it comes to the same amount of money, it can be done, and this note suffices for it.

Item: I offer to take as my personal equipment the following things:

Twenty-five horses.

Twenty-five mules with their equipment.

Two coaches with their mules.

Two iron-tired [herrados] carts with their mules.

Six light cavalry saddles.

Six troopers' saddles.

Six leather shields.

Six lances.

Twelve halberds.

Six coats of mail.

Six cuishes.

Six helmets with beavers.

Six sets of horse armor.

Six harquebuses.

Six swords and daggers.

Two complete corselets.

Two stands of arms.

Six buckskin jackets. 
Que se le acepta lo que ofrece y constando por testimonio de escrito que lo llevava se ha visto haber cumplido $y$ ha de estar presto por todo henero de 96 años.

Que se le darian cinco Sacerdotes y un Lego, cuatro campanas y lo demas necesario para ellos conforme á lo que han pedido y se contiene en el Capitulo 26 de la hordenanzas de nuevas poblazones y descubrimientos.

Que se le daria la polvora y $\mathrm{mu-}$ nicion que pareciere necesaria por esta vez y tres piezas de campaña que á de tener por su Magestad como lo son treinta quintales de polvora y ciento de plomo.

Que se le daran una docena de Cotas obligandose á pagar el costo á su Magestad, y Arcabuces no los hay de presente.

Que se le daran diez quintales de Azogue con la obligacion que of-
Todo lo cual tendré en el Pueblo de Santa Barbara que es el ultimo de lo conquistado lo mas presto que me sea posible procurando sea para fin del mes de Marzo de noventa y seis.

Demas de todo lo cual me ha de dar Vuestra Señoria para la dicha jornada á costa de su Magestad lo siguiente.

Seis Frailes con todo el bastimento necesario para ellos y sus mozos para toda la jornada, y sus vestuarios, hornamentos y recaudo para celebrar y administrar los Sacramentos, libros y lo demas que para este efecto pareciere ser necesario; y asi mismo seis companas del tamaño corriente, y algunas trompetas ó instrumentos de musica de Iglesia como su Magestad lo manda en el Capitulo veinte y seis de sus hordenanzas, y hordenando como entre el Obispo que por mas cercania caé el dicho descubrimiento y los tales Religiosos no aya contencion ni diferencia para que no sea estorbo á la conversion y pacificacion de los Naturales.

Iten se me ha de dar la polvora y monicion que fuere necesaria para esta jornada teniendo atencion á la mucha gente que ha de ir y mucha distancia de leguas que hay para poder ser socorrido faltando, y seis piezas de Artilleria.

Iten se me han de dar dos docenas de Cotas otros tantos Arcabuces de la Armeria de su Magestad, que estos han de ir fuera de lo que cada uno llevare para la defensa de su persona.

Iten diez ó doce quintales de Azogue, de las Cajas de los Zacte- 
Let his offer be accepted if it appears by certified written proof that he is taking it [the above]. It is seen that he has fulfilled it, but he must be entirely ready by January, I 596 .

Let him be given five priests and one lay-brother, four bells, and all else necessary for them, in conformity with what they have petitioned and is contained in article 26 of the ordinances of new settlements and discoveries.

Let him be given the powder and ammunition that seem to him to be necessary for this occasion; three fieldpieces, which he should have through his Majesty, as they are his; thirty quintals of powder; and one hundred quintals of lead.

Let him be given one dozen coats of mail under obligation to pay the expense to his Majesty. Of harquebuses there are none at present.

Let him be given ten quintals of quicksilver under the obligation
All of which I will have at the pueblo of Santa Bárbara, which is the last in the conquered territory, as soon as I possibly can, and will try to make it by the end of the month of March, 1596.

Besides all this your lordship will have to give me for the said expedition, at his Majesty's expense, the following: Six friars, with all the supplies necessary for them and their servants for the entire journey, and their vestments, ornaments, and means for celebrating and administering the sacramentsbooks and the like that for this purpose may seem to be necessary; and at the same time six bells of the usual size and some trumpets or church musical instruments, as his Majesty orders in article 26 of his ordinances; and [your lordship] should order that between the bishop to whom, as being the nearest, the discovery falls, and the said religious, there shall be no contention or dispute, so that there shall be no disturbance in the conversion and pacification of the natives.

Item: In view of the large number of men who are to go and the many leagues between them and assistance if it were lacking, I must be given the powder and ammunition that may be necessary for this expedition and six pieces of artillery.

Item: I must be given two dozen coats of mail and as many harquebuses from the armory of his Majesty; these must be in addition to what each one will take for the defense of his person.

Item: Ten or twelve quintals of quicksilver from the treasuries of 
rece, y facultad para tomar los Carros de los que tienen por oficio carretear, no haciendoles vejacion pagandoles justamente sus fletes.

Que se le daria instruccion asi para la prision de los culpados que han entrado al Nuevo Mexico contra orden de su Magestad, como para la pacificacion y conquista de aquellas Provincias y conservacion de las Naturales dellas. cas para ensayes, con obligacion de volverlos o pagarlos, y para llevar todo lo susodicho y el hato de toda la gente que fuere conmigo á la dicha jornada se me ha de dar facultad para embargar los Carros y Carretas que fueren necesarios pagando su valor fletes y Carretages y salarios que fuere justo.

Primeramente me obligo que en todo lo á mi posible el dicho descubrimiento y poblazon se hará con toda paz, amistad y Cristiandad, y el gobierno de la gente de mi cargo la tendré en la mayor Cristiandad y trato que pudiere para que en todo sea nuestro Señor y su Magestad servidos, y que Vuestra Señoria me ha de mandar dar la instruccion ó instrucciones que le pareciere convenir y que mas en servicio de Dios nuestro Señor y de su Magestad bien y pacificacion de aquella tierra, conversion de los Naturales della y predicacion del Santo Evangelio y Doctrina Cristiana, y el modo que se ha de tener en la pacificacion, conviniere, y en caso que por bien de paz no quisieren al verdadero conocimiento de la fé Cristiana y á oir la palabra Evangelica y dar la obediencia al Rey nuestro Señor, lo que se ha de hacer con ellos, para que en todo se proceda conforme á Ley Evangelica y lo que la Iglesia Catolica y hordenanzas de su Magestad enseña y manda en estos casos, y lo que debe convenir para que se puedan llevar Cristianamente los tributos que se les hicieren de imponer para la Corona Real y para los que entendiesen en la dicha conquista. 
which he offers; likewise the power to take the carts of those who practise the trade of carters, committing no injustice upon them but paying them their charges justly.

Let him be given instruction not only for the arrest of the guilty persons who have entered New Mexico, contrary to the orders of his Majesty, but also for the pacification and conquest of those provinces and the conservation of the natives of them.
Zacatecas for assays, under the obligation to return them or pay for them. And, in order to carry the above and the baggage of all the men who may go with me on the said expedition, permission must be given me to requisition the carts and wagons that may be necessary, paying for their value and the freights and cartages and salaries that which is right.

First I obligate myself that in every way possible to me the said exploration and settlement shall be made in all peace, friendship, and Christianity, and that I will conduct the government of the people in my charge with the greatest Christianity and kindness that I can, so that in all our Lord and his Majesty may be served. And your lordship must order that I be given instruction as to what seems to you to be best and most in the service of God, our Lord, and of his Majesty, the good and pacification of that land, the conversion of the natives of it, the preaching of the Holy Gospel and Christian doctrine, and the method which it will be best to use in the pacification, and, for the sake of peace, in case they do not wish for the true knowledge of the Christian faith or to hear the evangelical word and give obedience to the king, our lord, what must be done with them, so that all may be done in accordance with the evangelical law and what the Catholic Church and the ordinances teach and order in these cases. And [your lordship should order also] what arrangement must be made so that the tributes that will be imposed upon them for the royal crown and for those who may take part in the said conquest may be collected in a Christian manner. 
Que se le darian los Indios que parecieren ser de aquella provincia y la India que pide si fuere viva.
Que cumpla la hordenanza de su Magestad que está dada en las hordenanzas de las nuevas poblazones que son desde el Capitulo 23 hasta el 56 inclusivo.

Que se le concede todo lo que por los Capitulos de las dichas hordenanzas de nuevas poblaciones su Magestad concede á los que hacen semejantes jornadas sin eceptar cosa alguna cumpliendo el de su parte con lo que tuviere obligacion conforme á ellas, para cuyo efeto se le entreguen, y se escribirá á su Magestad le haga merced y gratifique sus meritos y servicios.
Yten se me han de dar los Indios que pareciere haber en esta Ciudad de Mexico de Nacion Tataragueyes que son los mas Comarcanos á esta Provincia y en especial una India que se trajo del Nuevo Mexico para que puedan servir de interpretes en la jornada.

Llegado á las Provincias y poblazones primeras del Nuevo Mexico y repoblando con gente Española segun y como conviniere y el tiempo y dispusicion de la tierra mostrase.

Lo que Vuestra Señoria siendo servido me ha de conceder y mandar guardar en nombre de su $\mathrm{Ma}$ gestad es lo siguiente.

$I^{\circ}$ Primeramente en virtud de la permision que Vuestra Señoria tiene de su Magestad para el efeto deste descubrimiento pacificacion y poblazon, me ha de hacer merced de dar provision para ello, inserta en ella la Real Cedula y comision y capitulos de cartas que Vuestra Señoria tiene de su Magestad con titulo de Gobernador y Capitan General de las dichas Provincias del Nuevo descubrimiento, con las fuerzas y firmezas para su validacion por las dos vidas que concede la hordenanza cincuenta y seis encargandose Vuestra Señoria de Suplicar á su Magestad conceda desde luego otras dos para que sean cuatro atento la mucha costa y trabajo de la dicha Jornada para que como tal Gobernador y Capitan General pueda egercer y egerza en nombre de su Magestad toda la jurisdicion Civil y Criminal alta y baja mero misto imperio y despues de mis dias las dichas vidas como yo lo nombrare ó como lo conceda la dicha hordenanza. 
Let him be given the Indians who seem to be of that province and the Indian woman for whom he asks if she be living.

Let the ordinance of his Majesty which is given in the ordinances for new settlements, articles 23 to 56 inclusive, ${ }^{7}$ be carried out.

Let him be granted all that which his Majesty concedes by the articles of the said ordinances for new settlements to those who make such expeditions without excepting anything whatever, on condition that he fulfills on his part the obligation that he may have in accordance with them; for which purpose let them [the ordinances] be delivered to him, and let it be written to his Majesty that he should show him favor and reward his merits and services.
Item: They must give me the Indians that are to be found in this City of Mexico of the nation Tataragueyes, ${ }^{6}$ for they are the nearest to that province, and in particular an Indian woman who was brought from New Mexico, so that they may serve as interpreters on the expedition.

When the provinces and first settlements of New Mexico are reached they are to be resettled with Spanish people as may seem best, and as the climate and nature of the land may demonstrate.

That which your lordship, if you please, should grant to me and order to be observed in the name of his Majesty is the following:

I. First, in virtue of the permission which your lordship has from his Majesty for the purpose of this exploration, pacification, and settlement, you should do me the favor of issuing a writ for it, inserted in that of the royal cédula and commission and paragraphs of letters which your lordship has from his Majesty, with the title of governor and captain-general of the said provinces of the new discovery, with the strength and security for its validation for the two lives granted by ordinance $56 .{ }^{8}$

And your lordship should take it upon yourself to supplicate his Majesty to immediately grant two other [lives], making them four in view of the great expense and labor of the said expedition, so that, as such governor and captain-general, I may exercise in the name of his Majesty every jurisdiction, civil and criminal, upper and lower, mero mixto ${ }^{\circ}$ power, and after my days, the said lives as I may appoint and as is granted by the said ordinance. 
Concedesele lo contenido en el Capitulo precedente como en el está dicho.

Que se le daran de la Caja Real de Zacatecas seis mil pesos prestados dando fianzas devolverlos para fin de Henero de 96 años.

Que se le concede en conformidad del Capitulo 58 de las hordenanzas, y se escrivirá á su Magestad para que le haga merced y gratifique sus servicios como está dicho en el primer Capitulo desta Capitulacion. $2^{\circ}$ Yten que luego que tome posesion de la dicha tierra en nombre de su Magestad he de tener titulo de Adelantado, de que yo y mis subsesores hemos de gozar en las dichas vidas del Gobierno comforme á la dicha hordenanza guardandose las preeminencias que gozan los tales Adelantados, que dando asi mismo á cargo de Vuestra Señoria el suplicar á su Magestad alargue otras dos vidas como se contiene en el Capitulo antes de este.

$3^{\circ}$ Yten Vuestra Señoria ha de ser servido de que para que yo pueda mejor y con mas brevedad cumplir lo que tengo obligacion y acudir á los excesivos gastos de la dicha jornada se me ha de hacer merced de prestar de la Real Caja de las Zacatecas veinte mil pesos, obligandome y dando fianzas de pagarlos en seis años, pues el negocio es de tan gran importancia para el servicio de su Magestad y yo tengo de gastar tanta suma de pesos de oro en ello.

$4^{\circ}$ Yten que á los Soldados conquistadores y pobladores que fueren á la dicha jornada debajo de mi vandera ó de los dichos mis subsesores pueda repartir los dichos Pueblos y Vasallos que me pareciere, y que esto se entienda con los que fueren segundos y terceros conquistadores y pobladores y los demas que ayudaren á la conquista y pacificacion de aquella tierra y han de gozar de esta encomienda ellos y sus subsesores en las tres vidas que concede la hordenanza cincuenta y ocho, que dando ansi mismo á cargo de su Señoria el suplicar á su Magestad se los dé perpetuos ó por lo menos por otras tres vidas mas. 
Let him be granted what is contained in the preceding article as is stated in it.

Let him be given from the royal treasury of Zacatecas a loan of six thousand pesos, on condition that he gives security to return them by the end of January, I 596.

Let it be granted in conformity with article 58 of the ordinances, and let his Majesty be written to so that he will show him favor and reward his services, as is stated in the first article of this agreement.
2. Item: That as soon as I take possession of the said land in the name of his Majesty I am to have the title of adelantado, which I and my successors are to enjoy for the said lives of the governorship, in accordance with the said ordinance, and I am to have the privileges that such governors enjoy. At the same time it is to be charged to your lordship to supplicate his Majesty to add two more lives, as is contained in the article before this.

3. Item: Your lordship should be pleased, in order that I may the better and more quickly fulfill my obligation and meet the great expenses of the said expedition, to do me the favor of lending me from the royal treasury of Zacatecas twenty thousand pesos, requiring me to give security to repay them in six years, for the business is of very great importance for the service of his Majesty and I have to spend a large amount of money on it.

4. Item: That I shall have the power to divide among the soldiers, conquerors, and settlers who may go on the said expedition under my banner, or under that of my said successors, the said pueblos and vassals as may seem right to me, and that this shall be extended to those who may be the second and third conquerors and settlers, and to others who may aid in the conquest and pacification of that land, and that they and their successors shall enjoy this encomienda during the three lives granted by ordinance 58 . And also it shall be charged to his lordship to supplicate his Majesty to give them in perpetuity, or at least for three lives more. 
Que se le concede conforme al Capitulo 85 de las dichas hordenanzas de nuevas poblaciones.

Que se le concede lo que dispone el Capitulo 99 de las dichas hordenanzas.

Que atento que el nombramiento de los dichos oficiales ya que su egercicio es precisamente necesario para el efecto de esta jornada y sin ellos no se podrá hacer se le concede y dá facultad para que los nombre, y se le advierte que dija personas en quien concurran las calidades que se requiero para estos oficios.

Lo proveido en el Capitulo primero desta Capitulacion. $5^{\circ}$ Yten que á los dichos conquistadores y pobladores y á sus hijos y descendientes se les ha de hacer todo favor y honra, dandoles Solares, tierras de pasto y labor y estancias, y á los tales se les guarden todas las preheminencias y esenciones de la hordenanza ochenta $y$ cinco.

$6^{\circ}$ Yten que á los dichos conquistadores y pobladores se les ha de comunicar la merced que su Magestad les concede en la hordenanza noventa y nueve, haciendolas hijos dalgo de solar conocido á ellos y á sus descendientes y subcesores para que gocen de todas las honras y preheminencias y puedan hacer todas las cosas que todos los hombres hijos dalgo y cavalleros de los Reinos de Castilla segun fuero, Leyes y costumbres de Castilla, puedan y deban hacer y gozar conforme á la dicha hordenanza.

$7^{\circ}$ Yten se me ha de dar facultad para nombrar deste luego Maese de Campo, Alfereces, Sargentos, Capitanes, Veedor y los demas oficios que convengan y me pareciere y fueren necesarios para la dicha jornada, y siendo conveniente, mudarlos y nombrar otros.

$8^{\circ}$ Yten por la mucha costa y excesivos trabajos y cuidados que en la dicha conquista y pacificacion y poblacion hemos de tener yo y los mis subcesores pueda tomar y repartir para mi y para ellos perpetuamente para siempre prejamas treinta leguas de tierra en cuadra en una parte ó dos, donde yo señalare con todos los Vasallos que en el dicho termino hobiere, y si alguna cabezera de Pueblo cayera dentro 
Let it be granted in accordance with article 85 of the said ordinances for new settlements.

Let him be granted what is provided in article 99 of the said ordinances.

Since the naming of the said officials and their employment are indispensably necessary for the purpose of this expedition and it cannot be made without them, let him be granted and given power to name them, and let him be warned that he must name persons in whom occur the qualities required for these offices.

This is provided in article I of this agreement.
5. Item: That to the said conquerors and settlers and their children and descendants all favor and honor shall be given, and they shall be granted lots of land for pasture and farms, and as such they shall be allowed all the privileges and exemptions of ordinance 85 .

6. Item: That to the said conquerors and settlers the favor which his Majesty grants them in ordinance 99 shall be extended, making them and their descendants and successors gentlemen of noble family, so that they may enjoy all the honors and privileges, and be empowered to do all the things that all noblemen and knights of the kingdoms of Castile, according to the statutes, laws, and customs of Castile, have the power and right to do and enjoy, in conformity with the said ordinance.

7. Item: That power shall be given me to name immediately maese de campo, alfereces, sergeants, captains, inspector, and the other officials that may be necessary and that it appears to me are needed for the said expedition, and, if it should be expedient, to change them and name others.

8. Item: That because of the great expense and excessive labor and trouble which I and my successors must have in the said conquest, pacification, and settlement power shall be given to take and divide, for me and for them, perpetually and always and forever, thirty square leagues of land, in one part or in two, wherever I shall point out, with all the vassals that there may be in the said territory. 
Que se le concede lo contenido en el Capitulo 57 de las dichas hordenanzas, y se le dará desde luego titulo de gobernador y Capitan General, el cual le daré como Gobernador y Capitan General que soy de aquellas provincias, y aunque tendrá el este titulo por las dichas hordenanzas desde que las comenzare á poner en egecucion como en ellas se declara por la razon de que yo le diere para en el interin, no ha de tener ni llevar salario, y para desde que comenzare la jornada y pacificacion en adelante le señalo seis mil Ducados de Castilla en cada un año de salario conforme al Capitula 57 de las hordenanzas. del dicho termino Señalado, se entienda que los demas Pueblos sugetos á la dicha Cabecera aunque esten fuera de las dichas treinta leguas sean de mi repartimiento con las tierras, pastos y aguas y montes de los distritos á donde cayeren los dichos Vasallos, y que con ello se me dé para mi y para mis herederos y subcesores para siempre prejamas titulo de Marques con la jurisdicion Civil y Criminal Mero misto emperio, con los honores y prerrogativas que tienen semejantes titulos en los Reino de Castilla para que los hereden perpetuamente mis hijos ó hijas legitimas y naturales, y en defecto de no tener hijos ó hijas, las dichos mis hijas ó hijos ó otros decendientes por lignea recta, herede el dicho titulo de Mayorazgo el pariente mas cercano, con condicion que pueda yo hacer la fundacion del dicho Mayorazgo con las condiciones que me pareciere.

$9^{\circ}$ Iten que yo he de tener con el cargo de Gobernador y Capitan General ocho mil Ducados de Castilla en un cada año, atento á que las Provicias de la dicha Gobernacion estan lejanas y muy apartadas de las partes donde me tengo de proveer de las cosas necesarias y han de costar excesivos precios, el cual dicho salario haya de correr y corra desde el dis que tomare la posesion del dicho Gobierno, y se mande librar y pagar de la Real Hacienda de su Magestad, de lo que yo y los dichos mis subcesores comquistaremos á mi voluntad, y lo propio hayan de llevar los dichos mis subcesores en el dicho Gobierno, y si en lo conquistado y decubierto 
And if any capital town falls within the said indicated territory, it shall be understood that the rest of the towns subject to the said capital, even though they may be outside of the said thirty leagues, shall come in my division, with the lands, pastures, waters, and mountains of the districts where the said vassals happen to be: and with it I shall be given, for myself and my heirs and successors for always and forever, the title of marquis, with civil and criminal jurisdiction mero misto emperio, ${ }^{10}$ with the honors and prerogatives that such titles always have in the kingdoms of Castile, so that my sons and daughters legitimate and natural, may inherit them perpetually; and, in default of my said sons and daughters not having any daughters or sons or other descendants in a direct line, let the said entailed title be inherited by the nearest relative, with the proviso that I shall have the power to found the said entailment with the conditions that seem best to me.

Let him be granted what is contained in article 57 of the said ordinances, and let him be given immediately the title of governor and captain-general, which I shall give him as governor and captain-general, as I am, of those provinces. And although he will have this title by the said ordinances from the time that he begins to put them in execution, as is stated in them, for the reason that I would supply him in the interim, he is not to receive any salary then. But, after he commences the expedition and pacification, from then on, I assign him six thousand ducats of Castile as annual salary, in accordance with article 57 of the ordinances.

9. Item: That I shall have with the office of governor and captaingeneral eight thousand ducats of Castile yearly, in view of the fact that the provinces of the said government are distant and far away from the parts where I have to provide myself with the necessary things and they must cost excessive amounts; the said salary to run from the day when I shall take possession of the said government. And it shall be ordered to be issued and paid at my pleasure from the royal property of his Majesty which I and my said successors shall conquer, and the same shall be enjoyed by my said successors in the said government. And if in the con- 
Que se le concede lo que dispone el Capitulo 59 de las dichas hordenanzas.

Que se le concede por los Capitulos 43 y 64 de las dichas hordenanzas.

Que se le concede lo proveido en el Capitulo 80 de las dichas hordenanzas, y se escribrá á su Magestad le haga merced. desde luego no hubiere cantidad bastante para satisfacerme y pagarme el dicho salario en cualquier tiempo que lo haya aunque yo $y$ mis subcesores seamos fallecidos se nos ha de pagar lo corrido que se nos deviere á nosotros ó á nuestros herederos prefiriendonos á otro genero de gasto ó salario aunque sea de Gobernador que actualmente estuviere sirviendo.

Io ${ }^{\circ}$ Yten que su Magestad me haga merced de las Varas de Alguacil mayor de toda la Gobernacion para mi y para un hijo ó heredero, el que yo nombrare, y pueda quirar y poner los Alguaciles conforme se concede en la hordenanza cincuenta y nueve quedando á si mismo á cargo de Vuestra Señoria suplicar á su Magestad me conceda esto perpetuo, ó por lo menos por otras tres vidas mas.

I I ${ }^{\circ}$ Yten que despues de entrado en la dicha mi Gobernacion y tomado posesion della, pueda llegar ${ }^{8}$ y nombrar Caja Real y Oficiales Reales, Tesorero, Contador y factor y los demas que convinieren á la dicha Real Caja, con salario competente, el cual salario se pague de la hacienda que á su Magestad perteneciere en la dicha Gobernacion.

I $2^{\circ}$ Iten que no embargante que yo y mis herderos y subcesores en el dicho Gobierno estemos adminestrandole podamos tomar Minas y partes de Minas por nuestras personas y por otras, conforme á las hordenanzas y no pague ni paguemos de la Plata, Oro, ó otros metales y Piedras mas del diezmo por tiempo de diez años como lo dis-

g Evidently a miscopy for "elegir". 
Let him be granted what is ordered in article 59 of the said ordinances.

Let him be granted what is ordered in articles 43 and 64 of the said ordinances.

Let it be granted to him as provided in article 80 of the said ordinances, and let his Majesty be written to grant him the favor. quest and country explored there should not be a sufficient sum immediately to satisfy me and pay me the said salary, for whatever time that it may be, even though I and my successors may be deceased, the amount due us shall be paid, either to us or to our heirs, we to be preferred to any other kind of expense or salary, even that of the governor who may be actually serving.

Io. Item: That his Majesty shall grant me the right to appoint to the office of alguacil mayor in the entire government, for myself and a son or heir whom I may name, so that I can remove or appoint the alguaciles, in accordance with what is granted in ordinance 59. And it is charged also to your lordship to supplicate his Majesty to grant me this in perpetuity, or at least for three more lives.

I I. Item: That after I have entered upon my said governorship and have taken possession of it, I shall have the power to choose and name a royal treasury and royal officials, treasurer, contador, factor, and the others who may be needed for the said royal treasury, with a suitable salary, which shall be paid from the property that will belong to his Majesty in the said government.

I2. Item: That notwithstanding that I and my heirs and successors in the said government will be administering it, we shall have the power to take up mines, or parts of mines, for our persons and for others, in accordance with the ordinances, and shall not pay more than a tenth of the silver, gold, or other metals or stones for the term of ten years, as is provided by ordinance 
Que no ha lugar por agora.

Que se le concede lo dispuesto en el Capitulo 60 de las hordenanzas.

Que se le concedo lo dispuesto por el Capitulo 65 de las hordenanzas.

Lo dispuesto en el Capitulo 66 de las hordenanzas.

Lo despuesto en el Capitulo 67 de las hordenanzas. pone la hordenanza ochenta, quedando á cargo de Vuestra Señoria suplicar á su Magestad que no se pague sino el veinteno por espacio de cincuenta años.

I $3^{\circ}$ Iten que atento á que hermanos y deudos mios me ayudan y socorren para esta jornada, y despues de puesta en egecucion me han de ir siempre ayudando desde estos Reinos con lo que fuere pidiendo, que pueda á los tales encomendar Yndios y hacer otras gracias, no embargante que no vayan á la jornada, pues es del mismo efecto.

I $4^{a}$ Iten que yo, ó mis hijos ó herederos podremos hacer tres Fortalezas, y habiendolas hecho y sustentado tengamos la tenencia en ellas perpetuamente con salario competente de la Real Hacienda y frutos de la tierra como lo dispone la hordenenza sesenta.

I $5^{2}$ Iten que si sucediese algun Rebelion en el dicho Gobierno pueda librar y gastar de la Real Hacienda lo que para esto fuere necesario.

I6 $6^{\mathrm{a}}$ Yten que pueda hacer los hordenanzas que convengan para la Gobernacion de la tierra y lavor de Minas.

I $7^{\mathrm{a}}$ Iten que pueda dividir la Provincia del dicho Gobierno en Distritos de Alcaldias Mayores y Corregimientos, y Alcaldias hordinarias, y poner Alcaldes Mayores y Corregidores, y señalarles salarios de los frutos de la tierra, y confirmar los Alcaldes hordinarios que eligieren los Concejos, de todos los cuales 
8o, it being left in charge of your lordship to supplicate his Majesty that only the twentieth part shall be paid for the term of fifty years.

There is no occasion at present.

Let him be granted what is provided in article 60 of the ordinances.

Let him be granted what is provided in article 65 of the ordinances.

[Let him be granted] what is provided in article 66 of the ordinances.

[Let him be granted] what is provided in article 67 of the ordinances.
I3. Item: That in view of the fact that my brothers and relatives are assisting and succoring me for this expedition, and that after it is put into execution they will always go on helping me from these kingdoms with whatever I may ask for, I shall be empowered to grant Indians to the said persons and to do them other favors, notwithstanding that they do not go on the expedition, for it is to the same effect.

I4. Item: That I or my heirs shall have the right to build three forts; and, having built and maintained them we shall hold the lieutenancy of them in perpetuity, with a suitable salary from the real hacienda and the products of the land, as is provided in ordinance 60.

I 5. Item: That if any rebellion should occur in the said government I shall have the power to issue and spend from the real hacienda what may be needed for this purpose.

I6. Item: That I shall have the power to issue the ordinances which may be necessary for the government of the land and the working of the mines.

I7. Item: That I shall have the power to divide the province of the said government in districts of alcaldias mayores, corregimientos, and alcaldias ordinarias, and to appoint alcaldes mayores and corregidores, and to assign them salaries from the fruits of the land, and to confirm the alcaldes ordinarios who 
Lo proveido en el Capitulo 69 de las hordenanzas.

Lo dispuesto en el Capitulo 73 de las hordenanzas.

Lo dispuesto en el Capitulo 76 de las hordenanzas.

Lo dispuesto en el Capitulo 77 de las hordenanzas.

Que se le concede comforme al Capitulo 79 de las hordenanzas. tenga la jurisdicion Civil y Criminal en grado de apelacion y de Teniente de Gobernador.

I $8^{\circ}$ Yten que yo y los tales mis herederos y subcesores en la dicha Gobernacion y jurisdiccion hayamos de ser y seamos inmediatos al Real Consejo de las Indias, de manera que ninguno de los Virreyes de esta Nueva España ni Audiencias Comarcanas, se puedan entremeter en el distrito del dicho Gobierno.

I9 ${ }^{\circ}$ Yten que pueda levantar gente en cualquiera parte de los Reinos de su Magestad para la poblacion y pacificacion, nombrando para ello los Capitanes y Oficiales necesarios, arbolando vanderas y tocando $\mathrm{Ca}-$ jas y publicar las jornadas.

$20^{a}$ Yten se me han de dar recaudos bastantes para que las justicias de las tierras comarcanas de adonde hubiere de salir á hacer esta jornada y la gente que á ella fuere y por las donde hubiere de pasar, me den y les den toda favor y ayuda, y me den y les hagan dar los bastimentos y provisiones que fueren menester á justos y moderados precios, y segun y como se contiene en la hordenanza setenta y seis.

$2 \mathrm{I}^{\mathrm{a}}$ Yten que las justicias no estorven á la gente que quisiera ir á la jornada aunque hayan cometido delito no habiendo parte que lo pida.

$22^{a}$ Yten que pueda traer cada año dos Navios para provision de la tierra y lavor de las Minas que hu- 
[Let him be granted] what is provided in article 69 of the ordinances.

[Let him be granted] what is provided in article 73 of the ordinances.

[Let him be granted] what is provided in article 76 of the ordinances.

[Let him be granted] what is provided in article 77 of the ordinances.

Let it be granted to him in conformity with article 79 of the ordinances. may be chosen by the councils, over all of whom I shall have civil and criminal jurisdiction in the proceeding of appeal and as lieutenant-governor.

I8. Item: That I and my said heirs and successors in the said government and jurisdiction must and shall deal directly with the royal Council of the Indies, so that none of the viceroys of this $\mathrm{New}$ Spain or of the neighboring audiencias can interfere in the administration of the said government.

I9. Item: That I shall have the power to recruit men in any part of the kingdom of his Majesty for the settlement and pacification, naming for it the captains and officials necessary, raising banners, beating drums, and proclaiming the expeditions.

20. Item: That I shall be given sufficient warrants, so that the magistrates of the neighboring lands from which I and the people who may go on it would have to set out on this expedition and through which we would have to pass, shall give me and them all favor and help, and shall give me and cause me to be given the supplies and provisions which may be needed at just and moderate prices, as is contained in ordinance 76 .

2r. Item: That the magistrates shall not interfere with the men who may wish to go on the expedition even though they may have committed crimes, if there be no party who asks for it.

22. Item: That I shall have the power to bring every year two ships for the provisioning of the land and 
Lo dispuesto por el Capitulo 8I de las hordenanzas, é se escribirá á su Magestad le haga merced.

Como lo pide en conformidad del articulo 82 de las dichas hordenanzas.

Que se le concede lo que dispone el Capitulo 145 de las dichas hordenanzas.

Que no ha lugar sin particular horden ó licencia de su Magestad.

Concedesele lo dispuesto en el Capitulo 56 de las hordenanzas, y para en caso si falleciere antes de haber cumplido con ellas, y no tuviere hedad su hijo, ó heredero se biere, libre de Almojarizfazgo y derechos.

$23^{\mathrm{a}}$ Yten que no se pague en la dicha Gobernacion Alcavala por tiempo de veinte años como lo concede la hordenanza ochenta y una, quedando asi mismo á cargo de Vuestra Señoria suplicar á su Magestad sea esto por tiempo de cincuenta años.

$24^{a}$ Iten que no se pague Almojarifazgo de todo lo que se llevare para proveimiento de la dicha Gobernacion como lo dispone la hordenanza ochenta y dos, suplicando á su Magestad se sirva alargar el tiempo á cincuenta años.

$25^{a}$ Iten que pueda tasar los tributos que los Indios hubieren de dar conforme á los frutos de su tierra yo y mis subcesores, asi los que han de acudir al Rey nuestro Señor como á los demás encomenderos y subirlos ó bajarlos ó comutarlos en cualquier manera como me pareciere á mi y á mis subcesores con libre y absoluto poder, sin dependencia del Virrey ni Audiencia.

26 Iten que en habiendo de hacer ausencia de la dicha tierra y provincia pueda dejar en mi lugar Teniente, para que en todo tenga el mismo poder que yo, asi para ir á los Reiños de España como á otras partes de las Indias.

$27^{a}$ Iten que si estandome aprestando para la dicha jornada antes que me parta á ella, ó yendo caminando, ó estandola descubriendo, pacificando ó poblando, falleciere, 
[Let him be granted] what is provided in article $8 \mathrm{I}$ of the ordinances, and let his Majesty be written to to grant him the favor.

[Let him be granted] what he asks in accordance with article 82 of the said ordinances.

Let him be granted what is provided in article $\mathrm{I} 45$ of the said ordinances.

That this cannot be permitted without special order or license from his Majesty.

Let him be granted what is provided in article 56 of the ordinances, and in case he should die before fulfilling them, and his son or heir should not be of age, let him be per- for the exploiting of what mines there may be, free of import tax and duties.

23. Item: That there shall not be paid in the said government any excise tax for the term of twenty years, as is granted in ordinance 8I, your lordship being charged at the same time to supplicate his Majesty to extend this for the term of fifty years.

24. Item: That no customs duties shall be paid on all that is carried for the provisioning of the said government, as is provided in article 82 , your lordship to supplicate his Majesty to be pleased to extend the time to fifty years.

25. Item: That I and my successors shall have the power to appraise the tributes which the Indians will have to give in accordance with the fruits of their land, both those which must go to the king, our lord, as well as to the other encomenderos, and to raise or lower or commute them in any way that may seem right to me and to my successors with free and absolute power, and independent of the viceroy and the Audiencia.

26. Item: That in case I shall have to absent myself from the said land and province, to go either to the kingdoms of Spain or to other parts of the Indies, I shall have the power to leave in my place a lieutenant, who shall have the same power in everything as I.

27. Item: That if while I am making ready for the said expedition, before I depart upon it, or while I am on the road, or while I am engaged in exploring, pacifying, 
le permite que nombre persona que prosiga y cumpla estas Capitulaciones conforme al dicho Capitulo 56 con aprovacion del Virrey desta Nueva España.

Que yo hago este asiento y Capitulacion por Comision y horden de su Magestad cuyo derecho se le concede desde el dia que aqui se firmare y se asentare y della, luego en la primera ocasion le daré cuenta, y sucediendo el caso que refiere en lo que toca á los gastos y pertrechos que hobiere hecho para la jornada se le reservava su derecho para que los cobre de la persona que se la pretendiere quitar. atento que mis hijos tienen poca edad para poderles dar estado para que me suceda el primer subcesor, yo pueda nombrar la persona y personas que me pareciere para que en el entre tanto que el llamado mio pareciere ó tuviere hedad, gobierne y prosiga la jornada, que el con $\mathrm{mi}$ nombramiento lo pueda hacer, luego y Vuestra Señoria y los que á Vuestra Señoria subcedieren, esten obligados en nombre de su Magestad á confirmar el tal nombramiento, y que desde luego pueda gobernar sin esperar la dicha confirmacion, y no se le pueda poner impedimento, y teniendo hedad y pareciendo el asi llamado, luego entre en el Gobierno y Conquista y poblaciones conforme á esta Capitulacion.

$28^{a}$ Iten que despues de haber yo hecho este asiento con Vuestra Señoria y Vuestra Señoria firmadalo viniere de españa persona que con el Rey nuestro Señor haya capitulado sobre ello y tragere Cedula é recaudos para que Vuestra Señoria le ampare sea visto no derogar los tales recaudos al asiento que con Vuestra Señoria hubiere firmado yo, y los que mi poder tuvieren pare ello y estar Vuestra Señoria obligado á dar cuenta á su Magestad de lo asentado conmigo antes que Vuestra Señoria mande cumplir las Cedulas y Recaudos que sobre ello trugere, para que su Magestad sepa que en virtud de su Real Cedula y comision cometió á Vuestra Señoria esta jornada, y que yo pueda efectuarla segun lo capitulado, y atento que desde luego voy 
mitted to name a person to continue and carry out these agreements in accordance with the said article 56 , with the approval of the viceroy of this New Spain.

[Let it be granted] that I make this contract and agreement by commission and order of his Majesty, and let this right be granted to him from the day when it is signed and sealed here, and I shall give account of it to him [his Majesty] on the first opportunity that offers. And if the event should happen to which he refers, in so far as concerns the expenses and preparations which he may have made for the expedition, the right shall be reserved to him to collect them from the person who may attempt to take it from him. or settling, I should die, in view of the fact that my sons are too young to be given that state, in order that there shall be a first successor to succeed me, I shall have the power to name the person or persons who may seem suitable to me, so that, in the interim until the one called mine shall arrive at a suitable age to manage and continue the expedition, the one whom I name can do it immediately. And your lordship and those who succeed you shall be obligated in the name of his Majesty to confirm the said appointment, and that he [the appointee] shall have the power to govern without waiting for the said confirmation, and that no impediment shall be placed in his way. And as soon as he who is called [mine] shall reach the age and seem [fit], he shall immediately enter upon the government and conquest and settlements in accordance with this agreement.

28. Item: That if, after I have made this contract with your lordship and your lordship has signed it, a person should come from Spain who has made an agreement with the king, our lord, in regard to it, and should bring a cédula and orders for your lordship to support him, it shall be understood that the said orders shall not annul the contract which I shall have signed with your lordship or interfere with those who may have my power of attorney for it. And your lordship shall be obligated to give account to his Majesty of the contract with me before your lordship shall order the cédulas and orders which he [the person from Spain] may bring in regard to it to be carried out, so that his Majesty may know that, in virtue of his royal cédulas and 
Que en tal caso use de su asiento y recaudos que se le daran en cuya virtud y conformidad esto se hace.

Que se enviaré á su Magestad este asiento y capitulacion y se le dará cuenta de lo bien que está á su Real servicio lo que se ha hecho y asentado.

Lo proveido en el Capitulo primero y los demas de este asiento, y se escribirá á su Magestad que le haga merced como de suso está dicho haciendo mucha costa para el cumplimiento de lo Capitulado con $\mathrm{Vu}$ estra Señoria, asi por la dicha razon me saliere incierto lo asi tratado y concertado, y se hubiere de encargar á otro la dicha jornada, se me ha de pagar y satisfacer de la Real Hacienda todo lo que yo hubiere costeado en la dicha jornada y prevenciones della con los perdidas, daños y menoscabos.

$29^{\mathrm{a}}$ Iten que aunque se haya hecho Capitulacion y tomado asiento sobre el dicho descubrimiento y poblazones por los Virreyes antecesores de Vuestra Señoria, con cualquiera persona no perjudique á este asiento y Capitulacion, ni les quede derecho alguno para la dicha jornada debajo de lo que esta dicho.

$30^{a}$ Iten Vuestra Señoria se ha de obligar en nombre de su Magestad que me seran guardadas estas dichas Capitulaciones y lo que comigo y con los que mi poder tuvieren se Capitulare y concertare en todo y por todo sin que en ello falte cosa alguna para siempre jamas y enviarlos á su Magestad para que sea sabidor de lo que Vuestra Señoria en virtud de su Real Cedula y capitulo de carta á capitulado.

$3 \mathrm{I}^{\circ}$ Iten que se ne han de guardar á mi y á mis subcesores en el dicho Gobierno todas las hordenanzas hechas por su Magestad para nuevos descubrimientos y poblaciones nue- 
commission, he entrusted to your lordship this expedition, and that I shall have the power to carry it out according to the agreement. And in view of the fact that from the beginning I shall be incurring great expense for the fulfillment of the agreement with your lordship, if for the said reason the said contract and agreement shall turn out uncertain, and the said expedition shall be given to another person, I must be paid and satisfied from the real hacienda for all that I shall have spent in the said expedition and the preparations for it, with the losses, damages, and deteriorations.

In such a case he shall make use of the contract and orders which will be given him, in virtue and conformity with which this is done.

This contract and agreement shall be sent to his Majesty, and a statement shall be given to him to the effect that what has been done and contracted is for the good of his royal service.

[Let him be granted] what is provided in article $I$ and the others of this contract, and let it be written to his Majesty that he shall grant him what is above stated.

29. Item: That, although an agreement and contract may have been made in regard to the said exploration and settlements by the viceroys preceding your lordship, no matter with what person it may have been made, it shall not prejudice this contract and agreement, nor shall any right remain to them for the said expedition under what has been said.

3o. Item: Your lordship shall be obligated, in the name of his Majesty, to carry out these said agreements and what may be agreed and contracted with me, and those who may have my power of attorney, in everything without failing in anything, for always and forever, and to send them to his Majesty, so that he may be made acquainted with what your lordship, in virtue of his royal cédula and paragraph in a letter, has agreed to.

3I. Item: That there shall be observed for me and my successors in the said government all the ordinances made by his Majesty for new explorations and new settlements, 
vas, en cuanto no fueren contrarias á estas Capitulaciones, las cuales se mos han de guardar irremisiblemente á mi y á los dichos mis subcesores y a los que fueren conquistadores y pobladores de las dichas Provincias en cuyo nombre ansi mismo las pongo-Don JUAN DE OnATE.-Sacado del original y corregido-Martin Lopez de GAUna -Rubricado.

\section{Carta de don luis de velasco a Su Magestad. ${ }^{h}$ [Mexico, I4 de Octubre de 1595.]}

La flota deste presente año General Pedro Melendes Marques entro a salvamento en el puerto de san juan de Ulua lunes 18 de septienbre y en ella el conde de monterrey a quien Vuestra Magestad proveyo por virrey desta nueva españa e yo Recevi el titulo de Virrey del Piru y la que Vuestra Magestad me mando escrivir en $2 \mathrm{I}$ de junio passado y en los dias que quedan de aqui a que el conde entre en esta ciudad que seran pocos acudire como devo a lo que por ella Vuestra Magestad ordena y manda y lo que no pudiere cunplir comunicare con el conde para que el lo cunpla y de todo dare Razon a Vuestra Magestad en el primero de avisso que se despachara con brevedad.

Por lo que en otras ocassiones he significado a vuestra Magestad se avra podido entender la pobreza y necesidad que padezco despues que sirvo este cargo y las causas de do ${ }^{1}$ procede que por haverlas manifestado antes de agora no las refirire en esta y aunque hasta aqui he pasado con mucha estrechura y demasiada limitacion no gastando mas que lo muy forçosso y necesario, el viaje del peru que tengo entre manos me obliga a salir de paso y a hazer mayores gastos assi para el avio de mi cassa como para proveerme de algunas cossas que la auctoridad de aquel puesto pide mas que la del deste que hasta aqui a mas no poder havia escussado lhegase a esto otra mayor difficultad que es la de mi enbarcacion a causa de no aver navios en el puerto de acapulco sino desde el peru pequeños y muy desacomodados por ser de una cubierta y no tener reparo para el sol y aguas que haze en aquel viaje con que se corre notorio riesgo en la salud esperava de la grandeza de Vuestra Magestad para Remedio de destas dificultades que se oviera servido de mandarme dar la enbarcacion que se a dado a los otros mis antecessores que han ido de aqui a servirle en aquel Reyno y alguno socorro desta rreal caxa para mi avio pues debaxo del cielo no tengo otro ni de donde me venga ni aun credito para empeñarme mas de

h A. G. I., 58-3-I2. Copy of transcript in Ayer Collection; copy compared by Miss Clara A. Smith.

'Evidently a miscopy for "que". 
in so far as they may not be contrary to these agreements, which are to be secured to us irremissiblyto me and to my said successors and to those who may be conquerors and settlers of the said provinces, in whose name I also agree to them. Don Juan de Oñate. Copied from the original and corrected. MARtín López de GaUÑa. With rubric.

\section{Letter of Don Luis de Velasco to his Majesty. [Mexico, October I4, I595.]}

The fleet of this present year, [in command of] General Pedro Melendes Marqués, entered safely into the port of San Juan de Ulua on Monday, September I8, bringing with it the Count of Monterey, whom your Majesty appointed as viceroy of this New Spain. By it I received the commission of viceroy of Peru and the [letter] which your Majesty ordered to be written to me on the twenty-first of last June. In the few days that remain from now until the Count will enter this city, I will hasten to do, as I ought, what your Majesty orders me by it; what I am not able to do I will communicate to the Count so that he may carry it out, and I will give account of everything to your Majesty by the first despatchboat, which will soon be sent.

By what I have pointed out on other occasions to your Majesty you will have learned of the poverty and need which I have been experiencing since I have been serving in this office and the causes from which it arises; since I have stated them before now I will not relate them in this. Although up to this time I have lived very penuriously and with extreme circumspection, not spending more than what was indispensable and necessary, the journey to Peru which I have in hand compels me to depart from this conduct and to incur greater expenses, not only for the provisioning of my household, but also to provide myself with some things which the importance of that post demands more than this and which I had done without up to this time as far as I possibly could. There is added to this another and greater difficulty - that of my transportationfor there are no ships in the port of Acapulco except those of Peru, which are small and very uncomfortable, as they have but one deck and no cover from the sun and rains that occur on that voyage, which would evidently be the cause of great danger to health. I hoped from the greatness of your Majesty that as a remedy for these difficulties you would be pleased to order that I be given the same means of transportation as my predecessors who have gone from here to serve you in that kingdom, and some aid from this royal treasury for my preparations, for, under the heavens, I have no other place whence it can come to me, nor any credit by which 
lo que estoy por el poco posible que todos saven que alcanço hallome con esto tan ataxado que puedo certificar a Vuestra Magestad con toda verdad que desespero de poderme aprestar para la jornada en el tiendo que Vuestra Magestad me ordena que procure hazerla que es otra nueva circunstancia que me causa harta pena y cuydado por el deseo con que bivo de cunplir puntualmente lo que Vuestra Magestad me manda sin enbargo desto me boy previniendo en el ynterin que se me embian los Recaudos que faltan para mi avio y el usso de mi officio y quando ellos y la merced que espero de vuestra magestad no venga me ire como pudiere aunque sea solo con mi capa y espada y por tierra lo que se sufriere no dandome el conde algun navio de los de Vuestra Magestad que se esperan de la Philippinas a que necesariamente de aguardar por no aver otro en que poderme yr sin peligro de mi salud y de la de los que conmigo fueren.

La pacificacion del nuevo mexico tengo asentada con don juan de oñate vezino de la ciudad de nuestra señora de los çacatecas hijo de christobal de oñate que fue uno de los principales hombres y mas Ricos que huvo en este Reyno su hedad suerte y buenas partes son quales el negocio las pide y mas a proposito que las de los que antes del lo han pretendido, Halo aceptado con las condiciones que Vuestra Magestad concede a los que hazen semejantes descubrimientos en las ordenancas que desto tratan sin pretender mas ventajas que las que Vuestra Magestad fuere servido hazerle conforme a lo que travajare gastare y sirviere en la jornada por que todo lo que fuera desto le ha concedido es de poco momento como lo escrivire a Vuestra Magestad mas en particular en el primero de aviso el se queda aprestando para salir con brevedad espero en nuestro señor que ha de suceder todo bien a gloria y onrra suya y servicio de vuestra magestad cuya catolica persona guarde nuestro señor mexico I 4 de octubre I 595 .

Don Luis de velasco.

\section{Carta del Conde de monte Rey a Su Magestad.j [Mexico, 20 de Diciembre de I595.]}

\section{Señor.}

Sobre la entrada del nuevo Mexico tomo el virrey don luis de velasco cierto assiento con don juan de oñate quando yo venia caminando desde el puerto para aqui y poco antes hiço cierta concesion a un sevastian vizcaino sobre la entrada de las californias a donde por asiento avia de yr a pescar perlas yo he visto los papeles deste ultimo negocio para lo que tocava a dar orden en la execucion y los otros por que el virrey an ynstado en que yo los vea antes de la entrada y dificulte en lo que me pareciere y holgara de no enbarazar el tienpo con nueva deliveracion pero haviendo de

1 A. G. I., 58-3-10. Copy of transcript in Ayer Collection; copy compared by Miss Clara A. Smith. 
to pledge myself more than I have already. Because of the smallness of the means which everyone knows are at my command, I find myself so obstructed that I can assure your Majesty with all truth that I despair of being able to get ready for the journey in the time that your Majesty orders me to try to do so; this is another circumstance which causes me great pain and anxiety, for I live in the desire of punctually fulfilling what your Majesty orders me. Nevertheless I am continuing to prepare in the interval until I shall receive the warrants that are necessary to me for my provision and the practice of my office, and even though they and the favor that I expect from your Majesty do not come, I shall go as best I can, though it be with my cloak and sword, alone and by land, which I shall have to suffer if the Count does not give me some ship from those of your Majesty which are expected from the Philippines, and which it is necessary to await because there is no other on which I can go without danger to my health and that of those who will go with me.

The pacification of New Mexico I have arranged for with Don Juan de Oñate, resident of the city of Nuestra Señora de los Zacatecas, and son of Cristóbal de Oñate, who was one of the principal and richest men in this kingdom. His age, fortune, and qualifications are such as the business demands, and more appropriate than those of the persons who have heretofore attempted it. He has accepted it with the conditions which your Majesty grants to those who make such discoveries in the ordinances ${ }^{11}$ which treat of this, without claiming any more advantages than your Majesty may be pleased to grant him in conformity with what he may bring about, spend, and serve in the expedition, for all that has been granted to him besides this is of little moment, as I shall write to your Majesty in more detail by the first despatch-boat, which is preparing to sail soon. I trust in our Lord that everything will happen to His glory and honor and the service of your Majesty, whose Catholic person may our Lord guard. Mexico, October I4, I 595.

Don Luís de Velasco.

\section{Letter from the Count of Monterey to his Majesty. [Mexico, December 20, I595.]}

Sir: In regard to the entrance into New Mexico, Viceroy Don Luís de Velasco made a certain agreement with Don Juan de Oñate while I was on the road from the port to this place, and a little while before he made a certain concession to one Sebastian Vizcaino in regard to the entrance into the Californias, where he was to go by agreement to fish for pearls. I have seen the papers of this last affair as far as they touched upon the giving of orders for its execution; I have also seen the other papers, for the viceroy insisted that I should see them before the entrance [into New Mexico]. It is difficult for me to form an opinion at my leisure without filling my time with new deliberations, but, since I have to do it, it is necessary that it shall be done with attention and counsel, in order to take information on the matter. I have therefore not corne to a deci- 
hacerla es forçosso que sea con atencion y consexo para tomar ynteligencia de la materia y assi no me he rresuelto sobre las dudas que se me ofrecen que son algunas y por no tener estado estos negocios para escrivir mas largo sobre ellos lo dexo para el segundo navio de avisso contentandome con darle a Vuestra Magestad de lo que voi haziendo y de que muy presto me determinare para que si algo se huviere de rreformar se haga y lo demas se ponga en execucion brevemente sera vuestra magestad servido de yr aguardando mis cartas aunque las partes pidan alguna confirmacion o cedula por que assi conviene a su servicio hasta que yo escriva.

En levantar gente para las yslas Philipinas me fui deteniendo con la llegada del navio que arrivo acapulco a I9 del passado por esperar, que llegando, luego los otros huviera cartas y havisso de la gente que sera menester ogaño pero viendo la tardança de los navios me he resuelto a prover officiales de Mar y de guerra para la leva de la gente y apresto de las naos y se a començado y poseguira con todo calor y priessa y esso mismo en el despacho del virrei don luis de velasco para el piru que en esto $y$ en començar las prevenciones para que la plata que ha de ir en la flota se vaya rrecoxiendo piensso gastar los dias de punto que ay en las pascuas.

Guarde Dios a Vuestra Magestad Mexico 20 de dizienbre de I 595.

El CONDE DE MONTEREY.-[Rubricado.]

[En el dorso se lee:] A1 Rey nuestro señor en su Real Consejo de las yndias.

Duplicada.

\section{Carta del Conde de monterey a Su Magestad. ${ }^{k}$ [Mexico, 28 de Febrero de 1596.$]$}

\section{Señor.}

El acidente que en este Govierno se a ofrecido ogaño con el concurso de despachos de mar y jornadas de guerras de las que por aca puede aver que con estos socorros de las islas de poniente y descubrimientos de provincias tenia nescesidad de Virey mas experimentado y mas platico en estas partes y tierras que yo pero ya que el virey don luis de velasco que desto y de prudencia tenia tanta parte a hecho ausencia en el tienpo de la execcucion que suele ser lo mas enbaraçosso y quando mas hera menester su persona yo he procurado atender con el cuydado que devo a suplir en quanto me es posible sus faltas el despacho de las naos de las yslas philipinas creo que suele dar pedaço de cuydado cada año al Virey y aora se an juntado los descubrimientos y pacificacion del nuevo mexico y de las californas y el viaje del mesmo virey don luis para el peru que no solo an estrechado el tienpo para las obligaciones y ocupacion hordinaria que este cargo tiene pero enbaraçadose todo ello entre si para el breve y anticipado despacho

k A. G. I., 58-3-I2. Copy of transcript in Ayer Collection; copy compared by Miss Clara A. Smith. 
sion of the doubts that occur to me, which are various, and, as these affairs are not in a state to write more at length concerning them, I am leaving it for the second despatch-boat, contenting myself with giving an account to your Majesty of what I am doing now, and [by stating] that very soon I shall come to a decision, in order that if any change is to be made it may be carried out. The other matters I will attend to shortly. Your Majesty will be pleased to await my letters even though the parties ask for some confirmation or cédula, for this will be best for your service until I can write.

In raising men for the Philippine Islands I delayed until the arrival of the ship that reached Acapulco on the nineteenth of the past month, expecting that when the others should arrive there would be letters and advices as to how many men it would be necessary to raise this year. However, seeing that the ships were late, I resolved to appoint officials of sea and war for the recruiting of men and the preparation of the ships. This has begun and will go on with all vigor and haste, as likewise the despatching of Viceroy Don Luís de Velasco to Peru. In this and in beginning measures for collecting the money that is to go by the fleet, I expect to spend entirely the days of the Christmas festival.

May God keep your Majesty. Mexico, December 20, I 595.

The Count of Monterey. [With rubric.]

[On the back is zeritten:] To the king, our lord, in his royal Council of the Indies.

Duplicate.

\section{Letter from the Count of Monterey to his Majesty. [Mexico, February 28, I596.]}

Sir: For the situation that has come about this year in this government with the concurrence of expeditions by sea and for war-for those wars that may happen here, for aid for the islands of the West, and for the explorations of provinces-there was need for a viceroy more experienced and expert in these parts and lands than I. But since Viceroy Don Luís de Velasco, who properly had such a great part in this, has absented himself at the time of the execution, which is usually the most trying and when there would be most need of his presence, I have endeavored, with the care that I owe, to supply as far as possible his absence. The despatching of the ships to the Philippines I believe usually gives its piece of care every year to the viceroy, and now there are added the explorations and pacifications of New Mexico and the Californias, and the voyage of Viceroy Don Luís himself to Peru. Not only has the time been limited for the obligations and ordinary occupation which this charge brings, but the early and prompt despatch that I wished to give to each expedition has been embarrassed by the small supply of tackle for ships which your Majesty has in this South Sea. Aside from that of New Mexico, the other three expeditions make their journey by sea, and thus there has been. 
que yo quisiera dar a cada jornada de por si el aparejo y recado de navios que Vuestra Magestad tiene en esta mar del sur es bien poco y fuera de la del nuevo Mexico las otras tres jornadas tienen el viaje por mar y asi a havido alguna dificultad en acomodar el despacho con todo esso se ha ydo con poniendo bien Respecto de que con parescer del acuerdo de hazienda se conpro el navio santa margarita que el capitan estevan Rodriguez de figueroa fabrico por su quenta en las yslas y vino ogaño dellas antes que el navio san pedro y san Pablo de Vuestra Magestad tubose aqui muy buena relacion desta nao no solo de ser tan nueba sino muy suficiente y biene labrada y de porte de quatrocientas y cinquenta toneladas con esto y no tener Vuestra Magestad mas de quatro navios en esta carrera haviendose ordenado al Virey que sienpre bayan dos y quede uno en el puerto me yncline a conprarle estando certificado el Virey don luis de belasco y de muchas personas platicas deste despacho de ques casi ynpusible que buelban el mismo año las naos que van ni pueda cunplirse con menos que cinco la Horden que Vuestra Magestad tiene dada sin este navio tenia Vuestra Magestad quatro como e dicho y desas las dos en las yslas que no havian de bolver este año pasado porque fueron el mismo y el uno para darse alla al traves con el por inutil segun saven con esto parescio mas nescesario el comprar este otro y hizo mas forzosa la resolucion el haver los dos navios de Vuestra Magestad San Pedro y San Pablo que se aguardavan tardo muchos dias despues que vino santa Margarita y ultimamente haver venido San Pedro y haver tenido con el muy mola Relacion de la dispusicion en que venia este navio San Pablo y del Recelo que podia haver de que por esto y por demasiada carga se perdiese vimonos amenaçados de no tener para el viaje de las yslas y el birey mas que un navio de Vuestra Magestad siendo tres los forçosos y muy costosso el fletar qualquier de particulares por quenta de la Real hazienda de vuestra magestad y asi, tomando este medio por mas conviniente hize efectuar la conpra en veynte y dos mill y quinientos pessos pasando lo paga de ocho mill a San juan despues de la flota partida di a escoger al virey de los navios que havia en el puerto y eligio este nuevo y asi se le mande aprestar conforme a la cedula de Vuestra Magestad que al principio de diciembre me la havia mostrado y hordene con parezer del acuerdo de Hazienda y veneplacito del Virey a los oficiales Reales de acapulco que para ayuda de costa al prescio que se da por este navio fletasen Ropa de Mercaderes en la quarta parte de las toneladas pues con todo esso yria bien desenbaraçado y boyante para la comodidad y buen viaje del virey y para las Philipinas mande aparejar la nao San Pedro paresciendo que otro navio San francisco del mariscal gabriel de Rivera questava en acapulco podria suplir por san pablo pero despues llego el y se an puesto en orden para el viaje de los navios de Vuestra Magestad san Pedro y san Pablo y aunque el Governador a ynstado mucho en que fuese tanbien el dicho nombrado san francisco del mariscal y creo se quexara a Vuestra Magestad de no haverlo proveydo yo asi e tenido la mano en ello por que como quiera que ay artos Religiosos y Gente y el governador dize que no an de poder caver en las dos naos yo lo he comunicado diversas vezes con el acuerdo de hazienda y sienpre se a hechado quenta de que son quinientas o pocas mas personas y que sin desacomodarle al Governador el navio en que a de yr que yo mande como es justo que fuese a su 
some difficulty in arranging for their despatch; but with all this it has been finally managed. In respect to this, with the agreement of the council of the hacienda, the ship Santa Margarita was bought. Captain Estévan Rodríguez de Figueroa built it on his own account in the islands and came from there this year ahead of your Majesty's San Pedro and San Pablo. There was a very good report here of this ship, not only that it was new, but also that it was very strong and well built, and of a portage of 450 tons. For this reason, and since your Majesty had no more than four ships on this route, and it had been ordered by the viceroy that two should always go and leave one in the port, I decided to buy it, having been assured by Viceroy Don Luís de Velasco and many persons experienced in this business that it is almost impossible for the ships that go to return the same year; neither can the order ${ }^{12}$ which your Majesty has given be carried out in less than five. Without this ship your Majesty had four, as I have said, and of these two in the islands were not to come back the past year because they went in that same year, while one, because it was sent there as a useless old ship, was not to return at all, as is known. For this reason it seemed more necessary than ever to buy this other, and made more urgent the need [for that route] of your Majesty's two ships, San Pedro and San Pablo, which were not expected for many days after the Santa Margarita arrived. Finally when the San Pedro did arrive a very bad report was brought of the state in which the ship San Pablo was coming and the fear which, for this reason and because of her over-load, might be felt that she might be lost. We saw ourselves threatened with having for the voyage to the islands and that of the viceroy only one of your Majesty's ships, although three were necessary, and it would be very expensive to charter one belonging to some private person against the account of the real hacienda of your Majesty. Therefore, taking this means as the most convenient, I caused the purchase to be made for 22,500 pesos, sending the payment of eight thousand to San Juan, after the departure of the fleet. I gave the viceroy the choice of the ships that were in the port, and he chose this new one; I therefore ordered her to be made ready, in accordance with the cédula of your Majesty which he [the viceroy] showed me in the first part of December. I also ordered, with the agreement of the council of the hacienda and the approval of the viceroy, that the royal officials of Acapulco, to aid in paying the expense of the purchase of this ship, should load her with goods for trading to the fourth part of her tonnage, for with this she would go free and buoyant for the comfort and good voyage of the viceroy. For the Philippines I ordered the ship San Pedro to be prepared, it appearing that another ship, the San Francisco del Mariscal, [Captain] Gabriel de Rivera, which was in Acapulco, could supply the place of the San Pablo; but afterwards she [the San Pablo] arrived, and your Majesty's two ships, the San Pedro and the San Pablo, have been put in order for the voyage. Although the governor ${ }^{13}$ [of the Philippines] has insisted that the aforesaid San Francisco del Mariscal should go also, and I believe will complain to your Majesty because I did not take that measure, and although there are many religious and people going, and the governor says that the two ships will not hold them, when I have mentioned this on various occasions 
election podra enbarcarse toda la gente y escusarse Vuestra Magestad de fletar el dicho tercer navio san francisco o la costa que se Hiziera en conprarlo que aunque por ventura fuera menor hera peor enpleado por ser navio viejo y mal tratado y de que aqui no avia buena opinion y aunque diversas vezes havia desseado su dueño benderle a Vuestra Magestad nunca se havia quaxado aora se a deshecho del segun me han referido y en bien barato prescio para un fin para que yo le deseava arto ques para la jornada de las californias comprandole los armadores della que yban muy pobres de enbarcacion con solo un navichuelo y lanchas y este otro sera de mucha Reputacion para su jornada y segun me dizen muy util deshaziendole alla para fabricar barcos de los que se usan en esta mar del sur que sean acomodados para descubrir puertos yo e tenido por de mucha ynportancia el quedar con esto bien conpuesta la enbarcacion del birey la del Governador y gente que lleva y la destos armadores que van a las californias aunque no quede navio en el puerto por este año que si bien debe tener algunas conveniencias ${ }^{1}$ comunicadas con personas de buen parescer lo han tenido por escusable a lo menos ogaño siendo tanta la necesidad de que todos hagan viaje y haviendo tan corto Recado que no fuera posible cunplir sin los medios y trasca ${ }^{\mathrm{m}}$ que esta Referida, la nave santa margarita en que va el Virey me escrivieron los oficiales de acapulco en carta de ocho deste como estava aguardando a que el Virey llegase para hazerse a la vela yo creo questo huviera sido dias ha sino huviera caydo malo en el camino donde le toco la gota con calenturas y se detubo dias pero convalesciendo prosiguio su jornada y me escrivio desde cerca del puerto de donde espero que a esta ora abra salido para su viaje y por enbiar a Vuestra Magestad este avisso que tanto podra aliviar el cuydado de las cosas del peru e ydo entreteniendo el pliego deste navio y para que se dispusiesen las del Marques de cañete y de lo que de su partida depende en el despacho de la plata y flota enbie a instancia del birey don luis de belasco al peru con el aviso de su yda a un navichuelo de Vuestra Magestad en que fueron algunos criados del Virey fletando parte del a Mercaderes en veneficio de la Hazienda de Vuestra Magestad para ayuda a la costa que por tantas partes ogaño se junta-Dios guarde a Vuestra Magestad Mexico A 28 de Hebrero 1596.

El CONDE DE MONTEREY.-[Rubricado.]

[En el dorso se lee:] Vista en 27 de maio de I 596 Respondasele que a hecho bien en conprar el navio que dijo i agradezcasele el cuidado que a tenido en acomodar al virei del piru i al governador de las philipinas.[Rubricado.]

1 Evidently a miscopy for "desconveniencias".

m Evidently a miscopy for "traza". 
to the council of the hacienda, the report has always been that there are only five hundred or a few more persons going and that without turning the governor out of the ship in which he is to go (for I ordered, as is right, that he should have his choice), all the people could be embarked and your Majesty saved from hiring the third ship, the San Francisco, or the expense of buying her, which, though it might seem less, would be worse in fact, for she is an old ship, in bad condition, and there is a poor opinion of her here. Although on several occasions her owner had tried to sell her to your Majesty he had never succeeded, and I am informed that he has now disposed of her, at a very cheap price, for a purpose for which I desired her very much, the promoters [armadores] of the expedition to the Californias-which was very poorly equipped for navigation, with only one small vessel and launches-having bought her. They tell me she will be of great value for their voyage and can be made very useful by breaking her apart there and constructing boats of the sort that are used in this South Sea. These will be convenient in exploring ports. I consider it to be a matter of great importance that, with this, the voyage of the viceroy, that of the governor and the people whom he is taking, and that of the promoters who are going to the Californias are well arranged, although there remains no ship in the port for this year. Although this must result in some inconveniences, when it has been explained to persons of good sense they have held it to be excusable, at least for this year, the necessity being so great for all to make the voyage and the provision being so small that it was not possible to carry it out except by the method and scheme related above. The ship Santa Margarita, in which the viceroy is going, as the officials of Acapulco wrote to me in a letter of the eighth of this month, was waiting for the viceroy to come to set sail. I believe this must have taken place some days ago, had he not fallen sick on the road, where he had an attack of gout, with fever, and was delayed for days; but after convalescing he continued the journey and wrote to me from a point near the port, from which I hope that at this hour he will have set out on his voyage. In order to send your Majesty this report, which may so greatly relieve your care for the affairs of Peru, and in order that the affairs of the Marquis of Cañete shall be arranged, since his departure depends upon the despatch of the silver ${ }^{14}$ and fleet, I have been delaying the packet of letters for this ship. At the instance of Viceroy Don Luís de Velasco I sent a small vessel of your Majesty to Peru with advices of his coming, in which went some servants of the viceroy, part of the boat being loaded with merchandise for the benefit of the hacienda of your Majesty in aiding to pay the expense that is being incurred in so many directions during this year. May God keep your Majesty. Mexico, February 28, I 596.

The Count of Monterey. [With rubric.]

[On the back is written:] Examined on May 27, I 596. Let him be informed in reply that he did well in buying the ship which he spoke of, and let him be thanked for the care that he took in making arrangements for the viceroy of Peru and the governor of the Philippines. 
Las capitulaciones que el Virrey Don Luis de Velasco hizo con Don Juan de Oñate gobernador y capitan general de las provincias de la Nueva Mexico en conformidad de las ordenanzas y las moderaciones del Virrey Conde de Monterrey con las conveniencias que se siguen de que confirmen las capitulaciones del Virrey Don Luis y los inconvenientes que traen consigo las dichas moderaciones que hizo el dicho Conde de Monterrey. ${ }^{n}$ [I595?]

I. Capitulacion.-Iten que pueda levantar gente en cualquiera parte de los reynos de su Magestad para la poblacion y pacificacion nombrando para ello los capitanes y oficiales necesarios arbolando banderas y tocando caxas y publicar la jornada, Lo dispuesto en el capitulo 73 de las ordenanzas.

Ordenanza 73.-Dense cedulas para que pueda la ventar gente en cualquiera parte destos nuestros reynos de la corona de Castilla y de Leon y para la poblacion y pacificacion y nombrar capitanes para ello que puedan enarbolar banderas y tocar atambores y publicar la jornada sin que a ellos ni a los que a ella ubieren de ir se les pida alguna cosa.

Moderacion.-Que el poder levantar gente no sea generalmente y siempre sino por esta vez; y que cuando se acabe o fuere necesaria mas pida licencia al Virrey como se concedia a Urdiñola.

Que el nombrar oficiales de guerra no sea siempre que quisiere sino por esta vez y con consulta como se concedia a Urdiñola y que si ubiere de hacerse la gracia que esto para adelante desde agora se entienda por el tiempo que estuviere sugeto al cargo de los Virreyes de esta Nueva España que no lo estando seria en desautoridad suya venir capitanes y oficiales nombrados por otro a levantar gente en ella.

Convenencias de la I. capitulacion. Para jornada de tan gran importancia es muy necesario el poder levantar gente todas las veces convenga asi por lo que toca al mayor servicio de su Magestad en cuyo nombre autoridad conviene que la tenga el gobernador para poder levantarla a su eleccion y voluntad y asi estava en su mano escoger tan calificada y de prendas y tan platica y esperta en semejantes conquistas de indias cuanto es necesario y Juntamente por la confianza que ha de hacer de cada uno donde son menester tan platicos y entendidos soldados como los propios capitanes y oficiales de guerra por ser las que se tiene con los indios muy diferentes que las demas. Porque como el numero de indios es tan excesivo al de los españoles hacese todo con traza y estratagemas y asi es menester que los soldados sean de pedro ${ }^{\circ} \mathrm{y}$ valor que esperen mucho premio y esten a eleccion del gobernador que inmediatamente hace la conquista y ve las ocurrencias de ella estando tan alejado del Virrey de Mexico cuyo recurso es dificilisimo por las mismas razones dichas debe tener mano el gobernador para nombrar los oficiales de guerra. Con que podra premiar a los que la han de hacer y los que en ella fueren trabajando mejor. Y si esto no se hace puedense temer muchos yerros en la eleccion de los tales oficiales y mas si estuviesen dependientes del dicho virrey sin que el gobernador

n A. G. I., Patronato Real, I-I-3/22-3. Copy of transcript in Ayer Collection; copy compared by Miss Clara A. Smith.

- Probably a miscopy for "pecho". 
The articles of agreement which the viceroy, Don Luis de Velasco, made with Don Juan de Oñate, governor and captain-general of the provinces of New Mexico, in accordance with the royal ordinances for such discoveries, ${ }^{15}$ together with the modifications of the viceroy, the Count of Monterey, and with the advantages that follow from the confirmation of the articles of the viceroy, Don Luis, and the disadvantages brought with them by the modifications made by the said Count of Monterey. [1595?]

I. Article. Item: That I shall have the power to recruit men in any part of the kingdoms of his Majesty for the settlement and pacification, naming for it the captains and necessary officials, raising banners, beating drums, and proclaiming the expedition, as is provided in article 73 of the ordinances.

Ordinance 73. Let cédulas be issued granting power to raise men in any part of these our kingdoms of the crown of Castile and León for the settlement and pacification, and to name captains for it, to raise banners, to beat drums, and to proclaim the expedition, without anything being required for them or of those who may go upon it.

Modification. The power to raise men shall not be general nor permanent, but for this occasion only. And when they are used up, or more are necessary, let permission be asked of the viceroy, as was granted to Urdiñola.

The naming of officials of war shall not be for as long a time as he may wish but for this time only and with consultation, as was granted to Urdiñola. And if the favor should be granted him, this from now on shall be understood to be for the time that he may be subject to the charge of the viceroys of New Spain, for if he were not it would be contrary to their authority for captains and officials to be named by another and for people to be raised in it [New Spain].

Advantages of article I. For an expedition of such great importance it is very necessary to be able to raise men whenever they are required, as it conduces to the greater service of his Majesty that the governor shall have authority in his name to be able to raise men at his choice and will, for it would thus be in his power to select those qualified and experienced and expert in such conquests of the Indies, as is necessary, and at the same time [to choose them] for the confidence that must be felt in each one where it is necessary for the soldiers to be as experienced and expert as their own captains and officers of war. For those [wars] which are had with the Indians are very different from others, for, since the number of the Indians is so far in excess of that of the Spaniards, everything is done by tricks and stratagems; therefore it is necessary that the soldiers shall be men of courage and valor, that they shall expect much reward, and that they shall be chosen by the governor who is in immediate charge of the conquest and is a witness of its occurrences, and who is so far away from the viceroy of Mexico that recourse to him is most difficult. For exactly the same reasons the governor ought to have the power to name the officials of war, whereby he can reward those who have to take part in it and those who work the best in it. If this is not done many 
pudiese ponerlos o removerlos viendo y esperimentando que hacian mal sus oficios ó que no eran para ellos.

Ynconvenientes de la I. Moderacion.-Que los virreyes proveeran a los que fueren de su gusto y a los que quisieren los oidores sus criados y parientes con que se ocupan los plazas para los benemeritos y para los que tienen posible para hacer la jornada y llevar otros que tambien la hagan y los favorecidos de los virreyes y ministros siempre son necesitados y que han menester ayuda de todos, y es lo peor lo que le ha sucedido a Don Juan que envio por gente de socorro y por haber de aguardar a que el virrey conde de monterrey diese licencia para que se hiciese se pasaron diez meses antes que fuese el socorro y al cabo no fue de cien hombres que es causa de que no se sepa de D. Juan ni de su egercito desde dos de Marzo de noventa y nueve que fueron las ultimas relaciones $Y$ cartas que se tuvieron suyas.

2. Capitulacion.-Iten que despues de entrado en la dicha mi gobernacion y toma de posesion de ella pueda elegir y nombrar caja real y oficiales reales tesorero Contador y factor y los demas que conviniere a la dicha real caja con salario competente el cual salario se pague de la hacienda que a su magestad perteneciere en la dicha gobernacion. Que se le concede por los capitulos 43 y 64 de las dichas ordenanzas.

Ordenanzas 43 y 64 . - Eligida la tierra provincia y lugar en que se ha de hacer nueva poblacion y averiguada la comodidad de aprovechamientos que puede haber el gobernador en cuyo distrito estuviere o con cuyo distrito confinare declare el pueblo que se ha de poblar si ha de ser ciudad villa ó lugar y conforme a lo que declarare se conforme el consejo republica y oficiales y miembros de ella segun se declara en el libro de la republica de España les dé manera que si ubiere de ser ciudad metropolitana tenga un juez con titulo y nombre de Adelantado o gobernador o alcalde mayor o corregidor o alcalde ordinario que tenga la jurisdiccion universal y juntamente con el regimiento tenga la administracion de la republica. Tres oficiales de la hacienda real. Doce regidores. Dos fieles egecutores. Dos jurados. De cada parroquia un procurador un mayordomo, un escribano del consejo dos escribanos publicos, uno de minas y rejistro, un pregonero mayor, un corregidor de Lonja, dos porteros; y si diocesana ó sufraganea ocho regidores y los demas dichos oficiales perpetuos, para las villas y lugares alcalde ordinario cuatro regidores un alguacil un escribano de consejo y publico, un mayordomo. No habiendo oficiales de hacienda real los pueda nombrar y proveer entre tanto que los proveemos o que van los por nos proveidos.

Moderacion.-Que el poder nombrar oficiales reales con salario sea con la condicion que se le ponia a Urdiñola que no pueda exceder el salario de los oficiales de Mexico.

Convenencias de la 2 capitulacion.-A su magestad importa muy poco poder nombrar ú no a los principios oficiales reales y de que el gobernador lleve facultad para hacerlo se puede esperar que vayan a la jornada 
errors are to be feared in the choice of such officials, and especially if they are dependents of the said viceroy, without the governor having power to appoint them or to remove them when he sees and learns that they are filling their offices badly or that they are not fit for them.

Disadvantages of article $I$, modification. That the viceroys shall provide with supplies those who go at their own choice and those whom the oidores wish to go, their servants and relatives, for they thus take away the places from the deserving and from those who have the means to make the expedition and to take others who might also make it; the favorites of the viceroys and ministers are always necessitous and have to be aided with everything. The worst thing is what happened to Don Juan, who sent for men to help him, and because he had to wait until the viceroy, the Count of Monterey, gave permission for it to be done, ten months passed before the relief went, and at last it did not number one hundred. men, which is the reason why nothing is known of Don Juan or his army since March 2, I $599,^{16}$ when the last reports and letters were received from him.

2. Article. Item: That after I have entered upon my said government and have taken possession of it, I shall have the power to choose and name a royal treasury and royal officials, treasurer, contador, factor, and the others who may be necessary for the said royal treasury, with a suitable salary, the said salary to be paid from the property that will belong to his Majesty in the said government. Let it be granted what is ordered in articles 43 and 64 of the said ordinances.

Ordinances 43 and 64 . When the land, province, and place has been chosen in which the new settlement is to be made, and investigation made of what supply of provisions may be in the possession of the governor in whose district it may be, or upon whose district it borders, let it be declared whether the pueblo that is to be settled is to be a city, town, or village. And in conformity with what is declared let the council of the commonwealth and the officials and members of it be established, as it is stated in the book of the commonwealth of Spain shall be done; so that, if it be a metropolitan city, it shall have a judge with the title and name of adelantado, or governor, or alcalde mayor, or corregidor, or alcalde ordinario, who shall have universal jurisdiction and together with the regimiento shall have the administration of the commonwealth. [In addition there shall be] three officials of the real hacienda, twelve regidores, two executive clerks, two jurymen, and in each parish one attorney, one mayordomo, one clerk of the council, two public clerks, one of mines and registry, one chief town crier, one corregidor de lonja, and two constables. And if it be diocesan or suffragan it shall have eight regidores and the other said officials perpetually. For the towns and villages there shall be an alcalde ordinario, four regidores, one alguacil, one clerk of the council and public clerk, and one mayordomo. If there are no officials of the real hacienda power shall be given to name and provide them in the interval until we shall provide them or until those whom we have provided go. 
hombres de caudal y casados con hijos y familia en confianza de que tiene con que premiarlos y honrarlos y teniendo oficios de asiento permaneceran en la tierra que es lo que mas importa a su magestad y con esto se ensancharan los reinos y no con temores y gravamenes que tan en los principios no sirven de mas que de atemorizar con que cada uno se esta en su casa y despues de ganada la tierra y pacificada le queda á su magestad la manoabierta para nombrar a su voluntad los oficiales reales faltando los que puso el gobernador.

Ynconvenientes de la 2 moderacion.-No tiene su magestad hasta agora en aquellas provincias ningunas rentas y modera el conde que los salarios de los oficiales no excedan a los de Mexico; y no se repara a que estan aquellas provincias a 350 leguas mas adelante por tierra de Mexico donde han de valer las cosas tres doblado y si la tierra es mas rica justo sera que sean mayores los salarios que de los frutos y aprovechamientos della se han de pagar y si no los hubiere ni se pagaren ni hay para que recateallo en especial a los que han de ser el todo en la conquista y ganar la tierra para su rey y señor natural.

3. Capitulacion.-Iten que yo y los tales mis herederos y sucesores en la dicha gobernacion y jurisdiccion hayamos de ser y seamos inmediatos al real consejo de las indias de manera que ninguno de los Vierreys desta Nueva España ni audiencias comarcanas no se puedan entremeter en el distrito del dicho gobierno-Lo proveido en el capitulo 69 de las ordenanzas.

Ordenanza 69.-El y su hijo ó heredero sucesor en la gobernacion y jurisdiccion sean inmediatos al consejo de las indias de manera que ninguno de los virreyes ni audiencias comarcanas se puedan entremeter en el distrito de su provincia de oficio ni a pedimento de parte ni por via de apelacion ni proveer jueces de comision, el consejo de las indias pueda conocer de las causas de la gobernacion de oficio o a pedimento de parte o por via de apelacion y en caso de justicia entre partes conozca por vea de apelacion de las causas civiles de seis mil pesos arriba y en causa criminales de las sentencias en que se pusiere pena de muerte ó mutilacion de miembros.

Moderacion.-Que la independencia que pretende El Virrey y audiencia de Mexico se renuncie en forma concienta estar subordinado a ellos respectivamente en todo lo que fuere guerra y hacienda al Virrey en todo y por todo y en lo que fincare en agravios de justicia á la audiencia y esto hasta en la cantidad que pareciere conveniente y que su magestad sea consultado sobre la escepcion que pretende para que si fuere servido se le conceda.

Conveniencias de la 3. Capitulacion.-Concede su magestad en la ordenanza 69 que los gobernadores sean inmediatos al consejo de las indias y en los reynos y provincias pacificas se guarda tan inviolablemente que ningun Virrey se entremete en el distrito de los gobiernos con ofrecerse 
Modification. That the power to name royal officials with a salary shall be with the condition that was placed upon Urdiñola, namely, that it shall not exceed the salary of the officials of Mexico.

Advantages of article 2. To his Majesty it matters very little whether he has the power to name the first royal officials or whether the governor shall have authority to do it. It is to be expected that married men of fortune, with children and families, will go on the expedition in confidence and that he [the governor] will have the means with which to reward them and honor them, and since they hold settled offices that they will remain permanently in the country, which is what most concerns his Majesty, and with this the kingdoms will be augmented and will not have the fears and burdens which, when they occur so near the beginnings, serve for nothing but to alarm [the people]. In this way each one will be in his own home, and after the country is won and pacified the way will be left open for his Majesty to name at his will the royal officials in case those named by the governor shall fail.

Disadvantages of modification 2. His Majesty has not at present any rents in those provinces, and therefore the Count makes the modification that the salaries of the officials shall not exceed those of Mexico. But he does not take notice that those provinces are 350 leagues further inland than Mexico, where the prices of things must be three times as high. If the land is richer it will be right that the salaries shall be greater, since they are to be paid from the fruits and products of it; if there are none they will not be paid, nor is there any reason for reducing them, especially for those who are to be the chief ones in the conquest and in winning the land for their king and natural lord.

3. Article. Item: That I and my said heirs and successors in the said government and jurisdiction must be and shall be under the immediate control of the royal Council of the Indies, so that none of the viceroys of this New Spain or of the neighboring audiencias shall have the power to interfere in the administration of the said government-as is provided in article 69 of the ordinances.

Ordinance 69 . He and his son or heir or successor in the government and jurisdiction shall deal directly with the Council of the Indies, in such a manner that none of the viceroys or neighboring audiencias shall have the power to interfere in the administration of his province, either officially or on petition of a litigant or by writ of appeal, nor to provide commissioned judges. The Council of the Indies shall have the power to try the cases of the government officially or on petition of a litigant or by writ of appeal; in case of litigation between parties it shall try by writ of appeal civil cases of six thousand pesos up, and criminal cases in which the sentences impose pain of death or mutilation of members.

Modification. That the independence that he asks for of the viceroy and Audiencia of Mexico shall be renounced, and he shall formally con-sent to be subordinated to them respectively, to the viceroy in everything and for everything in all that has to do with war and finances, and to the Audiencia in what touches upon grievances of justice, this even to the 
todos dias ocasiones en que podello hacer y cosas que parece fuera justo que lo hiciesen y quiere el conde que Don Juan sea inmmediato al Virrey en lo que fuere guerra que el esta haciendo a su costa y riesgo estando tan distante del y mas en materias de guerra y conquistas cuyas execuciones no piden dilacion en las execuciones de lo que conviene hacerse y en lo toca a la hacienda real no la teniendo de presente su magestad no hay para que poner dependencia hasta que la haya que entonces su magestad dara el orden que se ha de tener y en lo que toca a la justicia la ordenanza quiere que este pendiente de solo el consejo real de las indias e inmediatamente sugeta a los gobernadores cuanto y mas que estando aquel reyno tan distante de Mexico y siendo tan rico y delante gente es claro de entender que muy en breve se podra en el audiencia y el propio Virrey pareciandole cosa grave el moderar esta tan importante capitulacion dio resguardo con decir que fuese su magestad consultado sobre la dicha ecepcion para que si fuere servido se le conceda.

Ynconvenientes de la 3 Moderacion.-Una de las cosas que mas ha resfriado a los que estaban movidos para esta jornada es lo poco que el conde ha ayudado en autorizar la persona de Don Juan porque como le forzó a Don Cristobal su hermano renunciase el derecho de ser inmediato al consejo de indias parecioles a todos que por cualquier ocasion le habia de quitar y embiar otro en su lugar y asi no se dispusieron a ir los muchos que estaban movidos porque todo cuanto el conde ha hecho ha sido disminuir y acortar los poderes y facultades a Don Juan llamandole siempre de vos en cuantas cartas le escribio bien diferentemente de lo que el Virrey Don Luis de Velasco padre deste virrey Don Luis hizo con Don Tristan de Arellano cuando fue a la florida que desde Mexico se fue con el hasta la ciudad de Tlaxcala que hay veinte leguas donde con alarde de todos los soldados se despidio del llamandole de Señoria con que autorizo ser persona y dio esfuerzo a la gente y jornada que lo uno y lo otro ha faltado en esta y cada dia se hechara mas de ver si su magestad no alienta y favorece lo que esta tan desfavorecido y siempre ha estado del Conde de Monterrey.

4. Capitulacion.-Iten que pueda traer cada año dos naos para provision de la tierra y labor de las minas que hubiere libre de almojarifazgo derechos.-Que se le concede en conformidad del capitulo 79 de las ordenanzas.

Ordenanza 79.-Pueda llevar cada año dos navios con armas y provision para la tierra y labor de las minas libre de almojarifazgo de lo que se ha pagar en las indias con que salgan con las flotas que destos reynos fueren a tierra firme ó Nueva España estando prestas o cuando para ello se les diere provision.

Moderacion.-Que no pueda poner en egecucion el traer navios en la mar del norte y carrera de España hasta segun da orden y licencia del Virrey por lo que importa que se traigan con tiento en el descubrimiento de puertos en aquella mar que es medio necesario para lo [bien] de las naos. 
amount that may seem right to it. Let his Majesty be consulted in regard to the exemption that is asked for, so that if it pleases him he may grant it.

Advantages of article 3. His Majesty grants in ordinance 69 that the governors shall be under the immediate control of the Council of the Indies, and that in the pacified kingdoms and provinces this shall be practised so inviolably that no viceroy shall interfere in the administration of the governments, for every day occasions arise in which they have the power to do it and affairs in which it seems right [to them] that they should do so. The Count wishes that Don Juan shall be under the control of the viceroy in what concerns the war which he is carrying on at his own expense and danger, although he is so distant from him, especially in matters of war and conquests, whose execution does not admit delay in carrying out what it is necessary to do. And in what touches upon the real hacienda, as his Majesty has none at present [in that country] there is no occasion for disputing about it until it exists, and then his Majesty will give the order that is to be obeyed. And as to what concerns justice, the ordinance requires that it shall depend solely upon the royal Council of the Indies and be immediately subject to the governors, the more so as, since this kingdom is so distant from Mexico, and is so rich and full of people, it is clearly evident that in a very short time it will be placed under the jurisdiction of the Audiencia. The viceroy himself, perceiving that it is a very serious thing to modify this very important article, guarded himself by saying that his Majesty should be consulted in regard to the said exemption, so that if he pleased he could grant it.

Disadvantages of modification 3. One of the things that has done most to moderate the ardor of those who were moved to make this expedition is the little aid which the Count has given in conferring personal authority upon Don Juan, for, since he compelled Don Cristóbal, his brother, to renounce the right to be under the immediate control of the Council of the Indies, it seemed to everybody that for any occasion he would take it from him and send another in his place. For this reason many who were inclined to go did not get ready, for everything that the Count has done has been to diminish and cut down the powers and dignity of Don Juan, always addressing him as "you" in such letters as he wrote to him, very differently from what the viceroy Don Luís de Velasco, father of this viceroy Don Luís, did with Don Tristán de Arellano when he went to Florida, for he accompanied him from Mexico as far as the city of Tlaxcala, twenty leagues away, where, with the applause of all the soldiers, he took leave of him, calling him "your lordship", whereby he dignified him as a personage and gave strength to the people and expedition. Both the one and the oher have been lacking in this, and it will become more evident every day if his Majesty does not encourage and favor what is now so discouraged, and always has been, by the Count of Monterey.

Article 4. Item: That I shall have the power to bring every year two ships for the provisioning of the country and for the exploiting of what mines there may be, free of import duties. Let it be granted to him in conformity with article 79 of the ordinances. 
Conveniencias de la 4 capitulacion.-Parece muy conveniente mandar que en la mar del norte no se traigan navios sin consultallo con el Virrey por lo que se debe andar con tiento en aquella mar en hecho de descubrir puertos lo que no se entiende en la mar del sur que seria una de las cosas de mas importancia que pueden suceder en aquellos reynos descubrir puertos en aquella costa asi por la facilidad para la conquista que Don Juan hace como por el gran bien que se haria para los navios y flotas que van y vienen a las filipinas y asi para la mar del sur podra valerse desta capitulacion como se le concede sin que le perjudique la moderacion del conde.

5. Capitulacion.- - Yten pueda tasar los tributos que los indios hubieren de dar conforme a los frutos de su tierra yo y mis sucesores ansi los que de ocurrir ${ }^{\mathfrak{p}}$ al Rey nuestro señor como a los demas encomenderos o subirlos ó bajarlos ó comutarlos en cualquier manera como me pareciere a mi y a mis sucesores con libre y absoluto poder sin dependencia del Virrey y audiencia. Que se le concede lo que dispone el capitulo 145 de las ordenanzas.

Ordenanza I45.-A los indios que se redujeren a nuestra obediencia y se repartieren se le persuada que en reconocimiento del señorio y jurisdicion universal que tenemos sobre las indias nos acudan con tributos en moderada cantidad de los frutos de la tierra segun y como se dispone en el titulo de los tributos que desto tratan y los tributos que ansi mismo dieren queremos que los lleven los españoles a quien se encomendaren porque cumplan con los cargas a que estan obligados, reservando para nos los pueblos cabeceras y los puertos de mar y de los que repartieren la cantidad que fuere menester para pagar los salarios a los que han de gobernar la tierra y defenderla y administrar nuestra hacienda.

Moderacion.-Que si pudieren enderezarse y persuadirse los indios a ofrecer y consentir tributos como su magestad manda que se procure la tasacion que de ello se hubiere de hacer sea con parecer de los oficiales reales y prelados de las religiones como se mandaba a urdiñola y no a solas.

Conveniencias de la 5 Capitulacion.-A los virreyes por estar en nombre de su magestad y por tener el negocio presente se les da tan absoluto poder en todo lo que es gobierno y corriendo la misma razon en el gobernador justo es que a quien tiene los partes necesarias para serlo y hacer una jornada de tan gran importancia pues entre muchos se escogio para que la hiciese tenga el mismo poder para que solo tase los tributos a los indios que con la esperiencia que tiene delo que pagan todos en la Nueva España los impondra mandando a los principios que los paguen de los frutos de la tierra como se hizo en Nueva España y cuando haya permuta es justo que se haga mandandolo su magestad y su real consejo de indias que pues el gobernador ha de dar larga razon todos los años siempre se iva advirtiendo y mandando lo que debe hacer sin que haya quien tenga igual poder al suyo.

"Evidently a miscopy for "acudir". 
Ordinance 79. He shall have the power to bring each year two ships with arms and provisions for the land and for the exploiting of the mines free of the import duties that must be paid in the Indies, on condition that they shall go out with the fleets that may be going from these kingdoms to Tierra Firme or New Spain if they are ready or when provision shall have been made for them.

Modification. That the plan of bringing ships by the North Sea and the course from Spain cannot be put into execution except by order and permission of the viceroy, because it is important that they shall be conducted with attention to the exploration of ports in that sea, which is a necessary measure for the good of the ships.

Advantages of article 4. It seems very proper to order that ships shall not be brought by the North Sea without consultation with the viceroy, for the reason that it is necessary to proceed with caution in that sea in the act of exploring ports, which is not required in the South Sea. It would be one of the most important things that could happen in those kingdoms to explore ports on that coast, not only for the facilitating of the conquest that Don Juan is making, but also for the great good that it would be for the ships and fleets that go to and come from the Philippines. However, this article may be made use of for the South Sea, as it is granted without prejudicing the modification of the Count.

Article 5. Item: That I and my successors shall have the power to appraise the tributes which the Indians will have to give in accordance with the fruits of their land, both those which must go to the king, our lord, as well as to the other encomenderos, and to raise or lower or commute them in any manner that may seem right to me and to my successors, with free and absolute power and independent of the viceroy and the Audiencia. Let him be granted what is provided in article 145 of the ordinances.

Ordinance I45. The Indians who may be reduced to our rule and divided among us shall be persuaded, in recognition of the lordship and universal jurisdiction which we have over the Indies, to assist us with tributes in moderate quantity of the fruits of the land, as is provided in the Titulo de los Tributos ${ }^{17}$ which treats of this. And we desire that the tributes which they thus give shall be collected by the Spaniards to whom they [the Indians] are apportioned, so that they may fulfill the duties with which they are charged, reserving to us [the king] the principal cities and the sea-ports, and from those [tributes] that are divided the sum that may be necessary to pay the salaries of those who are to govern the land and defend it and administer our exchequer.

Modification. That if the Indians can be guided and persuaded to offer and consent to tributes as his Majesty orders, an effort shall be made to have the appraisement of it made with the opinion of the royal officials and the prelates of the religious orders, as was required of Urdiñola, and not by themselves alone.

Advantages of article 5. To the viceroys, because they rule in the name of his Majesty and have the business present before them, absolute power is given in all governmental matters. Applying the same reasoning to the 
Ynconvenientes de la 5 Moderacion.-Una de las cosas de mas importancia que se puede ofrecer en aquella jornada es el tasar el tributo de los indios y como tal ha de tener solo mano el gobernador para imponerlos pues no siendo asi sino con parecer de los religiosos y oficiales reales, los oficiales para aprovecharse de la facultad que se les da, con esta moderacion contradicion de lo que el gobernador mandare aunque sea muy justo por solo mostrarsele iguales y si los frailes tienen mano en esto no daran consentimiento para que se les señale tributo antes querran que sean libres y escentos como vemos por esperiencia que hay hoy muchos que lo procuran en todas las indias y aun tratan de esto en estos reynos y algunos muy pesadamente en deservicio de su magestad y en gran daño y destruccion de aquellos reynos.

6 Capitulacion.-Yten que a los soldados conquistadores y pobladores que fueren a la dicha jornada debajo de mi vandera o de los dichos mis sucesores pueda repartir los dichos pueblos o vasallos que me pareciere y que esto se entienda con los que fueren segundos y terceros conquistadores y pobladores y los demas que ayudaren a la conquista y pacificacion de aquella tierra y han de gozar desta encomienda ellos y sus sucesores en las vidas que concede la ordenanza 58: Quedando asi mismo a cargo de Vuestra Señoria el suplicar a su magestad que por lo menos sea por otras tres vidas. Que se le conceden en conformidad del capitulo 58 de las ordenanzas y se escribira a su magestad para que le haga merced y gratifique sus servicios como está dicho en el primer capitulo desta capitulacion.

Ordenanza 58.-Puedan encomendar los indios vacos y que vacaren en los distritos de las ciudades de españoles que ya estuvieren pobladas por dos vidas y en lo de las que se poblaren por tres vidas dejando los puertos y cabeceras para nos.

Moderacion.-Que de las encomiendas de indios que hiciere haya de dar cuenta a su magestad y traer confirmacion dentro tres años.

Conveniencias de la 6 capitulacion.-Su magestad hace esta jornada a costa de Don Juan y de los que van con el y con ser de tan grande gasto y costa no la tiene su magestad en ella ni tendra hasta acabarla: y lo que movio a Don Juan y los conquistadores para hacerla de mas del gran servicio a Dios nuestro señor y el de su magestad fue el gran premio que se les prometio y el que han de tener y respecto desto han gastado tan gran suma de hacienda para disponer la jornada y han padecido y padecen tantos trabajos en ella y si antes que la acabasen se les acorta el poder y las gracias y mercedes que su magestad of rece por las ordenanzas reales a Don Juan

- y a los que con tanto gusto estan sirviendo se acabaran las fuerzas y perderan los brios con que han empezado con tanta pujanza; y asi es muy justo que Don Juan tenga mano de encomendar sin haber de dar parte a su magestad sino conforme los servicios que cada uno tuviere que esta gran merced es la que ha de hacer la jornada y la que ha de acabarla con tan grande aumento del patrimonio real que della ha de resultar.

Ynconvenientes de la 6 moderacion.-Si se les manda que haya de dar cuenta a su magestad y traer confirmacion parecerles ha dudoso y que han 
governor, it is just that one who has the necessary abilities to be it [governor] and to make an expedition of such great importance (for he was chosen among many to do it), shall have the same power himself alone to appraise the tributes of the Indians. For, with the experience that he has had of what all pay in New Spain, he will order that they shall pay from the fruits of the land, as was done in New Spain. And if there be any change it is proper that it shall be done by order of his Majesty and his royal Council of the Indies, and since the governor must give a long report every year he will be informed and advised as to what he must do without any one having equal power to his.

Disadvantages of modification 5. One of the most important things connected with that expedition is the fixing of the tributes of the Indians. As such the governor alone must have power to impose them, for, if it be not so, but with the opinion of the royal officials and the religious, the officials, in order to use the power thus given them, will oppose what the governor orders, even though it may be right, in order to show themselves to be his equals. And if the friars have a hand in this they will not give their consent for tributes to be imposed upon them [the Indians], but will rather desire that they shall be left free and exempt, as we have seen by experience, for there are to-day many who are trying to have this done in all the Indies and are even attempting it in these kingdoms, some very determinedly, to the disadvantage of his Majesty and the great injury and destruction of those kingdoms.

Article 6. Item: That I shall have the power to divide among the soldiers, conquerors, and settlers who may go on the said expedition under my banner or that of my said successors the said pueblos or vassals as may seem right to me, and that this shall be extended to those who may be the second or third conquerors and settlers, and to others who may aid in the conquest and pacification of that land, and that they and their successors shall enjoy this encomienda for the lives granted in ordinance 58 . Also it shall be charged to your lordship to supplicate his Majesty to extend it for at least three more lives. Let them be granted to him in conformity with article 58 of the ordinances, and let his Majesty be written to so that he will show him the favor and reward his services, as is stated in the first article of this agreement.

Ordinance 58 . Let them be given power to apportion the Indians who are or may become unattached in the districts of the cities of Spaniards that may have been settled for two lives, and in those that will be settled for three lives, leaving the ports and capitals for us [the king].

Modification. That account must be given to his Majesty of the apportionments of Indians that he may make, and confirmation obtained within three years.

Advantages of article 6. His Majesty is making this expedition at the expense of Don Juan and of those who are going with him, and, although it is an affair of such great expense and cost, his Majesty has not done with it nor will he have until it is finished. What moved Don Juan and the conquerors to do it, besides the great service to God, our Lord, and that of his Majesty, was the great reward that was promised them and which 
de gastar mas en esto que lo que les cuesta la jornada como sucedera si cada uno no viene a su propio negocio; y lo que mas importa a su magestad es que el mundo entienda que el governador tiene mano para encomendar y para poner y quitar y con esto dalle fuerza y gente con que se ha de hacer la jornada y lo demas es quitarsela como ha sucedido desde que el conde de Monterrey hizo moderaciones y esto no es novedad pues hoy en dia en algunas provincias conquistadas y pacificas del peru y Nuevo reyno y en la de Guatemala los presidentes de las audiencias dan estas encomiendas en vacando por sola su voluntad sin mas dependencia y con esto esta poblada la tierra de gente noble y segura y se conserva en paz.

7. Capitulacion.-Iten que a los dichos conquistadores y pobladores se les ha de comunicar la merced que su magestad les concede en la ordenanza 99 haciendoles hijos dalgo de solar conocido a ellos y sus descendientes y para que gocen todas las honoras y preeminencias y puedan hacer todas las cosas que todos los hombres hijos dalgo y caballeros de los reynos de Castilla segun fuero leyes y costumbres de Castilla puedan y deban hacer y gozar conforme a la dicha ordenanza.- que se le concede lo que dispone el capitulo 99 de los ordenanzas.

Ordenanza 99.-A los que se obligaren de hacer la dicha poblacion y la hubieren poblado y cumplido su asiento por honrar sus personas y de sus descendientes y que de ellos como de primeros pobladores quede memoria loable, los hacemos hijos dalgo de solar conocido a ellos y a sus descendientes legitimos para que en el pueblo que poblaren y en otras cualesquier partes de las indias sean hijos dalgo y personas nobles de linage y solar conocido y por tales sean habidos y gocen de todas honras y preeminencias y puedan hacer todas las cosas que todos los hombres hijos dalgo y caballeros destos reynos segun fuero leyes y costumbres de España puedan y deban hacer y gozar.

Moderacion.-Que las prerrogativas que los conquistadores han de gozar conforme a la dicha ordenanza se entienda en los que duraren en la conquista cinco años como se hacia con Urdiñola.

Convenencia de la 7 capitulacion.-Las propias razones militan en la 7 capitulacion que quiere el conde que para haber de gozar los conquistadores de las prerrogativas conforme los hijos dalgo de Castilla se entienda en los que duraren cinco años en la conquista; y no es tierra la de Nueva Mexico donde sean menester estos gravamenes siendo de tan buen temple y de tanta abundancia de gente lo que se ha de procurar son muchos que bayan á ella y todos gocen de la merced que su magestad les hace sin limite de tiempo que esto les ha de llevar a ella.

Ynconvenientes de la 7 moderacion.-Porque si les atemorizan que han de estar cinco años aunque los lleven a ser señores no iran como se tiene por esperiencia en las islas Filipinas que con ser tierra tan rica y tan abundante de todo no hay quien se quiera alistar para ir a ella por la gran dificultad con que los gobernadores dan licencia para que vengan de ella, y lo que para esta jornada es menester es mucho premio a los que la hicieren que el gobernador sabra a quien ha de encomendar y el que ha perma- 
they must have, and in consideration of which they have spent a very great sum of money to prepare for the journey, and have suffered and are suffering great troubles in it. And if before they complete it they are deprived of the power and grants and favors which his Majesty offers by the royal ordinances to Don Juan and those who are serving with such pleasure, their strength will be exhausted and the ardor lost with which they have begun so strongly. It is therefore just that Don Juan shall have the power to apportion the Indians, without having to give account to his Majesty, but in accordance with the services that each one of the conquistadores may have given, for this great favor is what is needed to make the expedition and to bring it to completion, to the great increase of the royal patrimony that must result from it.

Disadvantages of modification 6. If they are ordered to give account to his Majesty and to secure confirmation of it, it will appear doubtful to them and that they will have to spend more in this than the expedition will cost them, as will happen if each one does not come in his own behalf. What is most important to his Majesty is that the world shall understand that the governor has the power to apportion [the Indians] and to appoint and remove [officials], for this will give him strength and people with which to make the journey, while the other is to take it from him, as has happened since the Count of Monterey made modifications. This is nothing new, for to-day in some of the conquered and pacified provinces of Peru and the new kingdom ${ }^{18}$ and in that of Guatemala the presidents of the audiencias give these apportionments when they fall vacant [en $v a-$ cando] by their own authority and without subordination to anyone else, and by this means the land is settled with noble and reliable people and is kept in peace.

Article 7. Item: That to the said conquerors and settlers, the favor which his Majesty grants them in ordinance 99 shall be extended, making them and their descendants gentlemen of noble family, so that they may enjoy all the honors and privileges and may be empowered to do all the things that all nobles and knights of the kingdoms of Castile, according to the statutes, laws, and customs of Castile, have the right to do and enjoy, in conformity with the said ordinance. Let him be granted what is provided in article 99 of the ordinances.

Ordinance 99. In order to honor the persons of those who shall obligate themselves to make the said settlement, and who shall make the settlement and fulfill their agreement, and their descendants, and so that there shall remain honorable memory of them as the first settlers, we make them and their legitimate descendants gentlemen of noble estate, so that in the pueblos that they may settle and in all other parts of the Indies they shall be gentlemen and nobles of recognized lineage and estate. And they shall be received as such and shall enjoy all the honors and privileges and have the right to do all the things that all gentlemen and knights of these kingdoms, according to the statutes, laws, and customs of Spain, have the power and right to do and enjoy.

Modification. That the prerogatives which the conquerors are to enjoy in conformity with the said ordinance are to be understood as applying 
necer o no y con la confirmacion de las capitulaciones que hizo el Virrey Don Luis de Velazco hara su magestad la jornada y la podra acabar Don Juan en pocos años se remediara tan grande y pernicioso estorvo como el que la jornada ha ténido con las moderaciones que hizo el conde de Monterrey y siempre iva adelante sin que haya quien se quiera alistar hasta que se entienda que su magestad manda y gasta fue gocen de las prerrogativas que les conceden las ordenanzas reales y que ha de guardar el primero asiento y capitulaciones del Virrey Don Luis de Velasco en virtud del cual se animaron a querer ir muchos, y en oyendo las moderaciones del conde de Monterrey se entiviaron y quedaron pareciendoles y con mucho fundamento que arriesgan sus vidas y haciendas sin esperanza de Premio. 
only to those who shall remain in the campaign for five years, as was done with Urdiñola.

Advantages of article 7 . The same reasons that militate for article 7 are against what the Count wishes-that in order for the conquerors to have the right to enjoy prerogatives in accordance with the noblemen of Castile it shall be understood that it shall apply only to those who shall remain for five years on the campaign. New Mexico is not a land where these obligations are necessary, for it is a land of good climate and a great abundance of people. What should be done is to induce many people to go there [by promising] that all shall enjoy the favor which his Majesty grants them without limit of time that they are to remain there.

Disadvantages of modification 7 . If they are threatened with having to remain there for five years, even though they shall come to be gentlemen, they will not go. This has been experienced in the Philippine Islands, for, although it is such a rich land and so abundant in everything, no one wishes to enlist to go there because of the great difficulty in getting permission from the governors to come away. What is necessary for this expedition is a large reward to those that make it, and the governor will know to whom he ought to apportion [Indians] and who ought to remain or not. With the confirmation of the articles made by the viceroy, Don Luís de Velasco, his Majesty would make the expedition and Don Juan could finish it in a few years, and the great and pernicious disturbance which the expedition has endured from the modifications made by the Count of Monterey would be remedied, and it would proceed. No one wishes to enlist until it is understood that his Majesty orders that they shall enjoy the prerogatives that are granted them by the royal ordinances, and that the first agreement and articles made by the viceroy, Don Luís de Velasco, are to be observed, in virtue of which many were inspired to go, but upon hearing the modifications of the Count of Monterey they lost their zeal, for it seemed to them, with much reason, that they would be risking their lives and property without hope of reward. 
[Nota de lo que ofrecen Don Juan de Oñate y Don Pedro Ponce de León para hacer el descubrimiento, pacificación y población de Nuevo Mexico. I596? ] $]^{q}$

Lo que ofrece Don Juan de Oñate: Lo que Don Pedro Ponce de León ofrece mas que Don Juan es lo siguiente :

De doscientos hombress para arriba aderezados de todo lo necesario y bastimentos para llegar a las poblaciones a su costa y de los dichos soldados sin que su Magestad sea obligado a dar sueldo mas del que su hacienda y voluntad les diere. Mil y 500 pesos de arina y mays. 500 pesos de trigo para sembrar. 500 pesos de tasajos y carne.

Mil cabezas de ganado mayor.

Tres mil ovejas.

Mil carneros.

Mil cabras.

Ioo cabezas de ganado prieto.

I 50 potros.

I 50 yeguas.

Dos pares de fuelles con su recado de herreria.

4 pares de fuelles para minas.

2000 pesos de herrage con su clavo. 500 pesos de calzado.

500 pesos de medicina.

600 pesos de yerro labrado. ${ }^{\mathrm{r}}$

500 pesos de cosas para rescatar y regalar indios.

200 pesos de papel.

500 pesos de jerga y sayal.

20 carretas de buyes abiados de todo lo necesario.

Todo lo sobredicho se ofrece a llevar fuera del matalotage y sustento de los soldados hasta llegar a las poblaciones porque antes no se a de tocar a lo referido.
Cien hombres mas y todos de á caballo.

Diez mil reales mas.

7000 reales mas.

2400 reales mas.

Mil mas.

Dos mil mas.

Dos mil mas.

Dos mil mas.

300 mas.

I0O mas.

Ioo mas.

Cuatro mas.

Cuatro mas.

6000 reales mas.

4000 reales mas.

8000 reales mas.

6000 reales mas.

8000 reales mas.

Iooo reales mas.

8000 reales mas.

Diez mas.

Lo mismo ofrece Don Pedro.

q A. G. I., Patronato Real, I-I-3/22-I2. Copy of transcript in Ayer Collection; copy compared by Miss Clara A. Smith.

Immediately following this item in Oñate's original contract occurs the following item: "Iten seiscientos pesos de hierro por labrar." See p. 228. 
[Statement of what Don Juan de Oñate and Don Pedro Ponce de León offer for the exploration, pacification, and settlement of New Mexico, I596?]

What Don Juan de Oñate offers :

Two hundred men and over, equipped with everything necessary and provisions sufficient to reach the settlements, at his own expense and that of the said soldiers, without his Majesty being obliged to pay them any salary beyond what he [Don Juan] will voluntarily give them from his own funds.

I 500 pesos in flour and maize. 500 pesos in wheat for planting. 500 pesos in jerked beef. Iooo head of cattle. 3000 sheep for wool. IOoO sheep for mutton. I0oo goats.

Ioo head of black cattle.

I 50 colts.

I 50 mares.

Two pairs of bellows with their equipment of irons.

Four pairs of bellows for mines. 2000 pesos in iron for horse shoes with nails.

500 pesos in footgear.

500 pesos in medicine.

600 pesos in iron tools. ${ }^{19}$

500 pesos of things for trading gifts to the Indians.

200 pesos of paper.

500 pesos of frieze and sackcloth.

20 ox carts provided with everything necessary.

All the above he offers to take, over and above the supplies and food for the soldiers until they reach the settlements, for the abovementioned is not to be touched before then.
What Don Pedro Ponce de León offers more than Don Juan is as follows :

One hundred men more, all mounted.

I0000 reales more.

7000 reales more.

2400 reales more.

IOOO more.

2000 more.

2000 more.

2000 more.

300 more.

Ioo more.

roo more.

Four more.

Four more.

6000 reales more. 4000 reales more.

8000 reales more.

6000 reales more.

8000 reales more. Iooo reales more.

8000 reales more.

Io more.

Don Pedro offers the same. 
Ofrece a llevar mas para el adorno de su persona.

25 caballos.

25 mulas de carga aparejadas. 2 carrozas con sus mulas.

Seis sillas estradiotas.

Seis sillas ginetas.

Seis adargas.

Seis lanzas.

doce partesanas.

seis cotas.

seis escarcelas.

seis celadas con sus vistas. ${ }^{t}$

seis pares de armas de caballo.

Seis arcabuces.

Seis espadas y dagas.

Dos coseletes enteros.

Dos sillas de armas.

Seis cueros de ante.

Lo que se le concede a D. Juan de Onate a lo que pide.

Cap. $\mathrm{I}^{\circ}$. que se le darian cinco sacerdotes y un lego cuatro campanas y lo demas necesario para ellos a costa de su Magestad.

$2^{\circ}$ que se le daria la polvora y municion que pareciese necesaria por aquella vez y tres piezas de campana que estuviesen por del Rey y treinta quintales de polvora y cien de plomo.
Otros tantos demas de otros 30 que a de dar a 20 criados que llevara tambien armados como los 300 hombres que tiene of recidos.

8 mas.

Estas no quiere llevar Don Pedro sino en su lugar seis carros herrados con sus mulas.

Seis mas.

Seis mas.

Seis mas.

Seis mas.

24 mas.

6 mas.

6 mas.

6 mas.

otras tantas.

44 mas.

44 mas.

otros tantos.

las mismas.

24 mas.

Añade Don Pedro que no ofrece don Juan.

4 rodelas aceradas con sus morriones.

50 Mosquetes.

50 ballestas.

Lo que se le concede á Don Pedro y el ofrece.

Don Pedro ofrece de llevar seis religiosos y darles ornamentos calices y campanas todo a su costa.

Parece al consejo que se le den a Don Pedro cuatro piezas que esten por su Magestad y cuarenta quintales de polvora y ciento treinta de plomo.

s Immediately following this item in the original contract occurs the following:

"Dos Carros herrados con sus Mulas." See p. 228.

t "Sobrevista," in the original contract. 
He offers to take besides for his personal equipment the following: 25 horses

25 pack mules with harness. 2 coaches with their mules. ${ }^{20}$

Six light cavalry saddles.

Six troopers' saddles.

Six leather shields.

Six lances.

Twelve halberds.

Six coats of mail.

Six cuishes.

Six helmets with beavers.

Six sets of horse armor.

Six harquebuses.

Six swords and daggers.

Two complete coats of armor.

Two stands of arms.

Six buckskin jackets.

What is granted to Don Juan for what he asks:-

Article I. That there be given to him five priests and one lay brother, four bells, and all else that is necessary for them at the cost of his Majesty.

2. That there be given to him the powder and ammunition that may seem necessary for that time; three field-pieces, at the king's expense; thirty quintals of powder; and one hundred quintals of lead.
As many more, besides thirty that are to be given to twenty servants that he would take also armed like the 300 men whom he has already offered.

8 more.

These Don Pedro does not wish to take, but in their place six iron shod carts with their mules.

Six more.

Six more.

Six more.

Six more.

24 more.

6 more.

6 more.

6 more.

As many more.

44 more.

44 more.

As many more.

The same.

24 more.

Don Pedro adds that which Don Juan does not offer, namely:

4 steel shields and helmets.

50 muskets.

50 crossbows.

What is granted to Don Pedro and what he offers:-

Don Pedro offers to take six religious and give them ornaments, chalices, and bells all at his expense. It is the opinion of the Council that

Don Pedro should be given four field-pieces at his Majesty's expense and forty quintals of powder and 'one hundred and thirty quintals of lead. 
3. Que se le diese una docena de cotas de la armeria de su Magestad pagando el costo.

$4^{\circ}$. Que se le darian diez quintales de azogue con obligacion de pagarlos y facultad de tomar carros pagandolos.

$5^{\circ}$. Que se le daria instruccion asi para la prision de los culpados que han entrado en nuevo Mexico contra orden como para la pacificacion y descubrimiento de aquellas provincias.

6. Que se le darian los indios que pareciesen ser de aquella provincia $\mathrm{y}$ una india que trujeran doncella para interpretes.

7. Que cumpla la orden de su Magestad que esta dada en las ordenanzas de nuevas poblaciones que son del capitulo 23 al 56 .

$I^{\circ}$ Que se le concede lo que por los capitulos de las ordenanzas de nuevas poblaciones á los que hacen semejantes jornadas.

$2^{\circ}$ Pide titulo de adelantado desde luego que entre y tome la posesion de la tierra.

Concedesele lo que en las dichas ordenanzas de nuevas poblaciones.

$3^{\circ}$ Que se le daran de la caja real de Sacatecas seis mil pesos prestados por seis meses.

$4^{\circ}$ Pidio que los soldados pobladores y pacificadores primeros segun dos y terceros les pueda dar pueblos de encomiendas por tres vidas. Concediosele lo que en el
No lo pide Don Pedro.

Tampoco esto.

Parece se le puede dar a Don Pedro la misma instruccion que a de guardar puntualmente y se le remite el perdon ó castigo de los que hubieren entrado contra el bando de los Virreyes en el nuevo Mexico.

Esto se le concede.

Lo mismo parece ordenar a Don Pedro.

No lo quiere por agora Don Pedro.

Tampoco quiere esto.

Parece que se le conceda lo mismo a Don Pedro. 
3. Let him be given one dozen coats of mail from the armory of his Majesty on condition that he pay for them.

4. Let him be given ten quintals of quicksilver with the obligation to pay for them, and the right to take carts by paying for them.

5. Let him be given instructions both for the arrest of the guilty persons who have entered New Mexico contrary to orders, as well as for the pacification and exploration of those provinces.

6. Let him be given the Indians who seem to be of that province, and an Indian woman who was brought away as a girl, to serve as interpreters.

7. Let the order of his Majesty which is given in the ordinances of new settlements, articles 23 to $56,{ }^{21}$ be carried out.

I. Let him be granted that which is given to those who make similar expeditions by the articles of the ordinances for new settlements.

2. He asks for the title of adelantado as soon as he enters and takes possession of the land.

Let him be granted this according to what is provided in the said ordinances for new settlements.

3. Let him be given from the royal treasury of Zacatecas a loan of six thousand pesos for six months.

4. $\mathrm{He}$ asked for the power to give to the soldiers, settlers, and pacificators, first, second, and third, pueblos of Indians encomendados for three lives. It was granted to
Don Pedro does not ask for this.

Nor this.

It is the opinion [of the Council] that Don Pedro should be given the same instruction, which he should observe strictly, and that he should be given power to pardon or chastise those who entered contrary to the edict of the viceroys into New Mexico.

This is granted to him.

It is the opinion that the same should be granted to Don Pedro.

Don Pedro does not ask this at present.

Nor does he ask for this.

It is the opinion that the same should be granted to Don Pedro. 
capitulo 58 de las dichas ordenanzas de nuevas poblaciones.

5. Pide que a los pobladores y conquistadores se les den tierras de pasto y labor y estancias.

Lo concedido en el capitulo 85 de las ordenanzas.

$6^{\circ}$ Concedesele lo que por el capitulo 99 de las dichas ordenanzas acerca de gozar todas las preeminencias de hijosdalgo los pobladores.

$7^{\circ}$ Concedesele que pueda nombrar desde luego maese de campo y los mas capitanes y oficiales necesarios.

$8^{\circ}$ Pide que pueda tomar y repartir para el y sus sucesores treinta leguas de jurisdiccion. Concedesele.

$9^{\circ}$ Que se le dara titulo de gobernador y capitan general con seis mil ducados de salario.

$\mathrm{IO}^{\circ}$. Concedesele la vara de alguacil mayor por dos vidas conforme al capitulo 59 de las dichas ordenanzas.

I I $^{\circ}$ Concedesele que pueda elegir caja real y oficiales de ella conforme a los capitulos 43 y 64 de la dichas ordenanzas.

I $2^{\circ}$ Que el y sus sucesores puedan tomar minas. Concedesele.
Yden.

Yden.

Yden.

A esto respondio Don Pedro que lo queria merecer primero con aber servido y volviendole a mandar el consejo que lo acetase dixo que habia of recido lo contrario a su Magestad.

Que lo que toca al titulo de gobernador y capitan general se le concede y en cuanto al salario aunque lo receso se le señalan ocho mil ducados en los frutos de lo que descubriese.

No pide sino solo el poder nombrar esta vara y las demas de su gobernacion. Concedesele.

Lo mismo a Don Pedro parece a el consejo.

No las quiere Don Pedro. 
him in accordance with article 58 of the said ordinances for new settlements.

5. He asks that lands for pasture and planting and farms be given to the settlers and conquerors. It was granted in article 85 of the ordinances.

6. Let him be granted what is provided in article 99 of the said ordinances in regard to the enjoyment of all the privileges of noblemen by the settlers and pacificators.

7. Let him be granted the right to name immediately the maese de campo and the other captains and necessary officials.

8. He asks that he be given the right to take and divide for himself and his successors thirty leagues of territory. Let it be granted to him.

9. Let him be given the title of governor and captain-general, with six thousand ducats salary.

Io. Let him be granted the power to appoint alguaciles mayores for two lives, in accordance with article 59 of the said ordinances.

I I. Let him be granted the power to establish a royal treasury and choose officials for it, in conformity with articles 43 and 64 of the said ordinances.

I2. That he and his successors shall have the right to take up mines. Let it be granted to him.
The same.

The same.

The same.

To this Don Pedro replied that he wished to merit it first by his services, and when the Council again ordered him to accept it he said he had offered the contrary to his Majesty.

In respect to the title of governor and captain-general let it be granted to him; in the matter of the salary, even though he refuses it, let eight thousand ducats in the fruits of the land that he may discover be assigned to him.

He asks nothing but the right to appoint persons to this office and the others of his government. Let it be granted to him.

The Council is of the opinion that the same should be granted to Don Pedro.

Don Pedro does not want them. 
I $3^{\circ}$ Que á sus hermanos y deudos pudiese repartir indios, no se le concedio.

$14^{\circ}$ Que el y sus herederos pudiesen hacer tres fortalezas y tener la tenençia de ellas perpetuamente con salarios de la caja real. Concedesele.

I $5^{\circ}$ Que si sucediere alguna rebelion pueda para apaciguarla tomar de caja real lo que conviniere y concedesele.

I6 $6^{\circ}$ Que pueda hacer las ordenanzas que convinieren para la gobernacion y labor de minas.

I7. Que pueda dividir el gobierno en distritos y alcaldias mayores y corregimientos y nombrarlos, lo dispuesto en el capitulo 67 de las ordenanzas.

$18^{\circ}$ Que el y sus sucesores ayan de ser inmediatos al consejo. Se le concede lo proveido en el capitulo 96.

I $9^{\circ}$ Que pueda levantar gente en cualquiera parte de los reinos y arbolar banderas lo dispuesto en capitulo 73 .

20. Pide los recados necesarios para que las justicias y las demas partes por donde hubiere de pasar a esta jornada le den los bastimentos necesarios lo dispuesto en el capitulo 76.

$2 \mathrm{I}^{\circ}$. Que las justicias no impidan el ir a la jornada a los que quisieren aunque ayan cometido delitos no habiendo parte que los diga lo dispuesto en el capitulo 77.
Don Pedro no lo pide.

Don Pedro se ofrece a hacerlas y solo pide el nombramiento de los alcaldes con salario competente y darsele facultad para ello.

Lo mismo a Don Pedro.

Lo mismo a Don Pedro.

Lo mismo.

Lo mismo a Don Pedro.

Lo mismo a Don Pedro en las indias pues no sea de llevar gente de acá.

Lo mismo.

Lo mismo. 
I3. That he should have the power to divide Indians among his brothers and relatives. This was not granted to him.

I4. That he and his heirs shall have the right to construct three forts and have the command of them forever, with salaries from the royal treasury. Let it be granted.

I5. That if any rebellion should occur he shall have the power, in order to suppress it, to take from the royal treasury what may be necessary. Let it be granted.

I6. That he shall have the power to make the ordinances necessary for the government and working of the mines.

I7. That he shall have the power to divide the government into districts, alcaldías mayores, and corregimientos, and to name officers for them, in accordance with what is provided in article 67 of the ordinances.

I8. That he and his successors shall be under the direct control of the Council. Let it be granted to him as provided in article 96.

I9. That he shall have the power to recruit people in any part of the kingdoms and to raise banners, as is provided in article 73.

20. He asks for the necessary warrants so that the magistrates of the parts through which he may pass on this expedition shall give him the necessary provisions, as is provided in article 76 .

2I. That the magistrates shall not oppose those who may wish to go on the expedition, even though they may have committed crimes, if there be no party to bring charges against them. What is provided in article 77 .
Don Pedro does not ask it.

Don Pedro offers to build them and only asks for the appointing of the alcaldes with a suitable salary, and that he be given the power for it.

The same to Don Pedro.

The same to Don Pedro.

The same.

The same to Don Pedro.

The same to Don Pedro in the Indies, for people are not to be recruited here.

The same.

The same. 
$22^{\circ}$ Que se le puedan enviar cada año dos navios para provision de la tierra y labor de las minas libres de almojarifazgo y otros derechos lo que en ello se llevare que se le concede conforme el capitulo 79.

$23^{\circ}$ Que no se pague en la gobernacion alcabala por tiempo de veinte años. Se le concede.

24. Que no se pague almojarifazgo de lo que se llevara para proveimiento de la dicha gobernacion y que sea por .... años. concedesele en conformidad del capitulo 82 .

$25^{\circ}$. Que pueda tasar los tributos que an de pagar los indios que se le concede conforme al capitulo.

$26^{\circ}$. Que habiendo de hacer ausencia pueda dexar teniente en la tierra que no ha lugar.

27. Que si antes de hacer la jor- nada falleciese pueda nombrar persona que la prosiga. Concedesele lo dispuesto en el capitulo 58 .

$28^{\circ}$ Que sin embargo de que baya otra persona a quien se aya encomendado esta jornada se le guarde su capitulacion y si le saliere incierta y la prosiguiere otro se le haya de pagar lo que hubiere gastado de la real hacienda. E1 Virrey responde que si sucediere caso semejante se reserva su derecho a salvo para que cobre la que ubiere gastado de la persona que le pretendiere quitar la jornada.
Don Pedro no pide mas que sea libre de todos derechos lo que por esta sola vez llevare en un navio de trescientos tonelados que se le a concedido.

Lo mismo a Don Pedro.

Lo mismo.

Lo mismo.

Lo mismo.

Lo mismo.

Que sin embargo de esto parece se den recaudos a Don Pedro para que se guarde lo que con el se capitula con apercibimiento al virrey que sera a su costa cualquier inpedimento que le fuere puesto.

Don Pedro Suplica se le de licencia para que si dentro de seis años tuviere pacifica y poblada la tierra 
22. That he shall have the power to send every year two ships for the provisioning of the land and the machinery for the mines, what is taken for this purpose to be free of import and other duties. Let it be granted in accordance with article 79.

23. That no excise tax be paid in the government for the term of twenty years. Let it be granted.

24. That no customs duties shall be paid on what may be taken for the provisioning of the said government, and that it shall be for ... years. Let it be granted in accordance with article 82 .

25. That he shall have the power to fix the tributes to be paid by the Indians. Let it be granted, in accordance with the article.

26. That in case he must be absent he shall have the power to leave a lieutenant in the land. Let it not be permitted.

27. That he shall have the power to name a person to continue the expedition in case he should die before doing it. Let it be granted to him as is provided in article 58 .

28. That notwithstanding that some other persons may go to whom this expedition may have been entrusted, his [Don Juan's] agreement shall be maintained, or if it turns out uncertain and the other continues he shall be paid for what he has spent from the real hacienda. The viceroy replies that if such a thing happens the right shall be reserved to him to save himself by recovering what he may have spent from the person who may attempt to take the expedition from him.
Don Pedro asks nothing except that what he will take for this time only, in a ship of three hundred tons, shall be free of all duties. Let it be granted.

The same to Don Pedro.

The same.

The same.

The same.

The same.

Notwithstanding this the Council is of the opinion that warrants should be given to Don Pedro that the agreement with him will be kept, with a warning to the viceroy that any impediment placed in his way will be as his [the viceroy's] cost.

Don Pedro begs that he be given permission, if after six years he shall have the land pacified and set- 
pueda venirse dexando en su lugar persona cual convenga y parece que se le puede conceder.

Tambien que pueda llevar treinta criados sin informaciones por no haber tiempo para hacellas ni acostumbrarse con los soldados.

Tambien que pueda pasar destos reinos a aquellos todas las armas ofensivas y defensivas polvora $y$ municiones que quisiere de mas de la que se le a de hacer merced.

Concedesele tambien un navio de trescientos tonelados a su costa para embarcar su persona y criados y hacienda.

Asi mismo se le concedan cincuenta esclavos sin pagar derechos.

Que si en Mexico tuviere necesidad de mas polvora se le de al mismo precio que a su Magestad.

Consejo de Indias. 7 de Abril [de I596]. Consulta sobre lo que parece en la pretension de Don Pedro Ponce de León."

Señor: En los memoriales inclusos de don Pedro Ponze de leon que vuestra magestad mandó remitir a mi el Presidente dize que hallandose con mas obligazion que otro ningun vasallo de servir a vuestra magestad y con honrra y hazienda procedida de la clemencia y justicia de vuestra magestad le parece que no dara buena quenta de si dejando de ponerlo todo en sus Reales manos y por muestra de su buena intencion of rece hazer el descubrimiento del nuevo Mexico presuponiendo que por aver estado en la nueva España donde paso con el Conde de coruña y dejo muchos amigos se podra hazer la jornada sin que sea nezessario llevar gente de aca.

E1 Virrey don luis de Velasco escrive que avia hecho asiento sobre este descubrimiento con don joan de oñate hijo de vezino de la ciudad de los Zacatecas y que es mas aproposito que otro ninguno de los que alla lo avian pedido y el conde de Monterrey dize en otra carta que don luis de velasco tomo este assiento yendo el caminando para Mexico y le embio

w A. G. I., I $40-7-38$. 
tled, to come away, leaving in his place some suitable person. The opinion is that he should be granted it.

Also that he shall have the right to take thirty servants without evidence submitted, through lack of time to do it and accustom them to the soldiers.

Also that he shall have the power to take from these kingdoms all the arms, offensive and defensive, and the powder and ammunition that he may wish, besides what is to be granted to him.

Let him be granted also a ship of three hundred tons at his expense upon which to transport himself, his servants, and his goods.

At the same time let him be granted fifty slaves without having to pay duty.

If he should have need of more powder in Mexico let it be given him at the same price as to his Majesty.

The Council of the Indies. April 7, [I596.] Statement of opinion with regard to the claim of Don Pedro Ponce de León.

Sir: In the enclosed memorials of Don Pedro Ponce de León which your Majesty ordered to be sent to me, the president, he says that, finding himself under greater obligations than any other subject to serve your Majesty, with honors and property derived from the kindness and justice of your Majesty, it seems to him that he will not be giving a good account of himself unless he puts it all in your royal hands; and, as a proof of his good intentions, he offers to undertake the exploration of New Mexico, presuming that, because of his having been in New Spain-where he went with the Count of Coruña ${ }^{22}$ and left many friends-he will be able to make the expedition without its being necessary for him to take people from here.

Viceroy Don Luís de Velasco wrote that he had made a contract in regard to this exploration with Don Juan de Oñate, son of a citizen of the city of Zacatecas, and that he is the most suitable of all those there who have asked for it. The Count of Monterey states in another letter that Don Luís de Velasco made this contract while he [the count] was on the way to Mexico and sent him the papers so that he might examine them 
los papeles para que los viese antes que se comenzase la entrada y que por hazerlo con la atencion y consejo que se rrequeria no se avia resuelto en las dubdas que se le ofrecian y se daria prissa y abisaria y en entre tanto convernia entretener la confirmacion si aca se pidiese, y aviendose visto en el consejo, parece que sin enbargo de lo que alla se avia tratado con don joan de oñate pues no quedava efectuado se podra encargar esta jornada a don Pedro Ponze de leon pues como se deja entender la hara mucho mejor y con muchas y conocidas ventajas ansi por ser cavallero cuerdo y tan calificado con que no se puede dudar de que en la nueva España allara muchos que le sigan y demas de hazerse el efeto se desocupara la tierra de gente ociossa y valdia que como alli no ay salida de cosas a que acudir dan mucho en que entender a los que goviernan en corregillos como porque siendo como es tan rico podra sufrir los gastos de la jornada y esperarse muy buen subceso que pues pudiendo tener sosiego y vida descansada en su casa con el estado que a conseguido se ofrece a enpresa tan travajossa y costossa no ay dubda sino que su fin y desseo es de hazer en esto un gran servicio a vuestra magestad como el lo dize en sus memoriales y que ansi se le podra encargar esta jornada dandosele los despachos en la forma que pareciere convenir para su mejor efecto y ordenar al Virrey que si don joan de oñate oviere hecho algunas prebenciones por donde merezca recompensa se le haga en proveelle en algun cargo de los de alla que sea equivalente, Vuestra Magestad mandara lo que fuere servido. En Madrid a siete de abril $\mathbf{1} 596$.

[Hay seis rubricas.]

Don Pedro Ponce de León suplica a vuestra merced proponga a los señores del consejo le hagan merced en las capitulaciones siguentes." [Madríd, 23 de Abril de I596.]

I. Primeramente que se le entregue la ultima resolucion que se tomo con los teologos para que entienda la orden justificada que ha de guardar en descubrir el Nuevo Mexico.

2. Que se le de licencia para llevar consigo á fray Hieronimo Leon guardian de San Francisco de Ubeda por uno de los seis religiosos que se han hallar en la jornada.

3. Que por cuanto ha llegado a esta corte una persona de todo credito que afirma que los capitanes de Don Juan de Oñate eran salidos de Mexico con muy poca gente y la mas de ella mestizos y mulatos y que abian concurado a hacer tantas insolencias por el camino a los indios amigos y aun

$\checkmark$ A. G. I., Patronato Real, I-I-3/22-I2. Copy of transcript in Ayer Collection. Copy compared by Miss Clara A. Smith. 
before the entrada should be commenced; and because he had done this with the attention and care which the case required, he had not yet decided the doubts that occurred to him, but that he would make haste and report upon it, and in the meantime it would be best to delay the confirmation if it should be asked for here. After consideration by the Council, it is the opinion that notwithstanding the contract which had been made there with Don Juan de Onate, since it has not been carried out, it will be possible to grant this expedition to Don Pedro Ponce de León. For it is believed that he will do it much better and with many and well-known advantages, not only because he is an intelligent and qualified gentleman, and because it cannot be doubted that in New Spain there will be found many who will follow him-which, besides accomplishing the purpose, will relieve the country of idle and lazy people, who, because there is no alternative but to assist them, give a great deal of trouble to the officials in correcting them-but also because, being very rich, as he is, he will be able to bear the expense of the expedition and to expect very good success from it. And, although he might enjoy peace and a quiet life in his house with the fortune that he has secured, since he offers himself for an undertaking so arduous and costly, there is no doubt but that his purpose and desire is to do in this a great service to your Majesty, as he says in his memorials.

This expedition may, therefore, be granted to him, by giving him the warrants in the form that may appear most suitable for its better accomplishment, and by ordering the viceroy that if Don Juan de Oñate shall have made any preparations that merit recompense he shall repay him by providing him with an equivalent load of merchandise of the country. Your Majesty will order according to your pleasure. Madrid, April 7, I 596 .

[There are six rubrics.]

Don Pedro Ponce de Leon prays that your worship will propose to the members of the Council that they shall grant him what is stated in the following articles: [Madrid, April 23, I 596.]

I. First, that he be given the last decision that was handed down with respect to the clergy, so that he may understand the legal order that he must keep in discovering New Mexico.

2. That he be given permission to take with him Fray Hierónimo León, guardian of San Francisco de Uveda, as one of the six religious who are to go on the expedition.

3. Inasmuch as a person of entire credit has arrived at this court who declares that the captains of Don Juan de Oñate had left Mexico with very few men, most of them half-breeds and mulattos, and that they had joined together in committing so many outrages along the road upon the friendly Indians, and even upon the Spanish residents themselves, that they forced the viceroy and Audiencia to send an alcalde of the court to chastise them vigorously, Don Pedro prays that he be sent quickly, 
a los propios españoles vecinos que obligaron a que el Virrey y Audiencia enviasen un alcalde de corte para castigarlos regurosamente. Suplica Don Pedro que sea despachado muy brebemente para que baya a prevenirlos daños que si se arraigan en el principio del descubrimiento sera mas dificil de remediarlos que acabar bien toda la jornada y para no detenerse en Mexico levantando gente le parece acertado y forzoso llevar la mas de aca y ansi suplica que la licencia que tiene de cien soldados sea de trescientos y que los pueda juntar en Sevilla y su tierra arbolando banderas y tocando cajas.

4. Que cuatrocientas tonelados que es le han concedido en dos navios se le acrecienten en mas o menos pequeños o grandes conforme a lo que le estuviere mejor y que puedan partirse luego antes de la flota.

5. Que todo lo que oviere dispuesto Don Juan de Oñate en razon de repartir indios y otras cosas no sea balido.

6. Que se le haga merced del gobierno de la Nueva Vizcaya para cuando cumpla el que lo tiene que aya cuatro años por ser importante a la buena espedicion de la jornada y por que el lugar teniente que dexare le baya secorriendo de gente bastimentos y municiones sin aber menester rogarlo sino mandarlo.

7. Que se le de licencia para sacar de Vizcaya quinientos arcabuces y cien mosquetes al precio que lo paga su Magestad.

8. Otra al mesmo precio de Magestad para llevar cincuenta quintales de azogue para las minas que ovieren en el descubrimiento.

9. Que se le haga merced de sesenta quintales de mecha que no suplico cuando se le concedio la polvora y plomo entendiendo que.usaban en las indias de arcabuces de pedernal y ahora sabe que aunque los aya no conbiene llevarlos á este descubrimiento.

Don Pedro Ponce de Leon suplica a Vuestra Señoria mande de ponga entre las capitulaciones que queriendoseme hacer merced de lo que se ofrece a los generales en los descubrimientos de que se les daran vasallos perpetuos con titulos de adelantados y marqueses que la he sensado " para cuando la tenga muy merecida.

Don Pedro Ponce suplica a vuestra merced proponga al consejo lo siguiente.

La encomienda de los cien soldados capitulacion 29.

El brebe despacho de sus titulos y provisiones para que pueda alcanzar a Don Juan de Oñate.

Que se conviertan en frailes franciscos los teatinos que se obligó a llevar.

El señalar el tiempo de año y medio en que se ha de obligar a la entrada del descubrimiento capitulacion $2 \mathrm{I}$.

Don Pedro Ponce de Leon.

I. Que los cien soldados añadidos gozen en todo de las preheminencias que los otros ciento y treinta criados y soldados.

w Evidently a miscopy for "rehusado". 
so that he may go to prevent the injuries, for, if they are rooted at the beginning of the exploration, it will be more difficult to remedy them than successfully to complete the entire expedition. In order not to be delayed in Mexico in raising men it seems to him right and necessary to take the most of them from here; he therefore prays that the license that he has for one hundred soldiers be for three hundred, and that he shall have the right to collect them in Seville and his country, raising banners and beating drums.

4. That the four hundred tons that have been granted to him may be divided between the two ships in more or less amounts, smaller or larger, according to what seems best, and that they shall be permitted ${ }^{23}$ to depart immediately, before the fleet.

5. That everything that may have been arranged by Don Juan de Oñate in the matter of apportioning Indians and other things shall be invalid.

6. That he be granted the governorship of Nueva Vizcaya, when the one who has it completes his term, which may be four years, for it is important to the success of the expedition that he shall leave a lieutenant there to succor him with men, provisions, and ammunition, without having to beg for it but rather to command it.

7. That he be given permission to take from Vizcaya five hundred harquebuses and one hundred muskets at the price that his Majesty pays for them.

8. Another license to take at the same price as his Majesty fifty quintals of quicksilver for the mines that may be found in the discovery.

9. That he be granted the favor of sixty quintals of match fuse which he did not ask for at the time that he was granted the powder and lead because he understood the flint-lock harquebuses were used in the Indies, and now he knows that even though they are used it will not be best to take them on that discovery.

Don Pedro Ponce de León begs that your highness will order to be placed among the articles that when you wished to grant me what is offered to the generals in the discoveries-that they shall be given perpetual vassals, with titles of adelantados and marquises-I refused it until such time as I shall have thoroughly merited it.

Don Pedro Ponce begs that your honor will propose to the Council the following:

The grant of the one hundred soldiers, article 29.

The prompt despatch of his titles and commissions, so that he may overtake Don Juan de Oñate.

That the Theatines ${ }^{24}$ whom he agreed to take shall be changed to Franciscan friars.

That the term of a year and a half shall be assigned as the time when he shall be obligated to enter upon the discovery. Article $2 \mathrm{I}$.

Don Pedro Ponce de León.

I. That the hundred soldiers added shall enjoy in everything the same privileges as the other hundred and thirty servants and soldiers. 
2. Que por la capitulacion de la polvora municiones y artilleria dice que se le dara donde mas convenga suplica que se declare luego para que se despachen las cedulas atendiendo a que en Mexico no hay ahora artilleria.

3. Que se despache nueva cedula para que el Virrey detenga a Don Juan de Oñate declarando que esta ya concluido el asiento porque la pasada solo decia que entonces se iba tratando.

4. Que las quinientas tonelados que se le han concedido para su embarcacion en dos navios se declare que no pasando del numero referido puedan ser los navios mas ó menos segun que ubiere la comodidad.

5. Que no se le niegue el arbolar vanderes y tocar cajas en Sevilla atento que habra detenimiento a levantar la gente a la sorda y sera muy dañoso a la brevedad de la embarcacion.

Cuando escribi a Vuestra Magestad ofreciendo a su real servicio todo lo que puedo y valgo para procurar descubrir el nuevo Mexico no adverti á significar que mi principal intento a sido siempre que el mundo conozca que no me sacara de este reino otro interese mas que solo el servir á Vuestra Magestad pues para vivir en el honradamente y con alguna comodidad puede bastarme el condado de baylen con que pasaron bien y servieron mejor mis predecesores á Vuestra Magestad y a los suyos y por adelantarme a ellos me e dispuesto a tan larga jornada protestando que no sean de capitular conmigo ningunas ventajas porque no pretendo otras que las que sucediendo prosperamente obligaren a que Vuestra Magestad me honre y acreeciente como se debe esperar de tan gran señor a quien Dios guarde muchos y felices años. de Madrid a 23 de Abril de 1596.-Don Pedro Ponce de Leon.

\section{[DeCREto.]}

A dos de Mayo I596. Al presidente del consejo de Indias.

Que se junte este memorial con lo demas que hay esto.-[hay una rubrica.]

Consejo de yndias. 25 de Abril I596. En el particular de don Pedro ponce de leon, Sobre el descubrimiento de la nueva mexico. ${ }^{x}$

Señor: En la consulta que buelve aqui donde se trata de la pretension de don Pedro Ponce de Leon cerca de hazer el descubrimiento y pacificacion del nuevo mexico fue Vuestra Magestad servido de responder y mandar se le abisase de la qualidad de la persona con quien se tomo el asiento y con que condiciones y la sustancia que tiene para ponella en execuzion y lo que sobre ello a escripto el conde de monterrey.

En razon de lo qual lo que al consejo se of rece que dezir es que despues que se tuvo noticia desta entrada se a procurado mucho que se prosiga y

× A. G. I., I40-7-38. 
2. That by the article of the powder, munitions, and artillery, it shall be declared that it shall be given to him wherever most convenient, and he begs that it be declared immediately so that the cédulas shall be issued, in view of the fact that there is now no artillery in Mexico.

3. That a new cédula be issued for the viceroy to detain Don Juan de Oñate, declaring that the agreement is now concluded, for the former [cédula] only stated that it was then being arranged.

4. That in regard to the five hundred tons that were granted to him for his transportation in two ships, let it be declared that on condition that they do not pass beyond the number [of tons] mentioned the ships may be more or less [in size] according to what is convenient.

5. Let him not be denied the right to raise banners and beat drums in Seville, because there would be a delay in raising the men quietly and it would be detrimental to the speed of the embarkation.

When I wrote to his Majesty offering for his royal service all that I am and have in the endeavor to explore New Mexico, I did not think to point out that my principal purpose has always been that the world shall know that no other interest would take me out of this kingdom except anly to serve his Majesty, for in order to live in it honorably and with some comfort the estate of the Count of Bailén would be sufficient for me. With it my predecessors lived well and served your Majesty and their families better; and to outdo them I have resolved to make this long journey, protesting that no rewards be stipulated for me, for I ask for none except those which a successful accomplishment will compel your Majesty to honor and advance me with, as is to be expected of such a great lord, whom may God keep for many happy years. Madrid, April 23, I 596. Don Pedro Ponce de León.

\section{[DECREE.]}

May 2, I 596. To the president of the Council of the Indies.

Let this memorial be joined with the rest that there may be on this matter. There is a rubric.

The Council of the Indies. April 25, I596. In the matter of Don Pedrc Ponce de León, with respect to the exploration of New Mexico.

Sir: In the answer returned here which deals with the claim of Don Pedro Ponce de León with respect to making the exploration and pacification of New Mexico, your Majesty was pleased to reply by ordering that you be informed of the character of the person with whom the contract was made and under what conditions it was done and what property he has to put it into execution, and what the Count of Monterey has written about it.

As regards this, that which the Council has to say is that after information was received of this entrance great efforts were made to further it, 
que haviendose hecho assiento con un capitan Joan de Lomas y traydose al consejo la capitulacion parecieron las condiziones desaforradas y assi se ordeno al virrey que buscase otro medio y ello hizo capitulando de nuevo con el capitan urdiñola sin que tuviese efecto porque con aver sido acusado que mato a su muger ceso la jornada y ansi aunque con diligenzia y cuidado se a buscado persona, nunca se ha allado aproposito hasta que se ofrecio a hazerla Don Juan de Oñate que segun se a entendido es hijo de Christoval de oñate minero rico de las Zacatecas, y que ha dado tan mala quenta de la hazienda que deve agora mas de treynta mill pesos y las deudas mal contraydas y entretenidos los acreedores con trampas y que en otra Jornada que enprendio los soldados le tenian en poco y desobedezian, y aun dizen personas de mucho credito que le conozen, y an tratado, y saben bien el estado de sus cosas que sera impossible conseguirse el efecto de esta Jornada por su mano por que demas que es menester mucho caudal para ella el qual el no tiene, siendo como es hombre particular ninguno que sea de quenta querra seguirle ni yr debajo de su govierno y assi la gente que se juntare sera de los desterrados y bagamundos que no sirben mas que de inquietar y hazer motines con que se infaman las Jornadas y vidose esto en esta misma una vez que entro el capitan Castaño que costo mucho cuydado y travajo sacar de alli los soldados ociosos y alborotadores que no quisieron reconozer cabeza todo lo qual sera muy al contrario con don Pedro Ponce de Leon que siendo como es cavallero tan principal y cuerdo y $\tan$ conozido en aquella tierra se calificara mucho la jornada y Le siguira la gente mas principal con esperanza de ser alla muy acrecentada pues es gran cosa ir con satisfazion de que Don Pedro les dará los aprovechamientos de la tierra sin procurar los para si pues ha de volver a su lugar permaneziente que es donde tiene su cassa y estado y esto desde agora lo va el diziendo y procurando que las comodidades seran para la gente que le siguiere Sin querer capitular ni pedir ninguna cossa para el remitiendo el premio de sus servicios a la grandeza de Vuestra Magestad segun fuere la qualidad dellos y bese bien que el Conde de Monterrey no se inclino a la capitulacion de don Juan de Oñate por lo que escrive en su carta de que aqui va copia con otra de la sustancia de la mesma capitulacion para que aviendolo Vuestra Magestad visto todo provea y mande lo que fuere servido teniendo entendido que no solamente parece al consejo que entre don Pedro Ponze de Leon y don Juan de Oñate es muy notable la desproporzion que ay, y que por ninguna mano se podia hazer el negozio como por la de don Pedro Sino que convernia mucho que la resoluzion se tomase a tiempo que se pudiese avisar en este navio para que alla no se pasase adelante Vuestra Magestad Mandara lo que fuere servido de Madrid 25 de Abril I596. [Cinco rubricas.]

[Al reverso:] recibida en 2 de Mayo. 
and, a contract having been made with one Captain Juan de Lomas and the agreement brought to the Council, the conditions appeared to be excessive; therefore the viceroy was ordered to seek some other way. $\mathrm{He}$ did so, making a new agreement with Captain Urdiñola, but without results, for, being accused of the murder of his wife, the captain gave up the expedition. Thus, although diligent and careful search has been made for a suitable person, none has ever been found until Don Juan de Oñate offered to do it. He, it has been learned, is the son of Cristóbal de Oñate, a rich miner of Zacatecas, and [it is said] that he has so wasted the property that he now owes more than thirty thousand pesos, the debts having been ill contracted and the creditors held off by trickery, and that in another expedition which he undertook the soldiers had no respect for him and disobeyed him. It is even said by persons of much credibility who know him and have had dealings with him and are acquainted with the state of his affairs that it will be impossible to accomplish the purposes of this expedition by his hand, for, besides the need of a large fortune for it, which he does not possess, being, as he is, a private man, no one of importance will care to follow him or go under his government; therefore the people whom he may collect will be desperadoes and vagabonds, who serve for nothing but to cause disturbances and riots with which expeditions are disgraced. This was experienced in this same country once when Captain Castaño ${ }^{25}$ entered, and it cost much anxiety and trouble to get the idle and riotous soldiers away from there, for they refused to recognize any leader.

All this will be to the contrary with Don Pedro Ponce de León, for, being as he is a gentleman of such high standing and good sense and so well known in that country, he will give great credit to the expedition, and the most important people will follow him in the hope of advancement there, for it is a great thing for them to go with the certainty that Don Pedro will give them the profits from the country without attempting to secure them for himself, since he has to return to his permanent home, which is where he has his house and estate. This he is constantly saying, and he is endeavoring to see that the profits shall be for the people who will follow him, without wishing to make any agreement or ask for anything for himself, and leaving the reward for his services to the grandeur of your Majesty, according to their nature. From what he writes in his letter, of which a copy is enclosed together with another containing the substance of the same agreement, it is clear that the Count of Monterey was not inclined to the agreement with Don Juan de Oñate; accordingly after your Majesty has examined it all, you may take measures and order what may be your pleasure, bearing in mind that not only is it the opinion of the Council that between Don Pedro Ponce de León and Don Juan de Oñate there is a very notable disproportion, and that by no hand can the business be done so well as by that of Don Pedro, but also that it is very important that the decision be made in time for notice of it to be sent by this ship, so that the matter will go no further there. Your Majesty will act according to your pleasure. Madrid, April 25, I 596. [Five rubrics.]

[On the back:] Received on May 2. 


\section{[ReAl Decreto.]}

Escriviase al Virrey que suspenda la execucion de lo capitulado con don Juan de oñate y entre tanto vea el Consejo que condiciones pide el don Pedro Ponce de Leon y las que conviene concederle. ${ }^{\mathrm{y}}$ [Rubrica.]

Al birrey de la nueba españa que suspenda la ejecucion de lo capitulado con don Juan de oñate sobre el descubrimiento del nuebo mejico asta que Vuestra magestad mande otra cosa. ${ }^{z}$ [Aceca, 8 de Mayo de I596.]

E1 Rey: Conde de monte Rey pariente my birrei governador y capitan general de la nueba españa o a la persona o personas a cuio cargo fuere el govierno della aviendo Visto la carta que me escrivistes en 20 de diciembre del año pasado en que tratais del asiento que el Virrey Don luis de belasco Vuestro antecesor avia tomado con don Juan de oñate sobre el descubrimiento del nuebo mejico y las causas porque decis os deteniades en la resulucion adbirtiendo que combenia no aprobar el concierto si acaso acudiese a pedirle por parte del dicho Don Juan de onate asta que me bolbiesedes a escrivir y consultadoseme por los del mi rreal consejo de las yndias con ocasion de aberse ofrecido don pedro ponce de leon señor que diz que es de la Villa de bailen a de hacer el dicho descubrimiento e determinado se suspenda la execucion de lo capitulado con el dicho don Juan de oñate y ansi os mando no permitais que aga la entrada ni la prosiga si la Ubiere comencado sino que entretenga asta que yo probea y mande lo que me pareciere conbenir de que os avisare con brevedad fecha en açeca a ocho de mayo de mill y quinientos y noventa y seis años YO EL REY Refrendada de JUAN DE yBARRA y señalada del presidente y los del consejo. [Hay una rúbrica.]

Consejo de Yndias. Io de Mayo I596. Con la Relazion de lo que se a tratado y asertado con Don Pedro Ponze de Leon. ${ }^{a}$

Señor: En conformidad de lo que Vuestra Magestad fue servido responder y mandar en la consulta que buelve aqui se escrivio al Virrey de la nueva España que suspendiese la execucion de lo capitulado con don Juan de oñate sobre el descubrimiento de la nueva mexico y se encargo al Lizenciado Augustin Alvarez de Toledo que oyese a don Pedro Ponce de Leon y viese las condiziones que podia muestrandole lo que ofrezia don Juan de Oñate y de su voluntad mejora lo que siendo Vuestra Magestad

y F. R. B., Sevilla, June I, I9I5.

z A. G. I., 87-5-I. This cédula is printed in Villagra, Historia, canto VII., and also in Duro, Don Diego de Peñalosa, p. I53.

a A. G. I., I $40-7-38$. 
[Royal Decree.]

Let it be written to the viceroy that he shall suspend the execution of the agreement with Don Juan de Oñate; meanwhile let the Council look into the conditions asked by Don Pedro Ponce de León and what it is best to grant him.

To the viceroy of New Spain: That he shall suspend the execution of the agreement with Don Juan de Oñate in regard to the exploration of New Mexico until your Majesty shall order otherwise. [Aceca, May 8, I596.]

The King. Count of Monterey, my relative, viceroy, governor, and captain-general of New Spain, or the person or persons in whose charge the government of it may be: Having examined the letter which you wrote me on December 20 of last year, in which you spoke of the contract made by Don Luís de Velasco, your predecessor, with Don Juan de Oñate, in regard to the exploration of New Mexico, and the reasons why you said you were holding back the decision, advising that it was best not to approve of the agreement, if by chance request should be made for it on the part of Don Juan de Oñate, until you should write again to me, and having been advised by my royal Council of the Indies on the occasion of an offer made by Don Pedro Ponce de León, who they say is lord of the town of Bailén, to make the said exploration, I have determined to suspend the execution of the agreement with the said Don Juan de Oñate, and I therefore command you not to permit him to make the entrance nor to continue it if he shall have begun it, but that it shall be delayed until I shall take measure and order what seems best to me, of which I will inform you shortly. Done at Aceca, May 8, I 596. I the King. Countersigned by JUAN DE YBARRA and signed by the president and members of the Council. [There is a rubric.]

The Council of the Indies. May I9, I596. With account of what was discussed and agreed upon with Don Pedro Ponce de León.

Sir: In conformity with what your Majesty was pleased to reply and order in the answer which is returned here, [an order] was written to the viceroy of New Spain to suspend the execution of the contract with Don Juan de Oñate in regard to the discovery of New Mexico; and the licentiate Agustín Álvarez de Toledo was commissioned to hear Don Pedro Ponce de León and examine into the conditions that he was able to offer, showing him what Don Juan de Oñate offered, and of his own free will he improves upon it, as, if your Majesty please, you may see in the account that goes with this, and he asks for the other things therein contained. Since the advantages which Don Pedro offers are so well known and his character so much more suitable, it seems that hand could be set to the 
servido podra mandar ver en la relazion que va con esta y pide las demas cosas alli contenidas y siendo tan conozidas las ventajas que don Pedro haze y su persona tanto mas aproposito Parece se podria poner luego la mano en la capitulacion porque alcanzase a ir con la flota de nueva España que seria de gran importancia para el buen efecto del negozio. Vuestra Magestad mandara lo que fuere servido en Madrid i9 de Mayo I 596. [Seis rúbricas.]

\section{[Real Decreto.]}

Podrase concluir con don Pedro Ponce de Leon lo que esta tratado en la forma que parece al consejo. ${ }^{\mathrm{b}}$ [Rúbrica.]

Primer despacho de Consejo de Yndias [con Don Pedro Ponce de León]. 7 de Septiembre 1596. ${ }^{\circ}$

Lo que sea asentado Y capitulado Con Don Pedro ponce de Leon Sobre el descubrimiento pacificacion y poblacion de nueva Mexico. Esta bien, y va firmada. [Rúbrica.]

Señor: En cumplimiento de lo que Vuestra Magestad fue servido responder y mandar en la ultima consulta de las que buelven aqui se efectuo el asiento con Don Pedro Ponce de Leon por medio del Licenciado Augustin Alvarez de Toledo que apuro las condiciones y dio quenta en el Consejo, y se aprobo y hizo en la forma que va aqui para que siendo Vuestra Magestad servido de firmarle, se hagan los demas despachos, y trate desde luego de aviarse Vuestra Magestad mandara lo que fuere servido. En Madrid, Siete de Septiembre I 596. ${ }^{\mathrm{d}}$

Assiento y cappitulacion con don pedro Ponze de leon sobre el descubrimiento Pacificaçion y poblaçion de là Nueva mexico.e [San Lorenzo, 25 de Septiembre de I596.]

E1 Rey.-Por quanto Vos don Pedro Ponce de Leon cuya diz que es la Villa de Vaylén, me aveys hecho Relacion que deseando que nuestra santa ley evangelica sea ensalçada Publicada y Resavida en mas partes y mi corona Rentales y Patrimonio Real acrezentado querriades Theniendolo yo por bien descubrir Pacificar y Poblar La provincia de La nueva mexico de cuya Grandeza y Prosperidad se ha tenido noticia por medio de algunos Religiosos Y Seculares que en diferentes Tiempos y ocasiones an entrado en la tierra De La qual tanbien. Se dize que es muy poblada De naturales

b A. G. I., I40-7-38.

- A. G. I., I $40-7-38$.

d F. R. B., Sevilla, May 20, 1915.

e A. G. I., Indif. Gen., I39-I-2. 
agreement immediately, so that he might be ready in time to go with the fleet to New Spain, which would be of great importance for the success of the business. Your Majesty will order according to your pleasure. Madrid, May I9, I 596.

\section{[ROYAL DeCree.]}

Let what has been discussed be closed with Don Pedro Ponce de León in the form that seems best to the Council. [Rubric.]

First patent of the Council of the Indies [with Don Pedro Ponce de León]. September 7, I596.

What shall be contracted and agreed with Don Pedro Ponce de León in regard to the exploration, pacification, and settlement of New Mexico. It is properly drawn up and signed. [Rubric.]

Sir: In fulfillmient of what your Majesty was pleased to reply and order in the last answer among those returned here, the contract with Don Pedro Ponce de León was put in effect through the licentiate Agustín Álvarez de Toledo, who minutely examined the conditions and made a report to the Council, and it was approved and done in the form that goes here, so that, if your Majesty will deign to sign it, the other warrants may be made and he may proceed at once to make his preparations. Your Majesty will order according to your pleasure. Madrid, September 7, I 596.

Contract and agreement with Don Pedro Ponce de León with regard to the exploration, pacification, and settlement of New Mexico. [San Lorenzo, September 25, I596.]

The King. Inasmuch as you, Don Pedro Ponce de León, whose residence is said to be in the town of Bailén, have informed me that, desiring that our holy Catholic faith shall be exalted, proclaimed, and received in more parts, and my crown, revenues, and patrimony increased, you wished, with my approval, to explore, pacify, and settle the province of New Mexico, of whose great size and wealth and extensive native population information has been received through religious and laymen who have gone to that country at different times and occasions;

And inasmuch as you promise that you will endeavor, in the form that I have given for making such explorations and in no other way, before everything else to have our faith and gospel proclaimed, preached, and received, and after this is done to have the natives of the said province give 
y os Ofreceys a que por Los medios como en la forma que tengo Dada Para hazer semejantes Descubrimientos y no en otras Procurareys Ante todas cossas Se publique Predique y Resciva nuestra fee y el ebangelio y que hecho esto Los de la dicha provincia De Su boluntad Me den La obediencia y Reconozimiento Reconozcan por Su Rey y señor natural segun Lo Soy y me pertenece el Supremo Senorio de la dicha Provincia y de todas Las demas descubiertas y por descubrir de las indias occidentales Por los indultos y conseciones apparentes de que e gozado y gozo Sin aprovecharos $\mathrm{Ni}$ baleros de las armas exercitos y gente con que entharedes en la dicha provincia Sino por defender y Amparar Las personas eclesiasticas que aveys de llevar Para La publicacion del Santo ebangelio y para Vuestra Defensa en las cossas y como Lo podeys y deveys azer y usar de ello sin eceder desto en cosa alguna ni por ningun casso ofreciendo os como os ofreceys a que Gastareys en esto de Vuestra propia Voluntad por el servicio de dios y mio todo Lo que para ello fuere nescessario de las rentas de Vuestro estado y patrimonio y con esperanza De la gratificacion y merced que yo os hare conforme a la qualidad De Vuestra persona y servicio y Por ser la obra y empresa Tan en servicio de dios y mio e tenido y tengo Por Vien que en Razon dello se asiente y capitule con bos En La forma que se sigue:

I. Primeramente Vos el dicho Don pedro ponze de leon os ofreceys a yr a descubrir pacificar y poblar La dicha Provincia de la nueva mexico a Vuestra costa sin que Yo sea obligado a socorreros en cossa alguna De Mi hazienda y para yr a Ponerlo En execucion embarcaros dentro de seys meses despues que yo aya firmado esta capitulacion.

2. Yten os ofreceys A que llevareys seys Religiossos de La compañia de Jesus. Dos que se os daran en estos Reynos y quatro En La nueva españa como ya Se a tratado. Por Mi horden Con sus Superiores y Vos Le saveys de dar a Vuestra costa ornamentos Calices y campanas y todo lo demas necesario para celebrar el culto divino.

3. Yten os ofreceys que En la dicha nueva españa Levantareys y Juntareys trecientos soldados casados y solteros y labradores Para cultivar La tierra y guardar ganados y oficiales de todos oficios Para Lo qual os Doy Licencia que arboleys Banderas y Toqueys caxas En todas Las ciudades Villas y Lugares de aquellos Reynos que os pareciere que Combendra hazer esta Diligencia y os obligays A meterlos Dentro de las Provincias Del nuevo mexico bien armados y encababalgados sin que yo Les Deba dar sueldo ni otra ninguna Recompensa.

4. Yten os obligais a que llevareys Asta en cantidad De Veynte y dos mill Reales Empleados en arina y Mayz.

5. Onze mill Reales En trigo Para sembrar.

6. Seys mill y quatrocientos Reales en tasajos y carne Dos mill Cabezas de ganado mayor para cria y para el mesmo efecto cinco mill obejas Tres mill Carneros tres mill Cabras quatrocientas Cabezas del ganado prieto Duzientos y noventa potros y otras tantas yeguas De Vientres.

7. Yten os ofreceys A que llebareys Seys pares de fuelles con sus Recaudos y erramientas de Herreria.

8. Yten que Asimesmo llevareys otros ocho pares de fuelles para minas.

9. Yten os ofreceys A que llevareys Empleados asta en cantidad de Veynte y dos mill Reales en ferraje con Su clavo. 
me voluntary obedience and recognition as their king and natural lordas I am, since the supreme lordship belongs to me in the said province and in all the other provinces discovered or to be discovered in the West Indies, because of the well-known grants and concessions which I have enjoyed and do enjoy ${ }^{26}$ - without making use of the arms, soldiers, and people with whom you enter the said province except to defend and protect the ecclesiastical persons whom you have to take with you for the proclamation of the holy gospel, or in your own defense, nor going beyond what you ought to do in this in any manner or case;

And inasmuch as you voluntarily offer to pay all the expense that may be necessary for this service of God and myself from the rentals of your estate and patrimony, with expectation of the reward and favor which I shall grant you according to your character and service;

And inasmuch as the work and undertaking are so greatly to the service of God and myself, in consideration of all this I have decided that a contract and agreement shall be made with you in the following form:

I. First. You, the said Don Pedro Ponce de León, agree to go to explore, pacify, and settle the said province of New Mexico at your own expense, without any obligation on my part to aid you in any manner from my funds, and in order to put it into execution [you promise] to sail within six months after I shall have signed this agreement.

2. Item: You agree to take with you six religious of the Company of Jesus, two to be given to you in these kingdoms and four in New Spain, as has already been arranged. By my order to their superiors and you it is understood that you are to give them at your expense the ornaments, chalices, bells, and everything else necessary for the celebration of divine worship.

3. Item: You agree that in the said New Spain you will raise and assemble three hundred soldiers, married and single, workmen to cultivate the land and herd cattle, and officials for all the offices. For this I give you permission to raise standards and establish treasuries in all the cities, villages, and towns of those kingdoms where it appears proper to you to take this measure, and you bind yourself to conduct these persons into the provinces of New Mexico well armed and mounted without obligation on my part to give them pay or any other recompense.

4. Item: You bind yourself to purchase flour and maize up to the sum of 22,000 reales to take with you.

5. I 1,000 reales in wheat for sowing.

6. 6400 reales in jerked beef, 2000 head of cattle for breeding, and for the same purpose 5000 wool-bearing sheep and 3000 for mutton, 3000 goats, 400 heads of black cattle, $290^{27}$ colts, and as many breeding mares.

7. Item: You agree to take six pairs of bellows with tools and implements for a forge.

8. Item: You agree to take also eight more pairs of bellows for mines.

9. Item: You agree to purchase iron for horseshoes with their nails to the amount of 22,000 reales to take with you. 
Io. Yten os ofreceys A que llevareys Ocho mill Reales empleados en calçado.

I I. Yten que ansimesmo llevareys Hasta en cantidad de doze mill Reales empleados en medecinas de botica para que se curen Los enfermos.

12. Yten os ofreceys a que llevareys asta en cantidad de diez mill y ochocientos Reales empleados En fierro labrado.

I3. Ansimismo os of receys a que llevareys asta en cantidad de dos mill Reales empleados En cossas Para rescates ${ }^{\mathrm{f}}$ y Regalar yndios.

I4. Yten os obligais A que llevareys Hasta en cantidad de dos mill y seyscientos Reales empleados en papel.

I5. Y doze mill Reales en jerga y sayal.

I6. Yten A que llevareys Treynta carretas de bueyes abiadas con todo Lo nescesario.

I7. Todo lo Sobredicho os ofreceys A llevar fuera del matalotaje y sustento de los Soldados asta llegar a las poblaciones porque Antes no se a de tocar En cossa ninguna de lo Referido.

I8. Yten os offreceys y obligays A que para el servicio de Vuestra cassa adorno y atabio de Vuestra persona llevareys Las cossas Siguientes:

I9. Hasta ciento y Treynta oficiales soldados y criados de Vuestra casa que An de yr en Vuestra compania $Y$ servicio los que fueren casados con sus mugeres y familia desde estos Reynos para lo qual Os mandare Dar licencia aparte $y$ an de entrar Con bos en la Jornada dandoles para ello armas y cavallos como a los trecientos soldados arriva rreferidos y que ciertamente ellos sean Utiles para Entrada y efectos della.

20. Yten que llevareys Veynte y cinco cavallos Treynta y tres mulas de carga parejadas y seys carros herrados Con Sus mulas doze Sillas ginetas doze adargas doze lanças Treynta y Seys partesanas Doze cotas Doze escarçelas Doze celadas con sus cubiertas Seys pares De Armas de acosballo cinquenta arcabuzes cinquenta espadas Con Sus dagas dos coseletes Enteros dos Sillas de Armas, Treynta cueras de Ante quatro rodelas aceradas con sus Morriones cinquenta mosquetes cinquenta Ballestas Todo lo Sobredicho de Respeto para Vuestra Persona Demas de Las Armas y adereços de los soldados.

21. Todo Lo qual os of receys y Haveys destar obligado a tenerlo a punto en la forma y manera sobredicha Dentro de Año y medio a Contento y satisfaccion del dicho conde de monterey Virrey de la nueva españa que Aunque como Adelante Se dira no lo haveys destar Subordinado Le aveys de comunicar Todo Lo que hicieredes y Hazeren Su presencia muestra y alarde de la gente que llevaredes La que estubiere en mexico Personalmente y La que en Los demas Lugares Por Lista y testimonio signado de escrivano y todas Las demas Cossas armas Bastimentos y Pertrechos o Recaudos autenticos De modo que quede satisfecho de que Cumplis Con Vuestra obligacion Segun Lo aveys offrecido.

22. Yten os ofreceys de Guardar y Cumplir y Procurar que Con effecto se Guarden y Cumplan Las Hordenanças ynstruciones y çedulas que estan Proveydas Sobre la horden que se ha de tener en Los nuevos descubrimientos pacificaciones y poblaciones que se huvieren de hazer en Las yndias Sin exceder ni traspasar de todo ello en todo ni en parte para Cuyo ynbiolable Cumplimiento: y descargo de mi Real conciencia Se os entregaran

t Evidently a miscopy for "rescatar". 
IO. Item: You agree to take 8000 reales worth of foot-gear.

II. Item: You agree to take as much as 12,000 reales worth of drugs for the cure of the sick.

I2. Item: You agree to take as much as 10,800 reales worth of iron tools.

I3. Item: You also agree to take as much as $2000{ }^{28}$ reales worth of articles for barter and gifts to the Indians.

I4. Item: You also agree to take as much as 2600 reales worth of paper.

I5. Item: And I2,000 reales in frieze and sackcloth.

I6. Item: And to take thirty ox-carts provided with everything necessary.

I7. All of the above you offer to take over and above the supplies and provisions for soldiers until they arrive at the settlements, for none of the above-mentioned is to be touched before then.

I8. You agree and bind yourself, for the honor of your house and the adornment and embellishment of your person, to take the following:

I9. As many as I 30 officials, soldiers and servants of your house, to go in your company and service from these kingdoms, the married ones with their wives and families. For this I will order that you be given a separate license to take them with you on the expedition, you to arm and mount them the same as the three hundred soldiers above mentioned. They will certainly be useful for the expedition and its purposes.

20. Item: You agree to take twenty-five horses, thirty-three packmules with their harness, six iron-tired carts with their mules, twelve troopers' saddles, twelve leather shields, twelve lances, thirty-six halberds, twelve coats of mail, twelve cuishes, twelve helmets with their beavers, six sets of horse armor, fifty harquebuses, fifty swords with their daggers, two complete coats of armor, two stands of arms, thirty buckskin jackets, four steel shields with their steel helmets, fifty muskets, fifty crossbows, all the above to be extra for your own person, besides the arms and accoutrements of the soldiers.

$2 \mathrm{I}$. To all of this you agree, and you are under obligation to fulfill it exactly in the form and manner above stated, within a year and half, to the content and satisfaction of the said Count of Monterey, viceroy of New Spain, to whom, although, as is stated further on, you will not be subordinate to him, you will have to communicate all that you do and make in his presence a muster and review of the people whom you are taking with you. This is to be done in Mexico personally and in the other towns by list and certified copy signed by a clerk, all the other things, arms, provisions, and stores to be legally attested, so that he may be satisfied that you are fulfilling your obligation. according to your agreement.

22. Item: You agree to keep, fulfill, and try to have effectually kept and fulfilled, the ordinances, instructions, and decrees which are provided concerning the system that is to be maintained in the new explorations, 
con esta Las dichas hordenanças ynstrucciones y cedulas que Ansi abeys de guardar En la dicha pacificacion y Descubrimiento, Conforme A Las quales dichas hordenanças ynstruciones y cedulas os ofreceys ansimismo a Hazer La dicha pacificacion Poblacion y descubrimiento con toda paz y cristianidad escusando En quanto fuere posible todo genero de Violencia y fuerça si no en quanto fuere necesaria para amparar y defender Los ministros del evangelio y Vuestra persona y gente No pudiendolo defender de otra manera y que en esta Comformidad os Governareys y La gente que con bos Llevaredes De manera que proceda con el mejor concierto que fuere posible de manera que dios nuestro Señor sea servido, y los naturales edificados sin que resçiban daño en sus personas honrras Ni Haziendas Antes toda buena Amistad y tratamiento Para que se haga mas Con Vuestro buen exemplo diciplina y Vondad de la gente que con bos Llevaredes que se pudiera Hazer con las armas En casso que huubieredes de entrar Usando dellas.

23. Yten os offreceys que de todo Lo que Pacificaredes y poblaredes En la dicha Provincia En la forma y como Lo haveys de pacificar y poblar Conforme a dichas ordenanças ynstruciones y cedulas tomareys la posesion En mi nombre y de mi corona y suscesores en ella Con La solenidad autos y ceremonias acostumbradas y que se Requieren. En cassos y cossas Semejantes y a que hazys Lo mismo En todas las otras tierras y provincias De mas de la del nuevo mexico que espero en dios que descubrireys Con Su ayuda y Vuestra Buena yndustria y calor.

24. Yten os offreceys A que si este descubrimiento Llegare A La mar del Sur y del norte o a ambas mares Hareys Vergantines para costear y descubrir Los puertos y Rios que huviere en todas Las costas que Yo os Remito el hordenar y proveer que sean quales combengan Para los Hefectos que se ayan de Hazer.

25. Ansimismo os offreceys A que dentro de seys años contados desde el dia en que por testimonio signado de escrivano constare haver Entrado en la primera tierra de La dicha provincia de la nueva mexico tendreys Poblados en ella tres ciudades La Una Provincial y Las otras Dos Sufragantas En Las partes mas comodas fertiles y abundantes que Alleredes y Vieredes Ser mas Convinientes para que desde ellas mejor y Con mas comodidad Se pueda hazer y proseguir el dicho descubrimiento y poblacion y pacificacion y que demas de Las dichas Tres ciudades hareys Las mas Poblaciones que Pudieredes y os pareciese Convenir y en cada Una De todas un fuerte Para Su defensa Para que Se asegure Lo que se fuere Ganando y el Primer año hareys Las mas Poblaciones que fuere Posible.

26. Yten Nos offreceys A que Como se fuere haziendo el dicho Descubrimiento y mostrando Dios El fruto que consiguieren Para Su salvacion de Los naturales de Aquella tierra y para siempre En augmento Vaya Pedireys y metereys en aquellas provincias Los clerigos de Misa o frayles De Una de Las tres hordenes O Religiosos de la Compañia Los que fueren nescesarios Para que por esta falta no la haya en La doctrina y cristiandad En los yndios y no estorvareys La entrada $\mathrm{A}$ los demas Religiosos de las tres Hordenes que quizieren entrar a tratar de la Combersion. 
pacifications, and settlements that are to be made in the Indies, without exceeding or transgressing them either in the whole or in part. For the inviolable fulfillment of this and the discharge of my royal conscience, there will be conveyed to you with this the said ordinances, instructions, and decrees that you must thus keep in the said pacification and exploration. In accordance with the said ordinances, instructions, and decrees, you agree also to make the said pacification, settlement, and exploration in all peace and Christianity, avoiding as far as possible every sort of violence and force, unless it be necessary to protect and defend the ministers of the gospel and your person and people, in case it be not possible to defend them in any other manner. You will govern yourself and the people you are taking with you in conformity with this and in such a manner that all will go on as agreeably as possible, so that God, our Lord, will be served and the natives instructed without receiving any harm to their persons, morals, or property, but rather all good friendship and treatment; you will accomplish more by your own good example and the discipline and kindness of the people with you than might be done by the use of arms, in case you should enter with them.

23. Item: You agree that of all that you may conquer in the said province, in the manner and form in which you ought to pacify and settle them, in conformity with the said ordinances, instructions, and decrees, you will take possession in my name and that of my crown and the successors to it, with the formality, autos, and ceremonies customary and required in such cases. You will do the same in all the other lands and provinces besides New Mexico which I hope to God that with His aid and your good industry and zeal you may explore.

24. Item: You agree that if this exploration extends to the South or the North Sea, or to both seas, you will construct brigantines to sail along the coast and examine the ports and rivers that there may be on those coasts, and I convey to you the power to order and take measures for them, provided that they shall be such as the purposes for which they are to be used require.

25. You also agree that within six years, counting from the day when it will be shown by the certified testimony of the clerk that you have entered the first land of the said province of New Mexico, you will have established in it three cities-one provincial and the other two suffragan -in the most suitable, fertile, and abundant places that you may find and consider to be best and most convenient to make and continue the said explorations from; in addition to the said three cities you will make as many settlements as you can and as seem to you desirable. In each one of all these cities you will construct a fort for its defense, so that there may be security for what may be gained, and the first year you will make as many settlements as possible.

26. Item: You agree, as the said exploration goes on and God shows the fruit that may be gathered in the salvation of the natives of the land, and so that it may always go on increasing, to ask for and take into those provinces the necessary presbyters or friars from one of the three orders or religious of the Company so that there may be no lack of in- 
27. Y Para que cumplireys Con todo lo Sobredicho os offreceys ansimimo de obligaros Por Vuestra persona Vienes y Rayzes Por escriptura Publica otorgada ante escrivano.

28. Y Para que con mejor Animo y mas comodidad de La gente que llevaredes y os fuere de nuevo a ayudar Se pueda Hazer el dicho descubrimiento pacificacion y Poblacion y sustentaros en aquellas nuevas tierras os offresco Para Vos y ellos hazeros Merced en Las cossas siguientes.

29. Primeramente os doy Licencia y facultad Para que En La forma Sobredicha podays descubrir Pacificar y Poblar Las dichas Provincias y Reynos De la nueva mexico, quanto Se estendiesen Por aquellas partes Como no toque A Provincia Reyno ni tierra cuyo Govierno sea Encomendado a otra persona con titulo De Governador y cappitan General Por todos los dias de Vuestra Vida o por el tiempo que Castase ${ }^{\mathrm{g}}$ y Vos quisieredes ocuparos en la dicha Poblacion y pacificacion Con que no sea menos que Los seis años que le vayo Licencia para poderos Venir y con Los dichos Cargos Os señalo Doze mill Ducados que balen quatro quentos, y quinientas Mill maravedis De Salario En los fructos y Rentas que tuviere y me perteneciesen en Las dichas provincias que asi Pacificaredes.

30. Yten bos doy Licencia y facultad Para que Podays abrir marcas y Punzones con mis armas Reales y Ponerlos En Los Pueblos de españoles que estuvieren Poblados se poblaren y Se marque con ellos El oro y plata y otros metales que huviere.

3I. Yten os doy licencia y facultad Para que Podays elejir el Lugar o Lugares que os Paresciere Para que en ellos Se pongan mis caxas Reales y nombrar officiales De mi hazienda En Las partes que Conbenga Señalandoles salarios Moderados En Los fructos de La tierra y Les concedo por esta Vez Solamente a Vuestra Suplicacion que Les podays Repartir yndios haviendose ellos Hallado A ser descubridores y Pobladores y gozarlos Juntamente Con Los officios aunque les sea Proybido.

32. Yten Os Doy Licencia y facultad para que Sucsediendo en Las dichas Provincias alguna Rebelion O alteracion contra el Servicio De dios nuestro Señor o mio Podays Librar con Acuerdo De mis officiales O De Lla mayor parte dellos Lo que fuere menester Para Reprimir La dicha Rebelion con que no sea de la Hazienda que me pertenesciere En Las dichas Provincias.

33. Yten os doy Licencia y facultad Para que Para La governacion De La tierra y Labor de las minas Podays Hazer ordenanças que no sean Contra derecho ni Lo que por mi esta Hordenado $\mathrm{Ni}$ en perjuicio de los Yndios, antes para su bien augmento y conservacion y con que sean Confirmadas Por mi dentro de Tres años y en el entretanto Lo podays hazer guardar biendo primero Las que aca Se os entregaran De las quales oviren hecho En cassos semejantes Para que procedays Con mas Luz.

34. Yten os doy Licencia Para que Podays dividir Las dichas Provincias En distritos y alcaldias mayores corregimientos y alcaldias hordinarias que eligieren Los consejales con que tanpoco sea esto en Perjuicio de Los dichos yndios sino En su beneficio, embiando Relacion de vuestra division para que se Aprueve O reforme.

B Evidently a miscopy for "gustase". 
struction in Christianity of the Indians; and that you will not interfere with the entrance of other religious of the three orders who may wish to enter and undertake their conversion.

27. And you also agree to bind yourself to carry out all the abovesaid by your person, goods, and property, in a public writing executed before a clerk.

28. In order that the said exploration, pacification, and settlement may be made with better spirit and comfort by the people whom you may take, or who may afterwards go to aid you, and for your support in these new countries, I agree to grant the following favors to you and to them:

29. First, I give you license and authority to explore, pacify and settle, in the aforesaid manner, the said provinces and kingdoms of New Mexico as far as they extend in those parts-provided that they do not touch upon a province, kingdom, or land whose government has already been committed to another person-with the title of governor and captaingeneral for all the days of your life, or for the time that you are satisfied and wish to occupy yourself in the said settlement and pacification, provided that it be not less than the six years that I have allowed you for your return. With the said offices I grant you a salary of 12,000 ducats, which amounts to $4,500,000$ maravedis, ${ }^{29}$ from the products and revenues that may belong to me in the said provinces that you may thus pacify.

3o. Item: I give you license and power to engrave stamps and dies with my royal arms and place them in the towns settled by Spaniards and stamp the gold and silver and other metals that may be there with them.

3I. I give you license and power to choose the places that seem best to you for my royal treasuries, and to name the officials of my exchequer in the places that seem suitable and to fix a moderate salary for them in the products of the land; and I permit you for this time only, upon your supplication, to divide the Indians among them after they have become discoverers and settlers, so that they may have possession of them together with the offices, even though they may be prohibited from doing so.

32. Item: I give you license and power, in case there shall occur any rebellion or uprising in the said provinces against the service of God, our Lord, or mine, to give an order for payment, with the agreement of my officials or the majority of them, for whatever may be necessary to suppress the said rebellion, provided that it does not ${ }^{30}$ come from property belonging to me in the said provinces.

33. Item: I give you license and power to pass ordinances for the government of the country and working of the mines, provided that they are not unjust nor contrary to what I have ordered, nor to the injury of the Indians, but rather to their advancement and preservation, and provided further that they shall receive my confirmation within three years. In the meantime you shall wait for it, observing first those ordinances that will be delivered to you here, and which have been passed in similar cases, so that you may proceed with greater light.

34. Item: I give you license to divide the said provinces into districts, alcaldias mayores, corregimientos, and alcaldias ordinarias, which shall elect counsellors, provided also that this also shall not be to the prejudice 
35. Yten Se os offrece que se os daran quatro Pieças de Artilleria quarenta quintales de polvora ciento y Treynta de Plomo Lo qual se Vera Si se puede proveer desde aca y si Se pudiere Se tray sino Se cometera Al Virey Para que Lo haga, conque en las dichas Pieças se Pongan mis armas y queden y sean siempre Para mi.

36. Y Porque se tiene entendido que algunos soldados desmandados y sin Licencia y horden entraron en aquellas Provincias en que Cometieron delito por que merecian ser castigados gravemente Os Remito el perdonarlos O castigarlos Los que Huvieren entrado contra el Vando De los Vireyes Como mejor os Pareciere Ansi para el exemplo como para el Pacifico govierno de Aquellas Provincias y buenos effectos de la Jornada.

37. Yten se os concede y ofrece que se os daran Los yndios que paresciere Ser de aquella provincia Para que buelvan A Su natural y sirvan De Ynterpretes y Particularmente Una yndia que para este hefecto Se traxo de aquella Tierra.

38. Yten se os concede y doy Licencia y facultad Para que Los Soldados Pobladores y pacificadores Primeros Segundos y Terceros que entrasen Con bos y despues os fueren a ayudar en esta Jornada y descubrimiento Les podays Repartir y encomendar Los pueblos de yndios que Huviere En aquellas Provincias Segun y en La forma que se contiene en el capitulo cinquenta y ocho de Las dichas ordenanzas de nuevas Poblaciones y descubrimientos Dexando para mi Los Puertos y cavezeras.

39. Yten se os concede que para Poder Hazer el Viaje y Llevar Los oficiales y soldados y criados ariva Referidos Se os dara Licencia Para llevar y fletar dos navios de a cada duzientas toneladas.

40. Yten Hago merced a Vos y a los Sobredichos ciento y treynta Soldados oficiales y criados que fuesen en Vuestra Compañia y servicio Para el dicho Descubrimiento pacificacion y poblacion de todos los derechos De Almoxarifasgo que me pertenecieren En estos Reynos y en Las yndias De todo lo que llevaredes y Llevaren En este Viaje Y Tan Solamente Por esta Vez Para Vuestra Cassa y Las Suyas y mantenimientos en cuya conformidad Se os dara cedula para que a Vos y ellos no se os Pidan, ni lleven los dichos derechos.

4I. Yten Hago merced a todas las personas que Con bos fueren a Poblar En Las dichas Provincias y Reyno de La nueva mexico que del oro Plata perlas y piedras Preciosas que se sacaron En ellas no me paguen mas de Solamente el diezmo En Lugar Del quinto Por tiempo de Veynte años que corran desde el dia que Poblaredes el primer pueblo.

42. Yten os hago merced a Vos el dicho don Pedro Ponce De leon y a Los dichos Descubridores y pobladores de las dichas Provincias del nuevo mexico de la alcavala que se me deviere y fueredes obligados a Pagar En ella por tiempo de Veynte años que corran desde el dia que poblaredes el primer Pueblo y mando que durante esto no se os pida a Vos ni a ellos.

43. Yten hago Merced a Vos el dicho don Pedro Ponce de leon y a los dichos Pacificadores y Pobladores De que de todo Lo que por tiempo de Diez años Llevaredes y llevaren parra proveymiento De Vuestra cassa y La suya, no se os pidan Ni lleven derechos de almoxaraje de Los que en aquellas partes $\mathrm{Me}$ pertenescieren Con que las cossas que assi llebasen Sea para el efecto Sobredicho y no para otro Alguno y si Las 
of the said Indians but to their benefit-you to send a statement of your divisions so that it may be approved or amended.

35. Item: It is promised you that you shall be given four pieces of artillery, forty quintals of powder, and a hundred and thirty of lead, which will, if possible, be provided from here, or if not, the viceroy will be charged with it-my arms to be placed on the said pieces and they to remain and be always my property.

36. And because it has been heard that some disbanded soldiers entered these provinces ${ }^{31}$ without license or order and committed crimes there for which they deserved to be severely punished, I give you the power to pardon or punish those who may have entered against the edict of the viceroys as may seem best to you, not only as an example, but also for the peaceful government of those provinces and better results from the expedition.

37. Item: It is promised and granted you that you shall be given the Indians that appear to be of that province, so that they may return to their native land and serve as interpreters, in particular one Indian woman who was brought from that country for that purpose.

38. Item: I grant and give you license and power to divide and give in encomienda among the soldiers, settlers, and pacificators, of the first, second, and third [generations], who may enter with you or afterwards go to aid you in this expedition and exploration, the Indian towns that may be in those provinces, according to the form that is contained in article 58 of the said ordinances of new settlements and discoveries, leaving for me the ports and capital cities.

39. Item: I grant you, so that you may be able to make the voyage and take the officials, soldiers, and servants above mentioned, permission to charter and take two ships, each of two hundred tons.

40. Item: I grant to you and the aforesaid one hundred and thirty soldiers, officials, and servants who are to go in your company and service on the said exploration, pacification, and settlement, exemption, for this time only, from the export duties which pertain to me in these kingdoms and in the Indies upon all that you are taking and may take on this voyage for the maintenance of your house and theirs, in conformity with which I will give you a decree, so that the said duties may not be charged or taken from you.

4I. Item: I grant to all the persons who may go with you to settle in the said provinces and kingdoms of New Mexico that they shall pay me but a tenth, instead of a fifth, of the gold, silver, pearls, and precious stones that they may take from them, for the space of twenty years, running from the day when you shall have settled the first town.

42. Item: I give grace to you, the said Don Pedro Ponce de León, and to the said explorers and settlers of the said provinces of New Mexico, from paying the excise tax which would be due me and which you would be under obligations to pay me there, for the space of twenty years, running from the day when you shall have settled the first town, and I command that during this time it shall not be required of you nor of them.

43. Item: I grant grace to you, the said Don Pedro Ponce de León, and to the said pacifiers and settlers, that for the space of ten years no 
Vendieren O parte dellas que De todo enteramente se cobren Para mi Los derechos.

44. Yten os doy Licencia y Ffacultad Para que a Las personas que con bos fueren a Los dichos descubrimientos Pacificaciones y Poblacion De las dichas Provincias De La nueva Mexico y que en ello os ayudaren y a ssus hijos y descendientes Podays dar tierras y Solares De pasto y Labor y estancias No quitando a Los yndios Las que fueren suyas. Sino antes Dandoles todas Las que mas ovieren Menester, Para que anden Muy alibiados y descansados y para que Los que Huvieren Poblado y residido tiempo de cinco años, por las dichas provincias Las tengan En Perpetuydad y a Los que Huvieren Hecho y Poblado yngenio de Açucar y Los tuvieren y mantuvieren Con esclavos Negros no se les Pueda Hazer execucion En ellos ni en Los dichos esclavos eremientas ni pertrechos con que Se labrasen.

45. Yten os Doy Licencia y facultad Para que en las partes De Las dichas Provincias de la nueva mexico que mas Convenga A su buena guarda y conservacion Podays Hazer Tres fortalezas y Haviendo Las hecho y sustentado Os hago merced Por Vuestros dias De Las tenencias dellas Con cien mill maravedis de salario En cada Un año en cada Una el qual se a de pagar de La Hazienda que me pertenesciere en Las provincias que asi Pacificaredes.

46. Yten tengo por bien y es mi Voluntad que conoscays en grado de apelacion De todas Las sentencias que se dieren Por Los Juezes y Justicias que pusieredes En mi nombre o que yo pusiere En toda La dicha Provincia y provincias que pacificaredes y Poblaredes y descubrieredes Para lo qual os doy otro tal y el mismo poder que yo tengo.

47. Yten os Hago merced y tengo por Vien que Seays ynmediato a mi Real consejo de Las Yndias y mando que ninguno de Los Vireyes ni audiencias Comarcanas No se puedan Entremeterse En el distrito de las dichas Provincias de officio ni a pedimento De parte ni por Via de apelacion a proveer ni provean Juezes De comision para ellas y que el dicho mi consejo de Las Yndias pueda conocer de las cossas de La dicha governacion De officio y a pedimento de Parte y por Via De apelacion, de las causas cebiles de cien pesos arriva y en causas criminales En que se pusiere Pena de muerte o mutilacion de miembro con que puedan ir a la audiencia de La nueva galicia Los que quisieren y lo mismo en Los que Vos Proveyeredes.

48. Yten os doy Licencia Para que Podays dar exidos y abrevaderos A los Pueblos en Nueva Mexico se poblaren y abrir caminos y sendas Juntamente Con los cabildos dellas Sin perjuycio de los yndios Sino antes para $\mathrm{Su}$ beneficio.

49. Y ansimismo os La doy Para que podays nombrar Regidores y otros oficiales De Republica de Los pueblos que se poblaren Por el tiempo que fuere mi Voluntad Con que dentro de quatro años ayan de llevar confirmacion mia Los ansi nombrados y para que podays Hazer y levantar En la nueva españa y nueva galicia y en todas Las ciudades Villas y lugares de Ambas provincias Los dichos trecientos hombres.

Y Para nombrar maese De campo y agora y despues Los demas capitanes y oficiales de guerra necessarios Desde el mayor hasta el menor os mandare dar Luego Provision Mia y Para que las justicias no solo 
duties shall be charged you upon all that you and they may take for the provisioning of your house and theirs for what may belong to me in those parts, provided that the things that you thus take are for the aforesaid purpose and none other, and if you sell them or any part of them, duties shall be collected for me upon the whole.

44. Item: I grant you license and power to give to the persons who may go with you to the said explorations, pacifications, and settlement of the said provinces of New Mexico and who may aid you there, and to their children and descendants, lands and ground for pasture and farms, not taking away from the Indians those that belong them, but rather giving them what they need. In order that they may rest content and satisfied, those who shall have settled and resided in the said provinces for the term of five years shall have the lands in perpetuity, and upon those who shall have erected sugar-mills and maintained them with negro slaves no execution shall be made, nor upon the said slaves, tools, or stores with which they are worked.

45. Item: I give you license and power to erect, in the parts of the said provinces of New Mexico most suitable for their guarding and preservation, three forts, and after you have built and supported them, I grant you for the rest of your days the lieutenancies of them, with a salary of 100,000 maravedis $^{32}$ annually for each one, which is to be paid from the property belonging to me in the provinces that you may thus pacify.

46. Item: I agree and it is my will that you should act as a court of appeal in all the verdicts given by the judges and justices that you may appoint in my name or that I may appoint in all the said province and provinces that you may pacify and settle and explore, for which I grant you the same and equal power as that which I have.

47. Item: I grant you and I consider it to be right that you shall be in immediate contact with my royal Council of the Indies and I order that none of the viceroys or neighboring audiencias shall interfere in the district of the said provinces officially nor a pedimento de parte ni por via de apelación appoint commissioned judges for them. My Council of the Indies shall try the affairs of the said district officially and a pedimento de parte y por via de apelación, in civil cases of one hundred dollars up and in criminal cases in which the sentence would be death or mutilation by the removal of a member, provided that those who wish to do so may go to the Audiencia of Nueva Galicia, and the same with those whom you may appoint.

48. Item: I grant you permission to give public lands and watering places to the towns in New Mexico that may be settled, and to open roads and paths in conjunction with their councils, without prejudice to the Indians but rather to their benefit.

49. Item: I likewise grant you permission to appoint aldermen and other administrative officials for the towns that may be settled, for the time that I may will, provided that those who are thus appointed shall receive my confirmation within four years; and I grant you permission to raise and recruit in New Spain and Nueva Galicia and in all the cities, towns, and places of both provinces, the said three hundred men. 
pongan impedimento ni estorvo a Vuestros officiales antes Los ayuden y favorescan para Levantarla y para que a La gente que se asentare para yr con ellos no se les ympidan La jornada y Les Haga dar Los Bastimentos necesarios y aloxamientos Ajustes y moderados Precios Segun que Entre ellos Valieren.

50. Asimismo os mandare dar cedula mia para que Los que Una Vez se huvieren asentado y alistado Para esta Jornada os obedescan y no se aparten ni deroten ni Vayan a otra sin Vuestra Licencia So pena de muerte.

51. Yten os mandare dar Cedula mia para que Los presidentes y juezes oficiales de la cassa de La contratacion De Sevilla os den toda La ayuda y asistencia necessaria y acomoden para facilitar Vuestra enbarcacion y de Las dichas ciento y Treynta Personas y que a Vos ni a ellos no os pidan ynformacion alguna Con que los que fueren casados No vayan sin sus mugeres y que ninguno Sea de Los Proybidos A pasar a aquellas partes.

52. Ansimismo mandare que si se os oviere de tomar Residencia quando se combenga Se tenga Consideracion en Vuestra Persona calidad y Servicios.

53. Y Para que Con mas animo y mejor Voluntad Se dispongan A seguiros a esta Jornada Hago merced a Los que La hicieren y Poblaren y ayudaren a cumplir Con lo Aqui capitulado por Honrrar Sus personas y sus decendientes y que dellos Como de primeros pobladores que de memoria Loable que sean hijos dalgo de solar conocido ellos y sus descendientes para que en los pueblos que poblaren de todas aquellas provincias sean avidos y tenidos por Hijos dalgo y personas nobles de linage y gozen de. todas Las preheminencias y honrras de los tales y puedan Hazer todas las cossas que todos los Hijos dalgo y cavalleros destos Reynos, segun fueros leyes y Costumbres de españa pueden y deven hazer Con que no an de gozar De la dicha Hidalguia y nobleza En dexando La dicha provincia ellos o sus descendientes.

54. Yten os concedo y doy Licencia y facultad Para que podays nombrar alguacil mayor y todas Las demas baras de Las ciudades y Pueblos De la governacion de Aquellas provincias por el tiempo que fuere mi Voluntad Encargandole que Las personas que nombrare tengan Las Partes que Conviene.

55. Yten Se os dare Cedula Mia para que ningun Juez ni justicias De aquellas partes no ympidan la Jornada A los que la quizieren Hazer Aunque Ayan cometido delitos No Haviendo parte que Los Siga Conforme A lo dispuesto en el capitulo sesenta y siete de Las dichas ordenanzas de descubrimientos.

56. Yten Se os dara cedula Para que Podays Encomendar todos los yndios de aquellas provincias como dicho es que no fueren puertos $\mathrm{Ni}$ caveceras y tasar Los tributos que an de pagar Los Indios Encargandole que los tributos Sean moderados.

57. Yten Se os concede que Si Antes de acavar La dicha Jornada fallecieredes Al tiempo de Vuestra muerte Podays nombrar persona que La Prosiga conforme a lo dispuesto En el Capitulo cinquenta y seis de Las 
And for the naming of the maestre de campo and now and later the other captains and necessary military officials, from the greatest to the least, I shall shortly order that you be given my decree and that the justices shall not only not place any impediment or interference in the way of your officials, but rather shall assist and favor them in the recruiting; that they shall not prevent the people who have enlisted to go with them from going on the expedition; and that you shall cause them to be given the necessary provisions and equipment at just and moderate prices, according to what they are worth among them.

50. I shall likewise give you my decree that those who have once enlisted for this expedition shall obey you and not break away or go with any other without your permission, under pain of death.

5I. Item: I shall give you my decree that the president and official judges of the Casa de Contratación of Seville shall give you all the aid and assistance necessary and shall help to facilitate your embarkation and that of the said hundred and thirty persons, and that they shall not ask for any report from either you or them, provided that those who are married do not go without their wives and that none shall be of those who are prohibited from going to those parts.

52. I shall likewise order that if you be required to render an account at the proper time consideration shall be had for your person, character, and services.

53. And in order that they shall be disposed to follow you on this expedition with more spirit and better will, I grant to those who go upon it and make settlements and aid in carrying out what is here agreed upon, in honor to their persons and their descendants as first settlers of praiseworthy memory, that they shall be hidalgos of recognized estate-they and their descendants - and that in the towns which they may settle in all those provinces they shall be known and held as hidalgos and persons of noble lineage, and shall enjoy all the privileges and honors of such persons and be permitted to do all the things that all the hidalgos and caballeros of these kingdoms, according to the statutes, laws, and customs of Spain, can and have the right to do, provided that they are not to enjoy the said privileges of nobility if they or their descendants leave the said province.

54. Item: I grant to you and give you license and power to name the alguacil mayor and all the other officers of administration of the cities and towns in the jurisdiction of these provinces, for such time as I may will, charging you to see that the persons whom you name shall have the abilities required.

55. Item: I will give you my decree that no judge or justice of those parts shall interfere with those who may wish to go on the expedition, even though they may have committed crimes, provided that there is no party to prosecute them, according to what is ordered in article 67 of the said ordinances of discoveries.

56. Item: I will give you a decree giving you the power to place all the Indians of the said provinces in encomienda, except, as has been said, the ports and capital cities, and to fix the tributes that the Indians are to pay, charging you to see that the tributes are moderate. 
dichas Hordenanzas De nuevos descubrimientos siendo de Las partes y Como Conbiene.

58. Y Por que el Virey Luys de Velasco en Virtud de Una cedula mia Tomo asiento y capitulacion con Juan de oñate sobra La dicha Jornada y despues Le me jorro el Conde de monterrey y por otra mi çedula e embiado A mandar Al dicho Conde de monterrey que suspenda el dicho Asiento y Capitulacion y si el dicho don Juan de oñate, oviese començado La Jornada Le Hiziese Detener y que no la Prosiguiese Avisandolo tanvien de Como se quedava capitulando Con bos Os mandare dar Los despachos nescesarios Para que se guarde y Cumpla esta Capitulacion Sin embargo Ansimismo del estado en que estuviere Su cumplimiento y execucion y de que aya Començado a entrar y Hazer La dicha Pacificacion poblacion y descubrimiento Por ser Como es mi Real y determinada Voluntad que Vos la Hagays y no otra persona alguna La dicha Pacificacion Poblacion y descubrimiento y començado Por otro Lo Prosiguayz y acavays.

59. Yten os mandare dar Licencia para que Si dentro de Seys años tubieredes pacificas y pobladas Las dichas provincias y Reynos Podays Veniros Dexando en Vuestro lugar Persona qual conbenga hasta que yo provea y mande otra cossa a satisfacion del Virey quel ${ }^{\mathrm{h}}$ o fuere de la nueva españa.

6o. Yten os mandare dar Licencia para que destos Reynos podays llevar a aquellas provincias todas las armas ofensibas y defensibas polvora y municiones que quicieredes.

6I. Tanbien os mandare dar Licencias para que podays llevar cinquenta esclavos negros Libres de derechos asi de Los Treynta ducados de La licencia como de otro qualesquiera que Me pertenecieren en Las yndias esto de los ciento que Reserve a mi disposicion En cada Un año en el Asiento de pedro Gomez Reynes.

62. Ansimismo os mandare dar cedula mia para que si tuvieredes Nescesidad de mas polbora de los quarenta quintales arriva dichos os den en la ciudad de Mexico al mismo precio que esta Concordado, Se de La que es menester para Las cossas de mi servicio Por ende Cumpliendo Vos el dicho Don Pedro Ponce de Leon Lo contenido En esta Capitulacion de La manera que Lo Offreceys de mas de que manda tener quanta y Consideracion Con Vuestros servicios Para que Conforme a La calidad dellos y de Vuestra Persona Rescivays merced por La Presente os Prometo y aseguro por mi ffé y palabra Real que de mi parte Se os ofrece Lo mandare cumplir y que contra ello No se vaya ni pase, en manera alguna Con. que si Vos no cumplieredes Lo que Conforme a este asiento soys obligado No solamente no se os guardara Lo que aqui se os Promete pero meter no por de servido y mandare que se proceda contra Vos y Para Vuestrah seguridad os mando dar La presente firma De mi mano ques fecha en Sancto Lorenzo a Veynte y cinco de Septienbre De mill y quinientos y noventa y Seys años, Yo EL REy.-Por mandado del Rey nuestro Señor JUAN DE YBARRA.

h Evidently a miscopy for "que es". 
57. Item: I grant to you, if you should die before the said expedition is finished, the power to name at the time of your death the person who shall continue it, in accordance with what is ordered in article 56 of the said ordinances of new discoveries, provided that he shall possess the abilities required.

58. And because Viceroy Luís de Velasco, in virtue of a decree of mine, made a contract and agreement with Juan de Oñate with regard to the said expedition, which was afterwards confirmed by the Count of Monterey, and I, by another decree, sent an order to the Count of Monterey to suspend the said contract and agreement, and, in case the said Don Juan de Oñate had commenced the expedition, to detain him and not permit him to continue it, informing him also of the agreement made with you, I will order that you be given the necessary warrants so that this agreement may be kept and fulfilled, notwithstanding the state in which the fulfillment and execution of the said pacification, settlement, and exploration may be, or that it may have been commenced, for it is my royal and determined will that you and no other person whomsoever shall undertake the said pacification, settlement, and exploration, or if it has been commenced by another that you shall continue and finish it.

59. Item: I will order that you be given permission, if within six years you have pacified and settled the said provinces and kingdoms, to come away, leaving in your place a person suitable and satisfactory to the viceroy who is now or may be then governing in New Spain, until I shall provide and order otherwise.

6o. Item: I will order that you be given permission to take from these kingdoms to those provinces all the arms, offensive and defensive, and powder and munitions that you wish.

6I. I will also order that you be given permission to take fifty negro slaves, free of duties, not only of the thirty ducats for the license but also of any other that may belong to me in the Indies, except the hundred that I reserved for my disposition yearly in the contract with Pedro Gómez Reynes.

62. I will likewise order that you be given my decree that if you have need of more powder than the forty quintals abovesaid they shall give you in the City of Mexico, at the same price that is agreed upon, whatever is necessary for the affairs of my service. Finally, if you, the said Don Pedro Ponce de León, carry out what is contained in this agreement in such manner as you have promised, besides the order given that in consideration for your services you shall receive favor commensurate with their character and your person, I promise and assure you in the present decree, by my faith and royal word, that what is offered you on my part I shall order to be carried out, and that no step whatever be taken against it, provided that, if you do not fulfill what in conformity with this agreement you are under obligations to do, not only will what is promised you not be kept but you will be set down as having failed in your duty and I shall order that proceedings be taken against you. For your protection I order that you be given the present decree, signed by my hand, dated at San Lorenzo, September 25, I 596. I the KING. By order of the king, our lord, JuAN DE YBARRA. 
Facultad para encomendar yndios a don pedro ponce de Leon que ba por governador y cappitan general a las provincias del nuevo mexico. ${ }^{i}$ [San Lorenzo, I6 de Octubre de I596.]

Don Phelipe Q. ${ }^{j}$ Por quanto en el asiento y Capitulacion que mande tomar con don Pedro ponze de leon Sobre La poblacion y pacificacion de La provincia de nuevo mexico ay dos capitulos por los quales Le doy facultad para que pueda encomendar Los Repartimientos de yndios que Huviere en Las dichas provincias a Los Pacificadores y Pobladores dellas Como se contiene en Los dichos Capitulos y Son del Thenor siguiente:yten se os consede ... y Porque Mi Voluntad es que Lo Contenido en ellos se guarde y Cumpla Por la presente doy Poder y facultad Al dicho don Pedro Ponze de Leon Para que conforme A los dichos capitulos Pueda encomendar todos los Repartimientos de yndios de Las dichas provincias de $\mathrm{La}$ manera mexor teniendo Consideracion $\mathrm{A}$ que no aya eceso en ello sino que Los dellos que sirvieren en lo sobredicho A Cada Uno Conforme A su qualidad y servicios Lo que biere que mereciere Con que los puertos y caveceras Se pongan en mi corona y que las encomiendas Las Haga Conforme a La ley de la suscesion con las cargas y Condiciones que por mi esta hordenado Haziendo que se guarden Las Hordenanzas cedulas y provisiones que estan dadas Sobre el Buen tratamiento y doctrina de los yndios tasando haziendo tasar Conforme A las nuevas leyes y lo que cerca del tributo que huvieren de dar a sus encomenderos esta hordenado para que aquello paguen y no otra cosa alguna Con el precavimiento que Los que exedieren en esto seran Pribados de Los dichos encomiendas y quedaran ynabiles y encapaces para tener aquellas ni otras dada en san lorenço a diez y seys de otubre de mill y quinientos y nobenta y seys años yo EL REy Refrendada de JUAN DE ybARRA.

Para que don pedro Ponce de Leon que ba por governador y Cappitan general de la nueva mexico pueda nombrar maese de campo Capitanes y oficiales de guerra nesçesarios y Levantar en la mueva españa y nueva galicia 300 Soldados Casados y Solteros Conforme a Un capitulo de su Asiento. ${ }^{\circ}$ [San Lorenzo, IO de Octubre de I596.]

Por La presente Doy licencia A Vos Don pedro Ponze de leon Con quien e mandado tomar asiento y Capitulacion Sobre el descubrimiento pacificacion y Poblacion de Las Provincias del nueva mexico para que en Conformidad de Uno de los capitulos del dicho Asiento podays nombrar maese de Campo capitanes y oficiales de guerra nesçesarios y Levantar Vos o ellos en Las ciudades Villas y Lugares de las provincias de la nueva españa nueva galicia trezientos Soldados Casados y Solteros y Labradores para cultibar La tierra y oficiales de todos oficios y Publicar

1 A. G. I., Indif. Gen., I39-I-2.

1 It is not clear for what this abbreviation stands.

k A. G. I., Indif. Gen., I39-I-2. 
Power granted to Don Pedro Ponce de León, who is going as governor and captain-general to the provinces of New Mexico, to give Indians in encomienda. [San Lorenzo, October I6, I596.]

Don Felipe, $Q$ : Inasmuch as in the contract and agreement which I ordered to be made with Don Pedro Ponce de León concerning the settlement and pacification of the province of New Mexico, there are two articles by which I give him power to give in encomienda the divisions of Indians that there may be in the said provinces among the pacifiers and settlers of them, as is contained in the said articles as follows:- "Item, you are granted. . . ." And because it is my will that what is contained in them be kept and fulfilled, I give, by these presents, power and authority to the said Don Pedro Ponce de León, in conformity with the said articles, to give in encomienda all the divisions of Indians of the said provinces in the best manner, bearing in mind that there shall be no excess in it, but that each of those who may serve in the above shall receive in proportion to his character and services, as may be seen that he deserves, provided that the ports and capital cities shall be assigned to the crown, and that he shall grant the encomiendas in accordance with the law of succession, with the charges and conditions that have been ordered by me, taking care that the ordinances, decrees, and measures that have been given upon the food, treatment, and instruction of the Indians be kept, and taxing them according to the New Laws and what has been ordered concerning the tribute that they are to give to their encomenderos, so that they shall pay that and nothing more, with the warning that those who exceed in this shall be deprived of the said encomiendas and shall be disqualified and incapacitated from holding those or any others. Given at San Lorenzo, October I6, I596. I the KInG. Countersigned by JuAN DE YBARRA.

Power granted to Don Pedro Ponce de León, who is going as governor and captain-general of New Mexico, to name the maese de campo, captains, and necessary military officers, and to recruit in New Spain and Nueva Galicia three hundred soldiers, married and single, in accordance with an article of his contract. [San Lorenzo, October I9, I596.]

By these presents I give power to you, Don Pedro Ponce de León, with whom I have ordered a contract and agreement to be made concerning the exploration, pacification, and settlement of the provinces of New Mexico, to name, in conformity with one of the articles of the said agreement, the maese de campo, captains, and necessary military officers, and to you and to them to raise in the cities, towns, and villages of the provinces of New Spain and Nueva Galicia, three hundred soldiers, married and single, laborers to cultivate the land, and officials for all the offices, and to publish the expedition and raise banners and cause fifes and drums to be sounded in all the aforesaid places that seem suitable to you. 
La Jornada y enarbolar banderas y Hazer tocar pifanos y atambores En todas Las Partes Sobredichas que os pareciere y mando a mi Virey de la dicha nueva españa y al presidente y oydores De mi audiencia Real de la dicha Provincia de la nueva Galieia y a otros quales de mis Juezes y Justicias de Las dichas provincias A quien esta mi cedula o su traslado signado de escrivano Publico fuere mostrado que no os pongan a Vos $\mathrm{Ni}$ a las personas que Nombraraedas para el dicho he fecho ympedimento alguno en Hazer y levantar Las dichas gente antes a Vos y a ellos os den y Hagan dar el favor y ayuda nescesarias para ello y que a la gente que asentare para la dicha jornada no se la impidan y les hagan dar Los aloxamientos y bastimentos y Vastimentos nescesarios Ajustos y moderados precios Segun que entre ellos balieren Sin Los mas en carecer fecha en san Lorenzo a diez y nueve de octubre de mill y quinientos y noventa y Seys años yo EL REy: Refrendada de JuAn DE ybarRa y Señalada del presidente y los delegados.

Titulo de Governador y cappitan general de Los Reynos y Provincias de la nueva mexico para don Pedro Ponce de leon. ${ }^{2}$ [San Lorenzo, 26 de Octubre de I596.]

Don Phelipe Q. ${ }^{\mathrm{m}} \quad$ Por quanto en el asiento y Capitulacion que e mandado Tomar Con bos don Pedro ponce de leon, cuya diz que es la Villa de Vaylen Sobre el descubrimiento pacificacion y Poblacion de los Reynos y Provincias de la nueva mexico os prometi que se os dara titulo de Governador y cappitan general de Las dichas provincias y Cumpliendo de mi parte con Lo que asi Se Conserto porque Teniendo consideracion a Los muy buenos y Señalados servicios que Buestros pasados Hizieron a Los señores Reyes mis progenitores y a los que Vos me aveis Hecho y esperando que Los continuareys himitandolos y que por Buestro medio se conseguiran Los buenos efectos que deseo principalmente En que los naturales de Aquellas Provincias Vengan en Verdadero Conocimiento de dios Su criador y Redemptor para que Puedan salvarse y que mi corona rentas y patrimonio sea augmentado y tanbien a las Costas y gastos que Haveys de Hazer en esta jornada En Cunplimiento del dicho asiento quiero y es mi Voluntad que por todos Los dias de Vuestra Vida o por el Tiempo que bastare ${ }^{\mathrm{n}}$ o Vos quisieredes ocuparos En La dicha Pacificacion y Poblacion con que no sean menos de seys años Seays mi governador y cappitan general de las dichas Provincias y Reynos de La nueva Mexico quanto Se estendieren por aquellas partes como no Toque A Provincia Reyno ni tierra cuyo govierno este encomendado a otra persona y que Como tal mi governador y cappitan general Vos y Vuestros Tenientes que os doy licencia Para poner donde y en las Partes que quisieredes y Combiniere y no otra persona Alguna Useys y exerceys Los dichos Cargos

1 A. G. I., Indif. Gen., I39-I-2.

$m$ It is not clear for what this abbreviation stands.

n Evidently a miscopy for "gustase". 
I order my viceroy of the said New Spain and the president and oidores of my royal Audiencia of the said province of Nueva Galicia and all my other judges and justices of the said provinces, to whom my decree or a copy of it signed by a public clerk shall be shown, not to place in your way or in that of the persons whom you may name any impediment whatsoever to what I have decreed for recruiting the said soldiers, but rather to give, and cause you to be given, all the favor and assistance necessary for it, and not to interfere with the people that shall be enlisted for the said expedition, and to cause them to be given the equipment and provisions necessary at a just and moderate price, according to what they are worth among them, without raising the price. Done at San Lorenzo, October I9, I 596. I the King. Countersigned by JuAN DE YBarRa and signed by the president and the delegates.

\section{Title of governor and captain-general of the kingdoms and provinces of New Mexico in favor of Don Pedro Ponce de León. [San Lorenzo, October 26, I596.]}

Don Felipe, Q. Inasmuch as in the contract and agreement that I have ordered to be made with you, Don Pedro Ponce de León, whose [residence] is said to be in the town of Bailén, concerning the exploration, pacification, and settlement of the kingdoms and provinces of New Mexico, I promised that you would be given the title of governor and captain-general of the said provinces, in fulfillment on my part of what was thus agreed upon, and in consideration of the very good and distinguished services which your ancestors rendered to my royal progenitors, and those which you yourself have rendered to me, and in the expectation that you will continue to imitate them, and that through you the good results that I desire will be accomplished, especially in that the natives of those provinces shall come to a true knowledge of God, their creator and redeemer, so that they may be saved, and that my kingdom, revenues, and patrimony shall be increased, and also [in consideration of] the expenses that you have to incur in this expedition in fulfillment of the said contract, I desire, and it is my will, that for all the days of your life, or for the time that you are pleased and wish to occupy yourself in the said pacification and settlement, provided that it shall not be less than six years, you shall be my governor and captain-general of the said provinces and kingdoms of New Mexico, as far as they shall extend in those parts, provided that they do not touch upon any province, kingdom, or land whose government has been already committed to another person. As my governor and captain-general, you and your lieutenants, whom I give you permission to appoint where and in the parts that you wish and it is most suitable, and no other person, shall use and exercise the said offices, administering my justice, civil as well as criminal, and in all the other cases and affairs related to and concerned with it, according to the 
administrando Mi justicia asiento, cevil como en lo criminal y en todos Joos demas cassos y cossas al anexas y Concernientes segun y de la manera que Lo azen y Pueden azer Los otros mis governadores y Capitanes generales de semejantes provincias y tierras y repartir y encomendar entre los soldados que os Acompañaren En el dicho descubrimiento pacificacion y poblacion y los que despues fueren a ayudar en ella Los Repartimientos de yndios de todas aquellas provincias Por tres Vidas comforme a la ley de La suseccion En La forme y manera que se contiene en Uno de los capitulos de Vuestro Asiento y en el cinquenta y ocho de las ordenanzas de nuebas poblaciones y descubrimientos dexando Para mi los Puertos y Caveceras $\mathrm{Y}$ por esta mi cassa ${ }^{\circ}$ o Su traslado Signado de escrivano Publico mando a los consejos Justicias regidores Cavalleros escuderos officiales y hombres buenos de todas las ciudades Villas y Lugares que estuvieren pobladas y Vos poblaredes que Las dichas provincias y a Los oficiales de mi Hazienda que nombraredes que aviendo Vos el dicho don Pedro Ponze de Leon Hecho el Juramiento y con La solenidad que en tal caso se Requiere y deveys Hazer en manos de las Justicias del pueblo que estuviere poblado el primero que Poblaredes en ellas os ayan Recivan y tengan Por mi governador y cappitan general y Como a tal os dexen governador todas las dichas Tierras y provincias y Juntamente exercer el dicho cargo de cappitan general En las cossas de la guerra y pacificacion y que como tal Os obedescan y acudan a Vuestros llamamientos alardes muestras y Reseñas ansi Para las faciones de Guerra y buen asiento y Pacifico estado de la tierra como para executarlos estando siempre Prestos y obedientes a Vuestras ordenes Con sus armas y cavallos y Criados como Si yo se Lo Hordenase y mandase y que lo mismo hagan Con Vuestros Tenientes Maeses de campo capitanes oficiales, Ansi por tierra Como por mar Si en Vuestros distritos descubrieredes que llegan a Aquellas Tierras A La mar del Sur o del norte y os dexen Libremente oyr Librar y Conocer de todos Los Pleytos y caussas ansi ceviles como criminales que en las dichas Provincias se offrecieren de que pudieredes y devieredes conocer y tomar y Recevir todas y quales quieres Pesquisas y ynformaciones en Los casos y cossas de dichas Premisas ${ }^{p}$ que entendieredes que a mi servicio execucion de mi Justicia y buena governacion de las dichas provincias Conbiene y llevar y lleveys Vos y los dichos Vuestros Tenientes Los derechos a Los dichos cargos anexos y Pertenecientes y que para Los Usar y exercer cumplir y executar mi Justicia todos se Conformen Con Vos Con Sus personas y gentes y os obedescan y acaten den y Hagan dar todo el favor e ayuda que Les pidieredes y ubieredes menester y que en ello ni en parte dello no os pongan $\mathrm{Ni}$ contan Poner embargo ni contrario alguno Yo por la presente os Recivo y e por Recivido a los dichos cargos y al Uso y exercicio dellos y os doy poder y facultad para los Usar y exercer cassos que por ellos o Por alguno dellos a ellos no seays Recivido... y otrosi es mi Voluntad y mando que si Vos el dicho don pedro entendieredes que Cumple a mi servicio y a la execucion De mi Justicia que qualquiera persona que durante el tiempo de Vuestro govierno Resi-

- Evidently a miscopy for "cédula".

p Clearly a miscopy for "Provincias". 
manner in which my other governors and captains-general of such provinces and lands do and have authority to do.

And I give you permission to divide and give in encomienda among the soldiers who may accompany you in the said exploration, pacification, and settlement, and those who may afterwards go to take part in it, the Indians of all those provinces, for three generations according to the law of succession, in the form and manner that is contained in one of the articles of your contract, and in article 58 of the ordinances of new settlements and discoveries, leaving for me the ports and chief towns. By this my decree or a copy of it, signed by the public clerk, I order the councils, justices, councilmen, knights, squires, officials, and notable men of all the cities, towns, and villages that may be settled and that you may settle in the said provinces, and the officials of my exchequer that you may name, that, after you, the said Don Pedro Ponce de León, shall have taken the oath, with the ceremony that in such a case is required and is your duty to use, at the hands of the justices of the first town that may be settled, they shall receive and hold you for my governor and captain-general, and that they shall allow you as such to govern all the said lands and provinces, and at the same time to exercise the said office of captain-general in matters of war and pacification, and that they shall obey you as such and respond to your calls, reviews, and musters, being always ready and obedient in executing your orders in military affairs and in maintaining the peace and quiet of the land with their arms, and horses and servants, as though I myself had ordered it. And they shall do likewise with regard to your lieutenants, maestres de campo, captains, and other officials. This shall be the same by sea as by land, if the districts that you explore extend to the South or the North Sea. They shall permit you freely to hear, pass sentence on, and try all the lawsuits and cases, civil as well as criminal, that may occur in the said provinces, in which you are authorized and it is your duty to hold and take and receive all and every inquiry and report in the affairs of the said provinces that you consider to be necessary for my service, the execution of my justice, and the good government of the said provinces. They shall permit you and your said lieutenants to collect the fees belonging and pertaining to the said offices, and in order to use, exercise, fulfill, and execute my justice, all shall yield to you, with their persons and people, obey you, respect you, give, and cause to be given, to you all the favor and assistance that you may ask or need from them, and they shall not put in your way, nor even consider it, any obstacle or interference whatever. By the present decree I receive, and hold you as received, in the said offices and the use and exercise of them, and I give you power and authority to use them in the practice of such cases as you may not have received power for, by them or any one of them. Moreover it is my will and I order that if you, the said Don Pedro, consider that it is to the advantage of my service and the exercise of my justice that any person residing in those provinces during the time of your government shall leave them and not return to them and shall appear before me, you shall have the power to order them in my name to leave there, in accordance with the edict that speaks about this. informing the person 
diere en Aquellas provincias Salgan y no entren mas en ellas y se Vengan Ante mi Se Lo podays mandar de mi parte y los Hagays Salir dellas conforme a la prematica que Sobre esto abladando a la persona que desterraredes La Causa Porque La desterrarays y si os paresciere que Conbiene sea secreta se la dareys cerrada y sellada y Un traslado me embieys Por dos Vias para que Sea informado dello pero aveys destar advertido que quando Ubieredes de desterrar a alguno a de ser con muy gran caussa Para Lo qual todo que dicho es os doy Poder Cumplido con sus Yncidencias y dependencias anexidades y Conexidades y Los Unos y Los otros no agays cossa en Contrario, dada en San Lorenzo a veynte y seys de octubre de mill y quinientos y noventa y seis Yo EL REY referendada de JUAN DE YBARRA y firmada del presidente y los delegados.

[Copias o extractos de treinta y cuatro cédulas reales relativos a la capitulación que se tuvo con Dón Pedro Ponce de León. I de Octubre de I596 hasta 2 de April de I597.]

E1 Rey:-Mis presidentes y Juezes oficiales de la casa de la contratacion de Sevilla por Uno de los Capitulos del Asiento que Mande tomar Con Don Pedro Ponze de leon Sobre el descubrimiento pacificacion y Poblacion de las provincias del nuevo mexico Le offresçi de que se le darian quatro pieças de Artilleria quarenta quintales de Polvora y ciento y treynta de Plomo para llevar a las dichas provincias y por que me a Supplicado ademas de aquello Le mandase dar Sesenta quintales de mecha Visto Por Los de mi gobernacion de Las yndias Lo e Havido por Vien y asi os mando que de qualquier haçienda mia que tuvieredes Compreys todo lo sobredicho y lo entregueys al dicho don Pedro para que Lo lleve a Las dichas provincias y en Las dichas pieças hareys que se pongan mis Armas por que An de quedar y Ser para mi fecha En san Lorenzo a diez y Seys de octubre de mill y quinientas [y noventa] y seys años yo el Rey Refrendada de JuAN DE yBaRRa, etc.

El Rey.-Por La Presente doy Licencia a Vos don pedro Ponce de Leon a quien e proveydo por Mi governador y cappitan General de las provincias de el nuevo mexico para que En conformidad de Uno de los capitulos del asiento que mande tomar Con bos Sobre el descubrimiento Pacificacion etcétera de las dichas provincias podays dibidirlas En distritos de Alcaldias mayores y Corregimientos para lo qual os doy Poder y facultad Con que no sea perjuicio de los Yndios Sino en su beneficio y que me agays de embiar Relacion de La dibision a mi gobierno Real de las yndias para que se aprueve o Reforme fecha en san Lorenzo A dies y Seys de octubre de mill y quinientos y noventa y seys años yo EL REY etc.

El Rey.-Don pedro Ponce de Leon A quien e Proveydo por mi governador y cappitan general de las provincias del nuevo mexico en

q A. G. I., Indif. Gen., I39-I-2. 
whom you banish of the cause of his banishment; and if it seems best to you that it should be secret, you will give it to him closed and sealed and send me a copy by two roads, so that I may be informed of it; but you must take warning that if you banish anyone it must be for very great cause. For all that has been stated I give you full power, with its incidents, accessories, relations, and connections, and no one shall do anything in opposition to it. Given at San Lorenzo, October 26, I 596. I THE KING. Countersigned by JUAN DE YBARRA and signed by the president and the delegates.

[Copies or extracts of thirty-four royal cédulas relative to the contract which was made with Don Pedro Ponce de León. October I2, I596, to April 2, I597.]

The King. My president and official judges of the Casa de Contratación of Seville: By one of the articles of the contract which I ordered to be made with Don Pedro Ponce de León concerning the exploration, pacification, and settlement of the provinces of New Mexico, I agreed that he should be given four pieces of artillery, forty quintals of powder, and one hundred and thirty of lead, to take to the provinces. But because he has petitioned that he be given in addition sixty quintals of fuse, with the approval of my department of the Indies I have decided upon it favorably; therefore I command you to buy from whatever funds of mine that you may have all the above-said and deliver it to the said Don Pedro for him to take to the said provinces, and that you cause my arms to be placed on the said pieces, for they are to remain and be mine. Done at San Lorenzo, October I6, I596. I THE KING. Countersigned by JUAN DE YBARRA. Etc.

The King. By these presents I give power to you, Don Pedro Ponce de León, whom I have appointed as my governor and captain-general of the provinces of New Mexico, in conformity with one of the articles of the contract which I ordered made with you concerning the exploration, pacification, etc. of the said provinces, to divide them into districts of alcaldías mayores and corregimientos, for which I give you power and authority, provided that it be not to the prejudice of the Indians but rather to their benefit. You are to send me a statement of the division to my royal department of the Indies, so that it may be approved or altered. Done at San Lorenzo, October 16, I 596. I the King. Etc.

The King. Don Pedro Ponce de León, whom I have appointed as my governor and captain-general of the provinces of New Mexico: In conformity with the contract that $I$ have ordered made with you concerning the said exploration ... I give you permission and authority to name 
Conformidad del Asiento que e mandado tomar Con bos sobre el dicho descubrimiento. . . os doy Licencia y facultad para que podays nombrar personas que sirven Las baras de Alguacel mayor y todas Las demas Baras de Las ciudades y Pueblos de La governacion dellas por el tiempo que fuere mi Voluntad Con que sean de Las partes y calidades que Convienen para Servir Los dichos officios fecha en San Lorenzo a doze de octubre de mill y quinientos [y noventa] y seys yo EL REY etc.

E1 Rey.-Conde de monterey Pariente mi Virey governador y cappitan General de la nueva españa o a la Persona o personas a cuyo cargo fuere el govierno della como teneys entendido y e mandado tomar asiento Con don pedro ponce de leon Sobre el descubrimiento etcetera, etcetera. de nuevo mexico y por que Por Un capitulo del dicho asiento le offresco que Si tuviese nescesidad de mas polvora de Los quarenta quintales que aca Le e mandado dar para Hazer La Jornada Se Le daria en esa ciudad Os mando que si el dicho don pedro tuviese necesidad de mas Polvora Le Hagays dar La que mas Ubiere menester al prescio que era Concertado Se de para cossas de mi servicio fecha en san Lorenzo a diez y seys de octubre de mill y quinientos y nobenta y seys años yo el Rey. Etc.

E1 Rey.-Por La presente Doy Licencia a Vos don pedro Ponce de Leon a quien e Proveydo Por mi governador ... para que dessos Reynos y Señorios podays llevar a aquellas provincias todas las armas ofensibas y defensibas polvora y municiones que quizieredes y mando que en ello no se os Ponga ympedimento alguno fecha la misma.

El Rey.-Don pedro Ponce de Leon A quien e proveydo Por mi governador y cappitan general de la provincia del nuevo Mexico en el asiento que Mande tomar Con Vos En Veynte y cinco de septiembre deste presente año Sobre el descubrimiento pacificacion y Poblacion de La dicha provincia ay Un capitulo por el qual os Doy Licencia para que Podays dar exidos y abrevaderos a Los pueblos que en nueva mexico se Poblarren y abrir Caminos Como se Contiene en el dicho capitulo ques del Thenor siguiente: . . . fecha en san Lorenço a doze de octubre etc.

E1 Rey.-Por la presente doy licencia a Vos etc. ... o a quien Vuestro poder huviere para que destos Reynos y Señorios Podays Llevar a aquellas Partes cinquenta esclavos negros Libres de derechos asi de Los dos dueños ${ }^{\mathbf{r}}$ de La licencia de Cada Uno dellos como de todos y qualesquier derechos que dellos Se me devan en Las yndias Por quanto de Lo que en ello Se monta os Hago merced y mando a los officiales De mi Hacienda de la ciudad de mexico tomen en su poder esta mi cedula y La Rasguen para que por Virtud della no se puedan pasar mas de Una vez Los dichos cinquenta esclavos ni ninguno dellos octubre I6. . .

r Evidently a miscopy for "duros". 
the persons to serve in the offices of alguacil mayor and all the other offices of the cities and towns of that district for the time that may be my will, provided that they shall possess the parts and qualities that are required for serving in the said offices. Done at San Lorenzo, October 12, I 596. I THE KING. Etc.

The King. Count of Monterey, my relative, viceroy, governor, and captain-general of New Spain, or the person or persons in whose charge its administration may be: As you have heard, I have made a contract with Don Pedro Ponce de León concerning the exploration, etc., of New Mexico. And, since I agree in one article of the contract that if he should have need of more powder than the forty quintals which I have ordered him to be given here for the expedition, it should be given to him in the City [of Mexico], I order that if the said Don Pedro has need of more powder you will cause him to be given what more he needs for the affairs of my service at the price agreed upon. Done at San Lorenzo, October I6, I596. I the King. Etc.

The King. By these presents I give power to you, Don Pedro Ponce de León, whom I have appointed as my governor . . . to take from these kingdoms and principalities to those provinces all the arms, offensive and defensive, and powder and munitions that you may need. And I command that no obstacle be placed in your way in this. Done the same.

The King. Don Pedro Ponce de León, whom I have appointed as my governor and captain-general of the province of New Mexico: In the contract which I ordered to be made with you on September 25 of the present year concerning the exploration, pacification, and settlement of the said province there is an article by which I give you authority to give public lands and watering places to the towns that may be settled in New Mexico, and to open roads, as is contained in the said article, which runs as follows: .... Done at San Lorenzo, October I2. Etc.

The King. By these presents I give permission to you ... or to whomever you may authorize, to take from these kingdoms and principalities fifty negro slaves, free of charges, not only for the two dollars for the license of each one of them, but also for all and whatsoever duties that pertain to me from them in the Indies. For, whatever this amounts to, I exempt you therefrom and I command the officials of my exchequer of the City of Mexico to take this decree into their possession and tear it up, so that the said fifty slaves, or any one of them cannot be passed through more than once by virtue of it. October $16 . .$.

The King. Count of Monterey, my relative, viceroy, governor . . . or the person or persons in whose charge the administration may be: Since by one of the articles of the contract which I ordered made with Don Pedro Ponce de León . . . I agreed to give him for the expedition the Indians that seemed to belong to those provinces, and particularly an 
E1 Rey.-Conde de Monte Rey pariente mi Virey governador etc. o a la persona o Personas a cuyo Cargo fuere el govierno della por Uno de los capitulos del asiento que mande tomar con don pedro ponce de leon ... Le offreci que se le darian Para Hazer la jornada Los yndios que pareciesen ser de Aquellas provincias y Particularmente Una yndia que se traxo dellas, os mando deys orden Como se le den para que los buelva A su natural y Sirvan de ynterpretes. (La misma fecha)....

El Rey.-Por la presente doy licencia a Vos don pedro ponçe de leon ... Podays nombrar Regidores y otros oficiales de Republica en Los pueblos que se poblaren en ellas por el tiempo que fuere mi voluntad Conque dentro de quatro años ayan de llevar Confirmacion mia de los dichos oficios las personas en quien Las proveyeredes. (La misma fecha)....

E1 Rey.-Por quanto en el asiento y capitulacion que mande tomar Con don pedro ponçe de leon etc. ay Un capitulo Por el qual Le Hago merced y a los Descubridores y pobladores della de la alcavala que se me deviere y fueren obligados a Pagar En aquella provinçia por tiempo de Veynte años como se contiene En el dicho capitulacion del Thenor siguiente :- . . . fecha en San lorenço a doze de octubre. yo EL REY etc.

E1 Rey.-Oficiales de mi real Hazienda de la provincia del nuevo mexico por Un capitulo de asiento que mande tomar con . . . Le Hago merced a el y a los pacificadores y pobladores de esa provincia que de todo lo que por tiempo de diez años se llevare a ella para Proveymiento de sus casas no se les Pida derechos de almoxarifazgo como se contiene en el dicho Capitulo que es del thenor siguiente. . . . (La misma fecha). . . .

El Rey.-Por quanto en el asiento ... ay Un capitulo Por el qual hago merced a las personas que con Vos fueren a ella Al dicho descubrimiento que del oro Plata perlas y piedras preciosas no me paguen mas que el diezmo En lugar del quinto por tiempo de Veynte años como se contiene en el dicho capitulo. . . . (La misma fecha).

El Rey.-Mis presidentes y juezes oficiales de la casa de la contratacion de sevilla Por Uno de los capitulos ... se ofrece el dicho don pedro A que llevara destos Reynos ciento y treinta oficiales y Soldados y porque Agora entendos por Vien de darle licencia Para que lleve otros cient soldados mas que por todos sean dozientos y treynta y quede a su voluntad el llevarlos que quisiere sin obligarle a que lleve toda La cantidad Sobredicha enteramente Os mando que Le dexeys pasar asta el dicho numero de los dichos docientos y treynta Soldados y oficiales y criados Los quales parescieren y como quisieren Sin obligarles tanpoco A que lleven mas que las armas Hordinarias o Las que pudieren Con que Los que fueren casados Lleven sus mugeres y que puedan llevar sus hijos A Los Unos y a los otros Sin les pedir ynformaciones Algunas certificando el dicho don pedro

"Evidently a miscopy for "e tenido". 
Indian woman who was brought from there, I command you to give orders that they be given to him, to be returned to their native land, there to serve as interpreters. [The same date]...

The King. By these presents I give permission to you, Don Pedro Ponce de León . . . to name councilmen and other administrative officers in the towns that may be settled in them for such time as I may will, provided that the persons whom you may appoint shall be confirmed by me in the said offices within four years. [The same date]. . . .

The King. Inasmuch as in the contract and agreement which I ordered made with Don Pedro Ponce de León . . . there is an article by which I exempt him and the explorers and settlers from paying the excise tax which otherwise would be due me and which they would be under obligations to pay in that province for the term of twenty years, as is contained in the said article, which runs as follows: . . . Done at San Lorenzo, October I2. I the KING. Etc.

The King. To the officers of my real hacienda of the province of New Mexico: By an article of the contract which I made with . . . I grant to him and to the pacifiers and settlers of this province that upon all that they take to it for the term of ten years, for the provisioning of their houses, no import duties shall be charged them, as is contained in the said article, which runs as follows:... [ ['The same date]. . .

The King. Inasmuch as in the contract .. . there is an article by which I grant to the persons who may go with you on the said exploration that they shall pay me but a tenth instead of a fifth of the gold, silver, pearls, and other precious stones, for the term of twenty years, as is contained in the said article. . . . [The same date].

The King. My presidents and official judges of the Casa de Contratación of Seville: By one of the articles .... it is agreed that the said Don Pedro shall take from these kingdoms I 30 soldiers and officials. But because $I$ have now decided to give him permission to take a hundred more soldiers, making in all 230, of whom it is left to his decision to take as many as he pleases, without obligation to take all of the above-said number, I command you to permit him to pass through as many of the said number of the said 230 soldiers, officials, and servants, as may appear and may wish to go, without requiring them to take more than the ordinary arms, or what they are able to take, provided that those who are married shall take their wives and children, they to be permitted to take both without being asked for any report. And the said Don Pedro Ponce shall certify that they are not of those who are prohibited from going to those parts, with which I consider that the said Don Pedro will have fulfilled his duty, notwithstanding what is contained in the said abovementioned article. Done October 16. 
ponce que No son de los proveydos A pasar A aquellas Partes con lo qual tengo por Vien Aya Cumplido el dicho don pedro no embargante lo contenido en el dicho capitulo de que arriva se Hace mincion fecha diez y seys de octubre.

El Rey.-Don pedro Ponce de Leon ... en el Asiento . . . ay Un Capitulo por el qual os doy licencia para que a las personas que Con bos fueren Al dicho descubrimiento ... y que en ello os ayudaren y a sus hijos y descendientes Podays dar tierras y solares y para que los que Ubieren Poblado y Residido tiempo de cinco años en las dichas provincias La tengan en perpetuidad y a los que Ubieren hecho y poblado yngenio de açucar y lo tuvieren y mantuvieren Con esclavos No se les pueda Hazer execuzion En ellos ni en los dichos esclavos erramientas ni pertrechos Con que se labraren Como mas largamente se contiene en el dicho capitulo que es del thenor siguiente: ... misma fecha.

El Rey.-Conde de Monte Rey pariente mi Virey . . . Con don pedro Ponce de leon que dize ques de la Villa de Vaylen e mandado tomar asiento . . . eso sin embargo de Haver entendido que el Virey don Luys de Velasco havia Capitulado alla en la misma Razon Con don Juan de oñate En Virtud de Una cedula mia y de que Vos me escrivistes cerca desto y aunque Luego que se Recivieron Vuestras Ultimas cartas mande despachar cedula en que se os ordenava no Pasasedes adelante en Los conciertos y que si don Juan de oñate en Virtud dellos huviese Començado La Jornada se detuviese y le hiciecedes desistir della por quanto ya se avia aceptado el offrecimiento del dicho Don pedro ponce de leon y por que despues Se a efectuado y sabido tanbien que don Juan de oñate avia començado la Jornada y mi Voluntad es que no lo haga Os mando que Luego questa Reciveys proveys que se desista desta Jornada y no pase adelante parando en qualquier Parte donde llegare Vuestra Orden en La qual embiareys ynserta esta mi cedula Para que sabiendo mi Voluntad pare o buelva atras desaziendo La gente que tuviere teniendo Por desfecho su asiento que yo Por la presente Le Reboco y doy por ninguno y hareys que se le Proteste ansi el Castigo de su ynobediencia no lo Cumpliendo Luego Como todos Los daños o Costas y perdidas que se siguieren al dicho Don pedro Ponce de Leon que Un traslado de Su Asiento; os mando embiar Con esta para que esteys capaz de todo Lo que aca se a tratado y sepays Como se a de cumplir y asimismo mando a mi Real audiencia de La nueva galicia y a otras qualesquier mis Justicias de todas essas provincias guarden y cumplan esta mi cedula fecha en San lorenço a diez y nueve de octubre de mill y quinientos y noventa y seys años EL REY refrendada de JUAN DE YBARRA etc.

E1 Rey.-Por quanto Vos don pedro Ponze de Leon A quien e proveydo por mi governador .... me aveys supplicado que para que Los Vezinos de las dichas provincias acudan con mas animo y cuydado A La poblacion de Los pueblos que en ella se fundasen os Hiziesse merced de que a los tales pueblos les pudiesedes dar titulos de Villas y ciudades e Visto por Los de mi Consejo de las yndias Acatando Lo sobre dicho Lo 
The King. Don Pedro Ponce de León ... . in the contract... . there is an article by which I give you permission to give lands and lots to the persons, their children and descendants, who may go with you on the said exploration, and may aid you in it, and that those who shall have settled and resided for a period of five years in the said provinces shall hold it in perpetuity. I further order that no tax shall be levied upon those who shall have erected sugar-mills and maintained them with slaves, either upon themselves, or the said slaves, tools, and equipment with which they work, as is more fully stated in the said article, which runs as follows: ... Same date.

The King. Count of Monterey, my relative, viceroy . . . I have ordered a contract to be drawn with Don Pedro Ponce de León, said to be from the town of Bailén . . . notwithstanding that $I$ have heard that the viceroy Don Luís de Velasco had made an agreement there for the same purpose with Don Juan de Onate in virtue of a decree of mine ${ }^{33}$ and of which you wrote to me. Although as soon as your last letters were received I ordered a decree to be sent in which I ordered you not to go ahead with the arrangements and that, if, in virtue of them, Don Juan de Onate had begun the expedition he should be detained and made to desist from it-inasmuch as I had already accepted the offer of the said Don Pedro Ponce de León-it has since been learned that Don Juan de Oñate had commenced the expedition. It is my will that he shall not do it, and I command that as soon as you receive this you shall take measures to cause him to desist from this expedition and not go forward with it, stopping in whatever part he may be when he receives your order, in which you will send enclosed this my decree, so that, having learned my wish, he will stop and return, releasing the people that he may have with him, and understanding that his contract is broken, for by these presents I revoke it and hold it as void. You will see that he be warned of the punishment for his disobedience if he fails to do this promptly, as well as of the damages, costs, and losses that will ensue to the said Don Pedro Ponce de León. I order that a copy of his contract be sent to you with this, so that you shall be informed of all that has been arranged here and shall know how it is to be carried out, and I likewise command my royal Audiencia of Nueva Galicia and any others of my justices in all those provinces to keep and carry out this my decree. Done at San Lorenzo, October I9, I596. I the KIng. Countersigned by Juan de YbarRa. Etc.

The King. Inasmuch as you, Don Pedro Ponce de León, whom I have appointed as my governor ... have petitioned me-in order that the citizens of the said provinces shall take part with more spirit and zeal in the settlement of the towns that may be founded there-that I should grant you the power to give titles to the said settlements as towns and cities, and this having been approved by my Council of the Indies, I have, in view of the aforesaid, decided favorably upon it, and by these presents I give power to you, Don Pedro Ponce de León, to give in my name titles of towns and cities to the settlements that you may found in the said 
E havido por Vien y Por la Presente doy facultad a Vos el dicho don pedro Ponce de Leon para que en mi nombre podays dar titulos de Villas y ciudades a Los pueblos que En las dichas provincias del nuevo mexico poblaredes y Hazer repartimiento de Las Juridiciones entre los lugares como mas Conbenga Fecha En san lorenço a diez y nueve de octubre etc.

El Rey.-Por quanto Vos .... me aveys hecho Relacion que para el buen govierno de Las dichas provincias y Para que los que me sirviesen en su pacificacion y poblacion acudiesen con mejor animo y Voluntad Convernia mandar que Los officios de Paz y guerra que en ellas Huviesen de Prover fuesen los Hijos o nietos de los Primeros y Segundos Pobladores y no en otras Personas e Visto Por Los de mi gobierno de Las yndias Lo e avido Por Vien y Por la presente mando que no se puedan Dar ni den los dichos officios Sino fuere a las dichas Personas y que contra lo aqui contenido no se Vaya $\mathrm{Ni}$ pase, en manera alguna . . . la misma fecha. Etc.

El Rey.-Mi governador de la nueva Vizcaya Como lo teneys Entendido yo e mandado tomar asiento ... y Porque mi Voluntad es que sea ayudado y favorescido Os mando: que en todo lo que se Le offreciere para el dicho descubrimiento y Poblacion Le deys y hagays dar el favor y ayuda que Convenga y de su Parte se os Pidiere y si se uyeren ${ }^{\mathrm{t}}$ Algunos Soldados Los areys Volver adonde el estuviere y que se le entreguen . . . misma fecha. Etc.

El Rey.-Por quanto Vos . . . me aveys suplicado que para que Con mas Animo mejor Voluntad y esperanzas Puedan acudir a servirme En el dicho descubrimiento etc. de las dichas provincias. Los que Con Vos fueren Entendiendo que an de ser Premiados de sus servicios y despues Los segundos y terceros pacificadores y Pobladores Les Hiziese merced en que Las Provisiones De Paz o guerra que en ellas Hiziesen en las dichas provincias No Las Pudiese alterar ni remover La persona que os sucediese en el govierno dellas Sino dexarselos gozar Por su Vida e Visto Por los de Mi consejo de Las yndias e teniendo Consideracion a lo sobredicho Le e abido por Vien y Por la presente mando que Las provisiones que en la forma sobredicha Hicieredes no Pueda el dicho Vuestro sucesor Alterar Ni Removerlas Sino que Conserve Los cargos a Los que dexaredes Proveydos Para que los puedan goçar Por sus Vidas. . . . La misma fecha. Etc.

El Rey.-Por la presente Doy Licencia a Vos don Pedro Ponce de Leon ... para que suscediendo en ellas algun Rebelion o alteracion Contra el servicio De dios o mio Con Acuerdo de Mis officiales de las dichas provincias $\mathrm{Y}$ de la mayor Parte dellos Podays Librar Lo que fuere menester para Reprimir La dicha Revelion y mando a Los dichos mis officiales que lo que en esta conformidad y para el dicho efecto Libraredes

i Huieren. 
provinces of New Mexico, and to make a division of the jurisdictions among the towns as may seem best. Done at San Lorenzo, October I9. Etc.

The King. Inasmuch as you . . . have made a statement to me that, for the good government of the said provinces, and in order that those who may serve me in their pacification and settlement shall take part with better spirit and will, it would be well to order that the civil and military offices that are to be filled there should be given to the sons and grandsons of the first and second settlers, and to no other persons, this having been approved by my department of the Indies, I have decided upon it favorably, and by the present writing I order that the said offices are not to be given to any one except the said persons and that no step whatever be taken against what is ordered here ... The same date. Etc.

The King. My governor of Nueva Vizcaya: As you have heard, I have ordered a contract to be made . . . and because it is my will that he be aided and favored, I command you to give him assistance in whatever he may need for the said exploration and settlement, as may be required and he may ask you upon his part. If any soldiers run away you will cause them to be returned to where he is and turned over to him ... Same date. Etc.

The King. Inamuch as you ... have petitioned me that, in order that those who go with you may aid and serve me with better spirit and hopes in the said exploration, etc. of the said provinces, through the knowledge that they are to be rewarded for their services, and, after them, the second and third generations of the pacifiers and settlers, it should be granted to them that they shall not be removed from the civil and military offices that may be given to them in the said provinces by any person that may succeed you in the government of them, but that they shall be permitted to enjoy them during their lives, this having been approved by my Council of the Indies, I have, in view of the aforesaid, decided favorably upon it, and by the present writing I order that your said successor shall not change the appointments that you may make in the abovesaid manner, but that he shall retain in office those whom you have appointed, so that they may enjoy them during their lives. . . . The same date. Etc.

The King. By the present writing I give permission to you, Don Pedro Ponce de León . . . in case any rebellion or uprising may occur in those provinces against the service of God or myself, with the agreement of my officials of the said provinces or of the majority of them, to take out what may be necessary to suppress the said rebellion. And I order my said officials that whatever you shall take out under this agreement and for this purpose they shall pay for with any property belonging to me in the said provinces. ... Done October I2. Etc.

The King. By these presents I give permission to Don Pedro . . . that, in conformity with an article of the said contract, for all that the said 
Lo Paguen de qualquier Hazienda mia que me perteneciere en Las dichas provincias. . . . Fecha doze de octubre. Etc.

El Rey.-Por la presente doy Licencia a don pedro . . . para que Conforme a Un capitulo del dicho asiento de todo lo que Los dozientos y treynta Soldados y Criados que lleva Consigo Llevaren a Las dichas provincias para Sus casas y mantenimientos por esta Vez no se le lleven en estos Reynos ni en Las yndias derechos Algunos por quanto de Lo que en ellos se montan Les Hago merced y mando a mis officiales de la nueva españa y de las otras partes de las yndias por donde llevaren Las dichas cossas y mantenimientos que no Les pidan derechos dellas ni tampoco en estos Reynos con que no las Vendan y si Las Vendieren o Parte dellas que de todo enteramente cobren para mi Los dichos derechos. . . . Fecha octubre 19. Etc.

[El dicho dia se despacho otra del mesmo thenor y forma para el corregidor de los Cacatecas.

Yden en el dicho dia otra para la audiencia de La nueva galicia.F. R. B.]

El Rey.-Por la presente doy Licencia a Vos don pedro Ponce de leon . . para que en conformidad de Lo Con Vos capitulado podays Hazer abrir marcas y Punçones Con mis armas Reales y Ponerlos en los Pueblos de españoles que estuvieren Poblados y se poblaren en Las dichas Provincias para que Con ellos y no con otros, se marque el oro plata o otros metales quen ellas oviere. . . . fecha octubre 12. Etc.

E1 Rey.-Don Pedro Ponce de leon ... os doy licencia y facultad para que podays eligir en ellas el lugar o lugares que os paresciere para que en ellos se pongan mis caxas Reales y nombrar oficiales de mi Hazienda en las Partes que Convenga y señalarles salarios moderados En Los frutos de la tierra y que por esta Vez solamente Les podays Repartir yndios Haviendose ellos allado a ser descubridores y pobladores y goçarlos juntamente con los oficios no embargante lo Proveydo en contra o que por esta vez y para en quanto a esto yo dispenso con ello fecha en san Lorenço a diez y seys de octubre. yo EL REY etc.

El Rey.-Conde de Monterey ... o a la persona o personas A cuyo cargo fuere el govierno della como lo terneys entendido yo e mandado tomar asiento ... y Porque es mi Voluntad es que sea ayudado y favorescido Os mando que en todo Lo que se le offreciere Para el dicho descubrimiento y poblaçion Le deys y Hagais dar el favor y ayuda que convenga y de su parte Se os pidiere y si se le Uyeren algunos soldados Los Hareys Volver adonde el estuviere y que se le entreguen fecha en San Lorenço a diez y nueve de octubre de mill y quinientos y noventa y seys años Yo EL REY etc.

El Rey.-Oficiales de mi Real Hazienda que por tiempo fueredes en los reynos y provincias de la nueva mexico porque mi Voluntad es que don pedro Ponce de Leon mi governador y Cappitan General dellas aya 
230 soldiers and servants whom he is taking with him may carry to the said provinces for the provisioning of their houses, no duties shall be charged for this time, either in these kingdoms, or in the Indies, and I exempt them from paying this amount. I order my officials of New Spain and the other parts of the Indies to which they may take the said articles and provisions not to charge them duties for them there, nor in these kingdoms, provided that they do not sell them; if they do sell them, or a part of them, the said duties shall be collected for me to the full amount on the whole ... Done October I9. Etc.

[On the said day another decree of the same tenor and form was sent to the corregidor of Zacatecas.

Ditto on the said day another to the Audiencia of Nueva Galicia.F. R. B.]

The King. By the present writing I give permission to you, Don Pedro Ponce de León . . . in conformity with what has been agreed with you, to engrave stamps and dies with my royal arms and place them in the towns that may be settled by Spaniards in the said provinces, so that with them and no others the gold, silver, and other metals which may be in them shall be marked. . . . Done October I2. Etc.

The King. Don Pedro Ponce de León . . . I give you permission and power to select the place or places in them that may seem suitable to you for establishing my money-chests, to name officials of my exchequer in the parts that seem best to you, and to assign them moderate salaries in the products of the land. For this time only you shall be empowered to divide Indians among them, after they shall have become explorers and settlers; and they shall enjoy them jointly with the offices, notwithstanding what has been decreed against it, of which, for this occasion and as regards this, I absolve them. Done at San Lorenzo, October I6. I тHE KING. Etc.

The King. Count of Monterey . . . or the person or persons in whose charge the government of it may be: As you have been informed, I have ordered a contract to be made . . . and as it is my will that he be aided and favored, I command you that in whatever he may need for the said discovery and settlement you shall give him the favor and assistance that are proper, and that he may ask you for on his part. And if any soldiers run away from him you will have them returned to wherever he may be and turned over to him. Done at San Lorenzo, October I9, I 596. I THE KING. Etc.

The King. Officials of my royal exchequer who may be at the time in the kingdoms and provinces of New Mexico: Since it is my will that Don Pedro Ponce de León, my governor and captain-general of them, shall receive as yearly salary, during all the time that he may wish to serve in the said offices, I2,000 ducats, which amount to 4,500,000 maravedis, so that he may be able to maintain himself with them according to the quality of his person and carry out the obligations of the said offices. I 
y lleve de salario en cada Un año Con los dichos Cargos todo el tiempo que Los quisiere Servir A raçon de doze mill ducados que suman y montan quatro quinientos ${ }^{\text {y }}$ y quinientas mill maravedis para Con ellos Se pueda Sustentar Conforme A la calidad de su persona y Cumplir Con las obligaciones de Los dichos Cargos os mando que de qualesquier Rentas y provechos que yo tuviere en esos dichos Reynos Le deys y Pagueys en Cada Un año Los dichos doze mill ducados desde el dia que por testimonio signado de escrivano Publico os constare haver echo a la Vela En Uno de Los puertos de San lucar de Varrameda o cadiz para yr a acer el dicho descubrimiento por todos Los dias de Su Vida o por el tiempo que alla se detuviere que con su carta de Pago y el dicho Testimonio y esta mi çedula de que an de tomar La razon mis contadores de quentas que residen en mi consejo Real de Las yndias mando Se os Reciva y Pase en quenta Lo que ansi Le dieredes y Pagaredes de los dichos frutos y Rentas porque si no Los Ubiere no e de ser obligado a Le pagar Cossa alguna. La misma fecha. Etc.

El Rey.-Mi presidente y Jueces oficiales de la casa de la contratacion de Sevilla y porque como Lo terneys Entendido e mandado tomar asiento ... y entre otras cossas se a offrecido a llevar destos Reynos a esta dozientos y treynta personas entre Soldados y Criados y otros pertrechos mantenimientos Armas y municiones y para esto se Le a Concedido que pueda fletar Los Uaxeles que quisiere asta Por cantidad de quinientas toneladas con que no sean Urcas o Lancesas ${ }^{v}$ ni esterlinas Sino navios Vizcaynos o filibotes o otros de buen galigo que sean a proposito Para La navegacion y Conbiene mucho al servicio de dios y mio que esta Jornada se aga Con mucha Vrevedad por lo que toca a La salvacion da las almas de Los naturales de aquellas provincias propagacion del Santo evangelio y augmento de mi corona os mando que Luego que se a Llegado a yr el dicho Don pedro Ponce o La persona que embiare adelante Con esta cedula admitays Los Vaxeles que asta En La dicha cantidad de toneladas Se nombraren por parte del dicho don Pedro ponce y aquellos deys Visita registrays el despacho nescesario Para que puedan azer biaje Sin aguardar flota sino que salgan Luego que entren a punto yendo en ellos el dicho don Pedro Ponce de Leon y llevando Las dichas docientas y treynta personas y los marineros que tuviere necesidad Todo Lo qual a de Governar como caudillo y Caveça dexandole ansimismo embarcar y que lleve todas Las cossas asi de mantenimiento de Comida y Vebida Vestidos pressas " $\mathrm{y}$ alhajas armas y municiones erramientas y todo lo demas para que tiene Licencia mia y nombrando Uno de Los Visitadores que baya a san lucar a despacharle y Haver lo que se carga y que no se lleve en Las dichas Vaxeles ningun otro genero de mercadurias y encargo os mucho que Le deys toda la asistencia favor y ayuda nescesaria para que pueda partir con la mayor Vrevedad que fuere Posible

\footnotetext{
u A miscopy for "cuentos".

"Evidently a miscopy for "lanchas".

"Evidently a miscopy for "prendas".
} 
command you that from whatever revenues and profits that I may have in the said kingdoms you shall give and pay him every year the said I2,000 ducats, from the day when, by a deposition signed by a public clerk, you will be informed that he has set sail from one of the ports, San Lucar, Barrameda, or Cádiz, to go on the said exploration, for all the days of his life or for the time that he shall remain there. With the memorandum which my accountants who are employed in my royal Council of the Indies shall make of his receipt of payment, the said deposition, and this my decree, I order that you prepare and transmit a report upon what you thus give and pay him from the said products and revenues, for if there are none I am not under obligations to pay him anything at all. The same date. Etc.

The King. My president and official judges of the Casa de Contratación of Seville: Since, as you have been informed, I have ordered a contract to be made ... . and among other things it has been agreed that he shall take from these kingdoms to that province 230 persons, including soldiers, and servants, besides tools, provisions, arms, and munitions, and for this purpose it has been granted to him to charter such vessels up to five hundred tons burden, as he may wish, provided that they are not hookers or launches or esterlinas but Biscayan boats or fly boats or others of good model that are suitable for the voyage, and since it is very important to the service of God and myself that this expedition shall be accomplished as soon as possible, because of its bearing upon the salvation of the souls of the natives of those provinces, the propagation of the holy gospel, and the increase of my crown, I command you that as soon as the said Don Pedro Ponce reaches [Seville] ready to go, or the person whom I shall send in advance with this decree, you shall admit the vessels up to the said tonnage named by the said Don Pedro Ponce and inspect them and issue the necessary clearance so that they may set sail without waiting for the flota ${ }^{34}$ but may go as soon as they enter, the said Don Pedro to go on them and take the said 230 persons and the sailors that he needs, all of whom he is to command as their chief and head. [I command you] also to permit him to embark and take all the things for their support-food and drink, clothing, jewelry and ornaments, arms and munitions, tools, and everything else for which he has my permission, and [I command you] to name one of the inspectors to go to San Lucar to clear him and see what is taken on board and that no other kind of merchandise is taken on the said vessels. I charge you especially to give him all the assistance, favor, and help necessary so that he may depart with the least delay possible, by which I shall be pleased. Done at San Lorenzo, October 26. Etc.

The King. By this writing I give permission to you, Don Pedro Ponce de León ... to name a cosmographer to make the description of the said provinces and designate the sites that seem suitable to you for the towns, to whom you will assign a sufficient salary, as I order by this my decree. It is also my will that my officials of the said provinces shall be paid from the products of the land and not from any other source, and 
que en ello me terme ${ }^{x}$ por servido fecha en san lorenço a Veynte y Seys de octubre etc.

E1 Rey.-Por la presente doy licencia a Vos don pedro ponce de leon ... para que podays nombrar Un cosmographo que haga la discrepçion de Las dichas Provincias y señalarle Los terminos que Convinieren y os pareciere Para las poblaciones dellas al qual señalareys Salario competente que por Esta mi cedula mando A mis oficiales de las dichas Provincias Se lo paguen de los frutos de La tierra y no de otra parte que Asi es mi Voluntad y teneys cuydado de Avisarme de lo que en esto se fuere Haziendo. La misma fecha. Etc.

El Rey.-Venerable y deboto Padre Provincial de La Horden de San francisco de la nueva españa yo e mandado Tomar Asiento ... y Porque Conviene que bayan Con el Personas doctas y qual combengan para que se ocupen en la Conversion y doctrina de los naturales de Aquellas provincias os Ruego y encargo Le deys seis Religiosos de Vuestra Horden que sean de las Partes sobredichas para que Entiendan En el dicho Ministerio que en ello Sere servido. La misma fecha. Etc.

El Rey.-Por quanto en el Asiento ... ay Un capitulo en que os ofreci de Hazeros ynmediato a mi Real Consejo de las yndias ques del thenor siguiente: . . . La misma fecha.

Don Phelipe .... por quanto en el asiento ... ay Un capitulo en que se trata de que todos los que le ayudaren en la Jornada y poblacion y sus descendientes sean hijos dalgo de solar conoscido y goçen todas Las preeminencias y excepsiones que conforme a Las leyes fueros de estos Reynos goçan los cavalleros hijos dalgo como mas en particular se contiene en el dicho capitulo ques del thenor siguiente: . . . .

aqui el cappitulo 53 del asiento

y capitulacion.

dada en san lorenço a tres de nobiembre etc.

El Rey.-Por quanto Vos don Pedro Ponce de leon . . . me aveys echo Relacion que siendo Como es Vuestro Principal yntento hacerme algun muy grande y señalado servicio en aquel descubrimiento deseays tanbien acudir a las obligaciones de Vuestra casta y grado ansi por Lo que toca a la Conservacion del como por tomarle Vos me haveys suplicado que para esto tenga por bien de concederos que Cumpliendo con lo de halla os podays bolver y aviendose Visto por Los de mi Consejo de las Indias y consultadoseme pareciendome Cossa Justa y pugra ${ }^{\nabla}$ en Razon Lo E tenido Por Vien y assi por La Presente os doy Licencia para que hecho el dicho descubrimiento y cumpliendo Con las Cossas que soys obligado Por Vuestra Capitulacion Os podays Volver quando y Como quisieredes

x Probably a miscopy for "tendre".

"Evidently a miscopy for "puesta". 
you will take care to inform me of what is done in this matter. The same date. Etc.

The King. Venerable and devout Father Provincial of the Order of Saint Francis of New Spain: I have ordered a contract to be made . . . and since it is desirable that learned persons shall accompany him, in order to occupy themselves in the conversion and instruction of the natives of those provinces, I entreat and charge you to give him six religious of your Order who shall be endowed with the qualities aforesaid so that they may engage in the said ministry, by which I shall be pleased. The same date. Etc.

The King. Inasmuch as in the contract . . . there is an article in which I agreed to place you in direct relationship with my royal Council of the Indies which runs as follows:.... The same date.

Don Felipe. . . . Inasmuch as in the contract . . . there is an article in which it is agreed that all those who may assist him in the expedition and settlement, and their descendants, shall be hidalgos of recognized estate and shall enjoy all the privileges and exemptions which, according to the statute laws of these kingdoms, knights and hidalgos enjoy, as is contained in more detail in the said article, which runs as follows: . . . Here follows article 53 of the contract and agreement.

Given at San Lorenzo, November 3. Etc.

The King. Inasmuch as you, Don Pedro Ponce de León . . . have informed me that though it is your principal purpose to do me a very great and signal service in that exploration, in what concerns the preservation of it as well as in taking it, you desire also to fulfill the obligations of your caste and rank, and you have petitioned me to permit you, after you shall have fulfilled your duty there, to return, and this having been approved by my Council of the Indies and referred to me, and, it appearing to me to be a just and reasonable thing, I have decided upon it favorably. Therefore I give you by these presents permission, after the said exploration has been made and the affairs carried out for which you are under obligations according to your agreement, to return when and as you please, provided that it be not less than six years that you remain there. And you will leave some person in your place who will serve me in those offices during such time as I may will. By these presents I order my viceroy, presidents and oidores of the audiencias of those provinces and the other justices and judges of them not to put any impediment in the way of your coming when the six years shall have passed, and to retain the person whom you leave in your place in the use and exercise of the said offices so that he may use and exercise them in the manner that you would have the power to do by virtue of your titles, until, as has been said, I shall order and provide differently. Done at San Lorenzo in the latter part of October. Etc. 
con que no sea menos de seys años Los que os detubieredes y entonces dexeys Persona en Vuestro Lugar que me Sirva En aquellos cargos por el tiempo que fuere mi Voluntad que Por La Presente mando a mi Virey Presidentes e oydores de las audiencias de Aquellas provincias y otras Justicias y Jueces dellas que no os pongan ympedimento En la venicla Pasados los dichos seys años y que a la persona que dexareys en Vuestro lugar la Conserven en el Usso y exercicio de los dichos Cargo para que Los Use y exerça de la manera que Vos Lo Podeys hazer en Virtud de Vuestros titulos Hasta que Como dicho es yo mande y Provea otra Cossa fecha En san lorenço a Postrero de octubre etc.

El Rey.-Conde de Monterey Pariente mi Virey .... haviendo Visto La Carta que me escrivistes en quince de nobiembre del año pasado y papeles que enbiastes en rraçon del estado en que quedava el descubrimiento del nuevo Mexico Sobre que alla Capitulo el Birrey don Luis de Velasco Con don Juan de oñate y Consultadoseme Por el Pressidente y Los de mi consejo de Las Indias he acordado de escriviros esta por la qual os encargo y mando que si entendieredes que el dicho don Juan de Oñate tiene en esa La gente y lo demas necesario Para la Jornada deis orden en que La prosiga y en caso que no pueda Cumplir me avissareis Con toda La Vrevedad que sse pudiere para que Visto y entendido tome La Resolucion que me pareciere Convenia de madrid a dos de abril de mill y quinientos y noventa y Siete años. yo EL Rey. Etc.

Consejo de Indias. 7 de Febrero 1597. Que conviene se tome Resolucion en lo que sea consultado cerca de las pretenciones de Don Pedro Ponce de Leon.

Señor: Don Pedro Ponce de Leon aguarda la resoluzion que Vuestra Magestad sera servido de mandar tomar en lo que ha suplicado cerca de que se le de facultad para tomar a tributo sobre su estado lo que le falta para la Jornada del Nuevo Mexico, o que se le preste alguna quantidad, que junta con la Hazienda que podra allegar Le vaste para la enpresa, y por que conviene mucho, que se vaya presto porque la gente que tenia junta don Juan de Oñate con quien alla se avia tomado asiento estando tanto tiempo suspensa y detenida no cause algun mobimiento que segun se a entendido por cartas, que aora se an recevido del virrey, ya avia llegado alla La cedula en que Vuestra Magestad mando no se prosiguiese la jornada Vuestra Magestad provera lo que fuere servido. Madrid 7 febrero 1597.

[REAL DECRETO.]

Embieseme copia de los papeles que sobre esto han venido, para segun el estado que aquello tiene pueda mejor resolverme. ${ }^{a}$ [Rúbrica.]

z A. G. I., I 40-7-38.

a F. R. B., Sevilla, May 20, I915. 
The King. Count of Monterey, my relative, viceroy. . . . Having examined the letter which you wrote me on November I 5 , of the past year, and the papers which you sent in regard to the state of the exploration of New Mexico, concerning which the viceroy Don Luís de Velasco made an agreement with Don Juan de Oñate, and having consulted with the president and those of my Council of the Indies, I have agreed to write you this, by which I order and charge you that if you know that the said Don Juan de Oñate has the people and other things necessary for the expedition you shall order him to continue with it, and in case he cannot carry it out you will inform me of it as soon as possible, so that after due consideration I may take the measures that seem best to me. At Madrid, April 2, I 597. I the King. Etc.

The Council of the Indies. February 7, I597. It is necessary that a decision be made as to what shall be advised in the matter of the claims of Don Pedro Ponce de León.

Sir: Don Pedro Ponce de León awaits the decision which your Majesty will be pleased to order in regard to his petition that he be given authority to raise by a mortgage on his estate what is lacking to him for the expedition to New Mexico, or that he be lent a certain sum, which, added to the funds which he will be able to collect, will be sufficient for the undertaking; for it is very desirable that he go soon, so that the people gathered by Don Juan de Oñate, with whom a contract had been made there, being held and delayed for such a long time, shall not cause any disturbance, for, according to what has been learned from letters just received from the viceroy, the decree in which your Majesty ordered that the expedition should not be continued had reached there. Your Majesty will take measures according to your pleasure. Madrid, February 7, I 597.

\section{[Royal Decree.]}

Let a copy be sent me of the papers that have come in regard to this, so that according to the state in which it is I can the more readily come to a decision. [Rubric.] 
Consejo de Indias, I8 de Febrero I597. Con todas las consultas que se an hecho y papeles que an benido En Raçon del descubrimiento del nuevo Mexico Sobre que se a tomado asiento Con don pedro ponce de leon y capituló alla El virrey don luys de belasco con don Juan de Oñate.

Aqui estan las consultas que se an hecho a Vuestra Magestad sobre este negocio desde su principio hasta que Vuestra Magestad tomo la ultima resoluzion de que se efectuase el assiento con Don Pedro . . . . ansi por la diferencia que parecia avia de su persona a la de Don Juan de Onate con quien alla avia capitulado el virrey don Luis de velasco como por la notable mejora y ventajas de las condiziones con que don Pedro se quiso encargar dello.

$\mathrm{Y}$ tambien los papeles que agora se an recivido y una relazion aparte de todo para que siendo Vuestra Magestad servido lo pueda ver con mas comodidad y dejaronse de embiar a Vuestra Magestad estos ultimos Papeles con la susodicha consulta de 7 del pasado por aver yo el Presidente quedado encargado de ablar a don Pedro. . . . que esta convaleciente de una grabe enfermedad para saver la dispusizion que tenia para hazer la Jornada con la brevedad que se requiere y con su respuesta dar quenta a Vuestra Magestad de todo Las caussas en que el consejo se fundo para anteponer la persona de Don Pedro Ponce a la de Don Juan de Oñate se refieren en las mismas consultas y en ellas tanbien se dize como el virrey escrivio que si aca se pidiese confirmacion por parte de don Joan de Oñate se entreteniese mostrando poca satisfacion de la persona y del concierto todo bien diferente de lo que agora dize lo qual visto, y que don Pedro tiene todos sus despachos y que esta tan adelante en su apresto que con qualquier resoluzion que Vuestra Magestad se sirva de tomar en esta ultima pretencion avia de partir dentro de ocho dias y que un hermano suyo a muchos que esta en Sevilla aprestando los navios, vituallas armas y municiones y que si agora se hiziere nobedad seria con mucha quiebra de su reputacion y no corresponderle al buen animo y liberalidad con que se a of recido a servir a Vuestra Magestad y que el que alla a movido todas estas difficultades y hecho dudas al virey a sido un oidor de la Audienzia que es cuñado de don Juan de Oñate y que todas las dificultades que propone cesan con llegar Don Pedro pues toda la gente que agora esta junta a de proseguir la jornada y pagarle Don Pedro todo lo que a gastado conque no se haze mas que mudar la persona y no se puede dudar de que yran de mejor gana con don Pedro Parece que no convernia hazer nobedad sino que pues el virrey escribe que entreternia a don Juan de Oñate hasta que Vuestra Magestad le respondiesse lo que fuese servido y ansi hasta que este llegue a de estar todo parado y suspenso sea el que lleve la respuesta el mesmo don Pedro dandole tanta prissa que pueda partir dentro de un mes como el ofrece que lo ara Vuestra Magestad mandara lo que fuere servido en Madrid i8 de hebrero I597. 
The Council of the Indies. February 18, 1597. With all the communications that have been made and papers that have come in regard to the exploration of New Mexico, about which a contract has been made with Don Pedro Ponce de León, and an agreement made there by the viceroy Don Luis de Velasco with Don Juan de Oñate.

Here are the communications that have been made to your Majesty in regard to this business from its beginning, until your Majesty made the final decision by which the contract was put into effect with Don Pedro ... both because of the difference that there appeared to be between his character and that of Don Juan de Oñate, with whom an agreement had been made there by the viceroy Don Luís de Velasco, as because of the notable betterment and advantages with which Don Pedro wished to take charge of it.

And also the papers that have just been received and a separate statement of everything, so that if your Majesty please you can consider it with more convenience. These last papers were not sent to your Majesty with the above-mentioned communication of the seventh of the past month because I, the president, had been charged with speaking to Don Pedro ... who is convalescing from a grave illness, in order to learn what disposition he had to make the expedition at the early date that is required, and with his reply to give an account to your Majesty of all the reasons upon which the advice was founded for preferring the character of Don Pedro Ponce to that of Don Juan de Oñate. They are referred to in the same communications, and in them also it is related how the viceroy wrote that if confirmation should be requested here on the part of Don Juan de Oñate it should be delayed, showing little satisfaction with his character and with the agreement, all very different from what he says now. This having been considered, and that Don Pedro has all his warrants and is so forward with his preparations that no matter what decision your Majesty may be pleased to make in this last claim he could leave within eight days, and that a brother of his has been for some time in Seville preparing the ships, victuals, arms, and munitions, and that if a change should be made now it would be with great damage to his reputation and a poor response to the good spirit and generosity with which he has offered to serve your Majesty. The one who has stirred up all these difficulties and aroused the viceroy's doubts is an oidor of the Audiencia who is a brother-in-law of Don Juan de Oñate. But all the difficulties which he presents will cease with the arrival of Don Pedro, for all the people who are now ready will continue the journey, and Don Pedro will pay them for what they have spent, so that only the person [in charge] will be changed and it cannot be doubted that they will go with a better heart with Don Pedro. It is best, therefore, that there shall be no change. However, since the viceroy writes that he would hold Don Juan de Oñate until your Majesty should reply with your decision, and that until such should arrive all is to be stopped and delayed, the one to carry the reply should be Don Pedro himself, haste being made so that he can depart within a month, as he offers to do. Your Majesty will order according to your pleasure. Madrid, February 18, I 597. 


\section{[REAL DECRETO.]}

Pues se entiende que don Pedro Ponce, no esta tan a punto, ni con la salud que seria menester para yr a esta enpresa ni con el caudal que para ella se requiere, sera bien entretenerle con buenas esperanças y entretanto con mucho secreto y brevedad se escriva al Virrey diziendole que si entiende que don Juan de Oñate tiene en ser la gente, y lo demas necesario para la jornada que prosiga, y quando no, que lo avise con brevedad, para que entonces entendido por mi, pueda tomar resolucion que mas convenga. ${ }^{\mathrm{b}}$ [Rúbrica.]

Consejo de Yndias. 7 de Março I597. Lo que pareze se podria Responder a Don Pedro Ponce de Leon porque no se entretenga con esperanzas haciendo gastos aqui y en Sevilla. ${ }^{\circ}$

Señor: En el particular de don Pedro ponce de leon sobre que ultimamente Consulto El Consejo a Vuestra Magestad diziendo las Causas porque le parecia no se devia hazer novedad en lo que Con el Se avia capitulado cerca del descubrimiento del nuevo mexico fue Vuestra Magestad servido de responder y mandar.

Pues se entiende que Don Pedro Ponce de Leon no esta tan aparejo ni con la Salud que seria menester para yr a esta enpresa ni con el caudal que para Ella se requiere Sera bien entretenerle con buenas esperanças y entretanto con mucho secreto y brevedad se escriva al Virrey diziendole que si entiende que Don Juan de Oñate tiene en ser la jente y lo demas necesario para la jornada que la prosiga y quando no que lo abise Con brevedad para que entonces entendido por mi pueda tomar la resolucion que mas Convenga $\mathrm{Y}$ Visto en el Consejo a parecido que porque Don Pedro hace ynstancia porque se le responda acudiendo a la Continua a mi el presidente diziendo que no aguarda otra cosa y que se esta gastando y su hermano hace lo mesmo en Sebilla donde asiste al despacho de los navios entretiniendo jente y comprando armas bastimentos y municiones convenia desenganarle desde luego para que no pase adelante con los gastos y prebenciones o a lo menos dezirle que por Un Año ó ano y medio no se puede tomar Resolucion para entretenerlo Con esperanzas de propinqua determinacion no se Vaya Enpenando ni consumiendo Vuestra Magestad mandara lo que fuere sabido-en madrid A siete de março I 597.

\section{[REAL DECRETO.]}

Digasele que por un año no se podra tomar resolucion. ${ }^{\mathrm{d}}$

b F. R. B., Sevilla, May 20, I9I5.

c A. G. I., I40-7-38.

d F. R. B., Sevilla, May 20, I9I5. 
[Royal Decree.]

Since it is understood that Don Pedro Ponce is not so well prepared nor in such a state of health as would be necessary for this undertaking, nor with the fortune that is required for it, it will be well to keep him waiting with good hopes, and in the meantime to write, secretly and soon, to the viceroy, telling him that if it is learned that Don Juan de Oñate has the people and the necessary things in readiness for the expedition that he shall proceed with it, and if not, let information of it be sent promptly so that, being informed of it, I can then make the decision that may seem best. [Rubric.]

The Council of the Indies. March 7, I597. Opinion as to the answer that should be given to Don Pedro Ponce de León so that he shall not be kept in hopes and be spending money here and in Seville.

Sir: In the matter of Don Pedro Ponce de León, in regard to which the Council recently advised your Majesty, telling you the reasons why it held the opinion that no change ought to be made in the agreement made with him about the exploration of New Mexico, your Majesty was pleased to reply and order [as follows:]

Since it is understood that Don Pedro Ponce de León is not so well prepared nor in such a state of health as would be necessary for this undertaking, nor with the fortune that is required for it, it will be well to keep him waiting with good hopes, and in the meantime to write, secretly and soon, to the viceroy, telling him that if it is learned that Don Juan de Oñate has the people and other things ready for the expedition that he shall proceed with it, and if not, let information of it be sent promptly, so that, being informed, I can then make the decision that may seem best.

[This reply of your Majesty] having been considered in the Council, it is the opinion that, since Don Pedro is urgently pressing for an answer and is constantly applying to me, the president, and saying that he waits for nothing else, and that he is spending money, and his brother is doing the same at Seville, where he is assisting in the preparation of the ships, in entertaining the people, and in buying arms, provisions, and munitions, it would be better to undeceive him immediately, so that he will not go on with the expenses and preparations, or at least to tell him that a decision cannot be made for a year or a year and a half, rather than to hold him with hopes of an early determination, so that he will not go on mortgaging and consuming his property. Your Majesty will order according to your pleasure. Madrid, March, I 597.

\section{[ROYAL DECREe.]}

Let him be told that the decision cannot be made for a year. 
Notificacion a don juan de oñate. [Río de las Nazas, Nueva Vizcaya, 9 de Septiembre de I596.]

En el Rio de las Nassas de la nueba Vizcaya a nuebe dias del mes de setienbre I 596 años por mandado de don lope de Ulloa y lemos capitan de la guarda del Virrey de la nueba españa mi señor Visitador y teniente de capitan general de la gente, armas municiones vastimentos y demas cossas que al presente ba y se lleva a la conquista y descubrimiento de las provincias del nuebo mexico yo antonio negrete escrivano de su magestad y secretario de la dicha Visita ley y notifique el traslado de la real cedula de su magestad questa al principio de las tres ojas antes desto escriptas autorizadas de juan Martinez de guillestegui secretario del birey mi señor y el aucto de su señoria escripto en las dichas dos ojas siguientes a la dicha Real cedula a don juan de oñate que va por governador y capitan general de la dicha gente y provincias para que la guarde y cumpla como en ello se contiene y en su cumplimiento luego haga alto y no passe adelante ni conssienta passar los capitanes soldados vastimentos municiones y bagajes que lleva ni otra cossa alguna ni prosiga la dicha jornada antes la sobresea y entretenga hasta ber nueba horden de su magestad o de su señoria en su Real nonbre so las penas y apercevimientos en el dicho aucto contenidos el qual tomo la dicha Real cedula en sus manos y la beso y pusso sobre su caveza y obedecio con el acatamiento debido como mandacto de su Rey y señor natural, y aunque por muchas y muy justas causas y los grandes y notables gastos que a el y a sus soldados se seguiran de la suspension y detenimiento de la dicha jornada, asi en menoscavo de los vastimentos perdidas de cavallos buyes mulas Ganados mayores y menores que al presente todo esta junto como en que se ausentaran y Uyran muchos soldados luego que lo sepan o sospechen, tomandolo por ocassion, pudiera supplicar de la dicha Real cedula no lo haze como leal vasallo de su magestad no obstante de las dichas caussas y otras muchas y que hasta oy tiene gastado en la dicha ocassion mas de cient mill ducados de castilla y sus capitanes y soldados mas de docientos mill haviendo bendido para ella todas sus haziendas muebles y Rayzes por estar satisfecho que Haviendo visto su magestad y los señores de su Real consejo de las yndias papeles que despues de la carta que refiere la dicha cedula enbio su señoria en el segundo navio de haviso sobre lo asentado y capitulado acerca de la dicha jornada se abia despachado otra Real cedula en contrario de la susodicha para que la prosiga y continue y que llegara en la flota que se espera aora de proximo en todo este mes de setienbre aunque del detenimiento hasta entonces se causen los dichos daños y perdidas antes esta presto de hazer y cunplir lo que por la dicha Real cedula y aucto que se le a notificado se le manda segun y como en ello se contiene pero en casso que la dicha Real cedula que agora espera, todabia por algunos respectos su magestad mande que el zesse en la dicha jornada y la dexe de prosiguir y continuar conforme a lo capitulado y asentado en virtud de sus Reales cedulas y provisiones con su señoria y don luis de Velasco su antecesor, o que la dicha jornada se aya encargado a otra alguna persona desde aora para

e A. G. I., 140-7-38. 
Notification to Don Juan de Oñate. [Río de las Nazas, Nueva Vizcaya, September 9, I596.]

At the Río de las Nazas in Nueva Vizcaya, on the ninth day of September, I596, by order of Don Lope de Ulloa y Lemos, captain of the guard of the viceroy of New Spain, my señor inspector and lieutenant captain-general of the people, arms, munitions, provisions, and other things which at present are going and are being taken on the campaign. and exploration of the provinces of New Mexico-I, Antonio Negrete, clerk to his Majesty and secretary to the said inspection, read and gave notice of the copy of the royal decree of his Majesty-which is at the beginning of the three leaves written before this, attested by Juan Martínez de Guillestegui, secretary to my lord the viceroy, and of the auto of his lordship written on the two leaves following the said royal decree, to Don Juan de Oñate, who is going as governor and captain-general of the said people and provinces. [I did this] so that he should obey and carry out the orders contained in it, and, in fulfillment of it, to halt immediately and go no further, and not to permit the captains, soldiers, provisions, munitions, and baggage which he is taking, or anything else whatsoever, to go on, nor to continue the said expedition, but rather to desist from it and to delay it until a new order is received from his Majesty or his lordship in his royal name, under the penalties and warnings contained in the auto. He took the said royal decree in his hands, kissed it, and place it upon his head, and obeyed with the respect due to the mandate of his king and natural lord. Despite the fact that-for many and very just reasons, and the great and extraordinary expenses which will follow to him and his soldiers from the suspension and delay of the said expedition, in the deterioration of the supplies, losses of horses, oxen, mules, cattle, both great and small, which are now collected, as well as in the fact that many soldiers, taking advantage of the occasion, will absent themselves and run away as soon as they learn or suspect it-he might appeal from the said royal decree, he, like a loyal subject of his Majesty, does not do it, notwithstanding the said reasons and many others, and that up to to-day he has spent in this business more than roo,000 ducats of Castile. His captains and soldiers have spent more than 200,000 more, they having sold for the expedition all their property, furniture, and lands, through being convinced that after his Majesty and the gentlemen of his royal Council of the Indies should have seen the papers which, after the letter mentioned in the said cédula, his lordship sent by the second dispatchboat in regard to the contract and agreement concerning the said expedition, there would be despatched another royal decree contrary to that spoken of above and ordering that it be continued, and that it would arrive by the fleet which is now expected any time in this present month of September. Although the delay until then may cause the said injuries and losses, he is nevertheless ready to do and fulfill that which he has been informed by the said royal decree and auto he must do, according to its content. In case, however, by the said royal decree which is now expected, his Majesty, for further reasons, orders him to cease the said expedition and leave off its prosecution in conformity with what was con- 
entonzes y desde entonces para aora, con el devido respeto suplica de entranbas las dichas Reales cedulas y otros qualesquier despachos en quanto fueren contrarios al dicho asiento y capitulacion para ante su magestad y los dichos señores y su señoria el birey mi señor donde protesta ocurrira dezir y alegar de su justicia y expresar las dichas causas agravios y daños pidiendo en todo lo que a su derecho convenga y protestando todos los daños e intereses y menoscavos que se le hubieren causado y causaren y esto dio por su respuesta y lo firmo de su nonbre y pidio testimonio della y la dicha Real cedula y aucto para en guarda de su derecho siendo a ello presente y por testigos francisco de esquibel comisario de la dicha jornada y jaime fernandez alguacil de la dicha visita a los quales se les encargo el secreto de lo sus dicho y firmaronlo asi mismo don juan de oñate francisco de esquibel jaime fernandez escrivano de su magestad.

En ffee de todo lo qual yo el dicho antonio negrete fize mi signo, ANTONIO NEGRETE.

Copia de la carta de don juan de oñate para el Conde de monterey su Fecha en el Rio de las Nasas a I3 de setienbre I596.'

Estando para passar El Rio de las Nasas que es el passo mas dificultoso que ay hasta las provincias del nuebo Mexico con la mayor parte de la gente que va a esta jornada, y con todo el resto de ganados Vastimentos y Pertrechos que para ella son necesarios y estoy obligado a llevar me dio don lope de Ulloa dos de Vuestra Señoria ambas de un mismo tenor, ffecha a I 2 del pasado y me manifesto la cedula de su Magestad y la horden que Vuestra señoria le da para que se me intime y notifique como lo a hecho que hasta aqui pudo llegar la contradizion y estorvo que el demonio como enemigo de todo bien a puesto para inpedir y dilatar el que con esta jornada se a de Hazer a tanta multitud de almas questan debajo de su dominio deseando el pan de la divina doctrina, trayendolos al conocimiento de nuestra sagrada fee en tan gran servicio de dios y del Rey nuestro señor y augmento de su Real corona, como tan leal y fiel vasallo suyo e deseado y deseo enplearme continuando lo que mis padres y proxenitores an hecho siempre.

El sentimiento que me a causado lo contenido en la Real cedula y lo que amenaza el tenor della, es de Manera que me tiene apuradisimo y fuera de mi y que Havia bien menester el alivio de las esperanzas que Vuestra Señoria mira tener, del Remedio que espera en la flota, en Retorno y Respuesta de los Recados y cartas que en el segundo de Haviso se sirvio de enbiar a Su Magestad y a su Real Consejo de las Yndias de cuya Retitud

1 A. G. I., 140-7-38. According to the catalogue of Spanish transcripts in the Ayer Collection of the Newberry Library what is presumably the original letter is in A. G. I., 67-I-2. 
tracted and agreed by virtue of his royal decree and provisions with his lordship, and with Don Luís de Velasco, his predecessor, or in case that said expedition is given to another person from now until then or from then until now, he asks for, with all due respect, both of the said royal decrees and any other despatches, in so far as they may be contrary to the said contract and agreement. He asks this so that [he may appear] before his Majesty and the said gentlemen, and his lordship, my lord, the viceroy, where he insists he will go to declare and state his cause and explain the said considerations, grievances, and injuries, asking for his rights and protesting against all the injuries and the diminution of profits that they may have caused or will cause him. This he gave as his answer and signed it with his name and asked for a certified copy of it and of the said royal decree and auto in defense of his rights, the witnesses being Francisco de Esquivel, commissary of the said expedition, and Jaime Fernández, alguacil of the said inspection, to whom he entrusted the secret of the aforesaid; and they also signed it. Don Juan de Oñate, FranCISCO DE ESQUIVEL, JAIME FERNÁNDEZ, clerk of his Majesty.

In witness to all of which I, the said Antonio Negrete, affixed my signature. Antonio Negrete.

\section{Copy of the letter of Don Juan de Oñate to the Count of Montercy, dated at the Rio de las Nazas, September I3, I596. ${ }^{35}$}

As I was about to cross the Río de las Nazas-which is the most difficult crossing as far as the provinces of New Mexico-with the greater part of the people who are going on this expedition, together with all the cattle, provisions, and ammunition which are necessary for it, and which I am under obligations to take, Don Lope de Ulloa gave me two letters from your lordship, both of the same purport, dated the twelfth of last month, and showed me the decree of his Majesty and the order which your lordship gave him [Ulloa] to inform and notify me, as he did. Thus it was that even here there finally arrived the interruption and interference which the devil, as the enemy of all good, has set to prevent and delay that which was to have been done by this expedition for a multitude of souls-who are under his dominion but who are longing for the bread of the divine gospel-by bringing them to the knowledge of our sacred faith; in which great service of God and of our lord, the king, and the increase of his royal crown, I as his loyal and faithful subject have desired and do desire to employ myself, continuing that which my fathers and ancestors have always done.

The distress caused me by the contents of the royal decree and the threatening tenor of it is such that I am quite beside myself with grief and have great need of the comfort of the hopes which your lordship seems to have of the remedy which you expect by the fleet in answer to the messages and letters that you were pleased to send by the second despatch-boat to his Majesty and his royal Council of the Indies. Of their rectitude and Christian zeal no less can be expected than that they 
y zelo cristianisimo no se puede esperar menos que aprovar lo que Vuestra Señoria con tan madura consideracion y acuerdo tiene visto y aprovado y Mandarme continuar la jornada que tengo comenzada tan a costa de excesivios gastos y travajos aunque no son menos los que promete la dilacion, y el suspenderme la execucion, y progresso della, sino mucho mas y Muy mayores los inconvinientes que Refiere adelante, que quanto mas considero tanto mas acrecientan mi pena y sentimiento.

$\mathrm{Y}$ siendo este el que no se puede encarescer con palabras es mucho mayor, sin comparacion, el que tengo del Rigor y clausulas de prebencion contenidas en el aucto de Vuestra Señoria para obligarme a ovedeszer y cumplir lo contenido en la cedula de su magestad pues vastavan ser letras de mi Rey y señor para, ovedezerlas y ponerlas sobre mi caveza como fiel basallo suyo y quando se temiera alguna dificultad bastava ser yo criatura de Vuestra Señoria y hechura de sus manos para fiar de mi que con medio Ringlon de una simple carta, atropellara quantas dificultades perdidas y Razones se me podian offrescer para suplicar de la dicha cedula y aucto pues hasta aora no a sentido Vuestra Señoria en mi menos que deseo Muy Grande de servirle y Mucha puntualidad en ovedezer y cunplir todo quanto me a ordenado y mandado como lo e hecho y hago en esta ocasion que con ser la mas dificultossa que se me podia ofrescer pues en ella se aventura, a perder tanta suma de Hazienda como se a gastado el fruto de tan excesivos travajos como se han padezido y padezen el acrescentamiento que mi persona y cassa podrian tener y tanto menoscabo de mi Reputacion y estima con todo esso sin Reparar en estos inconvinientes y otros inumerables que se me ofrescen para con justisima causa suplicar de lo que se me hordena, y Manda por Su Magestad en su Real cedula y por Vuestra Señoria e estimado mas la conprovacion de mi lealtad y fidelidad que todo lo que se puede perder la e ovedezido y ovedezco y pongo sobre mi caveza, y cumplire lo que en ella y en el aucto se me hordena con tanta puntualidad que aunque sea como en efecto a de ser a costa de mayores y mas excesivos gastos y perdidas entretendre la dicha jornada y procurare conservar toda la gente que tengo hecha con la mayor disimulacion que sea posible como Vuestra Señoria lo manda sin tocar en los pertrechos y ganados vastimentos y demas cossas que para ella tengo prebenidas hasta que Su Magestad Vuestra Señoria en su Real nombre otra cossa hordene y mande satisfecho que como tan catolico y cristianisimo principe no permitira que Resciva yo tan notable agravio como se me haria en quitarseme la dicha jornada sino que vistos los Recados que Vuestra señoria enbio en el segundo de havisso y las Razones que ay para no quitarseme me mandara continuarla como la e comenzado y porque por falta de la prebencion y diligencia que Vuestra Señoria me encarga no aya quiebra alguna en lo que se teme de la gente ni se dilate mas tienpo la conservacion de los buenos efectos que de la jornada se pretenden, en tan gran servicio de dios y de su magestad holgara tener el dia de oy quinientos mill pesos para gastarlos en esta ocassion con la misma voluntad y largueza que e gastado cient mill ducados de castilla en poner las cossas de la jornada en el punto que aora estan porque lo que Vuestra Señoria manda tubiesse mejor y mas cumplido efecto para que de beras se hechara de ber y se entendiera mi zelo y lealtad y que el principal fin y desseo que tengo en 
will approve of what your lordship has decided upon after mature consideration and consultation and will order me to continue the expedition which I have begun with excessive expense and labor, although the expense promised by the delay and the suspension of my execution and continuance of it are not less but much more, and the difficulties which I shall mention further on are much greater. The more I consider it the more my pain and grief increase.

And although this is such that it cannot be exaggerated in words, that which I feel because of the harsh and threatening expressions contained in the auto of your lordship designed to compel me to obey and fulfill the orders contained in the decree of his Majesty, is beyond comparison much greater. For it was sufficient that such were the orders of my king and lord for me to obey them and place them upon my head as his faithful vassal, and even though any difficulty should have been feared, it was enough that I was the creature of your lordship and the work of your hands to be sure that with half a line in a simple letter I would have trampled under foot any difficulties, losses, or reasons that might have occurred to me to appeal from the said decree and auto. Indeed it is enough that your lordship has never known in me anything less than a very great desire to serve you and much punctuality in obeying you and carrying out whatever you have ordered me to do, as I have done and do on this occasion, in which-although it is the most difficult that could occur to me, for by it is risked the loss of a considerable sum of money, the waste of the fruit of excessive labors, the failure of the advancement which my person and house might have had, and great diminution of my reputation and prestige-with all this, and without heeding these and other innumerable difficulties which occur to me as very just cause for appealing from the commands given me in his Majesty's decree and by your lordship, I have esteemed the proof of my loyalty and fidelity more highly than all that which may be lost, and I have obeyed it, and do obey it, and place it upon my head. I shall carry out what is commanded me in it and the auto with such punctuality that, although it may be, as in fact it must be, at the cost of greater and more excessive expenses and losses, I will delay the said expedition and try to retain all the people whom I have gathered with the greatest dissimulation that may be possible, as your lordship orders, without touching the ammunition, cattle, provisions, and other things which I have provided for it until his Majesty, or your lordship, in his royal name, orders otherwise. I am satisfied that as a Catholic and Christian prince he will not permit that I should receive such a notable injury as would be done to me in taking from me the said expedition, but rather that, after considering the notes which your lordship sent by the second despatch-boat and the reasons which there are for not removing me, he will order me to continue it as I have begun it. That there might be no failure-through lack of care and diligence which your lordship urges upon me-as a result of possible action by the people that might be feared, and that there might be no longer delay in the accomplishment of the good results which are claimed for the expedition in the great service of God and of his Majesty, I would be glad to have to-day 500,000 dollars to spend on this occasion with the same good-will and 
esta jornada y e tenido siempre a sido solamente el servicio de dios y del Rey nuestro señor y el bien y conbersion de aquellas almas con muchas mas beras que el provecho y acrescentamiento propio de ques dios buen testigo.

Pero tengo por muy inposible por muchas diligencias que yo haga, poder detener la gente y que toda ella quede en veynte hombres el dia que supieren que ay mudanza, y que se me quita la jornada y biene otro a hazerla, por muchas Razones Urgentisimas y muy ebidentes que ay entre las quales es la primera por ser mis deudos los que llevan los principales officios del exercito y yr atenidos a ellos mucha gente, unos por amistad y otros por otras obligaciones particulares y dexando de yr los unos como ban, es cosa sin dubda que tanbien dexaran de yr los otros la otra porque de la misma manera, ban otros muchos deudos de deudos mios, y que qualquier dellos trae sus allegados y amigos consigo que se quedaran sin Remedio el dia que huviere novedad y mudanza demas desto ban otros muchos soldados viejos Repartidos en diversos officios por los quales y por conozerme del tienpo que servi a Su Magestad en la guerra de los chichumecos los e movido a hazer la jornada y ellos an movido a otros sus camaradas y amigos que todos la dexarian no Haziendola yo como piensan por seguirme mas por aficion que por respecto del provecho que della se les a de seguir y Ultra desto llevo yo mucha parte de la gente atenidos a mi con socorros que les e hecho y boy Haziendo que el dia que esto zesare no quedaria hombre de todos ellos: y lo que a los unos y a los otros mas les a obligado y les obliga a hazer conmigo esta jornada fuera de los prebilegios y prerrogativas que $\mathrm{Su}$ Magestad les concede es el conocimiento que yo tengo a todos y el modo y trato que con ellos tengo tan diferente del que terna el que viniere de nuebo por seguir yo en todo el estilo que en esta tierra se a tenido en la guerra y en el trato de la gente della como aquel que a tantos que la e seguido y exercitado y el que viniere haver de guardar el que se tiene en españa siendo como es muy distinto el estilo y modo de proceder de la guerra de los yndios que en españa se tiene con las demas naciones: que sino es con los años de experiencia, y exercicio que yo tengo no se puede alcanzar ni entender como es nescesario.

Y si Por estas Razones y causas se tiene por ynposible poder detener la gente, que biene en la forma que tengo dicho con mayor dificultad se podrian detener los que no bienen con estas obligaciones y Respectos particulares porque como gente trabajadora y officiales a quien en qualquier tiempo que buelban a los lugares de donde salieron no les a de faltar lo mismo que antes de su partida tenian, y Ganavan como se movieron, a hazer esta jornada teniendo respecto a los premios que della havian de conseguir sin adbertir en los travajos del camino y gastos que son tan forcossos comenzaronla con mucho gusto haziendoles todo muy facil y llano y aora que los an experimentado y ben lo mucho que les cuesta y les a de costar de travajo y gasto de conseguir el fin que desean estan de los cavellos y muy pequeña ocassion bastara para bolverse todos sin que quede alguno: pues sin haverrla me es nescesario usar de Artificio y Maña y de cuydado y no poca guarda para sustentarlos y detenerlos y ninguna causa mayor se les puede ofrescer para desbaratarse todos y bolverse sin 
liberality as I have spent I00,000 ducats of Castile in bringing the affairs of the expedition to the state in which they now are, so that your lordship's orders might be more completely and fully carried out, and so that my zeal and loyalty might be truly seen and understood, as well as that the principal end and desire which I have and always have had in this expedition has been solely the service of God and of our lord the king, and the happiness and conversion of those souls, with many other aims than my own profit and advantage, of which God is the witness.

But I consider it to be quite impossible, no matter what efforts I may make, to hold the people, or that twenty in the whole number will remain the day that they learn that there has been a change and that the expedition has been taken from me and that no other person is coming to take it up. There are many strong and obvious reasons for this, the first of which is that those who fill the principal offices of the army are my relatives, and many of the people are going because of attachment to them, some through friendship and others through other special obligations; if the first leave there is no doubt that the others will also. In the same way many relatives of my relatives are going, each one of whom brings his allies and friends with him, who will leave without fail the day the news of the change comes. Besides this many old soldiers are going divided among the various offices, for which reasons and because they knew me at the time when I served his Majesty in the war with the Chichimecos, I have induced them to join the expedition, and they have induced others of their comrades and friends. All of these will abandon it unless I lead it, as they expect, for they are following me more through affection than because of any advantage that may result to them. Outside of this I hold many of the people attached to me because of help which I have given them and am now giving them, and the day that this ceases not a man of all those will be left. What has most strongly influenced all of these people to make the expedition with me, apart from the privileges and prerogatives which his Majesty is granting them, is the acquaintance which I have with them and the different treatment which I give them from what they will receive from the new person who will come. For, in everything, I have followed the custom which has been used in this country in war and in the treatment of its people, as one who has followed and practised it for years; on the other hand the one who comes will have to follow the customs of Spain, although the methods of war with other nations used in Spain are very different from those practised with the Indians, and it is only by the years of experience and practice which I have that one may understand how it should be done.

And if for these reasons and causes it is held to be impossible to detain the people who are going, for the reasons which I have said, with still greater difficulty could those be detained who are not coming for these obligations and special reasons. For they are working people and officials who will not fail to find, at any time that they may return to the places whence they came, the same that they had and were earning before their departure. Furthermore they were persuaded to join this expedition because of the profit which they were to receive from it, and they began it willingly without paying attention to the hardships of the road 
poderse remediar que haver novedad y mudanza y dilacion en la jornada y entender que la a de hazer otro que yo y es cosa muy averiguada y cierta que si el dia de oy no tengo mas de mill hombres conmigo es por haver dilatado tanto el librarseme mis despachos con que se dio lugar a las dubdas que desto nacieron en si havia de yr yo a la jornada o no todo lo qual tiene bien visto conocido y experimentado don lope de Ulloa y los que con el bienen en el poco tiempo que a que llegaron a este Real y caminado con el, el qual cumpliendo con su obligacion sin faltar en lo que esta a su cargo a acudido con tanto balor y prudencia a hazerme merced y a todo lo que a tenido necesidad de Reparo que me tiene obligadisimo porque a sido gran parte para que el dia de oy no este toda la gente y la jornada desbaratada como lo estuviera si otro alguno biniera a la legacia que el a venido porque an sido tantas las novedades que por esta tierra se an dibulgado contra ella y en mi disfavor que a sido bien nescesario el averla el acreditado con la autoridad de su persona y con representar en todo la de Vuestra Señoria y el haver animado la gente, con su nobilisimo termino a que dexado el pesso de, su Remission caminassen a prissa para este rreal como lo an hecho y hazen los que vienen todabia caminando a cuya caussa Rindo de nuevo a Vuestra Señoria las devidas gracias por la merced y favor que me hizo en cometerle este negocio y en que sus ministros fuesen los que son que en todo miran bien ser criados de tal cassa y señor.

Tanbien es muy justo que considere Vuestra Señoria el desman tan grande que bendria a los que se an movido a hazer esta jornada para servir en ella a Su Magestad por hazerla yo que son muy muchos como tengo referido pues para abiarse para ella unos an gastado el caudal que tenian y otros an vendido sus Haziendas bienes Raizes para benir como bienen con sus mugeres e Hijos y otros que por no tener lo uno ni lo otro bienen allegados a mi entre los quales ay algunos cavalleros de calidad y los unos y los otros el dia que yo no continuare la jornada como la e comenzado es inposible que puedan ni quieran yr a ella y que dexen de quedar desanparados y desabrigados y en suma pobreza y nescesidad que a de ser una de las mayores lastimas que se pueden imaginar ber tanta gente perdida y que considerandolo me tiene penadissimo y con gran cuydado y que no se yo con que pueda Su Magestad Restaurar tan gran daño como este sino para que se les haga mas merced y aun es bien que considere Vuestra Señoria lo que se debe temer de gente que se a de ber tan perdida por aver querido yr a servir a Su Magstad.

Asimismo adbierta Vuestra Señoria que por muy poco que se entretenga la gente a de ser mucho tiempo si se a de esperar a que el conde de baylen que pretende hazer la jornada llega de españa porque quando no sea mas que el tiempo que a menester para llegar de la bera cruz a esta ciudad y della haviendose despachado de Vuestra Señoria para llegar a santa barvora es fuerca ocupar en esto todo el inbierno y no comencarse la jornada hasta la primabera del año que biene de que se siguen inconvinientes muy grandes principalmente los que se siguen de dilatarse la jornada en daño de aquellas almas que pudieran convertirse y salvarse con la brevedad della y los que podrian resultar de no reparar, con tiempo los daños que el capitan leyba y los suyos abian hecho con su entrada en aquella 
and the inevitable expenses-all appearing to them very easy and plain. But now that they have learned and seen how much it is costing them, and will cost them, in labor and expense to accomplish the end which they desire, they are all now hanging by a hair, and a very slight occasion would be sufficient to turn them all back without leaving a single one. Indeed, without having it, it is necessary for me to practise artifice and craft, with not a little trouble to detain and hold them, and no greater cause could happen to break them up and turn them back, without the possibility of stopping them, than for them to hear the news of the change and delay in the expedition, and to learn that some other person than $\mathrm{I}$ is to make it. It is very certain that if $I$ have no more than a thousand men with me to-day it is due to the delay in delivering my warrants to me, with which occasion was given for doubts to arise as to whether I was to go on the expedition or not. All of this has become thoroughly well known to Don Lope de Ulloa and those with him in the little time since they reached this army and have travelled with it, and he, fulfilling his duty, without failing in what he is charged with, has come to my assistance with such courage and judgment with whatever I had need of that he has placed me under deep obligations, and this is the chief reason why all the people and expedition are not to-day broken up, as they would have been if any other person had come on the errand on which he came. The rumors that have been spread through this country against it and in my disfavor have been so many that it has been very necessary to have it accredited by him with the authority of his person as the representative of your lordship in everything, and by the encouragement of the people by his generous conduct to lay aside the burden of their indolence and hasten to this camp, as they have done and those who are still on the road are doing. For this reason I render anew to your lordship the thanks due for the favor which you did me in committing this business to him and that his agents are such as they are, for they certainly appear in every respect to be servants [worthy] of such a house and master.

It is also right that your lordship should consider what a great disaster it would be for those who have been induced to join this expedition in the service of his Majesty for the reason that I was conducting it; these are many, as I have already said. For, in order to provision themselves for it some have spent their fortunes, others have sold their lands to come as they are coming, with their wives and children, while others, who have neither the one [fortunes] nor the other [families], are coming attached to me. Among them there are some gentlemen of quality, and, on the day when I do not continue [to conduct] the expeditions as I have begun it, it is impossible that any of them will be able or will wish to go upon it, or that they will fail to remain abandoned and shelterless, and in the most extreme poverty and necessity, and it will be one of the greatest misfortunes that can be imagined to see so many people ruined. The thought of it causes me the greatest pain and trouble, and I do not know how his Majesty can repair such a great injury as this unless he shows them more favor; it is even well that your lordship should consider what may be feared from people who must see themselves ruined for having wished to go on the service of his Majesty. 
tierra que son dignos de mucha consideracion y segun diariamente los que se siguen en daño mio propio y de la misma jornada, porque como es tanto el numero de la gente questa junta y cada dia se ba juntando y todos comen a mis espensas de mas de dos meses a esta parte que an ydo llegando a donde yo estava es fuerca haver de gastar y consumir no solo los vastimientos de pan y carne que ay en esta tierra y comarca, que me cuesta a mucho mas del justo prescio sino tanbien los que tengo prebenidos para la jornada de manera que quando se aya de comenzar al tiempo que digo de la primabera, se abran gastado todos los dichos vastimentos y sera nescesario sin poderlo escusar esperar por falta dellos a que se haga la cosecha del año que biene, que todo Redunda en deservicio de dios y de Su Magestad en daño y dilacion de la misma jornada, y del efecto, que della se pretende y en grande perjuicio y agravio mio lo ques justo se considere y mire en conciencia y si Su Magestad Y Vuestra Señoria podran con seguridad della dar lugar a estos daños e inconvinientes que aunque Vuestra Señoria me dize en su carta que en los gastos de fletes y nuebas compras me limite y tenga la mano segun me paresciere no me es posible aunque quiera ; apena de gastar consumir todos los ganados y bastimentos que tengo prevenidos y apunto para la jornada o que se me desbarate toda la gente por faltarles el bastimento nescesario porque no lo tienen si yo no se le doy que como es buen testigo don lope y los que con el bienen, a todas las conpañias que an ydo llegando a mi rreal an llegado sin grano de mayz ni polvo de Arina que paresce que tasaron estrechamente lo que hasta alli avian menester y aunque es verdad que yo por mi asiento y capitulacion no estoy obligado a sustentarlos sino desde santa barvora adelante no se sirviera dios ni el Rey nuestro señor que cumpliera yo esto con tanta puntualidad que por ello y por no socorrerlos en su nescesidad se bolvieran y desbaratara la gente con ello la jornada, antes entiendo que en averlos anparado y substentado hasta aqui y hasta que su Magestad ordene otra cossa le hago no pequeño servicio y acudo a mi propria obligacion quedandole a $\mathrm{Su}$ Magestad de gratificarlo pues lo mereze el zelo con que a esto acudo ques de manera que considerando la nescesidad con que an llegado las compañias que oy estan juntas en este Real prebiniendo a la que podrian traer las demas que quedan atras que todabia son mas de cinquenta o sesenta hombres sin los Religiossos que son los postreros me a sido forcosso dexarles en el peñol blanco en la estancia de hernando de ontiberos toda la Arina que abian menester hasta santa barvora la qual queda alli hecha y pagada para solo este efecto y aviso en los puertos por donde an de pasar para que lleguen alli; por ella que aunque me an juzgado y publicado por hombre muy inposibilitado y es asi berdad que lo estava quando comenze esta jornada dios cuya es la causa della, y conoze el animo y zelo con que yo la comence y e perseguido a acudido y acude, con larga mano para esto y para todo y por esta Razon merezco, que Su Magestad y Vuestra Señoria me hagan merced mas que a otro alguno y favorezcan mas mi caussa y justicia.

$Y$ no es menor inconviniente que los que e dicho ni el menos dañoso a la jornada, la dificultad Grande con que se an de conservar los cavallos y mulas estando como estan el dia de oy mas de mill y docientos juntos sin mas de trecientos cavallos y mulas que de treynta dias a esta parte an fal- 
Your lordship should also take notice that however little success may be had in keeping the people together, it will have to be for a long time if one is to wait until the Count of Bailén, who is petitioning the conduct of the expedition, arrives from Spain. For even though it should be for no longer time than that which he needs to travel from Vera Cruz to this city [Mexico] and from it, after being commissioned by your lordship, to Santa Bárbara, it must necessarily occupy the whole winter, and the expedition could not be commenced until the spring of next year. From this, very great difficulties would follow, chiefly those arising, as a result of the delay of the expedition, to the souls who might be converted and saved if it were quickly done, and those difficulties which might result from not repairing in time the injuries committed by Captain Leyva ${ }^{36}$ and his men in their entrance into that country, all of which are worthy of much consideration. Likewise they will result in daily injury to me and the expedition itself, for, since the number of people who are assembled and are each day assembling is large, and since they have all been eating at my expense for the more than two months that they have taken to arrive at the place where I was, it has been necessary to use up and consume not only the provisions of bread and meat which there are in this country and district-all of which cost me much more than the rightful price-but also those which I have prepared for the journey, so that if it be commenced at the time that I say, in the spring, all of the said provisions will have been consumed, and it will be necessary, without any possibility of avoiding it, to wait, for lack of them, until the crops of next year are harvested. All of this redounds to the disservice of God and his Majesty, to the injury and delay of the expedition itself and of the results which are hoped from it, and to my own great prejudice and hurt-which it is right should be earnestly considered, likewise [it should be considered] whether his Majesty and your lordship can, with the approval of your consciences, allow these injuries and difficulties. Although your lordship tells me in your letter that I should limit myself and hold my hand in the expenses of freights and new purchases it does not seem to me possible to do that, even though I should wish to do so, under penalty of using up all the cattle and provisions which I have, prepared and ready for the journey, or that all the people shall abandon me, because provisions are lacking to them, they having none except what I give them. As Don Lope and those with him can testify, all the companies which have come to my camp have arrived without a grain of maize, or any powder, or flour, for it seems they calculated what they would need thus far too scantily, and, although it is true that by my contract and agreement I am not under obligation to support them except from Santa Bárbara on, it would not serve God, nor our lord, the king, if I should carry this out with such exactness that through failure to succor them in their necessity they should return and the expedition be broken up. On the contrary, I believe that by having aided and sustained them thus far and until his Majesty orders otherwise I am doing him no small service and am carrying out my own obligations. It remains to his Majesty to reward it, for the zeal with which I am supporting it is such that, remembering the needy state in which the companies now gathered in this camp arrived, and foreseeing 
tado del Real por ser como son tantos y la tierra tan larga y tan llena de yeguas cimarronas y la dilacion y detenencia de la jornada a de ser parte por esta misma Razon de que se pierdan todos o los mas y bengan a quedar a pie los soldados y a no yr a la jornada.

$Y$ si estas causas de dilacion e inconviniente que della nacen amenazan sin dubda ni Reparo tan gran quiebra en la gente pertrechos y bastimentos y en el efecto de la misma jornada en tanto perjuicio y agravio mio y de la aucion y derecho que a ella tengo no entiendo que permitira Vuestra Señoria ni lo tendra, por descortessia que el dia que en la flota biniere persona que aya de hazerla quitandoseme a mi teniendola ya comenzada y en el estado que oy esta, dexe yo de suplicar dello con el devido acatamiento como desde agora para entonces lo hago: en mi respuesta por tenerlo hecho en tiempo y no perder en nada el derecho que a la dicha jornada tengo para pedir y suplicar a su Magestad el cumplimiento del que en su Real nombre y en virtud de sus Reales cedulas y capitulos de cartas Vuestra Señoria me tiene concedido y cometido pues es asi que aunque el señor virey don luis de belasco tenia hecho asiento conmigo y me tenia dado el mesmo derecho en la mesma virtud y mandado que luego con toda presteza, me aperceviesse y aprestasse para la dicha jornada, e yo la tenia ya aceptada en forma con todo esso saviendo que Vuestra Señoria le subcedia en el Govierno, no quisse poner mano en cossa alguna hasta que Vuestra Señoria despues que en buena a allegase a esta tierra y yo le di la bien venida y la devida ovediencia con razon del negocio que se me havia encomendado aprovo mi nombramiento y el asiento que tenia hecho como lo hizo desde oculma por la carta que desde alli me escrivio cuya copia sera con esta por la qual no solo aprovo y confirmo Vuestra Señoria lo hecho por el señor don luis de belasco pero me mando que me aperceviesse y pertrechas con la mayor brevedad que fuesse posible para hazer la dicha jornada prometiendo con la misma ber las capitulaciones y enbiarmelas haviendo reformado en ellas lo que paresciesse convenir como lo Hizo, y en virtud de la dicha carta y de la aprovacion y confirmacion de mis despachos titulos y Recados hecha despues por Vuestra Señoria comenze a prebenir y prebine todas las nescesarias para la dicha jornada y la tengo en el punto que agora esta sin que falte cossa alguna.

Y Pues el principal fin de la benida de don lope de Ulloa y de su Procurador fue para tomar Razon mira y cata del cumplimiento de mi asiento en lo questa a mi cargo asi por lo que ynporta al servicio de su Magestad y a mi propia Reputacion, como para cumplir Vuestra Señoria con su obligacion Rescivire singular merced la qual supplico con el devido encarescimiento en que Vuestra Señoria se sirva de mandar a don lope tome la dicha Razon mira y cata asi de la gente como de todos los pertrechos y municiones gandos y vastimentos y de todas las demas cossas que conforme al assiento que tengo hecho con $\mathrm{Su}$ Magestad estoy obligado a llevar para que conste a la Magestad del Rey nuestro señor y a todo el mundo de la puntualidad y ventajas con que tengo cumplido lo que capitule y que la nescesidad que de mi se a publicado para desbaratar mi negocio no a sido parte para que en nada aya havido falta sino sobra en las cossas mas inportantes porque de hazerme Vuestra Señoria esta merced pende toda mi Reputacion honor y credito y la Razon fundamental del derecho 
how the others coming behind, who are still more than fifty or sixty men, not counting the religious, who come last, would arrive, it has been necessary for me to leave for them at Peñol Blanca on the ranch of Hernando de Ontiberos all the flour which they would need as far as Santa Bárbara; there it is, bought and paid for, for this purpose only, and I am leaving notice at all the mountain passes through which they have to go in order to get there and find it. Although I have been judged and spoken of as a man without means, and it is true that I was so when I began this expedition, God, whose cause it is, knows the spirit and zeal with which I began it and have continued it and have maintained it and do maintain it with a free hand for this and for all; for this reason I deserve that his Majesty and your lordship shall, in justice to me, favor me and my cause more than any other.

Not the least of the troubles among those of which I have spoken, nor the least injurious to the expedition, is the great difficulty that must occur in keeping the horses and mules, being, as they are to-day, more than twelve hundred altogether, not to speak of the more than three hundred which in the last thirty days have strayed away from the camp. As there are so many and the country is so extensive and so full of wild mares, the delay of the expedition must be the cause, for this same reason, of the loss of all or the most of them; the soldiers, being left on foot, will not go on the expedition.

And if these causes of delay and the difficulties which arise from them threaten without doubt or hope of repair, such a great break-up of the people, ammunition, and provisions, and in the purpose of the expedition itself-to my great prejudice and injury and that of the share and right that I have in it-I do not believe that your lordship will permit it, or will hold it as a discourtesy if, on the day when the person who is to take the expedition from me, after I have begun it and have it in the state where it is to-day, arrives by the fleet, I shall cease to appeal from it with the proper respect, as I am doing from now until then in my reply, through having made it in time and before having lost any of my rights in the said expedition to appeal to his Majesty for the fulfillment of what, in his royal name and by virtue of his royal decrees and articles and letters, your lordship has granted and committed to me. It is true that, although the señor viceroy, Don Luís de Velasco, had made a contract with me, and had given me the same right by the same authority, and had ordered that I should get ready as rapidly as possible for the said expedition, and although I had formally accepted it, in spite of all this, knowing that your lordship had succeeded him in the governorship, I did not wish to put hand to anything until after your lordship had reached this country, in good time, and I had given you welcome and the proper respect, together with an account of the business that had been committed to me, and until you had approved my appointment and the contract which I had made, as you did by the letter which you wrote to me from Oculma, a copy of which will be with this. By this your lordship not only approved and confirmed what had been done by the señor Don Luís de Velasco, but you ordered me to gather my provisions and ammunition in the shortest time possible for the said expedition, promising in the same letter to examine the articles of the agreement and send them to me, after correcting anything in them 
y justicia que a la dicha jornada tengo para pedirla a Su Magestad con el acatamiento que debo y a Vuestra Señoria en su Real nombre quando mi ventura sea tan corta que sin enbargo del asiento que conmigo esta hecho venga en la flota otro que aya de hazerla, demas de que con tomarse la razon y mira que pido se se entretendria mejor la gente con entender se acercava ya su partida y no se hecharia de ber que la dilacion que ay es por esperar nueba horden y mudanza en la flota.

Asi mismo supplico a Vuestra Señoria se sirva de enbiar su veneplacito y licencia para yr marchando con todo el campo hasta el valle de santa barvora ques junto a santa barvora, para que alli se tome la dicha mira y se asiente el Real hasta tanto que Su Magestad y Vuestra Señoria en su Real nombre otra cossa me hordene y mande por ser aquel paraje el mejor y mas comodo para poder substentar la gente a menos costa sin tocar en los ganados y vastimentos questan prebenidos para la jornada y tanbien para entretenerla y desbelar la mejor de qualquiera sospecha que los pueda inquietar con protestacion que hago a Vuestra Señoria en ffee de cavallero de no pasar de alli adelante sin nueba horden y mandacto suyo y que no me muebe otra cossa sino el cumplir mejor la voluntad de Vuestra Señoria en conservar y entretener la gente y todos los pertrechos y bajages sin que la dilacion sea parte para consumirlos ni desbaratarlos aunque es fuerca aya de ser a costa de excesivo gasto mio pero muy mayor lo seria sino llegasemos al puesto que digo porque a costa de los vastimentos que abremos menester para nuestro substento se avria de añidir el de los portes y fletes de traer los a donde estubieremos lo qual es Razon se me escusse quando para ello no concurrieran las demas Razones y causas que tengo dichas.

Y casso que permita dios que venga en la flota proveydo por su Magestad otro que aya de hazer la jornada quitandoseme a mi puede Vuestra Señoria muy cierto y siguro que por mi parte ni por la de ninguno de los que comigo estan no abra alteracion alguna antes la escusare y ebitare con todas mis fuercas y no solo entregare la jornada a quien su Magestad mandare pero tanbien entregare los pertrechos ganados y bastimentos y demas cossas que para ella tengo prevenidos si nescesario fuere hazerlo asi y Su Magestad y Vuestra Señoria se sirvieren dello solo porque no se inpida ni dilate el efecto del servicio de dios y de Su Magestad tan grande que tengo comenzado porque se entienda como dixe atras queste solo a sido y es mi principal fin y intento y que por el e deseado enplear mi vida y Hazienda mas que por lo ques provecho y acrescentamiento propio con satisfecha que tengo de la Rectisima justicia y Christiandad del Rey nuestro señor y de su Real consejo de las Yndias que siendo informado de mi justicia y del derecho y aucion que a la dicha jornada tengo y se me a concedido por sus Vireyes en su Real nombre y la gran suma de Hazienda que para ella tengo gastada en su servicio me hara merced de mandarme que buelba a continuar la dicha jornada y descubrimiento del nuebo mexico y para esto me la hara Vuestra Señoria de favorezer mi justicia y derecho con particular eficacia, pues por lo que debe Vuestra Señoria a si propio y a su gran balor y cristiandad y por lo que merescen mis buenos desseos de servirle y la llaneza y puntualidad con que e acudido y acudo a todo lo que se a servido de mandarme y por ser yo criatura suya 
that seemed to need it, as you did. In virtue of the said letter and the approval and confirmation of my warrants, titles, and vouchers, made afterwards by your lordship, I began to prepare all the necessaries for the said expedition, and $I$ have it at the point where it is now without the lack of a single thing.

And since the principal purpose of the coming of Don Lope de Ulloa and his attorney was to make a minute account and inspection of the fulfillment of my contract, in what was committed to me-not only for its importance to the service of his Majesty and my own reputation, but also so that your lordship may fulfill your obligation-it will be a singular favor to me, which I beg with all due earnestness, if your lordship will be pleased to order Don Lope to make the said account and inspection of the people, as well as of the arms and ammunition, cattle and provisions, and all the rest of the things which, according to the contract that I have made with his Majesty, I am under obligation to take. [I desire this] in order that his Majesty and all the world may learn of the exactness and liberality with which I have carried out my agreement, and that poverty, which has been ascribed to me in public talk, in order to break up my business, has not caused anything to be lacking, but rather that there are more than enough of the most important things. Upon your lordship's doing me this favor depend all my reputation, honor, and credit, and the fundamental reason for the right and justification that I have in the said expedition, so that I may ask for it with the respect that I owe to his Majesty and to your lordship, as his royal representative, if fortune fails me to such an extent that despite the contract that has been made with me another shall come by the fleet to undertake it. Besides, by taking the account and inspection which I ask for, the people will be more easily held, by believing that their departure is drawing near, and will not perceive that the delay is because a new order and change are expected by the fleet.

At the same time I beg that your lordship will be pleased to send your gracious permission for the entire camp to march on to the valley of Santa Bárbara, which adjoins [the town of] Santa Bárbara, so that the said, inspection may be made there and the army settle down there until such time as his Majesty and your lordship order me otherwise. That is the best and the most convenient place to support the people at the least cost, without touching the cattle and provisions that have been provided for the expedition; it is also the best place to hold them and to watch out for any suspicion that may disquiet them. I declare to your lordshop, on my knightly faith, that I will not go further on from there without a new order and mandate from you, and that nothing else moves me but to carry out in the best way the will of your lordship in holding and delaying: the people and all the stores and baggage, so that the delay may not be the cause of their being consumed or scattered. Although this will necessarily be at great expense to me, it would be still greater if we should not go to the place that I speak of, for, to the expense of the provisions of which we would have need for our support, there would have to be added that of the portage and freightage to bring them to where we wot1l be, which it is reasonable that I should be excused from, even though the other arguments and considerations that I have stated did not coincide with [this plan]. 
y Vuestra Señoria dueño desta jornada que tengo comenzada y por quien tengo gastada tan gran suma de Hazienda Pues hasta que tube carta de Vuestra Señoria y horden para ello no quise poner mano en cossa aunque me la havia dado el señor don Luis de belasco para hazerlo por las quales Razones y causas y otras muchas tiene Vuestra Señoria mill obligaciones a defenderme y ampararla, pues le constan los grandes inconvinientes que de quitarseme se siguen, que son los que en esta tengo Referidos y los demas que dexo a la consideracion de Vuestra Señoria y de su Reta conciencia, y los que a la Real conciencia se le siguen que todos claman, por mi justicia, la qual y todas mis cossas pongo en mano de Vuestra Señoria y debajo de su protection y anparo nuestro señor guarde a Vuestra señoria muchos años del Rio de las Nasas A I 3 de setienbre I 596 .

Olvidavaseme adbertir a Vuestra Señoria que para que la gente questa por aca hecha para la jornada se conserbe y entretenga mejor y con menos travajo y la que queda atras venga con diligencia y no se buelba que Vuestra Señoria ponga algun Rigor y aun mucho aunque sea aparente en que se prendan y castiguen los culpados-soldados que se quedaron y se an buelto que por las listas que tengo faltan mas de docientos de los que se hizieron en essa ciudad y comarca y sea de manera el mandar Vuestra Señoria esto que supplico que llegue la voz aca dello y carta a don lope y a mi en que nos mande Vuestra Señoria con Rigor que le pongamos en el castigo no solo de los Vydos y ausentados sino tanbien de los que pretendieren yr o ausentarse.

Criado de Vuestra Señoria. Don Juan de oñate. 
In case God allows that there shall come by the fleet another commissioned by his Majesty to undertake the expedition and supersede me in it, your lordship may depend upon me most certainly and positively, and upon those with me, not to make any disturbance whatever. On the contrary I shall try with all my strength to prevent it, and not only will I deliver the conduct of the expedition to whomsoever his Majesty orders, but I will also hand over the arms, cattle, provisions, and other things which I have provided for if it be necessary to do so, and his Majesty and your lordship would be served by it, simply not to impede or delay the great undertaking in the service of God and his Majesty that I have begun, for it is understood, as I said further back, that this has been and is my chief end and purpose and that I have desired to employ my life and fortune for it rather than for my own profit and advancement. Believing in the upright justice and Christianity of the king, our lord, and of his royal Council of the Indies, I am satisfied that, after being informed of the justice of my right and claim to the said expedition, which was granted to me by his viceroys in his royal name, and the great amount of property which I have spent in his service, he will do me the favor to order me to go on with the said expedition and exploration of New Mexico, and that your lordship will favor my claims with special earnestness, for that is what your lordship owes to yourself and to your great worth and Christianity, and that is what is due to my earnest desire to serve you and the sincerity and promptness with which I have hastened to do all that you have been pleased to order me to do, and because I am your creature and your lordship is master in this expedition which I have begun, and for which I have used up such a large amount of property. Indeed, until I had a letter from your lordship and your order for it I did not wish to put hand to anything, although the señor Don Luís de Velasco had given me authority to do it. For these reasons and considerations, and many others, your lordship is under a thousand obligations to defend and support me, for the great difficulties that will follow from my removal, which I have mentioned in this, are known to you, besides others which I leave to the consideration of your lordship and your upright conscience, and those that will pursue the royal conscience, all of which cry aloud for my justification. This and all my affairs I put in the hand of your lordship and under your protection and favor. May our Lord preserve your lordship for many years. At the Río de las Nazas, September I3, I 596.

I forgot to say to your lordship that in order that the people who are here ready for the expedition may be more easily kept and held, and that those who are coming behind shall come more quickly and not turn back, your lordship should set some punishment, even a severe one, if only in appearance, by which arrest and punishment might be meted out to offenders-soldiers who remained behind or turned back, for it seems by the lists that I have that there are lacking more than two hundred of those that were recruited in this city and district. And let your lordship give this order that I ask for in such a way that rumors of it shall reach here, besides a letter to Don Lope and to me in which your lordship gives us strict orders to punish, not only those who depart or absent themselves, but also those who attempt to do so.

Servant of your lordship. Don Juan de Oñate. 


\section{[Carta del Doctor Santiago del Riego á Su Magestad sobre lo de Juan de Oñate. ${ }^{g}$ Mexico, Io de Noviembre de I596.]}

Señor: Por las que escrevi en la flota que partio este año si a sido dios servido que llegase a salbamento avra Visto Vuestra Magestad algunas cosas que yo hasta la fecha entendia conbenian al servicio de Vuestra Magestad Proveer y lo que cerca desto despues puedo dezir contiene esta.

Por mandado de Vuestra Magestad con orden particular que para ello hubo trato el Virrey Don luis de Velasco de que se hiziese la jornada del nuevo mexico asi para la combersion de aquella gentilidad de que tanto se a de servir nuestro señor y tanto se an de augmentar los Reinos de Vuestra Magestad como para castigo de los que sin orden ultimamente se entraron en aquellas grandes Provincias y aunque pudiera el Virrey don luis conforme a la orden que tenia despachar el negocio que tan al cabo tenia sin aguardar que llegara el Virrey Conde entendida su venida lo diffirio hasta que llegase y con su acuerdo se pussiese en execucion y se aprobo el acuerdo y election y capitulaciones que el Virrey Don luis avia hecho con Don juan de oñate a quien se encomendo la jornada aunque despues el Virrey Conde Por justas consideraciones modero y enmendo algunas de las capitulaciones y con esto despacho al don juan de oñate para que se aprestase Para la jornada Porque se entendio y es cierto que ninguno En la nueva españa la Pudiera hazer mejor ni aun tanbien como el consideradas las calidades y circunstancias que en el concurrian como heran la virtud meritos y nobleza de su persona su buen entendimiento Prudencia y manera de proceder el mejor aparejo Para juntar gente Por los muchos deudos Principales que tiene en este Reino y el de la nueva galizia tenia y el amor de todos los soldados de aquel Reyno de donde se avia de sacar la principal gente assi por aver militado con ellos en aquel rreyno Por espacio de algunos años y aver Resivido del muchas y muy buenas obras y de su padre cristoval de oñate que en este Reyno fue amparo de soldados y hidalgos Pobres como consta de informaciones que estan en ese Real consejo con lo qual se facilitava la jornada que de suyo era tan difficil por este Respecto porque para el proveerse de lo necessario para la jornada Por hallarse en el camino y tener tantos amigos y tan aficionados estava tan apto o mas que otro para prevenir los vastimentos carros cavallos y lo demas que avia de llevar, y conforme al despacho de ambos Virreyes se comenco a aprestar de Gente y todo lo demas necessario y la junto en esta ciudad y en la de los angeles de Alguna de la qual se hizo aqui buena muestra y el Resto en el Reyno de galizia con que tuvo cumplido con su capitulacion en quanto a esto aunque despues con las dilaciones le a faltado alguna gente y esta no es falta de consideracion Para quien entienda lo que es la jornada antes muy conveniente que a los principios vaya menos gente Por los inconvenientes que de la multitud podria resultar en todo lo demas segun se entendio por la Relacion de Don Lope de Ulloa a quien el conde enbio a entender si don juan avia cunplido con las capitulaciones se satizfiso a lo capitulado como parecera por los papeles que en Razon dello hizo don

B A. G. I., 140-7-38. 
[Letter from Doctor Santiago del Riego to his Majesty with regard to the affair of Juan de Oñate. Mexico, November IO, I596.]

Sir: By the [letters] which I wrote [and sent] by the fleet which left this year, if God has been pleased to grant its safe arrival, your Majesty will have learned of some things which I, up to that date, believed it would be advantageous to the service of your Majesty to provide for; what I have to say since with regard to this [matter] is contained in this letter.

By command of your Majesty, with a special order for it which existed, Viceroy Don Luís de Velasco made arrangements for the undertaking of the expedition to New Mexico, not only for the purpose of converting the heathen, by which our Lord would be so greatly served, and the kingdom of your Majesty augmented, but also for the purpose of punishing those who recently made an unauthorized entrance ${ }^{37}$ into those great provinces. And, although the viceroy, Don Luís, with the order which he held, could have gone on with the business which he had so well on the way, without waiting for the arrival of the viceroy, Count [of Monterey], yet, after the latter's coming had been heard of, he deferred it until his arrival, and, with his agreement, put it into execution. The contract, election, and articles which Viceroy Don Luís had made with Don Juan de Oñate were approved, and the expedition entrusted to him, although afterwards the viceroy count, for just reasons, moderated and amended some of the articles, and, with this, directed Don Juan de Oñate to prepare for the expedition. It was understood and is certain that no one in New Spain could do it better than he or even as well, considering the qualities and conditions that were united in him, as, for instance, the virtue, merits, and nobility of his character, his good understanding, judgment, and management in providing the best machinery for collecting the people, through the many relatives among the important people whom he has in this kingdom and in Nueva Galicia, and the love of all the soldiers of the latter kingdom, from which the main part of the people were to come, which he had gained through having served in the army with them in that kingdom for some years and having lived there for many more, and the good deeds of his father Cristóbal de Oñate, who was the refuge of soldiers and poor gentlemen in this kingdom, as appears from records that exist in this royal Council. By this the journey, which in itself was so difficult in this respect, was facilitated, for, in the matter of providing the necessaries for the expedition, through finding and having on the road so many and such attached friends, he was as well fitted or better than any other to collect the provisions, carts, horses, and the rest that he had to take. In conformity with the order of both viceroys he began to get the people and the other things ready, assembling them in this city and in Los Ángeles, ${ }^{38}$ of some of which he made a proper muster here and of the rest in the kingdom of Galicia, with which he carried out the article of his agreement in regard to this. Although afterwards, through delays, some of the people failed him, the loss of them is of no consequence to anyone who knows what the expedition is, for it is rather better that fewer people should go at the beginning, considering the 
lope estando a pique para partir don juan a su jornada parece que el demonio que tan interesado es en la dilacion della porque no se salben las animas de aquellos infieles les puso en esos Reynos encoraco a algunos que la pretendiessen y entre ellos don Pedro ponce de leon que sucedio en el señorio de Vaylen a cuya instancia y por aver escrito el Virrey Conde en el Primero de aviso que Vuestra Magestad dilatase la confirmacion hasta que mas se enterase de lo que avia en esta jornada mando despachar su Real cedula para que se entretubiese hasta que Vuestra Magestad Proveyesse otra cossa en cuyo cumplimiento el Virrey Conde Procediendo con prudencia y bueno celo Por no desbaratar lo hecho que tan adelante estava y que con tanta dificultad se avia de tornar a juntar [mando] secretamente que se le notificase a don juan no partiese lo qual el cumplio y va cumpliendo conforme a su obligacion y en este estado queda este negocio el dia que esta se escrive de que he dado tan larga Relacion Por dezir cerca del como quien tiene tan larga expiriencia de las cosas de aca lo que me parece que conviene al servicio de dios y Vuestra Magestad conforme a mi obligacion y a lo que jure el dia que fuy Recivido a servir los officios de que Vuestra Magestad me a hecho merced.

Todas las jornadas que en essos Reynos se an encomendado Para estas partes con orden que de alla viniese Gente para ellas que sucesso a tenido y que tendra siempre mejor sabe esse Real consejo que yo Podre significar, la de serpa, la de juan ponce, la de artieta, la de luis de carvajal, la de don gonsalo y otras de que ay noticia harta la causa es Porque la Gente que de ordinario viene de alla a estas jornadas es gente pobre atrayda por los pretensores y Rescatada ${ }^{\mathrm{h}}$ y engañada con falsas promesas de montes de oro y de otras comodidades que se les promete de las quales como quando aca llegan se veen frustrados claman a dios abominan del que los paso que no puede cunplir con ellos Por poderoso que sea y assi cada uno dispara y se va Por su parte y es ynpossible de toda ymposibilidad que esto dexe de ser y para que se entienda Supplico a Vuestra Magestad se sirva de entender que para la jornada de que aora trato en que an de yr Docientos hombres conforme a lo capitulado y para qualquier otra cada soldado por lo menos a de llevar quatro y cinco cavallos y algunos mas sin vestias de carga, cota escarcelas celada y sobre vista que a no nada vale mas de sesenta Pesos acortando un tercio del valor armas del cavallo y arcabuz que sin esto no podra servir en la jornada que a no nada le costara mas de otras setenta pesos dexo el carruaje para llevar su rropa y lo demas necessario Pues que hombre de essos Reynos querra ni podra socorrer en estos a esta gente que espacio sera menester Para proveerlo como podra acudirla prevenir quatro o cinco mill Reses de ganado mayor que a de llevar por delante para sustento sino quiere entrar Robando los indios su miseria como Proveera quatro o cinco mill quintales de viscocho que avra menester Para el camino y estada Para mientras comienca a cultibar y labrar la tierra como Proveera cinquenta carros y mas que avra menester para el viage con sus toldos y lo demas necessario que es menester para tan largo viage y por lo menos mas de mill y docientos Vueyes que seran menester para el tiro que ningun buey destos costara menos de doze pesos

h Probably a miscopy for "resbalada". 
troubles that might arise in all other respects from a multitude. As was learned from the report of Don Lope de Ulloa, whom the count sent to ascertain if Don Juan had carried out the articles of his agreement, he fully satisfied them, as will appear by the papers of Don Lope's account of it. When Don Juan was on the point of setting out on his journey, it appears that the devil, who is much interested in delaying it, in order that the souls of the heathen may not be saved, encouraged some persons in those kingdoms to set up a claim to it, among them Don Pedro Ponce de León, who succeeded to the seigniory of Bailén, upon whose petition, and, because the viceroy count had written by the first despatch-boat that your Majesty should delay the confirmation until you should be better informed as to what there was in this expedition, you ordered your royal decree to be sent that it should be delayed until your Majesty should provide otherwise. In fulfillment of this, the viceroy count, proceeding prudently and carefully in order not to destroy the undertaking which was so well on the way and would be so difficult again to assemble, secretly notified Don Juan not to start, which he obeyed and is obeying, in accordance with his duty. This is the state in which the business stands on the day that this is written, and I have given such a long account of it in order to say, as one who has had long experience in the affairs of this country, what it seems to me would be conducive to the service of God and your Majesty, in conformity with my duty and with what I swore on the day when I was received into the service of the office with which your Majesty has favored me.

The result that has come, and will always come, from all the expeditions in these kingdoms which have been entrusted to people coming from there [Spain] to these parts with orders for them, this royal Council knows better than I can point out-as, for instance, that of Serpa, ${ }^{39}$ that of Juan Ponce, ${ }^{40}$ that of Artieta, ${ }^{41}$ that of Luís de Carvajal, ${ }^{42}$ that of Don Gonsalo, ${ }^{43}$ and others which are more than well known. The reason is that the people who usually come from there upon these expeditions are poor people, attracted by pretenders and tempted and deceived with false promises of mountains of gold and other riches that are promised them. But when they arrive here and find themselves disappointed in these [expectations] they cry out to God and execrate Him for what has happened to them, even though $\mathrm{He}$ cannot fulfill their wishes, however powerful $\mathrm{He}$ may be; and so it is that each one hurries away and returns to his country. It is utterly impossible for this not to happen, and in order that it may be understood I beg that your Majesty will deign to learn that for the expedition of which I am now speaking, there are to go two hundred men, in accordance with the agreement, and for every other soldier at least there must be taken four or five horses, or more, to say nothing of pack animals, coat of mail, cuishes, helmet and beaver, which, cutting off a third of the value, are worth, at the very least, more than sixty pesos, and in addition horse armor and harquebus, without which he cannot go on the expedition, and which will at the very least cost him in excess of seventy pesos more, not to mention the cart to take his clothing and other necessaries. What man, indeed, in these kingdoms will wish, or be able, to help the people procure these things? What length of time will he need to secure it all? 
y no los hallan a este precio y ningun carro herrado como forcoso lo an de ser para tan largo viaje le costara menos de ciento y cinquenta pesos como proveera de herraje para tanta cavallada sin el qual es inposible hazer jornada que todo esto sin otros muchos gastos de infinitas cosas que seran menester no lo podra proveer el que de esos Reynos viniere a hazer jornada con gente aviendoles forcosamente de proveer de lo necessario con cient mill ducados lo qual de aca se haze con mas facilidad y assi las jornadas que de aca se an hecho an lucido como la de hernando cortes y la del marques francisco picarro y otras y si esto es menester para semejante jornadas como diran todos los que tienen experiencia de cosas de indias que señor de essos Reynos podra acudir a ello y quando pueda que tienpo avra menester para aprestarse y Ponerse en orden las animas de estos gentiles que en este interin murieren que con la brevedad se pudieren hallar a cuyo cargo seran y dexado esto aparte que es a lo que a mi parecer se a de entender Principalmente con que seguridad se podra quitar la jornada al que capitulo y contrato con dos Virreyes que Representaron la persona de Vuestra Magestad lo que gasto en virtud desta capitulacion que hera summa Grandissima a lo de perder y los virreyes que trataron y contrataron en nombre de Vuestra Magestad an de engañar a sus vasallos no parece que es justo ni conforme a Razon de donde entiendo salvo' sienpre el mejor parecer Vuestra Magestad deve mandar que se prosiga esta jornada conforme a lo capitulado y que no se dilate mas la Redemption de aquellas animas que nuestro dios y señor Redimio con su preciossa sangre.

Desde la ciudad de los angeles aviendo vissitado Por mandado de Vuestra Magestad quarenta obrajes de ella di quenta a Vuestra Magestad como aunque tenia otras comisiones de Vuestra Magestad ganadas a pedimiento de los naturales de Tlaxcala y otras del Virrey y audiencia que es pacifique en particular y por ser tantas no las Refiero Remitiendome a aquella las dexava todas porque atento que Por las salas de lo civil y criminal se me yba a la mano y se me cortava el hilo de hazer justicia mi estada era sin fructo y assi me vine a esta ciudad a servir mi placa como la e servido y sirvo sin enbargo de la merced que Vuestra Magestad me a Hecho Reservandola para mayor necessidad y mejor occasion la orden que dexe y las ordenancas que para ello hize que mando publicar el Virrey don luis de Velasco solo se an publicado en la ciudad de los angeles de que se an agraviado y con razon los obrajeros de aquella ciudad. Yo trate con el Virrey conde que se publicasen en toda la nueva españa y quisolas ver y entender Primero y con mucha consideracion y sus continuas occupaciones no an dado lugar hasta aora a ello y assi no se an mandado Publicar en los otros lugares de la nueva españa donde ay obrajes porque no se an vissitado conviene al servicio de dios y de Vuestra Magestad se publiquen y guarden y no solo las que el Virrey Don luis mando guardar sino las otras tres o quatro ordenancas en que no se conformo con mi parecer que embie juntamente con las publicadas entiendo conbiene se publiquen y guarden Vuestra Magestad mandara lo que sea servido.

\footnotetext{
-i Evidently a miscopy for "sale".
} 
How will he succeed in providing it with four or five thousand head of cattle which must be taken ahead for food, unless he wishes to enter by robbing the Indians in their poverty? How will he provide four or five thousand quintals of biscuit which will be needed for the road and the interval until they begin to cultivate and work the land? How will he provide fifty or more carts with the awnings ${ }^{44}$ which will be needed for the trip, and other things that are necessary for such a long journey, and at the least more than twelve hundred oxen which will be needed to draw them? Not one of these oxen will cost less than twelve pesos, and are not to be found at this price, and no iron-shod cart, as is necessary for such a long journey, will cost him less than I 50 pesos. How will he provide iron for shoeing such a large troop of horses without which it is impossible to make the journey? All this, not to speak of much expense for an infinite number of other things which will be needed, cannot be provided for 100,000 ducats by any one who comes from those kingdoms with people for whom he is obliged to make provision of what is necessary. Such is more easily done from here, and therefore the expeditions that have been made from here have been brilliant successes, as, for instance, that of Hernando Cortés, that of Marquis Francisco Pizarro, and others. If this is necessary for such expeditions, as all those who have had experience in affairs of the Indies will say, what gentleman from those kingdoms would be able to undertake it, or if he should be able, what time would he need to prepare and put in order the souls of those heathen for whom he will be responsible who might die in this interval, which time, with prompt action, might be found? Leaving this apart, although it is in my opinion what ought to be chiefly considered, with what justice can the expedition be taken away from the one who made the contract and agreement with two viceroys who represented the person of your Majesty? What he spent in virtue of this agreement, which must be a very large sum, he must lose, and the viceroys, who make the contract in the name of your Majesty, must cheat their liegemen, which does not seem to be just, or according to reason, from which I believe that the best judgment always springs. Your Majesty ought to order that this expedition be continued, in accordance with the contract, and that there shall be no more delay in the redemption of those souls whom our Lord God redeemed with His precious blood.

From the city of Los Ángeles, ${ }^{45}$ where, by order of your Majesty, I inspected forty workshops, I gave account to your Majesty how-although I held other commissions from your Majesty, won by petition of the natives of Tlaxcala, and others from the viceroy and Audiencia, which I specified in detail, and, as they are so many, I do not mention them but refer to my former letter for them-I abandoned them all. For, in view of the fact that I was restrained and cut off from administering justice by the civil and criminal courts, my stay was fruitless; therefore I came to this city to serve in my office, as I have served and am serving, notwithstanding the leave that your Majesty has granted me, reserving it for greater necessity and a better opportunity. The order which I left and the ordinances that I made for it, which the viceroy Don Luís de Velasco ordered should be published, have only been published in the city of Los Ángeles, by which 
En las que escrevi ultimas di quenta a Vuestra Magestad como abiendome cabido este año la administracion del collegio de san juan de letran avia hallado Notable perdision en el y que llegando a tomar las quentas de las Rentas del hallava que de las penas de camara que Vuestra Magestad la avia hecho merced se le devian mas de quarenta mill pesos. La obra de aquel collegio es santa y buena si se administrase como era rrazon no tienen casa los niños porque toda se a ydo y ba abaxo ni el Rector ni el mayordomo ni el maestro de niños si Vuestra magestad fuese servido de mandarle pagar esto que se deve se podria hazer cassa conveniente obra es pia y de las a que acude vuestra Magestad, Supplico a Vuestra Magestad sea servido de favorecerla con la vrevedad posible.

Tambien en la ultima dixe como me avia cavido este año el juzgado de vienes de difuntos que esta poco menos perdido que la administracion del collegio suplique a Vuestra Magestad mandase proveer algunas cosas que convenian a su servicio como Parecera Por mi carta lo mismo supplico aora Porque se que conviene al servicio de dios y de Vuestra Magestad.

Huviera usado de la merced que Vuestra Magestad me hizo de los tres años, Pues servicios de treynta y tres años que a que sirvo en las audiencias me lo aconsejaban y hubierame ydo a essos Reynos sino temiera que dando medios vida y passados los tres años me avia de ser forcosso bolver a esta nueva españa para que Pudieramos comer yo y mi muger y hijos conforme a la merced que Vuestra Magestad hera servido de me hazer Passados los tres años que para tan cansada vejez y tantos travajos fuera cosa yntolerable, supplico a Vuestra Magestad se sirva hazerme la merced cumplida por todos los dias de mi vida que gose de mi placa estandome en mi cassa con las mismas calidades que aora la goco con licencia de irme a essos Reynos que mi edad es tanta y mi salud tan falta que quando llegue a los tres años con vida sera mucho y si pasare podra ser poco y la merced que yo Recivire grandissima-Nuestro señor guarde la catholica persona de Vuestra Magestad etc. de mexico Io de noviembre de I 596.

Doctor Santiago del Riego.-[Rubricado.] 
the workmen of that city have been aggrieved, and with reason. I arranged with the viceroy count that they should be published in all New Spain, but he wished to see and examine them first very carefully, and his constant occupations have not given him an opportunity for it until now; neither has the order been given for them to be published in the other places of New Spain where there are shops because they have not been inspected. It is necessary for the service of God and of your Majesty that they be published and observed. Not only should those be observed which Viceroy Don Luís ordered, but also the other three or four ordinances in which he did not agree with my opinion, which I sent together with those published, and which I believe ought to be published and observed. Your Majesty will order what suits your pleasure.

In the last letters which I wrote I gave account to your Majesty that, the administration of the College of San Juan de Letran having fallen to me this year, I found a notable shortage in it. When I came to take account of its income I found that of the penas de cámara, ${ }^{46}$ which your Majesty had granted for it, there were owing to it more than forty thousand pesos. The work of that college is pious and good, if it were properly administered. Neither the children, nor the rector, nor the majordomo, nor the children's teacher have a house, for all is falling to ruin. If your Majesty would be pleased to order that what is owing it be paid, a suitable house could be erected. The work is pious and of the sort which your Majesty supports, and I beg that you will deign to grant the favor to it as soon as possible.

In my last letter I also stated that this year there fell to me the judging of the goods of deceased persons, which is in little better state than the administration of the college, and I begged that your Majesty would issue certain orders that would be conducive to your service. As will appear by my letter I am asking the same now, for I know that it will conduce to the service of God and of your Majesty.

I would have made use of the three-year leave of absence which your Majesty granted me, because the services of thirty-three years which I have given in the audiencias urged me to do so and I would have gone to those kingdoms if I had not feared that, if God should give me life until the three years had passed, I should be compelled to return to this New Spain in order to find a support for myself, my wife, and my children, in accordance with the favor which your Majesty was pleased to grant me after the three years should be passed, but such a weary old age and so much work would be an intolerable thing. I beg that your Majesty will be pleased to grant me the favor complete for all the days of my life to enjoy my office while remaining in my house under the same conditions under which I now enjoy it, with permission to go to those kingdoms, for my age is so great and my health is failing so much that if $I$ am alive at the end of the three years it will be remarkable, and if I do last beyond them it will be but a little time, and the favor to me will be very great. May our Lord guard the Catholic person of your Majesty, etc. Mexico, November IO, I 596. Doctor Santiago Del Riego. [With rubric.] 
Carta del Conde de Monterey á Su Magestad sobre lo de la jornada á Nuevo Mexico.j [Mexico, I5 de Noviembre de I596.]

Señor: Con el Primero y segundo de avisso di quenta: a Vuestra Magestad entre otros negocios de lo que havia que dezir sobre la jornada del Nuebo Mexico y en substancia, avise que se quedava levantando gente y que se procuraria hazer la entrada, por junio quando comiencan las aguas despues al tiempo que la flota partio desta tierra, como Vuestra Magestad entenderia comenzava la gente a salir de aqui la buelta de cacatecas y de su jornada, en esta carta hare Relacion a Vuestra Magestad de lo que despues a ydo subcediendo en este negocio.

Luego que la gente arranco de aqui hubo muchas quexas de agravios en el transito enbie comisarios y no bastando llego el clamor a obligarme a enbiar con parescer del acuerdo un alcalde que con pocas leguas que andubo pusso temor a los soldados y atajo Muchos daños y remedio algunos de los hechos que fueron Menos que la voz Prometia.

Llegada la gente a çacatecas me parescio y al algunas personas de la audiencia y al acuerdo de Hazienda con quien lo comunique: que para poner el mismo remedio en el amparo de los ganados de la galicia y Vizcaya, y de las Mulas y indios y otros aliños de las Haziendas de minas de aquellas provincias que son cassi todas en el transito y alla y aca se temian, que Havian de quedar Rodadas y mas principalmente para tomar Visita y muestra, a don juan de oñate de la gente y generos de cossas que lleva fuese persona por quenta de Vuestra Magestad muy libre y de calidad y Respecto para que sin guardar ninguno averiguasse si don juan havia cunplido con el asiento y en este casso le dexasse entrar y en casso contrario le detubiese y a su gente como convenia, al derecho de Vuestra Magestad y a su real conciencia y autoridad, y Reputacion de nuestra nacion entre los indios de aquella tierra, nombre y enbie para esto a don lope de Ulloa capitan de mi Guarda y Hizo muy bien, lo que se le hordenava y fue recogiendo y encaminando la gente y poniendola muy adelante, dexando la Visita y muestra, conforme a su instrucion para la postrera poblacon porque no hubiese engaño con ganados y otros generos agenos y porque se tomase esta satisfacion al tiempo mismo de la entrada, sin que hubiese lugar ni espacio para poderse deshazer y Menoscavar Antes del efecto lo que por Visita se hallase y Reconociese.

Estando las cosas en este estado Rescevi a los Ultimos de jullio Una cedula de Vuestra Magestad fecha en aceça a 8 de Mayo deste año en que me manda Vuestra Magestad que no permita ni de lugar al dicho don juan de oñate para que haga este entrada ni la prosiga si la huviere comenzado sino que se entrenga hasta que Vuestra Magestad Provea y mande lo que mas paresciere convenir de que seria yo havisado con brevedad en cumplimiento de la cedula despache al punto con diligencia, y por duplicado Mandamiento con Rigurosas penas, Resciviolos don lope de Ulloa haviendo buelto algunas leguas atras a hazer ciertas diligencias y tornando a caminar, se notificaron, a seis de setienbre al dicho don juan so-

JA. G. I., I40-7-38. 
Letter from the Count of Monterey to his Majesty with regard to the expedition to New Mexico. [Mexico, November I5, I596.]

Sir: By the first and second despatch-boats I gave account to your Majesty, among other affairs, of what was to be said about the expedition to New Mexico, and, in substance, I informed you that people were being recruited and that an attempt would be made to make the entrance in June, when the rains commence. Afterwards, at the time when the fleet left this country, as your Majesty must know, the people began to leave here on the way to Zacatecas and their expedition. In this letter I will give an account to your Majesty of what has happened since in this business.

As soon as the people started from here there were many complaints of offenses committed in the passage. I sent commissaries, but that was not enough, and the clamor reached such a pitch that I was compelled to send, according to the decision of the real acuerdo, ${ }^{47}$ an alcalde, who, after travelling but a few leagues, put fear in the soldiers, stopped many outrages, and remedied some of the acts, which were not so bad as rumor indicated.

After the people had reached Zacatecas it seemed to me, and to some persons of the Audiencia and of the fiscal council with whom I consulted about it, that-in order to put into effect the same remedy for the protection of the herds of Galicia and Vizcaya, and of the mules and Indians and other appurtenances of the mining properties of those provinces, which are almost all in the passage and which, here and there, it was feared would be robbed, and more especially in order to take an inspection and muster from Don Juan de Oñate of the people and goods and things which he was taking - a person should go on account of your Majesty, entirely independent, and of character and standing, so that, without depending on anyone, he might ascertain whether Don Juan had carried out his contract, in which case he should permit him to enter, and, in the contrary case, he should detain him and his people, as would comport with the rights of your Majesty and your royal conscience and authority, and the reputation of our nation among the Indians of that land. Accordingly I named and sent for this purpose Don Lope de Ulloa, captain of my guard. He carried out his orders well, gathering the people together and getting them well on the way, and postponing the inspection and muster, according to his instructions, until the last settlement had been passed, so that there might be no misunderstanding about cattle and other property belonging to others and so that this examination should be made at the same time as the entrance, without giving time or opportunity for removal or damage of what was to be inspected before it could be carried into effect.

Affairs being in this state, I received in the latter part of July a decree from your Majesty done at Aceca on May 8, of this year, in which your Majesty orders me not to permit or give opportunity to the said Don Juan de Onate to make this entrance or to continue it if he has commenced it, but that it shall be given up until your Majesty shall decree and order what seems best to you, of which I would shortly be informed. In fulfillment of the decree, I immediately sent, in haste and in duplicate, an 
bre el Rio de las Nasas donde le alcanco ques veinte leguas o algunas mas desta parte de santa barvora, lugarejo muy señalado y de mas nonbre en las postreras poblazones, el mostro gran sentimiento y Respondio en cierta forma, como Vuestra Magestad Mandara ber por essa copia de la horden que enbie y de la notificacion della, y por el traslado que embio de su carta, esperando resolucion de Vuestra Magestad en la flota, y que don juan se podria entretener hasta entonzes como Vuestra Magestad manda, que se haga hordene que la dicha notificacion se hiziese como se hizo con secreto y que la hubiesse aca, de lo que Vuestra Magestad me enbio a Mandar en la dicha cedula porque no desamparase a don juan la gente que tenia junta, y antes en lo publico con demonstraciones que no heran de substancia procure desbelar ${ }^{\mathrm{k}}$ a la ciudad del Rumor que en ella andava, por cartas de particulares de Madrid sobre la venida de don pedro ponze y lo mismo Hizo alla, don lope haviendo llegado la Voz con Mucha dicimulacion y buena Maña y lo prosiguio de Manera que si la flota o despachos llegaran quando suelen o en todo octubre se hallara entero y en ser lo que alli se avia juntado.

Visto que no venia flota, y que tardavan despachos de Vuestra Magestad y que la dilacion en esto podria causar a don juan alguna confussion y dubda de lo que debia hazer y biendome perplexo de considerar los inconvinientes que se seguian, de que se desabiase su gente $o$ tomando ocassion desta demora, Usasse del atrevimiento y subcediesse algun casso de poca reputacion, entrandose sin horden y que hera negocio digno de consultarse y ber si convendria tomarse arbitrio y resolucion, para que esta entrada que tanto se a deseado no se desbaratasse determine comunicar la cedula y horden de Vuestra Magestad con las notificaciones y Respuestas al acuerdo desta Real audiencia para que me diesse su parescer en ello este fue que se aguardassen de Vuestra Magestad procurando que no se desaviasse don juan pero que no se arbitrasse contra lo que Vuestra Magestad hordena y manda, en especial siendo Posible venir luego algunos navios y en ellos otra persona con despachos y $\mathrm{Ze}$ dulas en conformidad desto, provey Un nuebo aucto en confirmacion del que estava, notificado a don juan mandole que so las penas que se le pusieron en el primero cumpliese lo que le estava hordenado y este despacho esta ya alla, de que aguardo respuesta: espero y tengo casi por cierto que ni yra ni consentira yr contra la horden no obstante que a mi $\mathrm{y}$ a la audiencia a parescido que en hombre de menos obligaciones y de menos prendas en esta tierra y mas arrojado se pudiera mucho temer este subceso no dandome la cedula de Vuestra Magestad horden ni mano como no la da, para despedirle deste asiento que tiene hecho ni para mandarle deshazer de lo que tubiere prevenido y aprestado sino antes que se entretenga, en el estado que se hallare hasta otra horden.

En los primeros deste a llegado avisos ciertos de sevilla de haverse salvado algunas naos que nombran y de que bernan ${ }^{1}$ para hebrero paresce conforme a esta cossa, Muy cierta que don pedro Ponze no a de ser partido a la llegada deste barco aunque se hubiesse capitulado con el de que puede

k Evidently a miscopy for " desvedar".

I Evidently a miscopy for "vendrian". 
order with rigorous penalties. Don Lope de Ulloa received them where he had turned back some leagues to attend to certain affairs, and turning back on the road again, they notified the said Don Juan on September $6^{48}$ at the Río de Las Nazas, where they caught up with him, twenty leagues or more from Santa Bárbara, a very noted village and the best known among the last settlements. He showed much feeling, and replied in a certain manner, as your Majesty will perceive by this copy of the order which I sent and of the notification of it, and by the copy which he sent of his letter. Awaiting the decision of your Majesty by the fleet, and in order that Don Juan should delay until then as your Majesty orders that he should do, I ordered that the said notification should be made, as it was in fact made, secretly, and that your Majesty's orders to me in the said decree should be carried out here so that the people whom Don Juan had assembled should not desert him. On the contrary, by vague statements in public I endeavored to counteract the rumor that was going about the city, through letters from individuals in Madrid, about the coming of Don Pedro Ponce. Don Lope did the same there, when the rumor reached him, and with great skill and dissimulation he managed it in such a way that if the fleet or despatches should arrive at the accustomed time, or any time in October, what had been gathered together there would be found still in existence and intact.

Seeing that the fleet did not come and that the despatches of your Majesty were delayed, and that the delay in this might cause Don Juan some confusion and doubt as to what he ought to do, and being myself perplexed at the thought of the difficulties that would follow if his people should stray away, or, taking advantage of this delay, should break out and commit some evil act, entering without order, and realizing that it was an affair worthy of considering whether some expedient might be found so that this entrance which had been so greatly desired should not fall through, I determined to communicate the decree and order of your Majesty, with the notifications and replies, to the regular session of this royal Audiencia, so that the members might give me their opinion upon it. This was that they would wait for your Majesty, contriving that while Don Juan should not let go what he had prepared for the expediton, he should not act contrary to your Majesty's orders and commands, especially since it was possible that ships would soon come bringing some other person with despatches and decrees in confirmation of this one. I issued a new auto in confirmation of the one by which Don Juan was notified, in which he was ordered that under the penalties imposed upon him in the first one he should carry out the orders that had been given him. This despatch is already there, and I am awaiting his reply. I expect and am almost certain that he will not go or permit any one to go contrary to the order, although it has seemed to me and the Audiencia that in a man of less integrity, fewer ties in this land, and more rashness, such an event might be feared, since the decree of your Majesty gives me neither order nor authority to release him from the contract which he holds nor to order him to undo what he had arranged and prepared, but rather that he should wait as he was for another order.

In the first days of this [month] certain information came from Seville that some ships, which are mentioned by name, had been cleared and 
justamente dubdarse por el estado y prissa desta jornada que yo escrevi por Marco en el segundo haviso y tanto mas por no haverse esforcado la horden que trae esta cedula como es de creer se Hiziera en efectuando el asiento con alguna carta siquiera por la havana en los pliegos que a haviso estos dias por estas razones y hallarse evidente dificultad por, todas las personas de buen consejo en Alterar lo tratado y benir persona de españa me e sentido obligado a adbertirlas y proponerlas a Vuestra Magestad luego que se a entendido que el haviso dellos puede llegar a buen tiempo y antes que don pedro si esta nombrado se embarque y considerando quan posible cossa fuera tenerse Vuestra Magestad por Muy servido de que la entrada de don juan estando tan adelante y con tan Razonables esperanzas de buen subcesso se pusiera en execucion se me a ofrescido justa Razon de dubdar sobre el arbitrio deste casso como a quien tiene la cossa presente y be que por bentura se elegiera lo mas acertado en dar licencia, a don juan para proseguir y executar lo que tanto travajo cuesta, hasta oy y tanto tiempo a que se dessea, y embiar a Vuestra Magestad con este barco el haviso desta determinacion, pero a me parescido que no puedo asegurarme de mi propio juycio en semejante negocio con menos que larga experiencia, desta tierra ni de que Vuestra Magestad aya de mudar su determinacion por solo mi havisso y parescer siendo tan recien venido y siento que tendria Muchos peligros y Grandes inconvenientes el haver entrado don juan de oñate en casso que Vuestra Magestad todavia mandasse Venir a don pedro Ponze o a otra persona y asi me e Resuelto de no determinarme en casso tan inportante sino es mudando la audiencia, su primer parescer y para este fin e buelto a tratar con ella desta Materia despues que se save que no ay que aguardar naos de españa hasta la primabera, sienten los mismos inconvenientes en el desavio desta jornada en el estado que oy tiene y la misma inposibilidad que yo en pueda conservarse y substentarse la Machina que en su tanto y a su Modo tienen movida: don juan y sus deudos sin deshazerse presto la gente, y lo demas o la mayor parte dello y ben las dificultades que ay en venir de alla persona y juzgan dellas con tanta mayor resolucion que yo quanto es mas la noticia, que tiene de las cosas de las yndias pero no se atreben con todo esso a Resolver de conformidad en que yo tome arbitrio en este casso dando licencia a don juan para dexarlo comenzado ni para proseguir en ello aunque la determinacion de Vuestra Magestad que conforme a la cedula podra aguardarse brevemente se aya Retardado tantos Meses, a me obligado la calidad deste negocio a cansar a Vuestra Magestad con Relacion particular y larga, para que se entienda el estado que tenia quando llego la cedula y la perplexidad que a causado esta novedad en especial con la tardanza de las cartas y el cuydado conque este negocio quedo sin poder remediarle.

Sera Vuestra Magestad servido de acomodar en lo de alla lo que mas paresciere convenir conforme a lo que se avra considerado y a lo que de aca se propone, en esa papel para en casso que algunas cosas del no se ayan adbertido o no se aya reparado tan de proposito en ellas que aca desa Manera se entienden por mi y por la audiencia y por otras personas platicas y de buen parescer. 
would come in February. According to this it seems a certain thing that Don Pedro Ponce could not have left at the time of the arrival of this vessel, even though the agreement had been made with him, of which one may justly doubt, since I wrote in March by the second despatch-boat of the advanced state of this expedition, and especially since the order brought by this decree has not been corroborated, as it is to be believed it would be, if the contract were being carried out, by some letter at least to Havana in the sealed packets of which news has come in these days. For these reasons, and because it is clearly objectionable to all persons of good judgment for the contract to be changed and a person sent from Spain, I myself have felt obliged to inform your Majesty of these [reasons] and set them before you as soon as it became known that the report of them can arrive in good time and before Don Pedro, if he has been appointed, embarks. Considering how very possible it is that your Majesty may be pleased to grant, since the entrance of Don Juan is so far on the way and with such reasonable hopes of success, that it be put into execution, it has occurred to me, as one who has the matter before him, that there is good reason for doubt on the decision of this case and that perhaps I would be choosing the right course if I should give permission to Don Juan to continue and carry out what has cost so much labor up to now and has been so long desired, and send to your Majesty by this vessel information of this decision. But it has seemed to me that I cannot be certain of my own judgment in such a business, with but short experience in this land, nor that your Majesty must change your opinion solely upon my advice and judgment, I being but recently arrived, and I feel that there would be many dangers and great difficulties if Don Juan de Oñate should have entered in case your Majesty should still order Don Pedro Ponce or some other person to come. Therefore, I have resolved not to come to a decision in a matter so important unless the Audiencia shall change its first opinion, and to this end I have again consulted with it upon this affair. Since it has been learned that ships are not to be expected from Spain until the spring, they perceive the same objections to the dismantling of the expedition in its present state as I perceive, and the same impossibility that the project, which, proportionably to their means, Don Juan and his relatives have put in motion, can be held and detained without the people and the rest or most of it being quickly scattered. Also they see the difficulties that there are in the coming of a person from there [Spain] and judge of them with more conclusiveness than $I$ in proportion as they have more knowledge of the affairs of the Indians. But with all this they do not venture to decide that I shall settle this matter by giving permission to Don Juan to leave it thus commenced or to go on with it, although the decision of your Majesty, which, according to the decree, might be expected soon, has been delayed many months. The nature of this business has compelled me to weary your Majesty with a detailed and long report, so that the state in which it was when the decree arrived, and the perplexity which this news has caused may be understood, especially with the delay of the letters and the anxiety in which the affair remained, without possibility of remedying it. 
De lo que toca a la conservacion de la gente y demas Generos que don juan tiene me paresce que no se puede hazer juycio siguro porque su Menoscabo y desavio paresce a todos que corre gran Riesgo por Mucho que el se procurasse esforzar y yo darle calor para conservarse.

La Visita y muestra que don lope havia de tomar no esta hecha, por no haver pasado de las postreras poblazones y llegado al tiempo de la entrada que quando convenia y se le hordeno que la hiziesse demas de que aora parescio a la audiencia como ya se le a mandado que sientiendo caudal de parte de don juan para el cumplimiento del asiento no haga esta diligencia por no justificar la causa del mismo don juan en el interese que a de poder pedir aunque si el le Requiere que haga estas diligencias con protesta de hazerlas sin su asistencia ante qualquier escrivano a parescido que en aquel casso las haga don lope por no dar lugar a algun fraude y engaño contra Vuestra Magestad y porque no parezca que se Vye de averiguar la Verdad.

Estoy con cuydado a bueltas destos otros Mayores que tengo Referidos del que hazen a Vuestra Magestad don lope y sus oficiales pero ni a mi ni a la audiencia a parescido hazedero Mandarle venir porque no conviniendo tomar la Visita y muestra agora por lo que tengo dicho, y viniendose sin hazerla, seria forcosso bolver alla, despues en casso que aora viniesse horden de Vuestra Magestad para que don juan continue su jornada y lo mas Principal Porque en biendo partir a don lope para aca se desengañaria la gente y se desbarataria todo con mucha prissa. Dios Guarde la Catholica persona de Vuestra Magestad.-Mexico a I 5 de novienbre I 596.

El Conde de Monterey.-[Rubricado.]

Las Razones que se ofrescen para que don Juan de oñate haga La entrada, en el nuebo Mexico como le esta encargada, en virtud de la capitulacion que con el se hizo y para que no venga de españa otro a hazerla alterando lo tratado son las siguientes: ${ }^{m}$ [Mexico, 15 de Noviembre de I596.]

I.-Don Juan de oñate paresce que se sentira agravido en que haviendo capitulado con el Virey Don luis de Velasco en conformidad de las hordenanzas de Su Magestad y de horden particular que el Virey tubo y dadole

m A. G. I., I40-7-38. 
Your Majesty will deign to arrange things there as seems most conformable with what will have been considered, and what is set forth about matters here in this paper in case some things may not have been made known or attention not given to them as they are understood by me and by the Audiencia and by other learned and well-informed persons here.

As to what touches upon the preservation of the people and other things that Don Juan has it seems to me that no certain decision can be made, for it is apparent to all that he runs great risk of their being lost and scattered, no matter what efforts he may make or how much I may urge him to preserve them.

The inspection and muster which Don Lope was to have made has not been made, because he did not pass the last settlements and arrive at the time of the entrance, as was proper, and as he was ordered to do. Besides this it has just occurred to the Audiencia that it had already ordered him not to put this proceeding into execution if he believed that Don Juan had the means to carry out the contract, in order not to justify the claim of Don Juan himself for the interest which he would be able to charge. Although if he should require him to carry out these measures, with the declaration that they would otherwise be done without his presence before some clerk, it was the opinion that in such a case Don Lope should do this, in order not to give any opportunity for fraud and deceit against your Majesty and in order that it should not appear as though the truth were not being sought.

Together with these other greater expenses which I have spoken of, I am troubled about that which Don Lope and his officials are causing your Majesty, but it has not seemed desirable either to me or to the Audiencia to order him to come back, for, although it is not advisable to make the inspection and muster now, for the reason that I have said, if he should come without making it it would be necessary for him to return there afterwards in case an order should come from your Majesty for Don Juan to continue his journey. The most important of all is that if Don Lope were seen to be returning the people would be undeceived and would quickly disperse. May God guard the Catholic person of your Majesty. Mexico, November I 5, I 596 .

The Count of Monterey. [With rubric.]

The reasons presented why Don Juan de Oñate should make the entrance into New Mexico as he was commissioned to do, in virtue of the agreement made with him, and why no other person should come from Spain to do it, in disruption of the compact, are as follows: [Mexico, November 15, I596.]

I. It is apparent that Don Juan de Oñate will feel aggrieved-after having contracted with the viceroy, Don Luís de Velasco, in conformity with the ordinances of his Majesty, and a special order received by the viceroy, and, having received in virtue of the agreement, his commissions and patents for the entrance and government from the same viceroy, and 
en virtud de la capitulacion el mismo Virey sus comisiones y patentes para entrada y governacion y consentidose despues por parte de don Juan las limitaciones con que se modero y aprovo el asiento y jornada no se le cumpla lo tratado y asentado sin preceder culpa ni falta de su parte para ello.

2.-Y que por razon desto paresce claro que cometiendose a otro la jornada querra y podra pedir don juan a Su Magestad en conciencia y en justicia el ynterese de los gastos hechos y que $\mathrm{Su}$ Magestad sobre esto sera vencido en tela de juycio oyendole y abra de mandar que se satisfecho dellos lastando alguna gruesa cantidad contra la intencion de las hordenanzas en Razon de que semejantes descubrimientos no se hagan a costa ninguna de la Real Hazienda.

3.-Que ay muchos deudos y amigos de don juan fuera de los que le an ayudado y socorrido con sus Haziendas para aviarse que van en persona a la jornada y llevan sus mugeres e Hijos y para aprestarse y conprar lo necesario para ella an vendido y enpeñado sus Haziendas y no yendo a ella y haviendose prevenido con buena ffee quedaran descompuestos y con las descomodidades que se devan considerar.

4.-Que de deshazerse la gente que don juan tiene en quanto buelbe a reduzirse con otro que Haya de hazer la jornada abra en la tierra muchos insultos y Rovos como quiera que an de derramarse por toda ella los que yban a este descubrimiento que siendo antes ombres destraydos con la desesperacion se haran peores.

5.-que este inconviniente es de mayor cuidado porque del puesto donde la gente se halla, la parte della que bolviere sin horden, y en quadrillas ha de passar por toda la tierra de chichimecos y puede Rezelarse que por ser muchos dellos delinquentes se anden por alla en los Montes como foraxidos y salteadores incitando a los yndios que Antes lo heran a que los acompañen en aquel exercicio bolviendo a su antigua costunbre y turbando la paz y quando esto no subceda puede temerse que con los mismos Rovos daños y malos tratamientos que los soldados haran por los caminos de la frontera a los indios chichimecos y a la demas gente los alteren y den ocassion para Alcarse y turbar la paz que tan Reciente esta y tan a peligro de perderse con qualquiera mediana ocasion.

6.-Que Puede temerse que parte de la gente, se junte y meta la tierra adentro al Nuebo Mexico y haga en el alguna entrada sin horden maltratando a los indios y desacreditando la religion y nacion de los españoles para lo que despues se intentare, o lo que peor seria que se junten con el capitan leyba que entro y esta tanbien alla sin horden y debe de hazer los mismos daños y trayendo grave inconviniente que se dilate el Remedio desto le traeria mayor si con juntarsele algunos destos soldados cresciesse en fuercas y tomasse alas para Resistirse al governador que entrare.

7.-Que las Molestias questas provincias an Rescevido en la leva y conducion de la gente desta jornada, se bolveran a sentir segunda vez y de nuebo quando la jornada tornare a entablarse y esto es de mucha consideracion por ser como se apunta la gente de nuebos descubrimientos mas desbaratada que otra ninguna y que se haze sentir mas por donde quiera que passa. 
Don Juan having agreed afterwards on his part to the limitations with which the contract and expedition were moderated and approved-if it be not carried out, without being preceded by any blame or fault on his part for it.

2. For this reason it is apparent that if the expedition be committed to another Don Juan will wish and will be able to ask from his Majesty, by right and justice, interest on the expenses incurred. His Majesty will be defeated in this if it be heard in judicial proceeding and will have to order that he be paid for them, at the expense of some large sum, against the intention of the ordinances, according to which such explorations are not to be made at any expense to the royal exchequer.

3. There are many relatives and friends of Don Juan, apart from those who have helped him in his preparations with their property, who are going in person on the expedition and are taking their wives and children, and who, in order to prepare and buy what was necessary for it, have sold or mortgaged their property, and if they do not go upon it, after having made their preparations in good faith, they will be left in disorder and discomfort, all of which ought to be considered.

4. If the people whom Don Juan has collected be disbanded during the interval until they are again brought together under the other who goes to conduct the expedition, there will be many robberies and outrages in the country. In any case there will be scattered all through it those who went on this exploration, and who, if they were dissolute men before, will be made worse by their desperation.

5. This difficulty is greatly to be apprehended, for that part of the people who will return from the place where they are, without order and in bands, will have to pass through all the country of the Chichimecos, and it is to be feared that, as many of them are delinquents, they will wander there in the mountains as forest robbers and bandits, inciting the Indians, who were formerly such, to accompany them in that exercise, returning to their ancient custom and disturbing the peace. Even though this does not happen, it is to be feared that the robberies, injuries, and ill conduct which the soldiers will commit on the roads of the frontier upon the Chichimecos Indians, and other people, will anger them and cause them to uprise and break the peace so recently made and so greatly in danger of being lost upon any slight occasion.

6. It is to be feared that part of the people will join together and make an unauthorized entrance into the interior of New Mexico, ill treating the Indians and discrediting the religion and nation of the Spaniards for later attempts. Or, what would be worse, that they will unite with Captain Leyva, ${ }^{49}$ who entered and is also there without authority and would probably commit the same outrages. And if, for this reason, it would cause serious trouble for the remedy to be delayed, it would cause still greater if by uniting with him the soldiers should make a sufficient force to embolden them to resist the entering governor.

7. The annoyances which these provinces have experienced in the levy and transportation of the people of this expedition they will have to experience a second time and all over again if the expedition is once more undertaken. This is important, for, as has been noted, the people engaged 
8.-Que Haviendo sido esta entrada del Nuebo Mexico de las mas bien Reputadas trocando opinion y credito entre la gente se an de dificultar mas los medios para hazer esta y otras y apenas se hallara persona natural destas provincias que osse capitular y aprestarse para nuebos descubrimientos ni que halle gente que le siga ni se atreba a disponerse a ello y bender la Hazienda y mover su cassa y familia siendo los cassados el nerbio principal para que las pacificaciones consigan.

9.-Que como quiera que se mira y considera si la massa que aora tiene don juan junta, se deshaze para Recoger la otra vez y poner la en el estado en que aora esta se a de tardar mucho y costar mucho travajo y sienpre en estos cassos se atrabiesan inconvinientes para que el efecto se dilate e. inposibilite que todo es de consideracion siendo este descubrimiento del nuebo Mexico tan inportante al servicio de dios y del rey nuestro señor y tan deseado por Su Magestad y su real consejo como es notorio y como se mostro bien claro en la entrada sin horden, que Hizo el capitan castaño en aquellas provincias porque fue mandado prender y castigar pues por averse esto executado sacandole de alla al tienpo que ya estavan poblados el y algunos soldados escrevio Su Magestad mostrandose por deservido de que esto se hubiesse executado por el desabio de aquel pequeño principio de poblazon siendo tan ligera prenda de la reducion y conbersion de aquella tierra, en comparacion de tanto aparato y tan concertado de Religiossos y ministros de doctrina y de gente de guerra y generos nescesarios como oy se entiende questan para entrar por horden procedida de asiento.

ro.-Que se dubda mucho aca por todas las personas platicas y de buen juicio y consejo que pueda quien viniere de españa sin tener Hazienda en esta tierra o ser enparentada en ella, con personas que las tengan Recoger y juntar a sola fuerca de dineros aunque sea con grande suma dellos la Gente y generos y cantidades que a Menester para la jornada, pues aun con todas estas comodidades a de gastar muchos millares de pessos.

I I.-Ques de grande inconviniente que el Governador no sea persona de mucha noticia y experiencia en el trato de los indios y que se sepa acomodar a la blandura y caricias y medios con que principalmente quieren hazerse estas entradas y paresce dificultosso que persona venida de españa aunque hubiesse estado aca algun tienpo sea tan intelligente y de tanta maña e industria en esta parte como quien nacio y se a criado en esta tierra y pasado la vida en ella con buena opinion en la edad mayor y antes della de hombre cristiano y de muy apacible condicion y de buen sesso.

I2.-Que la persona que viniere de españa por muy principal que sea no puede traer consigo muchos deudos cercanos parientes y amigos de quien fiarse para poder substentarse temido y amado de su gente como es muy inportante porque en estos cassos los caudillos son menos estimados y tenidos por no ser derechamente jornada hecha, en nonbre de Su Magestad y a despensas de su Real Hazienda y por ser mucha de la gente comun y perdida ocasionada por intentar atrevimientos insultos y Rovos y tan desenfrenada que faltandole a la caveza esta fuerca de deudos y amigos corre rriesgo el mismo en ocasiones que se ofrescen y quando esto 
in new discoveries are more dissolute than any others and cause the most resentment wherever they go.

8. Since this entrance into New Mexico was most highly esteemed, should the opinion and credit of it be changed among the people, it will be most difficult to find the means to make this or others, and there will scarcely be found one person native to these provinces who will dare to contract and prepare for new discoveries, or who will be able to find people to follow him and venture to get ready for it by selling their property and moving their households and families, for the married people are the principal avenue for the accomplishment of pacifications.

9. However it is looked at and considered, if the body of people which Don Juan now has gathered together is broken up, to collect it again and put it in the state in which it now is will cost long delay and much trouble; always in such cases difficulties are encountered which delay or prevent the undertaking, all of which is to be considered, since this exploration of New Mexico is so important to the service of God and our lord, the king, and so greatly desired by his Majesty and his royal Council, as it is publicly known to be, and as was very clearly shown in the unauthorized entrance made by Captain Castaño ${ }^{50}$ in those provinces, for orders were given for his arrest and punishment for having done this, and he was taken away from there after he and some soldiers had already made a settlement. He wrote to his Majesty, showing himself to be aggrieved because this was done, to the ruin of that little beginning of a settlement, although it was a very slight pledge for the reduction and conversion of that country in comparison with such a great and orderly gathering of religious and ministers of the gospel and soldiers and necessary goods as is known to be ready to enter according to order and contract.

ro. It is greatly doubted here, by persons who are well informed and of good judgment, that whoever comes from Spain, without possessing any property in this country or being related in it to persons who do possess it, will be able to collect by means of money alone, even though it be a large sum, the people and quantities of goods needed for the journey, for even with all these advantages it must cost many million pesos.

I I. It is a great disadvantage if the governor be not a person of much knowledge and experience in dealing with the Indians, and does not know how to accommodate himself to the endearments and caresses which are the principal means required in making such entrances. It seems unlikely that a person coming from Spain, even though he may have been here for some time, can be as clever and skillful in handling [the affairs of] this part as one who was born and reared in this country and has passed his life in it, with good reputation in middle life, and, before that, as a Christian man of affable temper and good sense.

I2. The person who may come from Spain, no matter how important a person he may be, cannot bring with him many near relatives and friends upon whom he can depend to keep himself feared and loved by his soldiers, as is very important. For in these cases the leaders are held in less esteem because the expedition is not made directly in the name of his Majesty, and at the expense of the real hacienda, and because many of the people are common vagabonds, accustomed to commit outrages and robberies, 
no sea son los desafueros de la gente tantos que Haviendo de Reduzir y pacificar a los naturales los indignan y en lugar de facilitar su conversion la estorban.

I3.-que Haviendose tomado diversas vezes semejantes asientos en españa con personas que an venido de alla a hazer entradas y nuebos descubrimientos sienpre se an visto flacos subcesos y resultado gran desabio y ningun efecto lo que a mostrado por el contrario la experiencia en la jornada que el Marques del balle Hizo desde Cuba al descubrimiento desta tierra y ciudad de Mexico y las que despues se an hecho desde aqui al de otros Reynos y provincias fecha en Mexico a quinze de novienbre I 596 .

El Conde de monterey.-[Rubricado.]

[Respuesta del fiscal:] Relación de lo que ha pasado acerca de quitar la jornada de nuevo Mexico á Don Joan de Oñate y darla á Don Pedro Ponce de Leon, y de los papeles que en el ultimo navio de aviso á embiado el Virrey acerca desto." [Sin lugar; sin fecha.]

El Virrey don Luis de Velasco en virtud de la orden que tubo de $\mathrm{Su}$ Magestad para tomar assiento con alguna Persona sobre el descubrimiento y poblazión del Nuevo Mexico y conforme á las ordenanzas de nuebos descubrimientos capituló con Don Joan de Oñate sobre el de la dicha nueva México y esto fué á tiempo que llegava á la nueva España el conde de Monterrey el qual quiso Don Luis que viese la capitulacion y el conde escribió en el primer navio de aviso que se le ofrecian algunas dificultades y que con brevedad las resolveria y en segundo de aviso volvió escrivir que aunque havia repasado en lo que Don Luis que era en que Don Joan tenia poco posible y muchas deudos pero por tener caudal algunos deudos suyos con algunas limitaciones que havia puesto en lo capitulado se resolvió en dar licencia á Don Joan de Oñate para usar de la capitulacion.

En este tiempo y haviendose visto acá la dicha capitulacion que la embio el Virrey Don Luis de Velasco, Don Pedro Ponce de Leon se ofreció de hacer esta jornada mejorando mucho la Capitulacion de Don Joan y sin pedir nada para si hasta haver acavado la jornada para que se le hiciese la merced que mereciese consultose a su Magestad quanto mas de proposito parecia la persona de don Pedro para esta enpresa que la de don Joan por ser un hombre particular y haverse entendido que devia gran suma de ducados y que en otra jornada que emprendio los soldados le tenian en poco y desobedecian y tenerse por imposible poder hacer la Jornada y si la hiciese la gente que se le juntase serian delinquentes foragidos y otra de mas ${ }^{\circ}$ vivir de que se podia temer algun riem ${ }^{\mathbf{p}}$ subceso, y su magestad

n A. G. I., 140-7-38. Copy of transcript in the Ayer Collection; copy compared by Miss Clara A. Smith.

o Evidently a miscopy for "mal".

D Evidently a miscopy for "ruin". 
and so unruly that if this force of relatives and friends is lacking to the chief he himself is in danger on occasions that may come up. Even if this does not happen the excesses of the people are so many that, though. it is their duty to reduce and pacify the natives, they irritate them, and in place of facilitating their conversion they interfere with it.

I3. Although at divers times such contracts have been made in Spain with persons who have come from there to make entrances and new discoveries, poor results have always been experienced, and great loss, and no effects have been the outcome. The contrary was experienced in the expedition made by the Marquis of the Valley ${ }^{51}$ from Cuba for the discovery of this country and City of Mexico, and in those which have been made afterwards from here to the other kingdoms and provinces. Done in Mexico, November 15, I596.

\section{The Count of Monterey. [With rubric.]}

[Report of the fiscal:] Statement of what has been done in regard to taking the expedition to New Mexico from Don Juan de Oñate and giving it to Don Pedro Ponce de León, and of the papers in regard to this which were sent by the viceroy on the last despatch-boat. [No place; no date.]

Viceroy Don Luís de Velasco, in virtue of the order which he had from his Majesty to make an agreement with some person concerning the exploration and settlement of New Mexico-in conformity with the ordinances for new discoveries-made a contract with Don Juan de Oñate in regard to the expedition to New Mexico. This was at the time of the arrival in New Spain of the Count of Monterey, who was requested by Don Luís to examine the contract. The Count wrote by the first despatchboat that several difficulties occurred to him which he would decide shortly. By the second despatch-boat he again wrote, saying that he had re-examined what had been done by Don Luís, and that although Don Juan had small means and many debts, yet as some of his relatives possessed property he had resolved to grant permission to Don Juan de Oñate to use the agreement, with some limitations which he placed upon it.

At this time, after the said agreement, which had been sent here by Viceroy Don Luís de Velasco, had been examined, Don Pedro Ponce de León offered to make this expedition under much better terms than those offered by the contract of Don Juan, and without asking anything for himself until the journey should be completed, so that he might then be given the reward which he might merit. His Majesty was advised that Don Pedro was a much more suitable person for this enterprise than Don Juan, as the latter was a man of no rank, and it was understood that he owed a large sum of ducats; also that in another expedition which he undertook the soldiers had no respect for him and disobeyed him, and that it was held to be impossible for him to make the journey, or that if he did do it the people whom he would collect would be criminals and highwaymen, or others of evil life, from all of which some disastrous occur- 
tubo por bien se capitulase con Don Pedro y luego se despachó cedula para que el Virrey no diese lugar á que don Joan prosiguiese la jornada sino que se entretubiese hasta que su Magestad mandase otra cosa.

Escrive agora El dicho Virrey en el ultimo navio de aviso en carta de I 5 de Noviembre pasado, que yendo ya Don Joan de Oñate marchando con su Gente y Vagajes, y el embiado al capitan de su Guarda en pos de dicha gente para que no hiciese agravios y en pasando las ultimas poblasiones le tomase muestra para ver si llevava lo que havia ofrecido y cumplido con la capitulación recibió la sobredicha Cedula y con un aucto se la enbió á notificar al dicho Don Joan que le alcanzo sobre el Rio de las Nasas casi en las ultimas poblasiones y á la notificacion le respondio la carta de que embia copia en qual dice que obedece mui obedientemente y que no pasará adelante como su Magestad lo manda aunque muestra gran sentimiento y representa los grandes gastos que ha hecho él y sus deudos y amigos, que los mas lleva consigo y los travajos que an pasado en llegarlo á aquel grado, y las dificultades grandes que abria en poder de tener la gente saviendo que el no ha de hacer la jornada y el estorbo que era para ella estando tan adelante y el descarrio de todos y la dificultad que habria en hazer la otro que el y finalmente pretende adquirir derecho en virtud de su capitulacion y de haver cumplido con ella hasta aquel dia y pedia al Virrey le dejase marchar hasta la ultima poblasion y que alli le tomase muestra el dicho capitan de la guarda asegurando al Virrey que no entravian en el descubrimiento él ni ninguno de los que con él yban.

$Y$ dice el Virrey que este negocio le ha tenido con grandisimo cuidado y perplexidad viendo lo que tardava la segunda orden de su Magestad y no sabiendo lo que ordenaria á Don Joan de Oñate que aunque se tenia por acertado darle licencia para proseguir la jornada por lo que se pudia temer de que la gente no se desabiase y se entrase sin orden y la dificultad que abria en ir de España persona que hiciese la jornada. La audiencia con quien por dos veces lo comunico no se resolvió en que arbitrase ni hiciese novedad, de lo que su Magestad mandava esperandose que en la flota yria orden de lo que se oviese de hacer aunque sienten los inconvenientes del desavio desta Jornada en el estado que tenia y la imposibilidad que abrá en poder de tener la gente y Machina que tiene junta Don Joan por mucho que se esfuerce á ello y el Virrey le ayude y que le avia vuelto á embiar á notificar otro auto en confirmacion del primero para que cumpliese lo que se le havia ordenado de que aguardava respuesta, y que tiene por cierto que ni yva ni consentira yr contra la orden aunque en hombre de menos obligaciones y prendas en aquella tierra y mas amojado se pudiera temer mucho este subceso.

$\mathrm{Y}$ dize tanbien que la visita y muestra que havia de hacer el capitan de la guarda en pasando las ultimas poblasiones no estava hecha y pareció á la audiencia ordenarle que no la hiciese sentiendo caudal de parte de Don Joan para el cumplimiento de lo capitulado para que no adquiriese derecho para la recompensa que quisiese pedir pero que si todavia le requiriese con protestacion de que la haria el mismo Don Joan ante escrivano la hiziese el dicho capitan de la guarda por no dar lugar á algun engaño y fraude. 
rence might be expected. His Majesty therefore decided to make the agreement with Don Pedro, and a cédula was immediately despatched that the viceroy should not give permission to Don Juan to continue the expedition, but that he should be detained until his Majesty should order otherwise.

The said viceroy writes now by the last despatch-boat, in a letter of last November, that after Don Juan de Oñate had already set out on the march with his men and equipment, and he [the viceroy] had sent his captain of the guard in the rear of the said men to see that they did no damage, and to take a muster after they had passed the last settlements ${ }^{52}$ for the purpose of ascertaining whether Don Juan was taking all that he had offered and whether he was carrying out the terms of his contract, he [the viceroy] had received the aforesaid cédula and had sent it with an auto to notify the said Don Juan. It overtook him at the Río de las Nazas, almost at the last settlements, and he replied to the notification in the letter of which he was sending a copy. In this letter he says that he yields very obediently and that he will not go on, as his Majesty orders him [not to], although he shows great feeling, and represents the great expense which he and his relatives and friends, most of whom he is taking with him, have incurred; the troubles which they have experienced in carrying it to that point; the great difficulty of detaining the men when they should learn that he was not to make the expedition; the disturbance that would result to it in its advanced state; the scattering of all the men; and the difficulty that one other than he would have in making it. Finally, he claims to have acquired the right to it by virtue of his contract and to have fulfilled it up to that day. Furthermore he asked that the viceroy should allow him to proceed as far as the last settlement, where the captain of the guard should take the muster, assuring the viceroy that neither he nor anyone with him would enter on the exploration.

The viceroy says this business has had him in a state of the greatest anxiety and perplexity, seeing that the second order of his Majesty was delayed and not knowing what orders it would give for Don Juan de Onate, but that nevertheless he had held it to be right to give him permission to continue the journey-led to this by fear that the men might break away and enter without orders, and by the fact that anyone coming from Spain to make the expedition would experience many difficulties. The Audiencia, with which he consulted on two occasions, did not resolve to make a decision or to make any change in what his Majesty ordered, expecting that instructions would come by the fleet for what was to be done; nevertheless they regret the inconveniences of the disruption of this expedition in the state in which it was, and the impossibility of holding the men and equipment which Don Juan has collected, no matter what effort he may make for it, or what assistance he may have from the viceroy. $\mathrm{He}$ [the viceroy] had again sent to notify him [Oñate] by another auto, in confirmation of the first, that he should obey the orders which had been given him, to which he was awaiting a reply, but that he was certain that Don Juan would not go or permit any one to go contrary to the order, although in a man of fewer obligations and pledges in that land and one of more irritable temper this event might be greatly feared. 
Que asi mismo le tenia con cuidado los gastos que hacen de la Hacienda Real el dicho Capitan de la guarda y sus oficiales y que á el ni á la audiencia les havia parecido mandarle volver, por que no conviniendo tomar la visita y muestra agora por lo referido seria forzoso volver allá despues en caso que se manda se á Don Joan proseguir la Jornada, y lo mas principal por que en biendo Partir al dicho capitan de la guarda se desengañaria la gente y se desbarataria todo.

Y embia el dicho Virrey demas de lo sobredicho un papel de advertencias de lo que á el y á la audiencia y á otras personas ha parecido acerca deste negocio para que se consideren en caso que se haga tomado o tome asiento con Don Pedro Ponce sobre esta jornada, y en instancia ${ }^{q}$ contiene.

Lo que se agraviaria Don Joan de Oñate de no se cumplir lo assentado y capitulado con el en conformidad de las ordenanzas y orden particular de su Magestad que tubo Don Luis de Velasco sin haber avido falta de su parte.

Que si se ha hecho la jornada en conciencia y justicia podra pretender el interese de los gastos que ha hecho y su Magestad será convencido á pagarlo de su hacienda.

La descomodidad que será para muchos de deudos y amigos de Don Joan que llevava consigo que habran gastado sus haciendas y otros que le havian socorrido con ellas.

Los inconvenientes que se siguirán de deramarse la gente y los insultos que aran, siendo peores los que antes eran destraydos.

Que en el puesto donde la gente se halla la que volviese sin orden y en quadrillas á de pasar por toda la tierra de chichimecos-y se fue de temer que siendo como son muchos de ellos delinquentes se queden en los montes foragidos y salteadores y inciten á los Indios ó les hagan malos tratamientos que turben la paz que está tan reciente.

Que se puede temer que se entre alguna gente la tierra á dentro sin orden maltratando á los Indios y desacreditando la religión y nuestra nación ó que se junten con el capitan Leyba que anda allá y resisten despues alguna que entrare.

Que las molestias que la tierra ha recivido con la leba y conducion de aquella gente se volverais á sentir mucho segunda vez.

Que se desacreditara la jornada y no havrá gente de aquella tierra que se quiera encargar de hacer otra ni quien los siga.

La dificultad grande que abria en bolver á recoger la massa que Don Joan tiene Junta y el tiempo que será menester y lo mucho que costará.

Que se dubda mucho que la persona que fuese de España sin tener hacienda en áquella tierra ó ser enparentado en ella con persona que la tengan pueda recoger á fuerza de dineros aunque sea con gran suma de ellos la gente-y lo demas necesario.

Que es de gran inconveniente que el que oviese de hazer esta jornada no sea persona de mucha notizia en el trato de los Indios y parece dificultoso que persona que vaya de acá aunque haya estado allá sea tan inteligente como quien ració y se ha criado en aquella tierra.

q Evidently a miscopy for "substancia". 
He says also that the inspection and muster which was to have been made by the captain of the guard after passing the last settlements was not made, and it was the opinion of the Audiencia that it should not be made if it should be learned that Don Juan had sufficient funds to carry out his agreement, so that he should not acquire the right to the recompense which he might ask for, but that if Don Juan demanded it, under protest that he would otherwise do it himself before a clerk, the said captain of the guard should do it, in order not to give opportunity for any deceit and fraud.

$\mathrm{He}$ says also that he regarded with anxiety the expenses which are being caused to the real hacienda by the said captain of the guard and his officials, but that it was not the opinion of either himself or the Audiencia that he should be ordered to return, for, as it is not advisable to take the inspection and muster now, for the aforesaid reasons, it would be necessary to send him back there in case it is ordered that Don Juan shall continue the journey, and especially since the men, in case they should see the said captain of the guard depart, would learn the truth and everything would be broken up.

The said viceroy also sent, besides the aforesaid, a paper of notes on the opinions of himself, the Audiencia, and other persons in regard to this business, so that they may be considered in case an agreement has been or shall be made with Don Pedro Ponce for this expedition. The substance of it is as follows:

The injury to Don Juan de Oñate if the contract and agreement made with him by Don Luís de Velasco, in accordance with the ordinances and the special order of his Majesty, should fail of fulfillment, without there having been any fault on his part.

If the expedition has been made, by right and justice he can claim the interest on the expenses which he has incurred and his Majesty will be compelled to pay it from his hacienda.

The inconvenience which it will be for many of the relatives and friends of Don Juan whom he was taking with him and who must have spent their fortunes, and for others who had helped him with theirs.

The disturbances that will follow from the scattering of the men and the outrages that will result, those who were previously dissolute becoming worse.

That from the place where the men now are they will have to return, in disorderly bands, through the whole country of the Chichimecos, and it is to be feared that since many of them are criminals, they will remain in the woods as robbers and highwaymen, and will incite the Indians to do the same, or ill-treat them and disturb the peace so recently concluded.

It is to be feared that some of the men will enter the country without orders and ill-treat the Indians and discredit the religion and our nation, or that they will join Captain Leyba, who is wandering about there, and will afterwards resist anyone who may enter.

The annoyances which the country has had with the recruiting and conduction of those men would be felt still more if done a second time.

That the expedition will be discredited and there will be no men in that country who will be willing to take charge of another nor any to follow them. 
Que la persona que fuese de España por muy principal que sea no puede llevar consigo tantos deudos cercanos parientes y amigos de quien fiarse como es menester para ser temido de la demas gente, que la mas que va á estas jornadas es libre y ocasionada para intentar atrebimiento.

Que por la mayor parte nunca se han tenido buenos subcesos en las jornadas que se han ido á hacer de España y por el contrario las que de allá sean hecho.

Carta del Gobernador y Capitan General de la Nueva Mexico, Don Juan de Oñate al Rey. ${ }^{r}$ [Río de las Conchas, I5 de Marzo de I598.]

Al Rey muestro señor, en sus Reales manos.

Señor: Las dificultades que se an puesto a la Jornada de las provincias del nuevo Mexico que esta a mi cargo por abiento que conmigo Tomo El Virey Don Luys de Velasco an sido tan grandes que se pueden Juzgar a milagro averlas podido compadescer e dado quenta de ellas a Vuestra magestad habiendo Relacion de los daños que con la detencion se me an causado $\mathrm{Y}$ de las perdidas que de ella se an seguido $\mathrm{Y}$ de lo mucho que me questa y e sufrido por no desistir del yntento con que mi dispuse a hazerla en Vuestro Servicio Y como si esto si viera alguna deformidad, o se pudiera Reputar por noscibo, tuve contradiciones y opposiciones yndignas de pechos christianos y tan poderossas que si la obediencia que guarde tan puntualmente faltara en algo bastara para destruir todo Lo echo $\mathrm{Y}$ ponerme en aprieto pues esta Claro que no hallando en que fundar los agravios que $\mathrm{He}$ Recevido se an multiplicado hasta que arrastrando sali con el campo a los ciete de Hebrero deste año llevando ochenta carretas y carros aderesçados y el avio y sustento nescessario fiado de la mysericordia de Dios que ayudando mi buen yntento e de conseguir el fin de la Jornada con augmento de la santa Fee chatolica y acresçentamiento de Vuestra Real Persona y rreparando en poco de lo mucho que he trabajado resistiendo la fuerça con que El Conde de Monterrey me a apretado y persuadido a no yr adelante no sabre dezir el yntento mismo salvar Lo

r A. G. I., Patronato, I-I-3/22 (legajo Simancas-Descubrimientos, etc.). 
There would be great difficulty in collecting another mass of supplies such as Don Juan has gathered, not to mention the time that it would require, and the large amount that it would cost.

That it is very doubtful whether any person coming from Spain, without property in that land or relationship to anyone that might have it, could collect by means of money, even though it should be a large sum, the men and other things necessary.

That it is a great drawback if the one who goes to make this expedition is not a person of great experience in dealing with the Indians, and it seems unlikely that a person going from here, even though he may have been there, can be as well-informed as one who was born and reared in that country.

That the person who goes from Spain, no matter how important a man he may be, cannot take with him as many near relatives and friends, upon whom he can depend, as are necessary to make the rest fear him, for the most of the men who go on these expeditions are bold and insolent enough to attempt audacities.

That for the most part the expeditions which have been made from Spain have never been successful, while the contrary is the case with those which have been made from there [Mexico].

\section{Letter from the governor and captain-general of New Mexico, Don Juan} de Oñate, to the king. [Rio de las Conchas, March I5, I598.]

\section{To our lord, the king, in his royal hands.}

Sir: The difficulties that have been put in the way of the expedition to the provinces of New Mexico, which is in my charge through a contract made with me by Viceroy Don Luís de Velasco, have been so great that it may be regarded as a miracle that it has been possible to adjust them. I gave an account of the expedition to your Majesty, making a statement of the damage caused me by the detention, and the losses which have followed from it, and how much it is costing me, and what I have suffered for not giving up my resolution to make it in your service. Also [I gave an account of] how, as though it were some wrongful act or might be esteemed as mischievous, I met with contradictions and oppositions unworthy of Christian breasts, threatening that if the obedience which I so punctiliously gave should fail in the smallest particular it would be sufficient to destroy all that had been done and put me in trouble. It is the truth, although nothing was found upon which to base the injuries which I have received, that they went on multiplying until, with the camp, I started very slowly on February 7 of this year, taking eighty carts and wagons loaded with the necessary stores and provisions, trusting that by the compassionate assistance of God in my good intent I shall accomplish the purpose of the expedition, to the increase of the holy Catholic faith and the advantage of your royal person. Dwelling little upon the great trouble which I have had in resisting the violent efforts of the Count of Monterey to dissuade me from going on, I do not know how to say that 
sino que voy caminando $\mathrm{Y}$ aun pienso que no se an acavado Los estropieços Me ponia a catorze del mismo mes embie a Vicente de saldivar sarjento mayor del campo a descubrir camino nuevo con diez y seis hombres desde el Rio de conchas con una guia que perdio el Camino y tino sin envargo desto passe ${ }^{\mathrm{s}}$ adelante y llegue ${ }^{\mathrm{t}}$ al pueblo rancherial de yndios de quienes fue bien recevido aunque unas e hasta sinquenta de ellos se pusieron en arma y le resistieron sin que aprovechase la garisia que se les mostrava y les obligaron a Representarles Rigor con que dieron lugar a passar de ally. Llego a los veynte y ocho del mismo mes al Rio que llaman del norte y hasta $\mathrm{I} 6$ o 20 leguas de las poblaçiones primeras del nuevo mexico de donde se volvio reconosçiendo el camino y Juzgando ser mui bueno y de vastantes aguajes y con certinidad se que se ahorraran sesenta leguas del que hasta aqui se savia y se salva el parage del llegar a los Pataragueyes yndios de guerra dejandole quarenta leguas a un lado, a la mano derecha; con este principio faborable prosigo La Jornada y hasta morir hare el dever sirviendo a Vuestra Magestad continuandola hasta alcançar el fin de ella y como para començar la tenia cerrada la puerta y al Virrey por contrario no hallava cossa que no fuese estorbo y temiendo esto me contento por ahora con que esta carta y el duplicado de la que tengo escripta a Vuestra magestad llegue a sus Reales manos sin osar embiar Le Razon de la poca que me hizo el que segunda vez me tomo La Muestra con gana de que alcansado de quenta me quedase. Suplico a Vuestra Magestad que asetando mi sufrimiento por meritorio se sirva de mandar Lo capitulado conmigo por el Virrey don Luys de Velasco se guarde y que la merced que meresco y se devea quien como yo a sufrido con paçiençia una lluvia de vexaçiones se me haga con ventajas en encomienda de mis trabajos que espero en dios sera de grande efecto el que voy siguiendo de que dare quenta a Vuestra magestad en llegando al nuevo mexico y prometiendome el premio del de mano de Vuestra magestad cuya Vida guarde nuestro señor con augmento de grandes Reynos en esta parte como Lo desseamos Los leales Vassallos de Vuestra Magestad del Rio de las conchas a I 5 de março de 1598 años.

Don Juan de oñate.

Don Juan de oñate. Titulo de adelantado de las provincias del nuevo Mexico para don Juan de oñate governador $Y$ capitan general dellas. ${ }^{.}$ [Villalpando, 7 de Febrero de I602.]

Don Phelipe ... por quanto por parte de Vos don Juan de oñate governador y capitan general de la provincia del nuevo mexico que es en

"Evidently a miscopy for "passo".

tEvidently a miscopy for "llego".

u F. R. B., Sevilla, May I9, I9I4.

v A. G. I., Indif. Gen., I39-I-2. 
the project itself can be saved unless I go on, even though I believe that he has not ceased putting stumbling-blocks in my way.

On the fourteenth of the same month I sent Vicente de Zaldivar, sargento mayor of the camp, with sixteen men, to search out a new road from the Río de Conchas with a guide, who lost the road and direction. Notwithstanding this, he went on and arrived at the village of the Indians, by whom he was well received, although some, as many as fifty, of them took up arms and resisted him, without appreciating the kindness which he showed them, and compelled him to treat them with severity, after which they permitted him to pass from there. On the twenty-eighth of the same month he reached the river called E1 Norte, sixteen or twenty leagues from the first settlements of New Mexico. From there he returned, examining the road and judging it to be very good, with plenty of springs of water, well placed for its conservation, for sixty leagues from there to here. He heard of and avoided the village of the hostile Pataragueyes Indians, leaving it forty leagues to one side, on the right hand.

With this favorable beginning I am continuing the expedition and shall go on with it until its purpose is accomplished, and, until I die, I shall do my duty in serving your Majesty. Since at the beginning the door to it was closed and the viceroy was in opposition and I encountered nothing but obstacles, fearing this now, I shall be content if this letter and the duplicate of the one which I have already written to your Majesty reach your royal hands, without daring to send an explanation of the small credit that was given me by the one who took the muster from me the second time, with the desire of making me appear impecunious. I pray your Majesty, in the belief that my suffering deserves reward, to deign to order that the agreement made with me by Viceroy Don Luís de Velasco be kept, and that the favor that I deserve and that is due to one who has endured with patience, as I have, a flood of vexations, be granted me, with rewards in return for my labors, for I hope in God that the one I am now following will have great results. Of this I will give an account to your Majesty when I reach New Mexico, and I promise myself the reward for it from the hand of your Majesty, whose life may our Lord guard, with increase of great kingdoms in this part, as we, loyal subjects of your Majesty, desire. At the Río de las Conchas, March I 5, I 598.

Don Juan DE OÑate.

Don Juan de Oñate. Title of adelantado of the provinces of New Mexico for Don Juan de Oñate, governor and captain-general of them. [Villalpando, February 7, 1602.]

Don Felipe ... Inasmuch as upon your part, Don Juan de Oñate, governor and captain-general of the province of New Mexico, which is in New Spain, the statement has been made to me that by one of the articles of the contract which was made with you by my orders in regard to the exploration, pacification, and settlement of the said provinces, Don Luís de Velasco being my viceroy of New Spain, it was promised you that you 
la nueva españa se me ha hecho relacion que por Uno de los capitulos del asiento que por mi mandado tome con Vos sobre el descubrimiento pacificacion y poblacion de las dichas provincias don luys de Velasco siendo mi Virey de la dicha nueva españa os ofrecio que se os darra titulo de adelantado de las dichas provincias por Vuestra Vida y de Un Hijo o Heredero, para qual Vos nombraredes en conformidad de lo contenido en Un capitulo de la ynstrucion de nuevos descubrimientos y poblaciones de las Yndias y Haviendoseme supplicado por Vuestra parte que atento a los gastos que haveys hecho en el Viaje y travajos que haveis padecido Lo mandase aprovar Haviendoseme consultado Lo He tenido por Vien y por la presente es mi merced y Voluntad que agora y de aqui adelante por todos los dias de Vuestra Vida serais mi adelantado de las dichas provincias de la nueva mexico $\mathrm{Y}$ de los pueblos que en ellas se poblaren y despues de Vos el dicho Vuestro hijo o heredero o persona que nombreredes. Y que como tal podais husar y huseis el dicho cargo en todos los casos y cosas a el anexas y convenientes segun y como Lo Husan Los mis adelantados de los mis reynos de castilla y de las dichas yndias y que cerca del Huso y exercicio del dicho cargo y en el llevar de los derechos a el pertenecientes guardeis y serais obligado Vos y el dicho Vuestro hijo o heredero o persona que nombraredes a guardar las leyes y pregmaticas de estos mis reynos que cerca dello disponen y que podais gosar $\mathrm{Y}$ goçeis y Vos sean guardadas todas las onrras gracias mercedes franquecas Livertades y exenciones preheminentias prerrogativas e ynmunidades y todas las otras cosas y cada Una dellas que por raçon de ser mi adelantado deveis haver y goçar y Vos deven ser guardadas y aravais y lleveis el salario derechos y otras cosas al dicho cargo de adelantado devidas y pertenecientes y por esta mi carta mando a los consejos Justicias e rregidores cavalleros escuderos officiales y Hombres buenos de todas las ciudades Villas y Lugares de la dicha provincia de la nueva mexico que a Vos y a Vuestro hijo o heredero o persona que os subcediere ayan recivan y tengan por mi adelantado y hucen con Vos y con el el dicho cargo en todos los casos y cosas a el anexas y concernientes y os guarden y hagan guardar todas las onrras gracias mercedes franqueças y Livertades prehiminencias prerogativas e ynmunidades y todas las otras cossas y cada Una dellas que por razon del dicho cargo deveis haver y goçar y os deven ser guardadas y os recudan y hagan recudir ante todos los derechos y salarios a el devidos y pertenecientes de todo Vien y cumplidamente en guisa que Vos no mengue en de cossa alguna segun y conforme y de la manera que se ha gusado y recudido y deve Husar y recudir y guardar a los otros adelantados que an sido y son en estos mis reinos de castilla y en las dichas Indias y que en ello ni en parte dello embargo ni ympedimiento alguno os no pongan ni consientan poner que yo por la presente os recivo y he por recivido al Huso y exercicio del y os doy poder y facultad para la husar y exercer caso que por ellos o por alguno dellos a el no seays recivido dada en Villalpando a siete de hebrero de mill y seiscientos Y dos años yo EL REY yo JUAN DE YBARRA secretario del rey nuestro señor La fue escrivido por su mandamiento el licenciado LAGUNA el doctor ANTONIO GONZALEZ el licenciado PEDRO BRABO DE SOTO 
should be given the title of governor of the said provinces for your life and for that of a son or heir, to which you should be appointed, in conformity with the contents of an article of the instructions for new discoveries and settlements of the Indies,

And, inasmuch as supplication has been made to me upon your part that, in view of the expenses which you have incurred in the journey and the troubles which you have endured, I should order that it be approved, I have decided favorably upon it, after being advised so to do, and by these presents it is my will and pleasure that now and henceforth, for all the days of your life you shall be my governor of the said provinces of New Mexico and of the towns that may be settled in them, and after you your son or heir or any person whom you may name. As such you shall have the power to exercise the said office in all affairs pertaining and belonging to it, according and as it is exercised by my governors of my kingdoms of Castile and of the said Indies.

In the use and exercise of the said office and the practice of the rights pertaining to it, you shall observe, and you and your said son or heir or person whom you may name shall be under obligation to observe, the laws and decrees of these my kingdoms which regulate it. You shall be empowered to enjoy and you shall enjoy and there shall be secured to you all the honors, grants, favors, franchises, privileges and exemptions, preferences, prerogatives, immunities, and all and every one of the other things which by reason of being my governor you have the right to have and enjoy and that ought to be secured to you. You shall have and receive the salary, rights, and other things owing and pertaining to the said office of governor, and, by this, my letter, I command my councillors, justices, regidores, gentlemen, squires, officials, and all good men of all the cities, towns, and villages of the said province of New Mexico, that they shall receive and hold you and your son or heir or person whom you may name as my governor; that they shall exercise the said office with you and with him in all the cases and affairs pertaining and belonging to it, and shall observe and cause to be observed all the honors, grants, favors, franchises, privileges, exemptions, preferences, prerogatives, immunities, and all and every one of the other things that by reason of the said office you have the right to have and enjoy and that ought to be secured to you; and that they shall pay and cause to be paid before everything the rights and salaries due and pertaining to it, in full and complete, with no decrease to you in anything, in accordance with the method which has been practised and in which payments have been made, and as they ought to be practised and made, with the other governors who have been and are in these my kingdoms of Castile and in the Indies. They shall not place or allow to be placed any obstacle or impediment against you in it or any part of it; for I by this writing receive and have received you into the use and exercise of it, and I give you the power and authority to make use of it [this writing] in case that you shall not be received in it [the office] by them or any one of them. Given at Villalpando, February 7, I602. I THE KInG. I, JUAN DE YBARRA, secretary to our lord the king, by whose order it was written. The licentiate LaGuna, Doctor 
MAYOR el doctor EUGENIO DE SALAÇAR el licenciado VILLAGUTIERRE CHUMACEN.

\section{[El Consejo de Indias al presidente de la Casa de Contratación. Valla- dolid, I2 de Junio de I602." ${ }^{w}$ ]}

El maestre de Campo de la Jornada del nuevo mexico bizente de zaldibar a quien don Joan de oñate a Cuyo cargo esta aquel descubrimiento enbio a estos Reynos sobre Cossas de aquella Jornada ha representado La necesidad que ay para proseguir La enpresa de que se enbien de estos Reynos algunos Soldados mosqueteros y oficiales Carpinteros de Rivera para hazer barcos y descubrir puerto en aquellas mares por haver falta dellos en aquella tierra y a supplicado se le de licencia para Levantar y Conducir en sevilla y en san locar asta numero de sesenta personas de este genero y que se le diese enbarcacion por quenta de su magestad y haviendosele Consultado a tenido su magestad por bien de dar Licencia para que se junten conduzgan y lleven en la flota asta quarenta onbres de esta profecion y que Vuestra Magestad ${ }^{x}$ y los Juezes officiales Concierten Los fletes y matalotaje dellos asta desenbarcase en san Joan de Ulua Con Los maestres de los navios de merchante de la dicha flota Para que Los lleven en allas y Lo que esto montare Como no pase de mill y quinientos ducados por Una Vez Conque Su magestad Socorre a don Joan de oñate para este efecto Lo libren en la nueva españa en La hazienda de su magestad en Una de las caxas Reales de la Vera cruz o mexico y tambien ha mandado su magestad que Vuestra merced y los Juezes officiales busquen dos pilotos experimentados y muy Platicos que se piden para la graduacion de los Runbos por donde se caminare en aquel descubrimiento y que los conciertos para que agan este biaje y se le dexaran hazer a costa del dicho don Joan de oñate y asi lo aran y prebenian todo Como Conbenga y por quanto que a su merced so $^{\mathrm{y}}$ tiene por bien su magestad de dar licencia para que se puedan llevar para la dicha jornada Las harinas ${ }^{z}$ Contenidas en La memoria que Va Con esta se las dexaran llevar al dicho maestre de Campo que Conociendolas muy bien y registrandolas y de las que se enbarcaren y llevaren daran memoria al marques montesclaros para que por ella en la nueva españa Las pueda hazer Reconozer y destribuyr Como conviene para La dicha jornada y que no se Conbiertan en otros efectos y al avio y despacho de todo esto daran mucha prisa por La que tiene La partida de la flota y Lo que conviene que Vaya en ella el maestre de Campo y en esta Conformidad se ha enviado afirmar de Su Magestad el dicho despacho y por ganar tienpo ha querido el consejo havisarles por esta de La resolucion que su magestad ha tomado en este de Valladolid a doze de junio de sesenta y dos años Señalada del consejo.

w A. G. I., Indif. Gen., I39-I-2.

x Evidently a miscopy for "merced," which probably refers to the president of the Casa de contratacion.

y Evidently a miscopy for "lo".

z Evidently a miscopy for "armas". 
Antonio González, the licentiate Pedro Bravo de Soto Mayor, Doctor Eugenio de Salazar, the licentiate Villagutierre Chumacen.

\section{[The Council of the Indies to the president of the Casa de Contratacion. Valladolid, June I2, $\left.1602 .{ }^{53}\right]$}

The maestre de campo of the expedition to New Mexico, Vicente de Zaldivar, whom Don Juan de Oñate, in whose charge this exploration is, sent to these kingdoms on business of that expedition, has represented that it is necessary for the prosecution of the undertaking that there be sent from these kingdoms some musketeers, and professional shipbuilders ${ }^{54}$ in order to construct vessels and discover a port in those seas, for there is a lack of such people in that country. Also he has petitioned that he be given permission to raise and recruit in Seville and San Lucar as many as sixty persons of this class, and that embarkation be given him on his Majesty's account. His Majesty, having taken advice with regard to it, has decided to grant him permission to collect, recruit, and take in the fleet as many as forty men of this profession, and that your grace and the official judges shall arrange with the masters of the merchant ships of the said fleet for the supplies and provisions for them until they disembark at San Juan de Ullua. Whatever this amounts to-provided that the aid which his Majesty is giving to Don Juan de Oñate, for this purpose, for this time only, does not come to more than I 500 ducats-shall be paid in New Spain from the funds of his Majesty in one of the royal treasuries of Vera Cruz or Mexico. His Majesty has also ordered that your grace and the official judges shall seek two pilots, experienced and expert, who are required for the mapping of the routes to be traversed in that expedition, and arrange with them to make this voyage, letting them make it at the expense of the said Don Juan de Oñate; this you shall do and arrange for everything, as is proper. And inasmuch as it is the pleasure of his Majesty to grant to his grace permission that they may take on the said journey the arms mentioned in the list that goes with this, you will allow the said maestre de campo to take them, after examining them carefully and making a record of them. For the Marquis of Montesclaros you will give a list of those which they carry on board and take with them, so that by it in New Spain he can inspect and distribute them to the best advantage for the said expedition and see that they are not converted into other merchandise. To the preparation and despatch of all this you will give much haste, because of the early departure of the fleet and the necessity that the maestre de campo shall go in it. In conformity with this the said despatch has been sent to be signed by his Majesty, and in order to save time the Council has resolved to inform you by this writing of the decision which his Majesty has made in this matter. Valladolid, June I2, 1602. Signed by the Council. 
Las harmas que piensa llevar el maestre de Canpo bizente de çaldivar y mendoza para la Jornada de nuevo mexico.

Setenta arcabuzes.

Treynta mosquetes.

Cien Cotas:

Cien escarzelas.

Cinquenta moriones con sus sobrebistas.

Cien espadas y dagas.

Cinquenta queras de anta o cueros para hacerlas.

[Real cédula. Al virrey de la Nueva España. San Lorenzo, 4 de Julio de $\left[602 .{ }^{a}\right]$

E1 Rey.-Por quanto don Luis de Velasco siendo mi virrey de la nueva españa en virtud de Una cedula del Rey mi señor que sea en gloria tomo asiento y capitulacion con Don Juan de oñate sobre el descubrimiento pacificacion y poblacion de Las provincias de La nueva mexico que Es en La nueva españa y por Uno de Los capitulos del Le concede Lo que en el capitulo ciento y quarenta y cinco de las ordenanças de nuevos descubrimientos y Poblaciones de Las yndias que Es del thenor siguiente:-a Los Indios que se reduxeren a nuestra obediencia y se Repartieren se Les persuada que en Reconocimiento del señorio y Juridicion universal que tenemos sobre las yndias nos acudan con tributos en moderada qantidad de los frutos de la tierra segun y como se Dispone En el titulo de los Tributos que de esto trata y Los tributos que assi nos dieren queremos que los lleven Los Españoles a quien se encomendaren por que cumplan con Las cargas a que estan obligados reservando para nos Los pueblos cavezeras y Los puertos de Mar y dellos que se Repartieren La que fuere menester para pagar Los salarios a Los que han de governar la tierra y defenderla y administrar nuestra hazienda y por parte del dicho don Juan de oñate se me ha suplicado que sin envargo de la moderacion que Hizo sobre Ellos el Virey conde de monterey mandasse aprovar Lo que como dicho Es le concedio y haviendoseme consultado he tenido y tengo por bien que despues de Haverme dado Las obediencias Los yndios de Las dichas provincias y persuadidoseles por buenos medios a que me paguen algun tributo como Lo disponen Las dichas ordenanzas de nuevos descubrimientos y poblaciones y biniendo en ello Los dichos yndios de su Voluntad El dicho don Juan de oñate pueda tassar y tasse Los dichos tributos con que no excedan de diez Reales al año cada tributario de Los que Los ovieren de pagar y por la presente mando al dicho don Juan de oñate que assi lo haga y cumpla y que contra esto no Vaya ni passe En manera alguna que assi Es mi voluntad fecha En san Lorenço a quatro de Julio de mill y seyscientos y dos años yo EL REY. etc. 
The arms which the maestre de campo, Vicente de Zaldivar y Mendoza, intends to take for the expedition to New Mexico:

Seventy harquebuses.

Thirty muskets.

One hundred coats of mail.

One hundred cuishes.

Fifty steel helmets with beavers.

One hundred swords and daggers.

Fifty leather jackets or skins for making them.

[Royal cédula. To the viceroy of New Spain. San Lorenzo, July 4, I602.]

The King. Inasmuch as Don Luís de Velasco, being viceroy of New Spain, in virtue of a decree of my lord, the king ${ }^{55}$ - may he be in glorymade a contract and agreement with Don Juan de Oñate in regard to the exploration, pacification, and settlement of the provinces of New Mexico, which is in New Spain, in one of the articles of which he grants him what is contained in article I 45 of the ordinances for new discoveries and settlements of the Indies, the purport of which is as follows: The Indians who may be reduced to our rule and divided among us shall be persuaded, in recognition of the lordship and universal jurisdiction which we have over the Indies, to assist us with tributes in moderate quantity of the fruits of the land, as is provided in the Titulo de Tributos ${ }^{56}$ which treats of this. And we desire that the tributes which they shall thus give us shall be collected by the Spaniards to whom the Indians are allotted, so that they may fulfill the duties with which they are charged, reserving for us the capital cities and the seaports, and from those that are divided the sum that may be necessary to pay the salaries of those who are to govern the country and defend and administer our exchequer.

And inasmuch as on the part of the said Don Juan de Onate petition has been made to me that, notwithstanding the restrictions made in them [the contract and agreement] by the viceroy, Count of Monterey, I should order that what has been granted to him, as has been said, be approved, and having taken advice, I have decided that after the Indians of the said provinces have yielded me their submission and have been persuaded by fair means to pay me some tribute, as is provided for in the said ordinances of new discoveries and settlements, the Indians having agreed to it voluntarily, the said Don Juan de Oñate may levy the said tributes, provided that they do not exceed ten reales a year for each tributary who has to pay them. By the present writing I order the said Don Juan de Oñate to do thus and to take no step whatever against it, for this is my will. Done at San Lorenzo, July 4, I602. I the King. Etc. 


\section{[Real decreto. San Lorenzo, 8 de Julio de I602. $\left.{ }^{\circ}\right]$}

Por quanto Don Luis de Velasco siendo virey y governador y capitan General de La nueva españa en Virtud de Una cedula del Rey mi señor que sea En Gloria tomo asiento y capitulazion con don Joan de oñate sobre El descubrimiento pacificacion y Poblacion de Las provincias del nuevo mexico en la nueva españa y Le concedio Lo contenido en Uno de los capitulos de la ynstruzion de nuevos descubrimientos y poblaciones de la India que es del thenor siguiente.

El y su hijo o heredero subcesor en La governazion sean ynmediatos al consejo de las yndias de manera que ninguno de Los Virreyes ni audienzias comarcanas se puedan entremeter en el distrito de su Provincia de offizio ni a pedimiento de parte ni por Via de apelacion ni proveer Jueces de comycion el que de las Indias pueda conozer de las caussas de governacion de officio o a pedimento de Parte o por Via de apelacion y en casso de Justicia entre partes conozca por Via de apelazion de las caussas ceviles de seys mill ducados arriva y en caussas criminales delas sentencias en que se pusiere pena de muerte o mutilacion de miembro y por parte del dicho Don Juan se me ha supplicado Lo mandasse aprobar sin envargo de La Moderacion que El conde de Monterrey hizo cerca dellos y haviendose Visto todo En mi consejo de las Indias y consultadoseme he tenido por bien de mandar dar esta mi cedula por La qual mando que sin envargo de La moderacion que $\mathrm{El}$ dicho conde hizo se guarde cumpla y execute Lo que $\mathrm{El}$ dicho don Luis de Velasco concedio al dicho don Joan de oñate en Virtud y conforme a la dicha ordenanza suso incorporada con que en Lo que tocare al govierno y Justicia Los que quisieren apelar a la mi audiencia Real de La nueva Galizia que es La mas cercana a Las dichas provincias del nuevo mexico Lo puedan hazer y alli conoscirse de sus caussas y mando al mi Virrey de La nueva españa y a las audiencias de mexico y nueva Galizia y otras qualesquier mis Justicias y Juezes que guarden y cumplan y hagan guardar y cumplir esta mi cedula y lo en ella contenido y que contra Ello no se vaya ni passe En manera alguna fecha en san Lorenzo a ocho de Julio de mill y seyscientos y dos años Yo EL REY etc.

[El Consejo de las Indias al Rey. Valladolid, I9 de Mayo de 1603.']

Don Alonso Oñate Hermano de don Juan de oñate ha hecho relacion en este Consejo que el maestre de campo Vicente de çaldivar no pudo llevar en la flota que Ultimamente partio para la nueva españa Los quarenta onbres mosqueteros y Carpinteros de Rivera y dos pilotos exsaminados que se le Conscedieron para La jornada del nuevo mexico por la brevedad Con que partio La flota y que esta gente haze mucha falta para la dicha

b A. G. I., Indif. Gen., I39-I-2.

- A. G. I., Indif. Gen., I39-I-2. 
[Royal decree. San Lorenzo, July 8, I602.]

Inasmuch as Don Luís de Velasco, then viceroy, governor and captaingeneral of New Spain, in virtue of a decree of my lord the king-may he be in glory-made a contract and agreement with Don Juan de Onate in regard to the exploration, pacification, and settlement of the provinces of New Mexico in New Spain, and granted to him that which is contained in one of the articles of the instructions for new discoveries and settlements of the Indies, of which the purport is as follows:

$\mathrm{He}$ and his son or heir succeeding to the government shall deal directly with the Council of the Indies in such a manner that none of the viceroys or neighboring audiencias shall have the power to interfere in the administration of his province either officially, or on petition of a litigant, or by writ of appeal; nor to provide commissioned judges. [The Council of the Indies] shall have the power to try government cases officially, or on petition of the litigant, or by writ of appeal. In case of a trial between litigants, it shall try by writ of appeal civil causes of six thousand ducats upwards and criminal cases in which the sentences impose pain of death or mutilation of members.

And inasmuch as petition has been made on the part of the said Don Juan that I order it [the contract and agreement] to be approved, notwithstanding the change made in it by the Count of Monterey, and the whole matter having been considered in my Council of the Indies and their opinion given to me, I have decided to order this, my decree to be issued, by which I command that, notwithstanding the alteration made by the said count, what the said Don Luís de Velasco granted to the said Don Juan de Oñate, in virtue of and in conformity with the said ordinance above incorporated, shall be kept, fulfilled, and carried out, with the proviso that in matters of government and justice those who may wish to appeal to my royal Audiencia of Nueva Galicia, which is the nearest to the said provinces of New Mexico, may do so, and may have their cases tried there. I command my viceroy of New Spain and the audiencias of Mexico and Nueva Galicia and all of my other justices and judges to keep and fulfill and cause to be kept and fulfilled this my decree and what is contained in it, and to take no step whatever against it. Done at San Lorenzo, July 8, I602. I the King. Etc.

\section{[The Council of the Indies to the king. Valladolid, May I9, I603.]}

Don Alonso de Oñate, brother of Don Juan de Oñate, has reported to this Council that the maestre de campo, Vicente de Zaldivar, could not take in the fleet that lately left for New Spain the forty men ${ }^{57}$-musketeers and ship-builders-and the two qualified pilots who were granted to him for the expedition to New Mexico, because of the early departure of the fleet, and because there is a great scarcity of this class of people for the said expedition, which he wishes to begin as soon as possible. For this reason he has petitioned that the warrant be held good that was given 


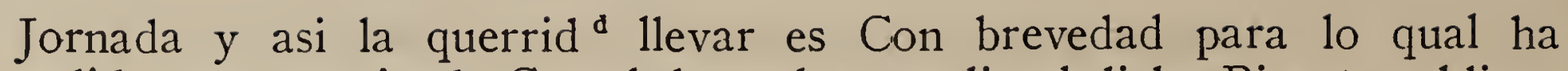
pedido que se entienda Con el despacho que dio al dicho Bicente zaldivar para levantar y llevar La dicha gente y el socorro que se mando hazer de mill y quinientos ducados por sasu ${ }^{\circ}$ matalotaje librados en la caxa de la nueva Vera cruz y que se le de licencia para llevar La dicha gente Sin esperar flota y Como quiera que se le ha concedido a Vicente de çaldivar para esto desea saver el consejo Lo que Se podra hazer en lo que toca a dar envarcacion desta gente y en que forma y tiempo Se podra hazer ynterna $^{\mathrm{f}}$ algun ynconviniente qualquiera $\mathrm{y}$ porque caussa Se encarga a Vuestra Magestad y los Juezes officiales que haviendo mirado y discutido Sobre ello avisen de lo que se les offresciere Con Su parescer y intervencion de prior y Consules de la Universidad de los mercaderes de Valladolid a diez y nueve de mayo de mill y seiscientos y tres años Señalada del consejo.

[Real cédula. Al presidente de la Casa de contratación. Burgos, 23 de Junio de $\left.1603 .{ }^{\circ}\right]$

E1 Rey.-Mi Presidente y Juezes oficiales de la casa de la contratacion de Sevilla Vizente de çaldivar maestre de canpo de la Jornada del nuevo mexico en nombre de don Joan de oñate a cuyo cargo esta aquel descubrimiento me ha Representado La necesidad que ay para proseguirlo de llevar destos Reinos algunos soldados mosqueteros y officiales Carpinteros de rivera Para hacer barcos y descubrir puertos en aquellas mares porque desta gente ay alla mucha falta y haviendome suplicado Lo mandase dar Licencia para Levantar cierto numero della y que Le mandase dar envarçacion en la flota que sea presta para aquella tierra Por lo mucho que ymporta ayudar a favorezer aquella Jornada para que della Resulten Los buenos efectos que se Pretenden en servicio de dios nuestro señor y Reduçion de aquellos naturales yndios a nuestra santa fe catolica $\mathrm{He}$ tenido por Vien de dar Licencia Para que el dicho maestre de campo Pueda juntar y llevar destos Reynos en la dicha flota asta quarenta hombres de la dicha profesion mosqueteros y officiales de Rivera y assi os mando que haviendolos buscado y juntado el dicho maestre de campo conzerteys Los fletes y matalotajes dellos asta desenvarcarse en Santo Juan de Ulua con los maestres de Las navios de merchante de la dicha flota Para que los lleve en ellas y lo que esto montare como no pase de mil y quinientos ducados que Valen quinientos y sesenta y doze ${ }^{\mathrm{h}}$ mil y quinientos maravedis con que tengo por Vien de socorrer al dicho don Joan de oñate Por esta Vez y Para el dicho efecto Librareys a los dichos maestres o dueños de los dichos navios con quien hizieredes Los conciertos en Una de mis caxas Reales de la Vera cruz o mexico que por la presente o su Traslado signado

\footnotetext{
d Evidently a miscopy for "quiere".

" "Por sasu" is evidently a miscopy for "para su".

IEvidently a miscopy for " sin tener".

g A. G. I., Indif. Gen., I39-I-2.

h A miscopy for "dos".
} 
to the said Vicente Zaldivar to raise and take the said people, and for the aid that was ordered of 1500 ducats for their stores to be paid from the treasury of Vera Cruz, and for the permission to take the said people without waiting for the fleet-everything, in fact, that had been granted to Vicente de Zaldivar for this purpose. The Council desires to know what can be done in the matter of giving passage to these people, and in what way and at what time it can be done without causing any trouble. For this reason your Majesty and the official judges are requested, after you have looked into the matter and discussed it, to state what you suggest, with the opinion and mediation of the prior and consuls of the Institute of Merchants [universidad de los mercaderes]. ${ }^{58}$ Valladolid, May 19, I603. Signed by the Council.

[Royal cédula. To the president of the Casa de Contratacion. Burgos, June 23, I603.]

The King. My president and official judges of the Casa de Contratación of Seville: Vicente de Zaldivar, maestre de campo of the expedition to New Mexico, has represented to me in the name of Don Juan de Oñate, in whose charge this expedition is, that it is necessary for the prosecution of the undertaking to take from these kingdoms some soldiers ${ }^{59}$-musketeers and professional ship-builders-in order to build boats and discover ports in those seas, for there is a great lack there of people of this class. Having been petitioned by him for permission to raise a certain number of them and to take passage on the fleet that will soon be ready to sail for that country, because of the great importance of aiding that expedition so that there may result from it the good effects hoped for in the service of our Lord God and the reduction of the native Indians to our holy Catholic faith, I have determined to give permission to the said maestre de campo to collect and take from these kingdoms in the said fleet as many as forty ${ }^{60}$ professional musketeers and ship-carpenters. I also order you, after the said maestre de campo has sought and collected them, to make arrangements for their supplies and provisions until they disembark at San Juan de Ullua with the masters of the merchant ships of the said fleet; whatever this amounts to, provided that it does not go beyond ${ }_{500}$ ducats-which come to 562,500 maravedis ${ }^{61}$-with which $I$ have resolved to aid the said Don Juan de Oñate for this time only and for this purpose, you will pay to the said masters or the owners of the said ships with whom you make the agreement, from one of my royal treasuries of Vera Cruz or Mexico, and by this writing or a signed copy of it I order my officials of any of the said treasuries to pay from any of my funds which you allow them, up to the said quantity for this purpose.

And since there have also been asked for on the part of the said Don Juan de Onate two pilots for the mapping of the roads which will be traversed in that exploration, it is necessary that you look for them and that they shall be qualified and experienced. You will make arrangements 
mando a mis officiales de qualquiera de las dichas caxas Paguen de qualquier hacienda mia Lo que en ellos Libraredes esta en la dicha Cantidad Para este efecto.

Y Porque asimismo se han pedido Por Parte de dicho don Joan de oñate dos pilotos Para La graduacion de Los Rumbos Por donde se caminare en aquel descubrimiento Conviene que Los busqueis que sean muy platicos y esperimentados y Los conzerteys y trateys con ellos que hagan este viage y se le dexareys hazer yendo a costa del dicho don Joan de oñate y tanvien dexareys llevar al dicho maestre de campo Las armas contenidas en la memoria que $\mathrm{Va}$ Con esta que se han pedido para la dicha Jornada Las quales Reconozerays muy bien y Las Registrareys y De las que se llevaren y envarcaren dareys memoria al marques de montesclaros Para que en la nueva españa Las pueda hazer reconozer y distribuir como Le paresciere que conviene Para la dicha Jornada y que no se conviertan en otros efectos y todo esto Preverneys con mucho cuidado para puedays en la dicha flota de Burgos a Veinte y tres de Junio de mill y seiscientos y tres años yo EL REY Refrendada de JUAN DE YBARRA señalada del Consejo.

[Real cédula. A los oficiales, de la Casa de Contratación. Valladolid, 8 de Septiembre de I603.] ${ }^{i}$

E1 Rey.-Mis presidentes officiales de la cassa de la contratacion de sevilla Como saveis Por Una cedula mia fecha de Veynte y tres de Julio deste año di Licencia a Vicente de Çaldivar maestre de campo de la jornada del nuevo mexico que esta a cargo de don Joan de oñate para que pudiese Juntar y llevar de estos Reynos para la dicha Jornada en la flota a que Ultimamente partio para la nueva españa asta quarenta onbres mosqueteros y officiales carpinteros de Rivera Concertando Vos otros el flete matalotaje dellos y librando para ello mill y quinientos ducados en mi caxa Real de La vera cruz Con que tube por Vien de socorrerle para el dicho efecto $\mathrm{Y}$ que tanbien pudiese llevar dos pilotos y las armas contenidas en una memoria que se os enbio como mas Largamente se contiene en la dicha cedula que es del thenor siguiente :- ... fecha en Valladolid a ocho de septiembre de mill y seiscientos y tres años YO EL REY etc.

[Real cédula. Al virrey de la Nueva España. Valencia, 2 I de Enero de $\left.1604 .^{3}\right]$

E1 Rey.-Marques de Montesclaros, pariente y mi Virey governador y capitan general de la nueva españa.-a Don Alonso de oñate Hermano

1 A. G. I., Indif. Gen., I39-I-2.

I A. G. I., Indif. Gen., I39-I-2. 
with them to make this voyage and let them make it at the expense of the said Don Juan de Oñate. You will also permit the said maestre de campo to take the arms mentioned in the list that goes with this and which have been asked for the said expedition. You will examine them very carefully and make a record of them; of those that are carried on board and taken away you will give a list to the Marquis of Montesclaros, so that in New Spain he can examine and distribute them as seems best to him for the said expedition and see that they are not converted into other merchandise. You will watch over all this as carefully as you can in connection with the said fleet. Burgos, June 23, I603. I THE KING. Countersigned by Juan de Ybarra. Signed by the Council.

[Royal cédula. To the officials of the Casa de Contratacion. Valladolid, September 8, I603.]

The King. My official judges of the Casa de la Contratación of Seville : As you learned by a decree of mine dated on July $23{ }^{62}$ of this year, I gave permission to Vicente de Zaldivar, maestre de campo of the expedition to New Mexico which is in charge of Don Juan de Oñate, to collect and take from these kingdoms for the said expedition in the fleet that lately left for New Spain up to the number of forty men ${ }^{63}$-musketeers and professional ship-builders-you to make arrangements for their baggage and stores and pay for them I 500 ducats from my royal treasury in Vera Cruz, with which sum I determined to aid him for the said purpose. Also [I gave him permission] to take two pilots and the arms mentioned in a list which was sent to you, as is stated more at length in the said decree, which is of the following purport: .... Done at Valladolid, September 8, I603. I the King. Etc.

[Royal cédula. To the viceroy of New Spain. Valencia, Jamuary 2I, I604.]

The King. Marquis of Montesclaros, my relative, viceroy, governor and captain-general of New Spain: To Don Alonso de Oñate, brother of Don Juan de Oñate, in whose charge the expedition to New Mexico is, I have granted permission to take in an independent ship ${ }^{64}$ to that country forty men ${ }^{65}$ - musketeers, professional ship-builders-and two pilots, who 
de don Joan de oñate a cuyo cargo esta La Jornada del nuevo mexico he concedido Licencia para que en un navio suelto pueda llevar a esa tierra quarenta Honbres mosqueteros officiales de rivera y dos pilotos que se an pedido para la dicha Jornada del nuevo mexico y algunas armas de que me ha parecido avisaros para que sin embargo de todo esto guardeis y Cumplais lo que os ordene y mande por cedula mia fecha a veynte y seys de Mayo del año pasado de seiscientos y tres que se os entrego antes de vuestra partida en que se os remitio La de Liveracion y execucion de la dicha Jornada del nuevo mexico para que entendido el estado que tenia y lo que oviese resultado de la aberiguacion de las Culpas de don Joan de oñate proveyeredes lo que os pareciese convenir para que tuviesce el efecto que se pretende aquel descubrimiento disponiendolo como mas convviniese al servicio de dios y mio y asilo haceis avisando me de lo que en todo se hiço de Valencia a XXI de enero de I604 Yo EL REY etc.

\section{[Instrucción del Consejo. Valladolid, 23 de Febrero de I604. ${ }^{k}$ ]}

Por Parte de Don alonso de oñate se ha hecho Relacion en el consejo que entre los soldados mosqueteros y Carpinteros de Rivera que tiene alistados para llevar a la nueva españa para la Jornada del nuevo mexico ay algunos cassados con mujeres y hijos y Particularmente Lo son Los Carpinteros de Rivera y que convernia que los que fueren cassados llevassen a sus mujeres y hijos para poblar alla y ha supplicado se de lizencia Para ello y al consejo $\mathrm{Ha}$ parescido que a los de los dichos soldados y officiales de Rivera Fuessen Cassados se Les podra Permitir que lleven Consigo a sus mujeres y hijos y assi Lo aran averiguando que Lo son y no Los dejaran yr sin ellas satisfaciendose Tanbien de que no es gente de la prohivida A passar a las yndias de Valladolid a Veynte y tres de febrero de mil y seiscientos y quatro años señalada del consejo.

\section{[Decreto del Consejo. Valladolid, I9 de Julio de $1604 .{ }^{l}$ ]}

Por parte de don Alonso de oñate se ha hecho relacion en el consejo que haviendo acudido a tratar del despacho del navio en que ha de llevar a la nueva españa los quarenta Hombres mosqueteros y officiales de rivera y dos pilotos para la Jornada del nuevo mexico por no se le permitir que vayan en el ningunas mercaderias no halla ningun maestre ni dueno de navio que le quiera llevar vacio si no es que el le pague el avio lo qual no podia hacer por ser tan grande la costa y ha suplicado se le de licencia para que en El dicho navio se puedan cargar algunas mercaderias o frutos de la tierra pues se han de pagar . . . . de almojari-

k A. G. I., Indif. Gen., I39-I-2.

1 A. G. I., Indif. Gen., I39-I-2. 
have been asked for the said expedition to New Mexico, and some arms. It has seemed proper that I should inform you of it, and that, notwithstanding all this, you shall observe and carry out what I ordered you in my decree done on May 26 of the past year of 1603 , which was delivered to you before your departure, and in which you were given authority for the liberation and execution of the said expedition to New Mexico, so that, after informing yourself of the state in which it was and what might have resulted from the investigation into the faults of Don Juan de Onate, you might take such steps as would appear right to you in order that the purpose which is sought in that expedition may be accomplished, arranging it to the best advantage of the service of God and mine. You will do thus and inform me of everything that was done. Valencia, January 2 I, I604. I the KING. Etc.

\section{[Instruction of the Council. Valladolid, February 23, 1604.]}

On the part of Don Alonso de Oñate it has been reported to the Council that among the soldiers ${ }^{66}$-musketeers and ship-builders-whom he has enlisted to go to New Spain for the expedition to New Mexico, there are some married men with wives and children, especially among the shipbuilders, and that it was desirable that those who were married should take their wives and children, in order to settle there. He has petitioned that permission be given for it, and it is the opinion of the Council that the married men among the said soldiers and ship-builders should be permitted to take their wives and children with them, and you will do thus, after ascertaining that they are such, and will not permit them to go without them, making certain also that they do not belong to the class of people who are prohibited from going to the Indies. Valladolid, February 23,1604 . Signed by the Council.

\section{[Decree of the Council. Valladolid, July I9, I604.]}

On the part of Don Alonso de Oñate report has been made to the Council that, after he has hastened here to make arrangements for the despatch of the ship which was to carry to New Spain the forty men ${ }^{67}$-musketeers and professional ship-builders-and two pilots, for the expedition to New Mexico, because it is not permitted that any merchandise shall go in it he cannot find any master or owner of a ship who is willing to take it empty, unless he pays for the provisioning, which he cannot do because the cost is so great. Accordingly he has petitioned that he be given permission for the said ship to carry some merchandise or products of the country, for they must pay . . excise tax and duties that are due in the Indies. It has been decided to arrange for your Majesty and the official judges, as it appears that there is no difficulty of any consequence in the 
fazgo y derechos que se devan en las yndias y ha parecido ordenar a vuestra magestad y los Jueces officiales como se hace que no haviendo ynconviniente de Consideracion den permision al dicho don Alonso de oñate para que en el navio en que ha de llevar la dicha gente se puedan Cargar y llevar hasta quarenta o cinquenta toneladas de frutos de la tierra o las que menos sea posible para que se pueda despachar y hacer su viaje de Valladolid a I9 de Julio de I604 señalada del consejo.

Al marques de montesclaros que haga cesar y que no pase adelante el descubrimiento del nuevo mexico y que ynvie a llamar y le detenga en Mexico a don joan de oñate que por via de asiento se encargo del dicho descubrimiento y que haviendo hecho desbaratar toda la gente de guerra ponga governador que Govierne lo descubierto. ${ }^{m}$ [Madrid, I7 de Junio de I606.]

El Rey: Marques de montesclaros Pariente mi Virrey Governador y Capitan General de las Provincias de la nueva españa, ya saveis que don joan de oñate vezino de esa Ciudad de Mexico se encargó por via de asiento del descubrimiento pacificacion y poblacion del nuevo mexico en que esta entendiendo y que aunque por su parte se represento que havia descubierto algunas poblaciones y que prometia la Tierra mucha grosedad sustancia y Riqueza y que tenian muy grande esperanças de conseguir lo que se pretendia por la gente que se yba convirtiendo pero que por la poca sustançia con que se hallaba no podia proseguir aquella enpressa si yo no le mandava ayudar y socorrer con Tresçientos hombres pagados y proveydos de lo necessario por haver tenido entonzes aviso por cartas de Religiossos y personas seglares que estavan en la dicha nueva mexico y fueron aquel viaje de algunos excesos desordenes y delictos que se havian cometido por El dicho don joan de oñate y otros deudos suyos ynvie a mandar el año de seysçientos y dos al conde de monterrey vuestro antecesor en ese govierno que haviendose ynformado primero secretamente, si estp era assi enviasse persona a la averiguaçion y castigo dello y que hallando. a don joan de oñate tan culpado y las cossas de manera que no conviniesse que quedase alli pusiesse cobro en la jornada para que se conservase lo descubierto y proseguiesse la conversion de los yndios y despues por promoviçion del dicho Conde al Govierno del Piru para que la execuçion de lo que asi le envie a mandar Tuviese efecto por cedula mia de veynte y seys de Mayo de seisçientos y tres se os advirtio dello y os Remiti la deliberaçion y execuçion de lo que por parte del dicho don joan de oñate se pedia y conviniese a la prosecucion de la dicha enpressa para que haviendo os ynformado del dicho conde de monterrey del estado que tenia y lo que huviese resultado de la averiguaçion de las culpas del dicho don joan de oñate proveyesedes Lo que os pareçiese Conviniente para que Tuviesse el efecto que pretendia en el descubrimiento y poblaçion favoreciendo y alentando mucho al dicho don joan en

m A. G. I., 87-5-I. 
way, to give permission to the said Don Alonso de Onate for the ship in which the said people are to be taken to load and take as many as forty or fifty tons of products of the country, or the least that will make it possible for them to be able to prepare and make their voyage. Valladolid, July ig, 1604.

To the Marquis of Montesclaros: He shall cause the exploration of New Mexico to cease and be discontinued, and he shall order the recall and detention in Mexico of Don Juan de Oñate, who was commissioned by contract to make the said exploration; when the soldiers have all been disbanded he shall place a governor over the explored country. [Madrid, June I7, I606.]

The King. Marquis of Montesclaros, my relative, viceroy, governor, and captain-general of the provinces of New Spain: You already know that Don Juan de Oñate, resident of the City of Mexico, was commissioned by contract to make the said exploration, pacification, and settlement of New Mexico, in which he is now engaged, and that it was represented upon his part that, although he had discovered some settlements and that the country promised much produce, substance, and riches, and that he had very great hopes of accomplishing what was sought for through the people whom he was converting, yet, because of the small means of which he found himself possessed, he could not continue the undertaking unless I should order that he be given assistance with three hundred ${ }^{68}$ men, paid and provided with the necessaries. Having received information at that time, through letters from religious and secular persons who were in the said New Mexico and who went upon the expedition, of lawless acts and crimes ${ }^{69}$ committed by the said Don Juan de Oñate and some of his relatives, in the year I602, I sent an order to the Count of Monterey, your predecessor in that government, that, after first informing himself secretly whether this was true, he should send a person to make an investigation and administer punishment; if Don Juan de Oñate should be found to be so guilty and affairs in such a condition that it was not desirable that he should remain there, the expedition should be put in a state of safety, so that what had been explored might be preserved and the conversion of the Indians be continued. Afterwards, the said count having been promoted to the governorship of Peru, in order that the command that I had given him might be carried out, by a decree of mine of May 26, I603, you were informed of it and I turned over to you the decision and execution of what was asked for on the part of the said Don Juan de Oñate, if it should be desirable for the prosecution of the said enterprise; so that, having learned from the said Count of Monterey of the state in which it was and what had resulted from the investigation of the offenses of the said Don Juan de Onate, you should take such measures as should appear best to you to accomplish the purpose 
casso que el la huviesse de proseguir pues estando tan adelante y tan dispuestos los naturales para reçevir la fee catholica no convenia çesase ni dexase de proseguir lo començado y que avisasedes de lo que en todo hiziessedes en cumplimiento de lo que por carta de treinta y uno de março del año passado me escrevisteis que haviendo visto los papeles diligençias y proçessos que envio el dicho don joan de oñate y los que el dicho conde de monterrey tenia hechos en la materia y pareciendo os de consideracion y que muchos dellos se Reducian a cassos de Justiçia soliçitados por gente que ynstava por vuestra satisfacion os resolvisteis a no fiallo de solo Vuestro pareçer y que hizisteis junta secreta de Tres oydores los mas desasidos de amistad particular ni deudo de las partes con asistençia del fiscal y que todos visteys los autos que perteneçian a culpas criminales y de lo que resulto de la dicha junta ynviasteys relaçion sumaria con el pareçer la qual aviendose visto en mi consejo Real de las yndias y considerado el modo de proçeder y los exçessos y crimenes de don joan de oñate y su maese de campo y algunos de sus capitanes y la forma en que cumple y ba cumpliendo lo que con el se asento y capitulo sobre el dicho descubrimiento y quan de poco fruto a sido asta agora y de la poca sustançia que aquella Tierra segun lo que Vos me escrevis y que el fin de los que an yntentado aquella enpressa es la duraçion della por sus particulares fines e yntentos Haviendoseme consultado me a pareçido ordenaros y mandaros como por la presente os ordeno y mando que luego que esta reçibays hagays que çesse y no passe adelante $\mathrm{El}$ dicho descubrimiento y que con maña y destreza envieys a llamar al dicho don joan de oñate con alguna causa sufiçiente y que mejor os pareçiere para que venga y no se altere, y luego que se a venido le tendreys en esa çiudad de mexico y hareys que se desabarate Toda la gente de guerra que huviesse $\mathrm{y}$ pondreys governador de satisfaçion prudente y christiano que Govierne lo que esta descubierto del dicho nuevo Mexico y vos Procurays Tenerlo en Justiçia y paz y amparareys y acariciareys los yndios naturales proveyendolos de Religiossos que los doctrinen y si algunos dellos quisieren entrar la tierra adentro a doctrinar con zelo cristiano se lo permitireis para que se saque, fruto y se tenga por este camino notiçia cierta de lo que esta por descubrir de aquella Provinçia sin usar de armas y de lo que en todo hizieredes y fueredes haziendo me dareys aviso para que lo tenga entendido y sepa como se cumple mi mandado fecha en Madrid a diez y siete de junio de mill y seyscientos y seys años yo EL REY refrendada de JOAN DE Cirica y señalada de los del consejo.

Respuesta al marques de Montesclaros en lo tocante $A$ la conquista del nuebo mexico. ${ }^{n}$ [San Lorenzo, Ig de Agosto de I606.]

E1 Rey:-Marques de Montesclaros Pariente mi Virrey governador y Capitan general de la nueba España Vuestra carta de los 28 de otubre

A A. G. I., 87-5-I. 
that was sought for in the discovery and settlement, favoring and greatly encouraging the said Don Juan in case he was to continue it-for, since it was so advanced and the natives so well disposed to receive the Catholic faith, it was not well to stop and fail to go on with what had been commenced-and that you should inform me of all that was done. In fulfillment of this, in a letter of March 3I, of the past year, you wrote me that, having examined the papers and proceedings sent by the said Don Juan de Oñate and those which the said Count of Monterey had made in the matter, and being of the opinion that it was important and that many of [the papers] resolved themselves into appeals for justice made by people who demanded satisfaction from you, you determined not to depend upon your own opinion alone, and called a secret council of three oidores, those freest from individual friendship and relationship to the parties, the fiscal being present, and all examined the autos pertaining to criminal offenses. Of the result of the said council you made a summarized report, with its opinion, and after this had been examined in my royal Council of the Indies and consideration given to the behavior and offenses and crimes of Don Juan de Oñate and his maestre de campo and some of his captains, and the manner in which he is carrying out his contract in regard to the said exploration, and what poor results have come from it up to now, and the poverty of the country, according to what you wrote me, and that the purpose of those who undertook the enterprise is its continuance for their own special ends-having taken advice, I determined to order you, as by these presents I do order you, as soon as you receive this, to cause the said exploration to cease and go no further. And you shall, with tact and discretion, cause the said Don Juan de Oñate to be recalled for some sufficient reason, as seems best to you, so that he may come without disturbance; as soon as he has come you will detain him in the City of Mexico, disband whatever military force he may have, and appoint a satisfactory governor, discreet and Christian, to govern what has been discovered in the said New Mexico, and you will endeavor to maintain it in justice and peace, and to protect and treat with kindness the native Indians, providing them with religious to instruct them, and if any of these wish to go into the interior of the country to teach with Christian zeal you will permit it, so that fruit may be drawn from it and by this road certain information of what is to be found in that province may be had without recourse to arms. And of what you do in all you will inform me, so that I shall learn and know how my order is carried out. Done at Madrid, June I7, I606. I the King. Countersigned by JUAN DE ÇIRIÇA and signed by those of the Council.

\section{Reply to the Marquis of Montesclaros in the matter of the campargn to New Mexico. [San Lorenzo, August I9, I606.]}

The King. Marquis of Montesclaros, my relative, viceroy, governor, and captain-general of New Spain: Your letter of the twenty-eighth of October of the past year, which treats of the affairs and state of the campaign to New Mexico, which is in charge of Don Juan de Onate, has been 
del año pasado que trata de las cossas y estado de la conquista del nuebo mexico que esta a cargo de don Juan de oñate se a Reçevido y Visto en mi Consejo Real de Las Yndias y quedo advertido de todo lo que decis y me avisais cerca desta materia en que tengo ya tomada la Resolucion que bereis por la cedula de $\mathrm{I} 7$ de Junio deste año que os encargo y mando la guardeis y cumplais en todo y por todo y que en Conformidad de lo que por ella se os ordena y manda hagais que f.ese el pasar adelante la dicha conquista y descubrimiento dando orden en la conservacion de los yndios Reducidos a nuestra santa fe catolica con la menos Costa de mi Real hazienda que os fuere posible y si lo fuere de que esto se haga con solo Religiosos lo hareis Como por la dicha cedula se os esta ordenando de san lorenço el Real a I9 de agosto de 1606 yo EL REY-Refrendada de JUAN DE ÇIRIÇA y señalada del consejo.

Ynformacion del tiempo que el capitan don luis Velasco sirvio a su magestad en las provincias y governacion de la nueva viscaya. ${ }^{\circ}$ [I596I6I4.]

Gaspar de lesquina en nombre del Capitan Don Luis de Velasco-Digo que mi parte a servido a Vuestra Alteza de veynte años a esta parte continuamente en todas las ocasiones que se an of recido a Vuestro Real servicio asi de guerra como de paz con sus armas y caballos y criados y hazienda en los nuebos descubrimientos de tierras y poblaciones que se an hecho asi en el nuebo mexico como en el Reyno de la nueba Vizcaya para cuyos efetos de orden del virrey don Luis de Velasco el gobernador don Juan de oñate le eligio por Capitan de los hombres de armas que llebo a la dicha Jornada donde mi parte fue a serbir a su costa y en presencia del dicho gobernador a bisto mucha cantidad de hacienda y bienes que llebo para gastar y serbir en la dicha ocasion y en virtud del nombramiento que tubo del dicho gobernador enarbolo estandarte en la ciudad de mexico y aviendo elegido y nombrado Alferez y los demas oficiales de su compañia hiço y junto cantidad de soldados que a su costa salieron a servir a Vuestra Alteza sin gaxes ni acostamiento alguno de la Real hazienda de cuya causa fue forcoso que mi parte como su capitan Les haviase de muchas cosas necesarias para el dicho viage y les hico muchos socorros de bastimentos armas caballos y municiones en que mi parte gasto mucha cantidad de pessos de oro y Respecto del buen celo con que fue sirviendo a Vuestra Alteza le nombre el dicho governador por comisario general para recoger a los Capitanes oficiales y soldados que se havian alistado para la dicha Jornada que estavan derrotados en pueblos villas y lugares de aquel Reyno y los congrego Junto y llebo al dicho exercito y mediante la dicha diligencia tubo efecto la dicha Jornada y por constar a Vuestro Virrey don Luis de Velasco lo bien que mi parte havia servido y la mucha hazienda que havia gastado en aquella ocasion dio orden al dicho don Juan de oñate para que le nombrase por Thesorero Juez 
received and examined by my royal Council of the Indies, and I am acquainted with all that you say and inform me of in regard to this matter, concerning which I have made the decision which you will see in the decree of June I7, of this year. I charge and command you to keep and fulfill it in everything and by everything, and that, in conformity with what is ordered you in it, you shall prevent the said campaign and exploration from going further, giving orders for the conservation of the Indians reduced to our holy faith with the least cost to my royal exchequer that may be possible to you, and, if it may be, let this be done with religious alone. You will do as you are ordered by the said decree. San Lorenzo el Real, August 19, I606. I the King. Countersigned by JuAN DE ÇIRIÇA and signed by the Council.

Evidence submitted concerning the time that Captain Don Luis Velasco served his Majesty in the provinces and government of Nueva Vizcaya. [1506-I614.]

Gaspar de Lesquina in the name of Captain Don Luís de Velasco: I declare that my client has served your Highness for twenty years continuously in this region on all the occasions that have arisen in your royal service, in war as well as in peace, with his arms and horses and servants and fortune, in the new discoveries of lands and towns which have been made in New Mexico as well as in the kingdom of Nueva Vizcaya. Because of these facts, by order of the viceroy, Don Luís de Velasco, Governor Don Juan de Oñate appointed him captain of the men-at-arms whom he took on the said expedition, with which my client went to serve at his own expense. In the presence of the governor a large quantity of property and goods was inspected, which he took to be used and to serve on the said occasion. In virtue of the appointment that he had from the governor, he raised his standard in the City of Mexico, and, having chosen and named the alférez and other officers of his company, he collected a number of soldiers, who went out at their own expense to serve your Majesty, without pay or any cost to the real hacienda.

For this reason it was necessary that my client, as their captain, should provide for them many things necessary for the journey, and he gave them much assistance in provisions, arms, horses, and ammunition, in which he spent a large sum in gold dollars. In view of the great zeal with which he continued serving your Highness, the governor appointed him commissary general, to collect the captains, officers, and soldiers who had enlisted for the expedition and who were scattered in the towns, villages, and places of that kingdom. He gathered them together, collected and took the army; and, because of this diligence, the expedition was carried out. Your viceroy, Don Luís de Velasco, having been informed of the good service given by my client and the large amount that he had spent on that occasion, gave orders to the said Don Juan de Oñate that he should be appointed official tesorero juez [treasury judge] of the real 
oficial de la Real Hazienda de las dichas Provincias del nuebo Mexico donde sirvio a Vuestra Alteza mucho tiempo haziendo muy buenos efectos en el aumento de la Real hazienda despues de lo qual por comision del dicho gobernador fue azer otras conquistas y descubrimientos de minas en las dichas Provincias cumpliendo con las ordenes que para ello tubo y despues fue nombrado por Procurador general del dicho exercito para los negocios que se ofrecieron tratar con el Conde de Monterrey Virrey de la nueba españa y audiencia Real della tocante a la dicha conquista que sirvio con mucha aprobacion y en el reyno de la nueba bizcaya uso el officio de capitan y alcalde mayor y en la provincia de santa barbara y en el Real $\mathrm{y}$ minas de mapemi administrando Justicia en las fronteras de ynehe ${ }^{\mathfrak{p}}$ y Guancebi ${ }^{q}$ donde a once años que esta haziendo vecindad a prestado con su cassa poblada armas caballos y criados para qualquier cosa que se ofrezca del servicio de Vuestra Alteza y por aver servido todo el dicho tiempo en las dichas ocasiones y que por ser tierra nueba fue necesario gastar mucha cantidad de hazienda en las dichas ocasiones esta pobre y con muger y hijos con obligaciones de tratarse conforme a su calidad como todo consta de la ynformacion titulos y Recaudos que pressentto atento Lo qual Suplico a Vuestra Alteza le haga merced de probehelle ${ }^{r}$ en uno de los gobiernos de aquella Provincia de la nueba españa con uno de los officios de Contador Thesorero o factor de la Real hazienda della que en ello recibira merced.

\section{GASPAR DE LESQUina.}

.. Y Estando en el ojo del agua que llaman de Sancto domingo donde esta alojado parte del exercito de su Magestad que va a la nueva mexico trece dias del mes de Julio de mill y quinientos y noventa y siete años ante don Juan de oñate governador y capitan general de La nueva mexico y de sus rreynos e provincias por el rrey nuestro señor e por ante mi Juan perez de denis ${ }^{\text {s }}$ escrivano de su magestad rreal se secretario de la dicha xornada presento esta peticion el contenido e pidiolo en ella contenido:

El Capitan don luis de Velasco digo que como Juez comisario de Vuestra señoria fui a los Valles de suchil y apoana a prevenir y apercevir a la gente cassada que va a esta jornada de la nueva mexico para que biniesen en prosecucion del Viaje y sobre ello hize muchas diligencias como consta del mandamiento y comision que Vuestra Señoria me dio y autos que hize $\mathrm{y}$ testimonio de que hago presentacion en cuya prosecucion los truxe hasta este paraje del agua de sancto domingo donde al presente estan aloxados y por que conbiene a mi derecho se me de testimonio dello A Vuestra Señoria pido y supplico mande al presente secretario me de Un traslado dos o mas auturissados del dicho mandamiento y diligencias sobre que pido Justicia con luis de Velasco.

\footnotetext{
p Evidently a corruption for "yndehe," now Indé.

q Evidently a corruption for Guanacevi.

r "Proveerle".

s Elsewhere spelled "donis". Gaspar Villagra, in canto XXV. of his epic history of the conquest of New Mexico mentions one Juan Pérez de Donis. Historia de la Nueva Mexico, I. (Mexico, I900), p. I3I.
} 
hacienda of the said provinces of New Mexico, where he served your Highness for a long time, bringing very good results in the increase of the real hacienda. After this, by commission of the governor he went to make other campaigns and discoveries of mines in the said provinces, carrying out the orders that he had for it. Afterwards he was appointed procurer general of the army to consult with the Count of Monterey, viceroy of New Spain, and its royal Audiencia, about matters that came up concerning the said campaign, and served very acceptably. In the kingdom of Nueva Vizcaya he served in the office of captain and alcalde mayor, and in the province of Santa Bárbara, and the camp and mines of Mapimi, administering justice on the frontiers of Yndehe and Guanacebi, where, during the eleven years that he has been a resident, he has lent, from his well-filled household, arms, horses, and servants for anything that contributed to the service of your Highness. Because he had served in all that time on the said occasions and because it was a new country, it was necessary to use up a large amount of his fortune on the said occasions. He is poor, with a wife and children, and with obligations to live according to his station. All of this appears from the evidence, patents, and documents which I present, in view of which I beg that your Highness will have the goodness to appoint him in one of the districts of the province of New Spain to one of the offices of auditor, treasurer, or factor of its real hacienda, where he will receive pay.

GaSPAR DE LesQUina.

... And being at the spring called Santo Domingo, where the part of the army of his Majesty which is going to New Mexico is encamped, on July I 3, I 597, before Don Juan de Oñate, governor and captain-general of New Mexico and its kingdoms and provinces for our lord, the king, and before me, Juan Pérez de Denis, ${ }^{70}$ clerk to his royal Majesty and secretary of the said expedition, he presented this petition [herein] contained and asked for what is contained in it:

I, Captain Don Luís de Velasco, declare that as commissary judge of your lordship I went to the valleys of Súchil and Apoana to prepare for the journey the married people who are going on this expedition to New Mexico. I took many measures concerning it, as appears in the order and commission which your Lordship gave me, and the autos which I made and evidence which I present, in the prosecution of which I brought them as far as this place of El Agua de Santo Domingo, where they are at present lodged. Because it is necessary for my interests that certification of it be given me, I ask and supplicate your lordship to order the present secretary to give me two or more certified copies of the said order and diligencias upon which I ask for justice. Luís DE VeLASCO.

This petition having been seen by the señor governor, he ordered that the certified copy asked for be given to the said Captain Don Luís de Velasco as he asks, these autos being with the papers of the expedition; and Don Juan de Oñate so ordered and signed it, and it passed before me. JuAn Pérez de Donis, clerk. 
E Vista por el dicho Señor gobernador mando que se Le de al dicho capitan don luis de Velasco el testimonio que pide como Lo pide quedando estos autos con los papeles de la xornada e asi Lo mando e firmo don JuAN DE OÑate passo ante mi Juan perez de donis escrivano.

En cumplimiento de Lo qual yo Juan perez de donis escrivano del Rrey nuestro señor e secretario de La Jornada de la dicha nueva mexico y de sus rreynos $E$ provincias hisse sacar y saque en testimonio que por esta peticion se pide el tenor del qual es como se sigue:

Don Juan de Oñate governador y capitan general caudillo y pacificador del nuevo mexico y de sus rreynos E provincias sus comarcanas e circunVessinas por el rrey nuestro señor ... Por quanto mi partida y deste mi exercito para las provincias del nuevo mexico esta tan apunto que solo rresta para salir de este puesto que llegue La gente cassada y soltera del balle de suchil Apoana chalchuites nombre de dios y el Illustrisimo Vissorrey de la nueva españa me manda que con todo rrigor apremie y fuerce que los susodichos que an hecho asiento Vayan a la dicha Xornada sin rremision ni larga alguna y para ello me enbio Un bando que en once de otubre mando librar en la ciudad de mexico cuyo traslado va con esta para que a todos conste y porque hagora tengo a Aviso de mi teniente francisco de sosa Peñalosa y de otros capitanes cassados y solteros de que no pueden tan presto Venir Lo qual es contra Lo que Su magestad manda y en gran daño y perjuicio de esta jornada y para que lo susodicho tenga rremedio y se execute lo que conbenga conbiene despachar persona de calidad y meritos y suficiencia y confianza y haciendola de la persona del capitan don luis de velasco Le doy poder y facultad para que como mi comisario Representando mi propria persona Vaya al balle de suchil La apoana, chalchuites, nombre de dios y en todas Las demas partes que viere conbenir y haga pregonar y pregone el dicho mandamiento y assimismo demas de pregonarle Le notifique a todos los capitanes y soldados que Viere convenir e si Viere o entendiere que esta diligencia no es suficiente para alguno o algunos Los prenda los cuerpos y secreste Los bienes y presos con ellos los trayga ante mi y si en lo que aqui se rrefiere Hubiere alguna rresistencia Los castigara a Usanza de guerra con todo rrigor Usando del que usan los comisarios de guerra que su magestad nombra y assimismo doy La misma comision y facultad al dicho capitan don luis velasco para que intime notifique y haga saber al capitan francisco de sosa peñalosa mi tiniente de governador y capitan general Un mandamiento que lleva mia La qual dicha notificacion La Hara por ante escrivano rreal o publico e no abiendolos nombrara escrivano con quien haga la dicha diljgencia de la qual me traera traslado con su rrespuesta y siendo necesario detenerse a ayudar y sacar al dicho francisco de sosa se quede y Viniendo el susodicho le dexara usar de sus papeles y rrecaudos que para todo le doy poder y facultad segun y como lo tengo de su Magestad Dada en el rreal y minas del caxco en doce dias del mes de nobiembre de mill y quinientos y noventa y seis años don JUAN DE OÑATE por mandado de su señoria JUAN BELARDE secretario. 
In fulfillment of which, I, Juan Pérez de Donis, clerk of our lord, the king, and secretary of the expedition to New Mexico and its kingdoms and provinces, caused to be drawn up and drew up the certified copy which is asked for in this petition, the tenor of which is as follows:

Don Juan de Oñate, governor and captain-general, chief and pacifier of New Mexico and its kingdoms and provinces and its neighboring territories for our lord, the king: As to my departure, and that of my army, for the provinces of New Mexico, it is now in such a state of readiness that it only remains for the married and single people to come from the valley of Súchil, Apoana, Chalchuites, and Nombre de Dios, to leave this post. The most illustrious viceroy of New Spain orders me to urge and force, with all rigor, the aforesaid who have enlisted to go on the said expedition without any remission or delay; and for this he sent me an edict which he ordered to be issued in the City of Mexico on the eleventh of October, and of which a copy goes with this, so that it may be clear to all. And because I have information that my lieutenant, Francisco de Sosa Peñalosa, and other captains, married and single, cannot come so soon, which is contrary to what his Majesty orders and is a great injury and prejudice to this expedition, and in order that the aforesaid may be remedied and that which is required may be done, it is necessary to despatch a person of character and merit and ability and confidence. Believing this of the person of Captain Don Luís de Velasco, I give him power and authority, as my commissary, representing me personally to go to the valley of Súchil, La Apoana, Chalchuites, Nombre de Dios, and all other parts that he may see to be necessary, and cause to be proclaimed and proclaim the said order, and also, in addition to proclaiming it, notify to assemble all the captains and soldiers whom he may see. If he sees or learns that this diligencia is not sufficient for any one or more persons, he shall seize their persons and sequester their goods, and making them prisoners, bring them before me; if there be any resistance to what is set down here he shall punish them according to the usage of war with all rigor, practising what is practised by the commissaries of war whom his Majesty names. Likewise I give the same commission and power to the said Captain Don Luís Velasco to inform, notify, and make known to Captain Francisco de Sosa Peñalosa, my lieutenant-governor and captain-general, an order of mine which he carries; and he shall make the said notification before a royal or public clerk, or, in the absence of any, he shall name a clerk with whom he may execute this proceeding. Of this he shall bring me a copy, with his answer, and if it be necessary for him to stop there to assist and bring out the said Francisco de Sosa, he may remain, and if he [Sosa] agrees to the aforesaid, he shall allow him to make use of his papers and vouchers. For all this I give him power and authority according and as $I$ have it from his Majesty. Given at the camp and mines of El Casco, on the twelfth day of the month of November, I 596. Don JuAN DE OÑATE, by order of his highness. JuAn BeLARDE, secretary.

I, Gabriel Ramírez, public clerk and [clerk] of the council of the town of Nombre de Dios and its district for the king, our lord, certify and attest that I know Captain Don Luís de Velasco and have seen him exer- 
Grabiel rramirez escrivano Publico y del cavildo de La villa del nombre de dios y su Jurisdicion por el rrey nuestro señor doy fee y verdadero testimonio que conosco al dicho capitan don luis de Velasco y Le e Visto Usar de La comision desta otra parte contenido en servicio de su magestad y en Virtud dello Le e Visto Hacer Muchas diligencias autos y pregones assi en estas minas y rreal de chalchuites como en los valles de Suchil y apoana y assi mismo e Visto que mediante su buena diligencia y solicitud que a tenido a ssido parte para que el capitan francisco de sosa peñalosa teniente de governador y capitan general de La Jornada del nuevo mexico se aprestasse e saliese como salio en prosecucion de su Viage y en ello hizo Las diligencias necesarias en tanto grado que entiendo que no pudiera salir si del dicho capitan no fuera ayudado y solicitado con tanto cuydado y diligencia como le a hecho Lo qual es publico y notorio Vos sy fama en toda esta tierra e lo a oydo practicar en la forma susoDicha y asimismo e Visto al dicho capitan hacer diligencias con los demas capitanes y soldados cassados y solteros y otras personas oficiales del dicho governador que tenian hecho asiento de ir a servir a su magestad en la dicha jornada con sus cassas mugeres i hijos y los arranco y saco y con gran avio de personas carros carretas bueyes bacas obexas y otras cossas en todo lo qual a ssido mucha parte el dicho capitan don luis de velasco, en todo lo qual a sido servido el rrey nuestro señor del dicho capitan don Luis de velasco como bueno fiel y leal Vasallo suyo y criado y e Visto que a sido de mucha ynportancia su diligencia y buen modo de proceder para que se consiga el fin que su magestad pretende de que se haga La dicha xornada, y e conocido de su prudencia y buen modo de proceder con todos generalmente con los que Le e Visto tratar es persona en quien concurren los rrequisitos necesarios para que su magestad se sirva del en negocios de calidad conforme a La de su persona a todo mi leal saber y entender y para que conste de lo susodicho de su pedimiento di el presente fecho en el balle de suchil Jurisdicion de la nueva galicia ocho dias del mes de henero de mill y quinientos y noventa y siete años siendo testigo el capitan domingo sanchess ervalexo y Juan martin y pasqual carrasco Vesinos y estantes en este dicho Valle yo graviel rramires escrivano de cavildo y publico de la Villa del nombre de dios y su Jurisdicion por el rrey nuestro señor y Vesino de las minas de chalchuites de La nueva galicia Lo fice escrivir y fice mi signo en testimonio de verdad GRAVIEL RRAMIRES escrivano publico.

Señor: escrivano del rrey nuestro señor y secretario de La muestra y Visita que por mandado y comision del Illustrisimo Visorrey de la nueva españa me esta tomado el señor francisco de esquivel comissario della de Las cosas que capitule con el dicho señor visorrey y avia de llevar para la Jornada de la nueva mexico digo que como consta al dicho señor comisario por La dicha muestra y visita que me a tomado y e dado e cumplido con mucho exceso a todo Lo que estava obligado y tanbien consta a su merced que en la comission que se le dio al señor don lope de Ulloa y lemos y a su magestad asimismo no solo manda su señoria se me tome muestra de Lo que tengo capitulado si no tanbien de todas Las cosas que ban a la xornada assi mias como de capitanes y soldados y gente del exercito por 
cise the commission contained in this other part in the service of your Majesty, and in virtue of it I have seen him execute many diligencias, autos, and proclamations, in these mines and camp of Chalchuites, as well as in the valleys of Súchil and Apoana. I have also seen that through his great efforts and care he brought it about that Captain Francisco de Sosa Peñalosa, lieutenant-governor and captain-general of the expedition to New Mexico, got ready and went upon the expedition in which he rendered services of much necessity and high value. I understand that he could not have gone out unless the said captain had assisted him with great care and assiduity, as he did. This is public and well known by report and rumor in all this country, and I have heard it repeated as stated above. I have also seen the said captain exert himself greatly with the rest of the captains and soldiers, married and single, and with other persons, officials of the governor, who had enlisted to go in the service of his Majesty on the expedition, with their households, wives and children, and he forced them out with a great array of people, wagons, carts, oxen, cows, sheep, and other things. In all this Captain Don Luís de Velasco has had a great part, and in it all he has served the king, our lord, like a good, faithful, and loyal subject and servant. I have seen also that his, diligence and good management have been very important in bringing about the end which your Majesty wishes to result from the expedition, and I have observed his good judgment and management generally with all those with whom I have seen him have dealings. He is a person in whom all the requisites concur for his Majesty to make use of him in affairs of a character suitable to his person, according to all my truthful knowledge and understanding. In order that what is stated above in his petition may be made clear, I issued the present in the Valley of Súchil, district of Nueva Galicia, on January 8, I 597, the witnesses being Captain Domingo Sánchez Ervalexo, Juan Martín, and Pascual Carrasco, residents and permanent citizens of this valley. I, Gabriel Ramírez, clerk of the council and public [clerk] of the town of Nombre de Dios and its district, for our lord, the king, and resident of the mines of Chalchuites of Nueva Galicia, caused it to be written and affixed my signature in testimony of the truth. Gabriel Ramírez, public clerk.

Señor clerk of our lord, the king, and secretary of the muster and inspection which by order and commission of the illustrious viceroy of New Spain has been taken from me by Señor Francisco de Esquivel, commissary, of the things which I listed with the señor viceroy and the supplies to be taken on the expedition to New Mexico: I declare, as is evident to the señor commissary from the manifest that he has taken from me, and which I have given and supplied with a thoroughness far beyond my obligations, and as is also known to his grace and to his Majesty, that in the commission which was given to Señor Don Lope de Ulloa y Lemos his lordship does not alone order that a manifest be taken from me of what I have listed, but also of all the things that are to go on the expeditionmine as well as those of the captains, soldiers, and people with the army; for, besides what I have already placed on the manifest, I have more than 40,000 dollars more to declare of slaves-negroes and Chichinecos, male and female-clothing, silverware, and many other materials that go to 
que demas de Lo que yo tengo manifestado tengo mas de otros quarenta mill pesos que manifiestar de esclavos negros y negras chichimecos chichimecas Vestidos rropa y plata Labrada y otros muchos generos que hacen La dicha cantidad y asi mismo Los dichos capitanes y soldados y gente del exercito llevan mas de ciento y cinquenta mill pesos de cossas. ynportantes y de mucho valor todo Lo qual es de mucha ynportancia De calidad y auturidad De La xornada y que su magestad y el Illustrisimo Visorrey de la nueva españa Lo sepa y entiendan para Lo qual deve Vuestra Magestad hacer Visita cala y cata y de no hacerla protesto hacerla yo con mi secretario para que hecha conste en todo lugar y tiempo y pido que este rrequirimiento Le Hagais al dicho señor comisario por parte de mi el dicho governador don Juan de oñate y de su letura se me de testimonio y que los presentes me sean testigos don JUAN DE OÑATE.

En Las minas Del caxco De la nueva Visscaya donde esta aloxado el rreal de la xornada que al presente $\mathrm{Va}$ a la nueva mexico ante mi antonio negrete escrivano de su magestad e secretario de La Visita della parescio don Juan de oñate governador y capitan general de la dicha xornada y me pidio notificase este rrequirimiento a francisco de esquivel comisario y Le diese testimonio dello y Lo que rrespondiese, yo se lo ley e notifique y Respondio que como bien save el dicho señor governador Don Lope de Ulloa y Lemos Visitador y tiniente de capitan general que a sido de la dicha xornada comensso a tomar La muestra Visita cala y cata a ynportunacion y persuasion de tres rrequirimientos que para ello hizo el dicho señor governador y sin averlo acavado Hizo ausencia de este rreal por aver sido llamado por su señoria del conde de monterrey mi señor para otras cossas del servicio de su magestad subdelegando para acavarla y fenicerla en francisco de esquivel comisario susodicho el cual La a acavado de lo que el dicho señor governador por su quenta avia ofrecido y capitulado llevar aun que es Verdad que al dicho comisario Le consta y por Las comisiones de su señoria se manda se tomase asimismo La muestra y Visita Cala y cata de las demas cossas que el dicho Señor governador y capitanes y oficiales y soldados llevan a la dicha xornada no la puede tomar por que el dicho Visitador no Le dexo orden ni comision para ello y assi el dicho señor governador podra hacer lo que a su derecho conbenga y esto rrespondio y lo firmo siendo testigos a todo el capitan Juan moreno de Carrua el capitan gregorio Zesar y alferes rromero francisco de esquivel ante mi ANTONIO NEGRETE.

En la estancia e paraxe y agua que llaman de pedro de la cruz veinte dias del mes de abrill de mill y quinientos y noventa siete años ante don Juan Oñate governador y capitan general de la nueva mexico e de sus rreynos e provincias por el rrey nuestro señor e por ante mi Juan Perez de donis escrivano de su Magestad rreal e secretario de la dicha xornada presentaron esta peticion ante su señoria los contenidos en este pedimiento e pidieron lo en el contenido.

E1 capitan francisco de sosa peñalosa teniente de governador e capitan general de la nueva mexico e de sus rreynos e provincias y Las a ellas circunvessinas y comarcanas por el rrey nuestro señor y alonso sanches con- 
make up the sum mentioned. Also, the captains and soldiers and people with the army are taking more than I50,000 dollars worth of important and valuable things. All of this is of much importance to the character and authority of the expedition and [it is necessary] that his Majesty and the illustrious viceroy of New Spain shall know and understand it.

For this your Majesty ought to make a complete manifest, and unless it is done I insist upon making it with my secretary, so that it may be clear in every place and time, and I ask that you make this requisition of the señor commissary on my part, and that a certified copy be given me of his manifest and that those present be witnesses for me. Don JUAN DE OÑATE.

At the mines of Casco, of Nueva Vizcaya, where the camp of the expedition which is now on the way to New Mexico is lodged, before me, Antonio Negrete, clerk of his Majesty and secretary of inspection, appeared Don Juan de Oñate, governor and captain-general of the expedition, and asked me to notify Francisco de Esquivel, commissary, of this requisition and to give him a certified copy of it and his reply to it. I read it to him [Esquivel] and notified him, and he replied that, as is well known to the governor, Don Lope de Ulloa y Lemos, inspector and former lieutenant-captain-general of the expedition, began to make the complete manifest after being requisitioned to do it three times by the governor, but before he had finished it he left this camp, having been called by his lordship, the Count of Monterey, my lord, for other matters in the service of his Majesty. He delegated the work of finishing it to Francisco de Esquivel, the aforesaid commissary, who finished it as far as concerned what the señor governor had offered in his account and had listed to be taken, and although it is true that the commissary is aware and it has been ordered by the commissions of his lordship that the complete manifest of the rest of the things which the señor governor and captains and officials and soldiers are taking on the expedition should be taken, it cannot be done because the inspector left no order or commission for it; therefore, the señor governor can do whatever is best for his interests. This he acknowledged and signed, Captain Juan Moreno de Carrua, Captain Gregorio Zesar, Alférez Romero, and Francisco de Esquivel being witnesses to all, before me, Antonio Negrete.

At the pool and spring called Pedro de la Cruz, April 20, I597, before Don Juan Oñate, governor and captain-general of New Mexico and of its kingdoms and provinces for the king, our lord, and before me, Juan Pérez de Donis, clerk of his royal Majesty and secretary of the expedition, those mentioned in this petition presented it before his lordship [Onate] and asked for what is contained in it:

We, Captain Francisco de Sosa Peñalosa, lieutenant-governor and captain-general of New Mexico and its kingdoms and provinces and neighboring territories for the king, our lord, and Alonso Sánchez, official contador juez of the real hacienda of his Majesty in the said kingdoms and provinces, and Captain Alonso de Sosa Albornos, and Captain Gerónimo Márquez, captain of artillery, and Captain Marcos Farfán de los 
tador Juez oficial de la rreal Hazienda de su magestad en los dichos rreynos e provincias, y el capitan alonso de sosa albornos y el capitan geronimo marques capitan del artilleria y el capitan marcos farfan de los godos y el capitan don luis de velasco por nosotros y por lo que a cada Uno de nosotros toca y en voz y en nombre de Los demas alferez sargentos y oficiales y soldados que Van A la dicha xornada Decimos que aviendo llegado a nuestra noticia el ardientissimo desseo que el sancto pontifice Vicario de dios en la tierra y el cristianissimo rrey don phelippe nuestro Señor an tenido $Y$ tienen De que nuestra sancta fee catholica se predique y plante en aquellos rreynos e provincias y se extirpen Las ydolatrias y se alabe el alto y poderoso dios y La bos del evangelio suene en todo el Uniberso enbio a mandar por sus cedulas y capitulos de cartas a los Virreyes marques de Villamanrrique e don luis de velasco y conde de monterrey Visorreyes de esta nueva españa nombrasen persona qual conbiniese para tan arduo negocio y despues de averse procurado y buscado con suma diligencia con deliveracion y acuerdo de los virreyes don luis de velasco y conde de monterrey fue elegido y nombrado vuestra señoria para tan arduo negocio y nosotros con voluntad y animo de servir a dios y a su magestad en tan sancta xornada como hasta aqui lo avemos hecho salimos de nuestras patrias y naturalezas con nuestras mugeres hijos criados cassas y familias y bendimos y malbaratamos nuestras haciendas para el dicho efecto en mas cantidad de docientos mill ducados esto con ocasion de aver Visto enarbolado el rreal estandarte en las ciudades de mexico y zacatecas para que Vuestra Señoria hiziese La dicha xornada e traemos mucha maquina de pertrechos de guerra y otras cossas para el dicho efecto y porque al tiempo y quando francisco de esquivel comissario de La dicha xornada hizo La lista y rreseña general de los capitanes oficiales y soldados que estamos movidos en los Valles de lapoana y suchil y fresnillo y que particularmente asentase Las mugeres hijos y familia y bienes que cada uno traya no lo quiso hacer excediendo de lo que devia y era obligado y por que en La Lista y rreseña general de La demas gente que hisso en sancta barbara y casco Vuestra Señoria pidio y rrequirio al dicho comissario que rezibiese La dicha muestra cala y cata De lo mismo A todos los demas capitanes y soldados que en ella se hallaron como consta de los autos que sobre ello pasaron a que nos rreferimos tanpoco no lo quiso hacer oviando que servicios tan grandes saliesen a Luz como La esperiencia lo a mostrado; y porque en prosecucion de nuestros of recimientos venimos actualmente a la xornada y estamos quatro Leguas del caxco en el agua y paraxe que llaman de pedro de la Cruz atento a lo qual A Vuestra Señoria pedimos y suplicamos y con devido acatamiento rrequerimos mande al presente secretario desta xornada ponga por ynbentario Las mugeres Hijos familia y bienes que cada Uno de nosotros trae para la dicha xornada para que conste a su magestad con lo que le emos servido y vamos serviendo y se nos de por testimonio Lo que a cada uno de nosotros toca y segun lo que manifestare poniendo por cavessa esta peticion y lo a ello proveydo para que su magestad y Vuestra Señoria haga mercedes conforme a los servicios que emos rrefierido y pedimos Justicia FRANCISCO DE SOSA PEÑALOSA ALONSO SANCHÉZ ALONSO DE SOSA ALBORNOZ, GERONIMO MARQUES MARCOS FARFAN DE LOS GODOS dON LUIS DE VELASCO PEDRO ROBLEDO. 
Godos, and Captain Don Luís de Velasco, for ourselves and what concerns each one of us, and in the name of the rest, the alféreces, sergeants, officers, and soldiers who are going on the expedition-declare, that having learned of the very ardent desire which the holy pontifical vicar of God in the land, and the most Christian king, our lord, Don Felipe, had and still have that our holy Catholic faith shall be preached and planted in those kingdoms and provinces, and that idolatries shall be extirpated and the high and mighty God be glorified, and the voice of the gospel sound in all the universe, [and that] he [the king] ordered, by his cédulas and capitulos de cartas, the Marquis of Villamanrique ${ }^{71}$ and Don Luís de Velasco and the Count of Monterey, viceroys of this New Spain, to name some suitable person for this difficult business, and that, after having sought and searched with the greatest diligence, with the deliberation and agreement of the viceroys Don Luís de Velasco and the Count of Monterey, your lordship was elected and chosen for this difficult business-we, with the will and spirit to serve God and his Majesty in this holy expedition as we have done up to this time, left our countries and native lands, with our wives, children, servants, households, and families, and sold our property, at a loss, for the said purpose, to the amount of more than 200,000 ducats. This [we did] because of having seen the royal standard raised in the cities of Mexico and Zacatecas for your lordship to make the said expedition, and we brought a great quantity of munitions of war and other things for the said purpose. And, because at the time when Francisco de Esquivel, commissary of the expedition, made the list and general muster of us captains, officers, and soldiers who have moved to the valleys of La Apoana and Súchil and Fresnillo and he [was asked] to list in detail the women, children, and families, and goods which each one brought, he refused to do this, as being in excess of his duty and obligation; and because, when in the list and general muster of the rest of the people which he made at Santa Bárbara and Casco, your lordship asked and requisitioned the said commissary to take the complete muster similarly of all the rest of the captains and soldiers that were there, as appears in the autos which were passed upon it and to which we refer, he again refused to do it, preventing these great services from coming to light, as experience has shown, and because, in fulfillment of our offers we are actually come upon the expedition and are now four leagues from Casco, at the spring and place called Pedro de la Cruz, in view of [all] this we ask and supplicate and with proper respect urge your lordship to order the present secretary of this expedition to make an inventory of the women, children, family, and goods that each one of us is bringing on the expedition, so that it may be made clear to his Majesty with what we have served and are serving him, and that he give a certified copy to each one of us of what belongs to him, as it appears on the manifest, this petition, and the measures taken, to be placed as a heading, so that his Majesty and your lordship may give rewards according to the services to which we have referred and for which we ask justice. Francisco de Sosa Peñalosa, Alonso Sánchez, Alonso de Sosa Albornóz, Gerónimo Márquez, Marcos Farfán de los Godos, Don Luís de Velasco, Pedro Robledo. 
El señor governador mando que se Haga como Lo piden Los contenidos en esta peticion y se ponga por caveza en este testimonio que a cada uno se diere el rrequerimiento que se hizo al comissario francisco de esquivel y esta peticion y auto y se haga ynbentario de todo atento a que le consta que es y pasa assi como en esta peticion se rrefiere y asi lo mando y firmo don JUAN DE OÑATE passo anti mi JU PEREZ DE DONIS escrivano.

Manifestacion que hisso el capitan don luis de Velasco de los bienes que lleva armas e cavallos Para servir a su magestad en la xornada de la nueva mexico de que va por governador y capitan general don Juan de oñate.

Estando en el paraxe e minas del caxco Donde esta aloxado el exercito de su magestad que va a la conquista y pacificaçion de Las provincias de La nueva mexico diez y nueve dias del mes de mayo de mill y quinientos y noventa y siete años ante el señor don Juan de oñate governador y capitan general de Las dichas provincias de La dicha nueva mexico y de sus rreynos e provincias a ellos circunvesinos y comarcanos por el rrey nuestro señor e por ante mi Juan perez de donis escrivano de su magestad rreal e secretario de La dicha xornada parecio el capitan don luis de Velasco a quien doy fee que conosco y dixo que en cumplimiento de lo que ante su señoria tienen pedido algunos capitanes y oficiales del rreal exercito quiere manifestar Los bienes que lleva y assi Lo haziendo manifesto e truxo a la presencia del señor governador e a la mia de que doy fee Las cossas siguientes :

Primeramente Manifesto e truxo ante su señoria Un estandarte de damasco blanco de castilla con Flecaduras y guarnicion de oro y seda carmesi que por La una parte tiene estanpada a nuestra señora y a san Juan bautista y al rededor de estas dos imagenes pintado el rrosario de nuestra señora con cuentas grandes doradas y a los pies Un escudo e armas del dicho governador, y Por La otra parte tiene La figura de señor santiago con un Letrero al rrededor que dize sic ut sanguino Centa y a los pies del cavallo de señor santiago Un escudo de armas de los belascos con sus borlas grandes guarnecidas con oro y seda carmesi.

Yten una gineta de plata en su asta para el uso De su oficio de capitan con borlas de oro y seda amarilla y morada.

Yten para el dicho efecto tres ternos de armas enteras para armarse assi y a otros dos soldados de cota de malla escarzela sobrevista e morrion todo cumplido sin que falte nada.

Yten tres arcabusses De rrueda con sus frascos e frasquillos e llaves esacapelatas moldes e todo lo demas que a cada uno pertenece.

Yten tres pares de armas de cavallo de cuero de anta e forradas en cuero crudio de hixadas testeras pechos pescozeras todo sin que falte cosa alguna.

Yten Una alabarda guarnecida en terciopelo amarillo e borlas moradas toda claveteada que la conpro para que la truxese su sargento. 
The señor governor ordered that the request of those mentioned in this petition be granted, and that the requisition made upon the commissary, Francisco de Esquivel, with this petition and auto, be placed as a heading to the copy to be given to each person, and that an inventory be made of all, since it is clear to him that the facts are as stated in this petition. It was so ordered and signed by Don Juan de Oñate and passed before me, JuAn PÉrez de Donis, clerk.

Manifest made by Captain Don Luis de Velasco of the goods, arms, and horses which he is taking to serve his Majesty in the expedition to New Mexico, of which Don Juan de Oñate goes as governor and captain-general.

Being at the mines of Casco, where is encamped the army of his Majesty, which is going to the conquest and pacification of the provinces of New Mexico, on the nineteenth day of May, I597, before Señor Don Juan de Oñate, governor and captain-general of the provinces of New Mexico and its kingdoms and the adjacent territories for the king, our Lord, and before me, Juan Pérez de Donis, clerk of his royal Majesty and secretary of the said expedition, appeared Captain Don Luís de Velasco, whom I swear that I know. He declared that in fulfillment of what some captains and officers of the royal army have petitioned before his lordship, he wished to make a manifest of the goods that he is taking; and, so doing, he exhibited and brought into the presence of the señor governor and myself, to which I swear, the following things: ${ }^{72}$

First, he exhibited and brought before his lordship a standard of figured white Castilian silk, with fringes and trimmings of gold and crimson silk, which has stamped on one side the pictures of Our Lady and Saint John the Baptist. Encircling these two figures is painted the rosary of Our Lady with large gold beads, and at their feet the escutcheon and arms of the governor. On the other side it has the figure of the lord Saint James, with an inscription encircling it which says Sic ut sanguino centa, ${ }^{73}$ and at the feet of the horse of the lord Saint James the escutcheon and arms of the Velascos, with large tassels trimmed with gold and crimson silk.

Item: A silver lance, in its handle, for the exercise of his office as captain, with tassels of gold and yellow and purple silk. ${ }^{74}$

Item: For the said purpose three complete suits of armor, to arm himself and two other soldiers in coat of mail, with thigh piece, beaver, and helmet, all complete, and with nothing lacking.

Item: Three calivers, with their large and small powder horns, firelocks, bullet screws, ${ }^{75}$ moulds, and all the rest that pertains to each one.

Item: Three sets of horse armor of buckskin, lined with undressed leather, for the flanks, foreheads, breasts, necks-all, without anything lacking.

Item: A halberd, garnished with yellow velvet and purple tassels, and all studded with nails, which he bought for his sergeant to carry. ${ }^{76}$ 
Yten treynta cavallos de Armas de diferentes hierros y señales señalados con su hierro que es el del margen.

Yten Dos mulas de silla para el dicho efecto de llevar a la xornada e dos mulas de carga.

Yten una espada y daga dorada con sus tiros pretina pespuntados de seda morada amarilla y blanca.

Yten otra espada ancha de a cavallo con su tahali y dos chimales para defensa de las flechas.

Yten dos sillas ginetas de cordovan con sus caparazores de paño azul de castilla con flores y flaxas de cordovan todas cumplidas e con sus estriveras de Laso.

Yten otras dos sillas estradiotas de cordovan estrivos e frenos e lo que les pertenece de cinchas cavezadas e Riendas e otro freno estradiote y dos ginetas.

Yten una cama con dos colchones cobertor sabanas almoadas azericos e Un almofrex de sayal guarnecido con baqueta.

Yten que lleva en su servicio dos criados españoles para servir a su magestad en la xoranada de diez y ocho a Veinte años que a cada uno dellos Le a dado quatro cavallos e armas enteras de sus personas e cavallos.

Yten un bestido de terciopelo azul de ytalia con pasamanos de oro anchos y es rropilla calzon e medias de seda presadas con ligas azules con puntas de encaxes de oro.

Yten otro Vestido de rraso Rosado de castilla e prensado y es rropilla ebalon ${ }^{t}$ guarnecido con pasamanos y alamares angostos de oro e un ferreruelo de rraja parda con franxon ancho de oro e plata y medias de seda rrosadas y Ligas de tafetan Listado rrosado.

Yten otro Vestido de rraso paxiso de castilla Acuchillado con cuchilladas anchas y entretelas de tafetan carmesi de castilla guarnecido y es calzon y rropilla y medias paxicas de seda y Legas de tafetan morado con puntas.

Yten otro vestido de Raxa morada de castilla y es calzon balen "y rropilla guarnecido con pasamanos angostos de oro e una capa con un franxon ancho de oro y bueltas de tafetan gorado ${ }^{\nabla}$ y medias de seda moradas y Ligas de tafetan morado con puntas y encaxes de oro.

Yten otro bestido de paño de Londres de casta ${ }^{\text {w }}$ otro vestido debalon rropilla y ferreruelo todo guarnecido con pasamanos de plata escarchada.

Yten otro Vestido de damasco de chuna ${ }^{x}$ Leonada y Verde guarnecido con pasamanos muy angostos de oro y es calzon y rropilla y un jubon de tela ordinaria.

Yten dos coletos de cabritillas adobadas en castilla el Uno de ciudad rreal guarnecido con pasamanos de seda morada y oro y el otro guarnecido con pasamanos anchos de plata.

Yten otro coleto de piel de leon rreal guarnecido con pasamanos de oro y morado con sus botones de lo mismo.

Yten una capa aguadera de paño pardo de la tierra.

tEvidently meant for "a la valona".

u Evidently a miscopy for "valón".

"Evidently a miscopy for "morado".

w Evidently a miscopy for "castaña".

"Clearly a miscopy for "China". 
Item: Thirty war-horses of different brands and marks, marked with his brand, which is in the margin.

Item: Two saddle mules to take on the said expedition and two pack mules.

Item: A sword and a gilded dagger with their waist belts stitched with purple, yellow, and white silk.

Item: One broadsword with shoulder belt, and two shields for defense against arrows.

Item: Two trooper saddles of Cordovan leather, with housings of blue flowered Spanish cloth bound with Cordovan leather, all complete and with loose stirrups.

Item: Two estradiotas ${ }^{77}$ saddles of Cordovan leather, with the stirrups, bridles, girths, halters, and reins that go with them, one estradiote ${ }^{78}$ and two troopers' bridles.

Item: One bed with two mattresses, a coverlet, sheets, pillow-cases, pillows, and a canvas mattress-bag bound with sole leather.

Item: He is taking in his service two Spanish servants, from eighteen to twenty years old, to serve his Majesty on the expedition, to each of whom he has given four horses and complete equipment of armor for themselves and their horses.

Item: One suit of blue Italian velvet trimmed with wide gold passementerie, consisting of doublet, breeches, and green silk stockings vith blue garters with points of gold lace.

Item: Another suit of rose-colored lustrous Castilian satin, consisting of a Walloon ${ }^{79}$ doublet, trimmed with narrow gold passementerie and a short cloak of gray cloth trimmed with wide gold and silver fringe, rosecolored silk stockings, and garters of striped rose-colored taffeta.

Item: Another suit of straw-colored Castilian satin, slashed with wide slashes and trimmed with interlinings of crimson Castilian taffeta, consisting of breeches, doublet, stockings of straw-colored silk and garters of purple taffeta with points.

Item: Another suit of purple Castilian cloth, consisting of Walloon breeches and doublet, trimmed with narrow gold passementerie, a cape with a wide gold fringe and ruffles of purple taffeta, purple silk stockings and garters of purple taffeta with points of gold lace.

Item: Another suit of chestnut-colored London cloth in the Walloon style, doublet and short cloak all trimmed with silver passementerie embroidery.

Item: Another suit of Chinese flowered silk, tan and green, trimmed with very narrow gold passementerie, consisting of breeches, doublet, and a jacket of ordinary cloth.

Item: Two doublets of kid dressed in Castile, one from the royal city being trimmed with gold and purple silk passementerie, and the other with wide silver passementerie.

Item: Another doublet of royal lion skin trimmed with gold and purple passementerie, with buttons of the same.

Item: One rain-cloak of gray cloth of the country.

Item: Two Rouen linen shirts with collars and cuffs of Holland cambric. 
Yten doce camisas de rruan con sus cuellos e puños de olanda guarnecidos.

Yten seis paños de manos de rruan y ocho pares de calzetas de lienzo con sus escarpines.

Yten seis pares de calzones de rruan guardecidos.

Yten ocho pares de botas de cordovan e seis pares blancas y las quatro nigras y quatro pares de borzeguies.

Yten catorze pares de zapatos de cordovan blancos e negros e quatro pares de botas de baqueta e venado.

Yten dos sombreros Uno negro guarnecido el y la toquilla de plata tirada con plumas negras moradas e blancas y el otro pardo con plumas amarillas e moradas.

Yten otro sombrero de tafetan morado con sus plumas azules moradas y amarillas e la toquilla guarnecida y con pasamanos de oro y plata.

Yten quatro pares de espuelas de bridal Dos de xineta y Unos azicates con borlas y cordones de seda.

Yten una tienda de xerga Listada de mechoacan de cinquenta baras con lo que Le pertenece para asentarla de estacas orcones y todo lo demas necesario.

E Assi manifestados Los dichos bienes El Dicho capitan don Luis de velasco Dixo a su señoria que le pide y suplica Los aya por manifestados e que demas de lo susodicho como a su señoria le consta y es notorio algunos de sus oficiales y soldados Le son a cargo muchos bienes en mucha cantidad que se le an ausentado e llevado por la dilacion que a avido en la dicha xornada con todo lo qual benia a servir a su magestad e assi dara ynformacion aparte presentando peticion para que se le rreciva e con esta declaracion dixo que de presente no tiene de que hazer mas manifestacion.

E Vista Por el dicho señor governador dixo que avia e obo por manifestados los dichos bienes e Certificava e certifico aver Los visto e constarle que los lleva todos e son suyos e que con ellos hizo obstentacion en la ciudad de mexico donde arbolo estandarte e mando que dello se le de testimonio ynserto con esta manifestacion el rrequerimiento que su señoria hizo a francisco de esquivel comisario de esta xornada en rrason de que se asentasen todos Los bienes que llevavan Los que yvan a servir a su magestad en la dicha xornada e asi lo mando e firmo don juan de oñate passo ante mi JUAN PEREZ DE DONIS escrivano.

Segun que lo susodicho consta e parese por La dicha Lista en nuestra original que queda con los papeles de la Jornada e de pedimiento del capitan don Luis de Velasco e por mandado del señor governador di el presente testimonio en el paraje del agua de sancto domingo donde esta aloxado parte del exercito de su magestad a diez de Julio de mill y quinientos y nobenta y siete años en quatro fojas de papel. Don JUAN DE OÑATE. E yo JUAN PEREZ DE DONIS escrivano rreal e secretario de la xornada de la nueva mexico fuy presente e fice aqui mi signo en testimonio de verdad. Etc.

Estando en el paraje del agua de Sancto domingo de la nueva viscaya ocho dias del mes de Junio de mill y quinientos y noventa y siete años 
Item: Six handkerchiefs of Rouen linen and eight pairs of linen breeches with their socks.

Item: Six pairs of trimmed Rouen linen breeches.

Item: Eight pairs Cordovan leather boots, six white pairs and four black, and four pairs of laced gaiters.

Item: Fourteen pairs of Cordovan leather shoes, white and black, and four pairs of boots of sole leather and buckskin.

Item: Two hats, one black, trimmed around the crown with a silver cord, with black, purple, and white feathers, and the other gray, with yellow and purple feathers.

Item: Another hat of purple taffeta with blue, purple, and yellow feathers, and trimmed with a band of gold and silver passementerie.

Item: Four pairs of spurs for long stirrups, two for short stirrups, and some Moorish spurs with tassels and cords of silk.

Item: Fifty yards of striped canvas of Michoacan bindweed for a tent, with all the appurtenances necessary for setting it up with forked stakes, and everything else belonging to it.

The said goods having been thus declared, Captain Don Luís de Velasco begged his lordship to declare them manifested. Besides the aforesaidas his lordship is aware, and, as is well known-some of his officers and soldiers are in debt to him for a large quantity of goods which they carried off when they absconded because of the delay in the expedition. With all this he came to serve his Majesty, and he will also give a report separately, presenting a petition that it be received. With this declaration he said that at present he has nothing more to manifest.

It having been examined by the señor governor, he declared that the said goods had been manifested and certified; that he had seen them; and that it is known to him that he [Captain Velasco] is taking all of them and that they are his, and that he manifested them in the City of Mexico, where he raised the standard. And he ordered that a certified copy be given him, attached to this manifest, of the requisition which his lordship made upon Francisco de Esquivel, commissary of this expedition, to the effect that he should set down all of the goods which those were taking who were going to serve his Majesty on the expedition. It was so ordered and signed by Don Juan de Oñate and passed before me, JuAn Pérez DE Donis, clerk.

As the above is evidenced and made apparent by the list in our original copy which is with the papers of the expedition and the petition of Captain Don Luís de Velasco, by order of the señor governor I issued, on four sheets of paper, the present certified copy at the spring of Santo Domingo, where is lodged a part of the army of his Majesty, on July ro, $\mathrm{x} 597$. Don Juan de Oñate. And I, Juan Pérez de Donis, royal clerk and secretary of the expedition to New Mexico, was present and here made my signature in testimony of the truth, etc.

Being at the spring of Santo Domingo in Nueva Vizcaya, on the eighth day of June, 1597 , before Señor Don Juan de Oñate, governor and captaingeneral of New Mexico and its kingdoms and provinces for the king, our Lord. . . . 
ante el Señor don Juan de oñate governador y capitan general de la nueva mexico e de sus rreynos e provincias por el rrey nuestro señor. . . .

El capitan Don luis de Velasco . . . por orden del dicho verrey me dispuse a servir a su magestad en esta jornada . . . y e Venido en prosecucion de la xornada hasta este paraje del agua de sancto domingo que dista de la dicha ciudad De mexico ciento y ochenta leguas con el campo de su magestad en cuya parte esta aloxado parte del con el teniente de general y demas cassados que Van a servir a su magestad en la dicha xornada en la qual y por La dilacion que a avido en el despacho y entrada yo e consumido todo Lo que tenia como Lo an echo todos los demas y se me a huydo La gente hurtado mucha summa de cavallos y armas y otros bienes que traya para servir a su magestad en la dicha xornada y ornato de mi persona y para que su magestad me haga merced conforme a la calidad de mi persona y a mis meritos tengo necesidad de hacer ynformacion de lo susodicho y que los testigos se examinen al tenor de este pedimento y me mande Vuestra Señoria dar un traslado dos o mas auturizados y en publica forma Juntamente con su parecer para que conste en el dicho rreal consejo de lo que digo A Vuestra Señoria pido y suplico mande que assi se haga y provea pues es Justicia que pido don LUIS DE VELASCO.

Testigos: Capitan gaspar lopez de tabora alguacil rreal del campo e jornada.

. . . que estando este testigo en la ciudad de mexico el año pasado de quinientos y noventa y seis Aviandose para venir a esta dicha xornada Vido en ella al dicho capitan don Luis de velasco que tenia como tal enarbolado Un estandarte blanco en la parroquia de sancta catalina de la dicha ciudad y en el barrio de sant Juan en las quales dos partes Vido este testigo enarbolado el dicho estandarte e hacia gente e lebantava para esta dicha xornada e tenia mucha copia de soldados y oficiales. . . .

Francisco De sosa Peñalosa alferez Real theniente de governador y capitan general De estas provincias de La nueva mexico Por el Rrey nuestro señor Por quanto don luis de velasco a servido al rrey nuestro señor mas de cinco años en esta xornada y descubrimiento de provincias De capitan de hombres de armas de a cavallo ... . siendo Uno de los primeros que se ofrecian al travajo assi en las belas y centinelas que se ofrecian forzocas como al desmontar el camino y passos no Hollados ni pisados de españoles para que pudiese pasar El dicho exercito hasta que llego a estas dichas provincias en las quales se a ocupado en compañia del dicho governador dellas en el descubrimiento y Visita que se hizo sirviendo a su magestad en todo como Leal vasallo suyo y dando grandisima aprovacion de su persona padeciendo grandes travajos y hambres en los tales descubrimientos particularmente en el que Hizo en el rrio salado y Vacas de Zivola llegando a tal estremo que comio carne de cavallo por faltar el bastimento. . . . Por la presente Le consedo y doy Lizencia al dicho capitan don luis de velasco en nombre del rrey nuestro señor para que libremente y sin contradiccion alguna pueda salir de estas dichas provincias y sacar toda su cassa muger hijos y familia a la parte y lugar que mas bien visto le fuere y pueda pedir al rrey nuestro señor y al señor viso- 
Captain Don Luís de Velasco ... By order of the viceroy I made ready to serve his Majesty on this expedition, and I have come in the prosecution of the expedition as far as this place, the spring of Santo Domingo, which is I8o leagues from the City of Mexico, with the army of his Majesty, a part of which is encamped in this place with the lieutenant-general and the rest of the married men who are going to serve his Majesty on this expedition. In this, and because of the delay which has occurred in the start and entrance, I have used up all that I had, as all the others have done, and the people ran away from me, stealing a great quantity of the horses and arms and other goods which I was bringing to serve his Majesty on the expedition and for the adornment of my person. In order that his Majesty may recompense me in conformity with the quality of my person and my merits, I am under the necessity of submitting evidence of the above. Let the witnesses be examined in compliance with this petition and let your lordship order that two or more copies, certified and in public form, together with your opinion, be given to me, so that it may be evident in the royal Council. I beg and pray that your lordship will order this to be done, for it is justice that I ask. Don Luís DE VELASCO.

Witnesses: Captain Gaspar López de Tabora, royal alguacil of the army and expedition.

.. This witness being in the City of Mexico, in the past year of 1596 , preparing to come on this expedition, saw there Captain Don Luís de Velasco, who had, as such, raised a white standard in the parish of Santa Catalina of the said city and in the suburb of San Juan, in both of which places this witness saw the said standard raised; and he raised and levied recruits for this expedition and had a great abundance of soldiers and officers.

Francisco de Sosa Peñalosa, royal alférez, lieutenant-governor and captain-general of these provinces of New Mexico, for the king, our lord; Inasmuch as Don Luís de Velasco has served the king, our lord, more than five years in this expedition and exploration of provinces as captain of cavalry troops ... . being one of the first who offered themselves for the work, in the necessary guard and sentry duties which occurred, as well as in opening the road and passes never before trod upon by Spaniard, so that the army could pass until it reached these provinces, in which work he has occupied himself in the company of their governor in the exploration and entrance which was made, serving his Majesty in all like a loyal subject and giving great proofs in his person, suffering much hardship and hunger in those explorations, especially in the one which he made on the Río Salado and Vacas de Cíbola, ${ }^{80}$ where he reached such an extremity that for lack of provisions he ate horse meat. . . .

By this writing I grant and give permission to the said Captain Don Luís de Velasco, in the name of our lord, the king, to leave these provinces, freely and without any opposition, and to take all his household, wife, children, and family to the place that best suits him ${ }^{81}$ and to ask the king, our lord, and the señor viceroy of New Spain, in his royal name, to grant 
rrey de la nueba españa en su rreal nombre Le haga La merced o mercedes que tan lleales servicios merecen ocupandole en cossas graves de yntivnidad y pesso pues en aver acudido y asistido el tiempo rreferido en esta dicha jorriada y sus provincias a cumplido con su obligacion no mobiendole otra cosa salir desta tierra si no sus estremas necesidades y no perezer de hambre sin rrecevir su magestad ningun servicio de su estada, y porque estan determinados cinco rreligiosos con licencia de su comisario de salir de estas dichas provincias y yr a las de la nueva españa por algunas causas que an alegado tocantes al servicio de dios y de su magestad y me an pedido Los dichos rreligiosos escolta por esta mando al dicho capitan don luis de velasco baya haciendo escolta a los susodichos rreligiosos con los demas compañeros que yo les señalare no desamparandolos hasta la parte y lugar que estubieren en salvo y fuera de peligro y mas conbiniere al servicio de dios y de su magestad . . . dada en este pueblo y rreal de sant gabriel de estas provincias en diez y seis dias del mes de septiembre de mill y seiscientos y Un años.

El capitan Juan de castañeda factor y behedor de la rreal hacienda e teniente de governador y capitan general de este rreyno de la nueva Vizcaya. . . . Por quanto don Juan felis dias que estava proveydo por capitan y alcalde mayor de la provincia de sancta barbola Valle de san bartolome minas de todos sanctos e su Juridicion a mucho tiempo que hizo ausencia de La dicha Juridicion dexando aquella juridicion como frontera que es de indios serranos desanparada de que seria causa sino se proveyese con brevedad persona que sirviese los dichos cargos de algun alzamiento e rruyna entre los dichos yndios atento a lo qual confiando de La de vos don luis gasco de velasco que sois tal persona que con cuydado y diligencia servireis a su magestad como lo aveis hecho en la conquista y descubrimiento de la nueva mexico haciendo oficio de capitan y caudillo de gente de a cavallo de que e sido ynformado e por la satisfacion que de Vuestra persona y balor tengo acudireis en lo que por mi os fuere Cometido e mandado en nombre de su magestad Os proveo y nombro por capitan y alcalde mayor de la dicha provincia de santa barbola, Valle de sant bartolome minas de todos santos y toda su juridicion segun y como Lo fue don Juan felis . . . .

Francisco De urdiñola governador y capitan general deste rreyno de la nueva vizcaya . . . por quanto don alonso maldonado saabedra que estava proveydo por alcalde mayor de las minas de santiago de mapemi y san lorenzo del caxco y su juridicion a cumplido el tiempo por que asi fue proveydo y combiene nombrar persona que exerza el dicho cargo y confiando de vos Don luis gasco de velasco que bien y fielmente servireis a su magestad en lo que por mi le fuere encargado como Lo aveis echo en la conquista y descubrimiento de Las provincias de la nueva mexico . . . . en compania del governador don Juan de Oñate de que tengo entera rrelacion atento a los qual en nombre de su magestad os proveo y nombro por capitan y alcalde mayor de las dichas minas . . . y terneis ${ }^{y}$ especial cuy-

y Evidently a miscopy for "tendreis". 
him the favor or favors which such loyal services merit, employing him in serious affairs of intimacy and weight. For, in having taken part during the time mentioned in this expedition and its provinces he has fulfilled his obligation, and he has no other motive in leaving this country than his extreme necessity, and in order that he may not die of hunger without his Majesty receiving any service from his stay. And, since five religious have determined, with the permission of their commissary, to leave these provinces and go to New Spain, for reasons they have alleged relating to the service of God and his Majesty, and as the said religious have asked me for an escort, for this reason I order Captain Don Luís de Velasco to go as escort to the aforesaid religious, with other companions whom I shall appoint, and not to leave them until they reach a place where they will be in safety and free from danger, which will be, moreover, for the good of the service of God and his Majesty. Issued in this town and camp of San Gabriel of these provinces, on the sixteenth day of the month of September, iбor.

Captain Juan de Castañeda, factor and overseer of the real hacienda, and lieutenant-governor and captain-general of this kingdom of Nueva Vizcaya. ... Inasmuch as Don Juan Felis Dias, who was appointed captain and alcalde mayor of the province of Santa Bárbara, valley of San Bartolomé, the mines of Todos Santos, and their district, by his long absence from the district, bordering as it does on mountain Indians, left it unprotected, and, as this will be the cause, unless some person is quickly appointed to undertake the said duties, of an uprising among the said Indians-in view of this, and being confident that you, Don Luís Gasco de Velasco, are the kind of person who will serve his Majesty with zeal and diligence, as you have already done in the campaign and exploration of New Mexico in the office of captain and chief of cavalry, of which I have been informed, and [believing], because of my confidence in your person and worth, that you will carry out what is entrusted to you by me and ordered in the name of his Majesty, I appoint and name you captain and alcalde mayor of the said province of Santa Bárbara, valley of San Bartolomé, mines of Todos Santos and all their district, as Don Juan Felis was. ...

Francisco de Urdiñola, governor and captain-general of this kingdom of Nueva Vizcaya. . . . Inasmuch as Don Alonso Maldonado Saavedra, who was appointed alcalde mayor of the mines of Santiago, of Mapimi, and San Lorenzo del Casco and their district, has completed the time for which he was so appointed, and it is necessary to name a person to exercise the said duty, and, being confident that you, Don Luís Gasco de Velasco, will well and faithfully serve his Majesty, in what you may be charged with by me, as you have done in the campaign and exploration of the provinces of New Mexico ... in the company of Governor Don Juan de Onate, of which I have complete account-in view of these things, in the name of his Majesty, I appoint and name you captain and alcalde mayor of the said mines. . . . You will take special care that the natives in your district are well treated and instructed in the articles of our holy 
dado en que los naturales de vuestra Juridicion sean bien tratados e yndustriados en las cossas de nuestra santa fee catolica y que Labren y beneficien sus cementeras a los tiempos necessarios y que no se carguen por ... contra lo dispuesto y hordenado por Su magestad ... y procurareis se castiguen los pecados publicos fechos y causados contra la magestad de dios y procurar a los Yndios naturales se aparten de sus rritos e ydolatrias y si acaso en Vuestra Juridicion tubieredes noticia de algun alzamiento Junta o rrebelion fecho entre los naturales me avisareis dello para que yo lo rremedie ....

En las minas de guanacevi de la governacion de la nueva Vizcaya a trece dias del mes de henero de mill y seiscientos y catorce años ante don gregorio de medrano capitan y alcalde mayor en ellas para su magestad. La presento $\mathrm{El}$ contenido:

El Capitan Don luis de Velasco Digo que como es publico y notorio yo fui a servir al rrey nuestro señor en el nuevo descubrimiento y conquista de las provincias del nuevo mexico por capitan de hombres de armas de a cavallo y con titulo de tesorero de La rreal hacienda en lo qual y ocupacion que tube en ellas asisti mas tiempo de cinco años Usando oficio de tal capitan y cavo de algunas compañias que el governador don Juan de Oñate me rremitio para hacer nuevos descubrimientos y conquistas de pueblos que se avian rrebelado del servicio de su magestad y en otras cosas de paz y guerra y socorros que hice al dicho exercito de bastimentos estando necesitado dellos como consta de los titulos y provisiones que para los dichos efectos se me dieron y aviendo asistido el dicho tiempo y acudido a todas mis obligaciones como leal servidor de su magestad como consta de los dichos mis titulos y Licencia Vine a este rreyno de la nueva Vizcaya con mi cassa y familia donde he rresidido mas tiempo de once años sirviendo al rrey nuestro señor En las fronteras de mapemi y en ellas Use officio de capitan y alcalde mayor y Lo propio hice en las fronteras de yndehe y provincia de sancta barbara, y el resto del dicho tiempo en estas minas de guanacevi donde asimismo e exercido El dicho oficio de Justicia y de tal capitan estando siempre apto dispuesto y aparejado con mis armas y cavallos y gente de servicio para ocurrir a servir a su magestad en las ocasiones de pas y guerra que se an Ofrecido en cuyos servicios e gastado mucha Cantidad de Hacienda y por ellos he quedado necesitado y con obligaciones de muger y hijos, y porque estoy determinado de yr a rrepresentar mis servicios al rrey nuestro señor y a sus rreales consejos y excellentissimo señor virrey de la nueva españa para que se me haga merced equivalente en rremuneracion dellos A Vuestra Magestad Pido y supplico me rreciva ynformacion sobre lo contenido en este mi pedimiento examinando Los testigos que Presente.

" Evidently a miscopy for "Presento". 
Catholic faith, and that they plant and reap their crops at the proper times, and that they be not charged for ... against what has been disposed and ordered by his Majesty . . . and you will endeavor to punish public sins committed against the majesty of God and try to separate the native Indians from their rites and idolatries. In case you have news of any uprising, gathering, or rebellion among the natives in your district, you will inform me of it so that I can remedy it. . . .

At the mines of Guanacebi in the province of Nueva Vizcaya, on the thirteenth day of the month of January, 1614, before Don Gregorio de Medrano, captain and alcalde mayor in them for his Majesty, he presented the following:

Captain Don Luís de Velasco. I declare, as is public and well known, that I went to serve our lord, the king, in the new exploration and campaign of the provinces of New Mexico, as captain of cavalry and with the title of treasurer of the real hacienda; in which occupation I was engaged there more than five years, exercising the office of captain and commander of some companies which Governor Don Juan de Oñate sent to me to discover and conquer anew towns which had rebelled against the service of his Majesty, and in other matters of peace and war and relief which I did in getting provisions needed by the said army, as appears in the patents and orders which were given me for the said purposes. Having served during the said time and fulfilled all my obligations, like a loyal servant of his Majesty, as appears from my said patents and licenses, I came to this kingdom of Nueva Vizcaya with my household and family, where I have resided more than eleven years, serving our lord, the king, on the frontiers of Mapimi. In them I exercised the office of captain and alcalde mayor, and I did the same on the frontiers of Yndehe and the province of Santa Bárbara, and the rest of the time in these mines of Guanacebi, where I have also exercised the said office of justice and of captain, being always able, ready, and prepared with my arms, horses, and servants, to proceed upon the service of your Majesty on the occasions of peace and war which have offered. In these services I have used up a great part of my fortune and on account of them have become poor, and I have a wife and children to support. And because I am determined to go to represent my services to our lord, the king, and to his loyal councils and the most excellent señor viceroy of New Spain, so that adequate relief may be granted me in remuneration for them, I beg and pray your Majesty to receive evidence from me upon the contents of this, my petition, by examining the witnesses whom I present. 
Ynformacion de officio Rescivida Por la audiencia Real de la nueva españa sobre la que dio Don fernando de Oñate sobre su calidad Meritos $Y$ servicios y de don fernando de oñate su padre y aguelos. ${ }^{a}$ [I6I2.]

En la ciudad de mexico a Veynte dias del mes de febrero de mill y seiscientos y doze años Los señores Presidente y oydores de la audiencia Real de la nueva españa dixeron que Por quanto Por don Fernando de oñate se a pedido en esta Rreal audiencia se Le rresziban formacion sobre su qualidad meritos e servicios Para ocurrir ante su magestad y su rreal consejo de las Yndias A pedir se le haga merced En rremuneracion dellos y de los de don fernando de oñate su padre de la presentacion que el dicho su padre ttuvo del habito de las hordenes mylitares o otra merced la que su magestad fuere servido y Por que conforme a su rreal çedula Esta rreal audiencia a de rrecsibir ynformacion de officio Mandavan y mandaron Se tome e rrecsiba La dicha ynformacion y Por el señor don Pedro de otalora como presidente de la dicha rreal audiencia por muerte del señor arçobispo y birrey de la dicha nueva españa nombro al Licenciado diego nuñez morquecho oydor della ante quien se haga Y Para ello hizo pareser ante ssi a todas las personas y de quien entendiere ser ynformado de la berdad y les hazer las preguntas y re-preguntas que convengan Le davan y dieron Poder y facultad que al derecho se rrequiere y hecha la dicha ynformacion al rreal acuerdo para dar sobre ello hazerla y assi lo proveyeron y mandaron Martin OSSORIO DE AGÜERO.

En la ciudad de mexico a tres dias del mes de março de mill y seiscientos y dosse años El señor Licenciado diego nuñez morquecho oydor desta rreal audiencia a quien el Real acuerdo della del veynte y dos de hebrero deste año se le cometieron Las provancas de los meritos y calidad de don Fernando de oñate el moso dixo que por quanto En la dicha rrazon su magestad a de hasser de officio ynformaçion en conformidad de lo dispuesto por Su magestad mandava e Mando que los testigos della se examinen Por las preguntas siguientes:

Primeramente si conosen el Licenciado Juan de Paz de Vallezillo fiscal de su Magestad En esta rreal Audiencia y al dicho don fernando de oñate El moço y a sus Padres y abuelos.

Yten si saven que siendo cassado y belado segun horden de la sancta madre yglesia don fernando de oñate con doña Leonor de rribadeneyra tuvo e procreo por su hijo legitimo y de legitimo matrimonio nacido y el mayor al dicho don fernando de oñate el moço criandole y alimentandole como tal y en tal e rreputacion a ssido avido y tenido y que el dicho don fernando de Oñate Padre del dicho don fernando es El Proprio que Hisso la ynformacion de Meritos por el año de quinientos y Setenta y siete que se mostrara a los testigos y que haran que se despache y enbio a la corte de su magestad Juntamente Con la que hisso de officio y parescer de esta rreal audiencia por ellos hasta agora no a conseguido merced $\mathrm{El}$ dicho don fernando digan Lo que saven $\mathrm{Y}$ si saven algo en contrario.

B A. G. I., I-4-33/2. 
Evidence officially received by the royal Audiencia of New Spain upon what was submitted by Don Fernando de Onate in regard to his character, merits, and services, and those of Don Fernando de Oñate his father, and his grandfathers. [I6I2.]

In the City of Mexico, on the twentieth day of February, I6I2, the señores president and oidores of the royal Audiencia of New Spain declared that inasmuch as it has been petitioned by Don Fernando de Oñate that evidence be received in this royal Audiencia in regard to his character, merits, and services, so that he may appear before his Majesty and his royal Council of the Indies to ask that he be granted the favor, in remuneration of his services and those presented by Don Fernando de Oñate, his father, of a knighthood in one of the military orders, or any other favor which it may please his Majesty to grant, and since, in accordance with his royal decree, this royal Audiencia has to receive evidence officially, they ordered that the said evidence should be taken and received. By the señor Don Pedro de Otalora, as president of the said royal Audiencia through the death of the señor archbishop and viceroy of the said New Spain, the licentiate Diego Núñez Morquecho was named as the oidor before whom it should be done. And for this he caused to appear before him all the persons whom he understood to be acquainted with the truth, and he was given the power and authority that the law requires to question and re-question them as might be necessary, and when the said evidence had been prepared to submit it to the royal court for its decision. And they thus provided and ordered. Martín Ossorio DE AGüEro.

In the City of Mexico, on the third day of the month of March, 1612, the señor licentiate Diego Núñez Morquecho, oidor of this royal Audiencia, to whom its royal court, on the twenty-second of February of this year, committed the taking of the proofs of the merits and character of Don Fernando de Oñate, the younger, declared that inasmuch as in the said matter his Majesty had to receive evidence officially, in accordance with what has been ordered by his Majesty, he ordered and directed that the witnesses in it should be examined by the following questions:

First, whether they know the licentiate Juan de Paz de Vallecillo, his Majesty's fiscal in this royal Audiencia, and the said Don Fernando de Oñate, the younger, and his parents and grandparents.

Item: Whether they know that Don Fernando de Oñate, being married and veiled, ${ }^{82}$ according to the order of Holy Mother Church, with Doña Leonor de Ribadeneyra, had and procreated, as his legitimate and eldest son, born of legitimate marriage, the said Don Fernando de Oñate, the younger, rearing and supporting him as such, and that common repute has held him to be such; that the said Don Fernando de Oñate, father of the said Don Fernando, is the same who presented the evidence of merits in the year I 577, which will be shown to the witnesses and will be ordered despatched and sent to the court of his Majesty together with that officially taken and judged by this royal Audiencia; and that up to the present time the said Don Fernando has not succeeded in securing any reward for 
Yten si saven que despues que el dicho don fernando de Oñate hisso La dicha informacion de meritos haviendo vacado El Corregimiento de esta ciudad de mexico gobernando El Marques de montesclaros Virrey desta Nueva españa Le eligio Por corregidor Y que usso El dicho offissio con mucha rrectitud $\mathrm{Y}$ que el dicho marques hisso En esta dicha election Por ser persona de estimacion $Y$ que don alonso de oñate hermano de el dicho don fernando En el dicho tiempo fue capitan de la guardia De el dicho Virrey y que el dicho Don fernando de oñate dio buena rresidencia de el dicho officio de corregidor digan lo que saven y si saven algo en contrario.

Yten si saben que poniendo Los ojos El dicho don Fernando de oñate El viejo En la ynportancia que tenia El descubrimiento de la nueva mexico y Servissio grande que En esto a la rreal corona se hassia aviendosse Encargado El adelantado don juan de oñate su hermano de hasser este viage a su costa y mincion $\mathrm{El}$ dicho don fernando de oñate su hermano Le ayudo $E$ hisso $E$ fue hassiendo socorro Con muy gran porcion de su hassienda En horden de que se consiguiesse El Efecto de la dicha Jornada de La dicha nueva mexico que el dia de oy ess de su magestad digan lo que saven.

Yten si saven que el dicho don Fernando de oñate es moço y es casado E velado Legitimamente Segun horden de la santa Madre Yglesia Con dispensacion con doña magdalena de mendoça su prima hija Legitima de viçente de saldibar y de doña Madalena de mendoca gente noble y de linpia Casta y generacion Sigun que assi mio, ${ }^{\mathbf{b}}$ Lo es El dicho don Fernando $Y$ hombre de gran Virtud Capacidad y entendimiento hechos grande estimacion En estos rreynos que esta es persona Venemerita en quien concurren Las qualidades necessarias Para que siendo su magestad servido de haserle qualquiera de las mercedes que el dicho don fernando de oñate su padre Pretendio $O$ Un habito de las hordenes mylitares se queden berificar En su persona por los meritos del dicho su padre y abuelos y suyos digan lo que saven.

Yten si saven que todo lo susodicho.

\section{Provanças.}

En la ciudad de mexico a quatro dias del mes de março de mill ceyscientos y doze años El señor Licenssiado diego nuñez morquecho oydor desta rreal audiencia a quyen Por el Real acuerdo della Estan Cometidas Las ynformaciones De meritos De don fernando de oñate $\mathrm{El}$ moço Para le que su merced a de hazer de officio parecer ante ssi Para testigo A lucas de lara serbantes Vesino de esta dicha ciudad del qual fue rressivido Juramento Por dios nuestro señor y la señal de la santa cruz En forma $Y$ so cargo del prometio de dessir verdad Y siendo preguntado Por en ynterrogatorio fecha de officio dixo lo siguiente:

De la primera pregunta dixo que conosce al licenciado Juan de Pas de Vallesello fiscal de su magestad En esta rreal audiencia y a don fernando de oñate El moço $\mathrm{Y}$ assimismo a don fernando de oñate y doña Leonor de rribadeneyra Su muger Legitima Padres del dicho don fernando El moço y Conosce a Cristoval de onate y doña Catalina de salazar su muger abue-

b Clearly this is a miscopy for "assimismo". 
these merits. Let them state what they know and whether they know anything to the contrary.

Item: Whether they know that after the said Don Fernando de Onate presented the said evidence of merits, the corregimiento of this City of Mexico having become vacant during the administration of the Marquis of Montesclaros, viceroy of this New Spain, he selected him as corregidor, and that he filled the said office with great rectitude, and that the said Marquis made this choice because he was a person held in high esteem; that Don Alonso de Oñate, brother of the said Don Fernando, was at the said time captain of the guard of the said viceroy; and that the said Don Fernando de Oñate gave a good account of the said office of corregidor. Let them say what they know and whether they know anything to the contrary.

Item: Whether they know that the said Don Fernando de Oñate, the elder, perceiving the importance of the exploration of New Mexico and the great service that was done to the royal crown in commissioning Governor Don Juan de Oñate, his brother, to make this expedition at his own cost and expense, assisted him and gave him help with a large part of his property, in consequence of which the purpose of the said expedition to New Mexico, which now belongs to his Majesty, was accomplished. Let them say what they know.

Item: Whether they know that the said Don Fernando is a young man, and is married and legitimately veiled, ${ }^{83}$ according to the order of Holy Mother Church, by dispensation, with Doña Magdalena de Mendoza, his cousin, legitimate daughter of Vicente de Zaldivar and Doña Magdalena de Mendoza, who are noble people of pure lineage and descent, as is also the said Don Fernando, and that he is a man of great virtue, capacity, and understanding, who is highly esteemed in these kingdoms, as a deserving person in whom are united the necessary qualities, so that, if his Majesty shall deign to grant him any of the favors that the said Don Fernando de Oñate, his father, claimed, or a knighthood in one of the military orders, the merits of his said father and grandfather, as well as his own, will be rewarded in his person. Let them state what they know.

Item: Whether they know that all the aforesaid [is the truth].

\section{Proofs.}

In the City of Mexico, on the fourth day of the month of March, I6I2, the señor licentiate Diego Núñez Morquecho, oidor of this royal Audiencia, who has been commissioned by its real acuerdo to take evidence of the merits of Don Fernando de Oñate, the younger, caused to appear before him officially as a witness Lucas de Lara Cervantes, resident of this city, who swore by our Lord God and the sign of the holy cross to speak the truth, and, being questioned by an interrogatory officially done, made the following statement:

To the first question he answered that he knows the licentiate Juan de Pas de Vallesillo, his Majesty's fiscal in this royal Audiencia, and Don Fernando de Oñate, the younger, and also Don Fernando de Oñate and Doña Leonor de Ribadeneyra, his legitimate wife, parents of the same Don Fernando the younger, and he knows Cristóbal de Oñate and Doña 
los Paternos del dicho don fernando de oñate el moço $\mathrm{Y}$ a hernando de rribadeneyra $\mathrm{E}$ doña maria de merida su muger abuelos maternos del susodicho E tiene noticia del efecto Para que se hasse esta provanca de las generales dellas y dixo que no le toca ninguna dellas y que es de hedad de mas de quarenta años.

De la segunda pregunta dixo que save vio y es verdad que el ssusodicho don fernando de oñate y doña leonor de rribadeneyra su muger son casados y Velados legitimamente E Ynfasce Eclesie Porque este testigo Los a visto hazer vida maridable $Y$ Por tales marido $E$ muger Legitimos Son avidos y tenidos Conmunmente Reputados de el dicho matrimonio a bisto que an avido y Procreado Por su hijo Legitimo y el mayor al dicho don fernando de oñate $\mathrm{El}$ moço $\mathrm{Y}$ como tal Le an criado y mantenido $\mathrm{E}$ alimentado Llamandole hijo $\mathrm{Y}$ el a los susodichos padre y madre y esto es publico E notorio E Cossa En que no se Puede tener duda y este testigo tiene noticia de estas ynformaciones que rrefiere la pregunta del tiempo En que el dicho don fernando de oñate El viejo Los hizo Por el año de quini. entos y sesenta ${ }^{\mathrm{C}} \mathrm{Y}$ siete y Por ello save que esta contenido y no a savido Este testigo ni a llegado a su noticia que aun que sea despachado a el rreal consejo de las yndias Por ellas ayan sido premiados y gratificados de los dichos servicios E meritos E si Los uvieren sido Este testigo lo supiera y no pudiera ser menos Por la mucha Comunicasion que a tenido En Cassa del dicho don fernando de oñate y esto rresponde.

De La tercera pregunta dixo que save $\mathrm{E}$ vio que despues que el dicho don fernando de oñate $\mathrm{El}$ biejo hizo La provansa de meritos Contenida En la pregunta antes desta Aviendo Vacado El corregimiento desta siudad de mexico En tiempo que gobernava esta nueva españa El marques de montesclaros birrey della Por la [ ] Satisfacion que se tuvo de la Persona del dicho don fernando de oñate El biejo E Por ser como el susodicho es de los Calificados cavalleros desta tierra El dicho birrey Le Eligio En nombre En el dicho corregimiento y este testigo Le vio Usar y exercer El dicho officio Con grande Entereça a satisfacion de toda esta rrepublica Como se berifica de la honrrada rresidencia que dio a este consejo de La qual se rremite $E$ save $E$ vio assi mesmo que en el dicho tiempo El dicho virrey Estimando La familia del dicho don fernando Por tan calificada como queda declarado Eligio E nombro Por su capitan De la guardia a don alonso de oñate Su hermano menor e tio del dicho don fernando el moço El qual dicho officio Exercio con mucha autoridad rrepresentandolo en conformidad de su mucha qualidad y esto corresponde y no save cossa en contrario.

De La quarta pregunta dixo que save $\mathrm{E}$ bio que el adelantado don juan de oñate hermano legitimo del dicho don fernando de oñate $E$ tio del dicho don fernando el moço Entro E hizo La Jornada de la conquista de la nueva mexico a su costa y myncion ayudandole E Socorriendole Para tan grandes gastos como En ello tuvo El dicho don fernando de oñate y don Cristobal de oñate sus hermanos Lo qual hissieron e manifestaron que hassian Por el servissio grande que dello Le rresultava a su magestad E save este testigo que en esto Procedio El dicho don Juan conforme a sus obligaciones

- Evidently a miscopy for “setenta”. 
Catalina de Salazar, his wife, paternal grandparents of the said Don Fernando de Oñate, the younger, and Hernando de Ribadeneyra and Doña María de Mérida, his wife, maternal grandparents of the aforesaid. $\mathrm{He}$ has been informed of the purpose for which this evidence is being taken, and declared that as to the general questions respecting competence he is nowise disqualified, ${ }^{84}$ and that he is more than forty years of age.

To the second question he answered that he knows and saw and that it is the truth that the aforesaid Don Fernando de Oñate and Doña Leonor de Ribadeneyra, his wife, are married and veiled legitimately and in fasce eclesie, $^{85}$ for this witness has seen them living in matrimony, and they have been commonly reputed and held to be legitimate husband and wife. From the said marriage it is known that they have had and procreated as their legitimate and eldest son the said Don Fernando de Oñate, the younger, and they have reared and supported and nourished him as such, calling him "son" and he calling the aforesaid "father " and "mother", and this is public and well known and is a thing of which there can be no doubt. This witness has knowledge of the evidence referred to in the question which was submitted by the said Don Fernando de Oñate, the elder, in the year I577, and he knows what was contained in it; and it has never come to the knowledge of this witness that, although it was sent to the royal Council of the Indies, there have ever come from it any rewards or remunerations for the said services and merits, for if there had been any this witness would know it without fail because of the constant intercourse he has had with the family of the said Don Fernando de Oñate. This he affirms.

To the third question he answered that he knows and saw that after the said Don Fernando de Oñate, the elder, presented the proofs of merits contained in the question before this, the corregimiento of this City of Mexico having become vacant during the time of the administration of the government of New Spain by the viceroy, Marquis of Montesclaros, ${ }^{86}$ because of his satisfaction with the character of the said Don Fernando de Oñate, the elder, and because the latter is one of the noble gentlemen of this country, the said viceroy selected him for the said corregimiento, and this witness saw him fill and exercise the said office with great integrity and to the satisfaction of all this community, as is proved by the excellent account which he made to this Council, to which reference is made. And this witness also knows and saw that at the said time the viceroy, esteeming the family of the said Don Fernando to be as worthy as has been stated, named as his captain of the guard Don Alonso de Oñate, his younger brother and uncle to the said Don Fernando, the younger, which office he filled with great credit, conducting it in conformity with his high rank. This he affirms, and knows nothing to the contrary.

To the fourth question he answered that he knows and saw that Governor Don Juan de Oñate, legitimate brother of the said Don Fernando de Oñate and uncle of the said Don Fernando, the younger, entered and made the expedition of the campaign to New Mexico at his own cost and expense, being aided and succored in the very great expenses which he incurred in it by the said Don Fernando de Oñate and Don Cristóbal de Onate, his brothers, which they did and declared that they did for the 
y que esto causo A la dicha conquista Porque este testigo Vio y Governando Esta nueva españa El Virrey Conde de monterrey ynbio A don Lope de Ulloa y a Juan de frias de salassar a Ynquirir E bisitar Si El dicho don juan cumplia con las capitulaciones y hechas Las diligencias nescesarias En rrasson de la dicha conquista El dicho don Juan La prosiguio de manera que oy dia Esta por ... . de su magestad Lo que conquisto $\mathrm{El}$ dicho don Juan de oñate $\mathrm{Y}$ esto rresponde.

De la quinta pregunta dixo que save $\mathrm{Y}$ es berdad que el dicho don fernando de oñate $E 1$ moço Ess Cassado E Belado segun horden de la santa Madre Yglesia con doña Madalena de mendoça Su prima hija legitima de Vicente de çaldibar y doña madalena de mendoça y que el dicho matrimonio se contrajo por dispensacion de su santidad y aun que este testigo no los bio cassar Por aver suscedido El dicho matrimonio fuera de esta ciudad Por aver sido Entre personas tan principales E conossidas En este rreyno $Y$ en el de la galicia Lo save este testigo $Y$ assimesmo save que el dicho bicente çaldibar $\mathrm{E}$ su mujer son tales personas calificadas como lo disse le pregunta que por serlo El dicho Vicente de saldiuvar fue teniente de capitan general de la dicha nueva galicia En tiempo del virrey don Martin Enrriquess $E$ del marques de salinas que assimesmo Lo fue desta nueva españa $E$ como dicho teniente Save este testigo que el dicho Don fernando de oñate tiene la mesma qualidad Esto Por deribacion $\mathrm{E}$ decendencia de los dichos sus padres $E$ abuelos $E$ por su Persona save $\mathrm{Y}$ a visto Este testigo que es cavallero principal de birtud y Pudencia y loables costumbres ... En su persona se Puede certificar qualquiera de las mercedes que se debian hasser al dicho don fernando de oñate su padre En virtud de los meritos y Servicios que tiene Representados En las dichas ynformaciones de meritos Por todo lo qual El dicho don fernando de oñate El moço Ess digno se le hagan Las mercedes que Presente Y Particularmente del habito de las ordenes mylitares $Y$ esto rresponde $E$ no save Cossa en contrario.

En La ciudad a ssinco dias del mes de março de mill y seiscientos $\mathrm{E}$ dosse aaños El Señor Licensiado diego nuñez mosquecho a oydor desta rreal audiencia Para la dicha Ynformacion de officio hisso Parecer ante ssi a baltasar Rrodriguez de los Rios Vessino de esta ciudad del qual fue rressibido Juramento etcetera. Y siendo preguntado Por el tenor De el dicho ynterrogatorio dixo lo siguiente:

De la primera pregunta dixo que Conosce al fiscal de su magestad desta rreal audiencia $\mathrm{Y}$ a don fernando de oñate el moço y a don fernando de oñate y doña Leonor de rribadeneyra su mujer sus Padres y Conosce a cristoval de oñate $\mathrm{E}$ doña catalina de salassar Padres del dicho don fernando $\mathrm{El}$ Viejo $\mathrm{Y}$ Conosce assimismo $\mathrm{A}$ hernando de rribadeneyra $\mathrm{E}$ doña magdalena de merida su mujer abuelos maternos del dicho don fernando e tiene noticia del efecto Para que se manda rressibir esta ynformacion de las generales de las que dixo que no le tocan ninguna dellas $\mathrm{Y}$ que es de hedad de sesenta y ssinco años.

"Elsewhere generally spelled "morquecho". 
great service that would result from it to his Majesty. And this witness knows that the said Don Juan acted in this according to his obligations, and that this brought about the said conquest; for this witness saw, while the viceroy, Count of Monterey, was governing in New Spain, that he sent Don Lope de Ulloa and Juan de Frias de Salazar to make an inquiry and inspection as to whether the said Don Juan was carrying out the articles and taking the necessary measures in the matter of the said conquest. The said Don Juan prosecuted it in such a manner that what he conquered is to-day under the dominion of his Majesty. This he affirmed.

To the fifth question he answered that he knows and it is true that the said Don Fernando de Oñate, the younger, is married and veiled, ${ }^{87}$ according to the orders of Holy Mother Church, with Doña Magdalena de Mendoza, his cousin, legitimate daughter of Vicente de Zaldivar and Doña Magdalena de Mendoza, and that the said marriage was contracted by dispensation of His Holiness, and, although this witness did not see them married, since the said marriage occurred outside of this city, yet, because it took place between persons of such high rank and so well known in this kingdom and that of Galicia, this witness knows of it. He also knows that the said Vicente Zaldivar and his wife are of such rank as the question says, for because he was such the said Vicente de Zaldívar was lieutenant-captain-general of the said New Galicia in the time of the viceroy Don Martín Enríquez, ${ }^{88}$ and of the Marquis of Salinas, ${ }^{89}$ and also in this New Spain [he filled the office] of said lieutenant. This witness knows that the said Don Fernando de Onate is of the same quality-this by derivation and descent from his said parents and grandparents and by his own character. This witness knows and has seen that he is a gentleman of high standing, and moral and discreet in his habits. . . In his person any of the favors which should have been given to the said Don Fernando de Oñate, his father, in virtue of the merits and services which he presented in the said evidence, may be confirmed. For all of this the said Don Fernando de Oñate, the younger, is worthy that the favors which he is applying for, especially that of knighthood in the military orders, shall be granted him. This he affirms and knows nothing to the contrary.

In the City [of Mexico], on the fifth day of the month of March, I6r2, the señor licentiate Diego Núñez Morquecho, oidor of this royal Audiencia, in the matter of the said evidence, officially caused to appear before him Baltasar Rodríguez de los Ríos, resident of this city, from whom the oath was received, etc., and, being questioned according to the purport of the said interrogatory, he made the following statement:

To the first question he answered that he knows his Majesty's fiscal of this royal Audiencia, and Don Fernando de Oñate, the younger, and his parents, Don Fernando de Oñate and Doña Leonor de Ribadeneyra, his wife. He knows Cristóbal de Oñate and Doña Catalina de Salazar, parents of the said Don Fernando the elder; he also knows Hernando de Ribadeneyra and Doña Magdalena de Mérida, his wife, maternal grandparents of the said Don Fernando. He has knowledge of the purpose for which this evidence has been ordered to be taken, and as to the general 
De La segunda pregunta dixo que save y es verdad que el dicho don fernando de oñate el moço es hijo legitimo de los dichos don fernando de onate y doña leonor de rribadeneyra porque hassiendo Como oy dia hasen Vida maridable En paz de la Santa madre yglesia a Visto este testigo que an Avido E procreado Por su hijo legitimo y del dicho matrimonio al dicho don fernando de oñate $\mathrm{El}$ moço e como tal Lo han tratado nombrando y alimentando y esto ess publico E notorio Publica Voss y fama $Y$ save este testigo que el dicho don fernando de oñate El biejo es el mismo que hisso las ynformaciones que rrefiere la pregunta Porque por ser tan conoscido todo este rreyno oy dello notoriedad $E$ no save Este testigo ny A llegado a su noticia que En virtud de los meritos que en las dichas ynformaciones se rrepresentan El dicho don fernando ny sus hijos ayan sido rremunerados con nynguna merced aunque se enviaron al consejo Las dichas ynformaciones y si se huviera hecho Este testigo Lo huviera sabido Por La comunycassion que con El dicho don fernando de onate a tenydo $\mathrm{Y}$ esto rresponde.

De la tercera pregunta dixo que save $\mathrm{E}$ Vio que despues de aver ffecho El dicho don fernando de oñate El biejo Las ynformaciones que contiene la pregunta que fue publico que las avia ffecho gobernando esta nueva españa Como virrey della $\mathrm{El}$ marques de montesclaros aviendo vacado $\mathrm{En}$ aquella ocasion El corregimiento desta Vecindad de mexico Por ser como El dicho don fernando Ess Persona de Calidad y de tales Partes quales para semejante officio se rrequerian $\mathrm{El}$ dicho birrey Le nombro y elixio Por tal Corregidor desta ciudad y este testigo Le vio Ussar y exercer $\mathrm{El}$ dicho officio Como buen caballero $\mathrm{E}$ rrecto juez Con mucha linpieça a satisfacion de el dicho virrey y desta rreal audiencia $E$ de toda la rrepublica segun que por la Buena rresidencia que dio constantemente A cuyo testymonio se rremite y este testigo vio que en el dicho tiempo don alonsso de oñate hermano legitimo del dicho don fernando $\mathrm{E}$ tio del dicho don fernando el moço fue capitan de la guardia del dicho birrey marques de montesclaros que tanvien lo usso con mucha autoridad a satisfacion y esto rresponde.

De la quarta pregunta Dixo que lo En ella contenido Al tiempo que el adelantado don Juan de oñate Entro a la conquista del nuevo mexico Lo entendio a este testigo assi por Publico E notorio y assi ni pone En ello duda Porque por ser cavalleros tan celossos de las cossas del augmento de la rreal corona no se puede entender de los susodichos cossa en contrario de lo que la pregunta contiene y esto rresponde.

A La quinta pregunta dixo que supuesto que el matrimonyo contraydo Entre el dicho don fernando de oñate el moço $E$ doña magdalena de mendoça Su muger que se hisso fuera desta ciudad y este testigo no lo vio Lo save por cossa publica e notoria $\mathrm{E}$ tanvien Lo de La mucha qualidad suerte de limpyeça de linage de vicente de çaldivar $\mathrm{E}$ doña madalena de mendoça mujer del dicho don ffernando de oñate $\mathrm{El}$ moço $\mathrm{El}$ qual save este testigo ques primo De La susodicha $E$ que el dicho matrimonio se contrajo Por dispensacion segun que fue publico e notorio $E$ save este testigo Por cosa cierta $\mathrm{E}$ sin duda que el dicho don fernando de oñate La calidad E linpieça que rrefiere La pregunta Porque este testigo a visto que son avidos $\mathrm{y}$ tenydos Por cavalleros notorios $\mathrm{E}$ por su persona $\mathrm{El}$ dicho don fernando 
questions respecting competence declares that he is nowise disqualified and that he is sixty-five years old.

To the second question he declared that he knows and it is true that the said Don Fernando de Oñate, the younger, is the legitimate son of the said Don Fernando de Oñate and Doña Leonor de Ribadeneyra, for, living as they are to-day in matrimony, in peace with the Holy Mother Church, this witness has seen that they have had and procreated as the legitimate son of the said marriage, the said Don Fernando de Oñate, the younger, and they have treated him as such, naming and supporting him, as is public and well known by public voice and rumor. This witness knows that the said Don Fernando de Oñate, the elder, is the same who presented the evidence referred to in the question, for through its being so well known throughout this kingdom he heard reports of it. This witness does not know, nor has it come to his knowledge that in virtue of the merits that are represented in the said evidence either the said Don Fernando or his children have been remunerated with any favor, although the said evidence was sent to the Council, for if it had been done this witness would have known it, through the intercourse he has had with the said Don Fernando de Oñate. This he affirms.

To the third question he declared that he knows and saw that after the said Don Fernando de Oñate, the elder, presented the evidence mentioned in the question-and it was publicly known that he presented it while the Marquis of Montesclaros was governing this New Spain as viceroythe corregimiento of the district of Mexico having become vacant at that time, and the said Don Fernando being a person of such character and abilities as are required for such an office, the said viceroy named and selected him as corregidor of this city, and this witness saw him fill and exercise the said office like a good gentleman and upright judge, with great rectitude and to the satisfaction of the said viceroy and this royal Audiencia and the entire community, according to the good reports that he constantly made, to which testimony reference is made. And this witness saw that at the said time Don Alonso de Oñate, legitimate brother of the said Don Fernando, and uncle of the said Don Fernando, the younger, was captain of the guard of the said viceroy, Marquis of Montesclaros, and he also filled it with much dignity and to the satisfaction of all. This he affirms.

To the fourth question he declared that what is stated in it in regard to the time when Governor Don Juan de Oñate went on the campaign to New Mexico was known to this witness as being public and well known, and he has no doubt of it, for, since the aforesaid gentlemen were very solicitous for the augmentation of the royal crown, it cannot be believed that they would do anything contrary to what the question contains. This he affirms.

To the fifth question he answered that notwithstanding the marriage contracted between the said Don Fernando de Oñate, the younger, and Doña Magdalena de Mendoza, his wife, was celebrated outside of this city and this witness did not see it, he knows it through its having been a public and well-known affair, as also the high rank and pure lineage of Vicente de Zaldívar and Doña Magdalena de Mendoza, wife of the said 
el moço a bisto que es virtuosso Prudente e de loables costumbres E Por todo lo que dicho tiene save este testigo que es digno $E$ merece que su magestad siendo servido Le haga la merced que pretende Verificandosse En su persona Lo que se debia haser al dicho su padre Por sus meritos E servicios y esto rresponde de lo que dicho tiene es verdad publico e notorio e lo ffirmo con el dicho señor oydor El Licenciado DIEGo NuñEz MoRquecho Baltasar Rodriguez de los Rios.

Ante mi Juan de quiros escrivano y Rector ${ }^{\theta}$ de La ciudad de mexico a quinze ${ }^{1}$ dias del mes de Março de mill y seisscentos y dosse años El dicho señor oydor hiso parecer ante ssi a alonso Lopez de bocanegra Provincial y Justicia mayor de la sancta hermandad En esta nueva españa del qual fue Rescibido juramento Por dios nuestro Señor E la señal de la cruz En fforma $E$ so cargo del prometio de dezir verdad y siendo Preguntado Por el dicho Ynterrogatorio dixo lo siguiente:

De la primera pregunta dixo que conosce a las Partes $E$ tiene noticia del Efecto Para que se haga esta ynformacion De las generales dixo que no le tocan ninguna dellas y que es de hedad de ssinquenta y ocho años.

De la segunda pregunta dixo que save $E$ a visto que don fernando de oñate $E 1$ biejo $E$ doña leonor de rribadeneyra Son cassados e velados Legitimamente Segun horden de la santa madre yglesia Porque este testigo Los bido desposar y que de su legitimo matrimonio an avido $\mathrm{E}$ procreado Por su hijo legitimo $Y$ el mayor al dicho don fernando de oñate $\mathrm{El}$ moço y Como tal Le an tratado $\mathrm{E}$ alimentado Llamandole hijo $\mathrm{Y}$ el a ellos Padre E madre y save este testigo que el dicho don fernando de oñate $E 1$ viejo es el mismo contenido En las ynformaciones de meritos que esta pregunta disse que se le an mostrado a este testigo Porque este testigo se acuerda de que las hisso E no save que en Virtud de ellas Se le aya fecho ninguna merced aunque se despacharon a la corte de su magestad $\mathrm{Y}$ si se le huviera ffecho alguna gratificacion Lo supiera este testigo Por ser el dicho don fernando el viejo su amigo E persona tan conoscida En este rreyno $Y$ assi La dicha merced no pudiera estar oculta y esto rresponde.

De la tercera pregunta dixo que la save y bio como aviendo ffecho El dicho don Fernando De oñate La dicha ynformacion de meritos que contiene La pregunta aviendo Vacado El corregimiento de esta ssiudad En tiempo del gobierno del birrey marques de montesclaros Por ser el dicho don fernando de oñate persona tan a proposito Para el dicho officio assi por su conoscida qualidad como por su mucho talento E capasidad El dicho birrey le elegio $E$ nombro en el dicho officio $Y$ este testigo se la vio Ussar $Y$ exerscer con grande aprobacion con mucha rrectitud Como consta de la buena rresidencia que de ello dio a que este testigo se rremedie ${ }^{\mathrm{g}}$ y en el mismo tiempo Vio este testigo que el dicho virrey dio el cargo y officio de su capitan De la guardia A don Alonso de oñate hermano Legitimo del dicho don fernando $\mathrm{E}$ tio del dicho don fernando $\mathrm{El}$ moço el qual dicho

e Evidently a miscopy for "Regidor".

¿Very likely a miscopy for "cinco".

g Very likely " rremite" was meant. 
Don Fernando de Oñate, the younger, whom the witness knows to be cousin to the aforesaid lady, and that the said marriage was contracted by dispensation, as was public and well known. This witness knows it to be a thing certain, and not to be doubted, that the said Don Fernando de Onate is of the rank and pure lineage stated in the question, for this witness has seen that they are held and regarded as well-known gentlemen; and he has seen that the said Don Fernando, the younger, in his own person is moral, discreet, and of laudable habits. From all that has been said this witness knows that he is worthy and deserving, if his Majesty please, that the favor he is asking for be granted him, confirming in his person what should have been given to his father for his merits and services. And he affirms that what he has said is true and well known to the public. $\mathrm{He}$ signed it with the said señor oidor, the licentiate DiEgo NúñEz MosqueCho, Baltasar Rodríguez de los Ríos.

Before me, Juan de Quiros, clerk and regidor of the City of Mexico, on the fifteenth ${ }^{90}$ day of the month of March, I6I2, the said señor oidor caused to appear before him Alonso López de Bocanegra, provincial and chief justice of the holy brotherhood in this New Spain, from whom was taken the oath by our Lord God and the sign of the cross, under promise to speak the truth. Being questioned by the said interrogatory, he made the following declaration:

To the first question he declared that he knows the parties and has knowledge of the purpose for which this evidence is being taken, and as to the general questions respecting competence declared that he is nowise disqualified and is sixty-eight years of age.

To the second question he declared that he knows and has seen that Don Fernando de Oñate, the elder, and Doña Leonor de Ribadeneyra are legitimately married and veiled according to the order of the Holy Mother Church, for this witness saw them married; that he knows that from their legitimate marriage they have had and procreated as their legitimate and eldest son the said Don Fernando de Oñate, the younger; and that they have treated and reared him as such, calling him "son" and he calling them "father" and "mother." And this witness knows that the said Don Fernando de Onate, the elder, is the same mentioned in the proofs of merits stated in this question, which have been shown to this witness, for this witness remembers that they were presented; he does not know that in virtue of them any favor has been granted, although they were sent to the court of his Majesty, and if any remuneration had been given this witness would know it, as the said Don Fernando, the elder, was his friend, and a person so well known in this kingdom that the said favor could not remain hidden. This he affirms.

To the third question he declared that he knows and saw how, after the said Don Fernando de Oñate had presented the said proof of merits mentioned in the question, the corregimiento of this city having become vacant in the time of the administration of the viceroy, Marquis of Montesclaros, because the said Don Fernando de Oñate was a person so suitable for the said office, not only for his known rank but also for his great talent 
officio Uso con mucha autoridad segun que para el dicho officio se rrequiere El a que por su calidad debio rrepresentar En el como tan conoscido Cavallero en este rreyno $Y$ esto rresponde.

De la quarta pregunta dixo que save $E$ vio Este testigo que el dicho adelantado Don juan de oñate fue a la Jornada de la conquysta del nuevo mexico Enpressa digna de mucha estimacion como cossa de que a su magestad rresultan tantos buenos effectos $\mathrm{E}$ siendo como la dicha Jornada fue tan costossa Por el largo tiempo que el dicho adelantado Se detuvo En la dicha conquysta a donde dexo algunas Poblaçiones a debossion y obediencia de su magestad Save este testigo que le seria forçosso assi para poder yr como Para sustentarse alla en la dicha conquysta Valerse de socorro que fue publico $\mathrm{E}$ notorio que el dicho don ffernando de oñate $\mathrm{E}$ don cristoval de oñate sus hermanos y hera ynposible sustentarse en la dicha conquysta de otra manera $Y$ assi tiene por ssierto como lo es contenido En la pregunta y esto rresponde.

A la quinta pregunta dixo que save y a visto y es berdad que el dicho don fernando de oñate $\mathrm{El}$ moço esta cassado Legitimamente segun horden de la santa madre yglesia con doña madalena de mendoça su prima hija ligitima de vicente de çaldibar y doña madalena de mendoça su mujer Personas Califficadas de linpio linaje y por tales avidos E tenidos En este rreyno $Y$ en el de la nueva galicia donde mucho tiempo el dicho vicente de çaldibar sirvio a su magestad en el officio de teniente de capitan general y el dicho matrimonio save este testigo se contrajo Entre los susodichos Por dispensassion $\mathrm{E}$ a visto que $\mathrm{Al}$ presente hasen vida maridable $\mathrm{E}$ como este testigo tiene dicho save que el dicho don fernando El moço Por deribacion $\mathrm{E}$ decendencia de los dichos sus padres Es cavallero notorio y a quien En esta nueva esspaña an estimado por tal todos Los nobles della $\mathrm{y}$ los dichos sus padres abuelos y antepassados y Por su persona save $\mathrm{E}$ a visto Este testigo que es Virtuosso hombre honrrado e conpuesto cavallero y de mucha capacidad y en quien caera muy bien qualquiera merced de las que pretende contenydas En la pregunta E no save cossa En contrario y lo que dicho tiene es verdad so cargo del dicho juramento $E$ lo firmo El dicho Señor oydor El licenciado DIEGO NUÑEZ MORQUECHO ALONSO LOPEZ DE BOCANEGRA.

En la sciudad de mexico a cinco dias del mes de março de mill y seiscientos y onze años $\mathrm{El}$ dicho Señor Licenciado diego nuñez morquecho Para la dicha informacion rrescebio Juramento del padre maestro En santa theologia Frai Juan de guzman del horden de san agustin Probincsial que a ssido de esta Provincia del santisimo nombre de Jesus Y Lo hisso in verbo saserdotis Poniendo La mano En el Pecho En forma $E$ so cargo del prometio de dessir Verdad y fue preguntado Por el dicho ynterrogatorio $E$ dijo lo siguiente:

De la primera pregunta dixo que conosce a el fiscal de su magestad de esta rreal audiencia y a don fernando de oñate $\mathrm{El}$ moço $\mathrm{E}$ a don fernando de oñate e doña leornor de rribadeneyra su muger Padres del dicho don fernando de oñate $\mathrm{E} 1$ moço $\mathrm{E}$ conosce a Cristoval de oñate e doña catalina de salazar su muger abuelos paternos de dicho don fernando de oñate el moço y a fernando de rribadeneyra $E$ doña maria de merida su muger 
and capacity, the said viceroy selected and named him for the said office, and this witness saw him fill and exercise it most acceptably and with much rectitude, as appears from the good report that he gave of it and to which this witness refers. And at the same time this witness saw that the said viceroy gave the commission and office of his captain of the guard to Alonso de Oñate, legitimate brother of the said Don Fernando, and uncle of the said Don Fernando, the younger, who filled the said office with much dignity, as it requires, and as he was able to do in his character as a gentleman so well known in this kingdom. This he affirms.

To the fourth question he declared that this witness knows and saw that the said governor, Don Juan de Oñate, went on the campaign to New Mexico-an enterprise worthy of great esteem as an affair from which many good results redounded to his Majesty. Since the said expedition was very expensive, because of the length of time that the said governor was detained in the said conquest, where he left some settlements reduced to the rule of his Majesty, this witness knows that it was necessary for him to avail himself of the help-not only to be able to go, but also to sustain himself there while on the said campaign, as was public and well known-of the said Don Fernando de Oñate and Don Cristóbal de Oñate, his brothers, and it was impossible for him to sustain himself on the said campaign in any other way, and this he knows to be true as it is stated in the question. This he affirms.

To the fifth question he declared that he knows and saw and it is true that the said Don Fernando de Oñate, the younger, is legitimately married according to the order of Holy Mother Church with Doña Magdalena de Mendoza, his cousin, legitimate daughter of Vicente de Zaldivar and Doña Magdalena de Mendoza, his wife, noble persons of pure lineage, and held and known to be such in this kingdom and in that of Nueva Galicia, where for a long time the said Vicente de Zaldivar served his Majesty in the office of lieutenant-captain-general. This marriage this witness knows was contracted between the aforesaid by dispensation, and he has seen that they are at present living in matrimony. As this witness has already said, he knows that the said Don Fernando, the younger, by derivation and descent from his said parents, is known to be a gentleman, and is esteemed as such in this New Spain, as well as his parents, grandparents, and ancestors, by all the nobles in it. This witness knows and has seen that in his person he is a virtuous man, and an honorable and serious gentleman of great ability, upon whom any one of the favors which he asks for, as stated in the question, will sit very well. He knows nothing to the contrary, and what he has declared under the said oath is true. It was signed by the said señor oidor, the licentiate Diego Núñez Morquecho. Alonso LÓPEZ DE BOCANEGRA.

In the City of Mexico, on the fifth day of the month of March, I6I I, the said señor licentiate Diego Núñez Morquecho received for the said evidence the oath from the father master in holy theology, Fray Juan de Guzmán, of the Order of Saint Augustine, formerly provincial of this province, in the sacred name of Jesus, which he gave in verbo sacerdotis, ${ }^{91}$ 
abuelos maternos del susodicho don fernando $E$ tiene noticia del efecto Para que se hace esta ynformacion.

De las generales de las dixo que no le tocan ninguna dellas y que es de hedad de cinquenta y cinco años.

De la segunda pregunta dixo que save y es berdad que el dicho don fernando de oñate El moço Es hijo legitimo E de ligitimo matrimonio de los dichos don fernando de oñate e doña leonor de rribadeneyra porque este testigo bio que siendo los susodichos cassados $\mathrm{E}$ velados segun horden de la santa madre yglesia del dicho matrimonio ovieron y Procrearon Por su hijo Legitimo y el mayor al dicho don fernando de oñate el moço $\mathrm{E}$ como a tal lo an tratado E Alimentado Llamandole hijo $\mathrm{Y}$ el a ellos Padre E. madre y en esta rreputacion e ssavido $E$ tenido sin que aya cossa En contrario $Y$ tuvo este testigo noticia de las probancas de meritos que el año passado de setenta siete En esta rreal audiencia El dicho don fernando de oñate $\mathrm{El}$ biejo las quales aunque se enviaron a la corte de su magestad con el Parecer desta rreal audiencia que assi fue publico $E$ notorio nunca despues aca a llegado a noticia deste testigo que los dichos meritos Se ayan premiado antes tiene por cierto este testigo que no se le a fecho ninguna merced al dicho don fernando Porque si se le huviere ffecho Lo supiera Este testigo Por ser mucho de su casa del dicho don fernando $\mathrm{Y}$ Por la mesma rrason save que es el contenido En las dichas Ynformaciones y esto rresponde.

De La tercera pregunta Dixo que save $E$ vio que despues de aver ffecho $\mathrm{El}$ dicho don fernando de oñate las ynformaciones de meritos contenidas En la pregunta antes de esta Aviendo Vacado El corregimiento de esta dicha ciudad de mexico El marquess de Montesclaros birrey que entonces hera desta nueva españa Poniendo los ojos En la mucha çuerte Calidad y buen del dicho don fernando de oñate Le eligio e nombro Por tal corregidor desta ciudad y este testigo Le vio Ussar y exercer El dicho officio con mucha linpieça rrectitud cristiandad Luciendo muy bien En esta rrepublica su buen nombre de que dexo loable opinion $E$ fama e supo este testigo que dio buena rresidencia de que no rresulto contra el culpa Sobre Lo qual se remite al $\operatorname{coss}^{\mathrm{h}}$ mayor della e vio este testigo que el dicho marques de montesclaros Esstimando En mucho al dicho don fernando y a todo ssus hermanos Por ser de la qualidad mas conossida deste rreyno nombro En el mismo tiempo Por su capitan de la guardia a don alonso de oñate hermano legitimo del dicho don fernando $\mathrm{El} \mathrm{moço}{ }^{1} \mathrm{El}$ qual dicho officio Le vio Ussar y exercer este testigo con la misma aprovacion y satisfacion que dicho don fernando su hermano tuvo En el suyo de corregidor y esto save.

De La quarta pregunta dixo que save $E$ vio que al tiempo $E$ qando $E$ l adelantado Don Juan de oñate hermano legitimo del dicho don fernando de oñate El biejo hizo la entrada que rrefiere la pregunta $\mathrm{A}$ la conquysta de la nueva mexico El dicho don ffernando de oñate Poniendo los ojos En su ynportancia que tenya La dicha Jornada $\mathrm{E}$ que dello avia descuta pal ${ }^{\mathrm{s}}$ servicio de su magestad como a Parescido Aviendo hecho esta entrada E

\footnotetext{
h Evidently meant as an abbreviation for "consejo".

1 This is perhaps a mistake for "viejo".

$f$ "Descuta pal" is probably a corruption for "resultado al".
} 
placing his hand on his breast and promising to speak the truth; being questioned by the said interrogatory, he made the following declaration:

To the first question he declared that he knows his Majesty's fiscal of this royal Audiencia and Don Fernando de Oñate, the younger, and Doña Leonor de Ribadeneyra, his wife, parents of the said Don Fernando de Oñate, the younger, and also Cristóbal de Oñate and Doña Catalina de Salazar, his wife, paternal grandparents of the said Don Fernando de Oñate, the younger, and Fernando de Ribadeneyra and Doña Maria de Mérida, his wife, maternal grandparents of the aforesaid Don Fernando, and he has knowledge of the purpose for which this evidence is being taken.

As to the general questions respecting competence he declared that he is nowise disqualified and that he is fifty-five years of age.

To the second question he declared that he knows and it is true that the said Don Fernando de Oñate, the younger, is the legitimate son of the legitimate marriage of the said Don Fernando de Oñate and Doña Leonor de Ribadeneyra, for this witness saw that the aforesaid persons, being married and veiled according to the order of the Holy Mother Church, had and procreated from the said marriage as their legitimate and eldest son the said Don Fernando de Oñate, the younger, and that they have treated and reared him as such, they calling him "son" and he calling them "father" and " mother," and in this repute he has always held and considered them, without anything to the contrary. And this witness had knowledge of the proofs of merits that were presented in the previous year of ' 77 , in this royal Audiencia, by the said Don Fernando de Oñate, the elder, and, although they were sent to the court of his Majesty with the opinion of this royal Audiencia, as was publicly known, it has never since come to the knowledge of this witness that the said merits have been rewarded; on the contrary this witness is certain that no favor has ever been granted to the said Don Fernando, for if it had been done this witness would know it, through his constant intercourse with the family of the said Don Fernando, and for the same reason he knows that what is stated in the said proofs is true. This he affirms.

To the third question he declared that he knows and saw that after the said Don Fernando de Oñate had presented the proofs of merits mentioned in the question, the corregimiento of this City of Mexico having become vacant previously to this, the Marquis of Montesclaros, ${ }^{92}$ then viceroy of this New Spain, observing the high lineage, character, and good abilities of the said Don Fernando de Oñate, chose and named him to be corregidor of this city. This witness saw him fill and exercise the said office with great integrity, rectitude, and Christianity, adding much lustre in this community to his name, of which he left laudable opinion and fame. This witness knew that he gave a good account, from which no blame resulted to him, in regard to which reference is made to the principal article in it. This witness saw that the said Marquis of Montesclaros, holding in great esteem the said Don Fernando and all his brothers, as being of the highest rank known in this kingdom, appointed at the same time as his captain of the guard Don Alonso de Oñate, legitimate brother of the said Don Fernando, the elder ${ }^{93}$ and this witness saw him fill and 
conquysta el dicho don Juan a ssu costa $\mathrm{E}$ mynssion Vio este testigo que el dicho don fernando de oñate el viejo Su hermano Le hisso $E$ fue hassiendo de su hassienda Particulares socorros de suerte que para Ello se Pusso En necessidad Por dar como dio con mano generossa Para los sussodicho Gran Parte de su hassienda de que rresulto lo que oy se be que rresulta mucha Gloria a dios nuestro Señor Por la ynfinidad de almas que an rrescibido El baptismo y estan a debossion y obediencia de su magestad y esto save de la pregunta.

De La quinta pregunta dixo que aunque este testigo no vio despossar al dicho don fernando de oñate el moço Con doña madalena de mendoça su prima que el dicho matrimonio ffue Por dispensacion si save este testigo que lo que en esta rrasson contiene la pregunta Ess todo berdad Porque assi Lo a entendido Por publico e notorio Y despues Save este testigo que los susodichos hazen Vida maridable y tanbien save que bicente de saldibar y doña madalena de mendoça su muger suegros del dicho don fernando El moço Son personas Prinssipales de linpio linage y Por tales Los tiene y a visto que son avidos $E$ tenydos $E$ siempre an ocupado En el servissio de su magestad y en lo que toca a la qualidad del dicho don fernando de oñate save este testigo que por deribassion $E$ descendencia de sus padres Ess cavallero notorio E de los mas Estimados Por tal de este rreyno $\mathrm{E}$ por su persona $\mathrm{El}$ dicho don fernando $\mathrm{El}$ moço a visto que es birtuosso $E$ de muy buen entendimiento de muy honrrado modo de proceder E muy Capazs Parra qualquiera merced que su magestad se sirva de hazerle berificando en su Persona La que se debia a sus abuelos E Padres y assi Cabra En el la merced que rrefiere la pregunta de Un abito de una de las hordenes militares $Y$ esto siente este testigo $E$ no cossa en contrario.

En la ciudad de mexico a seis dias del mes de março de myll y seisscientos y doze años Para la dicha Ynformacion de officio El dicho Señor Licenciado diego nuñez morquecho oydor de esta rreal audiencia rrescibio Juramento maestro En santa theologia frai diego de contreras del horden de San Augustin catedratico de propiedad de sagrada escriptura En esta rreal Unibersidad qualificador del Santo officio de la ynquission E Provinssial que a ssido de esta probincia del samto nonbre de Jesus El qual lo hizo $Y n$ berbo sacerdotis poniendo la mano en el pecho $\mathrm{E}$ so cargo del prometio de dessir berdad y siendo preguntado Por El ynterrogatorio dexolo siguiente :

A la primera pregunta dixo que conosce al dicho Juan de Paz de Vallecillo fiscal de su magestad de esta rreal audiencia $\mathrm{Y}$ a don fernando de oñate Por quien se hasse esta Probança y a don fernando de oñate $\mathrm{E}$ a dona leonor de rribadeneyra su muger Padres legitimos del susodicho $\mathrm{E}$ conosco a cristobal de oñate $\mathrm{E}$ doña catalina de salazar su muger abuelos paternos del dicho don fernando $E 1$ moço y assi my sobrino ${ }^{k}$ a hernando de rribadeneyra $E$ doña maria de merida su muger abuelos maternos del dicho donn ffernando $E$ tiene noticia del efecto Para que se haze esta ynformacion.

k Evidently a miscopy for "assimismo conosce". 
exercise the said office with the same approbation and satisfaction of all as the said Don Fernando his brother had done in his office of corregidor. This he knows.

To the fourth question he declared that he knows and saw that the time when Governor Don Juan de Oñate, legitimate brother of the said Don Fernando de Oñate, the elder, made the entrance mentioned in the question, in the campaign to New Mexico, the said Don Fernando, bearing in mind the importance of the said expedition and what would result to the service of his Majesty from it, as did in fact result when the said entrance and campaign were made by the said Don Juan at his own cost and expense, gave to his brother, as this witness saw, private aid from his own property. For this reason he fell into needy circumstances, through having given with a generous hand for the aforesaid purpose the greater part of his property. From this great glory resulted to our Lord God through the infinity of souls that have received baptism and have come under the rule of his Majesty. This he knows about the question.

To the fifth question this witness declared that although he did not see the said Don Fernando de Oñate, the younger, marry Doña Magdalena de Mendoza, his cousin, the said marriage being by dispensation, yet this witness knows that what the question states in this matter is all true, for he knew it to be so by public rumor. The witness knows that since then the aforesaid have been living in matrimony; he also knows that Vicente de Zaldívar and Doña Magdalena de Mendoza, his wife, parents-in-law of the said Don Fernando, the younger, are persons of rank and pure lineage, and he has always held them to be such and has seen that they have been regarded and held as such, and they have always been occupied in the service of his Majesty. In the matter of the rank of the said Don Fernando de Oñate, this witness knows that by derivation and descent from his parents he is known to be a gentleman, of the most highly esteemed in this kingdom, and he has seen that in his own person the said Don Fernando, the younger, is moral, of good intellect, honorable in his conduct, and very fit for any favor that his Majesty may deign to grant him, confirming in his person what was owing to his grandparents and parents, and therefore the favor mentioned in the question of a knighthood in one of the military orders will suit him very well. This the witness knows and nothing to the contrary.

In the City of Mexico, on the sixth day of the month of March, I6I2, for the purpose of the said official evidence, the said señor licentiate Diego Núñez Morquecho oidor of this royal Audiencia, took the oath from the master in sacred theology, Fray Diego de Contreras, of the Order of Saint Augustine, proprietary professor ${ }^{94}$ of the holy scriptures in this royal university, censor of the holy office of the Inquisition, and former provincial of this province, in the sacred name of Jesus, which he gave in verbo sacerdotis, ${ }^{05}$ placing his hand on his breast and promising to speak the truth. Being questioned by the interrogatory he made the following declaration:

To the first question he declared that he knows the said Juan de Paz de Vallecillo, his Majesty's fiscal of this royal Audiencia, and Don Fer- 
De las generales dellas dixo que no le toca ninguna dellas y que es de hedad de ssinquenta $E$ ssinco años Poco mas o menos.

De la segunda pregunta dixo que save y se ve que los dichos don fernando de oñate y doña leonor de rribadeneyra son cassados $E$ velados Ligitimamente segun orden de la santa madre yglesia Por que de muchos años a esta Parte Les a visto este testigo hasser vida maridable como tales marido $E$ muger Legitimos y en esta rreputacion an sido $E$ son Avidos $\mathrm{E}$ tenidos $\mathrm{E}$ comunmente rreputados $\mathrm{E}$ durante $\mathrm{El}$ dicho matrimonio Vio este testigo que huvieron y Procrearon por su hijo legitimo y el mayor al dicho don fernando de oñate El moço al qual an tratado nombrado y alimentado como a tal y el susodicho Los a rreconossido nombrado E rrespectado como a sus padres legitimos $\mathrm{Y}$ esto ess cossa Publica sin que en ello aya dubda y en lo que toca a las ynformaciones de meritos que hizo $\mathrm{El}$ dicho don fernando de oñnate $\mathrm{El}$ biejo $\mathrm{El}$ año passado de quynientos $\mathrm{E}$ setenta $\mathrm{Y}$ Siete que agora le an sido mostrados se rremute a ellas $\mathrm{E}$ tiene por ssierto ser El mismo contenido En ellas El dicho don fernando de oñate Por rreferirse En las dichas ynformaciones sus Padres a quienes este testigo Conosce como tiene dicho y esto rresponde.

De la tercera pregunta dixo que save $E$ vio y es verdad que despues de aver fecho el dicho don fernando de oñate $\mathrm{El}$ biejo Las dichas ynformaciones de meritos contenidas En la pregunta antes de esta gobernando Esta nueva españa El virrey marquess de montesclaros $E$ quedo Vaco $E 1$ corregimiento de esta ssiudad Por ser como El dicho don fernando de oñate ess Persona tan prinssipal $\mathrm{E}$ calificada como a todo este rreyno ess notorio El dicho virrey le Eligio E nombro Por coregidor Desta ciudad $\mathrm{E}$ usso y exerzo con mucha aprobassion hasta que bino $\mathrm{El}$ succesor de los rreynos de castilla que oy dia lo administra y del dicho officio dexo El dicho don fernando loable nombre fama y opinion y se rremite Este testigo al testimonyo de su buena rresidenssia que fue publico y notorio averla dado sin que della rresultasse cargo ni culpa contra el ytan bio Este testigo que el dicho birrey marquess de montesclaros nombro Por su capitan de la guardia a don alonso de oñate hermano de dicho don fernando y este testigo Le vio ussar y exercer El dicho officio de capitan de la guardia tratando su persona con $\mathrm{El}$ oman ${ }^{1}$ y descencia debida a su qualidad y esto rresponde.

De la quarta pregunta dixo que sienpre desspues que este testigo conosce al dicho don fernando de oñate El biejo y a sus hermanos a conossido dellos Particular Ynclinassion y affission De Entablarse sienpre En cossas arduas $E$ ynportantes del servicio de su magestad $E$ bien de estos rreynos En cuya consequensia vio $E$ supo Este testigo que el adelantado Don juan de oñate hermano legitimo del dicho don fernando de oñate hizo la jornada que rrefiere la pregunta a la conquysta de la nueva mexico que fue publico y notorio La hassia $\mathrm{A}$ su costa $\mathrm{E}$ minsion En que entiende este testigo Gastaria mucha suma de hasienda Por ser la Enpressa tan honrrosa ${ }^{\mathrm{m}} \mathrm{E}$ donde vio Este testigo que llebo mucho aparato de armas gente $\mathrm{E}$ bastimientos y Tiene este testigo Por cierto que el dicho don fer-

"Clearly a miscopy for "honor".

m Clearly a miscopy for "onerosa". 
nando de Oñate, for whom this evidence is being taken, and Don Fernando de Oñate and Doña Leonor de Ribadeneyra, his wife, legitimate parents of the aforesaid; he knows Cristóbal de Oñate and Doña Catalina de Salazar, his wife, paternal grandparents of the said Don Fernando, the younger, and also Fernando de Ribadeneyra and Doña Maria de Mérida, his wife, maternal grandparents of the said Don Fernando; and he has knowledge of the purpose for which this evidence is being taken.

As to the general questions respecting competence he declared that he is nowise disqualified and that he is fifty-five years of age, more or less.

To the second question he declared that he knows and has seen that the said Don Fernando de Oñate and Doña Leonor de Ribadeneyra are married and legitimately veiled according to the order of Holy Mother Church, for during many years that this witness has lived in this part he has seen them living in matrimony as legitimate husband and wife, and they have been commonly held and reputed as such. During the said marriage this witness saw that they had and procreated as their legitimate and eldest son the said Don Fernando de Oñate, the younger, whom they have treated, named, and reared as such, and the aforesaid has recognized, named, and honored them as his legitimate parents, and this is public knowledge, without possibility of doubt. In the matter of the proofs of merits presented by the said Don Fernando de Oñate, the elder, in the previous year of I 577 , which have just been shown to him, he refers to them, and is certain that the said Don Fernando de Onate mentioned in them is the same one that he knows, since his parents, whom this witness knows, as he has already said, are referred to in them. This he affirms.

To the third question he declared that he knows and saw and it is true that after the said Don Fernando de Oñate, the elder, had submitted the said proofs of merits mentioned in the question, the corregimiento of this city having become vacant before this, during the administration of the viceroy, Marquis of Montesclaros, in New Spain, and the said Don Fernando de Oñate being a person of rank and position, as is publicly known in all this kingdom, the said viceroy selected and named him as corregidor of this city, which office he filled and exercised very acceptably, until the successor, who is now administering it, came from the kingdoms of Castile. From his administration of the said office Don Fernando left a laudable name, fame, and reputation, and this witness refers to the testimony of his good report, which, as was publicly known, he rendered without any blame or charge being made against him. And this witness also saw that the said viceroy, Marquis of Montesclaros, named as his captain of the guard Don Alonso de Oñate, brother of the said Don Fernando, and this witness saw him fill and exercise the said office of captain of the guard, conducting himself with the dignity and decorum due to his position. This he affirms.

To the fourth question this witness declared that ever since he has known the said Don Fernando de Oñate, the elder, and his brothers he has observed in them a special inclination and desire always to be occupying themselves in arduous undertakings, important to the service of his Majesty and the good of these kingdoms, in consequence of which this witness saw and knew that Governor Don Juan de Oñate, legitimate 
nando de oñate su hermano como tan principal cavallero que el atendiendo En el servicio que dello rresultava a su magestad de semejante conquista ayudaria E socorreria A el dicho don Juan su hermano $Y$ este testigo save por publico E notorio que En la dicha nueva mexico en algunas Partes an rressibido Los indios Naturales de aquella tierra El santo baptismo y quedan a obediencia de su magestad y esto rresponde.

De La quinta pregunta dixo que save Por que assi es publico y notorio que el dicho don fernando de oñate el moço ess cassado $E$ belado Legitimamente con doña madalena de mendoça su prima hija legitima de bicente de çaldibar e su muger son personas Principales Porque en esta cciudad Entre la gente noble della son avidos E tenydos Por tales personas y de la qualidad que lo disse la pregunta $E$ assimysmo save este testigo que el dicho don fernando de oñate $\mathrm{El}$ moço Por deribassion $\mathrm{E}$ descendencia del dicho su padre y madre $\mathrm{E}$ abuelos es caballero notorio de los mas conoscidos deste rreyno que por tales estimado $\mathrm{El}$ y todos los susodichos $\mathrm{E}$ save assimysmo que el dicho don ffernando es caballero muy birtuosso de mucho assierto y Prudencia y sagacidad Para qualquier negossio grabe y de ynportancia Por todo lo qual save este testigo que se puede berificar En su persona La merced su magestad debia ser servido haser al dicho su padre Por sus meritos $\mathrm{E}$ qualidad y assi caera bien en su persona y con mucha aprobacion la merced del habito que rrefiere la pregunta y esto rresponde.

En La ciudad de mexico a nueve dias del mes de março de myll y seiscientos y dosse años Yo MARTIN OSSORIO DE AGÜERO esscrivano de camara del rrey nuestro Señor En su audiencia $E$ chancelleria de la nueva españa hisse sacar este traslado de la ynformacion de offissio. ${ }^{\mathrm{n}}$

Pareser de la Real audiencia de mexico sobre los meritos y servicios de don Fernando de oñate y de sus padres. ${ }^{\circ}$ [I6Iz.]

Don fernando de oñate hijo de don fernando de oñate y doña leonor de ribadeneyra pidio en esta real audiencia se le recibiese informacion de parte y oficio de los meritos y servicios de los dichos sus padres y de la legitimacion de su persona, calidad y estado, lo que tiene averiguado y probado de las informaciones hechas resultara esta audiencia le tiene por persona de las mas calificadas deste reyno y en quien con [-curren] partes y calidades para qualquier merced que Vuestra Magestad fuese servido hazerle en especial de algun officio de administracion de Justicia o real

n F. R. B., Sevilla, July I4, I9r4.

o A. G. I., I-4-33/2. 
brother of the said Don Fernando de Oñate, made the expedition referred to in the question about the campaign to New Mexico. As was publicly known, he made it at his own cost and expense, in which this witness knows that he would spend a large sum, as the undertaking was very onerous, and he took on it, as this witness saw, a great collection of arms, people, and provisions. This witness is certain that the said Don Fernando de Oñate, his brother, as a gentleman of high position, and bearing in mind the service that would result to his Majesty from such a campaign, would aid and succor the said Don Juan, his brother, and this witness knows, and it is publicly known, that in some parts of the said New Mexico the Indians native to the land have received holy baptism and have come under the rule of his Majesty. This he affirms.

To the fifth question he declared that he knows, and it is publicly known, that the said Don Fernando de Oñate, the younger, is married and legitimately veiled with Doña Magdalena de Mendoza, his cousin, legitimate daughter of Vicente de Zaldivar and his wife, who are persons of position, being held among the noble people of this city as such and as persons of the rank stated in the question. This witness also knows that the said Don Fernando de Oñate, the younger, by derivation and descent from his said father and mother and grandparents, is one of the best known gentlemen of this kingdom, and he and all the aforesaid are held to be such. He also knows that the said Don Fernando is a very moral gentleman, possessed of the necessary tact, judgment, and sagacity for any serious and important undertaking. For all of these reasons this witness knows that the favor which his Majesty should have deigned to grant to his father for his merits and rank, may be confirmed to him, and that the favor of the knighthood referred to in the question will be very fitting and appropriate to his character. This he affirms.

In the City of Mexico, on the ninth day of the month of March, 1612, I, Martín Ossorio DE Agüero, clerk of the chamber of our lord, the king, in his Audiencia and chancery of New Spain, caused this copy to be made of the official evidence.

\section{Opinion of the royal Audiencia of Mexico in regard to the merits and} services of Don Fernando de Oñate and his ancestors. [I6I2.]

Don Fernando de Oñate, son of Don Fernando de Oñate and Doña Leonor de Ribadeneyra, petitioned that evidence be received in this royal Audiencia, by command and officially, of the merits and services of his said ancestors and of the legitimacy of his person, rank, and estate. This he has verified and proved by the evidence submitted, with the result that this Audiencia holds him to be one of the most competent persons in this kingdom, in whom are united the requisite parts and qualities for any favor that your Majesty may be pleased to grant him, especially for some office of administration of justice or royal exchequer in this royal treasury 
hacienda en esta real caxa de mexico o de qualquiera de las ordenes militares a Un habito Vuestra Magestad hara la merced que quiere servido dios guarde la catolica persona de Vuestra Magestad de Mexico a I 2 de março de I6I2 años. [Firmas.]

Ynformacion de officios Recibidos En La Real audiencia de mexico sobre lo que dixo El Capitan Juan belarde colodro Sobre sus Servicios. Ba ante Su Magestad Y su real Consejo de yndias.p [I6I2-I6I4.]

En la ciudad de Mexico A nueve Dias del mes de Agosto de mill y seiscientis $Y$ dose años los Señores presidente $Y$ oydores de la audiencia Real de la nueba españa dixeron que por quanto Por parte de el cappitan Jhoan Velarde de colodro Se a fecho en esta Real audiencia informacion de parte De su calidad Meritos y servicios Para con ella ocurrir ante su magestad Y su Real consejo de yndias A supplicarle Le haga merced de que en Remuneracion dellos Se La haga de darle una pro ${ }^{q}$ alcaldia mayor o otro officio Honrroso de Justicia o lo que fuere Servido y por que conforme A lo por su magestad proveido Esta Real audiencia La ha de Resevir de officio mandaron Se tome Y Resiva La dicha ynformacion y que el Señor Llicenciado Don Pedro de otalora oydor mas antiguo y como presidente que preside en La dicha Real audiencia nombre un oydor ante quien se haga El qual nombro a el Señor Doctor Joan quesada de figueroa oydor della ante quien se haga $Y$ Resiva El qual para ello haga Pareser ante si a todas las personas de quien entendiere ser informado $\mathrm{Y}$ les haga Las preguntas y Repreguntas que sean nessesarias que para todo ello y lo de ello dependiente Le dieron poder y comission en forma qual de derecho se Requiere y fecha La dicha informacion Se trayga A el Real acuerdo para dar pareser en forma $\mathrm{Y}$ assi Lo mandaron asentar por auto MARTIN OSSORIO DE AGURTO. ${ }^{r}$

En la Ssiudad De mexico A dies y seis dias de el mes de Agosto de mill y seiscientos y doze años El señor Doctor Joan quesada de figueroa oydor de esta Real audiencia A quien por el Real acuerdo esta cometida La ynformacion de Los meritos Y servicios De el cappitan jhoan velarde colodro dixo Fue en conformidad de La çedula de su magestad Conbiene Haser La ynformacion de officio en Rason de Lo susodicho En el secreto $\mathrm{Y}$ recato que conbiene para cuyo effecto mandava y Mando que para Haser La dicha ynformacion de officio se traygan ante su mersed Los testigos que para este caso conbiene Se examinen y tiene nombrados para que con mas Justificacion se Sepa de Los meritos y serbicios de el dicho cappitan o si en Rason dello y de lo que pretende probar por su parte ay

p A. G. I., I-4-33/2. On the band around the manuscript is the following title: "Ynformacion de los servicios del capitan Juan de Velarde Colodro uno de los que fueron a conquistar el nuevo Mexico con el Capitan general Don Juan de Oñate. Mexico 9 de Agosto".-F. R. B.

q It is not clear what word these letters stand for.

$r$ Spelled elsewhere Aqüero. 
of Mexico, or for a knighthood in any one of the military orders. Your Majesty will grant the favor that pleases you. May God preserve the Catholic person of your Majesty. Mexico, March I2, I6I2. [Signatures.]

Statement of reports received in the royal Audiencia of Mexico concerning what Captain Juan Velarde Colodro said with regard to his services. This statement is to go to his Majesty and his royal Council of the Indies. ${ }^{96}$ [I6I2-I6I4.]

In the City of Mexico, on the ninth day of the month of August, I6I2, the president and oidores of the royal Audiencia of New Spain stated that, whereas there has been presented in this Audiencia a statement on the part of Captain Juan Velarde Colodro concerning his qualifications, merits, and services, wherewith to appear before his Majesty and his royal Council of the Indies to beseech that the king will be pleased, in remuneration of said services, to grant him a position, such as an alcaldía mayor or some other honorable judicial position, or whatever he may be pleased to grant ;

And whereas, conformably to his Majesty's orders, this royal Audiencia must take and receive this statement in official form:

It was ordered that the said statement should be taken and received, and that the licentiate Don Pedro de Otalora, senior oidor, should, as acting president of the royal Audiencia, name an oidor before whom the statement should be made. That official named Doctor Juan Quesada de Figueroa, oidor of the Audiencia, as the person before whom the statement should be made and received, and instructed him to cause to appear before him all persons whom he might find to be informed, and to examine and re-examine them as should be necessary. For all this, and for all matters pertaining thereto, the Audiencia gave him powers and a commission in the legally required form, and ordered him to present the statement when completed to the real acuerdo, so that formal opinion might be rendered thereon. And it was ordered that this should be recorded as an official decision.

Martín Osorio de Agurto. ${ }^{.7}$

In the City of Mexico, on the sixteenth day of the month of August, I6I2, Doctor Juan Quesada de Figueroa, oidor of this royal Audiencia, to whom is confided by the real acuerdo the taking of evidence of the merits and services of Captain Juan de Velarde Colodro, said that, in conformity with the cédula of his Majesty, it was desirable to make the official inquiry above mentioned with due secrecy and caution; for which purpose he was commanding and did command that, in order to obtain the said official statement, the witnesses whom it was desirable to examine and whom he had named should be brought before himself in order that the merits and services of the captain might be more definitely known, or whether there was anything ascertainable in this matter contrary to what he on his part proposes to prove. He also ordered that 
alguna cosa En contra $\mathrm{Y}$ assi Los testigos que asistan nombrados Se examinen por en tenor de las preguntas siguientes:

Primeramente digan de el Conocimiento de el dicho capitan Y fiscal de su magestad Si saven que en conformidad de La Cedula de su magestad para La Jornada del nuebo mexico Se nombro Por Governador y cappitan general a don Joan de onate y Conducio Jente en la provincia de Los sacatecas $\mathrm{El}$ año de quinientos $\mathrm{Y}$ noventa $\mathrm{Y}$ seis $\mathrm{Y}$ si el dicho Capitan Joan velarde colodro fue el primero que se alisto por soldado debajo de el estandarte Real y si fue a su costa llevando Jente de servicio y armas y otros pertrechos de guerra y asistio a Haser La Gente con el dicho General Y ayudo a todos Los despachos de La dicha Jornada En La qual por el camino Hasta llegar a el nuebo mexico tubo mucho travajo por ser de ynportancia su persona de Havilidad $Y$ suficiencia digan Lo que saven o si saven al contrario.

Si saven que haviendo llegado a las provincias de el nuebo mexico El dicho Governador y pacificado Los naturales dellas y Reducidolas a La obediencia De su magestad La dieron ante el dicho cappitan como Secretario Electo para el dicho effecto digan etcétera o si saven Lo contrario.

Si saven que el dicho Cappitan Asistio en la dicha conquista $Y$ pacificacion y poblacion No solo sinco años de el previlegio de la provicion de su magestad Sino otros Siete años mas Acudiendo con cuydado Y fidelidad a esplorar La tierra $E$ ynquirir Los Secretos dellas Que padecio muchos travajos digan etcétera o si saven Lo contrario.

Si saven que el dicho cappitan Con el dicho Jeneral hiso La Jornada de La mar del sur Y puerto Que tiene en que padecio Grandes travajos desnudes $Y$ Hambres con asistencia de el exercito $Y$ el proprio travojo tubo En el viaje de La gran Rancheria que dista de esta parte A otra Quatro cientas Y cinquenta Leguas $Y$ se descubrieron Los llanos De sibola fertiles de Barvaros $E$ ynfieles de que se descubrio Haver in La dicha tierra Gran Riquesa de plata y oro digan etcétera y si saven lo contrario.

Si saven que en la Refriega que se ofrecio Con los Enemigos Barbaros De la Rancheria que sin ocasion acometieron a el exercito español En su defensa $\mathrm{El}$ dicho Cappitan lo Hiso Valerosamente cobrando gran nombre y fama digan etcétera y si saven lo contrario.

$\mathrm{Si}$ saven que el dicho Cappitan fue querido $\mathrm{Y}$ estimado en el dicho Exercito español Por sus partes y sufficiencia $\mathrm{Y}$ balor $\mathrm{Y}$ tubo siempre officios de calidad $Y$ fue secretario De governacion y aconpañado De el comissario Apostolico Y tubo otras comisiones De que dio buena quenta digan etcétera $\mathrm{O}$ si saven lo contrario.

Si saven Que Haviendo servido El dicho cappitan los dichos dose años a su costa Y Bautisadose Mas de dies y ocho mill Ynfieles en que Gasto su Caudal $Y$ padecio travajos por Llebar adelante el Real servicio y anplificacion De la Real corona Y Haviendo buelto a esta provincia El dicho cappitan El virrey Marquez De salinas Le encargo La Gente de socorro que se enbio a el dicho nuebo mexico y lo llevo Por comissario della $Y$ se ocupo serca de dos años caminando mas de mill leguas digan lo que saven o si saven lo contrario. 
the witnesses named to be present should be examined in conformity with the purport of the following questions :

First, they shall tell whether they know the captain and the fiscal of his Majesty; whether they know that, in conformity with the cédula of his Majesty which ordered the expedition to New Mexico, Don Juan de Onate was named governor and captain-general, and that he led men into the province of Los Zacatecas in the year I596; whether Captain Juan Velarde Colodro was the first to enlist as a soldier under the royal standard; whether he went at his own expense, taking with him soldiers, arms, and other munitions of war; whether he took part with the general in enlisting the men; whether he aided in transmitting all the despatches during the expedition; and whether, in the performance of this duty along the road until New Mexico was reached, he was exceedingly busy for the reason that he was of importance on account of his skill and efficiency. They shall say whether they know this to be so, or whether they know to the contrary.

They shall tell whether they know that, when the governor had arrived at the provinces of New Mexico and the natives had been pacified and reduced to obedience to his Majesty, they gave their submission before the captain as secretary elected for this purpose. Let them say, et cetera, or whether they know to the contrary.

They shall say whether they know that the captain was present during the conquest, pacification, and settlement, not only during the five years which composed the term of the grant by his Majesty, but seven years in addition, during which he was at pains to explore the land faithfully and carefully and to inquire concerning the secrets of those parts, during which time he suffered many hardships. Let them tell, et cetera, or whether they know to the contrary.

Whether they know that the captain made the march with the general to the South Sea ${ }^{98}$ and the port which it has, a march upon which he suffered great hardships, nakedness, and hunger in common with the army; that he suffered the same hardships in the journey to the Gran Ranchería, ${ }^{99}$ a journey 450 leagues long, upon which were discovered the plains of the buffalos, abounding in barbarians and infidels; and that it was discovered that there was in this country great riches of silver and gold. Let them say, et cetera, or whether they know to the contrary.

Whether they know that, in the conflict with the barbarous enemies from the Ranchería, who without cause attacked the Spanish army, the captain valiantly defended the army, achieving thereby great renown and fame. Let them tell, et cetera, or whether they know to the contrary.

Whether they know that the captain was beloved and esteemed by the Spanish army for his qualities, efficiency, and valor, whether he always held positions of responsibility, was secretary of the government, adviser of the apostolic commissary, and held other commissions, in which he gave a good account of himself. Let them say, et cetera, or whether they know to the contrary.

Whether they know that the captain, having served the twelve years at his own expense-during which time more than eighteen thousand infidels were baptized-having exhausted his fortune, and endured great 
Si saven que el dicho Capitan Sea el Contenido en los titulos y Recaudos Que presenta Y si en el tiempo Que asistio En el nuebo mexico Se le gratificase sus servicios y siempre acudio en todas Las ocasiones De el servicio De su magestad con sus armas Cavallos y criados Con puntualidad Sin Perdonar travajo Ni ynclemencias de tiempo digan etcétera y si saven algo en contrario.

$\mathrm{Y}$ assi lo probeyo $\mathrm{Y}$ mando $\mathrm{El}$ dicho Señor Oydor y lo firmo el Doctor QUeSADA Ante my Bartolome Rodrigues torquemada Escrivano y Regidor.

En la Ciudad De mexico a dies Y siete Dias De el mes de Agosto de mill y seiscientos y dose años El señor Doctor Jhoan quesada de figueroa oydor de esta Real audiencia para la dicha ynformacion de officio Hiso pareser ante si a don Joan de oñate adelantado de el nuevo mexico y Governador Que a sido de aquellas provincias y de el fue Resevido Juramento y lo Hizo a dios Y a la cruz en forma de derecho y so cargo del Prometio desir Berdad y siendo preguntado por el ynterrogatorio de officio dixo lo siguiente:

A la primera pregunta dixo Que conose A el fiscal de su magestad Y A el dicho cappitan Joan Belarde Colodro.

De las preguntas Generales dixo que es de hedad De cinquenta y ocho años $Y$ las Generales no le tocan.

A la segunda pregunta Dixo que la save Como en ella se contiene Por que al tiempo que este testigo publico La dicha Xornada de el nuebo mexico En la dicha provincia De sacatecas fue el dicho Capitan Uno de los primeros que se alistaron Para la dicha Xornada debajo de el estandarte Real y que fue a su costa de el dicho cappitan llevando Cavallos Y criados y otros aderentes de guerra y Asistio a el Haser toda la Gente de la dicha Xornada En conpania deste testigo Como General della $\mathrm{Y}$ ayudo a todos los despachos della $Y$ en todo el camino Ayudo $Y$ travajo con Gran cuydado Por hombre abil $Y$ de gran fidelidad $Y$ esto es cossa muy Savida y que lo bio este testigo ocularmente $\mathrm{Y}$ esto Responde $\mathrm{Y}$ que no ay cosa en contrario.

A la terzera Pregunta Dixo que es berdad Lo contenido en esta pregunta Por que este testigo llegando de el nuevo mexico Y Redusidose a pas $\mathrm{Y}$ obediencia de su magestad los yndios de el dicho nuebo mexico dieron La obediencia en muchas Probincias y en algunas dellas fue delante de el dicho Capitan Por que este testigo Le nombro Por su secretario $Y$ le dio titulo Dello a que se Remite este testigo Y esto Responde Y no ay En contrario dello Cosa alguna.

A la quarta pregunta Dixo que save $\mathrm{Y}$ bio lo contenido En ella porque este testigo Como tal general y Governador de el dicho Nuebo mexico y por su orden mandado el dicho Capitan fue Por toda la tierra En conpania deste testigo A Pacificalla Y esploralla y saver Los secretos della En que el dicho Capitan En todo el tiempo de dose años que dise la pregunta Paso muy grandes travajos todo por ser persona cuydadossa y de confiança Para el Servicio de su magestad y esto Responde y no ay cosa En contrario.

A la quinta pregunta dixo Que este testigo save todo Lo en ella Contenido por que el dicho Cappitan fue con este testigo a las dos Xornadas 
hardships for the sake of advancing royal service and extending the power of the crown, returned to this province, whereupon the viceroy, the Marquis of Salinas, ${ }^{100}$ entrusted to him the relief expedition ${ }^{101}$ which was sent to New Mexico, which he led as commissary, occupying in this service about two years and travelling more than one thousand leagues. Let them tell what they know, or whether they know to the contrary.

Whether they know that the captain is the person described in the titles and documents which he presents, and whether, during the time he was in New Mexico, he was compensated for his services, and whether he presented himself punctually upon all occasions where required for the service of his Majesty with his arms, servants, and horses, without considering hardships or inclemency of weather. Let them tell, et cetera, or whether they know anything to the contrary.

This was the command and order of the oidor, and Doctor Quesada signed it before me.

BARTOLOMÉ Rodríguez TORQUEMADA, Notary and regidor.

In the City of Mexico, on the seventeenth day of the month of August, I6I2, Doctor Juan Quesada de Figueroa, oidor of this royal Audiencia, caused to appear before him for the preparation of the above-mentioned statement Don Juan de Oñate, adelantado of New Mexico and former governor of those provinces. The oath was received from him, he taking it before God with the sign of the cross in legal form, and promising under the obligation thereof to tell the truth. Being interrogated according to the official questionnaire, he said as follows :

To the first question he answered that he knows his Majesty's fiscal and the captain Juan Velarde Colodro. As to the general questions he declared that he is fifty-eight years old, and that he is not disqualified by the general questions.

To the second question he replied that he knows that the contents of the question are true, for when this witness announced the expedition to New Mexico in the province of Zacatecas, the captain was one of the first who enlisted for it under the royal standard; that he went at his own expense, taking with him horses, servants, and other adherents; that he helped to enlist all the men of the expedition in company with this witness, who was general of it; that he assisted in all the business of the expedition, and upon the march he aided and labored with great care, being a capable man of great trustworthiness. This is a well-known fact, of which this declarant was an eye-witness. This is his response, and there is nothing to say to the contrary.

To the third question he replied that the contents of this question are true, for when this witness had arrived in New Mexico, and the Indians thereof were reduced to peace and obedience to his Majesty, they gave their submission in many provinces, in some of them before the said captain, because this witness named him as his secretary and gave him a title as such, to which title the witness refers. This is his response, and there is nothing to say to the contrary.

To the fourth question he said that he knows and saw what is said therein, because this witness, being general and governor of New Mexico, 
que dise La pregunta Que dista la Una de la otra Las quatrocientas y cinquenta Leguas que Refiere $\mathrm{Y}$ en ellas Padescio Grandes travajos desnudes $Y$ Hanbres $Y$ en todo tubo gran balor $Y$ animo y no a desanparado Jamas a este testigo $\mathrm{Y}$ a el exercito $\mathrm{Y}$ esto saven etc.

A la sexta pregunta dixo que este testigo Como tal General y adelantado $\mathrm{Y}$ governador de el dicho nuebo mexico se hallo presente a la dicha Refriega donde bio que el dicho Cappitan Peleo balerosamente y cobro nombre de muy buen soldado y de fama Y por tal Siempre Lo tubo y estimo este testigo y esto responde etc.

A las Siete preguntas dixo que save $\mathrm{Y}$ bio lo en ella contenido por que siempre assi deste testigo como de todo El Exercito fue estimado Y querido el dicho Cappitan $Y$ assi tubo Los officios que dise La pregunta $Y$ otros de Calidad $\mathrm{Y}$ de todos dio siempre muy buena y loable quenta y satisfacion y esto responde.

A la octava pregunta dixo que este testigo save Lo Contenido en la pregunta por que Lo bio demas de que al cabo De los dose años de travajos y gastos de Hazienda que tubo $\mathrm{El}$ dicho Capitan en las dichas provincias de nuebo mexico fue enbiado Por este testigo a esta provincia de mexico por Gente de socorro Y el Señor Marquez de salinas birrey desta nueva españa Se la encargo a el dicho Cappitan Y fue por comisario della y la llevo con muy Gran cuydado travajo $Y$ solicitud $Y$ andubo mas de mill leguas De yda y buelta y tubo Gastos muy excesivos suyos propios Hasta quedar como ha quedado muy Pobre y necesitado y esto responde.

A las nuebe preguntas dixo que este testigo a bisto todos los titulos que tiene presentados $\mathrm{El}$ dicho Cappitan $\mathrm{Y}$ como quien le conose tanvien save [es blanco] que es en proprio contenido En los dichos titulos y save y bio este testigo que el dicho Capitan En todas las ocasiones De el servicio de su magestad que se ofrecieron en las dichas provincias acudio el dicho Capitan Con sus armas Y cavallo y Gente todo siempre a su costa minsion Sin que Hasta aora de los tales Servisios de el nuebo mexico Se le aya hecho merced alguna $Y$ esto responde etc. de todo lo que tiene dicho En esta pregunta ni en las demas por que si algo En contrario della Hubiera havido lo hubiera deber y saver este testigo como tal General Y Governador de las dichas provincias $\mathrm{Y}$ esto responde. Todo lo qual es la berdad y lo que save Para el Juramento que tiene fecho En lo qual Se afirmo Y Ratifico y lo bolbio A leer y lo firmo de su nombre con el dicho Señor oydor Joan quesada de figueroa El Doctor QUESADA don JoAn DE OÑATE.

Ante mi Bartolome Rodriguez torQUemada Escrivano Y Receptor.

En la dicha ciudad De mexico a Veinte y un dias De el mes de agosto de el dicho año el dicho cappitan Joan belarde Digo el dicho Señor doctor Joan quesada de figueroa oydor para la dicha ynformacion de officio Hiso Pareser ante si a Joan Rangel Vezino desta ciudad Alferes por su magestad en la Jornada de nuevo mexico que hiso don Joan de oñate y de el fue Resevido Juramento y lo hizo a dios y a la crus en forma de derecho So cargo de el qual Prometio Decir berdad y siendo preguntado por el ynterrogatorio de officio dixo lo siguiente:

A la primera pregunta dixo que conose a el fiscal de su magestad vallesiddo y a el Cappitan Joan Belarde Colodro. 
it was at his order and command that the captain went through all the land in company with this witness to pacify and explore it and to learn its secrets. In this work the captain, during all the twelve years mentioned in the question, underwent many hardships, all because he was a careful person and worthy of having his Majesty's service confided to him. This is his response, and there is nothing to say to the contrary.

To the fifth question this witness said that he knows all the contents thereof, because the captain went with this witness on the two expeditions mentioned, that they were distant one from the other the 450 leagues as stated, and that while on them the captain suffered great hardships, nakedness, and hunger, under all of which he showed great valor and spirit; that he never deserted this witness nor the army; this he knows, etc.

To the sixth question this witness said that he as such general, adelantado, and governor of New Mexico was present at the fray mentioned, in which he saw that the captain fought valorously and acquired a name as a good soldier of renown, and as such this witness always held and esteemed him. This he responds, etc.

To the seventh question he said that he knows and saw what is contained in it, for the captain was always esteemed and beloved by this witness and by the entire army; he did hold the offices mentioned in the question, as well as others of responsibility, in all of which he always gave a very good and praiseworthy account of himself. This he responds, etc.

To the eighth question this witness said that he knows the contents thereof to be true because he saw it; besides, at the end of the twelve years of hardships and expenditure of treasure on the part of the captain in the provinces of New Mexico, he was sent by this witness to this province of Mexico for a relief expedition, ${ }^{102}$ and the Marquis of Salinas, ${ }^{103}$ viceroy of this New Spain, entrusted it to the captain, and he went as commissary thereof, conducting it with great care, labor, and solicitude, travelling more than one thousand leagues in going and coming, and meeting excessive expenses with his own funds until he was left, as he is, very poor and in necessity. This he responds.

To the ninth question this witness said that he has seen all the titles which the captain has presented, and since he knows him he knows also that he is the person mentioned in the said titles; and this witness knows and saw that the captain, upon all occasions when service was needed in those provinces, by his Majesty was present with arms, horses, and men, always furnished at his own expense and maintenance, without his having received until now for such services in New Mexico any favor whatever. This he responds, etc., to all that is said in this question, and there is nothing concerning it or the other questions to be said to the contrary, for if there were, this witness would have known it as governor and general of the said provinces. This is his response. All of which is the truth and all that he knows under the oath which he has made. This he affirmed and approved, re-read, and signed with his name, together with the oidor Juan Quesada de Figueroa.

Before me, Bartolomé Rodríguez ToRQUemada.

Doctor Quesada.

Don Juan de Oñate.

Notary and secretary (receptor). 
A las generales de la ley dixo que es de hedad de treinta y seis años y que las generales no le tocan.

A la segunda Pregunta dixo que La save como en ella se contenido por que este testigo estando Haziendo la Gente para la Jornada de nuebo mexico don Joan de oñate En sacatecas En birtud de la Real cedula de su magestad bio este testigo que se alisto $\mathrm{Y}$ asento De los primeros debaxo de el estandarte Real El dicho Cappitan Joan belarde colodro y estubo a el haser toda la gente En conpania de el dicho general acudiendo En todo con cuydado y travajo y por todo el camino asta llegar a el nuebo mexico y todo a su costa armas Cavallos criados y otros aderentes de guerra y esto lo bio este testigo Por que fue En la dicha Jornada Por alferes $Y$ esto Responde de esta pregunta y no a havido cosa en contrario.

A la tersera pregunta dixo que la save por que bio que haviendose pacificado Cantidad de yndios de el nuebo mexico y venido a la obediencia La dieron delante de el dicho Capitan como Secretario Elexido Para el dicho effecto como persona de confiança y Se remite a el titulo y esto responde etc.

A la quarta pregunta dixo que este testigo bio que todo el tiempo de dose años que dise la pregunta estubo el dicho cappitan asistiendo en el dicho nuebo mexico con cuydado $\mathrm{Y}$ diligencia a todas las entradas que hubo y a explorar todas las tierras a ynquirir y saver los secretos dellos Pasando grandes travajos E ynfortunios todo En serbicio de su magestad y esto Responde etc.

A la quinta pregunta dixo que la save como en ella se contiene Por que este testigo fue a la xornada que cita la pregunta y en ella fue el dicho capitan Colodro en la qual paso grandes travajos frios $Y$ desnudes $y$ yelos que estubo todo el exercito casi ocho dias Sepultado En la nieve $Y$ tanbien fue a la entrada de la gran Rancheria que dista de la una parte a la otra mas de quatrocientas Leguas y se descubrieron los llanos de Sevola fertiles de muchos bastimentos y barbaros Y Ricas de plata y oro que fueron de gran ynportancia de bien de toda la tierra y exercito y esto responde etc.

A la sesta pregunta Dixo que la save por que este testigo bio que el dicho Capitan Joan belarde Peleo en la dicha Refriega Que cita la pregunta valerossamente cobrando Gran nombre y Reputacion de bravo soldado Por su baronil esfuerso y esto responde etc.

A la Sseptima pregunta dixo que siempre y hordinariamente bio este testigo que el dicho Capitan Colodro fue querido Y estimado de todo el exercito y General del $Y$ amado Por su afavilidad y buen entendimiento y Capasidad y asi tubo officios graves y de ynportancia y fue secretario de Govierno y aconpañado de el comisario apostolico y de todo dio buena quenta a satisfasion de todo el exercito y Religiossos y esto Responde etc.

A la octava pregunta dixo que es berdad lo que dise la pregunta por que este testigo bio que en todo El dicho tiempo de dose años que asistio y estubo En el dicho nuevo mexico el dicho capitan Colodro Se pacificaron y Bautisaron La cantidad De yndios que dise la pregunta y gasto muchos dineros Y caudal el dicho Capitan todo por que fuese adelante y se conserbase lo ganado en el Real servicio de su magestad y teniendo las dichas provincias de el nuevo mexico Nesesidad De socorro bino por El dicho 
In the City of Mexico on the twenty-first day of the month of August of the same year, Captain Juan Velarde, I should say Doctor Juan Quesada de Figueroa, oidor, caused to appear before him for the purpose of contributing to the formation of the official statement Juan Rangel, a resident of this city, and alférez of his Majesty upon the expedition to New Mexico made by Don Juan de Oñate. Oath was taken from him, which he made before God with the sign of the cross in legal form, promising under the obligation of the oath to tell the truth. Then, being questioned in conformity with the official interrogatory, he said as follows:

To the first question he said that he knows the fiscal of his Majesty, Vallesido, and the captain, Juan Velarde Colodro.

To the general legally prescribed questions respecting competence he said that he is thirty-six years of age, and that he is not disqualified by the general questions.

To the second question he said that he knows that the contents thereof are true, because this witness, being in Zacatecas when Don Juan de Oñate was enlisting the men for the expedition to New Mexico by virtue of the royal cédula of his Majesty, saw that captain Juan Velarde Colodro enlisted and was set down among the first to enlist under the royal standard, and he was present at the enlistment of all the men in company with the general, attending to everything with care and effort throughout the entire journey until arriving at New Mexico, providing at his own cost arms, horses, servants, and other armed followers. This witness says this, because he went on the expedition mentioned as alférez; and this he replies to this question, nothing to the contrary having occurred.

To the third question he said that he knows its statements to be true, because he saw that, when a number of the Indians of New Mexico had been pacified and brought to obedience, they rendered their submission before the captain as secretary chosen for that purpose because he was a trustworthy person; in confirmation of this fact he refers to the title, and this he responds, etc.

To the fourth question this witness said that he saw that, during the entire twelve years mentioned in the question, the captain participated in all the expeditions which occurred in New Mexico for the purpose of exploring all the lands and discovering their secrets; in these expeditions he underwent great hardships and misfortunes, all in the service of his Majesty. This he responds, etc.

To the fifth question he said that he knows its contents to be true, for this witness went upon the expedition mentioned in the question, and Captain Colodro went also, undergoing great hardships, cold, nakedness, and exposure, for the whole army was for nearly a week buried in the snow. The captain also went upon the expedition to the Gran Ranchería, ${ }^{104}$ a journey of more than four hundred leagues, when the fertile buffalo plains were discovered, these containing many supplies, wild Indians, and riches of gold and silver, all of which were of important benefit to all the land and to the army. This he responds, etc.

To the sixth question he said that he knows it to be true because this witness saw that Captain Juan Velarde fought valiantly in the fray men- 
Capitan Colodro y se le dio El birrey Marquess de salinas y fue a llevar la Gente de el dicho nuevo mexico por comissario Della En que se ocupo otros dos años y tubo muy gran gasto $\mathrm{Y}$ travajo por todo el camino $\mathrm{y}$ Entrego con mucho cuydado y diligencia La Gente que llebo a el dicho General y adelantado Don Joan de oñate Y se Remite a las Reales provisiones y esto responde etc.

A la novena pregunta dixo que este testigo a bisto los titulos presentados Por el dicho Capitan Colodro y assi save Y Le consta que es el contenido en ellos por que este testigo conose bien las firmas dellos y supo y bio quando se le dieron y assi sabe este testigo y bio que en todo el tiempo que tiene dicho que estubo El dicho Capitan en las dichas Provincias de nuevo mexico siempre y de hordinario asistio y sirbio En ellas y no se ofresio ocasion de el servicio de Su magestad En que dexase de Hallarse presente con sus armas y cavallos y criados andando siempre en pas y en guerra prebiniendo Lo nessesario con toda puntualidad Sin perder travajo a nada y esto responde etc.

En La ssiudad De mexico a treynta dias de el mes de Agosto de el dicho año el dicho Señor oydor para la dicha ynformacion de officio hiso pareser ante si a el capitan alonso nuñes Vessino desta sciudad etc.

A la primera pregunta dixo Que conose a los contenidos en la pregunta. y los a tratado y comunicado.

A las preguntas Generales de la ley dixo que es de hedad de treynta años poco mas o menos y Las Generales No le tocan.

A la Segunda pregunta dixo que este testigo fue por alferes Entretenido a las dichas xornadas de el nuevo mexico desde la Primera Lista que se hiso en virtud de la Cedula de su magestad por el Governador don Joan de oñate que la Gente se hiso y condusio en los Sacatecas y assi bio este testigo que de los primeros que se alistaron debaxo de el estandarte fue el dicho Capitan Joan verlarde colodro el qual asistio Personalmente a el haser la dicha Gente y a todo el avio nessesario a la dicha jornada con el dicho General Oñate en lo qual y por todo el camino asta llegar a el nuebo mexico paso grandes travajos Por que se le encargaban algunas cosas de ynportancia Por ser hombre Abil de ynportancia y confiança y esto bio y save. . . .

A la tersera pregunta dixo que este testigo bio que haviendo llegado a el nuevo mexico el capitan General don Joan de oñate con todo el exercito o parte del y pacificado cantidad de yndios Y Reducidolos a la fee luego trato de que los tales yndios Diesen la obediencia a su magestad y assi la dieron ante el dicho Cappitan colodro En todas las ocasiones que hubo como ante secretario para ello nombrado por ser hombre fiel y legal de que tubo y tiene titulo a que se Remite y esto Responde etc.

A la quarta pregunta dixo que este testigo como dicho fue por alferez entretenido a la dicha xornada y conquista De el nuevo mexico y assi en todo se hallo y bio que en toda La dicha Conquista se Hallo el dicho Cappitan No solo los Sinco años de la provicion de su magestad Sino otros siete mas acudiendo a todo con cuydado Y fidelidad ynquiriendo los Secretos de La tierra y en todo padecio Muy Grandes travajos Y esto save de la pregunta etc. 
tioned in the question, achieving great renown and reputation as a brave soldier because of his virile force. This he responds, etc.

To the seventh question this witness said that he always and habitually saw that Captain Colodro was beloved and esteemed by all the army and by the general, being beloved on account of his affability, good understanding, and capacity. For he held offices of seriousness and importance; he was secretary of the governor and legal adviser to the apostolic commissary, giving a good account of himself to the entire satisfaction of the whole army and the religious. This he responds, etc.

To the eighth question he said that the statement of the question is true, because this witness saw that in the whole time of the twelve years during which Captain Colodro was present in New Mexico, the number of Indians mentioned in the question were pacified; and the captain expended much money and treasure, all to the end that that which had been acquired in the royal service of his Majesty might be conserved and enlarged; and when the provinces of New Mexico were in need of aid, Captain Colodro came to get it, and the viceroy, the Marquis of Salinas, ${ }^{105}$ gave it to him, and he went as leader of the people who went to New Mexico, serving as commissary. In this service he was employed for another two years, during which he was at great expense and effort upon the entire journey, but he diligently and carefully turned over to the general and adelantado, Don Juan de Oñate, the people whom he led, in evidence whereof the witness refers to the royal orders; this he responds, etc.

To the ninth question this witness said that he has seen the titles presented by the said Captain Colodro, and hence he knows and is satisfied that he is the person specified in them, because this witness well knows the signatures therein, and he knew and saw when they were given; hence this witness knows and saw that during all the time specified while the captain was in the provinces of New Mexico, he was always and regularly on hand and in service in them, and there was never an occasion for service to his Majesty upon which he was not present with his arms and horses and servants, occupying himself continually, whether in peace or in war, in prearranging opportunely all that was necessary, entirely regardless of effort. This he responds, etc.

In the City of Mexico on the thirtieth day of the month of August of the year above mentioned, the oidor caused to appear before him for the purpose of contributing to the official statement Captain Alonzo Núñez, a resident of this city, etc.

To the first question he said that he is acquainted with the persons mentioned therein, and that he has had dealings and intercourse with them.

To the general legally prescribed questions respecting competence he said that he is thirty years old, somewhat more or less, and that he is not disqualified by the general questions.

To the second question this witness said that he went as prospective alférez upon the expeditions to New Mexico among those whose names were on the first list, which was made by virtue of the cédula of his Majesty by Governor Don Juan de Oñate. That the people were enlisted and led to Zacatecas, and thus this witness saw that Captain Juan Velarde 
De la quinta pregunta dixo que save lo contenido En La pregunta porque este testigo bio la xornada que el dicho general hiso asia la mar del sur en la qual fue el dicho cappitan Joan Velarde colodro y assi mismo en la jornada de la gran Rancheria que dista lo uno de lo otro quatrocientas y cinquenta leguas y se descubrieron los llanos de Cibola de gran fertilidad y probecho En todo Lo qual El dicho cappitan padesio grandes trabajos, hanbres Y desnudes Nunca Desamparando el exercito mostrando Gran balor y Paciencia en ellos $\mathrm{Y}$ lo save este testigo por havello bisto ocularmente y esto etc.

De la sexta pregunta dixo que este testigo bio que en la ocasion que dise la pregunta el dicho Cappitan Joan belarde Colodro hiso balerossos hechos mostrando Gran animo como hombre determinado y cobro Gran fama y esto save etc.

A la septima pregunta dixo Que este testigo bio que el dicho Capitan Joan Velarde por su buen proseder y Valor fue muy estimado en todo el exercito español y se lo dio muchos officios onrrosos y los que sita la pregunta como consta de sus titulos a que se Remite y siempre dio buena quenta con aprobacion de el General y de todos los españoles y esto responde etc.

De la octava pregunta dixo que despues de averse bautisado mucha cantidad de yndios Ynfieles de el dicho nuebo mexico y estado el dicho cappitan Los dichos dose años que tiene dicho y padecido Grandes travajos todo a su costa y Gastado Su Hazienda y caudal asta quedar pobre todo por llebar adelante La amplificacion de la Real corona bino el dicho Cappitan A esta ssiudad Por socorro de soldados y otras cosas y el birey Marquess de salinas Se lo dio Y Le encargo La Gente de el dicho socorro haziendolo comissario della y La llebo a el nuebo mexico que se ocupo mas de dos años dando de todo buena quenta y se Remite a el titulo que tiene presentado y esto save y a bisto etc.

De la novena pregunta dixo que este testigo a bisto los titulos que tiene presentados el dicho cappitan Joan belarde colodro y es el susodicho E1 contenido en ellos nunca en todo el tiempo que estubo en el nuevo mexico se le Gratifico sus servicios porque no hubo ocasion $Y$ nunca el dicho Cappitan dexo de acudir a todas las ocasiones de el servicio de su magestad con sus armas criados y cavallos con puntualidad Sin perdonar travajo ni ynclemencias de el tiempo y todo lo bio assi este testigo como persona que siempre asistio y estubo En toda La dicha conquista usando el officio de ayudante de sarjento mayor de el dicho exercito y esto save etc. Todo lo qual es la verdad Para el Juramento que tiene fecho etc.

En la ssiudad de mexico a seis dias del mes de septiembre de el dicho año el dicho Señor oydor para la provança de officio hiso pareser ante si a bisente de saldibar mendoça Maese de campo de la xornada de el nuevo mexico de el qual fue Resevido Juramento y lo hiso ante el dicho Señor oydor. etc.

Y Siendo preguntado Por el ynterrogatorio Dixo lo siguiente:

A la primera pregunta dixo que conose a el fiscal de su magestad y a el cappitan Colodro contenido en la pregunta. 
Colodro was among the first who enlisted under the royal standard, and that he personally participated in the enlistment of the people and the entire preparations necessary for the journey together with General Oñate. During the enlistment and throughout the entire journey until New Mexico was reached, he worked very hard, inasmuch as he was entrusted with several matters of importance because he was an able man, important and trustworthy. This he saw and knows. . . .

To the third question this witness said that he saw that after the captaingeneral, Don Juan de Oñate, had arrived in New Mexico with the whole or a part of the army, and had pacified a large number of Indians and had reduced them to the faith, he at once arranged that these Indians should render their obedience to his Majesty; this they did before Captain Colodro upon all the occasions which occurred, he having been named secretary for the purpose, because he was a faithful man and legally trained. He had and has a title whereby the office was conferred upon him, to which the witness refers. This he responds, etc.

To the fourth question this witness said that he went, as noted, as prospective alférez upon the expedition and conquest of New Mexico, and was hence present all the time, and saw that the captain was also present during the entire conquest, not only during the five years prescribed by the order of his Majesty, but seven additional years, during which he attended to everything with care and fidelity, inquiring into the secrets of the land. During all this service he endured very severe hardships. This is what he knows with respect to the question, etc.

To the fifth question he said that he knows the contents of the question to be true because this witness saw the journey which the general made toward the South Sea, ${ }^{106}$ upon which Juan Velarde Colodro went, as he also did upon the expedition to the Gran Ranchería, ${ }^{107}$ which is four hundred and fifty leagues distant, a journey upon which the very fertile and valuable buffalo plains were discovered. In all of this expedition the captain endured severe hardships, hunger, and nakedness, never neglecting the army, and displaying great valor and patience the while. This witness knows this because he saw it with his own eyes, and this, etc.

To the sixth question this witness said that he saw, upon the occasion mentioned in the question, that Captain Juan Velarde Colodro performed valiant deeds, showing great spirit as a man of determination, thereby acquiring great fame. This he knows, etc.

To the seventh question this witness said that he saw that Captain Juan Velarde, by reason of his proper procedure and valor, was much esteemed throughout the entire Spanish army, and that many posts of honor were entrusted to him, among them those mentioned in the question, as is manifest from his titles, to which the witness refers. In them all he gave a good account of himself, winning the approbation of the general and of all the Spaniards. This he responds, etc.

To the eighth question he said that after a large number of the infidel Indians of New Mexico had been baptized, and after the captain had been there the twelve years mentioned, undergoing great hardships entirely at his own cost, and had spent his estate and fortune until he was left poor, all for the purpose of carrying forward the extension of the holdings of 
A las preguntas Generales de la ley dixo que es de hedad De treynta y seis años y que no le tocan.

A la segunda pregunta dixo que lo que della save es que lo save como en ellas se contiene por que este testigo bio haser La dicha Jornada en conformidad De la cedula de su magestad de que fue por general Don Joan de oñate y este testigo por sarjento mayor y estubo a el haserse toda la Gente que fue a ella para el nuebo mexico y bio este testigo que el dicho Cappitan joan Belarde Colodro fue uno de los primeros que asento lista en la dicha jornada debaxo de el estandarte Real y acudio Con puntualidad A todo quanto este testigo y el dicho General Le ordenavan ayudando a todos los despachos nessesarios que se ofrecian En la dicha ocasion y en todo el camino asta llegar a las dichas probincias de el nuebo mexico en que tubo mucho travajo de su persona assi por acudir a su officio de tal cappitan como a las demas cossas que le encargaban como a hombre de ynportancia y esto responde etc.

A la tersera pregunta dixo que bio este testigo que Haviendo llegado todo el exercito a las dichas probincias de el nuebo mexico y Pacificadose mucha cantidad de yndios Naturales dellas Dieron La obediencia a su magestad ante el dicho Cappitan Joan Belarde colodro secretario Para ello nombrado como negocio de tanta ynportancia Sin que por ello dexase de acudir a las armas y a lo nessesario de la Guerra que se le mandaba assi Por este testigo como por el dicho general don Joan de onate y esto responde etc.

A la quarta pregunta dixo Que la save como en ella Se contenido porque este testigo bio que todo el tiempo de dose años Que dise la pregunta estubo el dicho cappitan Colodro ocupado En la dicha xornada y conquista Personalmente acudiendo con cuydado $\mathrm{Y}$ diligencia A todo lo que en la dicha guerra era de el servicio de su magestad explorando Ia tierra E ynquiriendo saver los secretos della en que bio este testigo que padecia muchos travajos y necesidades Porque tenia A cargo Saver De los asientos y Parages de los yndios de que yba Haciendo Relaciones para que lo que Hubiese $Y$ se fuese Saviendo Se abisase a Su magestad y esto responde etc.

A la quinta pregunta dixo que este testigo Supo de la Gente de el exercito La entrada que hiso el dicho capitan Colodro con el adelantado Joan de oñate En el biaxe y descubrimiento de el puerto de La mar de el sur y segun todos Dixeron de los grandes travajos que pasan fue milagro escapar hombre y en lo que toca a la Gran Rancheria este testigo fue a descubrilla con Parte de el exercito y fue en ella El dicho adelantado y el dicho Cappitan Joan belarde colodro y se descubrieron los llanos de Cebola fertiles y De Gran Cantidad de Ganado y noticias de grandissimas Riquesas en lo qual assi mismo el dicho Cappitan paso Grandes trabajos $\mathrm{E}$ ynfortunios por la mucha tierra que se andubo y frios que hiso y malos caminos y esto responde etc.

A la sesta pregunta dixo que este testigo bio Lo contenido en ella Por que estubo presente a La Refriega de los yndios de la Gran Rancheria en la qual bio este testigo que el dicho Cappitan Joan belarde Colodro lo hiso como Valerosso soldado y cobro nombre $\mathrm{Y}$ fama y esto responde.

A la Setima pregunta dixo que segun el buen modo Y Proseder de el dicho cappitan colodro todos los soldados Le querian y estimaban y tubo 
the crown, the captain came to this city for a relief party of soldiers and other things; the viceroy, the Marquis of Salinas, gave it to him and put the people of the party under his charge, making him their commissary. He led the party to New Mexico, consuming more than two years in this work, giving a good account of everything. For proof of this, reference is made to the title which he has presented. This is what the witness knows and has seen, etc.

To the ninth question this witness said that he has seen the titles which Captain Juan Velarde Colodro has presented, and that he is the person named in them. That never in all the time that he was in New Mexico did he receive any compensation for his services, for there was no opportunity; but never did the captain fail to respond punctually to the demands of his Majesty's service with his arms, servants, and horses, disregarding hardships and inclement weather. All this the witness saw, he himself having always been present during all the conquest in the capacity of adjutant [ayudante de] sargento mayor of the army. This he knows, etc.; and all the foregoing is the truth according to the oath which he has taken, etc.

In the City of Mexico on the sixth day of the month of September of the year mentioned, the oidor caused to appear before him for the purpose of testifying in this official investigation Vicente de Zaldivar Mendoza, maestre de campo of the New Mexico expedition. The oath was received from him, he taking it in the presence of the oidor, etc.

Being questioned according to the interrogatory he said as follows:

To the first question he said that he knows his Majesty's fiscal and the Captain Colodro mentioned in the question.

To the general legally prescribed questions respecting competence he said that he is thirty-six years old, and that they [the general questions] do not disqualify him.

To the second question he said that what he knows about it is that he knows the contents of the question to be true, for this witness saw the journey performed, in conformity with his Majesty's cédula, Don Juan de Oñate being general, and himself sargento mayor of the expedition. As such, this witness was present when the men who went to New Mexico were enlisted, and he saw the Captain Juan Velarde Colodro was one of the first who enlisted for the journey under the royal standard. The captain attended punctually to all which this witness and the general commanded him, assisting in all the official business which was necessary during the enlistment, as well as upon the entire journey until the provinces of New Mexico were reached. During it all he had many personal duties to attend to, in his capacity as captain and in attention to other matters confided to him as a person of importance. This he responds, etc.

To the third question this witness said that he saw that when the entire army had arrived in the provinces of New Mexico, and a great number of the Indians had been pacified, they gave their submission to his Majesty before Captain Juan Velarde Colodro, he being named secretary for the purpose because the business was so important; yet he did not for that reason fail to take part with his arms in the war or to do what was neces- 
officios de mucha honrra como fue secretario de Govierno y camara y acompañado De el comissario apostolico y otros officiales de calidad y de todos dio buena quenta Con Gran satisfacion deste testigo y de el adelantado y todo el exercito $\mathrm{Y}$ esto responde etc.

A la octava pregunta dixo que bio este testigo que el dicho cappitan Juan belarde Colodro asistio Los dose años que tiene dicho en la conquista de el nuebo mexico y en ella gasto toda su hazienda y a su costa se bautisaron cantidad de yndios Redusidos a La fee y en todo Padesio Grandes travajos todo por el acressentamiento de la Real corona y servicio de su magestad y bino a esta ssiudad Por socorro $Y$ el Señor marquess de salinas birrey Se lo dio y Hizole comissario de La Gente del dicho socorro y La llebo a el nuebo Mexico teniendo gran cuydado de que ningun Soldado hisiese mal Por los caminos En que se ocupo en benida y buelta mas de dos años $Y$ esto responde etc.

A la novena pregunta dixo que este testigo bio que el dicho cappitan Joan belarde colodro es el contenido en los titulos y Recaudos que tiene presentados el qual en todo el tiempo que estubo y asistio en el dicho nuebo mexico Siempre acudio a todo lo que se le mando y encargo y Hizo Otros muchos servicios mas de los que declara el ynterogatorio porque los bio este testigo Haser y nunca supo ni entendio que de tales Servicios Se le aya Gratificado ninguna cosa teniendo en todo gran travajo ocupacion de noche y de Dia con su persona Armas y cavallos y Criados y esto Responde todo lo qual es la berdad publico y notorio etc.

En la ssiudad de mexico a beinte y quatro dias del mes de septiembre de mill y seiscientos y dosse años el dicho Señor oydor quesada para su ynformacion de officio Hiso pareser ante ssi a un hombre que dixo llamarse Joan de mallea vessino desta ciudad y de el pueblo de culiacan Soldado que a servido a su magestad de el qual el dicho Señor oydor Rescivio Juramento.

A la primera pregunta dixo que conose a el fiscal de su magestad y a el Cappitan Joan belarde colodro.

A las preguntas Generales de la ley dixo que es de beinte y ocho y Las generales no le tocan.

A la primera ${ }^{\mathrm{s}}$ pregunta dixo que lo que della save es que este testigo bio que por el tiempo que la pregunta dise se hiso en birtud de la cedula de su magestad La xornada de el nuevo mexico y se hizo La gente en las Sacatexas donde se puso el estandarte Real debajo de el qual bio este testigo que fue uno de los primeros que se alistaron el dicho Capitan Joan belarde colodro el qual asistio a todos los despachos de la dicha Jornada assi a el Haser toda la Gente como por todo el camino y asta llegar a el nuevo mexico encargandosele a el muchas cosas Por ser hombre de ynportancia y de cuydado abilidad y Suficiencia y esto save y a bisto porque fue este testigo Por soldado en la dicha Jornada etc.

\footnotetext{
s For " segunda".
} 
sary as he was commanded by this witness as well as by the general, Don Juan de Oñate. This he responds, etc.

To the fourth question this witness said that he knows the contents of it to be true, for he saw, during all the twelve years mentioned in the question, that Captain Colodro was engaged in the expedition and conquest, and that he personally attended with care and diligence throughout the war to everything which was for the good of his Majesty's service, exploring the land and investigating its secrets; this witness saw that the captain endured many hardships and privations in this work, for it was his duty to ascertain the whereabouts of the Indians and to enter into relations with them in such manner as circumstances might direct, and to report to his Majesty from time to time as he acquired information. This he responds, etc.

To the fifth question this witness said that he had learned from the men in the army concerning the expedition which Captain Colodro made with the adelantado, Juan de Onate, on the journey of discovery to the port of the South Sea; and that, according to what they all said of the terrible hardships which they endured, it was a miracle that a single man escaped. With regard to the journey to the Gran Ranchería, this witness went upon that exploration with a part of the army, the adelantado and Captain Juan Velarde Colodro going also. They discovered the fertile buffalo plains and great numbers of herds, and they heard reports of great riches. On this journey the captain underwent great hardships and misfortunes on account of the length of the journey, the cold, and the bad roads. This he responds, etc.

To the sixth question this witness said that he saw happen that which is mentioned in the question, for he was present at the fray with the Indians of the Gran Ranchería, and saw that Captain Juan Velarde Colodro comported himself as a valorous soldier, acquiring name and fame. This he responds, etc.

To the seventh question he said that all the soldiers loved and esteemed Captain Colodro on account of his good manners and mode of procedure; he held offices of much honor, being, for instance, secretary of the government and legal adviser of the apostolic commissary. He also held other positions of importance, and gave a good account of himself in them all to the satisfaction of this witness, the adelantado, and the entire army. This he responds, etc.

To the eighth question this witness said that Captain Juan Velarde Colodro was present, as he says, during the twelve years of the conquest of New Mexico, and spent his entire fortune in it. Many Indians who had been reduced to the faith were baptized at his expense, and he endured great hardships, all for the aggrandizement of the royal crown and the service of his Majesty. He came to this city for assistance, and the viceroy, the Marquis of Salinas, gave it to him and made him commissary of the men in the relief party, which he led to New Mexico, taking great care that no soldier should do evil while on the road. On this errand the captain was engaged for two years, going and coming. This he responds, etc. 
A la tercera pregunta dixo que este testigo Bio que el dicho capitan Joan belarde fue secretario de el Governador don Joan de oñate por ser persona Abil y suficiente y de conffianssa y assi ante el dieron La obediencia todos los yndios que se pacificaron en el dicho nuevo mexico y se Redugeron a la obediencia de su magestad y este testigo responde.

A la quarta pregunta dixo que este testigo bio que el dicho cappitan colodro asistio en la dicha conquista y pacificacion del nuevo mexico casi dose años continnuos acudiendo Con cuydado $\mathrm{Y}$ fidelidad a ynquirir Los secretos de la tierra y a esplorallas en que padecio muchos travajos y calamidades y todo Gasto de su propria Hazienda y esto responde.

A la Quinta pregunta dixo que testigo Supo por cosa muy publica de todos los soldados que fueron a el descubrimiento de el puerto de la mar del sur en la qual fue el dicho Capitan Colodro con el dicho General que paso muchos travajos desnudes y anbres no desanparando el exercito y lo proprio Paso en la Jornada de la Gran Rancheria en la qual este testigo fue que dista La una de la otra Las leguas que dise la pregunta y se descubrieron Los llanos de Cibola fertiles y abundosos y de Gran Riquesa de plata y oro $Y$ esto responde etc.

A la sexta pregunta dixo que este testigo bio que en la refriega Contenida en la pregunta el dicho capitan Colodro mostro su gran animo y balor Haziendo cosa de Gran soldado en que cobro nombre de valerosso y baliente y de fama grandisima y esto responde etc.

A la septima pregunta dixo que siempre bio este testigo que el dicho cappitan Joan belarde por sus buenas partes y suficiencia Siempre fue querido y estimado de todo el exercito y por ser capas para todos tubo officios muy Graves como fue de tal secretario de Govierno y aconpañado de el comissario apostolico y de todos Los officiales bio este testigo que siempre dio buena quenta y rrason sin quexa de nadie y esto responde etc.

A la octava pregunta dixo que save este testigo que despues que el dicho capitan asistio en La dicha Conquista Los dose años que tiene dichos a Gastado gran cantidad de su hassienda y casi toda y en bautisarse mas de veinte mill ynfieles todo por llebar adelante el servicio de su magestad y anplificacion de su rreal corona bio este testigo que bino a esta ssiudad por Gente de Socorro Y La llebo a el nuebo Mexico encargandosela El Señor marquess de Salinas de que fue por cavo dellas en que travajo mucho Pasando Grandes travajos y caminando mucha cantidad de leguas y fue de grande ynportancia La Gente de el socorro que ansi llebo y metio Por que si no lo llevara se despoblara la tierra segun estaban de pobres La gente y pocos $\mathrm{Y}$ pocos $\mathrm{Y}$ apurados y esto responde etc.

A la novena pregunta dixo que este testigo conose bien a el dicho Cappitan Joan Velarde colodro dies y seis años, $Y$ sabe $Y$ a bisto Que es el contenido en los titulos que presenta $Y$ en todo el tiempo que sirvio y estubo en toda la dicha conquista de el nuevo mexico save y le consta que sirvio y estubo en toda la dicha conquista de el nuevo mexico save y le consta A este testigo no se le Gratifico sus servicios y siempre 
To the ninth question this witness said that he saw that Captain Juan Velarde Colodro is the person named in the titles and documents which he has presented, and that, during all the time while he was in New. Mexico, he always attended to whatever he was commanded to do, and that he performed many services other than those mentioned in the interrogatory, for this witness saw him perform them; and never did he learn or hear that he ever received any compensation for them, although he worked night and day with his person, arms, horses, and servants. This he responds, and it is all common and public knowledge, etc.

In the City of Mexico, on the twenty-fourth day of the month of September, I612, the oidor Quesada caused to appear before him for the purpose of contributing to the official report a man who said that his name was Juan de Mallea, that he was a resident of this city and of the town of Culiacán, and had been a soldier in his Majesty's service. The oidor received his oath.

To the first question he said that he knows his Majesty's fiscal and Captain Juan Velarde Colodro.

To the general legally prescribed questions respecting competence he said that he is twenty-eight years old, and that the general questions do not disqualify him.

To the first [second] question this witness said that what he knows concerning it is that he saw that about the time mentioned in the question the journey to New Mexico was made under authority of his Majesty's cédula, and the men were enlisted in Zacatecas, where the royal standard was placed. This witness saw that one of the first to enlist under it was Captain Juan Velarde Colodro; he attended to all the official business connected with the expedition, both that concerning the enlistment of the men and that needed on the journey until New Mexico was reached. $\mathrm{He}$ was entrusted with many affairs because he was an important man, careful, able, and efficient. This the witness knows and has seen, because he went as a soldier upon the expedition, etc.

To the third question this witness said that he saw that Captain Juan Velarde was secretary to the governor, Don Juan de Oñate, because he was an able, competent person who could be trusted, and that all the Indians who were pacified in New Mexico gave their submission before him and were reduced to obedience to his Majesty. This the witness responds, etc.

To the fourth question this witness said that he saw Captain Colodro present during the conquest and pacification of New Mexico for almost twelve continuous years, during which time he attended carefully and faithfully to inquiring into the secrets of the land by explorations in which he endured many hardships and calamities, paying his expenses entirely from his own estate. This he responds.

To the fifth question this witness said that he knew it to be common knowledge among all the soldiers who went on the discovery of the port of the South Sea, upon which Captain Colodro went with the general, that he underwent many hardships, nakedness, and hunger, but that he did not fail to care for the army. The same thing happened upon the 
acudio en todas Las ocasiones del servicio de su magestad con sus armas Y cavallos y criados y todo a su costa y Gastando su Hassienda y con Gran Riesgo de la bida y esto es cosa savida y no ay cosa en contrario y esto responde todo lo qual es La berdad etc.

emdo dicha ba la y Responde ba la.-

ba borrado quadra no bala. - $t$

En la ciudad de Mexico A dies dias del mes de mayo de mill Y seiscientos y catorze años Los Señores Presidente y oydores de gobierno Yo Juan gallegos osorio escrivano De Camara de La dicha Real audiencia Hise sacar este traslado de la dicha Ynformacion De oficio que ... se a hecho mincion de mandamiento de los dichos señores Pressidente y oydores de la dicha Real audiencia y va cierto $\mathrm{Y}$ verdadero siendo testigos Cosme de medina christoval Vicente y Juan Desquibel estantes En mexico.

Effise mi signo. En testimonio de verdad

JUAN GALLEGOS OSSORIO. ${ }^{u}$

$\mathrm{t}$ This is a series of unintelligible annotations.

u F. R. B., Sevilla, July 2, I9I4. 
journey to the Gran Ranchería, upon which this witness went, the distance being as stated in the question, at which time the fertile buffalo plains rich in gold and silver were discovered. This he responds, etc.

To the sixth question this witness said that he saw, during the fray mentioned in the question, that Captain Colodro demonstrated his great spirit and valor, showing himself to be a great soldier, acquiring a name for valor and bravery and great renown. This he responds, etc.

To the seventh question this witness said that he always saw that Captain Juan Velarde was always loved and esteemed by all the army for his excellent parts and his efficiency; and that, as he was capable of them all, he held offices of great responsibility; for instance, he was secretary of the government and legal adviser of the apostolic commissary, and this witness saw that in all these offices he gave a good account of himself, there being no complaint from anyone. This he responds, etc.

To the eighth question this witness said that he knows that after the captain had participated in the conquest for the twelve years mentioned, and had spent a great part, indeed, almost all, of his estate, in baptizing more than twenty thousand infidels, all for the purpose of advancing the service of his Majesty and the extension of the domain of the royal crown, he came to this city for men for a relief expedition, and led them to New Mexico, having been placed in their charge by the Marquis of Salinas. He went as leader of the party, enduring many hardships and travelling many leagues. The relief expedition which he led was of great importance, for if he had not taken them the land would have been laid waste, because the people in it were poor and very few and in straitened circumstances. This he responds, etc.

To the ninth question this witness said that he has known Captain Juan Velarde Colodro well for sixteen years, and knows and has seen that he is the person mentioned in the titles which he presents, and he knows that, all the time that he himself served in the conquest of New Mexico, Colodro was also there and served in it also. And this witness knows that Colodro received no compensation for his services, but that he was always present with his arms, horses, and servants whenever occasion arose in his Majesty's service, bearing all the cost himself, spending his estate and serving at great risk to his life. This is a thing well known, and there is nothing to the contrary to be said. This is his response, all of which is the truth, etc.

sent / said / it goes / and / he responds / it goes it is erased / it corresponds / it doesn't go. ${ }^{108}$

In the City of Mexico on the tenth day of the month of May, I640, the president and oidores composing the government, I, Juan Gallegos Osorio, escribano de cámara of the royal Audiencia, had this transcript made of the official statement which . . . mention has been made at command of the president and the oidores of the royal Audiencia, and it is a true and faithful [copy]. The witnesses are Cosme de Medina, Cristóbal Vicente, and JuAn DE Esquivel, residents of Mexico.

And I affixed my sign in testimony of truth.

Juan Gallegos Osorio. 


\section{Notes for Part II.}

1 Dorothy Hull, "Castaño de Sosa's Expedition to New Mexico in I59o," in Old Santa Fé, III. 307-332, is the recognized authority for this expedition. Miss Hull adduces proof to show that the expedition was not a violation of the Laws of Settlement of 1573 .

2 In the southern part of the present state of Vera Cruz.

${ }^{3}$ Cristóbal de Oñate was lieutenant-governor of Nueva Galicia at the time of the Coronado expedition to New Mexico in I540-I542. Winship, The Coronado Expedition, p. 408.

4 See Introduction, this volume, pp. I94, 206.

5 The regulations laid down for making new discoveries-referred to in the documents herein printed as the "ordinances for new settlements", but better known as the "Laws of Settlement of I573"-are found in "Ordenanzas de Su Magestad hechas para los Nuevos Descubrimientos, Conquistas, y Pacificaciones, Julio de I573," in Col. Doc. Inéd., XVI. I42-I87.

${ }^{6}$ Probably the Tarahumares Indians.

7 See above, note 5 .

8 Ibid.

9 Imperio mero mixto, the power conferred on magistrates to decide both civil and criminal cases of all grades, those punishable with death as well as the lesser kinds.N. V. S.

${ }^{10}$ See above, note 9 .

11 See above, note 5 .

12 Evidently an order for the construction of new ships for the Manila galleon service.

13 The new governor of the Philippines at that time was the Marquis of Cañete. See this volume, p. 263.

14 The west-bound Manila galleon carried bullion which was exchanged for merchandise in Manila; the latter was brought to Acapulco, New Spain, by the east-bound galleon. See W. L. Schurz, "Mexico, Peru, and the Manila Galleon", in the Hispanic American Historical Review, I. 389-402 (Nov., I918).

15 See above, note 5 .

16 The date 1599 is a miscopy.

${ }^{17}$ The regulations concerning tributes are found in the Recopilación, libros 6 and 8 .

18 Very probably reference is to the New Kingdom of Leon which had been founded a few years before by Luís de Carabajal. The standard authority on this episode is Alonso de León, Historia de Nuevo León. The book was written in 1650 but was not published until Igog.

${ }^{19}$ Immediately following this item in Oñate's original contract occurs the following:

"Item: 600 pesos worth of iron for making into tools". See this vol., p. 229.

20 Immediately following this item in the original contract occurs the following:

"Two iron-tired carts with their mules". Ibid.

21 See above, note 5 .

22 Lorenzo Suárez de Mendoza, Count of Coruña, was viceroy of New Spain from I580 until I583. Bolton, Guide to Materials for the History of the United States in the Principal Archives of Mexico, p. 469.

${ }^{23}$ Permits to go from Spain to the Indies and licenses for vessels going thereto had to be secured from the Casa de Contratación at Seville. See Bourne, Spain in America, pp. 284-285.

${ }^{24}$ The Theatines were members of a religious order founded by Pope Paul IV. when bishop of Chieti (Theate).

${ }^{25}$ Reference is made to the unauthorized expedition of Castaño de Sosa, lieutenantgovernor of Nuevo León, into New Mexico in I590. See Introduction, this volume, p. 193.

26 Reference is made to various papal bulls and treaties beginning with the papal Bull of Demarcation of I 493 and the Treaty of Tordesillas of I 494 with Portugal. 
27 Don Pedro Ponce de León offered to take with his expedition 250 colts and the same number of breeding mares (see this volume, p. 28I); the difference is evidently due to an error in copying.

28 Don Pedro offered to spend a total of 12,000 reales for articles for this purpose (see this volume, p. 28I) ; the difference here is evidently due to an error in copying.

29 An old Spanish coin worth about one-sixth of a cent.

${ }^{30} \mathrm{Cf}$. cédula of October I2, I596, this volume, p. 337.

31 Reference is evidently made to the unauthorized expedition of Bonilla and Humaña to New Mexico in I593.

32 See above, note 29.

33 Reference is to the cédula of March 29, I583. See Introduction, p. I94.

34 For the regular flota service between Spain and the Indies see Bourne, Spain in America, pp. $284 \mathrm{ff}$.

35 According to the catalogue of Spanish transcripts in the Ayer Collection of the Newberry Library, what is apparently the original letter is in A. G. I., 67-I-2.

${ }^{36}$ Reference is made to the unauthorized expedition of Francisco Leyva de Bonilla and Gutierrez de Humaña to New Mexico in I593. See Introduction, this volume, p. I94.

37 See above, note 36 .

38 Puebla de los Ángeles, capital of the present state of Puebla, and long the second most important city in New Spain.

39. Reference is probably to Diego Fernández de Serpa, governor of New Andalusia, on the north coast of South America. Having recruited several hundred soldiers and colonists in Spain he arrived at Cumaná in 1569. For further details see Moses, Spanish Dependencies, I. 43.

40 Apparently reference is to Juan Ponce de León, the discoverer and would-be colonizer of Florida. See Lowery, Spanish Settlements within the Present Limits of the United States, I5I3-I56I, pp. I46-I48.

41 The editor has been unable to find any reference to a conquistador by the name of Artieta.

${ }^{42}$ Luís de Carabajal was named governor of the New Kingdom of León, in New Spain, in 1579 and began his colonizing work there in 1583 . See Introduction, this volume, p. I8.

43 It is not clear to whom reference is here made.

44 Tilts or covers for camp wagons, which were made of native cloth or canvas of woven grasses, such as the bindweed of Michoacan.-N. V. S.

45 See above, note 38 .

46 "Penas de cámara"--fines imposed on places to be applied to the public treasury.N. V. S.

${ }_{47}$ Whenever the Audiencia formally met with the viceroy in an advisory capacity, such a meeting was called a real acuerdo.

48 Ulloa's official "Notificación" is dated Sept. 9, I596. This volume, pp. 35I-353.

${ }^{49}$ See above, note 36 .

50 See above, note 25 .

51 Cortes was created Marqués del Valle de Oaxaca in 1529, or ten years after his expedition from Cuba. See Introduction, this volume, p. 9.

52 The last, or northernmost, settlement was Santa Bárbara.

${ }^{53} \mathrm{Cf}$. royal cédula to the president of the Casa de Contratación, Burgos, June 23, I603. This volume, pp. 407-409.

54 Bolton (Spanish Exploration, p. 206) states that in Spain Zaldivar asked for 300 men as reinforcements for Oñate. The documents herein printed imply that Zaldivar only asked for 60 musketeers and professional shipbuilders and that he was authorized to recruit 40 such professionals.

55 Philip II., the predecessor of the then ruler, Philip III.

56 See above, note I7.

57 See above, note 54 .

58 The Consulado was a court appointed to try and decide cases concerning trade and navigation, the president being called prior and the members consules. The official title of the consulado of Mexico was Universidad de los Mercaderes (Priestley, op. cit., pp. 70-74). 
59 See above, note 54 .

60 Ibid.

61 See above, note 29.

62 The decree in question was issued on June 23. See preceding document.

63 See above, note 54 .

64 That is, a ship sailing alone and apart from the regular fleet, or flota.

65 See above, note 54 .

66 Ibid.

67 Ibid.

68 See above, note 54 .

${ }^{69}$ Reference is evidently to the charges filed by the colonists who abandoned New Mexico in the course of Oñate's expedition to Quivira. See Introduction, this volume, p. 212 .

70 Elsewhere the form "Donis" is found.

71 Álvaro Manrique de Zuñiga, Marquis of Villamanrique, was viceroy of New Spain from 1585 until 1590 .

$7^{2} \mathrm{~A}$ brief summary of the items composing the wardrobe of Don Luís de Velasco based upon the document printed herein for the first time, is in Bolton, Spanish Borderlands (New Haven, I92I), pp. I7I-I72.

73 This is evidently a corruption, probably of sicut sanguine innocenti.

${ }^{74}$ In ancient times this sort of short lance was a distinguishing mark of a captain.N. V. S.

75 Sacapclota: an ancient instrument for extracting balls.-N. V. S.

${ }^{76} \mathrm{It}$ was formerly the particular function of the sergeant to carry a halberd.N. V. S.

${ }^{77}$ The estradiotes (probably from the Greek word stratiotes) were a body of light cavalry, who had special equipment of their own-saddles, cushioned fore and aft, and with long stirrups, in which they rode stiff-legged.-N. V. S.

78 The bridles used by the estradiote cavalry, probably with long reins. -N. V. S.

${ }^{79}$ A la Valona: in the Walloon style, probably from the Walloons formerly employed as royal guards. $-\mathrm{N}$. V. S.

80 According to Bolton (Spanish Exploration, p. 200) the Río Salado was what is now called the Pecos; another name for the present Pecos was Río de las Vacas (op. cit., p. I89), these vacas being vacas de cíbola, or buffalos.

81 Permission for Luís de Velasco to leave New Mexico was, according to the date of the present document, granted during the absence of Oñate in Quivira. See Bolton, op. cit., p. 265.

82 It was formerly the custom to throw a veil over the bride and bridegroom at the nuptial mass.-N. V. S.

83 See above, note 82 .

84 Generales de la ley: objections made by the law to witnesses, such as minor age, friendship or relationship with the parties, enmity toward them, or personal interest in the case (Escriche).-N. V. S.

85 In fasce eclesie: probably a corruption of the Latin phrase in facie ecclesiae. 1607.

${ }^{86}$ Juan de Mendoza y Luna, Marquis of Montesclaros, was viceroy from I603 until

si See above, note 82.

88 Martín Enríquez de Almanza was viceroy from 1568 until 1580.

${ }^{89}$ Luís de Velasco, the Marquis of Salinas, was viceroy for a second term from 1607 until i6ri.

90 Very likely the "fifth" was meant.

${ }_{91}$ In verbo sacerdotis: a Latin phrase which might be freely translated as "in the words of a priest".

92 See above, note 86.

${ }_{93}$ Moco occurs where viejo evidently is meant.-N. V. S.

94 The holder of a form of endowed professorship. For details see H. I. Priestley,

"The Old University of Mexico", in University of California Chronicle, XXI. 8.

95 See above, note 9 I. 
96 On the band around the manuscript is the following title: "Statement of services of Captain Juan Velarde Colodro, one of those who went with Captain General Don Juan de Oñate. Mexico, August 9."-F. R. B.

${ }_{97}$ Spelled elsewhere Agüero. See pp. 44I, 46I.

98 Reference is to Oñate's expedition to the Gulf of California in I604-I605. Bolton, Spanish Explorations, pp. 206, 268-280.

99 Reference evidently is to Oñate's expedition to Gran Quivira in I6or. See Bolton, op. cit., pp. 205, 250-269.

100 See above, note 89 .

101 See Introduction, p. 215.

102 See Introduction, ibid.

103 See above, note 89 .

104 See above, note 99.

105 See above, note 89 .

106 See above, note 98 .

107 See above, note 99.

108 This is a series of unintelligible annotations. 



\section{INDEX.}

References are to the English text only. Bibliographical references are entered but once; they refer to the first mention, in the notes, of the work or collection referred to.

Acapulco, trouble over ships for Philippines, American Historical Review, 26n. 259-263

Acatlán, pueblo, encomienda, I22n.

Ácoma, pueblo, revolt, destroyed, 2 I I Spanish at, I93, 2 II

Adelantado, Oñate and Ponce de León and title, 212n., 237, 285, 297, 397 ; see also Governorship

Administration of estates, condition, 375

Administration of Spanish colonies, audiencia, 2I, 22; Casa de Contratación, 20; code, 20; Council of the Indies, I9; ecclesiastical, 25, 26; elements, I9; evils, I6I ; in Oñate's and Ponce de León's contracts, independence of New Mexican, 196, 197, 24I, 245. $247,267,269,27 \mathrm{I}, 287,289,309,3 \mathrm{I} 3,3 \mathrm{I} 7$, $319,325,329,333,343,405$; king, 19; local, 24 , 25 ; viceroy, 22 ; see also Officers

Aguilar, Capt. —, in Oñate's expedition, 2 ro Aguilar, Marcos de, and Cortés, 8

Agurto, Sancho López de, clerk, 59

Ahumada de Samano, Pedro de, Indian campaign, expenditures, 9I, 93

Alamán, Lucas, Méjico, 2on.

Alarcón, Hernando de, services, voyage, I2, I3,

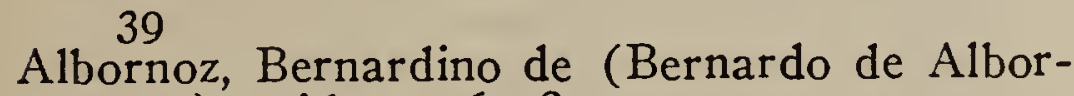
nos), evidence, 63,83

Albornoz, Rodrigo de, contador, $6 \mathrm{I}$

Alcaldes del crimen, $2 \mathrm{I}$

Alcaldes ordinarios, 25

Alcaldías mayores $y$ menores, status, 25

Alemán, Juan, report on services, 33,86

Alguacil mayor, 21 ; in Oñate's and Ponce de León's contracts, $243,287,319,331$

Almadén, migration to New Mexico, I93; temporary villa at Monclova, i 8

Almanza, Martín Enríquez de, see Enríquez de Almanza

Altamirano, Juana, wife of Torre, 8I

Altamirano, Doña Petronilla, 8I

Altamirano Saavedra, Juan, services, 8I

Alvarado, Hernando de, report on services, 39

Alvarado, Juan de, Mixton war, 43

Alvarado, Juan Sánchez de, 39

Alvarado, Leonor de, wife of Dávila, 35

Alvarado, Pedro de, and South Sea exploration, Mendoza partnership, I2, I3; governorship, 8; in Grijalva's expedition, 5; in southern Mexico, 7 ; Mixton war, killed, I3, 43, 45; return to Honduras, 43, 86

Alvares del Valle, Alonso, evidence, 5I

Âlvarez, Catalina, wife of Cepeda, 39

Álvarez de Toledo, Agustín, and Ponce de León's contract, I99n., 303, 305

Amichel, extent, attempted settlement, 5

Ammunition, in Oñate's and Ponce de León's contracts, 23I, 283, 293, 297, 299, 3I5, 32I, 329, 331

Ampues, Juan de, in Venezuela, 86

Ancona, Elígio, Yucatán, 87

Andalucía la Nueva, named, 4

Ángel de la Mota Padilla, Matías, Conquista de la Nueva-Galicia, 87

Anian, Strait of, search for, I94, I95

Antequera, José M., Legislación Española, $2 \mathrm{In}$.

Apoana valley, muster of Oñate's force, 4I9423,427

Appeal, in Oñate's and Ponce de León's contracts, 247, 3I7

Aranda, Juan de, treasurer, 223

Arce, Hernando de, 37

Arce, Juan de, report on services, 37

Arellano, Tristán de, Florida, 27 I

Arias Dávila, Pedro, see Pedrarias

Aristu (Aristo), encomienda, 95

Arms and armor, for Oñate from Spain, 212, 213, 403, 409; in Oñate's and Ponce de León's contracts, 229, 23I, 283, 285, 293, 297. 309, 32I, 33I, 429, 43I

Arriola, Pedro de, and Ibarra, I I7

Artieta, - exploration, 37 I

Artillery, in Oñate's and Ponce de León's contracts, 23I, 283, 299, 315, 329

Asesor, 25

Auction of Indian tribute, 173

Audiencia, and viceroy, 22, 23; districts in North America, duties, composition, and classes, 2I, 22 ; government for New Spain, 8; of New Spain, and Oñate's delayed expedition, 205, 379, 38I, 39I, 393; provincial, for Nueva Galicia, 15; with viceroyalty for New Spain, 9

Auditor de guerra, 23

Augustinians, and Indians, 79

Autos de $f e, 26$

Ávalos, Alonso de, region named for, 87

Avalos provinces, origin of name, 87

Ávila, Alonso de, see Dávila

Avilés y Márquez, Pedro Menéndez de, see Menéndez de Avilés

Avino mine, 9I

Awnings, Indian tribute, use, $137,373,485$

Ayer Collection, 209

Ayllon, Lucas Vásquez de, attempted settlement, 6

Ayuntamiento, status, 25
Azevedo, Fray Francisco de, and Indians, 79

Aztecs, at San Felipe, I6; Cortés's conquest, 6 
Babetacama, see Baustacama

Babeteme, encomienda, 95

Badarami, encomienda, 95

Baiame (Bayame), encomienda, 95

Bailén, Ponce de León's estate, 299

Balboa, Vasco Núñez de, as adclantado, and Pedrarias, 4 ; at Darien, 3

Bancroft, Hubert H., Arizona and New Mexico, 194n.; Central America, 20n.; error on Monterey and Oñate, 206n.; Mexico, I4n.; Native Races, 88; Northern Mexican States, Ion.

Bandelier, Adolph F. A., "Cíbola," Ion.; Gilded Man, Ion.; Journey of Cabeza de Vaca, Ion.

Bandelier Collection, 209

Banishment, power granted to Ponce de León, 327

Barrios León, Francisco de, petition on services of wife's grandfather, $6_{3}, 6_{5}$

Bartolomé, Don, Indian, 7 I

Bastidas, Rodrigo de, founder of Santa Marta, 86

Batán, measurement, I8I

Baustacama (Babetacama), encomienda, 95

Belarde, Juan, Oñate's secretary, 42I

Beltrán, Fray Bernaldino, expedition to Pueblos, I93

Benavides, Alonso de, services, 8I

Benavides, Fray Alonso de, Memorial, 2 I In.

Benavides, Doña Antonio de, wife of Ruís de Castañeda, 83

Bergrier, Margarita, wife of Gelique, 33

Beristain y (de) Souza, José M., "Audiencia de Megico," 22n.; Biblioteca Hispano Americana Setentrional, 22n.

Berlanga, Tomás, Monografía de Saltillo, I8n.

Beteta, Juan de, report on services, 35

Beteta, María López de, see López de Beteta

Big Williams Fork, Farfán at, 2II

Bitaremi, encomienda, 95

Blankets, Indian tribute, I 37

Bocanegra, Alonso López de, see López de Bocanegra

Bolton, Herbert E., "Cabrillo-Ferrelo Expedition," Ion.; Colonization of North America, Ion.; on Zaldivar's mission, 485 ; Guide to Archives of Mexico, 87 ; "Last Years of Oñate's Rule," 2I5; materials on Oñate's expedition, 209; "Missions as a Frontier Institution," 26n.; on names for Pecos River, 486; Spanish Borderlands, 2I6n.; Spanish Exploration in the Southwest, Ion.; "Spanish Occupation of Texas," I8n.

Bonanza mine, I7

Bonilla, Francisco Leyva de, see Leyva

Boundary, New Mexican southern, 208

Bourne, Edward G., Spain in America, ion.

Bravo de Soto Mayor, Pedro, signature, 40r

Bruselas, founding, 4

Buffalos, Alvarado's discovery, 39; vacas de cíbola, 486

Bullion, see Money

Bureau of American Ethnology, Anmral Repert, Ion.

Buscavida, Anton Pérez, see Pérez Buscavida

Bustamante, Juana de, wife of Arce, 37
Caballerias, measurement, I79, IS 3 ; out of a sitio or criadero, 177,179

Cabeza de Vaca, Alvar Núñez, claim to brigantine, imprisoned by rebels, 39, 4I ; letter of, 39 ; wanderings, influence on exploration, 6 , Io

Cabildo, status, 25

Cabo de Honduras, see Honduras

Cabrillo, Juan Rodríguez, voyage, I3

Cacao, Indian tribute, 173

Cadena, Baltasar de la, evidence, 79

Calderón, Alonso, contador, letter of, II 7 ; on conditions in Nueva Vizcaya, II7-II9, I2I

California, as an island, 214 ; first coast exploration, I3; Vizcaino's exploration, 207, $214 n ., 257,263$

Camistla, encomienda, 59

Campos, Pedro de, counter-signature, I I I

Cancer, Fray Luís, Florida designs, I8

Cañete, Marqués de, governor of Philippines, and Acapulco ships, 261, 263, 484

Caparra, founding, 4

Captaincy-general, in Oñate's and Ponce de León's contracts, 247, 289, 3I3, 325-329; status, 22

Carabajal, Luís de, frontier advance, Nuevo León, I8, 371, 484, 485

Carbajal, Antonio de, report on services, 3I, 33

Carbajal, Pedro González de, 3 I

Carillo, Luís, in Mexico, 53,87

Carrasco, Pascual, of Nombre de Dios, witness, 423

Carrillo de Guzmán, Gabriel, evidence, 59

Cartagena, founding, participant, 39, 86

Cartas de Indias, 87

Casa de Contratación, and re-enforcements for Oñate, 40I, 407, 409; as organ of administration, I9, 20; licenses and permits, 3I9, 484; munitions and permits for Ponce de León, 329, 333, 34I

Casas, Bartolomé de las, and encomiendas, 27 ; in Cuba, 4

Casas, Francisco de las, in Honduras, 8

Casas, Guillén de las, governor of Yucatán, evidence, 53,87

Casco mines, see San Lorenzo del Casco

Castañeda, Alonso de, report on services, 35

Castañeda, Antonio Ruís de, see Ruís de Castañeda

Castañeda, Juan de, lieutenant-governor of Nueva Vizcaya, appointment of Velasco, 437

Castañeda, Pedro de, "Relación de la Jornada de Cibola," 86

Castaño de Sosa, Gaspar, New Mexican expedition, arrest, 193, 195, 219, 301, 387

Castile, institutions as colonial model, I9

Castilian measuring yard, I 77

Castilla, Luís de, services, 37, 43, 86

Castilla del Oro, erection, extent, capital. 4, ro

Castillo, Bernal Díaz del, see Díaz del Castillo

Castillo, Bernardina Laínez del, see Laínez del Castillo

Castillo, Diego Díaz Laínez del, see Díaz Laínez del Castillo

Castillo Maldonado, Alonso del, wanderings, 6

Castro, $\longrightarrow$, signature, 93 
Cattle, introduction in New Spain, $4 \mathrm{I}$

Causino, Pedro Martyr, 3 I

Caxco mines, see San Lorenzo del Casco

Caypa pueblo, named San Juan, 210

Central America, exploration and settlement, 4. 7,8, io

Cepeda, Juan de, report on services, 39

Cepeda, Pedro de, 39

Cerralvo (León), frontier, post, founding, I4, 18

Céspedes, Juan de, report on services, 47, 49

Chalchiguitis, jurisdiction over Indians in, 169 , It I

Chalchuites, muster of Oñate's force, $42 \mathrm{I}, 423$

Chamuscado, Francisco Sánchez, see Sánchez Chamuscado

Charcas province, erected, extent, in Nueva Vizcaya, I7

Charcas Vieja, founding, I7

Chiametla. Coronado's expedition and, 63: jurisdiction, I6

Chiapas, bishop of, and colonial evils, I63

Chiapas, Marin's expedition, participant, 39, 86

Chichimecas, as bar to exploration, 7 ; jurisdiction over, I69, I7I; pacification by means of towns and monasteries, 155, I57; Porras's services, $7 I-79$; protection of other Indian towns from, I57; safeguarding roads from. I05; slaves in Oñate's expedition, 423; war, participant, 35, 37

Chiguantla. encomienda, 3 I

Chillarón de Pareja, I6;

Chinchón, Conde de, and Ibarra, II

Cholulans, Cortés's massacre, 6

Chontales, conquest, 37, 86

Church in Spanish colonies, and Indian tribute. I73; crown control. 25; explorations and contentions, 23I; prelate for Nueva Vizcaya, I09, I2I; responsibility for wrongs of natives, 165 ; viceroy as vice-patron, 23; see also Inquisition; Missions; Regular clerg:

Cíbola (Seven Cities), Coronado's expedition, I2; effect of Cabeza de Vaca's report, Io. II Fray Marcos's reconnaissance, II: rival claims to conquer, I2; services of participants in expedition, $33-39,43-53,57$ 63. 69, 71 ; see also New Mexico

Ciriça, Juan de, counter-signatures, 415,417

Cities, establishment in Ponce de León's contract, 3 II

Coatzacoalcos River region, conquest, participant, 67, 88; shipwreck on coast, 223

Cobaltama. encomienda, 95

Code, Spanish colonial, 20

Coiba province, erection, 4

Colección de Documentos Inéditos de Irdias. I22, 194 n.

Colima, founding, 7

College of San Juan de Letran, condition, 375

Colmenares, Bartolomé de, attestation, I I I

Colodro, Juan Velarde, see Velarde Colodro

Colorado River, discovery, I2, I3

Columbus, Christopher, and Española, 3; and Indian tribute. 26

Columbus. Diego, and Cuba and Jamaica, 4

Compostela, ericomienda, 37
Conquerors, see next title

Conquistadores, preference, 67 , I25, 337; reports on services of various, 3I-85; Velasco on conduct, 22I ; see also Encomienda system; Exploration; Land; Nobility

Consulado, 485

Contreras, Fray Diego de, age, 459; Evidence, 457-46r ; professorship, 457

Conversion of Indians, see Missions

Cordel, length, IJT

Córdoba. Francisco Hernández de, exploration of Yucatán, 5 ; in Honduras, 8; participant, 65

Cornejo, Diego Gómez, oidor, 77 .

Coronado, Francisco de, services, 35

Coronado, Francisco Vásquez de, grant of encomienda by, 95; origin of expedition, I0I2; progress of expedition, 12; report on services, 33 ; services of participants, $35-39$, $43-53,57-63,69,79$

Coronado, Juan Vásquez de, 33

Coronado, Pedro de, 35

Corregimientos, petitions to abolish in Indian towns, arguments, I25, I $35-139, I 43, I 45$; preference in appointments to, 67 ; status, 24

Cortés, Hernando, and ex:comicndas, 27, 127; and Garay's settlement, $6, \tau$; and Jalisco, 86; and Villalobos, 4I; conquest of Míexico, 5. 6; governor and captain-general, 7 ; in Cuba, 4 ; in Honduras, 8; Marqués del Valle de Oaxaca, privileges, 9; reports concerning participants in conquest, $3 \mathrm{I}-1,1,65 ;$ res:dencia, deposed, 8; southern and western explorations, 7 ; South Sea explorations and claims, 9. I I

Coruña, Conde de (Lorenzo Suárez de Mendoza), viceroy, and mining decree, I0\%; and Ponce de León, 293; order to, on saieguarding roads, 105

Cosasano, Gordián, treasurer ad isterim, contador general of excises, 223

Cosmographer, for Ponce de León's proposed expedition, $34 \mathrm{I}$

Cotton cloth, Indian tribute, 173

Cotton thread, Indian tribute, I73

Council of the Indies, and Indians, I63; and Onate-Ponce de León contest, opinions, I99. $200,202,293,295,299-305.345-349$; letter to, 39; on re-enforcement for Onate, 40I, 405, 4II; on shipping families, $4 \mathrm{II}$; power, composition, 19, 20, 22; support of New Mexico, 215

Courts, and jurisdiction over Chichimecas, I69, III ; audiencias, 2I, 22; consulado, 485 ; corregidor, 25 : crwzade, $5 T$. ST: personal jurisdiction in Oñate's and Ponce de León's contracts, $235.241,247,317,484$; responsibility for wrongs of natives. I6 3,165

Cozumel, governor of, 8 ; Grijalva at, 5 : province under audiencia of New Spain. 8

Criadero de garado mayor y meror, measurement, I79, I8 3

Cruzada, court. 57,87

Cruzate, Domingo Jironza Pétriz, on New Mexican boundary, $208 \mathrm{n}$.

Cwadra mayor y meror, measurement, ISI 
Cuba, as base for exploration, 5 ; settlement, 4 Cuellar Verdugo, Juan de, 3I

Culiacán, frontier post, I4

Cunningham, Charles H., Audiencia in the Spanish Colonies, 22n.

Cuno, encomienda, 95

Cuyupuztlan, encomienda, 37

Darién, renamed, 4 ; settlement, 3

Dávila, Alonzo [I], capture by French, 86; services, 35

Dávila, Alonzo [2], report on services of family, 35

Dávila, Francisco, corregidor, $8 \mathrm{I}$

Dávila, Gil González, see González Dávila

Dávila, Juan, report on services, 3I

Dávila, Pedro Arias, see Pedrarias Dávila

Delgadillo, Diego, oidor, arrival, 43

Delgadillo, Ysabel, wife of Carbajal, 3I

Denis, Juan Pérez de, see Pérez de Donis

Descubridora mine, 7I, I05

Desdevises du Desert, Georges, Espagne de l'Ancien Régime, 2on.

Desertion, in Ponce de León's contract, 319, 337 ; Oñate's request for punishment during delay, 367

Díaz, Melchior, in Coronado's expedition, 12; reconnaissance and report, 12

Díaz de Vargas, Francisco, proposals for exploration, I95

Díaz del Castillo, Bernal (Bernardo), Historia Verdadera, 88 ; report on services, $63-69$, 87

Díaz Laínez del Castillo, pension and office, $63-69$

Diocese, for Nueva Galicia, I5 ; for Nueva Vizcaya, I09, I2I

Dominicans, and encomienda system, I47; in New Spain, 26

Donis, Juan Pérez de, see Pérez de Donis

Dorantes, Andrés, wanderings, 6

Durango, founding, capital, I5; frontier advance from, $\mathrm{r} 4$; poverty, Io9

E1 Paso, Oñate's crossing at, importance, 210 Encinas, Diego de, notary, 99

Encomienda (repartimiento) system, agreement on, 95-Ior; alternative encouragements to settlers, I5I ; answer to arguments against, I47-I5I; as slavery, I59; attitude of clergy, I47; conditions in Nueva Vizcaya, III, II9; Cortés, 9; development in New Spain, 27, 127; grants in Peru, Nuevo León, and Guatemala, 277, 484; in contracts for conquest of New Mexico, 20I, $237,245,275,277,285,289,297,313,315$, $319,323,327,339$; means of preventing abuses, I53, I55; memorials of procuradores for permanent, I25-I5I ; New Laws, opposition, arguments against, $27, \mathrm{I} 25$, I29. I39, I47; operation, village life, 28 ; origin, 26,27 ; reasons for permanent: (inadequacy of corregimientos, I35, I37, I43, I45; increase of population, I39; justice, as promised remuneration, I27, I3I, I33; payments to Indians, I4I; peace and contentment, I37, I4I ; pensions not substitute re- muneration, I49, I5I ; personal service, I49; preservation of Indians, I4I ; prevention of idleness, I35, I37; prosperity, I43, I45; religious advantages, I33, I39; royal revenue, I37, I4I-I45; stability and cultivation, I33, I47; trade, I35-I4I, I 45, I49; treatment of Indians, I39, I47-I5I) ; status, 24; Velasco on problem (I 595), 22I, 223

Enríquez de Almanza, Martín, viceroy, 447, 486 Equipment, see Supplies

Eraso, Antonio de, counter-signatures, 93, 95. IOI, 105

Eredia, Alonso, petition as attorney, 83

Ervalexo, Domingo Sánchez, see Sánchez Ervalexo

Esmiquilpa, encomienda, $3 \mathrm{I}$

Española, see Santo Domingo

Espejo, Antonio de, New Mexican expedition, I22, I93; proposals for settlement, I95

Espinosa, Diego, memorial to, 157

Espinosa, Gaspar de, exploration, 4

Espinosa de la Plaza, - licentiate, 7I

Espinosa Santillana, María de, evidence, 5 I

Esquive1, Francisco de, commissary, inspection of Oñate's expedition, 423-427; witness, 353

Esquivel, Juan de, in Jamaica, 4

Esquivel, Juan de, witness, 483

Estevánico, reconnaissance, II ; wanderings, 6

Estrada, Alonzo de, treasurer, and Coronado, 33 ; and Cortés, 8

Estrada, Antonio de, 37

Estrada, Beatriz de, wife of Coronado, 33

Estrada, Francisco de, report on services, 37

Estradiotes, 43I, 486

Expenses of expeditions, 127, 227, 307, 417

Explorations, Cabeza de Vaca's wanderings, influence, 6, 10; California coast, I3, 207, 214n., 257, 263; Central America, 7, 8; Coronado's expedition, II-I3; Florida, 5; Gulf coast, 5 ; Mexico, $5-7$; results of those organized in Spain, 37I, 389; Soto's, I3; Tierra Firme, 3, 4; Villalobos in South Sea, I3, I4; waning interest in northern. I4; western coast of Mexico, 9, II, I3; West Indies, 4; see also Frontier; New Mexico; Settlements; Supplies

Export duties, see Import and export duties

Falces, Marqués de (Gastón de Peralta), viceroy, decree on Indian farms, I85; regulations for land measurement, I75-185, I76n.; return to Spain, 87

Families, see Married people

Farfán de los Godos, Isabel, wife of Castillo, 63

Farfán de los Godos, Marcos, in Oñate's expedition, declaration on manifesto, 425 ; exploration, 2 I I

Farms, sites for large and small cattle raising, size, method of measurement, I77, I8I-I85; space between Spanish, and Indian towns, controversy, I85-189

Felis Dias, Juan, absence from Santa Bárbara, 437

Fernández, Jaime, Oñate's alguacil, witness, 353 
Fernández de Serpa, Diego, expedition, 37I, 485

Ferrelo, Bartolomé, voyage, 13

Fifth, royal, from mines, 55, 87, I09, I13, Ir 5 ; reduction in New Mexican contracts, 243, 315, 333; see also Mining

Figueroa, Ana Gómez de, see Gómez de Figueroa

Figueroa, Estévan Rodríguez de, see Rodríguez de Figueroa

Flag, see Standard

Flores, Luís Alfonso, shipwrecked, 223

Florida, extended, I9; first exploration, 5; Luna's expedition, 49, 87; province under audiencia of New Spain, 8; settlement, I8; Soto's exploration, I3

Forces, in Oñate's and Ponce de León's contracts, 227, 28I, 297, 307, 333; see also Musketeers; Recruiting; Supplies

Forts, in Oñate's and Ponce de León's contracts, 245, 289, 3II, 3I7

Francés, Francisco Rodríguez, 35

Francés, Juan Rodríguez, see Rodríguez Francés

Franciscans, and encomiendas, I47 ; and Jesuits in Nueva Vizcaya, royal order, maintenance, I07, I09, I2I; for New Mexican expeditions, 2I I, 23I, 283, 297, 343; in Florida, I9; in New Spain, 26

Freedom from arrest, in Oñate's and Ponce de León's contracts, 247, 289, 319

French, in Florida, I8

Fresnillo, I7; muster of Oñate's force, 427

Friars, see Missions; Regular clergy

Frias de Salazar, Juan, inspection of Oñate's force, 447

Frontier of New Spain, basis of northern expansion, Io; central line of advance, $15-18$; control by viceroy, 23; development of Nueva Vizcaya, 15, I6; eastern line of advance, I8; Guzmán's advance, 9 ; line (I543, I590), I4; mining and advance, I5; western line of advance, I6; see also New Mexico

Fulling-mill, size of site, I8I, I90

Gallegos Osorio, Juan, attestation, 483.

Galván, Mariano, Ordenanzas de Tierras $y$ Aguas, i76n.

Gálvez, Francisco de, witness, 99

Gambling, royal order against, I67

Garay, Francisco de, governor of Jamaica, and Gulf coast and Cortés, 5

García, Francisco, 39

García, Genaro, on Díaz's Historia, edition of it, 88

García Icazbalceta, Joaquin, see Icazbalceta

Garden plot, size, I79

Gauña, Martín López de, see López de Gauña

Gelique, Hans, 33

General questions, 445,486

Generales de la ley, 445,486

Gentil, Francisco, portero, 53

Gíl de Laudenas, Pedro, witness, I7 I

Gobierno, status, 24

Gómez Cornejo, Diego, oidor, 77

Gómez de Figueroa, Ana, wife of Coronado, 35

Gómez de Salazar, Juan, evidence, 45, 47
Gómez Reynes, Pedro, slave contract, $32 \mathrm{I}$

Gómez Zapata, —-, signature, 93

González, Antonio, signature, 401

González, Juana, wife of Pérez Recio, 37

González Dávila, Gil, services, 4, 8, 35

González de Carbajal, Pedro, 3I

Government, see Administration

Governorship, in Oñate's and Ponce de León's contracts, 24I, 287, 313, 325-329; status, 24 ; see also Adelantado

Gran Ranchería, name for Quivira, 465; Oñate's march to, $2 \mathrm{II}, 465,469,47 \mathrm{I}, 475$, $479,483,487$

Granada, founding, 4

Grijalva, Juan de, on Mexican coast, 5, 9; participant, 65

Guachichiles Indians, revolts, participant in suppression, 71-79, 91, 93; peace, I7

Guadalajara, audiencia, power, presidency, I5, $2 \mathrm{I}$; in Mixton war, 43, 45; military power of viceroy, 23: seat of diocese, 15

Guadalcázar, Marqués de, and Porras, 71, 77, 79

Guadiana, mission in, I2I

Guanacebi, frontier and mines, Velasco's services, 419,439

Guanajuato, founding, mines, I6

Guarantee, in Oñate's contract, disregarded, I96, 20I, 25I, 253, 29I, 295, 299, 30I, 32I ; in Ponce de León's contract, $32 \mathrm{I}$

Guatemala, audiencia, 2I, 22; captaincy-general, 22,23 ; conquest, 7 ; encomiendas in, 277 ; independent jurisdiction, 8, Io; province under New Spain, 8

Guerrero, Marcos, licentiate, and gambling, I67

Guillestegui, Juan Martínez de, see Martínez de Guillestegui

Gulf of Mexico, Amiche1, 5; exploration of coast, 5,6 ; see also Florida

Gutiérrez, Felipe, and Porras, 69

Gutiérrez, Ysabel, wife of Causino, 3I

Gutiérrez de Humaña, Antonio, New Mexican expedition, I94, 210, 227, 315, 385, 393

Guzmán, Fray Juan de, age, 455 ; evidence, $453-$ 457

Guzmán, Nuño de, governorship, 8; northern advance and claim, 9, II, 12 ; president of audiencia, 9

Hackett, Charles W., "Delimitation of Political Jurisdictions," $3 \mathrm{n}$.

Hakluyt Society Publications, 88

Havana, audiencia, $2 \mathrm{I}$; founding, 4 ; scarcity at (I594), 221

Helps, Sir Arthur, Spanish Conquest, 28n.

Heredia, Pedro de, founder of Cartagena, 86

Hernández de Córdoba, Francisco, see Córdoba

Hernández de Lievana, Francisco, signature, 93

Hinojosa, - , signature, I05

Hispanic American Historical Review, 3n.

Hodge, Frederick W., Spanish Explorers, Ion.

Honduras, fight over, 7 ; independent jurisdiction, 8, I0; participant in conquest, 67 ; province under New Spain, 8

Horosco, - oidor, report on petition, 45

House, location on plot, I85; size of site, $18 \mathrm{r}$

Huerta, measurement, I79 
Hughes, Anne, Beginnings of Spanish Settlement, $\mathrm{r} 6 \mathrm{n}$.

Huipiles, Indian tribute, I73

Hull, Dorothy, "Castaño de Sosa's Expedition," I94n., 484n.

Humaña, Antonio Gutiérrez de, see Gutiérrez de Humaña

Hurtado de Mendoza, Diego, exploration, 9; participant, 37

Ibarra, Diego de, and appointment of nephew, purchase, II5-II9; and mines, I5; charges against, II7; governor of Nueva Vizcaya, I6; letters of, 105, I07, I09, II3, II5; on condition of Indians, IO9, III; on expedition to Pueblos, II3; on his frontier services, II5; on his health, II 3 ; on maintenance of friars and prelate, I07, ro9; on new mines, royal fifth and duties, rog-II5; on unpopular mining decree, I05, I07

Ibarra, Francisco de, capitulation on rights, II9; death, I6; frontier services, II5; governor of Nueva Vizcaya, I5; in Charcas, I7; mining activity, I5, I6; order to, on salt, ro3

Ibarra (Ybarra), Juan de, counter-signatures, I2I, I69, 303, 321, 323, 325, 329, 335, 399, 409

Ibarra, Juan López de, see López de Ibarra

Ibarra, Martín López de, see López de Ibarra

Ibarra (Ybarra), Miguel de, Mixton war, 43

Icazbalceta, Joaquin García, Colección de Documentcs, $27 \mathrm{n}$.

Imperio mero mixto, for Oñate, 235, 24I, 484

Import and export duties, exemption in Onate's and Ponce de León's contracts, 249, 27I, 273, 291, 3I5, 333, 339; in Laws of Settlement, 273

Indé mine, I6

Indians, and causes and effects of civil wars, I60; and conversion, I6I; and labor, I59; and lawsuits, III; and negroes in Nueva Vizcaya, III; as royal wards, 26,93 ; causes of evils, misinformation, inattention, I6I, I63; control of audiencia, 22; control of corregidor, 25; established at San Felipe, I6; enslavement in New Mexico, 219; increase in tribute ( $167 \mathrm{I}$ ), I73, I75; interpreters for Oñate's and Ponce de León's expeditions, 235, 285, 315, 33I ; jornadas against, I59; memorial on extinction, $157-167$; proposed council to consider evils, I65 ; reconcentration, I0I, I03, I57; space between Spanish farms and Indian towns, controversy, I85-I89; specimen order on control over, 437; tribute in Laws of Settlement, 273 ; tribute in Oñate's and Ponce de León's contracts, 233, 249, 273, 275, 291, 319, 403; Velasco on conduct of conquerors toward. 22I ; see also Aztecs; Chichimecas; Cholulans; Chontales; Encomienda system; Guachichiles; Mansos; Mascorros; Missions; Mixton war; Pataragueyes; Queres; Tanos; Tarahumares; Tlascaltecans; Tribute; Yopelgugos; Zacatecas; Zuñi

Inquisition in New Spain, cruzada, 57, 87; interference with civil courts, $22 \mathrm{I}$; status, 26 ; viceroy's supervision, 23
Inspection of Oñate's expedition, question of complete manifest, 423-429; see also Ulloa y Lemos, Lope

Institute of Merchants, 407

Interpreters, for Oñate's and Ponce de León's expeditions, $235,285,3 \mathrm{I} 5,33 \mathrm{I}$

Jalisco, Castilla's expedition, 86; Mixton war, $43,45,87$

Jamaica, settlement, 4

Jaramilla, Juan, evidence, 63 ; see also Xaramillo

Jarava, - , in Mexico, 53, 87

Jaumave, E1, province, 73

Jémez pueblo, Oñate at, 2 Io

Jesuits, and Ponce de León's contract, 307; at San Felipe, I6; in Florida, I8, I9; in New Spain, 26; in Nueva Vizcaya, royal order on, I2I

Jiménez, Fortun, exploration of western coast, 9

Jornadas, $\mathrm{I} 59$

Joseph, Don, Indian, 7 I

Juan, Don, Indian, $7 \mathrm{I}$

Juárez de Longorio, Pedro, oidor, 7I, 75

Juárez de Ovalle, Juan, licentiate, 75

Jumano pueblo, Oñate at, 2 I I

Junta de guerra, 23

Junta de guerra y hacienda, 23

Kansas, see Quivira

King, cédulas and other orders, 65, 83, 91, 93, 95, IOI, I03, I05, I2I, I55, I 57, I67, I85, $219,303,305,323(2), 325,329(3), 33 \mathrm{I}(5)$, $333(5), 335(3), 337(5), 339(4), 34 \mathrm{I}(2)$, $343(4), 345,349(2), 403,405,407,409(2)$, $4 \mathrm{I} 3,4 \mathrm{I} 5$; control over colonial church, 25 ; in colonial administration, I9; letters to, I05, I07, I09, II3, II7, I25, I27, I47, I 5I, $219,255,257,259,293,303,345,347,349$, 369, 377, 405; see also Philip II. ; Philip III.

Lacerna, Ambrosio de, evidence, 79

Laguna, - signature, 399

Lainez del Castillo, Bernardina, wife of Barrios León, 63

Lake Nicaragua, discovery, 8

Land, grants in Oñate's and Ponce de León's contracts, 239, 287, 3I7, 335; space between Indian towns and Spanish farms, controversy, 185-189; see also next title, and $E_{n-}$ comienda

Land measurement, batán, I8r ; caballería, I79; corrected regulations, I75-185, I74n., I76n.; criadero, I79; cuadra mayor y menor, I8I; huerta and suerte, I79; league, I8I; location of house, I85; means of access, I85; method for sitios and other plots, precedence, I8I-I85; molino, I8I ; sitios de ganado mayor y menor, I77; solar, I8I ; venta, I8I ; yard and ccrdel, I77

Lara Cervantes, Lucas, evidence, 443-447

Las Casas, see Casas

Laws, Spanish colonial code, 20 ; see also next title

Laws of Settlement of I573, I94, 484; obligation in Ponce de León's contract, 233, 309, 3 II ; on encomiendas, 275 ; on ennoblement, 
277 ; on exemption from import duties, 273 ; on independence of government, 269 ; on Indian tribute, 273 ; on local government, 267 ; on recruiting, 265

Lawsuits, Indians and, II I

League, length, I8I

Ledesma, Juan de, letter to, I I5

Ledesma, Pedro de, report on services, 37

Legaspi, Melchior de, financial officer, removed, 223

Legislative powers, power to make ordinances in Oñate's and Ponce de León's contracts, $245,289,313$; viceroy and, 23

León, Alonso de, Nuevo León, 484

León, Guillermo de, evidence, 77

León, Fray Hierónimo, and Ponce de León's proposed expedition, 295

León, Mexico, see Cerralvo

León, New Kingdom of, see Nuevo León

León, Nicaragua, founding, 4

Lesquina, Gaspar de, declaration as attorney, 417

Lewis, Theodore H., "Narrative of the Gentleman of Elvas," Ion.; Spanish Explorers, Ion.

Leyva de Bonilla, Francisco, New Mexican expedition, I94, 206, 227, 315, 36I, 385, 393

Libro de las Ordenanzas y Medidas de Tierras y Aguas, I74n.

Lieutenant-governor, in Oñate's and Ponce de León's contracts, 249, 29I

Lievana, Francisco Hernández de, signature, 93

Llenas, - , signature, I05

Llerena, town, I7I

Loans, requests by Oñate and Ponce de León, $237,285,345$

Loaysa, $-\longrightarrow$, licentiate, I76n., I89

Local government, in Laws of Settlement, 267 ; in Oñate's contract, 245, 3I3, 3I7, 3I9, 329, 333; Spanish colonial, 24, 25

Lomas y Colmenares, Juan Bautista de, New Mexican proposals, I95, 30I

Longorio, Pedro Juárez de, oidor, 7 I, 75

López, Diego, encomienda, 95

López, Fray Francisco, at Pueblos, fate, I93

López, Gonzalo, agreement on encomiendas, 95-IOI ; petitions for permanent encomiendas, I25-I $5 \mathrm{I}$

López de Agurto, Sancho, clerk of audiencia, 59

López de Beteta, María, wife of Probencio, 35

López de Bocanegra, Alonso, inquisitor, age, 45I ; evidence, 45I, 453

López de Gauña, Martín, attestations, I7 I, 255

López de Ibarra, Juan, in Espejo's expedition, I 22 ; treasurer, II5-II9

López de Ibarra, Martín, charges against, II7, I I9; deputy governor, treasurer, death, I I5

López de Salcedo, Diego, governorship, 8

López de Tabora, Gaspar, in Oñate's expedition, evidence, 435

López de Velasco, Juan, Geografía y Descripción, I5n.

López de Villalobos, Ruy, see Villalobos

Los Ángeles, see Puebla de los Ángeles

Lower California, attempted settlement, IO; exploration of coast, 9 , I I
Lowery, Woodbury, Spanish Settlements, Ion., I9n.

Luna y Arellano, Tristán de [I], Florida attempt, I8; services, 49,87

Luna y Arellano, Tristán [2], services, 49

Luxán, Ysabel de, wife of Coronado, 33

MacNutt, Francis A., Fernando Cortés, 86

Madrid Avendaño, Diego de, report on services, 69, 79, 8I

Mainland, see Tierra Firme

Maize, Indian tribute, I37, I73

Malcaltepec, encomienda, 37

Maldonado, Alonso de Castillo, wanderings, 6

Maldonado, Antonio, oidor, tax commissioner, 22 I

Maldonado, Francisco, services, 49

Maldonado, María, wife of Paladinas, in Coronado's expedition, 47

Maldonado Saavedra, Alonso, alcalde mayor at mines, 437

Mallea, Juan de, of Culiacán, age, 48I ; in Oñate's expedition, evidence, 48I, 483

Manifest, taking, in Oñate's expedition, 423427 ; see also Inspection

Manrique, Álvaro, shipwrecked, I09, I I3

Manrique de Zuñiga, Alvaro, see Villamanrique

Mansos Indians, origin of name, 2 ro

Manzera, Marqués de, viceroy, letter on revenue, I73

Mapimi, frontier and mines, 419, 437; Velasco's services, 439

Maravedi, value, 485

Marcos de Niza, Fray, see Niza

Mariana of Austria, regent, letter to, I73

Marín, Luís, expedition, participant, 35,86

Márquez, Gerónimo, in Oñate's expedition, declaration on manifest, 425

Married people, for New Mexico, 307, 309, 3I9, 333, 359, 4I I, 4I9, 423, 427

Marshall, Thomas M., Colonization of North America, Ion.

Martín, Christóbal, New Mexican proposals, I94

Martín, Estéban, in Coronado's expedition, evidence, $5 \mathrm{I}$

Martín, Juan, of Nombre de Diós, witness, 423

Martín de Ribera, Francisco, witness, I7 I

Martínez de Guillestegui, Juan, secretary of viceroy, 35 I

Martínez de Montoya, Juan, and New Mexico, 2 I 5

Mascorras Indians, pacification, 7I-79

Matehuala, founding, I7

Matienzo, Juan Ortiz de, oidor, arrival, 43

Matos, Mencia de, wife of Xaramillo, 3I

Mats, Indian tribute, I73

Maudsley, Alfred P., translation of Díaz's Historia, 88

Maxcalcingo, suit over encomienda, 83

Mayor España, as name for Nueva Galicia, 9

Mazapil, founding, I7

Measurements, see Land measurement

Medina, Cosme de, witness, 483

Medrano, Gregorio de, alcalde mayor at mines, 439

Melendes Marqués,_- shipmaster, 255 
Méndez, Cristóbal, report on services, 43,45

Méndez de Sotomayor, Beatrice, wife of Madrid Avendaño, 79

Mendoza, Antonio de, and report of Cabeza de Vaca, Fray Marcos's reconnaissance, II ; Coronado's expedition, 12; first viceroy, 9; land ordinances, I75, I76n.; Mixton war, 45 ; naval expeditions, I3

Mendoza, Magdalena de, wife of Oñate, 443, $447,449,453,457,46$ I

Mendoza, Magdalena de, wife of Zaldivar, 443, $447,449,453,457$

Mendoza y Luna, Juan de, see Montesclaros

Menéndez de Avilés y Márquez, Pedro, Florida, I8, I9

Mérida, María (Magdalena) de, wife of Ribadeneyra, 445,447

Merriman, Roger B., Rise of the Spanish Empire, 20 .

Mexía Melgarejo, Pedro, petition as attorney, $9 \mathrm{I}$

Mexico, see New Spain

Mexico, city of, capture, 6; muster of Oñate's force, $4 \mathrm{I} 7,435$; Temistitán, 43, 86

Military, power of viceroy, assistants, 23; power to name officers in Oñate's and Ponce de León's contracts, 239, 265, 319, 323

Mill site, size, I 8 I

Mining, and frontier advance, I4, I5; development in Nueva Vizcaya, Ibarra's activity, I5, I6, II I, II3; Guanajuato and Querétaro regions, 16; protest on decree in Nueva Vizcaya, I05, I07; reports of New Mexican prospects, I93, 2II ; rights in Oñate's and Ponce de León's contracts, tax, 243, 287, 3 I5, 333; royal fifth, 55,87 , I09, II 3 , II 5 ; salt and silver refining, 93; San Luís Potosí region, I7; see also Quicksilver

Miramaya (Miramamaya), encomienda, 95

Missions, aid to friars in Nueva Galicia, 93, 95; at Río Verde, 7I-75, 79; at San Felipe, I6; Florida, 18, 19; Franciscans in Nueva Vizcaya, maintenance, 107, I09; in Oñate's and Ponce de León's contracts, 233, 305, 307 , 3II, 343, 4I5, 4I7; monasteries for Chichimeca lands, I55, I57; number baptized in New Mexico, 465, 473, 483; permanent encomiendas and, I33, I39, I47; orders, political significance, 26 ; quality of conversions, I6I ; royal order on Franciscans and Jesuits in Nueva Vizcaya, I2I

Mixton war, I3, 87; encomiendas and, I39; Méndez's services, 43,45

Molinedo, Fray Juan Bautista, Indian mission, $7 \mathrm{I}-79$

Molino, measurement, I8I

Monclova, temporary villa at, I8

Money (bullion), as cargo, and fraud, 225: for Philippines, 263, 484; see also Silver

Monopoly, royal, salt in Nueva Galicia, 93

Montaño, Francisco, report on services, 3I

Montejo, Francisco de, governorship, 8; in Yucatán, grants, 53,87

Monterey, Conde de (Gaspar de Zuñiga y Acevedo), viceroy, and contract and preparations of Oñate, $197,257,265-279,293.363$, $369,377,389,391,421$; and Oñate-Ponce de León contest, reasons for supporting Oñate, 203-207, 303, 33I, 335, 345, 347, 377395 ; appeal to audiencia on contest, 205, 379, 38I, 39I ; arrival, 255; attitude toward Onate, 207,209, 267, 27I, 301, 395; investigation of Oñate's rule, $2 \mathrm{I} 3,4 \mathrm{I} 3$; letters of, 257, 259, 377; letter to, 353 ; on trouble over Philippine ships, 259-263; royal orders to, I2 I, 303, 33I (2), 335, 345

Monterey, founded as San Luís, I8; site reached, I7

Montesclaros, Marqués de (Juan de Mendoza y Luna), viceroy, and Oñate, 2I3-2I5, 4II$4 \mathrm{I} 5$; royal orders to, $409,4 \mathrm{I} 3,4 \mathrm{I} 5$

Montezuma, overthrow, 6

Montilla, Juan de, public crier, I75, I76n.

Montoya, Juan Martínez de, see Martinez de Montoya

Moqui pueblo, Espejo at, I93; Or̃ate at, 2 I I

Moreno de Carrua, Juan, with Oñate's expedition, witness, 425 .

Morlete, Juan, pursuit of Castaño, 219

Morquecho, Diego Núñez, see Núñez Morquecho

Moses, Bernard, Spanish Dependencies, $20 \mathrm{n}$.

Moya, Antonio de, petition as attorney, 57

Muñiz, Leonor, wife of Rodríguez Francés, 35

Muñon, Sancho Sánchez de, pension, 85

Muñoz, Alonso, in Mexico, 53, 87

Muñoz, Francisco, evidence, $5 \mathrm{I}$

Musketeers, from Spain for Oñate, 212, 213, 40I, 405-4II

\section{Nabolama, encomienda, 95}

Narváez, Pánfilo de, and Cortés, 6; Gulf coast expedition, 6 ; in Cuba, 4 ; participant in expedition, 35 ; search for survivors, 33

Negrete, Antonio, clerk with Oñate's expedition, 35I, 425

Negroes, see Slavery

New Laws, not executed, 165 ; petitions against, arguments, I25, I29, I43, I47 ; purpose, opposition, 27; see also Encomienda

New Mexico, Castaño's expedition, I93, 219, $30 \mathrm{I}$; charges against Oñate, investigation, resignation, 2I2-2I 5, 4I I-4I7; Cíbola, Coronado's expedition, IO-I2; claims to, II3, II5, I93, I94; colonists desert, brought back, 212 ; conquest authorized, I94; crisis, preserved, new governor, 2I5, 4I3-4I7; Council of the Indies and, 293, 295, 30I305; Espejo's expedition, I93; Espejo's proposals, I95; formal possession taken, 210 ; Humaña's expedition, 194, 227, 315; independence from New Spain, 196, 197, $213,247,269,271,289,309,317,343,405$; Lomas's proposals, I95, 30I ; Martin's proposals, I94; Monterey's attitude and responsibility for contest, 207 ; number of Indians baptized, $465,473,483$; Oñate agency to king, re-enforcements, 2I2-2I4, 40I-4I3; Oñate-Ponce de León contest for governorship, 196-207; Oñate's advance and conquest, 207-2I I, 395, 397; Oñate's contract and modifications, I96, 212, 225-257, 265$279,397,399,403,405$; Oñate's expedition checked, his attitude, efforts in his behalf, 200-206, 303, 32I, 335, 35I-395; Oñate's ex- 
plorations after conquest, 2 I I, 2I 4, 465, 469, 47I, 475, 479-483; Oñate's preparations, warrant, character of men, inspection, supplies and equipment, I98, 227-229, 295, 30I, 377, 4I7-435; Onate's renewed authorization, 203, 206, 345, 349, 403; Philip III.'s interest and support, 213, 2I5; Ponce de León's contract, and special authorizations, 200-202, 305-343; Ponce de León's proposals, modification, compared with Oñate's, 199-200, 28r-299, 303; Ponce de León's reversal, 202, 203, 345-349; relief expedition, $215,467,473,477,479,483$; revival of interest, I93, I94; Río Conchos route, I6; Rodriguez's expedition, I93; services of various of Oñate's officers, 4I7-423, 435439, 463-483; southern boundary, 208; Urdiñola's proposals, I95, 22I, 30I ; Velasco on requirements for leader of expedition, 221

New Spain, audiencia, powers, 2 I ; audiencia government, 8 ; basis of northern expansion, Io ; Cortés's expedition, conquest, 5, 6 ; elements of administration, I9; encomienda system, 27 ; erected, Cortés's commission, 7; exploration of eastern coast, 5; exploration of western coast, 9 ; independence of New Mexico, I96, I97, 247, 269, 27 I, 289, 309, 3I7, 343, 405; neglect of northern exploration, 7 ; Pánuco settlement. 5,7 ; provinces, 8 ; reports concerning participants in conquest, $3 \mathrm{I}, 4 \mathrm{I}, 65$; residencia of Cortés, 8; split up, 8, Io; Velasco on conditions (I 595), 2I9, 22I ; viceroy, powers and duties, 22-24; vice-royalty and audiencia, 9; western and southern exploration, 7, 8 ; see also Church; Explorations; Indians; Mining; Settlements

Nicaragua, exploration, 4; independent jurisdiction, Io

Nicuesa, Diego de, attempted settlement, exiled, 3

Nieto, Pedro, evidence, 47

Nieto de Avalos, Juan, petition for office based on ancestor's services, 57, 59

Nieto de Santillana, Anna, evidence, 5 I

Nieves mine, I5

Niño, Andrés, exploration, 4

Niza, Fray Marcos de, reconnaissance and report, II

Nobility, in Oñate's and Ponce de León's contracts, 239, 24I, 277, 279, 287, 297, 319, 343 ; Laws of Settlement on, 277

Nochistlan, rock in Mixton war, 43

Nombre de Dios, Mexico, founding, I5; Oñate's muster at, 42I, 423

Nombre de Dios, Panamá, isthmian road terminus, 86; negro insurrection, 39

Nuestra Señora de Zacatecas, see Zacatecas

Nueva Galicia, agreement on encomiendas in, 95-IOI ; aid to friars, 93, 95; Luna y Arellano, governor, 49; mines and northern extension, I5; Mixton war, I3, 43, 45, 87. I39; Nueva Vizcaya detached, I5; provincial audiencia, I5; reconcentration of Indians, IOI, I03; safeguarding roads, I05; salt question, crown monopoly, 93; services of Oñate, 227; see also Chichimecas
Nueva Vizcaya, and New Mexico, II3, II5, I94; and Ponce de León's proposals, 200, 297, 337; audiencia, powers, presidency, 2I ; charges against officials, II7, II9; condition of encomiendas, III, II9; erected, mining development, I5, I6, III, I I3; extent, I7; Franciscans in, maintenance, I05, I07; military power of viceroy, 23 ; negroes and Indians, III; prelate for, I09, I2I; royal fifth and duties, I09, II3, II5; royal order on Jesuits and Franciscans, I2I ; salt working, 103

Nuevo León, and Florida, I9; claim to New Mexico, I93; encomiendas in, 277, 484; erected, extent, development, I8

Núñez, Alonzo, age, 473 ; in Oñate's expedition, evidence, $473-477$

Núñez Cabeza de Vaca, Alvar, see Cabeza de Vaca

Núñez de Balboa, Vasco, see Balboa

Núñez Morquecho, Diego, oidor, hearing before, $44 I-46 I$

Oaxaca, founding, 35

Officers, civil, appointment in Oñate's and Ponce de León's contracts, 243, 245, 249, 267, 269, $287,313,331,333,337$; power to name expeditionary, 239, 265, 287, 3I9, 323; preference in appointment, $67,125,337$; purchase, 25, II5-II9, 223; Velasco on appointments, 223; see also Administration; Salaries

Oidores, 21

Ojeda, Alonso de, attempted settlement, 3

Old Santa Fé, I94n.

Olid, Cristóbal de, exploration, 7 ; in Honduras, 8

Oñate, Alonso de [I], captain of viceroy's guard, 443, 445, 449, 453, 455, 459

Oñate, Alonso de [2], as agent in Spain, 213, $405,407,4 \mathrm{II}$

Oñate, Cristóbal de [I], 443, 447, 455, 459; services, $43,45,87,227,484$

Oñate, Cristóbal de [2], and brother's expedition, $245,445,453$

Oñate, Cristóbal de [3], as governor in New Mexico, 2I 5

Oñate, Fernando de [I], and brother's expedition, $245,443,445,453,457,46 \mathrm{I}$; family, 44I, 445, 449, 45I, 455, 459; services, 44I$445,449,45 \mathrm{I}, 455,459$

Oñate, Fernando de [2], hearing on family, character, and services, 2 I $5,44 \mathrm{I}-463$

Oñate, Juan de, advance across Río Grande, 207-210, 395, 397; age, 467 ; agency to Spain, re-enforcements, 2 I2-2I4, 4OI-4I3; and deserting colonists, $2 \mathrm{I} 2$; and indemnification, 385; and Monterey, mutual attitude, 207, 209, 267, 27 I, 30I, 395; at Río de las Nazas, I98; character, fitness, 257, 30I, 357, 369, 389; character of men, I98, 295, 30I, 377; charges against, investigation, resignation, 2I2-2I 5, 4II-4I7; check to expedition, attitude during, I99-204, 303, 32I, 335, 35I-367, $377,379,391$; conquest, 210 ; contest with Ponce de León over governorship, I96-207; contract, Monterey's modifications, I 96 , 225-257, 265-279, 389; danger of dispersion of force, fear of results, 204, 357-363, 383 . 
$385,393,435$; efforts to regain authorization, Monterey, Riego, reasons, 202, 204$206,347,369-373,379-395$; explorations after conquest, $2 \mathrm{I}$ I, 2I 4, 465, 469, 47 I, 475, 479-483; further privileges, title of adelantado, 212, 397, 399, 403, 405; guarantee to, in contract, disregard of, I96, 20I, 25I, 253, 29I, 295, 299, 30I, 32I ; help from family, $245,357,385,393,443,445,453,457,46 \mathrm{I}$; inspection of expedition, services of Ulloa, completeness of manifest, I98, 208, 359, $365,37 \mathrm{I}, 377,383,39 \mathrm{I}, 393,423-429,447$; letters of, 353,395 ; materials on expedition, 209 ; order on preparations, 42I; personal equipment, $229,423,425$; preparations, warrant, time, supplies and equipment, r98, 227-23I, 369, 377, 4I7-423, 429-435; proposals compared with Ponce de León's, 198, 28I-293, 303; renewal of authorization, 203, 206,345 ; request for punishment of deserters, 367 ; services of various officers, $4 \mathrm{I} 7$; $435-439,463-483$; statement on services of officer, 467,469 ; takes possession, 210

Ontiberos, Hernando de, ranch, 363

Orantes, Andrés de, 83

"Ordenanzas hechas para los Nuevos Descubrimientos," I94n., 484

Ordinances, power in Oñate's and Ponce de León's contracts, 245, 289, 3I3

Orozco, Francisco de, exploration, 7

Orozco, Wistano Luís, Legislación sobre Terrenos Baldios, $25 \mathrm{n}$.

Ortiz de Matienzo, Juan, see Matienzo

Osorio (Ossorio) de Agüero (Agurto), Martín, clerk of audiencia, certifications, 44I, $46 \mathrm{r}, 463$

Otalora, Pedro de, acting president of audiencia, order by, 44I, 463

Ovacania (Ovaxania), encomienda, 95

Ovalle, Juan Juárez de, licentiate, 75

Pacheco de Figuera, Luís, evidence, 59

Pacific Ocean, see South Sea

Padilla, Antonio de, order issued by, I05

Paladines, Juan de, evidence, 6r, 63; report on services, 45,47

Palma (Palmar) de Vega mine, 7r, 77

Panamá, province, erection, 4.

Panamá, town, founding, capital, 4

Pañella Fuentes, Gonzalo, inspection, I7 I

Pánuco, frontier post and advance, I4, I8; governor, 8; province under audiencia of New Spain, 8; settlement, 5-7; survivors of Soto's expedition at, I4

Pardiñas, Bernardo Antonio de, counter-signature, 189

Paría, and Castilla del Oro, 4

Parra, see Rodríguez Parra

Pataragueyes Indians, 397

Paul IV., Theatines, 484

Paz, La, Cortés's settlement, 9

Paz de Vallecillo (Pas de Vallesillo), Juan fiscal, 44I, 443, 457

Pecos pueblo, Oñate at, 2ro

Pecos (Salado, Vacas) River, exploration, I93, 435

Pedrarias Dávila, governor, and Balboa, 4

Pedro, Don, Indian, 7 I
Pedro de la Cruz spring, Oñate at, 425

Peña, Juan de la, report on reconcentration of Indians, IOI

Penas de cámara, for the college, 375,485

Peñol Blanca, 363

Peralta, Gastón de, see Falces

Peralta, Pedro de, governor of New Mexico, and Santa Fé, 215

Peralta y Sidonia, Alonso, evidence, 77

Pérez, Alonzo, encomienda, 59

Pérez, Hernán, on permanent encomiendas, I5II 55

Pérez, Martín, takes over mining region, I5

Pérez, Melchior, 37

Pérez Buscavida, Anton, report on services, 37

Pérez de Donis (Denis), Juan, clerk of Oñate's expedition, certifications, 4I9, 425, 433

Pérez Recio, Alonso, 37

Peru, encomiendas in, 277 ; transportation of viceroy to, $255-263$

Petatlán River, I6

Pétriz Cruzate, Domingo Jironza, see Cruzate

Philip II., and colonial administration, I9; and Florida, I8; and New Mexico expedition, I99-203, 206, 303, 305, 349; see also King

Philip III., and Oñate, interest in New Mexico, 2I2-2I5; see also King

Philippines, archbishop delayed in New Spain, I2I ; named, I3; raising men for, 259 ; residence in, 279: Sandes's services as governor, 55; trouble over ships on Acapulco route, 259-363; under viceroy of New Spain, 23

Pilots, for Oñate, 2I2, 40I, 405-4II

Pineda, Alonso, exploration of Gulf coast, 5

Pinto, Agustín, clerk of audiencia, 45

Ponce de León, Juan, in Florida, 5, 371, 485; in Porto Rico, 4

Ponce de León, Luís, and Cortés, 8; and encomiendas, 127

Ponce de León, Pedro, consideration of proposals, contract, special grants, 200-202, 305-343; contest with Oñate for governorship of New Mexico, I96-207; estate, reasons for expedition, 299, 30I; in New Spain, 293; Monterey and contest, 207, 379$389,393,395$; opinions of Council of Indies on proposals and character, 293, 295, $30 \mathrm{I}-305$; proposals, modifications, compared with Oñate's, I98-200, 28I-299, 303; reasons against grant, $383-389$; reversal, 202 , 345-349; time of preparation, 307

Popayán, bishop of, and colonial evils, I63

Popayán, destruction of Indians, I 59

Porras, Estéban de, 69; services, 75

Porras y Ulloa, Juan de, report on services, $69-8 \mathrm{I}$

Porto Rico, as base of exploration, 5 ; settlement, 4

Presidency, status, 22

Priestley, Herbert I.. José de Gálvez, 23n., "Old University of Mexico," 486

Probencio, Francisco, 35

Procuradcres, petitions for permanent encomiendas, I25-I5I

Provinces, types of government, 24

Puebla de los Ângeles, muster of Oñate's force, 369; workshops, inspection, orders, 373 
Pueblos, see New Mexico

Puerto Príncipe, founding, 4

Puga, Vasco de, oidor, Provisiones, I5n.; report on petition, 45

Purchase of office, 25, II5-II9, 223

Queres Indians, Espejo's visit, I93; Oñate's pacification, 2 IO

Querétaro, town, founding, I6; frontier advance from, I4, I6

Quesada de Figueroa, Juan, oidor, hearing before, 463

Quevedo, Francisco de, encomienda, 33

Quicksilver, burned at Vera Cruz, 225; for Oñate's and Ponce de León's expeditions, 23I, 285, 297 ; royal, on board wrecked ship, 223

Quiros, Juan de, regidor, attestation, 45I

Quisahuistlan, name for Vera Cruz, 4I

Quivira, Alvarado's expedition, 39; called Gran Ranchería, 465; Coronado's expedition, I2; Humaña's expedition, I94; Oñate's expedition, 2 I I, 465, 469, 47 I, 475, 479, 483, 487

Quizcey (Quescrey, Quicerey), encomienda. 95, 99

Ramírez, Gabriel, public clerk, certificate, 42I

Ramírez de Velasco, Juan, and Ibarra, II7

Rangel, Juan, alférez in Oñate's expedition, evidence, 47I, 473; age, 473

Real acuerdo, 22, 377,485

Real patronato, 25

Rebellion, suppression in Oñate's and Ponce de León's contracts, 289, 313, 337

Recio, Alonso Pérez, 37

Recopilación de Leyes de los Reynos de las Indias, 20

Recruiting, in Laws of Settlement, 265 ; power, in Oñate's and Ponce de León's contracts, $247,265,267,289,297,299,307,317,319$. 323,325

Regidores, 25

Regino Ramón, R., documentary history of Saltillo, I8n.

Regular clergy, see Augustinians; Dominicans ; Franciscans; Jesuits; Theatines

Relator, 57

Remón, Alonso, and Díaz's Historia, 88

Repartimientos, see Encomienda system

Report of the Chief of the Weather Bureau, 2IOn.

Requisitions, power in Oñate's and Ponce de León's contracts, 233, 247

Residence, in Philippines, 279 ; requirement in Ponce de León's contract, 29I, 3I3, 32I, 343

Residencia, in Ponce de León's contract, 319; of Cortés, 8; purpose, 24

Revilla Gigedo Islands, discovery, 9

Revista de Archivos, Bibliotecas, y Museos, zon.

Reynes, Pedro Gómez, see Gómez Reynes

Ribadeneyra, Hernando de, 445, 447

Ribadeneyra, Leonor de, wife of Oñate, 44I$45 \mathrm{I}, 455,459$

Riego, Santiago del, letter to king, 369; on College of San Juan de Lateran, 375 ; on condition of administration of estates, 375 ; on Oñate's expedition, 204, 347, 369-373; on workshops at Puebla, 373 ; plea for pension, 375
Río Chuviscar, Oñate's expedition at, $208 \mathrm{n}$.

Río Conchos, expeditions down, I93; settlement on, I6

Río de Grijalva, named, 5

Río de las Conchas, Oñate at, identity, 208, 208n., 397

Río de las Nazas, as frontier, I7; Oñate at, I98, 35I, 353

Río de las Palmas (Río Grande), province, in Nuevo León, I8; jurisdiction, 6 ; under audiencia of New Spain, 8

Río de las Vacas de Cíbola, Pecos River, 435, 486

Río de Losa, Rodrigo del, and New Mexico, I94; governor of Nueva Vizcaya, and Urdiñola, I7 ; mines, I6

Río de Pánuco, see Pánuco

Río del Nombre de Dios, Oñate at, 208

Río del Norte, see Río Grande

Río Fuerte region, attempted occupation, I6

Río Grande, Oñate's expedition at, El Paso, 209, 210 ; Zaldívar's reconnaissance to, 209, 397 ; see also Río de las Palmas

Río Petatlan region, settlement, I6

Río Salado (Pecos), exploration, 435

Río Verde, convent at, 73, 75, 79

Ríos, Baltasar Rodríguez de los, see Rodríguez de los Ríos

Ríos, Pedro de los, factor, 223

Rivera, Gabriel de, shipwrecked, 261

Roads, safeguarding from Chichimecas, I05

Robledo, Pedro, in Oñate's expedition, declaration on manifest, 427

Rodríguez, Fray Agustín, expedition to $\mathrm{New}$ Mexico, fate, I I3, 122, 193

Rodríguez, García, report on services, $57-63$

Rodríguez, Juan, report on services, 39

Rodríguez. Cabrillo, Juan, voyage, I3

Rodriguez de Figueroa, Estévan, sells ship to government, $26 \mathrm{I}$

Rodríguez de los Ríos, Baltasar, age, 449; evidence, 447-45I

Rodríguez Francés, Francisco, 35

Rodríguez Francés, Juan, report on services, 35,37

Rodríguez Parra, Alonso, report on services, 49

Rodríguez Parra, Juan, report on services, 49

Rodríguez Torquemada, Bartolomé, regidor. attestations, 467,469

Roman Catholic Church, see Church

Romero, Alférez —, with Oñate's expedition, witness, 425

Ronquillo, Gonzalo, governor of Philippines, 87

Roxas, Isabel de, wife of Maldonado, and of Luna y Arellano, 49

Ruís de Alanís, Juan, services, 8I, 83

Ruís de Castañeda, Antonio, encomienda, 83; petition for aid, 83

Ruiz, Juan, evidence, $5 \mathrm{I}$

Ruiz Villafuerte, Juan, see Villafuerte

Sacramento River, and New Mexican southern boundary, 208

St. Augustine, founding, 18 
Salaries, in Oñate's and Ponce de León's contracts, 24I-245, 267, 269, 287, 3I3, 3I7, 339, $34 \mathrm{I}$

Salazar, Catalina de, wife of Oñate, 445, 447, 455,459

Salazar, Eugenio de, signature, 40I

Salazar, Juan Gómez de, see Gómez de Salazar

Salazar, Mencia, wife of Alvarado, 39

Salcedo, Diego López de, see López de Salcedo

Salcedo de Cuervas, Doctor, certification, 57

Salinas, Marqués de, see Velasco, Luís de [2]

Salt, gathering in Nueva Galicia, royal monopoly, 93; Indian tribute, I73; working in Nueva Vizcaya, I03

Saltillo, presidio, founding, I7; pueblo of San Estéban, I8; villa, I7

Salvador, exploration, 7

San Andrés mines, I05

San Bartolomé, founding, I6; Oñate's expedition at, 208; valley, 437

San Estéban, pueblo at Saltillo, i8

San Estéban del Puerto, founding, 7

San Felipe, frontier post, I4

San Francisco, Oñate's proposed city, 210

San Francisco del Mariscal, ship at Acapulco, $26 \mathrm{I}, 263$

San Francisco de los Patos, founding, I7

San Francisco de Río Verde, convent, 75

San Gabriel, capital of New Mexico, 2 I I

San Gerónimo, founding, I7; Oñate's expedition at, 208

San Hierónimo, founding, I2

San Juan de los Caballeros, capital of New Mexico, 2 IO

San Juan de Porto Rico, founding, 4

San Juan de Sinaloa, temporary settlement, I6

San Juan de Ulua Island, named, 5

San Juan mine, I6

San Lorenzo del Casco (Caxco) mines, Oñate at, 208, 42I, 425, 427; Velasco's appointment to, 437

San Lucas mine, I 5

San Luís, villa, see Monterey

San Luís Potosí, founding, jurisdiction, I7; frontier advance from, $14 ;$ mines, 16

San Marcos, Cabeza de Vaca's brigantine, 4I

San Martín, in Charcas, I7, I7I ; mines, 9I

San Mateo, Florida post, I8

San Miguel de Culiacán, founding, 9

San Miguel de Gualdape, Ayllon's colony, 6

San Pablo, royal ship on Acapulco-Philippine route, $26 \mathrm{I}$

San Pedro, royal ship on Acapulco-Philippine route, $26 \mathrm{r}$

San Pedro del Ålamo, estáncia, I7

San Sebastián de Chiametla, II9

Sánchez, Alonso, in Oñate's expedition, declaration on manifest, 425

Sánchez, Inez, wife of Garcia, 39

Sánchez, Luís, memorial on extinction of Indians, $157-167$

Sánchez Chamuscado, Francisco, expedition to New Mexico, I13, I22, I93

Sánchez de Alvarado, Juan, 39

Sánchez de Muñon, Sancho, pension, 85

Sánchez Ervalexo, Domingo, of Nombre de Dios, witness, 423
Sandes, Francisco de, report on services, fine, $53-57,87$

Sandoval, Gonzalo de, exploration, 7

Santa Bárbara, and Oñate's expedition, 204, 212, 231, 365, 427; mine, I5; Pueblo expedition from, I93; Velasco's services, 437, 439

Santa Cruz, Cortés's settlement, 8

Santa Fé, N. Mex., founding, 2I5

Santa Fé de Guanajuato, see Guanajuato

Santa Margarita, bought, 26I

Santa María, Fray, at Pueblos, killed, 193

Santa María de la Antigua del Darién, founding, 3

Santa Marta, founding, participants, 33, 39, 86

Santiago de Cuba, founding, 4

Santiago de Ojo de Agua del Saltillo, see Saltillo

Santiago Island, see Jamaica

Santiago mines, 437

Santibañez, Archb. Ignacio de, delayed in New Spain, I2I

Santillan, $12 \mathrm{l}$, signature, I05

Santillana, Francisco de, report on services, 5I, 53

Santillana, Pedro de, report on services, 5I, 53

Santo Domingo (Española), audiencia, 21, 22; base for colonization, 3,4 ; captaincy-general, 22, 23; loses primacy, 4 ; settlement, 3 Santo Domingo, Queres pueblo, 210

Santo Domingo, spring, Oñate's rendezvous, 4I9 Santo Domingo, town, founding, 3

Santo Espíritu, founding, 4

Sarmiento, Costanza, encomienda, 37

Schurz, William L., "Mexico, Peru, and the Manila Galleon," 484

Seal, in Ponce de León's contract, 313, 339

Segura, Father, mission, I8

Self-government, local, 25

Serna, Damián de la, witness, 99

Serpa, Diego Fernández de, expedition, 371, 485

Servants, in Ponce de León's contract, 29I

Settlements, attempt in Amichel, 5; Ayllon's attempt, 6; Florida, I8; Garay's attempt, 5; Tierra Firme, 3, 4; West Indies, 4; see also Explorations; Frontier; Laws of Settlement

Seven Cities, see Cíbola

Shepherd, William R., Latin America, $24 n$.

Shipbuilders, for New Mexico, 212, 213, 40I, 405-4II

Ships, grant in Ponce de León's authorization, 293, 297, 3I5; special for Oñate's re-enforcements, permit for cargo, 2I4, 409-4I3; trouble over, at Acapulco, 259-263

Shipwrecks, Velasco on dishonest, 223

Sichú mines, 7I, 77

Silao, founding, 16

Silver, dispatch to Philippines, 263 ; see also Mining; Money

Sinaloa region, jurisdiction, I6; opening of mines, I6

Sitio de ganado mayor y menor, measurement, I77, $18 \mathrm{I}-\mathrm{I} 85$

Slavery, accusation in New Mexico, 219; and encomiendas, 28, I59; negro and Indian slaves in Oñate's expedition, 423; negro 
slaves and Indians in Nueva Vizcaya, III; negro slaves in Ponce de León's contract, 293. 3I7, 32I, 33I

Smith, Buckingham, Colección de Varios Documentos, Ion.

Smith, Clara A., acknowledgment to, $218 \mathrm{n}$.

Solar, measurement, I8I

Soldiers, see Arms and Armor; Forces: Musketeers; Recruiting

Solórzano y Pereyra, Juan de, Política Indiana, $20 n$.

Sombrerete mine, I5

Sosa Abornóz, Alonso de, in Oñate's expedition, declaration on manifest, 425,427

Sosa Peñalosa, Francisco de, declaration or manifest, 425 ; in Oñate's expedition, $42 \mathrm{I}$, 423; jurisdiction over Chichimecas, I69, I7I ; lieutenant-governor, 425,435 ; on Velasco's services, 435

Soto, Hernando de, claim to Seven Cities, I2; exploration, I3; in Honduras, 8

Sotomayor, Beatrice Méndez de, see Méndez de Sotomayor

South Sea, Cortés's towns, 7 ; exploration of coast, 4, 9, II, I3; Oñate's attempts to reach, 2I I, 2I 4, 465, 469, 47 I, 475, 479, 48I ; Ponce de León's contract on exploration, 3II ; shipbuilders and pilots for Oñate, 212, 40I, 405, 407; Villalobos's voyage, I3, I4; Vizcaino's expedition, 207, 21 4n., 257, 263

Southwestern Historical Quarterly, I8n.

Standard in Oñate's expedition, 429

Strait, search for, 3, 5, I94, I95

Suárez de Mendoza, Lorenzo, see Coruña

Succession, in Oñate's and Ponce de León's contracts, 25I, 29I, $32 \mathrm{I}$

Súchil valley, muster of Onate's force, 4I9423,427

Suerte, measurement, 179

Sugar mills, in Ponce de León's contract, 3 I7

Supplies and equipment, Oñate's and Ponce de León's lists, 227-23I, 28I, 283, 307, 309, 37 I, $373,423,429-433$; see also Ammunition; Arms and armor

Tabasco, conquest, participants, 37, 39, 67, 86 Tabora, Gaspar López de, see López de Tabora Tagamasapa, crown town, 59

Taiacoato, see Tayacoato

Tampico, see Pánuco

Tanos Indians, Espejo's visit, I93

Tapira, encomienda, 95

Taracoato, see Tayacoato

Tarahumares Indians, interpreters for Oñate, 235,484

Tasco, crown town, 59; mines, 35

Taxation, and permanent encomiendas, 137 , I4I ; exemptions in Oñate's and Ponce de León's contracts, 249, 27I, 273, 29I, 3I5, $3 I 7,321,33 \mathrm{I}-335,339$; on lands and foreigners, 22I ; see also Fifth: Tribute

Tayacoato (Taiacoato, Taracoato), encomien$d a, 95,99$

Tedomo, encomienda, 95

Teguacán, encomienda, 83, 85

Tello, Francisco, oidor, and gambling, 167

Temistitlán, name for city of Mexico, 43, 86

Tenebama, encomienda, 95
Teniente de gran chanciller, $2 \mathrm{I}$

Tenorio, Juan, treasurer, I7 I

Tewa Indians, pueblo, 210

Theatines, and Ponce de León's contract, 283, 297,484

Tierra Firme, Castilla del Oro, 4; exploration and settlement, 3

Tiguex, Coronado in, 53, 87; Rodríguez in, I93

Tlascaltecans (Tlascalans, Tlaxcaltecos), and Cortés, 6; at San Estéban, 18; at San Felipe, I6; at San Pedro de Álamo, I7; settlement in Chichimeca lands, I55, I69

Tlaxcala, Luna y Arellano as governor, 49

Todos Santos mines, 437

Toledo, Agustín Ålvarez de, see Ālvarez de Toledo

Toperi, encomienda, 95

Torquemada, Bartolomé Rodríguez, see Rodríguez Torquemada

Torre, Luís de la, 8I

Torre, María de la, wife of Orantes, 83

Torre Altamirano, Agustín de la, petition for office, service of ancestors, $8 \mathrm{I}-85$

Towns, grants to, and administration in Ponce de León's contract, 3I7, 331, 335; Indian, space of Spanish farms from, I 85-189

Trade, permanent encomiendas and, I35-I4I, I 45, I 49

Transportation, in Ponce de León's contract, 293, 297, 299, 3I 5, 3I9, 34I

Treasury, in Oñate's and Ponce de León's contracts, 243, 287, 3I3, 339

Tres Marias Islands, discovery, 9

Tribute, Indian, articles, auction, I37, I73 ; increase (I67I), I73, I75; in Oñate's and Ponce de León's contracts, 233, 249, 273, 29I, 3I9; Oñate's later authorization, 403; see also Encomienda system

Trinidad, Cuba, founding, 4

Tula, in Charcas, I7

Turcios, Antonio de, clerk of audiencia, 43

Ulloa, Francisco de, voyage on western coast, II

Ulloa y Lemos, Lope de, as inspector of Oñate's expedition, and check of expedition, I 98, 203, 204, 208, 35I, 353, 359, 365, 37 I, $377,383,391,393,423,425,447$; Oñate on services, 359, 379

Universidad de los Mercaderes, 407, 485

University of California Chronicle, 486

University of California Publications, I6n.

Urabá, Ojeda's attempted settlement, 3

Urdiñola, Francisco de [I], death, I7; frontier advance, $16, \mathrm{I} 7$

Urdiñola, Francisco de [2], frontier advance, I7; governor of Nueva Vizcaya, appointment of Velasco, 437; New Mexican proposals, murder of wife, I95, 22I, 30I

Vaillo, —, signature, I05

Valderrama, _ signature, 93

Valle, second Marqués del. visita, 87

Valle de Oaxaca, Marqués del, see Cortés, Hernando

Vallejo, María de, wife of Estrada, 37

Valmaseda, Francisco de, witness, 99 
Valverde, Francisco de, in Panamá, 223

Vargas, Francisco Díaz de, see Díaz de Vargas

Vásquez, _ـ , signature, 93

Vásquez de Ayllon, Lucas, see Ayllon

Vásquez de Coronado, Francisco, see Coronado

Veitia Linaje, Joseph de, Norte de la Contratación, 20n.

Velarde Colodro, Juan, relief expedition, 467 , $473,477,479,483$; hearing on services with Oñate, 2I $5,463-483$

Velasco, Juan López de, see López de Velasco

Velasco, Juan Ramírez de, and Ibarra, II7

Velasco, Luís de [I], viceroy, and Arellano, $27 \mathrm{I}$; and settlements, I6

Velasco, Luís de [2] (Marqués de Salinas), viceroy, and Oñate's contract, 196, 199, 225257,389 ; and relief or abandonment of New Mexico, 215, 467, 469, 473, 477, 479, 483 ; decree on jurisdiction over Chichimecas, I69, I7I ; interest in New Mexico, I94; letters of, 219, 255; on an appointment, 223; on conditions in New Spain, taxation; 219, 22I ; on dishonest shipwrecks, 223 ; on encomiendas, 22I, 223; on requirements for leadership of New Mexican expedition, 22I; on Urdiñola, 22I ; royal order on gambling, I67; second term, 486; transfer to Peru, on need of financial aid, transportation, 255-263; Vizcaino's contract, 207

Velasco, Capt. Luís de, declaration on manifest, 427 ; manifest on equipment, petition for recompense, 216, 429-435; permission to leave New Mexico, 435; services with Oñate and elsewhere, 2I5, 4I7-423, 435-439

Velásquez, Diego, and Cortés's expedition, 6; and Mexico, 5 ; in Cuba, 4

Velásquez, Juan, recommendation on petition, 65

Venezuela, first settlement, 33,86

Venta, measurement, I8I

Vera Cruz, founding, 6; Quisahuistlan, 4I

Veragua, and Castilla del Oro, 4; independent jurisdiction, Io; Nicuesa's attempted settlement, 3

Vicente, Cristóbal, witness, 483

Viceroy, and audiencia, 22, 23; control over, 23; power and duties, 23; royal cédulas ignored, 63,65

Villafañe, Angel de, Florida attempt, I8

Villafuerte, Juan Ruíz, exploration, 7 ; participant, 37

Villagrá, Gaspar de, Historia de la Nueva México, I96n.; on Ponce de León, I96

Villagutierre Chumacen, _-, signature, 401

Villalobos, Gregorio, report on services, 4I

Villalobos, Ruy López de, voyage, death, I3, I4

Villamanrique, Marqués de (Alvaro Manrique de Zuñiga), viceroy, and New Mexico, 427, 486 ; royal order on pacifying Chichimecas, I 55, I 57
Villanueva, Alonso de, petitions for permanent encomiendas, I25-I5I

Villar de Franco, - counter-signature, I89 Villa Rica de la Vera Cruz, see Vera Cruz

$V$ isita, purpose, 24

Vitoria Garayana, attempted settlement, 5 ; governor, 8 : in Nuevo León, I 8

Vizcaino, Sebastián, contract and exploration, 207,214 n., 257, 263

Wardrobe, of one of Oñate's officers, 43I, 433

Welser family, control in Venezuela, 86

Wichita, Oñate on site, 2 I I

Winship, George P., Coronado Expedition, Ion.

Workshops, inspection and orders, 373

Xaramillo, Alonzo, 31

Xaramillo, Juan, report on services, 3I ; see also Jaramilla

Xilotepec, encomienda, 3I, 33

Yard, length, I77

Ybarra, see Ibarra

Ygueras, Las, province, 8

Yndehe frontier, Velasco's services, 4I9, 439

Yopelgugos, conquest, 37

Ysbabitu, encomienda, 95

Yucatán, exploration, participant, 5, 67 ; governor, 8; Montejo's services, 53, 87

Yvarguen, Carlos de, 223

Zacatecas, frontier advance from, I4 founding, I5; mines, I5; revolt of Indians, 9I, 93

Zacatlán, encomienda, 33

Zacatula, founding, 7

Zaenz de Escobar, Joseph, witness, I76n.

Zaldivar, Juan de, with Oñate, killed, 2 I I

Zaldívar, Vicente de, family, $443,447,449,453$, $457,46 \mathrm{I}$; services, 447

Zaldivar Mendoza, Vicente de, age, 477; as Oñate's agent in Spain, 2I2, 2I3, 40I, 405409; depositions, 2I6; evidence on Velarde's services, 477-48I ; explorations after conquest, 2II; in march to Quivira, 479; maestre de compo, 40I; punishes Ácoma, 2II; rear guard, 210; reconnaissance to Río Grande, 209, 397

Zapalinamé, in Charcas, I7

Zapata, —, Gómez, signature, 93

Zesar, Gregorio, with Onate, witness, 425

Zipotecas, conquest, 35

Zores de Ulloa, Isabel, wife of Porras, 69

Zuñi pueblos, Coronado's expedition, I2; Oñate at, 2II ; Rodríguez and Espejo at, II3, I22, I93

Zuñiga, - signature, I05

Zuñiga y Acevedo, Gaspar de, see Monterey, Conde de 


\section{Q78 \\ $3 \times+2$}

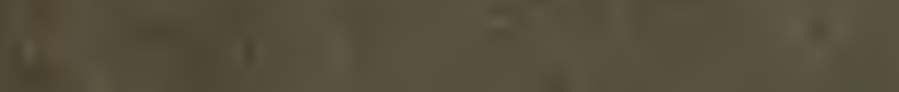

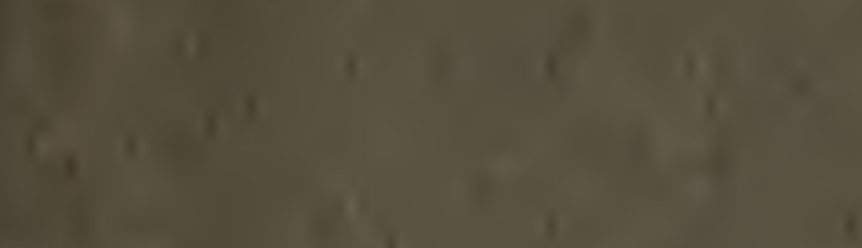

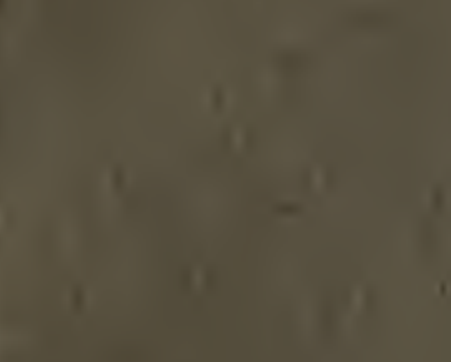

$x^{-1}+10$

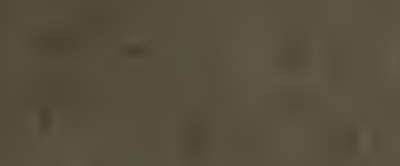

1
4
4

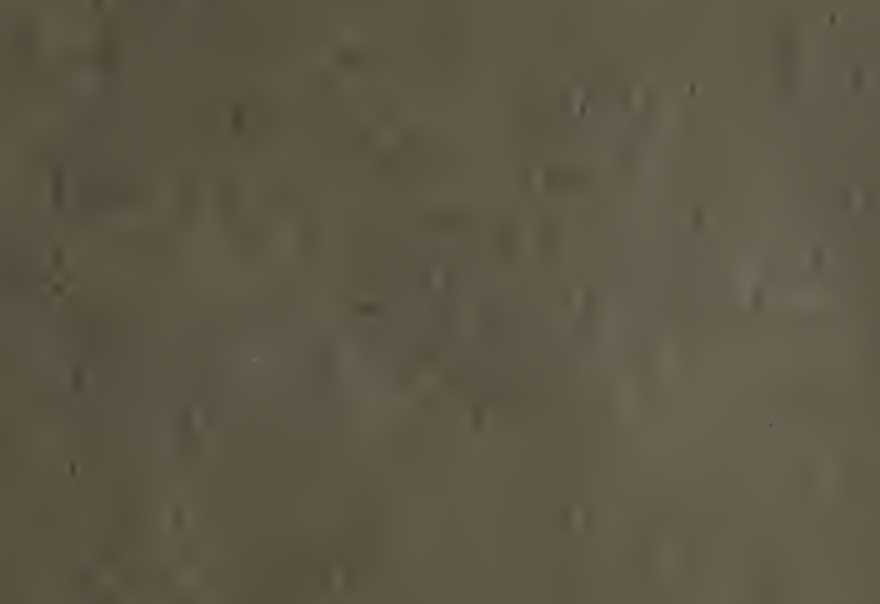

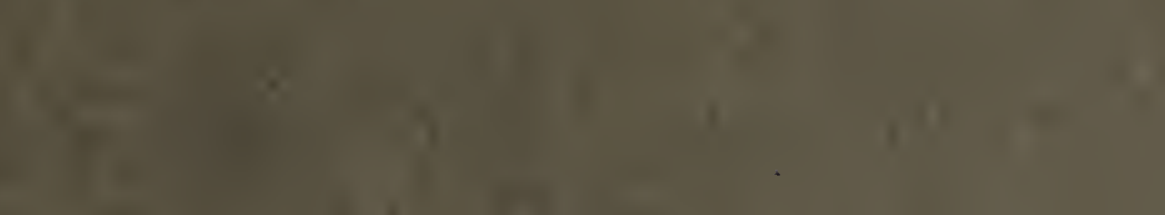

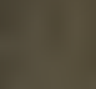

$(1)$

1.

1)

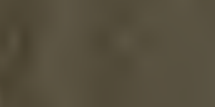

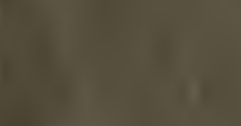

(i)

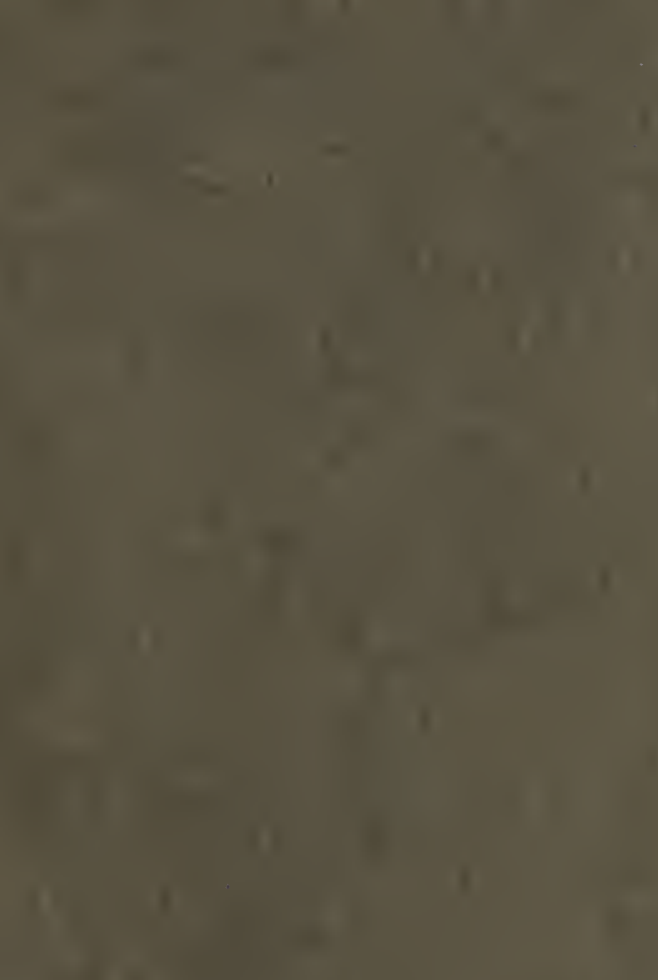

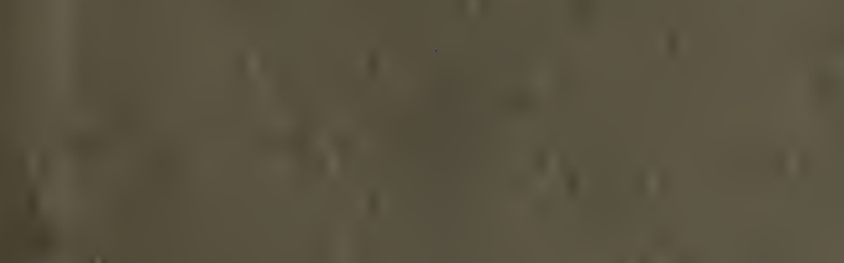

1)

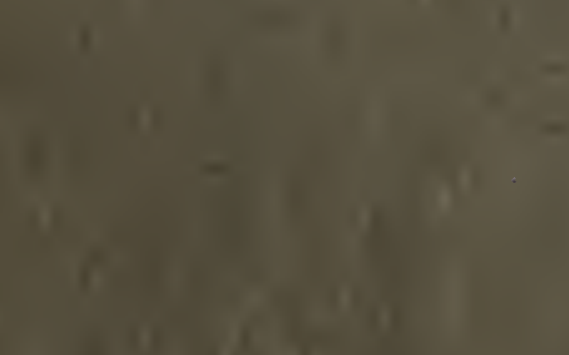

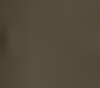

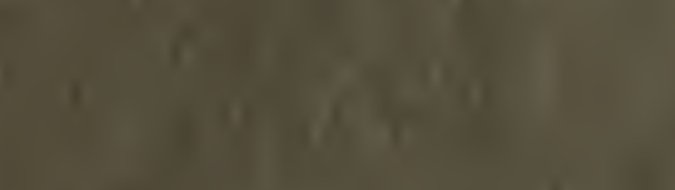

$x^{1}, 1=$

$3+76 \%$

$$
\text { in. }
$$

$x=14$

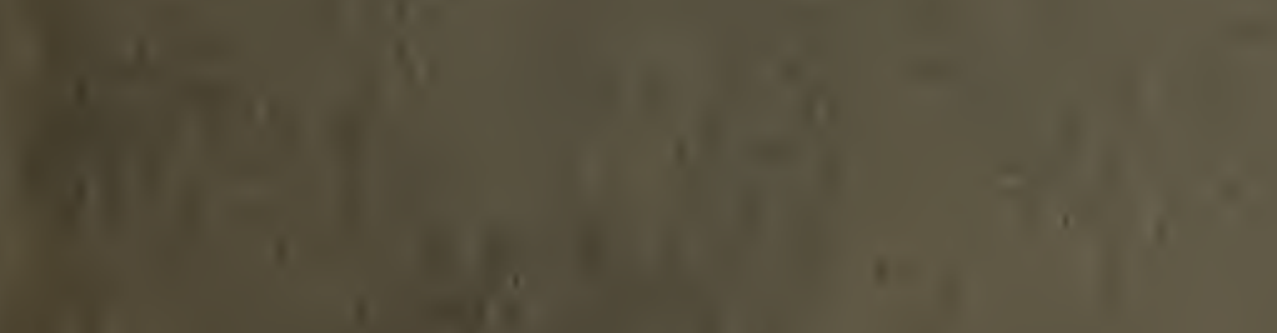

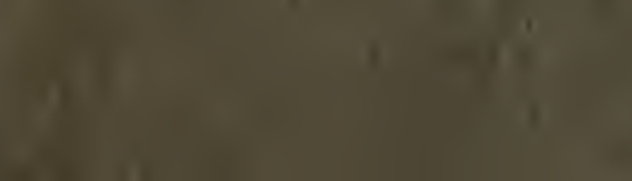

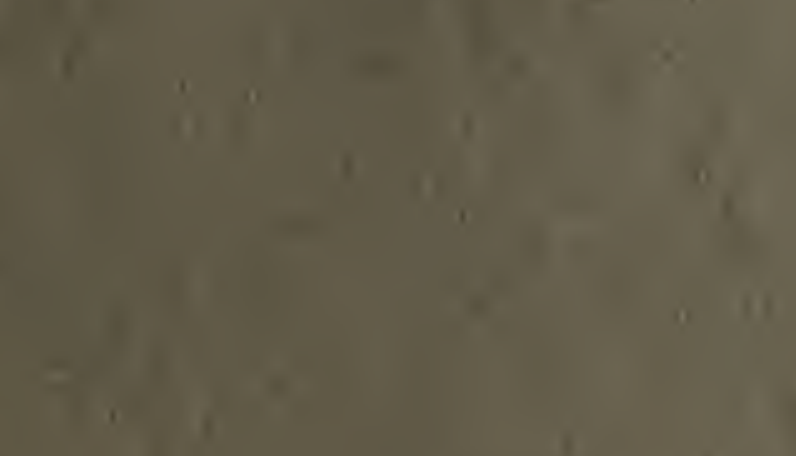

$\sqrt{1}+y^{3}$

in a n 4,1

(3) 18 


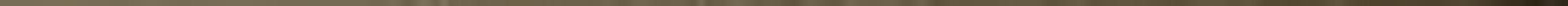






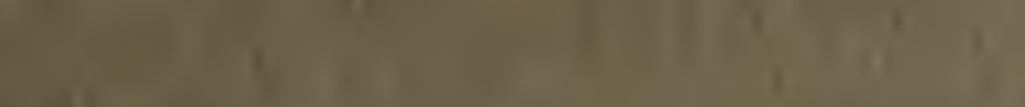

10

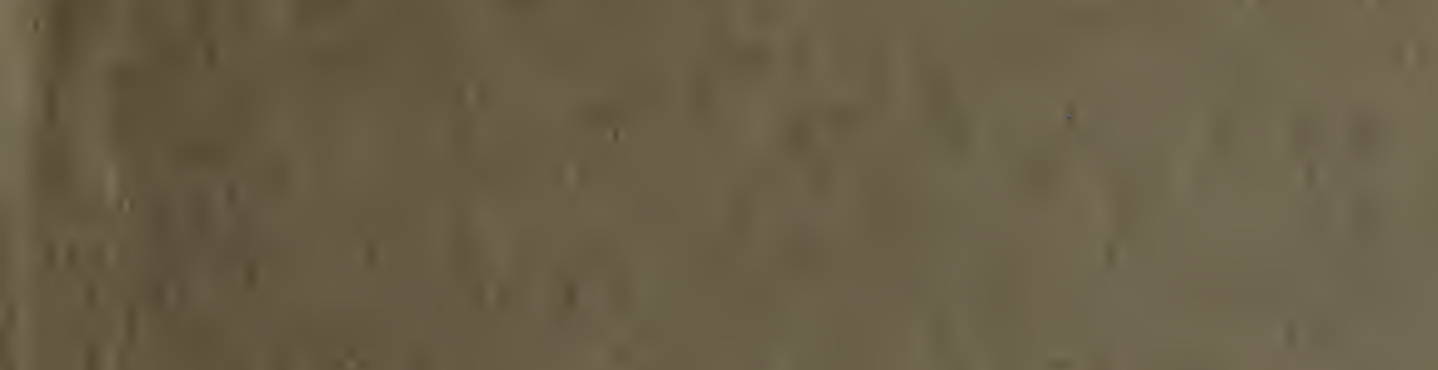

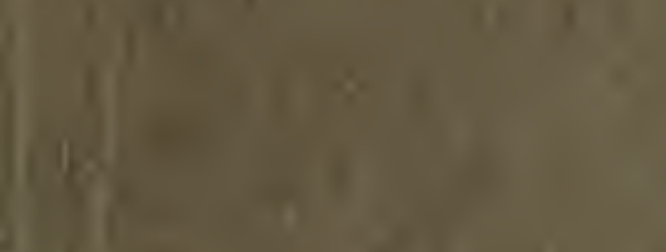
1

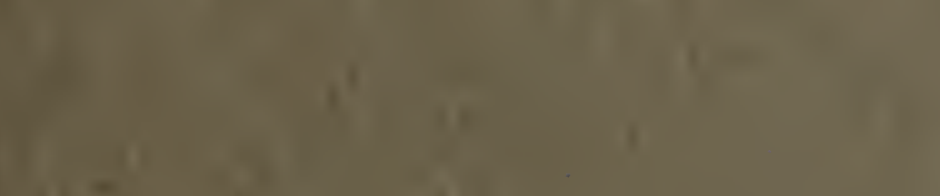

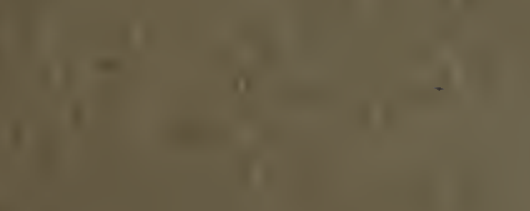

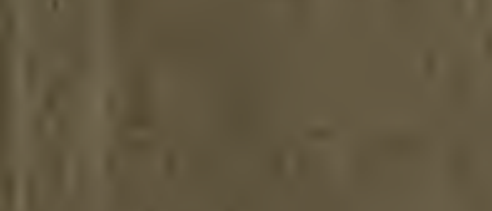

(6) $\frac{1}{1}+\frac{1}{2}+1$ $1+$

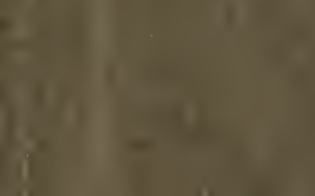

1

$+\frac{1}{2}$

a

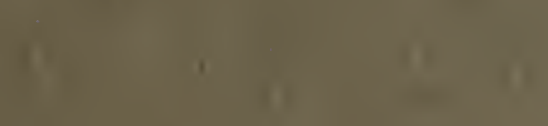

1)

(1)

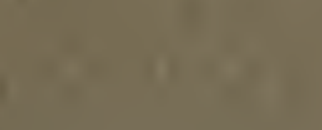

$x^{2}+x^{2}$

$10=0$ 


\section{UNIVERSITY OF ILLINOIS-URBANA

